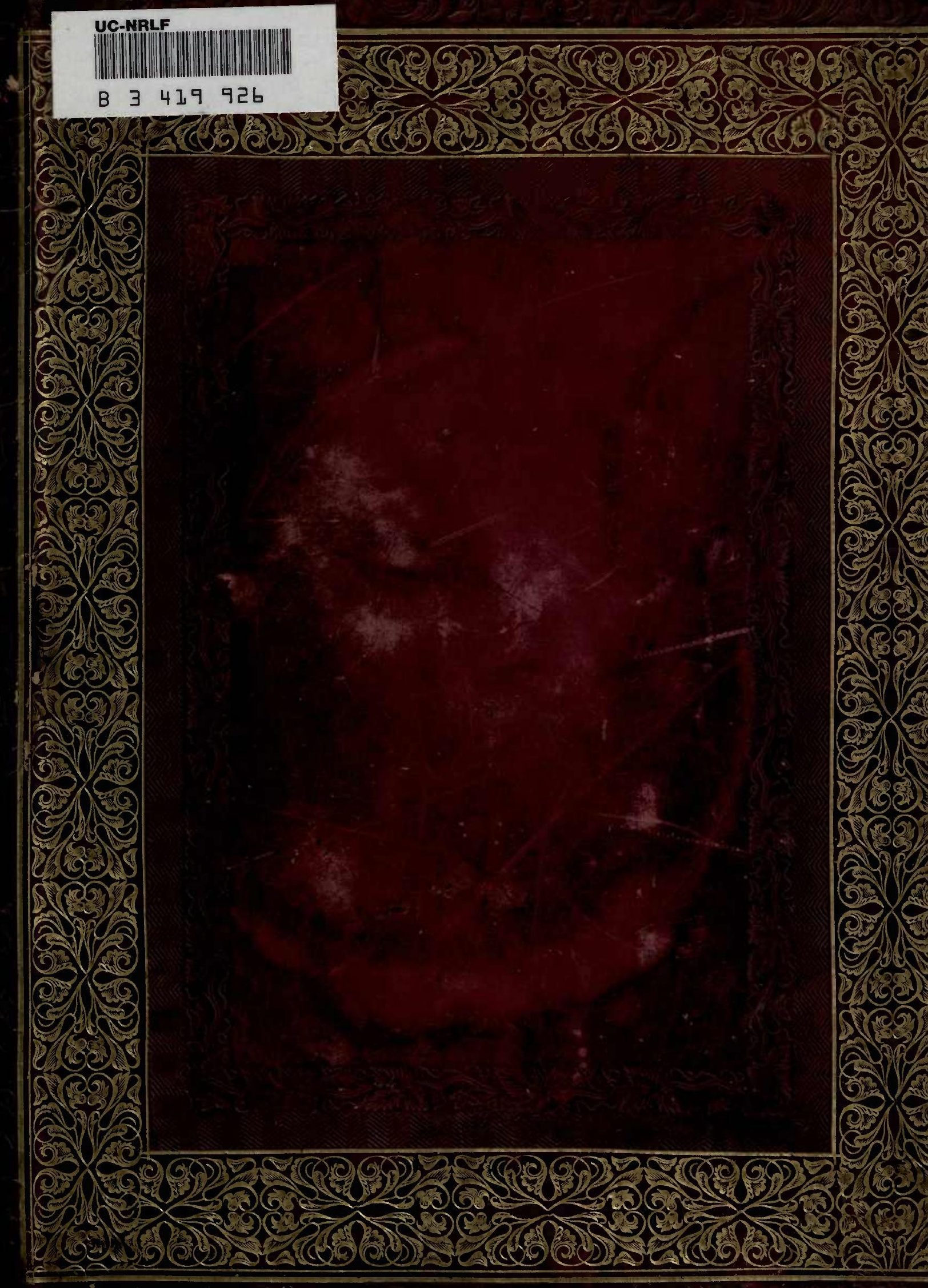




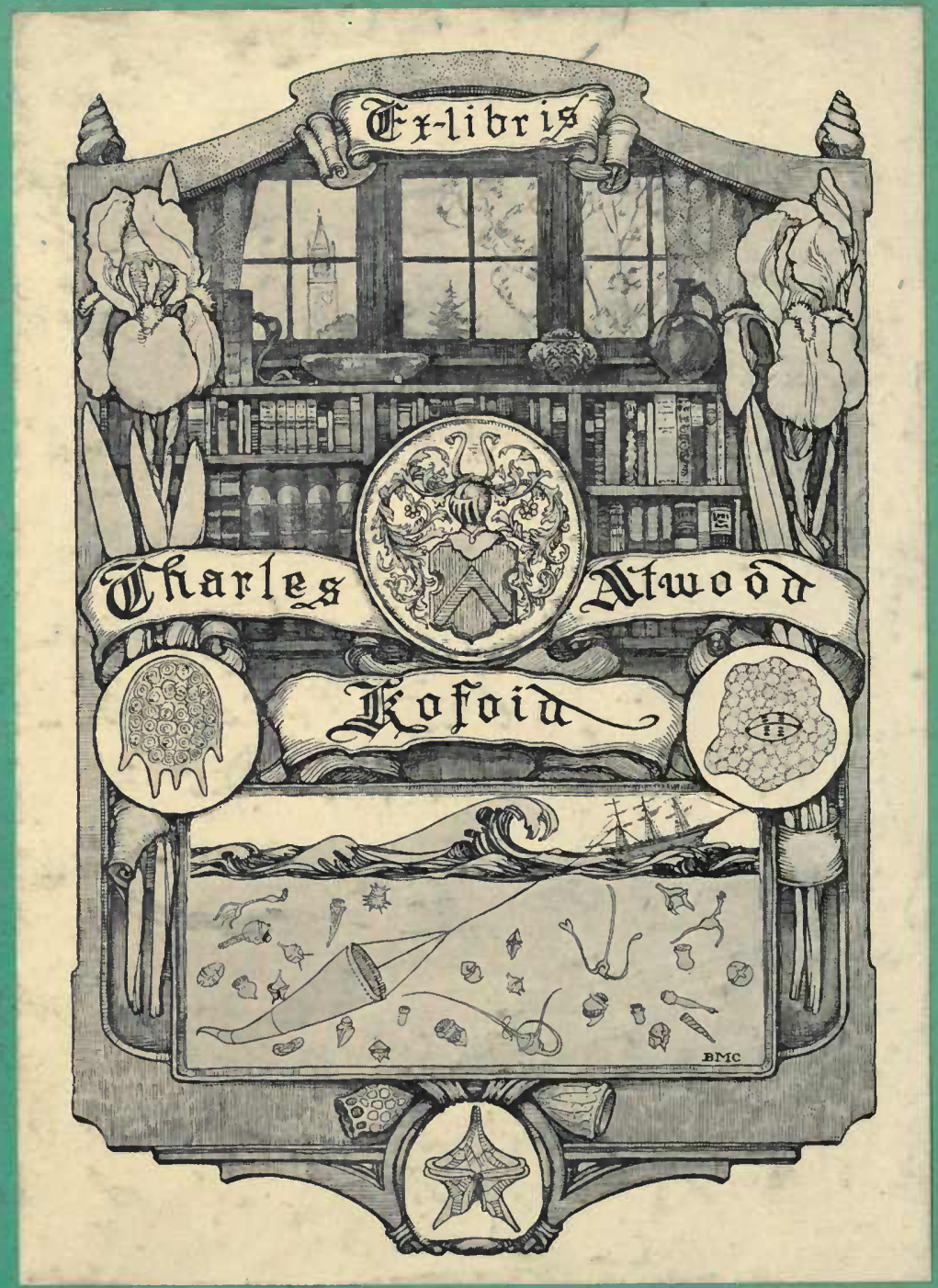


a a 
Nifs trances. Lly suston

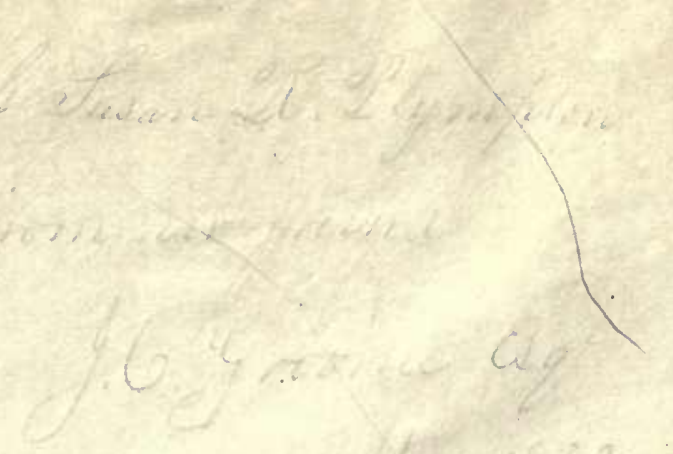

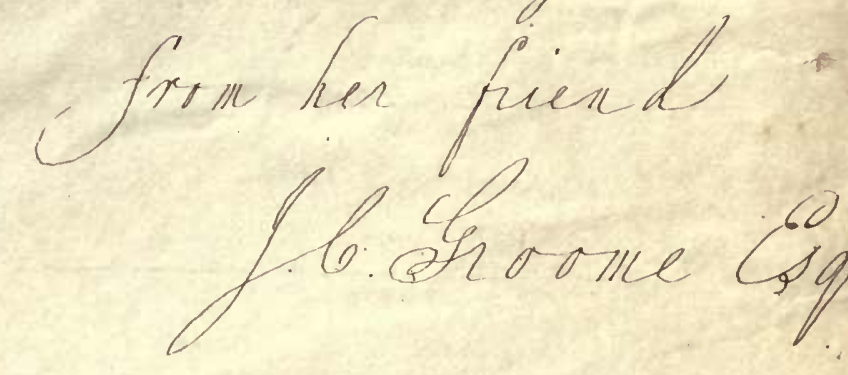
thy

$$
\begin{array}{r}
\text { Soistone cos } \\
\text { May } 1832
\end{array}
$$








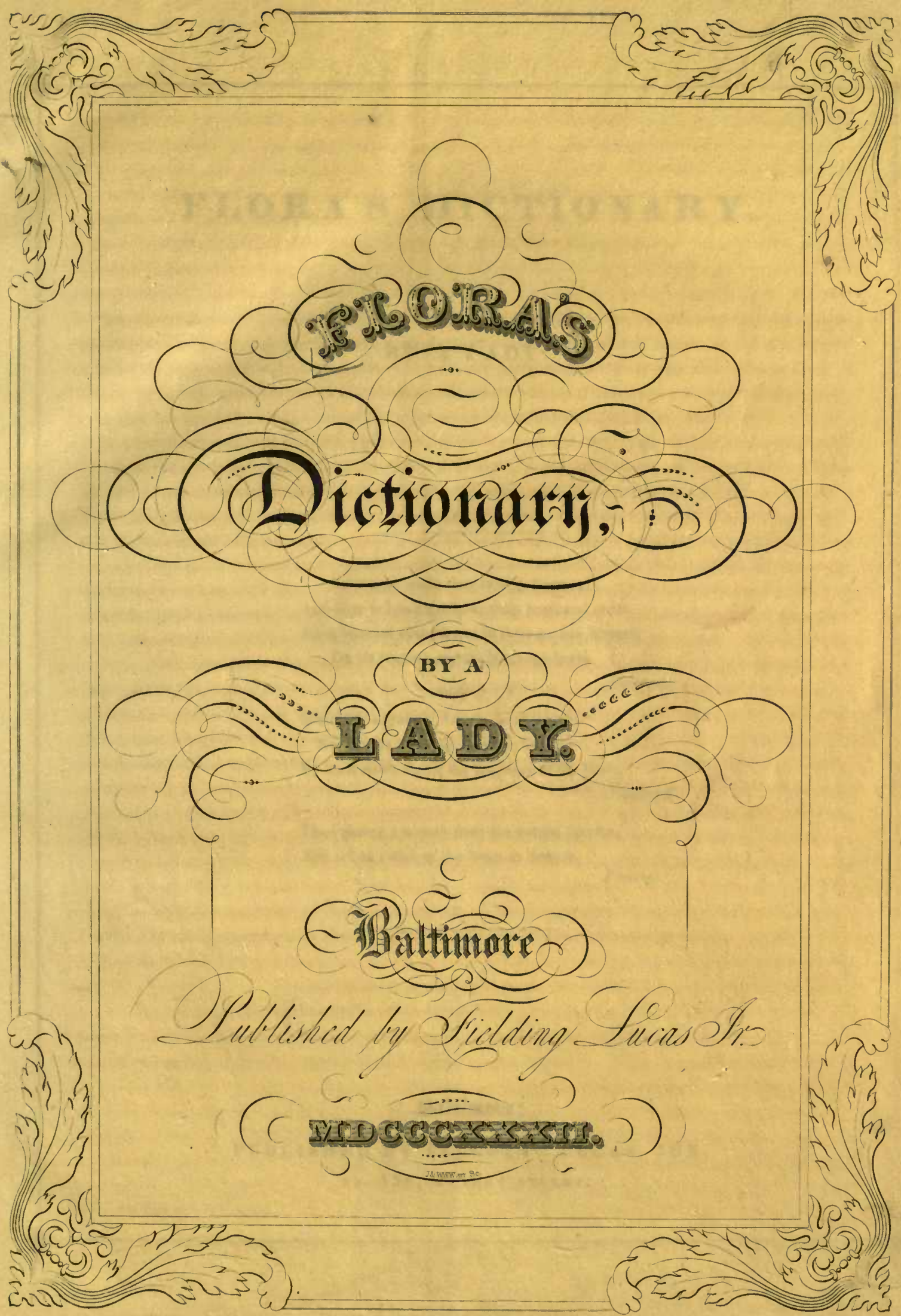

CBut 


\section{-}

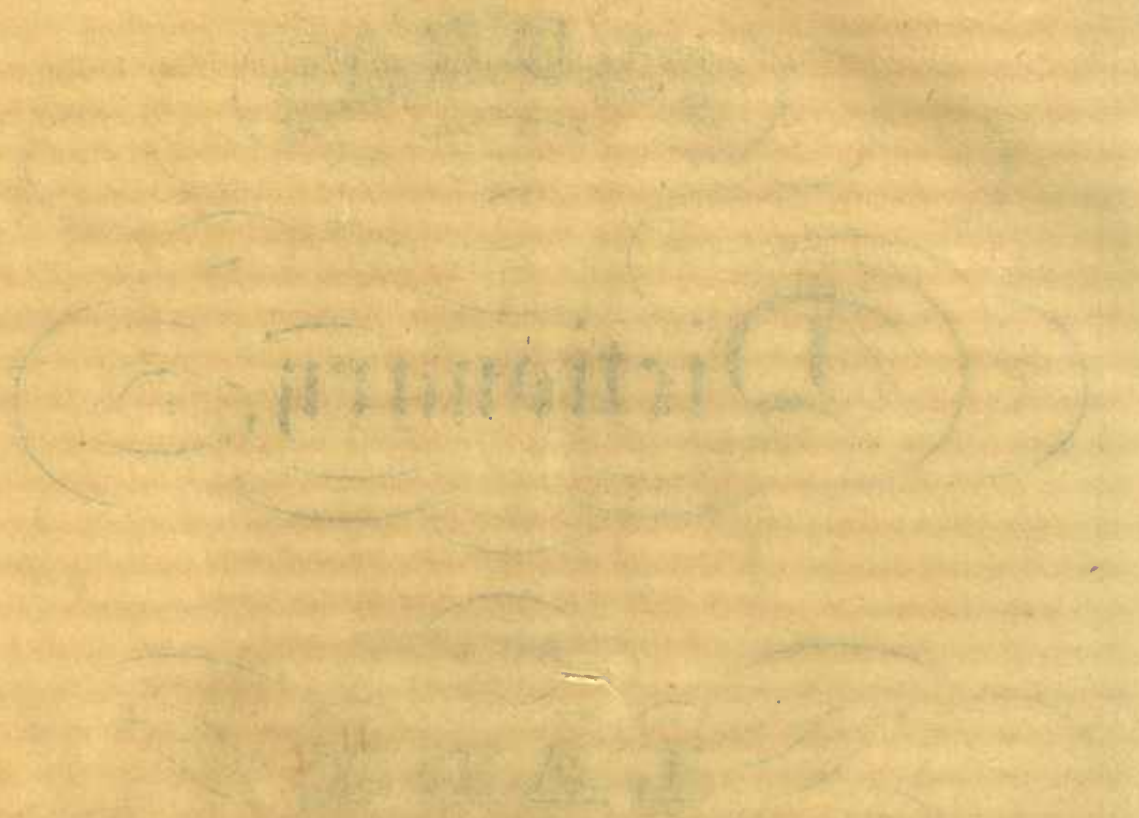

i.

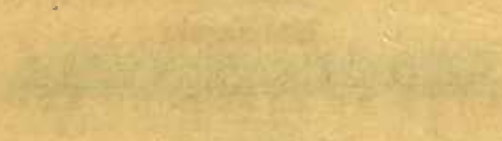




\title{
FLORA'S DICTIONARY.
}

\author{
B Y A L A D Y .
}

In eastern lands they talk in flowers, And they tell in a garland, their loves and cares;

Each blossom that blooms in their garden bowers

On its leaves a mystic language bears.

\section{Percival.}

Beautiful language! Love's peculiar own.

Not for the cold, the careless, to impart,

By such sweet signs, the language of the heart.

Pickersgill.

Then gather a wreath from the garden bowers, And tell the wish of thy heart in flowers.

Percival.

\section{Baltimore:}

PUBLISHED BY FIELDING LUCAS, JUN. No. 138 , MARET STREET. 


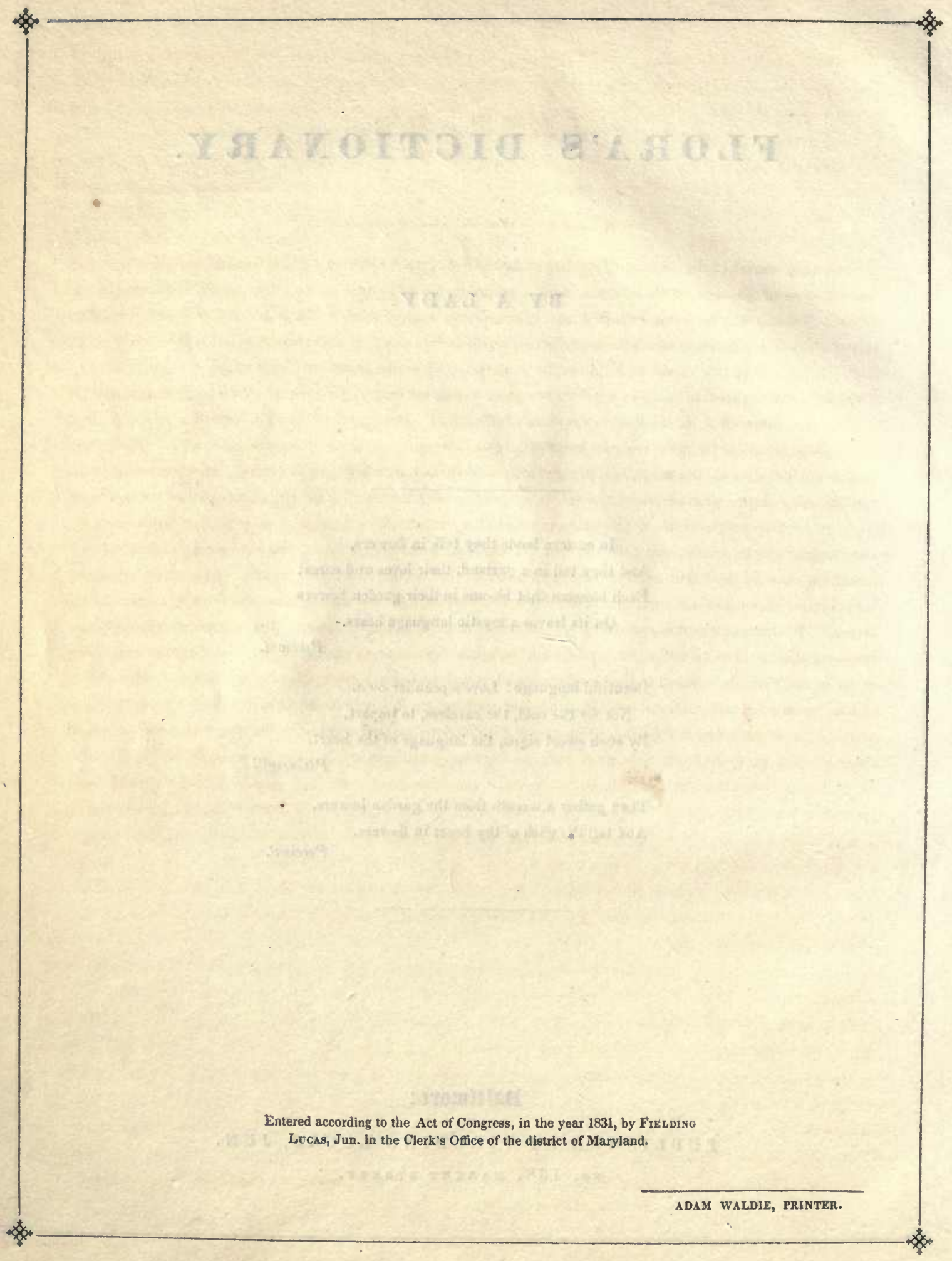




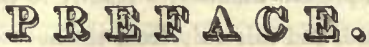

"Master I.ouis, where have you picked up so inany trifles ?"

Turs noted remark of the Cardinal Hyppolito to the author of the "Orlando Furioso," on his presenting him with the first copy of his work, would be much more appropriate to the present recueil, than to the "fine frenzy" of Ariosto. Yet one may be worse employed than in conversing with flowers. They are innocent companions, at least; and, in those hours in which the most industrious look for relaxation and amusement, it will be happy for us if we find no society more noxious, than that of these pure and beautiful parts of the creation.

Do we make the most of the objects which surround us-do we extract from them all the information, and all the inwocent amusement which they are capable of affording? The question is not addressed to the scientific; but to those, of whom the writer admits herself to be one, who are too often content to gaze with a vacant and transient admiration at the works of the creation, and then to remember them no more. Here, for instance, is this blooming earth: what an interest has the science of botany thrown over it! Yet how few are there, among us, who are disposed to taste of the banquet which this science affords !-Again, these flowers interest us by their beauty and fragrarice, and here we stop. Travellers, however, assure us, that the people of the East see something more in them than mere objects of admiration. In the hands of these primitive and interesting people, they become flowers of rhetoric, and speak their feelings with far more tenderness and force than words can impart. With them, there is something sacred in this mode of communication. It is a kind of religious worship-an offering of the fruits of the earth; and, though addressed to an earthly object, it still retains something of the sanctity which belonged to the rite from which it was probably borrowed, and is accompanied with a devotion far more true, and deep, and touching, than the artificial homage which distinguished the courts of Europe, even in the vaunted age of chivalry. Compared with modern manners, either in Europe or America, what is there that can vie, in picturesque beauty, with the Persian youth, gracefully presenting a rose to his mistress? What language can convey a compliment so delicate and exquisite? and if a communication of a still more interesting nature be intended, how much more refined, poetic and affecting is the mute eloquence of the eastern lover, than those awkward and embarrassing declarations which are in use in other countries ! How much easier is it to present a flower, than to make a speech !

It is upon the hint suggested by this oriental custom, and for the purpose of trying, as a matter of curiosity, how far this emblematic language could be carried, that the following collection has been made.

Mr. Percival tells us,

"Fach blossom that blooms in their garden bowers

On its leaves a mystic language bears."

Pity it is that we have no key to this mystic language of the East. Very few of their emblems have reached us. So far as they are known, they have been adopted in this collection. A few others have been borrowed from books and manuscripts. To supply the residue, which constitutes the far greater number, and to furnish the whole with appropriate illustrations, has been the chief amusement out of which this petit jeu has grown. Very few of the emblems have been attached without reason. In general, they have been suggested either by some allusion to the specific flower in British poets, or by its botanical, or its popular name, or by some property peculiar to it, such as its hue, form, odour, place and manner of growth, sensibility, medicinal virtue, or some 
other circumstance connected with its history or character. It would be idle to swell this preface, and to seek to give consequence to a trifle so light and airy as this, by indicating, in every instance, the reasons which led to the selection of the emblems : these will present themselves readily to the mind of the reader. A few, and but a few of them have been arbitrarily assumed, and this only from the necessity of giving sufficient range and variety to this symbolic language. If this be an objection, it applies with equal forcc to spoken language. For, although sach of our words as are intended to convey the idea of sounds, seem to be manifest imitations of these sounds, and "echoes to the sonse," as they have been happily called, yet, the far greater part of the words which com. pose our language, have no such resemblance, and must have been necessarily and arbitrarily assumed, in the first instance, as signs of the ideas to which they were applicd, and gradually adopted by common consent as cxpressive of those ideas. The adoption once made, whether in oral or emblematical language, the application of these conventional signs becomes as easy and accurate, and the use as great, as if there were a natural and inherent relation between the signs and the ideas which they represent; all that is necessary heing, that the purpose of the sign be understood in the same way by all who use it.

The quotations are designed as poetic translations of the several emblems to which they are respectively applied. They are the language of the emblem rendered in verse : and, from the intrinsic beauty of most of these quotations, may it not be added, that these are the flowers of poetry aptly employed in illustrating the flowers of the earth? Some of the lines are original contributions for this little work, and it is believed that they will be found worthy of this association with established poets. In some instances answers are furnished; these may be tacitly made by returning a part of the same flower which has been presented.

The first rude sketch of this little divertissement having been shown to a few young friends, copies were asked and given, and one of these, in the course of last year, found its way to the press in Boston, wherc, it is understood, a few copies werc struck, with great neatness and beauty of type and paper. The circumstance is mentioned merely to explain to those who may possess those copies, the identity of the work, and to cxempt the lady who has amused herself in compiling it, from any original purpose of publication. Since the collection has been enlarged, it las become so irksome to meet the request for manuscript copies, that it has been found expedient to call in the aid of the press to save the time and labour of transcription. This request for copies, and the circum. stance of its having been thought worthy of publication in Boston, while the little work was as yet an embryon bud, induce the belicf that the nore expanded and finished form which it has now taken, will make it not unacceptable to those who are themselves in the spring-time of life, the season of flowers and sentiment.

There are few little presents more pleasing to a Lady, than a bouquet of flowers; and, if the donor be disposed to give them greater significance, it will be easy, with this manual before him, to make his selection in such a way as to stamp intelligence and expression on a simple posy.

This mode of communieation may be carried even beyond the proper season of flowers, by the aid of an kerbarium, in whicl flowers are preserved by simple pressure between the leaves of an album. Such an herbarium would be an ornament to a parlour table, and would, moreover, encourage and facilitatc the study of botany : in promotion of which latter object, a botanical glossary has been added to the work.

The Lady who has given her leisure lours to this little play of fancy, has not the ranity to attach any serious consequence to it. The bagatelle, she trusts, is too light to attract the gravo censure of the critic by profession. It has been an innocent recreation to herself; and it is with no higher expectation than of affording the like amusement to others, that it is now given to the press.

Baltimore. 


\section{STRUCTURE OF PLANTS.}

A perfect plant consists of the root, the stem or trunk, the stalk, the leaves, the flower, and the fruit.

Roots are either annual, lasting one year, as the Poppy, Barley, \&c.; biennial, when produced in one year, and flowering the next, as Wheat, Canterbury Bell, \&c.; or perennial, when they last many years, as the Rose, Trees, \&c. There are various kinds of roots, some are bulbous, as the Tulip and Onion; tuberose, as the Potatoe and Turnip; fusiform, as the Carrot and Radish; or fibrous, as in Trees and Grasses. The root generally consists of two parts; the body and the fibres: the latter is the part which imbibes nourishment from the earth for the support of the plant. The seed of a plant committed to the ground, swells by the moisture it imbibes, and, in a few days, throws out two shoots; the first strikes downward into the soil, and forms the root or rudical; and the other forces its way into the air. As soon as the young plant feeds from the soil, it requires the assistance of leaves, which are the organs by which the plant throws off its superabundant fluid. Vegetation is then essentially injured by destroying the leaves of a plant. It not only diminishes the transpiration, but also the absorption by the roots; for the quantity of sap absorbed is always in proportion to the quantity of fluid thrown off by transpiration.

The Trunk, or Stem, is that part of a plant which produces the leaves and flowers, and serves to elevate them above the ground. It consists, 1 . Of the Epidermis, cuticle, or exterior thin membranous covering, furnished with pores, which transmit or throw off the excretory products of vegetation; answering to the skin of animals. 2 . The Corlex, or outer bark, consists of vesicles and utricles, (small membranous cavities or cells to receive the sap,) so very numerous, and close together, as to form a continued coating. It is among these glands that the work of digestion appears to be performed; and the product of this elaboration is afterwasds conveyed through the whole vegetable, by vessels propagated through all its parts; these conduits even passing through the body of the tree, crossing the ligneous strata. In this net-work it is that the colouring matter of vegetables is decomposed : the light which penetrates the Epidermis concurs in enlivening the colour: here, likewise, it is that oils and resins are formed, by the decomposition of water and the carbonic acid. 3. The

Liber, or inner bark, is the part in which the vital principle of a plant is chicfly seated; its parts are easily detached from each other; their lamina, (fibrous scales or layers,) are not extended lengthwise along the stem, but are curved in various directions; and leave openings, or meshes be. tween them, which are filled by the cellular matter itself, and it is from their resemblance to the leaves of a book, that they have been called liber. It is this part of the bark on which the ancients wrote, before the invention of parchment, or paper. In proportion as these coatings approach the ligneous body, or wood, they become hard; and at length form the external softer part of the wood, which workmen call the sap. The wood or ligneous part of the plant, is a compact fibrous substance, formed by new layers, which are added, every year, from the innermost part of the bark; so that the age of a tree, or shrub, may be ascertained by the number of ligneous circles which appear upon cutting the stem near tho root.

The bark is the most essential part of the vegetable, by means of which the principal functions of life, such as nutrition, digesting the secretions, \&c. are performed.

The bark of a tree is only a congeries of the roots of the individual buds of the plant. These roots spread themselves over the last year's bark, making a new bark over the old one, and thence descending, cover with a new bark the old roots also.

The wood, or ligneous part, is not essential, many plants being without it ; such as grasses, reeds, and all plants that are hollow within.

The hollow Oak-trees, and Willows, are often seen with the whole wood decayed and gone, and yet the few remaining branches flourish with vigour.

Grasses, properly speaking, have only the cortical part. The thin outside cover of the bark is of great consequence to them : it is of great strength, and appears to be constituted of a sort of glassy net-work, which is chiefly siliceous earth, as has been lately ascertained. This is the case in the Wheat, Oat, and in different plants.

The Stalks are those parts which branch out from the 
stem, and support the leaves, flowers, or fruits; as the straw in grasses; the flower stalks, leaf stalks, \&c.

The $P$ ith is a tolerably firm juicy substance, which is diffused through the inner part of the stalk, to give energy and vigour to the whole; it is abundant in young plants, diminishes as they grow up, and at length totally disap. pears.

The Sap is the fluid which nourishes the plant. The warmth of the spring dilates the vessels of plants, producing a kind of vacuum, into which the sap rises; but, when the cold weather returns, the fibres and vessels contract, the sap is forced down into the root; the leaves wither, and are no longer able to perform their offices of transpiration; the secretions stop, the roots cease to absorb sap from the soil, and if the plant be annual, its life then terminates; if not, it remains in a state of torpor during the winter. The basis of this juice, which the roots suck up from the soil, is water.

Heat promotes regetation; it excites the activity of plants; it increases the disposition of some of their constituent parts for new attraction and combination, to obtain such substances as may be requisite and proper for new growth ; it likewise causes them to reject such matters as would be hurtful to them; it hastens the dissolution or digestion, the formation and secretion of their different products. It enables them to dispose of their superabundant portion of fluids, by promoting perspiration and evaporation. Yet the heat must not be too great, or continued for too long a time, as it occasions a too rapid digestion, and perspiration of their nourishment, and consequently an exhaustion.

Plants have an independent heat of their own. But, if it be difficult to account for the spontaneous production of heat in animal bodies, as all physiologists have found, it must be much more so to account for the generation of vegetable heat. Light, and atmospheric air, at least, are known to be essential to the vital functions of both.

In all decomposition, caloric, or heat, is disengaged, and may not the chemical process which takes place within the plant, supply it with the heat which they are acknowledged to possess, and which, it is asserted, tempers the cold of the atmosphere; while the evaporation which takes place through the whole plant, continually moderates the scorching heat of the sun?

Dr. Hunter observed, upon this independent heat, that by keeping a thermometer placed in a hole made in a sound or healthy tree, it constantly indicated a temperature several degrees above that of the atmosphere, when it was below the fifty-sixth division of Fahrenheit; whereas the vegetable heat in hottcr weather was always several de. grees below that of the atmosphere. The same philosopher has likewise observed, that the sap which, out of the tree, would freeze at $32^{\circ}$, did not freeze in the tree unless the cold were augmented $15^{\circ}$ more.

But the most remarkable instance of heat in plants upon record, is what is related of the Arum maculatum. Lamarck says, in his Flore Française, "that when the flowers are in a certain state of perfection, the spadix is so bot as to seem burning, and not at all of the same tem. perature as the surrounding bodies."

Mr. Senebier noticed that this heat began when the sheath* was about to open, and the spadixt just peeping forth, and that it was perceptible from three or four o'clock in the afternoon till midnight.

The Leaves consist of an immense number of fibres or nerves, divided into two sets, one belonging to each surface. The surface of the leaf is full of minute pores, through which it imbibes the dew, air, \&c. necessary to the growth of the plant, so as to enable it, in some degree, to dispense with supplies from the root; as we sec in plants which live in the water, or swim in that element, which serves them for food; they have no roots, but receive the fluid at all their pores, and, by decomposition, the hydrogen gas of the water, which constitutes the chief aliment of the plant, is separated, and becomes a principle of the vegetablc; while the oxygen gas, the other constituent part of water, is thrown off by the vital forces, escaping by the pores, where the action of light causes its disengage. ment.-[See note 1st, upon Gas.]

Air is also necessary to the growth of a plant. But the air which it requires is not the same appropriated to the use of man.

Drs. Priestley and Ingenhousz have proved that it is the

* Sheath, or Spathe-a kind of calyx that opens lengthwise, and puts forth a flower-stalk or spadix, as in the palm arum, \&c.

It is also applied to the calyx of some flowers which have no $s p a-$ dix, as of the narcissus, cracus, iris, \& c. A membrane investing a stein or branch, as in grasses.

† spadix-the receptacle proceeding from a spathe, as in the palm, and some other plants, so called from being produced within a spatla, or sheath. 
nitrogen gas which more particularly serres them for aliment. Hence it arises that vegetation is more vigorous when bodies which afford this gas by their decomposition are presented to the plant ; these are, animals, or vegeta. bles, in a state of decomposition, or putrefaction.

Vital air, or oxygen gas, the other constituent part of atmospheric air, is necessary to the respiration of man, and other animals, and this air is copiously emitted by vegetables : this renovation of the atmosphere being necessary to make up for the great consumption of it by respiration and combustion.

Hence arises a mutual and essential dependence of the animal and vegetable kingdoms upon each other. Animals, in breathing, consume the oxygen air, but roturn the nilrogen for the use of the ver fabie; while the vegetable retains the nitrogen of the air, and the hydrogen of the water, for its own use, and returns the oxygen for ours. How admirable the designs of Providence, who makes every different part of the creation thus contribute to the support and renovation of each other !

The carbonic air dispersed in the atmosphere, or in water, is also necessary to the vegetation of plants, in order to provide their carbonic principle, which is a constituent part of the fibres, oils, mucilage, and other vegetable principle. It is the basis of all vegetable matter.[See Note 2d, on Carbon.]

Buds of trees may be truly estecmed individual plants; and, if onc of them be planted in the carth, with a cup inverted over it, to prevent its exhalation from being at first greater than its power of absorption, it will produce a trec similar to its parent.

Linnæus observes, that trees and shrubs are roots above ground; for, if a tree be inverted, leaves will grow from the root-part, and roots from the trunk part.

Buds and bulbs are all annual productions, termed, by Linnæus, the hybernacula, or winter cradles of the plant. And Darwin observes, that the same term might properly be applied to seeds also.

Each bud has a leaf, which is its lungs, appropriated to it.

Leaves absorb carbonic acid gas, or fixed air, by their upper surface, and give out oxygen gas, or pure respirable air, by their under surface; as first discovered by Dr. Priestley.

Dr. Ingenhousz improved upon this discovery, by observ- ing light to be necessary to these functions; remarking that in the dark, leares give out a bad, or carbonic air, and that fruits and flowers almost invariably give out the last mentioned kind of air, at all times, but especially in the dark.

It has long been known that light acts beneficially upon the upper surface of leaves, and lurtfully upon their under side; and, if the latter be repeatedly turned to the light, or forcibly kept in such an unnatural position, the leaves grow sickly, black, or discoloured; as may be seen in plants trained against a wall.

Some leaves, if separated from their parent branch, and suspended by a slender thread, will turn their upper sur. face to the light, and vary their position, as the sun pursues his course. Sword-shaped leaves are an exception; they have no upper or under surface, but are vertical, and do not alter their position.

Light is considered as a stimulus or agent which decomposes the various nutritive principles, to be found in the air and water. It seems, in many instances, to be the sole cause of the expansion of flowers and leaves; for when it is withdrawn, they fold together and droop, as if dying; this has been elegantly tcrmed by Linnæus, "the sleep of the plants;" and the Mimosa pudica, or sensitive plant, is a beautiful example of it. This plant, if kept in a dark room, for a considerable time, will require several minutes' exposure to the solar light before the stimulus of the light will dispose it to unfold, or expand its leaves.

Leaves always turn towards the light; this is necessary to the formation of their colour, as may be seen by the common practice of blanching celery, endive, \&c. by co* vering them from the light; and by plants raised in darkness, which are of a sickly white.

Vegetables become destitute of smell as well as of colour, and lose much of their combustibility by growing in the dark. The celebrated Dr. Robertson, of Edinburgh, gives an account of a plant found in the drain of a coalwork under ground, which was very luxuriant, with large indented foliage, and perfectly white. He had not seen any thing like it, nor could any one inform him what it was. He had the plant with a sod brought into the open air in the light, when in a little time the leaves withered, and soon after new leaves began to spring up, of a green colour, and of a different shape from tbat of the old ones. On rolling one of the leaves between his fingers, he found 
that it had the smell of common Tansy, and ultimately proved it to be that plant, which had been so changed by growing in the dark. Indeed it was recollected, that some soil had been taken into the drain from a neighbouring garden, some time before it was found so altered.

It has been ascertained, by experiment, that the green colour of vegetables may be produced by the light of a lamp, in the absence of the more perfect light of the sun; as discovered by the Abbe Tessier.

Leaves give out moisture by their under surface, in proportion to the intensity of light, and not of heat; so that there is scarcely any evaporation during the night. The water which exlales from vegetables is not pure, but serves as the vehicle of the aroma ; it is equal to the third part of their weight every twenty-four hours, in healthy plants.

Leaves also expose the sap which they receive from the wood, to the action of the air, and return it again to the bark by its fibres or vessels. They also serve to nourish and prepare the buds of the future shoots, which are always formed at the base of the leaf stalk, and to shade them, as wcll as the fruit, from the too powerful heat of the sun. Hence it is, that in tropical countries the tree is never divested of the leaf.

Water is the only aliment which the root draws from the earth; and a plant can live and propagate itself, without any other assistance than the contact of water and air; as may be seen every day, in the Hyacinth, and other bulbous plants, which adorn our mantlepieces, as well as gramineous, or grassy plants, such as wheat, \&c. raised in saucers or bottles, containing mere water.

In vegetables, hydrogen is the principle which fixes itself, while oxygen gas (tho other constituent part of water) makes its escape.

But although pare water is more proper for vegetation, than water charged with salts, yet water may be disposed in a more favourable manner to the developement of regetables, by charging it with the remains of regetabie and animal decomposition: the plant then receives juices already assimilated to its nature. Independent of those juices already formed, the nitrogen gas (which has alroady been mentioned, as constituting one of the nutritive principles of plants) is abundautly afforded by the alteration of vegetables and animals, and must facilitate their devel. opement.
Althougli it has been proved, by various experiments, that pure water is sufficient to the support of plants, we must not, therefore, consider the earth as of no use; it imbibes and retains water; it is the reservoir destined by nature to preserve the elementary juice which the plant continually requires; and to furnish that fluid in proportion to its wants, without exposing it to the cqually fatal alternatives of being either inundated, or dried up.

The nature of the soil must be varied accordingly as the plant requires a more or less considerable quantity of wator, in a given time; and accordingly as its roots extend to a greater or less distance. Every kind of earth is not suitable for every plant; and, consequently, a slip cannot be grafted, indifferently, upon every species.

A proper soil, is one which affords a sufficiently firm support to prevent the plant from bcing shaken; which permits the roots to extend themselves to a distance with ease; which becomes impregnated with humidity, and retains the water sufficiently, that the plant may not be without it when wanted.

To answer these several conditions, it is necessary to make a proper mixture of the prinitive earths, for none of them in particular possesses them.

Siliceous (white sand) and Calcarcous (limy) may be considered as hot and drying; the Argillaceous (clayey), moist and cold; and the Magnesian, (a primitivo earth, having for its base a metallic substance, called Magnesium, generally found in combination with other substanccs,) as possessing intermediate properties. Each, in particular, has its faults, which render it unfit for culture : clay absorbs water, but does not communicato it; calcareous earth receives and gives it out quickly ; but the propertics of these earths are so happily opposed, that they correct each other by mixture. Accordingly we find, that, by adding lime to an argillaceous earth, this last is divided; and the drying property of the lime is mitigated, at the same time that the stiffness of the clay is diminished.

Saline substancos have been supposed of importancc in vegetation by some, but they do not appear essential to the growth of any sort of plant except the Marine; such matters may, however, be of use to vegetation, though not essential to it. That of common salt may operate upon plants as it does upon the human body, by assisting to digest the food, without furnishing nutriment itself.

It is upon this principle, I presume, that common tuble 
salt mixed with water in a flower pot, will expedite the opening of a rose.bud, or other flower, when plucked from the parent branch.

Here I will observe, that if a small bit of nitre be added to the pure water, in a vase containing flowers; the water changed every day, and a small piece of the flower-stalk cut off each time of the change of water, the freshness of the flowers may be preserved for a considerable length of time.

Secretions.-The sap, when exposed to the action of the air, light, and heat, by the leaves, becomes a new fluid, which assumes the peculiar flavour and qualities of the plant. Gum is one secretion, which oozes from the cherry, and other trees; resin, and turpentine, are of the same nature; as is, also, the milky juice of the fig, poppy, \&c. Almost all the fruit trees yield some sort of gum. And a species of the Acacia tree, in Arabia, yields the Gum Arabic, which is the chief nourishment of the nations of those parts, who obtain it in great quantities from incisions which they make in the trees. This Gum Arabic is now in frequent use in our own country; and forms a good aliment for young children; particularly when on a sea royage, where milk cannot be commanded.

Another secretion is Caoutchouc, or Indian rubber, which is obtained from several species of trees in South America and the East Indies. The botanic names of the two species found in Cayenne, S. A. are Havea caoutchouc and Jatropha elastica. The fluid is collected from the tree by incision; the colour is, at first, a yellowish white, but, by exposure to the air, it becomes dark. Moulds made of clay, in the form of bottles, shoes, \&c. are dipped into it repeatedly, and afterwards dried, and, when of a sufficient thickness, the clay moulds are easily crushed, and the pieces emptied out.

The natives make vessels of it for containing water and other liquids; and, while soft, all sorts of designs are traced upon it. On account of its inflammability, it is used, at Cayenne, for torchos. When warmed, it gives out a peculiar odour, but not an unpleasant one; from its smoke, a considerable quantity of very fine lamp black may be col. lected.

Rectified oil of turpentine, at common temperature, will afford a complete solution of it; and, when mixed with a solution of wax, in boiled linseed oil, it composes an elastic varnish, with which they cover balloons; and which might be applied to a variety of useful purposes. The fresh'cut surface of the Caoutchouc will unite to: gether by simplo contact, and, by a proper pressure, may be brought so completely in union, as to be no more liable to separate in that part, than any other.

The Caoutchouc, when cut in slips and softened by im. mersion in boiling water, may be drawn out to seven or eight times its original length, and will afterwards, by its elasticity, resume very nearly its former dimensions. During its extension, a very sensible warmth is produced, as may be discovered by applying it between the lips. , is:

Another secretion to be found in every vegetable, in a greater or less degree, is sugar; but generally mixed with gum, sap, or other ingredients. It abounds most in fruits, and roots-as the beet, carrot, \&c. : but, more particularly in the Saccharum, or sugar-cane.

The odour of plants, is a volatile oil of a resinous nature, communicated to the surrounding atmosphere. This volatile oil is sometimes distributed through the whole plant, as in the Bohemia Angelica; sometimes it exists in the bark, as in Cinnamon. Balm and Mint contain their oils in the stem and leaves; Elicampane, and tho Iris of Florence, in the root; Rosemary and Thyme, in their leaves and buds; Lavender, and the Rose, in the calyx of their flowers; Chamomile, Lemon, and Orange Trees, in the petals. Many fruits contain it through their whole substance, such as Peppers, Juniper, \&c. ; Oranges and Lemons, in the zest or peeling which encloses them, \&c.

Fecula is the general name given to the farinaceous substance contained in all seeds, and in some roots-as Wheat, Indian corn, the Potato, Parsnip, \&c. : it is intended by Nature for the first aliment of the young plant.

Colour.-The fixed colours of opaque bodies are, in all probability, owing to their absorbing some of the coloured parts of white light, or rays of the sun, and reflecting others; their immense variety arising from a mixture of the reflected primitive colours, in various number and proportion. It is impossible to say upon what cause the disposition of reflecting certain colours, in preference to others, may depend. The probability is, that it arises from the different textures of the surfaces.

There are some flowers, the petals of which are, in difcrent parts of the same leaf, of different colours; as of the Heart's Ease, for instance, which, if examined with a good 
microscope, will be found to have a different textare of the blue and yellow parts. The texture, also, of the vohite and red Rose is very different.

It is from reflected rays that we judge of the colour of objects. The whiteness of paper, \&c. is occasioned by its reflecting the greatest part of all the rays of light that fall upon it : the blackness of bodies, from their absorbing all the seven coloured rays.

The whiteness of the sun's light arises from the union of all the primitive colours. These primitive colours are, red, orange, yellow, green, blue, indigo, and violet; according to Sir Isaac Newton. Dr. Wollaston, who has performed many experiments on the refraction of light, in a more accurate manner than had been previously done, confines them to four colours only-red, green, blue, and violet.

- Colours.-Some philosophers say thore are only three original and truly distinct, viz: the red, yellow, and blue.

Providence seems to have decorated Nature with an enchanting diversity of colours, for the purpose of beautifying the scene, and rendering it a sol cee of sensible gratification. His kindness is also evident in causing such a construction of plants and grasses, as that green, the colour most grateful and beneficial to the eye, should predominate.

Colours are but phantoms of the day,

With that they 're born, with that they fade away;

Like beauty's charms, they but amuse the sight,

Dark in themselves, till by reflection bright;

With the sun's aid, to rival him they boast,

But light withdrawn, in their own shades are lost.

Hughes.

Fairest of beings! first created light!

box Prime cause of beanty ! for from thee alone,

The sparkling gem, the vegetable race,

The nobier worids that live and breathe their charms,

The lively hues peculiar to each tribe,

From thy unfailing source of splendour draw.

Mallet. afiationge? fifin. HYMN TO LIGHT.

\section{aton tow * * * * * * * * *}

Say, from what golden quivers of the sky Do all thy winged arrows fly t ?

Swiftness and power by birth are thine:

From thy great slre they came, thy sire, the word divine.

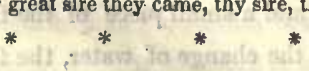

When, goddess! thou lift'st up thy waken'd head, Out of the morning's purple bed,

Thy quire of birds about thee play,

And all the joyful world salutes the rising day.

All the world's bravery, that delights our eyes,

Is but thy several liveries;

Thou the rich dye on them bestow'st,

Thy nimble pencil paints this landscape as thou go'st.

A crimson garment in the rose thou wear'st,

A crown of studded gold thou bear'st;

The virgin-lilies, in their white,

Are clad but with the lawn of almost naked light.

The violet, spring's little infant, stands

Girt in thy purpie swaddling-bands;

On the fair tulip thou dost dote;

Thou cloth'st it in a gay and party-colour'd coat.

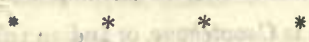

Conoley.

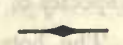

-Hither emerging from yon orient skies,

Botanic Goddess ! bend thy radiant eyes;

O'er these soft scenes assume thy gentle reign,

Pomona, Ceres, Flora, in thy train.

She comes! the Goddess! through the whispering air,

Bright as the morn, descends her blushing car;

Each circling wheel a wreath of flowers entwines,

And, gem'd with flowers, the silken harness shines;

The golden bits with flowery studs are deck'd,

And knots of flowers the crimson reins connect.

And now, on earth, the silver axle rings,

And the shell sinks upon its slender springs;

Light from her aily seat the goddess bounds,

And steps celestial press the pansied grounds.

Darroin. 


\section{FIOWERS.}

There are seven parts to a flower-the Calyx, Corolla, Stamens, Pistils, Pericarpium, Seed, and Receptacle.

The Calyx, sometimes called the flower cup, is formed of one or more green or yellow leaves, situated at a small distance from, or close to, the blossom; its chief use is to support and protect the other parts of the flower; it is the envelope in which, in most cases, the tender flower lies, for a time, concealed, as the green leaves of a rosebud, which cover the blossom, and burst as the flower opens. In the rose, it is situated above the germen, or seed vesscl; but, in the pea, it will be found beneath the seed vessel.

When remote from the flower, as in the Carrot, and other umbelliferous plants, [3] it is called an Involucre. When contiguous to the flower, or other parts of the fructification, as in the Primrose, \&c. it is called a Perianth.

Some flowers have no Calyx, as the Tulip-others have them double, as in the Mallow; but most flowers have them single, as in the Primrose.

Linnæus considered the Caly $x$ as a prolongation of the cortex, or outer bark of the plant.

Calyx.-The Perianth is not changed in double flowers : hence the genus, or family, may be often discovered by the calyx.

The Corolla is formed by the delicate leaves called the blossom; as the red leaves of a rose, each one of which is called a Petal. It is distinguished from the Perianth by the fineness of its texture, and, generally, by the gayness of its colours. The corolla is considered the termination of the inner bark, or Liber.

The Stamens are threads within a flower, which have two parts; the filament, or slender part by which they are fastened to the flower; and the anther (which holds the pollen, or fine powder) situated on the top of the filament. They are seatcd externally with respect to the pistils, internally with respect to the calyx and corolla. They are inserted either into the calyx, the corolla, or the receptacle, rarely either upon the germen, or the style. Their number differs in different genera and species of flowers, from one to a lundred or more.

The Stamens, according to their number, situation, and proportion, furnish the leading principles of distinction in the artificial, or sexual, system of Linnæus. These organs are liable to be changed into petals, in what are termed double flowers; and, if the change be complete, the flower will no longer bear a perfect seed.

Double flowers become what is botanically termed vegetable monsters, by the multiplication of their petals, or nectaries.

In those flowers which have many petals, the lowest series of the petals remain unchanged in respect to number : hence, the natural number of the petals is easily discovered, as in poppies, roses, nigella, \&c.

The Pistils are the threads situated in the centre of the flower; adhering to the fruit, for the reception of the pollen. A perfect pistil consists of three parts, the germen, slyle, and stigma. The thickest part, at the bottom of the pistil, is called the germen, or seed-bud, and contains the rudiments of the young fruit, or seed; the style stands upon the germen, and serves to elevate the stigma, or highest part of the pistil. The style is various in lengtb, and thickness, but not always present. The stigma which is indispensably necessary, is, in some cases, seated immediately upon the germen. The shape of the stigma is . either simple, being little more than a point; or it is capitate, like a pin's head, as in the Primrose. In most grasses, the stignuas are amply branched or feathery, to detain the pollen. In the Mallow tribe, there is an abun. dance of viscid moisture evident in the stigma, and their rich purple, or scarlet colour, contrasts beautifully with the large yellow pollen, whose bursting, or explosion, may almost be seen with the naked eye.

The Pericarpium, or seed-vessel, is the germen grown to maturity. It varies extremely, being pulpy in apples, fleshy in cherries, juicy in gooseberries, and hard in nuts. In other words, the fruit which we eat, is nothing more 
than the pericarps, serving to protect the seeds till ripe.

The Seed is that part of every plant by which it is propagated. The part of the seed which contains the future plant is the germen, vulgarly called the eye, no seed being capable of vegetation, if this be defective. The Anthera, or apex of the stamen, is provided with a fine dust, called the pollen, which, falling on the gummy matter at the top of the pistillum, or pistil, is there absorbed, and carried down into the germen, or seed-vessel, where the seed is perfected and made capable of reproducing the plant.

The Receptacle is the seventh part of fructification, distinguished by Linnæus; being the common basis, or point of connection, of the others. It is not always distinguished by any particular figure. In simple flowers, it is, often, little more than a point: in compound flowers, it is very remarkable, and important, serving, by its differences of structure, to afford very good generic distinctions.

The receptacle of the fructification is common both to the flower and the fruit, or it embraces the corol and the germ.

A proper receptacle belongs to ono fructification only; a common receptacle connects several florets, or distinct fructifications.

In some plants the receptacle undergocs great changes, acquiring a different texture in the fruit, from what it had in the flower. Thus, the whole fruit, as we call it, of the Fig, is a common receptacle, at first coriaceous, (resembling leather, or tough,) and, like the rest of the plant, containing a milky acrid juice. It forms a bag, lined with florets, or small flowers, and having a small aperture at the top; after the flowers are past, this bag becomes pulpy, coloured, and full of sweet aromatic juice. So the fruit of the Strawberry is, originally, a small, dry receptacle, subsequently enlarged, and become pulpy, whose outside is studded with naked seeds.

The Receptacle of the flower, in Linnæan language, means the area, or space between the stamens and styles, in certain genera whose germen is inferior; as the whole umbelliferous order, Hemlock, Parsley, \&c. in which the part in question is more or less tumid, often coloured, and assumes a glandular aspect.

According to another definition, the Receptacle of the flower, is the base to which the parts of the flower, exclusive of the germen, are fixed.
Nectary, or honey-cup, is that part of the flower, from which bees, and other insects, extract the honcy; a fluid found almost universally in flowers.

The shape and structure of the nectarium, or nectary, is extremely various; but commonly uniform in flowers of the same genus; very frequently, indeed, supplying the most clear and decisive marks, by which one genus is distinguished from another.

In the Crown Imperial, the nectary is a mere cup, or depression; in the Lily, a bordered furrow in the claw of each petal; in the Violet, the base of one petal is elongated into a spur, or bag, containing the honey; in the Nasturtium, the nectariferous spur is an elongation of the calyx.

In the Epimedium, or Barron-wort, the nectary is of the nature and texture of petals, but perfectly distinct from them, as well as from the calyx ; while, in the Larkspur, and Columbine, there are nectaries more or less agreeing with their petals, but no calyx. Hence, some botanists reckon their petals, though coloured, the calyx, and their nectaries the only corolla. The neighbouring genus Ranunculus, whose nectaries are pores in the claws of its petals, certainly gives weight to such a determination.

Some flowers display an elaborate apparatus, which cannot be demonstrated to have any concern in the secreting, or holding the honey. Such are the five green bodies, fringed with bristles, each of which bears a globe, in the elegant Parnassia, or Grass of Parnassus. These, not being referable to any other of the usual parts of fructification, all of which are present besides, are, by analogy, presumed to be nectaries.

The numerous and complex rays which decorate the Passion flower, are equally inexplicable in their nature. But they crown the cell where the copious honey is lodged, while their cellular texture, and vivid variegation of colour, indicate their connection with air and light, two great probable agents in the secretion of that saccharine fluid; nor does it appear at all improbable, that they share in its elaboration. In other cases, the richly coloured petals of flowers possibly answer the same end.

\section{ARRANGEMENT OF FLOWERS.}

Flowers are arranged into Classes, Orders, Genera, and Species. 
Linnæus has divided the vegetable kingdom into twenty. four classes, which are subdivided into orders. Distinc. tions in each order produce a further division into genera; and genera are again subdivided into species.

A Class has been aptly described as bearing some resemblance to an army, an order to a regiment, a genus to a company, and a species to a soldier.

In distinguishing a plant, two words are employed; the first, which is called the generic name, is common to all the species of the same genus; and the second, termed the specific name, is confined to a single species; as Rosa muscosa, the botanical name for the Moss Rose. Here, rosa is the generic name applicable to the whole genus or family of roses; and muscosa is the specific name, used to distinguish the particular kind or species of rose.

The families, or genera, are characterised by the analogy of all the parts of the flower, or fructification. The species.are distinguished by the foliage of the plant; and the varieties, by an accidental circumstance of colour, taste, or odour. The seeds of these do not always produce plants similar to the parent: this is more certainly accomplished by grafts or layers.

\section{CLASS.}

The names of the classes are formed of Greek words, expressive of the characters of each class. Those of the first ten may be easily remembered, by considering the word andria, as meaning stamens, and annexing. it to the Greek numerals.

The first ten classes are distinguished simply by the number of the stamens; except the fourth and sixththese have stamens of the same length. The fourth has four of the same length-the sixth, six of the same length.

\section{The Names of the Classes.}

1. Monandria-1 stamen-as in the Ginger, Cardamomom, Arrow root, Turmeric, \&c. The plants of this class are very few, and chiefly found in tropical countries. There are none of this class introduced into this Diclionary.

2. Diandria -2 stamens-as in the Lilac, Jasmine, Sage, Fringe tree, \&c.
3. Triandria-3 stamens, as in the Spring Crocus, Iris, \&c. In this class is found all the different species of Grasses that cover our fields, as also Wheat, Rye, Oats, Sugar-cane, \&c.

4. Tetrandria -4 stamens, as in the Dogwood, Holly, \&c.

5. Pentandria -5 stamens, as in the Violet, Parsley, Flax, Hemlock. This is the most numerous of all the classes, and comprehends more than one-tenth of the plants at present known. In this you find the Potato, Deadly Night Shade, Tomato, Capsicum, Tobacco plant, Coffee-tree, Currant, Gooseberry, \&c.

6. Hexandria-6 stamens, as in the Rice, Sorrel, Asparagus, Lily, \&c.

7. Heptandria -7 stamens, as in the Horsc-chesnut, \&c.

There are fewer plants in this class than in any other.

8. Octandria-8 stamens, as in the Whortleberry, Evening Primrose, \&c.

9. Enneandria-9 stamens, as in the Laurel, Rhubarb, \&c.

10. Decandria-10 stamens, as in the Locust tree, Rue, Pink, \&c.

11. Dodecandria-has from twolve to nineteen stamens in each flower, as in the Mignonette, House leek, \&c.

12. Icosandria-20, or more stamens, attached to the caly $x$, or sometimes, in part, to the corella. In this class the calyx is always of one piece, divided at its border, and usually permanent. The character of this class indicates the pulpy fruits, which belong to it, to be wholesome. "Sir J. E. Smith has observed, that no traveller, in the most unknown wilderness, need to be afraid to eat the fruit of any plant whose stamens grow upon the calyx."

The apple, cherry, pear, plum, 
\&c. belong to this class; as do the Rose, Hawthorn, \&c.

Flowers that aredouble ought not to be consulted, as they lose their distinctive characters; and are, therefore, useless to the botanist.

The Dog-rose, or Rosa canina, which grows wild in the woods, is a good specimen of this class.

13. Polyandria-has generally more than twenty stamens, sometimes less. The character depends on the part to which they are attached, which is the receptacle. The calyx of this class (if the flower have one) consists of two or more leaves, which generally fall off so soon as the blossom opens.

It is important to preserve the twelfth and thirteenth classes distinct; as some late botanists have injudiciously united them into one class. In this class is found the Butter-cup, Larkspur, Poppy, \&c.

14. Didynamia - has two short and four long stamensas in the Snap Dragon, Mint, Thyme, Isavender, \&c.

All plants of this class, which have naked seeds, are aromatic.

15. Tetradynamia - two short and four long stamensas in the Wall Flower, Cabbage, Radish, Turnip, etc.

The more readily to distinguish this class from the sixth, in which the stamens are of equal length, it may be noticed that the flowers of the 15 th class have always four petals, which form a cross, being regularly placed in pairs opposite to each other, and are thence called cruciform or cross-shaped.

In the 16th, 17th, and 18th classes, the stamens are united, by the lower parts of the filaments, into parcels or brotherhoods.

16. Monadelphia-The stamens are all united in a tube around the pistil, forming one brotherhood. They are united at the bottom, but separated at the top. In this class are the beautiful family of Geraniums, the Cotton Plant, Mallow, \&c.

17. Diadelphia-The stamens are united into two brotherhoods or parcels. The flowers belonging to this class are all of the same form, called papilionaceous, or butterfly-shaped-as the Pea, Clover, Broom, \&c.

18. Polyadelphia-The stamens are collected into more than two sets, each parcel united at the bottom by the filaments. This class does not contain many plants. In it are found the Orange, St. John's Wort, \&c.

19. Syngenesia-The stamens are united by their anthers, into a tube, but the filaments are separate. The Dandelion, Sun Flower, \&c. are in this class.

20. Gynandria-The stamens grow out of the pistil, as in the Ladies Slipper, Orchis, \&c. "Linnæus included in this class all plants of which the parts in question were in any sense united above the receptacle of the flower. Thus Passiflora, or the Passion flower, whose germen is elevated on a columnar basis, and the stamens inserted into the summit of the same part, just below it, was considered as Gynandrous. Such a principle is attended with great inconvenience, as in Grewia, an oriental shrub, some species of which have a considerable elevation of the germen, and others little or none. It is found, therefore, by far most convenient, not to consider such insertion or union at all as the character of a class or order, unless it takes place upon or above the germen; or, in other words, unless the stamens grono out 
of the germen or style. Such is the case decidedly in all the natural family of Orchidea, or Orchis tribe, as well as in Forestera and Stylidium. On these the class remains very firmly established."-See Rces's Cy. clopedia.

21. Monœcia-The stamens and pistils are in separate flowers, but on the same plant; as in the Cucumber, Gourd, PalmaChristi, Arbor Vita, Red Mulberry, Box tree, Indian Corn or Zea, Oak, Walnut, Pine, Amaranth, \&c.

22. Diøcia-The stamens and pistils in separate flowers, and on separate plants; as in the Hop, Willow, Spinage, Hemp, Juniper, Red Cedar, Yew, Poplar, (Lombardy, and other Poplars,) Mistletoe, \&c.

23. Polygamia-The stamens variously situated; the stamens and pistils being sometimes found in the same flower; sometimes, flowers with stamens only; others, with pistils only, and these are placed either on the same plant, or on two or three different ones. Such a diversity is very prevalent among the trees of tropical climates, which are, most of them, more or less polygamous, as is the case also with many grasses. Yet such a character, being not always permanent, leads to much difficulty in practice.

In this class are to be found the Ash-tree, Fig, Maple, Mimosa pudica, Acacia of Arabia, \&c.

The writer of the article under the head Polygamia, for Rees's Cyclopedia, suggests a limitation of this class to those Genera which have a difference of structure in the accessory parts of their flowers, (the calyx, corolla, \&c.) independent of the stamens and pistils; flowers so constructed being permanently distinct; and asserts, that "if the class cannot be supported on this foundation, it must fall to the ground." Some botanists have hastily abolished the class altogether.

24. Cryptogamia-The flowers of this class invisible to the naked eye. It includes Ferns, Mushrooms, Mosses, Sea-weed, Lichens, or Liverwort, \&c.

\section{ORDERS OF THE FOREGOING CLASSES.}

The names of the first thirteen orders are formed from the Greek numerals, but with the addition of the word gynia, instead of andria. The first thirteen distinguished entirely by the number of pistils. The styles to be counted from their base. When the styles are wanting, the number of stigmas determine the order.

NAMES OF THE First ThuRTEen ORDERS :

Monogynia-1 Pistil. Heptagynia-7 Pistils.

Digynia-2 Pistils. Octagynia -8 Pistils.

Trigynia-3 Pistils. Enneagynia-9 Pistils.

Tetragynia-4 Pistils. Decagynia-10 Pistils.

Pentagynia-5 Pistils. Dodecagynia-12 Pistils.

Hexagynia-6 Pistils. Polygynia-Many Pistils.

The 14th Class has 2 Orders-Gymnospermia, seeds naked at the bottom of the calyx; as in Lavender, Mint, \&c. And Angiospermia, where the seeds are enclosed in a seed ressel; as in the Fox Glove. None of the Genera of the 14th or 15 th Classes have more than one style. The characters of the Orders are, therefore, taken from the pericarp.

15th Class has 2 Orders; distinguished by the form of the pericarp, or seed vessel; as Siliquosa, long pods, as the Wall flower, \&c.; and Siliculosa, short pods; as Honesty, or Satin Flower.

The 16, 17, 18th Classes-In these the Orders are denominated from the number of their stamens.

19th Class has 5 Orders-distinguished by the epithet Polygamia. Intimating, that the flowers are compound, and consist of numerous florets, or small flowers, seated on a common receptacle. 
1. Polygamia Equalis.-In this Order, all the florets are equally possessed of stamens and pistils ; as the Dandelion.

2. Polygamia Superflua.-The florets of the disk, or central part of the flower, have both stamens and pistils; those of the ray, or circumference, have only pistils : but the latter, as well as the former, produce fertile seeds; as the China Aster.

3. Polygamia Frustanea.-The florets of the disk have both stamens and pistils; those of the ray neither one nor the other, or are only abortive pistils; as the Sun Flower, Arkansa coreopsis, \&c.

4. Polygamia Necessaria.-The florets of the disk have efficient stamens, but abortive pistils; those of the ray, fertile pistils, impregnated by the stamens of the disk; as the Marigold or Calendula.

5. Polygamia Segregata.-Distinguished by its doubly compound flowers, - each floret having its own calyx, in addition to that which surrounds the common receptacle, and forms the whole into one compound flower; as in the Globe Thistle.

20.21. Classes. In these, the Orders have the same names as the preceding classes, and are distinguished by the number of stamens, or by the union either of the filaments, or of the anthers, or by the attachment of the stamens to the pistils.

22. This Class has 8 Orders-the first seven denominated from the number of stamens. The eighth order, Monadelphia, by the stamens being united into one set; as the Juniper, Yew, \&c.

23. The Order, denominated from the number of the houses, or plants, on which the several kinds of flowers are to be found. It has three Orders: Monocia, when the stamens and pistils are in separate flowers, but on the same plant. Diocia, having the stamniferous and pistiliferous flowers on two separate plants. And Tricecia, when the different kinds of flowers are distributed among three distinct individual plants.

Linnous devoted the greater part of his life to the study of Botany. He was the first who pointed out the difference between the natural and the artificial method of arranging plants. His sexual system is an example of the latter, though many of its Classes, or Orders, happen to be likewise natural assemblages.

Many systems of classification have since been attempted, but, notwithstanding the acknowleged merit of these essays, the Linnæan system continues to be the prevailing system, to which all the new Genera, constituted for plants since discovered, are regularly referred. And it is to the advantage of the science, that it should, for a long time yet to come, preserve its ascendency.

It is the system of Linnæus that has chiefly been adopted in this little compilation.

Bernard de Jussieu, the father of the French botanists, detcrred, by excess of modesty, from giving his ideas to the world, was the first who laboured at a natural system of arrangement.

It was not before the year 1759 , when he was called upon, as Professor of Botany, to arrange the royal garden at Trianon, that he ventured to give any publicity to the natural system he had been projecting. What this was, may be seen by his nephew Antony de Jussieu's Genera Plantarum, published in 1789. Bernard de Jussieu became acquainted with Linnæus at Paris, in 1738, and was quite aware of his merits, and disposed to allow them.

The Natural Orders, as arranged by A. de Jussieu from his uncle's works, are also given in the glossary to this work: be has fifteen Classes, and a hundred Orders. His Orders are mostly named from some leading Genus, which appears to me to be a more satisfactory arrangement.

Natural Orders of plants are such as are founded on principles of natural affinity; bringing together, under one point of view, such Genera as have certain characters in common, independent of all artificial modes of classification.

In the conception of his Orders, Linneus ever kept the fructification principally in view, though the names of some few of them allude to the habit.

There are fifty-eight Natural Orders of Linnæus.

\section{NATURAL ORDERS OF LINN EUS.}

1. Palma-Palm Trees.

2. Piperite-Arum and its allies.

3. Calamaria-Grass-leaved plants, as Carex. 

4. Gramina-True Grasses.
5. Tripetaloideœ-Juncus, \&c.
6. Ensata-Sword-leaved plants.
7. Orchidea-Orchis tribe.
8. Scitaminea-Amomum, \&c.
9. Spathacea-Narcissus, \&c.
10. Coronarice-Liliaceous plants.
11. Sarmentacea-Convallaria, \&cc.
12. Holeracec-Chenopodium, and various anomalous genera.
13. Succulente-Succulent plants.

14. Gruinales-Geranium tribe.

15. Inundate-consists of Zannichellia, Ruppia, Po. tamogeton, Myriophyllum, Ceratophyllum, Proserpinaca, Elatine, and Hippuris. To these are added, in manuscript, by Linneus, Chara Naias, Aponogeton, Saururus, Serpicula, Callitriche, Lemna, and Pistia-rather a vague assemblage altogether.

16. Calyciflore-Osyris, Trophis, Hippopha, and Elaagnus.

17. Calycanthema-Epilotium, Melastoma, \&c.

18. Bicornes-Plants whose pollen is discharged by two pores, or sometimes tubes, as Erica, Vaccinium, \&c.

19. Hesperidea-Myrtle tribe.

20. Rotacee-Anagallis, \&c.

21. Precia-Primula, \&c.

22. Caryophyllei-Pink, Campion, \&.c.

23. Trihilate-Maple, \&c.

24. Corydales-Fumaria, \&c.

25. Putaminea-Capparis, \&c.

26. Multisilique-Helleborus, \&c.

27. Rhoeadea-Poppy tribe.

28. Lurida-Night Shade tribe.

20. Campanacea-Convolvulus, Campanula, \&c.

30. Contorte-Asclepias, Apocynum, \&c.

31. Veprecula-Daphne, and its allies.

32. Papilionacea-Pea kind.

33. Lomentucec-Cassia, Mimosa, \&c.

34. Cucurbitacea-Gourd family.
35. Senticosea-Rose, Bramble, \&c.

36. Pomacea-Apple, Plum, de.

37. Columnifera-Mallow tribe.

38. Tricocce-Euphorbia, \&c.

39. Siliquosce-Cruciform plants. This order Linnæus indicates as having no relationship to any other. It constitutes the Tetrady. namia.

40. Personate-Nearly equivalant to the Didynamia Angiospermia.

41. Asperifolia-Myosotis, Borago, \&c.

42. Verticillata-Answerable to the Didynamia Gymnospermia, with a few ringent Dian. drous genera.

43. Dumosa-Rhamnus, Euonymus, Ilex, Vibernum, \&c.

44. Sepiaria-The Jasmine tribe.

45. Umbellate-Umbelliferous plants-as Parsley, Hem$l o c k, \& c$.

46. Hederacea-Ivy, and its allies, including Vitis.

47. Stellatea-Galium, Madder, \&c.

48. Aggregate-Compound flowers, with separate anthers, as Scabiosa Protea-with some of their supposed allies.

49. Composita-Compound flowers, with combined an. thers, divided into capitate, as the Thistle: Semiflosculose-Dandelion: Discoidea-Tansy, Aster, \&c. Oppo. sitifolia-Sun flower: Nucamentacee -Wormwood: Parthenium, Xanthium, \&c.

50. Amentacea-Willow, Oak, \&c.

51. Conifera-Fir, Juniper, \&c.

52. Coadunata-Magnolia, \&c.

53. Scabrida-Nettle, Fig, \&c.

54. Miscellanea-A heterogeneous assemblage, latterly much diminished.

55. Filices-Ferns.

56. Mrusci-Mosses.

57. Alga-Sea weeds, Lichens, \&c.

58. Fungi-The Fungus tribe.

\section{Motes.}

Note 1.-GAS.

Gas is an aeriform fluid, composed of two parts. 1. The particular substance that is converted into gas, by heat or caloric. 2. The Caloric, which, by its chemical combination with the basis, constitutes $a$ gas, or permanently elastic fuid, capable of existing in an aeriform state, under the pressure, and at the temperature of the atmosphere.

To form a gas, or permanently elastic fluid, a chemical combination must take place between the caloric and the substance, at the time of its being converted into a gaseous state. This combination cannot be destroyed, except by the aid of some chemical agent that has a stronger affinity for either of the constituents of the gas.

Vapour is an elastic fluid, bearing a strong resemblance to a gas; but vapour is nothing more than the solution, or mechanical division, of any substance whatever in caloric. Caloric in vapour is only latent, and not chemically com- 
bined : its union is so slight, as to be separated by simply lowering the temperature.

\section{Note 2-CARBON.}

Carbon, or Charcoal, forms a considerable part of the solid matter of all organised bodies; but it is most abundant in the vegetable creation; and chiefly obtained from wood, when the oil and water (which are the other constituents of vegetable matter) are evaporated; the black porous brittle substance that then remains is called charcoal.

Charcoal, or artificial carbon, is properly called an Oxyd of Carbon. All carbon is not black-many substances consisting chiefly of carbon, are remarkably white ; cotton, for instance, is almost wholly carbon. In the diamond alone, carbon exists in its purest and most perfect state. We are ignorant of the means which nature employs to bring it to that state; it may probably be the work of ages, to purify, arrange, and unite the particles of carbon in the form of a diamond.

Oxygen, when in a state of combination with other substances, luses, in almost every instance, its respirable properties, and when combined with carbon, is not only unfit for respiration, but extremely deleterious if taken into the lungs. This accounts for the unwholesome fumes of burning charcoal. By the combustion of charcoal, it gradually combines with the oxygen of the atmosphere, for which it has a great attraction, and flies off in a gaseous state, called carbonic acid gas, or fixed air.
This carbonic acid gas produces many unhappy accidents at the opening of cellars, in places where wine, cider, or beer are suffered to ferment. The famous Lake Aver$n u s$, in Italy, by modern Italians called Lago di Tripergola, and which Virgil makes the entrance of hell, exhaled so large a quantity of carbonic acid gas, that birds could not fly over it with impunity.

Carbon, in a state of gas, is also found at the celebrated Grotto del Cani, near Naples. History informs us that criminals who were made to descend into the grotto were immediately stifled.

Water can absorb this gas, as is seen in many of our mineral waters, to which it gives a slight acid taste; and, although prejudicial to respiration, is is sometimes found to be beneficial to the stomach.

\section{Note 3.-UMBELLIFEROUS PLANTS.}

Umbelliferous plants (from the Latin umbella, and fero to bear,) are those plants producing the inflorescence called an umbel. A particular mode of flowering, which consists of a number of flower-stalks or rays, nearly equal in length, spreading from a common centre, their summits forming a level, convex, or even globose surface, as in hemlock; more rarely a concave one, as the carrot. It is simple or compound; in the latter, each peduncle bears another little umbel, umbellet, or umbellicle.

Umbel, is sometimcs called a rundle, from its roundness.

\section{A SKETCH OF THE}

It may not be deemed out of place to give a brief sketch of the life of the illustrious anthor of systematized botany, which has been so ncarly perfected by his indefatigable labours.

Charles Linnaus (afterwards Von Linné) was born at Râshult, in Sweden, in 1707. He father, Nicholas Linnæus, was minister of the parish of Stenbrohult, to which the hamlet of Râshult belongs. His was a great admirer of the vegetable productions of Nature, and adorned the environs of his rural mansion with the native plants of the neighbouring fields. Young Linnæus caught his parent's enthusiasm, and early imbibed the same tastc, with such warmth, that he was never able to bend his mind, with any great success, to other pursuits. He relates of bimself, that, when yet scarcely four years old, he heard his father descant, to a rural party, on the distinc. tive qualities of some particular plants, culled from the flowery bank on which they were seated, and that this first botanical lecture was ever after remembered as an epoch in his scientific life.

His father designed him for the church; but he had no particular relish for the profession, or its preparatory stu. dies, being a very inapt scholar in the study of languages,

\section{I F $\mathrm{OF}$ IINNAUS.}

either ancient or modern.' In his diary, written in later years, he confesses a peculiar inaptitude, and rather a blameable indifference, for the learning of languages : declaring, that in all his travels, he learned " neither Eng. lish, French, German, Laplandish, nor even Dutch, though he stayed in Holland three whole years. Nevertheless, he found his way every where well and happily."

At the age of nineteen, his tutors, like the sapient instructors of Newton at Cambridge, gave him up as a hopeless dunce; advising that he should be apprenticed to some mechanical trade. Fortunately for him, and for the world, one of the lecturers on Natural Philosophy, Dr. Rothmann, having observed his passion for the study of Nature, and his practical observation, recommended to lis disappointed parent to turn his attention to the study of medicine; which advice was adopted, and he, afterwards, became a practising physician of some eminence. The amiable professor who had thus interested himself for him, gave him private instruction in physiology. He first suggested to Linnæus the true principles upon which botany ought to be studied-founded on the parts of fructification, and put the systcm of Tournefort into his hands, whose orders are distinguished by the fruit. Its very im- 
perfections proved useful, in prompting him to attempt something more complete thereafter.

From that time, Linnæus devoted all his leisure to his favourite study. In early life he had to struggle with many difficulties; being so poor, as frequently to depend upon chance for a meal; and without the means of paying for a patch upon his shoes, which he sometimes endeavoured to repair himself, by the aid of folded paper. But merit and industry will always find their reward, and rise proudly superior to all impediments. The lustre of his abilities soon drew the attention of some of the most learned men in Europe, who encouraged and patronized him. He was, after a time, elected a member of various scientific academies throughout Europe; and, in his own country, made Secretary of the Upsal Academy, the only one then in Sweden; besides many other distinguished marks of the high estimation in which he was held in his native country, and in the literary world.

His studies were not wholly confined to botany, but extended to other branches of natural history, as may be seen by the publication of his many scientific and varied works.

In the spring of 1732 , he received from the Academy of Sciences at Upsal, an appointment to travel through Lapland, under the royal authority, and at the expense of the Academy. He was but slenderly provided with baggage, travelled generally on horseback, but visited the Lapland Alps on foot-descending to the coast of Norway, he returned by Tornca, \&c. to Upsal, by the 10th of October, having performed a journey of near 4000 English miles.

When in Lapland, he gathered at Lyksele, May 29th, 1732 , an elegant and singular little plant, formerly known to botanists as the Campanula Serpyllifolia. Linnæus, by his study of vegetables on the only certain principles, the structure of their parts of fructification, soon found this to constitute a new genus; but he reserved the idea in his own breast, till such time as his discoveries and publications had entitled him to botanical commemoration : and his friend Gronovius, in due time, undertook to make this genus known to the world under the name of Linnceait having been chosen by himself for this purpose.

In the course of his tour having learned the art of assaying metals, he in the following year gave a private course of lectures on this subject, which had never before been taught at Upsal.

The arts of his rival Rosen having disappointed him of his anticipated medical advancement in the college at Lund, and, by his intrigues, put a stop to all private medical lectures in the university of Upsal, thus depriving Linnæus of his only present means of subsistence, our indefatigable naturalist directed his energies into another channel; in furtherance of his study of mineralogy, he visited the mines of Sweden, and, at the clese of the year
1733, he gave a course of lcctures at Fahlun, on the art of assaying. Here he first became acquainted with Browal. lius (chaplain to the governor of the province of Dalecarlia, afterwards bishop of Abo) who advised him to take his doctor's degrees, in order to pursue the practice of medicine, in which he had already acquired some celebrity while at Fahlun.

In pursuance of this advice, Linnæus, having amassed the sum of fifteen pounds sterling, now commenced his travels, with a view of obtaining his degree at the cheapest university he could find, and, at the same time, seeing something more of the literary world. He spent five years in visiting the principal countries of Europe; his merit raised him up patrons and friends wherever he was known; through many difficulties, it is true, did he have to work his way, but still he went onward, supported by the native energy of his character, gaining information at every step, and extending his own fame. He tells us himsclf, he would perhaps never have returned to his own country, "had he not been in love ;" but hearing that he had a powerful rival in the affections of her to whom he bad plighted his faith, he suddenly returned to Sweden, and, after a time, having acquired such a degree of prosperity as to induce the father of his betrothed to consent to their union, he was married June 26, 1739.

How distant oft the thing we dote on most,

From that for which we dote, felieity!

This consummation of his ardent aspirations for the last five years of his life, brought with it no access either of happiness or prosperity. This idol of his heart, is represented as altogether unworthy; and of a kindred spirit with the unnatural mother of the unfortunate poet Savage, displaying the same hatred of her only son, and persecuting him by every means within her power, during the life of her husband, who was made miserable by her misconduct and petty tyranny, and, after his death, still pouring out the dregs of her wrath upon the admirable and sensitive being who naturally looked to her for support and comfort.

But let us turn from so disgusting and painful a theme, to bestow a double portion of admiration upon that being, who, amidst all these chilling blights to his happiness, still laboured with untiring zeal in the canse of literature.

About the year 1751, the queen of Sweden, Louisa Ulrica, sister to the great Frederic of Prussia, having a taste for natural history, which her royal consort, king Adolphus Frederick, also patronized, showed much favour to Linnæus, and employed him in arranging her collection of insects and shells, at her country-palace of Drotningholm, or Ulricksdahl, and he was frequently honoured with the company and conversation of their majesties, during his attendance there. The queen also interested herself in the education of her son, and was altogether gracious and 
obliging in all that concerned him, promoting his wishes and his interest, whenever opportunity offered. She took so much pleasure in the conversation of her distinguished naturalist, that she allowed him his habitual indulgence of smoking, even in her royal apartments, that bo might continue his labours with the more satisfaction to himself. Nor were his services accepted without suitable returns of royal munificence.

In 1753, he received, from the hand of his sovereign, the order of the Polar Star; an honour which had never before been conferred for literary merit. A still more remarkable, if not more grateful compliment, was paid him, not long after, by the king of Spain; who invited him to settle at Madrid, with the offer of nobility, the free exercise of his religion, and a splendid botanical appointment. This was handsomely declined by Linnæus, who declared, that if he had any merits, they were due to his own country. This patriotic moderation received its just reward in November, 1756, when be was raised to the rank of Swedish nobility, and took the name of Von Linné.

As the habits of Linnæus were temperate and regular, he retained his health and vigour in tolerable perfection, notwithstanding the immense labours of his mind, till beyond his sixtieth year; when his memory began, in some degree, to fail him. In 1774, at the age of sixty-seven, an attack of apoplexy greatly impaired his constitution. Two years afterwards, he had a second attack, which rendered him paralytic on the right side, and materially affected his faculties. He died of a different complaint, in 1778 , aged seventy-one. His sovereign, Gustavus III. com. manded a medal to be struck, expressive of the public loss his country had sustained in him; and honoured the Academy of Science, at Stockholm, with his presence, when the eulogy of this ornament to his country was pronounced there by his intimate friend Black. A still higher compliment was paid to his memory by the king, in a speech from the throne, in which he did justice to the splendid talents and acquirements of his illustrious subject, and testified his royal sympathy with the sorrow of a whole nation, in their irreparable loss. Nor was this sorrow limited to the narrow bounds of his native soil : the whole literary world, with whom he had become intimately connected, and to whoin he was endeared, felt the shock of such a bereavement. Eulogies were pronounced in the several scientific institutions of which he was a member. In his own country, there was a general mourning proclaimed at Upsal-his remains were deposited in a vault near the west end of the cathedral of the university, where a monument of Swedish porphyry was erected by his pupils. His obsequies were performed in the most respectful manner, by the whole university, the pall being supported by sixteen doctors of physic, all of whom had been his pupils.

Five years after this, the remains of his only son (then in his forty-second year, successor to his father in his botanical professorship, which he supported with ability) were laid by the side of the parent; the family coat of arms broken over them, and their mingled ashes strewed with flowers. 



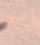

$r$

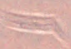




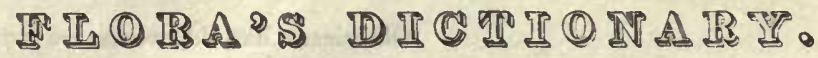

RETURN, SICILIAN MUSE,

AND CALL THE VALES, AND BID TIEM HITHER CAST

THEIR BELLS, AND FLOWERS OF A THOUSAND GuES.

Milton's Lycidas.

FROM FLOWERS WHICH WE TWINE FOR THE TEMPLE OF LOVE, LOVE ITSELF MAY INSTRUCTION RECEIVE.

J. H. Payne.

COME, MAKE UP A NOSEGAY

FOR HER WHOSE LOVE YOU PRIZE,

CHOOSE WHAT YOU WILL; HERE ARE ENOUGH,-

WILD BLOOMS, AND GARDEN FLOWERS.

Anonymous.

FROM GIANT OAKS, THAT WAVE THEIR BRANCHES DARK, TO THE DWARF MOSS, THAT CLINGS UPON TIEIR BARK.

Darwin.

OH! WHAT TENDER THOUGHTS BENEATH

THOSE SILENT FLOWERS ARE LYING,

HID WITHIN THE MYSTIC WREATH

MY LOVE HATH KISS'D IN TYING.

Moore.

Acacia, Rose.

Friendship.

If I do vow a friendship, I 'll perform it.

Shaks.

Robinia hispida.

Angels from friendship gather half their joy.

Heaven gives us friends to bless the present scene.

Young.

Friendship ! thou soft propitious pow'r !

Sweet regent of the social hour!

Sublime thy joys, nor understood,

But by the virtuous and the good!. . . Cotton.

Nor hope to find

A friend, but what has found a friend in thee.

All like the purchase, few the price will pay;

And this makes friends such miracles below.

Young. 
Acacia.

(Comtinued.)
The friends thou hast, and their adoption try'd,

Grapple them to thy soul with hooks of steel.

Shaks.

Old friends, like old swords, are trusted best. Webster.

Be good and friendly still, and oft return. . Milton.

Acacia, White.

R. Pseudo acacia.

Common Locust Tree.
Elegance.

Acacia, Yellow.
Concealed love.
Trifles themselves are elegant in him. . . Pope.

To these resistless graee impart,

That look of sweetness form'd to please,

That elegance devoid of art,

That dignity that's lost in ease. . . Cartwright.

So soft, so elegant, so fair,

Sure something more than human's there. - Smollet.

Hard is the fate of him who loves,

Yet dares not tell his trembling pain. . . Thomson.

Much he laboured to coneeal

That gentle passion of the breast,

Which all can feign, but few can feel.

Ingenuous fears suppress'd the flame,

Yet still he own'd its hidden power,

With transport dwelling on her name,

He sooth'd the solitary hour. . . . Cartwright.

How long must I coneeal,

What yet my heart could wish were known?

How long the truest passion feel,

And yet that passion fear to own? . Cartwright.

Fire, that 's closest kept, burns most of all. . . Shaks.

Nor less was she in heart affeeted,

But that she masked it with modesty,

For fear she should of lightness be detected.

Spencer's Faery Queen.

She felt lis flame; but deep within her breast, In bashful coyness, or in maiden pride,

The soft return conceal'd; save when it stole In sidelong glanees from her down-cast eye, Or from her swelling soul in stifled sighs.

Thomson.

She long'd her hidden passion to reveal, And tell her pains, but had not words to tell : She can't begin, but waits for the rebound, To catch his voice, and to return the sound.

Addison's Ovid. 



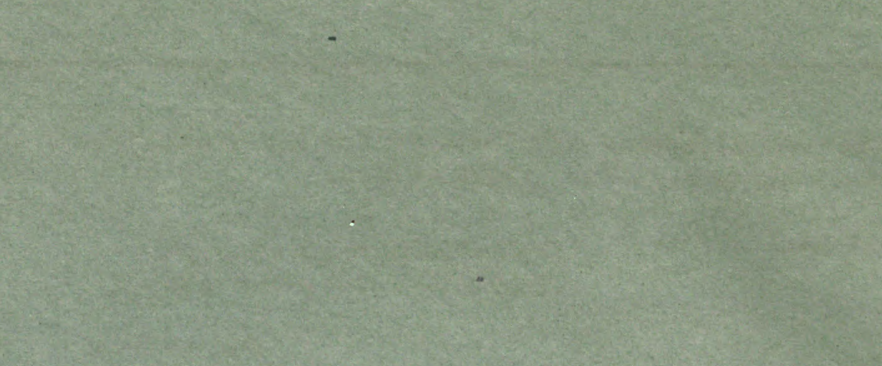


Adonis, Flos. Sorrowful remembrances.

Adonis autumn alis.

Pheasant's eye ; or, Red morocco.

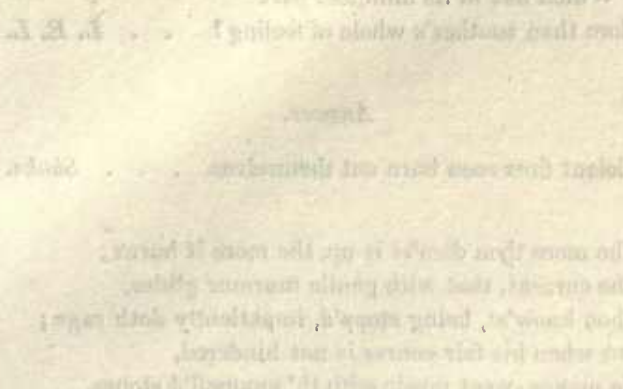

Almond. Dwarf.

Hope.

Amygdalus pumila.

\section{Althen. Frutex. Consumed by love.}

Hibiscus Syriacus.

Syrion Mallow.
Oh ! never yet hath love successfully with memory strove.

L. E. L.

Of all afflictions taught a lover yet,

'Tis sure the hardest science to forget! . . Pope.

Dost thou deem

It such an easy task from the fond breast

To root affection out ? . . . . . Southey.

Unequal task ! a passion to rcsign,

For hearts so touch'd, so picrc'd, so lost as mine. Pope.

Oh! to forget her !-but how vain each art,

Whilst every virtue lives imprinted on my heart. Shaw.

Too faithful memory - cease-oh cease-

How shall I e'er regain my peace! . . . Shaw.

There's not a garden walk I tread,

There 's not a flower I see,

But brings to mind some hope that's fled,

Some joy I 've lost with thee. . . . . . Song.

Hope ! thou sad lover's only friend! . . . Cowley.

Transmit one pitying ray-to lighten and to cheer!

Young.

Return, fair Hope, thy seat resume,

Dispel this melancholy gloom,

And to my soul thy gladsome light impart.

Aschylus' Agamemnon.

Come, gentle Hope ! with one gay smile remove

The lasting sadness of an aching heart:

Thy voice, benign enchantress! let me hear. Williams.

\section{Answer.}

The hope in dreams of a happier hour,

That alights on misery's brow,

Springs out of the silvery almond flower,

That blooms on a leafless bough. . . . Moore.

My heart 's on flame, and does like fire

To her aspire. . . . . . Couley.

His love was passion's essencc-as a trec

On fire by lightning : with ethereal flame

Kindled he was. . . . . . . Byron. 


\section{Altha灰A。}

(Continued.)
Love was to his impassion'd soul,

Not, as with others, a mere part

Of his existence, but the whole,

The very life-breath of his heart. . . . Moore.

What must love be in a heart

All passion's fiery depths concealing,

Which has in its minutest part

More than another's whole of feeling? . L. E. L.

\section{Answer.}

Violent fires soon burn out themselves. . . . Shaks.

The more thou dam'st it up, the more it burns;

The current, that with gentle murmur glides,

Thou know'st, being stopp'd, impatiently doth rage ;

But when his fair course is not hindered,

He makes sweet music with th' enamell'd stones.

Shaks.

Those edges soonest turn that are most keen,

A sober moderation stands sure,

No violent extremes endure. . . . . Alleyn.

Aloe.

Religious superstition.

Aloe.
In climes beneath the solar ray, Where beams intolerable day, And arid plains in silence spread, The pale.grecn Aloe lifts its head, Delighting most its shade to fling Where streams run not, nor fountains spring. Its mystic branch, at Moslem's door, Betokens travel long and sore

In Mecca's weary pilgrimage;

Or hangs a visionary charm

To shield him from the secret harm,

The spectre's form, the demon's rage.

In frames adust, in fervid minds, Its root thus superstition finds, Where'er that noxious growth is found, There spreads a moral descrt round, Where charity's sweet fount is dried, And only bitter waters glide.

Oh! never may its gloomy shade Darken my gate, my breast invade,

Proclaiming that the thorny path Of useless rigours $I$ have trod, With offered pangs to please a God

Not of compassion, but of wrath. 

Alue.

(Continued.)

\section{Amaranth. Immorlality.}

Amaranthus.
Against the demon passion's strife,

The phantom fears which shadow life,

Virtue a better spell supply!

And trust in that Benignant Eye

Which wills not, in all earth's wide sphere,

One idle pang, one needless tear. . . . . C C***e.

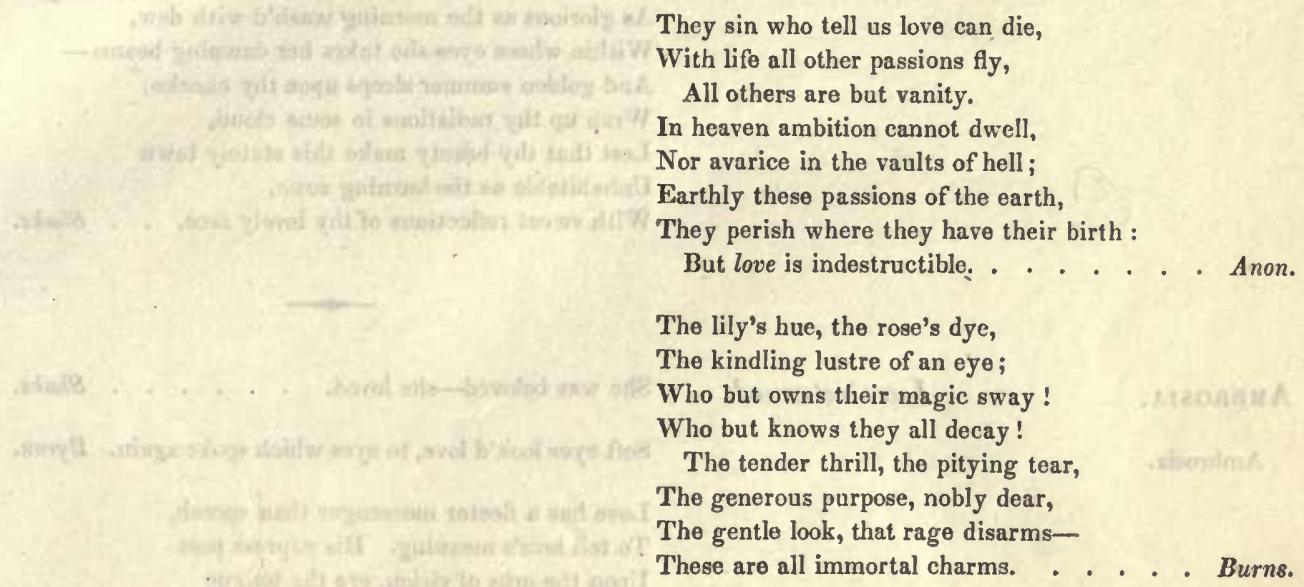

His love was an eternal plant, whereof

The root was fix'd in virtue's ground. . . Shaks.

They sin who tell us love can die,

With life all other passions fly,

All others are but vanity.

In heaven ambition cannot dwell,

Nor avarice in the vaults of hell

Earthly these passions of the earth,

ey perish where they have their birth

The lily's hue, the rose's dye,

The kindling lustre of an eye;

Who but owns their magic sway!

all decay

the pitying tear,

The rentle look, that rage disarms

These are all immortal charms.

Burns.

\section{Amaranth. GIobe. Unchangeable.} Gomphrena globosa.
Here still is the smile that no cloud can o'ercast, And the heart, and the hand, all thy own to the last.

Moore.

For ever thine, whate'er this world betide,

In youth, in age, thine own, forever thine. $A$. $A$. Watls.

The very thoughts of change I hate.

As much as of despair;

Nor ever covet to be great,

Unless it be for her. . . . . . . Purnell.

No change in love the seasons bring,

Love only knows perpetual spring,

Time destroying far and wide,

Love from the soul can ne'er divide.

Love will the universe control

When dying seasons cease to roll. . . . . Booth.

Unalterably firm his love entire. . . . Milton. 
Amaryluis.

A. Formosissina.

Ambrosia.

Ambrosia.

\section{Splendid beauty.}

Beauty, too rich for use, for earth too dear.

- Shaks.
A shape of beauty that bewitched mine eye. - $\Lambda$.

Her glossy hair was clustered o'er her brow,

Bright with intelligence, and fair and smooth:

Her eye-brow's shape was like the aerial bow.

Her eheek all purple with the beam of youth,

Mounting at times, to a transparent glow,

As if her veins ran lightning. . . . Byron.

Fair lovely lady, bright and erystalline!

As glorious as the morning wash'd witlı dew,

Within whose eyes she takes her dawning beams-

And golden summer sleeps upon thy cheeks;

Wrap up thy radiations in some cloud,

Lest that thy beauty make this statcly town

Unhabitable as the burning zone,

With sweet reflections of thy lovely faec. . . Shaks.

Love returned. She was beloved-she loved. . . . . . Shaks.

Soft eyes look'd love, to eyes which spoke again. Byron.

Love has a fleeter messenger than specch,

To tell love's meaning. His express post

Upon the orbs of vision, ere the tongue

Can shape them into words. . . . G. Colman, jr.

Theirs was love in which the mind delights

To lose itself. . . . . . . . Byron.

The all-absorbing flame

Which, kindled by another, grows the same,

Wrapt in one blazc. . . . . . Byron.

Answer.

What sweet delirium o'er his bosom stole! Beatie.

I am lost in ecstasy !-Dost thou love,

Thou charming maid?

This is life indeed! Life worth preserving.

Such life as "I have" never felt till now.

My joy, my best belov'd, iny only wish !

How shall I speak the transport of my soul! Addison.

My soul, my life,

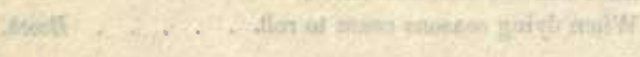

Seem'd all too little for your happiness. . . L. E. $L$.

Oh! 'tis a heaven worth dying for ! . . Watts. 


Amer. Star Wort. Cheerfulness in

Michaelmas Daisy.

Aster tradescanti.
Though time thy bloom is stealing,

There 's still beyond his art,

The wild-flower wreath of feeling,

The sunbeam of the heart. . . . . Halleck.

Virtue gives pleasure an eternal reign. . . . Young.

Virtue can brook the thoughts of age,

That lasts the same through every stage. . . Gay.

What nothing earthly gives, or can destroy,

The soul's calm sunshiue, and the heart-felt joy,

Is virtue's prize. . . . . . . Pope.

For him sle breathes the silent sigh forlorn,

Each setting day-for him, each rising morn. Darwin.

He used to come, in happier hours,

Upon my gift of token flowers. . . . . . C. G.

He comes not-sends not-faithless one !

It is no dream-and I am desolate . . . Byron.

That breathless, agoniz'd suspense

From whose hot throbs, whose deadly aching

The heart hath no relief but breaking . . . Moore.

Arbor Vite.

Live for me.

Thuja.

I live in pleasure, when 1 live to thee. . . . D.

Unless I look on Sylvia in the day,

There is no day for me to look upon.

She is my essence: and I leave to be,

If $I$ be not by her fair influence

Foster'd, illumin'd, cherish'd, kept alive. . . Shaks.

Gladly I

With thee would live, with thee would die. Horace.,

\section{Answer.}

Elvira blush'd the warm reply, (To love a language not unknown,

The milder glories fill'd her eye,

And there a softer lustre shone. . . Cartworight. 


\section{Auricula, Scarlet. Avarice.}

Primula auricula.

Avarice, whatever shape it bears,

Must still be coupled with its cares. . . . Gay.

Can gold calm passion, or make reason shine?

Can we dig peace, or wisdom, from the mine?

Wisdom to gold prefer; for 'tis much less

To make our fortune, than our happiness. . . Young.

What ever fortune lavishly can pour,

The mind annibilates, and asks for morc.

Wealth is a cheat; believe not what it says :

Like every lord, it promises-and pays.

The poor are only poor,

But what are they who droop amid their store? Young.

Gold hath no lustre of its own,

It shines by temperate use alone. . . . Horace.

Why lose we life in anxious cares,

To lay up hoards for future years? . . . Gay.

\section{BACHELOR's ButTon. I with the morning's \\ Lychnis dioica. love have oft made sport.}

When I said I would die a bachelor, I did not think

I should I live till I were married. . . . Shaks.

Love's a mighty lord;

And hath so humbled me, as I confess

There is no woe to his correction,

Nor, to his service, no such joy on earth !

Now, no discourse, except it be of love-

Now can I break my fast, dine, sup, and sleep,

Upon the very naked name of love. . . . Shaks.

Your beauty was the cause of that effect:

Your beauty which did haunt me in my sleep. same.

Your virtues, graced with external gifts,

Kindle love's settled passion in my heart. . . same.

Ever till now

When men were fond, I smil'd and wonder'd how. same.

Now 1 am

"As true a lover as ever sigh'd on midnight pillow." same.

Never man sigh'd truer breath. . . . . same.

\section{Answer.}

Flora's choice buttons of a russet die,

Is hope-even in the depths of misery. . . Brown. 

BALM.

\section{Sympathy.}

Melissa officinalis.
A world of earthly blessings to my soul

If sympathy of love unite our thoughts. . . Shaks.

Love's soft sympathy imparts

That tender transport of delight

That beats in undivided hearts.

What my tongue dares not, that my heart shall say.

\section{BALSAM, Red. Impatient resolves. \\ Impatient resoloen.}

Touch me not.

Impatiens.
Let me this fondness from my bosom tear,

Let me forget that e'er I thought her fair:

Come, cool indifference, and heal my breast,

Wearied at length, I seek thy downy rest :

No turbulence of passion shall destroy

My future ease with flattering hopes of joy. Lyttleton.

No more my eyes shall view her fatal charms.

Not all her arts my steady soul shall move,

And she shall find that reason conquers love. - same.

I 'Il not be made a soft and dull ey'd fool,

To shake the head, relent, and sigh, and yield. Shaks.

Yield up, $\mathrm{O}$ love! thy crown, and.hearted throne,

To tyrannous hate! swell, bosom ! with thy fraught,

For 'tis of aspic's tongues ! . . . . . same.

I am Misanthropos, and hate mankind. . . same.

\section{BaLSAM. Yellow. Impatience.}

Noli me tangere.

Impatiens.
Impatience waiteth on true sorrow. . . . Shaks.

Who in patience parts with all delight. . . Byron.

They can be meek, that have no other cause. Shaks.

Was she not all my fondest wish could frame?

Did ever mind so much of heaven partake? . Shavo.

Ah! what avail my love and truth?

She listens to no lowly swain;

Her charms must bless some happier youth, Some youth of Fortune's titled train.

Yet, will the youth, whoe'er he be, In truth or tenderness excel?

Or will he on thy charms like me, With fondness never-dying dwell? 
BaLSAM.

(Continued.)

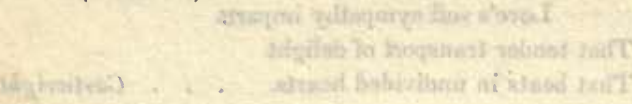

Basil. Sweet. Good wishes.

Ocimum.
What though his boast ful heart be vain Of all that birth or fortune gave,

Yet is not mine, though rude and plain, At least as noble and as brave?

Joy and fresh days of love accompany your hearts. Shaks.

I 'd have each hour, each minute of thy life

A golden holyday; and should a cloud

O'ercast thee, be it light as gossamer,

That Helen might disperse it with a breath,

And talk thee into sunshine. . . . Geo. Coleman.

Peace be around thee, wherever thou roamest,

May life be to thee a summer's day;

And all that thou wishest, and all that thou lovest,

Come smiling around thy suuny way-

As half in shade, and half in sun,

This world along its path advances,

May that side the sun's upon,

Be all that e'er shall meet thy glances.

May Time, that sheds its blight on all,

And daily dooms some joy to death,

O'er thee let years so gently fall,

They shall not crush one flower beneath. . . Moore.

O'er the sea,

Fain would I waft such blessings upon thee. Byron.

So fare thee well, - and may th' indulgent gods

$$
\text { * * * grant thee every wish }
$$

Thy soul can form ! Once more farewell!

Sophocles' Philocletes.

\section{Bay Leat. I change but in dying.}

Laurus.
No-let the Eagle change his plume,

The leaf its hue, the flower its bloom;

But ties around this heart were spun,

That could not, would not be undone. . : Campbell.

Changeless as the greenest leaves

Of the wreath the cypress weaves. - . L L. E. L.

Change as ye list, ye winds, my heart shall be

The faithful compass that still points to thee. - Gay.

How dear the dream in darlsest hour of ill,

Should all be changed, to find thee faithful still !

Be but thy soul like Selim's firmly shown;

To thee be Selim's tender as thy own.

To soothe each sorrow, share in each delight,

Blend every thought, do all-but disunite.

Byron. 
(5) 
BAY WREATH. The rewvard of merit. Laurus nobilis.

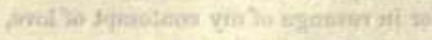

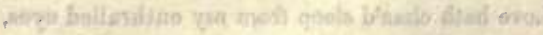

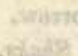

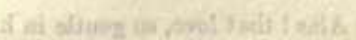

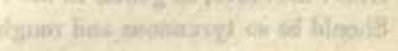

O, your desert speaks loud; and I should wrong it,

To lock it in the wards of covert bosom,

When it deserves with characters of brass

A forted residenee, 'gainst the tooth of time,

And razures of oblivion. . . . . . . Shaks.

The fame that a man wins himself, is best;

That, ho may call his own; * * *

So man's true fame must strike from his own deeds.

Middleton.

How vain are all hereditary honours,

Those poor possessions from anotlier's deeds,

Unless our own just virtues form our title,

And give a sanction to our fond assumption.

Shirley.

'Tis much he dares;

And to that dauntless temper of his mind,

He hath a wisdom that doth guide his valour

To act in safety. : . . . . . . . Shaks.

A spirit unequalled; and high,

That elaims, and seeks ascendancy. . . . Byron.

A sage in head, a demi-god in war. . . Teackle.

He sits 'mongst men, like a descended god :

He hath a kind of honour sets him off,

More than a mortal seeming. . . . . Shaks.

I've scanued the actions of his daily life,

And nothing meets mine eye but deeds of honour.

Hannah More.

Good actions crown themselves with lasting BAYs, Who deserves well, needs not another's praise. Heath.

\section{Belvidere. I declare against you. Miserable most, to love unlov'd. . . . Shaks. \\ Scoparia dulcis. \\ Pray you, no more of this;}

Wild Liquorice.

A veronica.

I would love you, if I could. . . . . . . same.

Reason and love keep little company together now a days.

same.

$\mathrm{Oh}$, 'tis the curse of love, and still appprov'd,

When women cannot love, where they 're belov'd. same.

Of all pains, the greatest pain

It is to love, but love in vain. . . . . Cowley. 
Bird's-foot Trefoil. Revenge. Lotus.

\section{Box.}

\section{Buxus.}

\section{Constancy.}

But I am constant as the northern star, Of whose true fix'd and resting quality There is no fellow in the firmament. . . . Shaks.

The proof of all the past,

Assures the future that my love will last. . . Moore.

Here is my hand for my true constancy;

And when that hour o'er-slips me in the day,

Wherein I sigh not, Julia, for thy sake,

The next ensuing hour some foul mischance

Torment me for my love's forgetfulness! . . Shaks.

The strong base and building of my love

Is as the very centre of the earth,

Drawing all things to it. . . . .

same.

His thoughts are high, his love is wise-

And though he does not always smile,

He loves unto the end. . . . . Montgomery.

Seasons may roll,

But my true soul

Burns the same, where'er it goes. . . . Moore.
The done penance for contemning love;

Should be so tyrannous and rough in proof! same.
Alas! that love, so gentle in his view,

\section{Broom.}

Genista.

\section{Humility.}




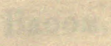

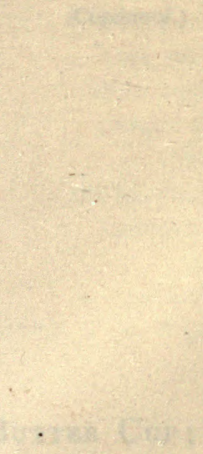

was $8 x^{2} x^{2}$

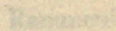

3.

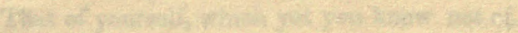

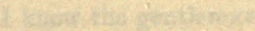

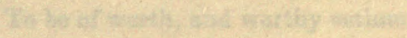

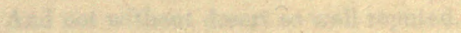

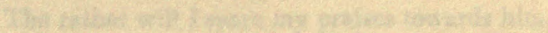

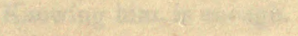

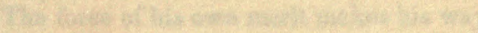

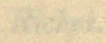

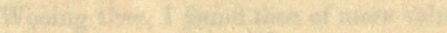

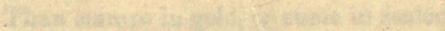

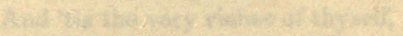

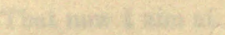

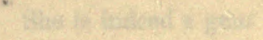

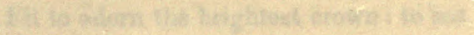

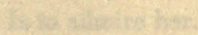

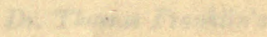

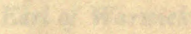

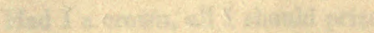

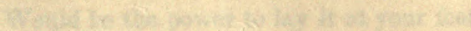

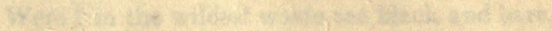

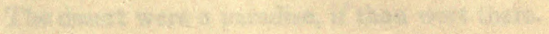

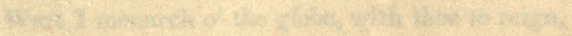

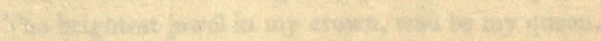

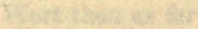

Whate

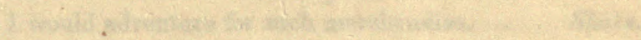

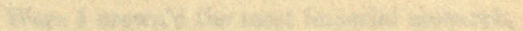

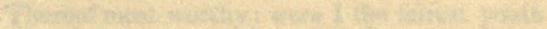

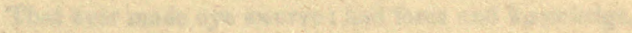

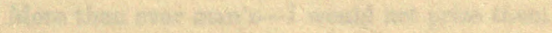

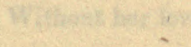

(3)

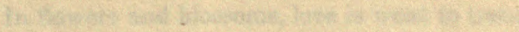

The

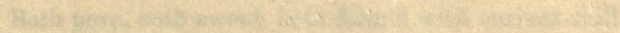

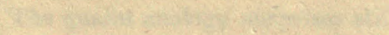

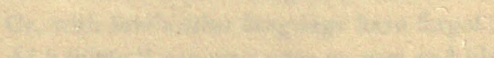

$-\quad a$ 


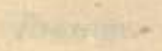

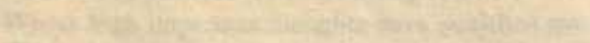

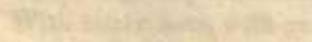

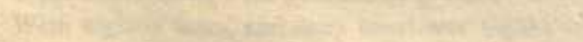

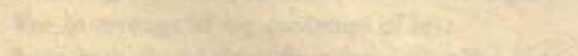

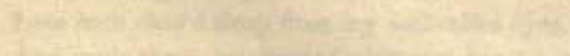

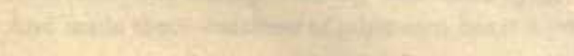

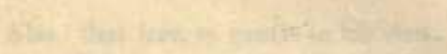

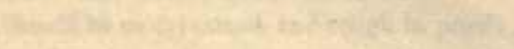

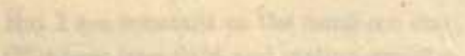

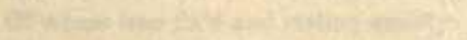

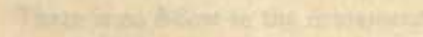

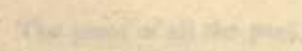

6.

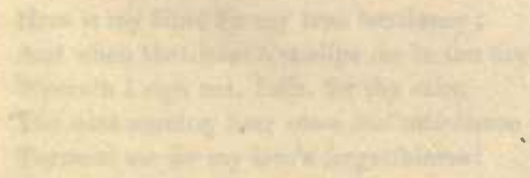

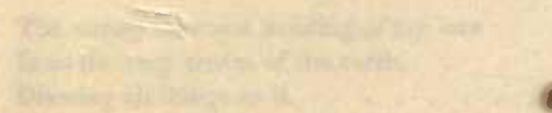

di:

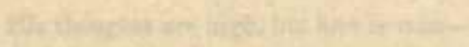

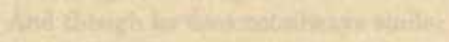

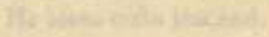

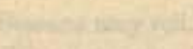

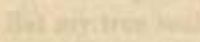

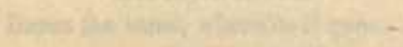

\section{$=$}

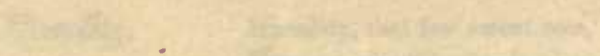

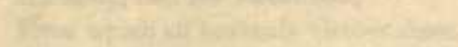

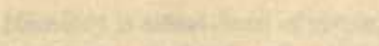

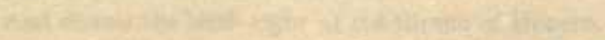

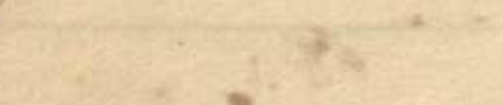


Broom.

\section{(Continued.)}

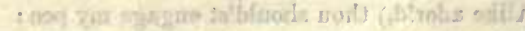

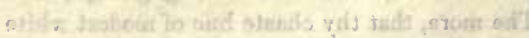

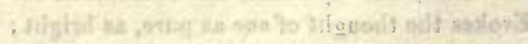

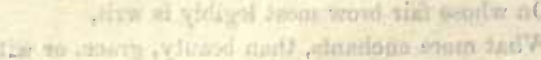

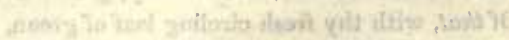

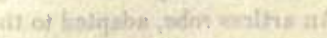

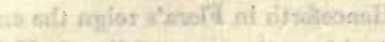

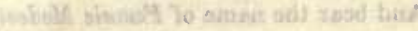

\section{Butter Cup;}

Riches.

or, King Cup.

Ranunculus acris.

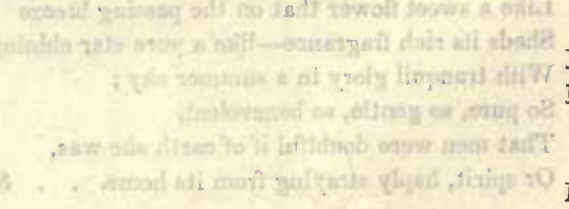

I a crown, all I shonld prize in it

Would be the power to lay it at your feet. . Dryden.

Were $I$ in the wildest waste sae black and bare,

The desert were a paradise, if thou wert there.

Were I monarch o' the globe, with thee to reign,

The brightest jewel in my crown, wad be my queen.

Burns.

Wert thou as far

As that vast shore washed by the distant sea,

I would adventure for such merchandise. . . Shaks.

Were I crown'd the most imperial monarch,

Thereof most worthy : wero I the fairest youth

That ever made eye swerve; had force and knowledge, More than ever man's-I would not prize them

Without her love. . . . . . . same.

\section{CaLla, Æthiopica. Feminine Modesty.}

Arum Athiopicum.
In flowers and blossoms, love is wont to trace

Emblems of woman's virtues and her grace;

Both pure, both sweet, both form'd with curious skill, The quaint analogy surprises still.

Hence rose a mystic tongue, which I know not, Or, with love's other language have forgot:

At " thirty," one may gaze on rose and lily, Nor grow poetic, amorous, nor--silly. 
Calla, Ethiopica.

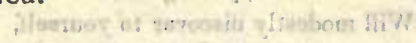

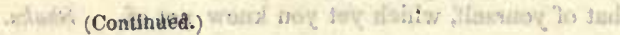

funtopiragy atis wond 3

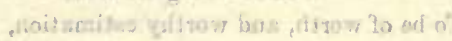

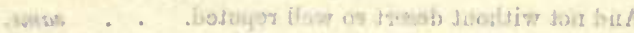

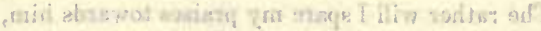

orits .

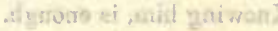

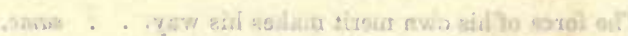

Calycantuus.

C. floridús.

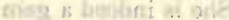

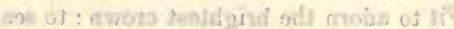

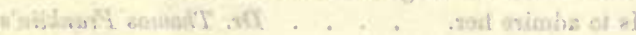

asingli $>$ akd

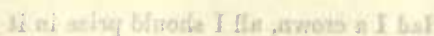

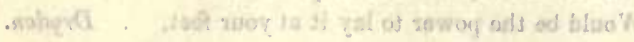

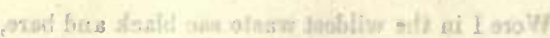

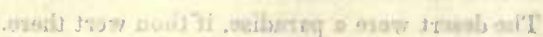

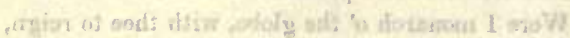

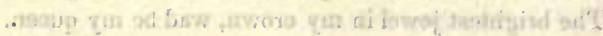

.817, जs:

Camella, Japonica. tân as pily.

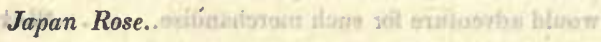

C. J.

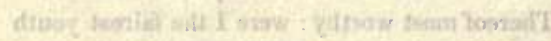

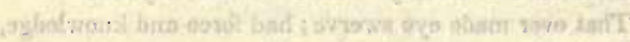

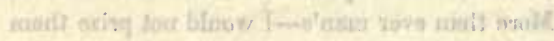

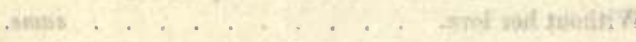

Yet, fair exotic ! by this single rule,

That thy name speaks thee of "the Beautiful,"

(A race by ancient gods and modern men Alike ador'd,) thou should'st engage my pen:

The more, that thy chaste hue of modest white

Evokes the thought of one as pure, as bright ;

On whose fair brow most legibly is writ,

What more enchants, than beauty, grace, or wit:

Of that, with thy fresh circling leaf of green,

(An artless robe, adapted to thy mien,)

Henceforth in Flora's reign the emblem be,

And bear the name of Female Modesty.* . . C***e.

Nature all, is blooming and benevolent like thee.

Thomson.

Like a sweet flower that on the passing breeze

Sheds its rich fragrance-like a pure star shining

With tranquil glory in a summer sky;

So pure, so gentle, so benevolent,

That men were doubtful if of earth she was,

Or spirit, haply straying from its home. . S. P.C.

His heart no selfish cares confin'd,

He felt for all that feel distress;

And still benevolent and kind,

He bless'd them, or he wish'd to bless. Cartwright.

Lucia, though sworn never to think of love,

Compassionates your pains, and pities you.

Addison.

Heaven has not cursed me with a heart of steel-

But given the sense to pity and to feel.

Homer's Odyssey.

Answer.

What is compassion, when 'tis void of love?

She pities me!

To one that asks the warm return of love,

Compassion 's cruelty,-'tis scorn, 'tis death. Addison.

If I could temporize with my affection,

Or brew it to a weak or colder palate,

The like allayment could I give my grief.

My love admits no qualifying dross;

No more my grief, in such a precious loss. . . Shaks.

* Note. To which the Romans erected two temples. 



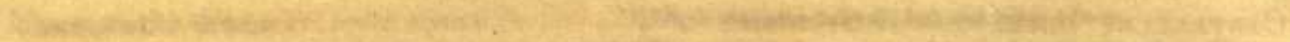

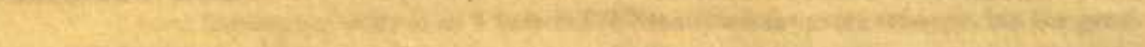

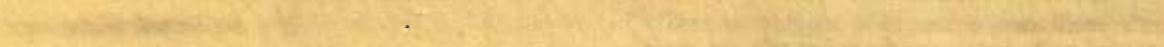

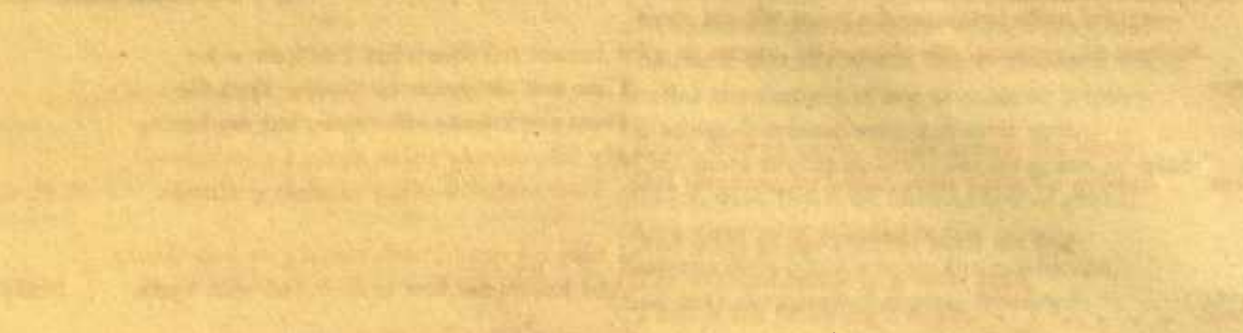

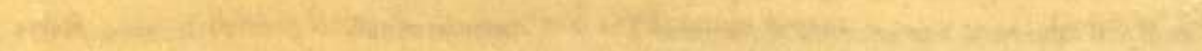

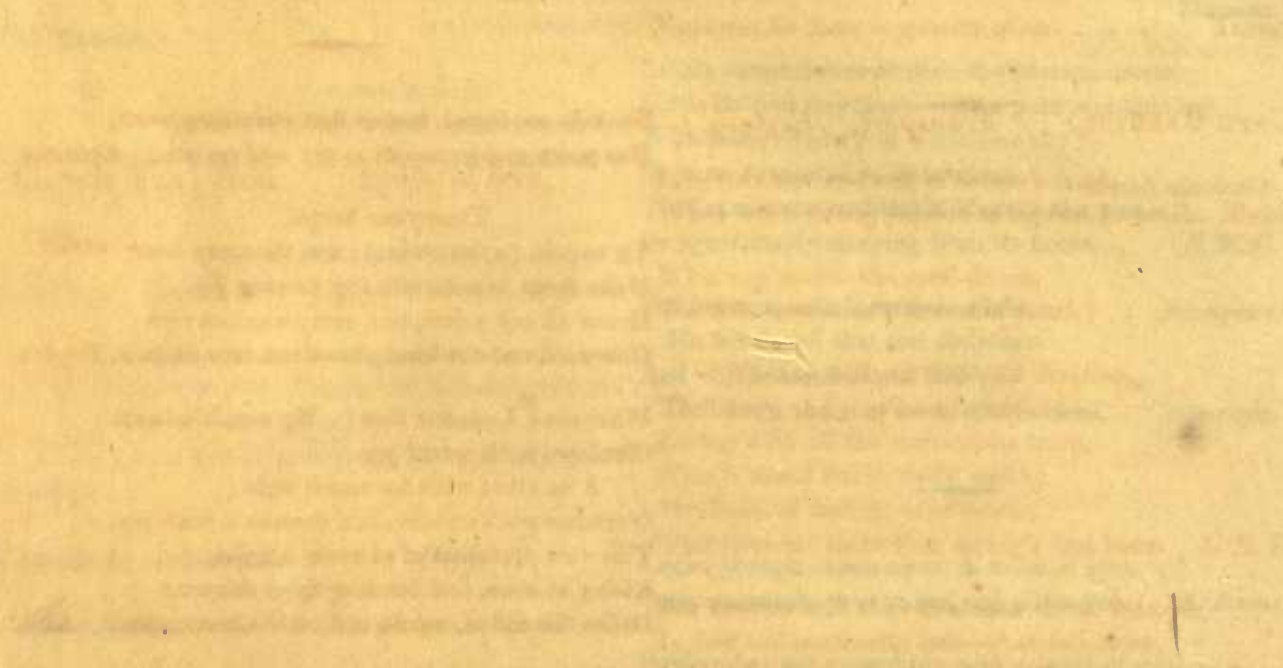

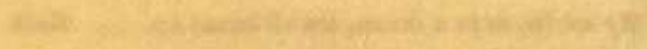

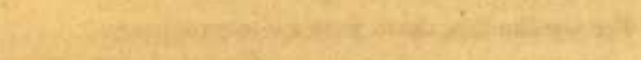

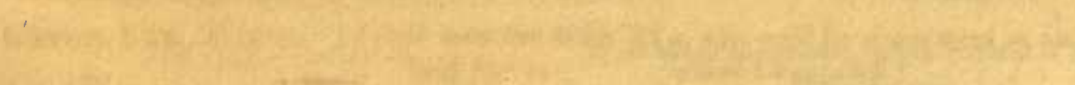

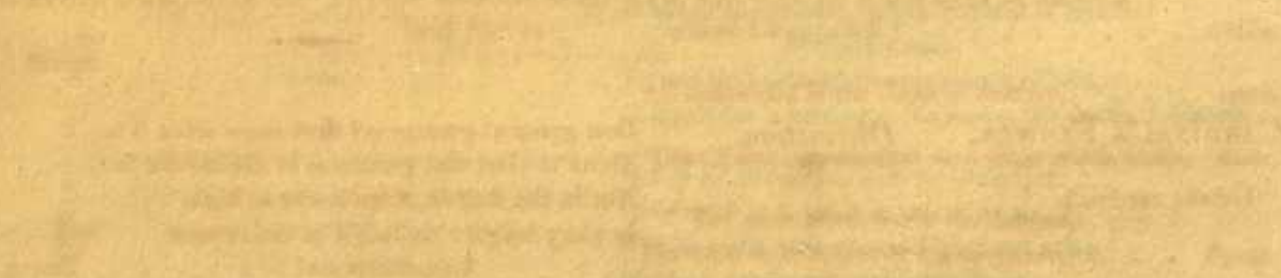

I

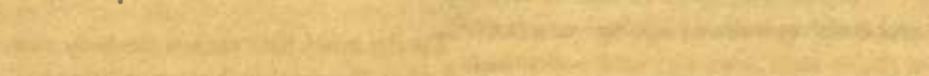

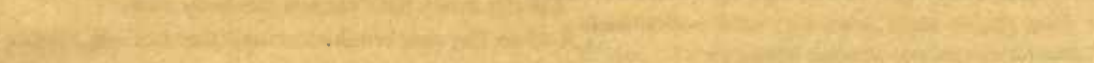


Canterbury Bele. Gratitude. And you, my dearest friend! How shall I thank you? C. I thery sift jefl. What shall I do to show my grateful heart?

Campanula medium.

Sophocles' Philoctetes.

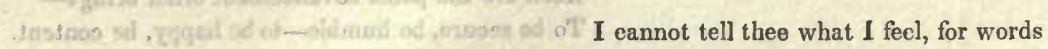

Have not the power to shadow forth the soul's

Deep and intense affections; but my heart,

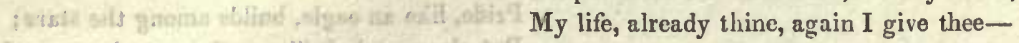

Poor evidence of my sumless gratitude. S. S. C.

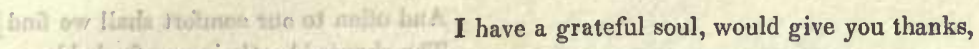

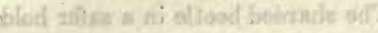

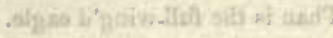

And knows not how to do it, but with tears. . Shaks.

sends oift

Take his thanks, that yet hath nothing else-

If fortune serve me, I 'll requite this kindness. same.

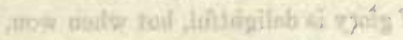

The debt immense of endless gratitude! . Milton.

Cape Jasmine. Transport. Ecstasy.

Gardenia florida.

She bids me hope! and in that charming word,

Has peace and transport to my soul restored. Lytlleton.

Tune your harps,

Ye angels, to that sound; and thou, my heart,

Make roon to entertain thy flowing joy.

Hence all my griefs, and every anxious care;

One word and one kind glance can cure despair. Dryden.

What shall I answer thee? My ravish'd heart

O'erflows with secret joy.

I'm blind with too much light:

O'ercome with wonder, and oppress'd with joy.

This vast profusion of extreme delight,

Rising at once, and bursting from despair,

Defies the aid of words, and mocks description.

Lillo.

My spirits, as in a dream, are all bound up. . Shaks.

For joy like this, death were a cheap exchange !

Aschylus' Agamemnon.

Cardinal's Flower. Distinction.

Lobelia cardinalis.
Dost grasp at greatness ? first know what it is:

Think'st thou that greatness in distinction lies?

Not in the feather, wave it e'er so high,

Is glory lodg'd : 'tis lodg'd in the revcrse;

A deathless soul . . . . Young.

'Tis the mind that makes the body rich:

And as the sun breaks through the darkest clouds,

So honour peereth in the meanest habit. . . Shaks. 


\section{Cardinal's Flower.}

(Continued.)

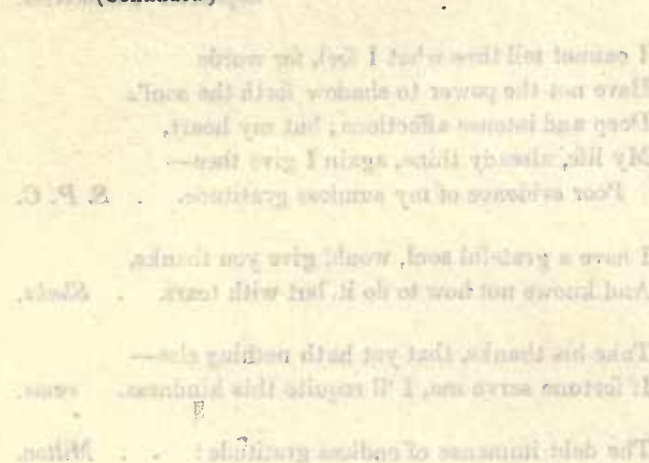

\section{Catch Fly, Red. Youthful love.}

Silene.
High stations tumult, but not bliss create,

None think the great unhappy, but the great. Young.

Keen are the pains advancement often brings-

To be secure, be humble-to be happy, be content.

same.

Pride, like an eagle, builds among the stars;

But pleasure, lark-like, rests upon the ground.

same.

And often to our comfort shall we find]

The sharded beetle in a safer hold,

Than is the full-wing'd eagle. . . . . Shaks.

The chase

Of glory is delightful, but when won,

It brings disquiet. . . . . Euripides' Iphigenia.

Fondness for fame is avarice of air. . . . Young.

It is the show and seal of nature's truth,

When love's strong passion is imprest in youth. Shaks.

What can match the spell divine,

The first impassion'd dream of youth! . Anonymous.

Loving with all that wild devotion,

That deep, and passionatc emotion--

Loving with all the snow-white truth,

That is found but in early youth;

Freshness of feeling, as of flower,

That lives not more than spring's first hour. $\quad$ L. E. $L$.

But sweeter still than this, than these, than all, Is first and passionate love-it stands alone,

Like Adam's recollection of his fall. . . . Byron.
Catch Fuy, White. I fall into the trap Silene.

Yet who could have suspected an ambush, where I was taken? . . . . . . Shaks.

All unavoided is the doom of destiny. . . . same.

What Fates impose, that men must needs abide. same.

Let none think to fly the danger,

For soon or late, love is his own avenger. . . Byron.

What e'er betides, by destiny 'tis done,

And better bear like men, than vainly seek to shun.

Dryden. 


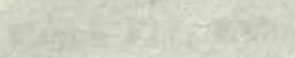

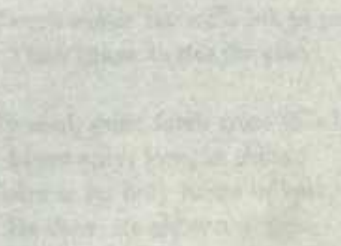



Catch Fly, White.

(Continued.)

Cedar.

I live for thee.

Juniperus.

Alas, what stay is there in human state,

Or who can shun inevitable fate? . . . Dryden.

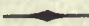

To thee, my love, my heart, my life are due. Langhorne.

Thou art my light of life! without thee, bliss,

Even the bliss of angels, were but pain;

But with thee, earth hath not a wilderness

So dark, but 'twould be blessed paradise. . S. P. C.

All that of myself is mine,

Lovely Amoret, is thine.

Waller.

Be mine, dear maid ! this faithful heart

Can never prove untrue;

'Twere easier far with life to part,

Than cease to live for you. . . . . . Terry.

My soul, gone forth from this lone breast,

Lives only, love, in thine;

There is its holy home of rest,

Its dear, its chosen shrine.

same.

China Aster, Double. I partake your Aster chinensis.
Mutual leve the crown of all our bliss! . Milton.

Each fear that chill'd their loves was past. . Moore.

'Tis not in fate to harm me,

While fate leaves thy love to me;

'Tis not in joy to charm me,

Unless that joy be shared with thee. . . . same.

Be mine the more refined delights

Of love, that banishes control,

When the fond heart with heart unites,

And soul's in unison with soul. . . Cartworight.

Where heart meets heart, reciprocally soft,

Each other's pillow to repose divinc. . . Young.
China Aster, Single. 1 will think of it. Aster chinensis.
Be not dishearten'd, then, nor cloud those looks That wont to be inore cheerful and serene. . Milton.

We would not sink thy soul

With fear in the excess, nor raise it high

With confidence. . . Aschylus. The Persians. 
China Asten, Single.

(Continued.)

Oft expectation fails, and most oft there

Where most it promises : and oft it hits

Where hope is coldest, and despair most sits. Shaks.

\section{Answer.}

Those gracious words revive my drooping thoughts, And give my tongue-tied sorrows leave to speak. Shaks.

I spy some pity in thy looks. . . . . same.

Do not hold forth a grace, then snatch it from me.

Aschylus' Prometheus Chained.

\section{Chrysanthemum, Rose colour.}

Chrysanthemum Indicum.
1 love.

My heart will burst, an if I speak,

And I will speak, that so my heart may burst. Shaks.

$$
\text { Yet, }
$$

Why should I blush to own I love ?-

'Tis love that rules the realms above.

Why should I blush to say to all,

That virtue holds my heart in thrall?

H. K. White.

Oh, she had yet the task to learn,

How often woman's heart must tarn

To feed upon its own excess

Of deep, yet passionate, tenderness !

How much of grief the heart must prove,

That yields a sanctuary to love!

L. E. $L$

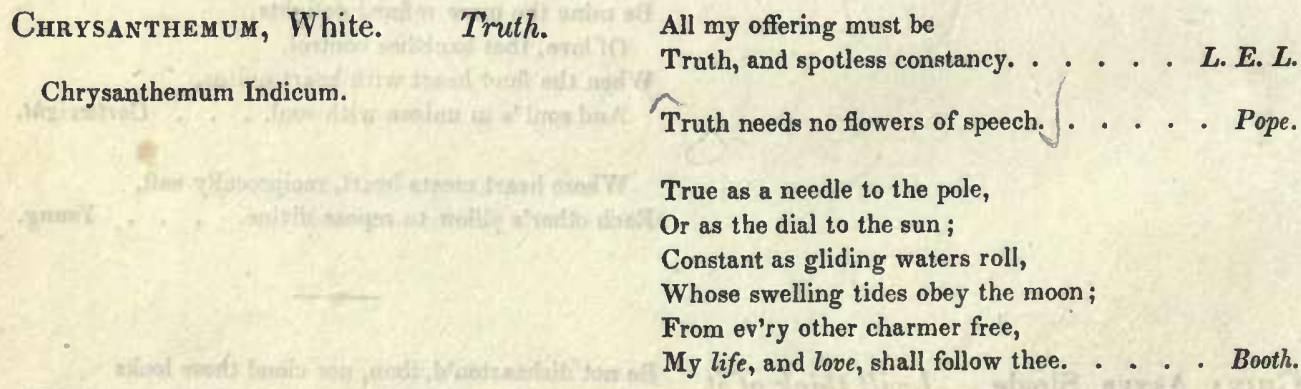

Answer.

How sweet the words of truth,

Breath'd from the lips of lovo. . . . Beattie. 



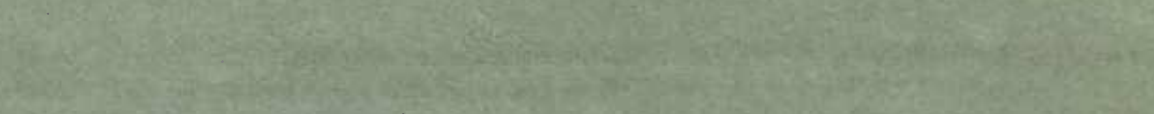

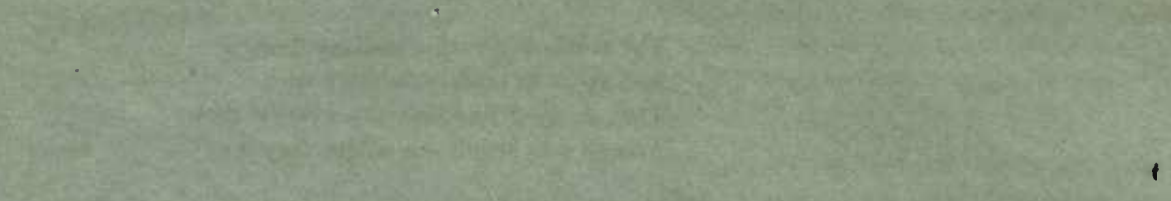

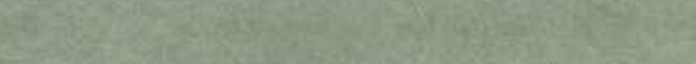

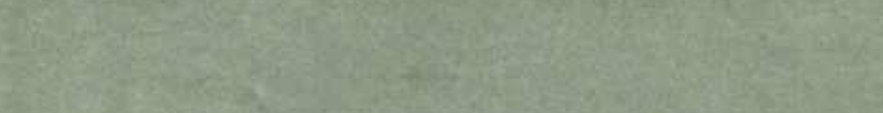

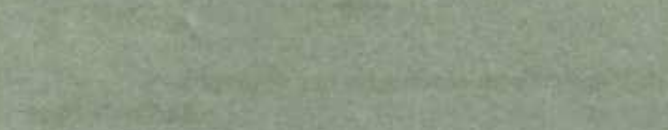

whing

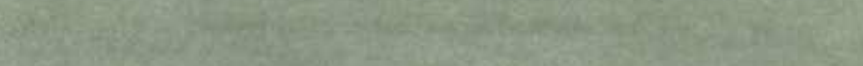

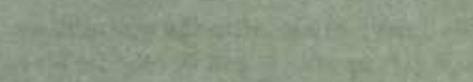

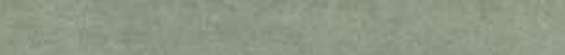

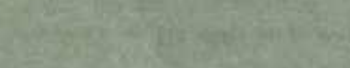

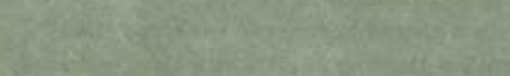

(1)

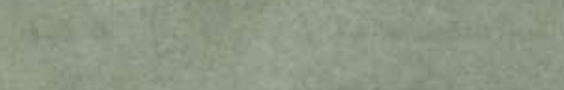

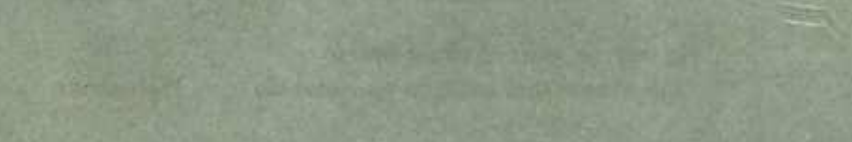

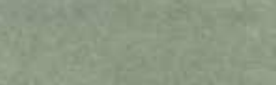

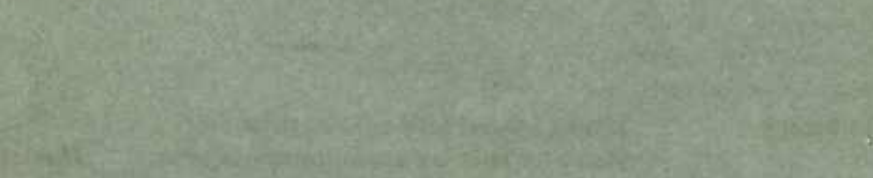

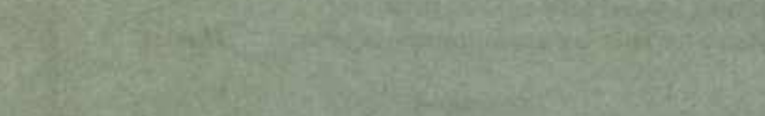

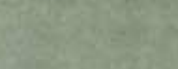

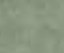

$x^{2} x^{2}=$

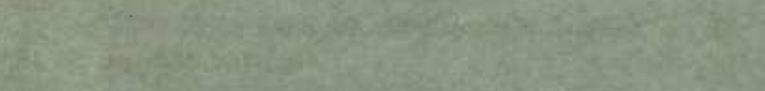

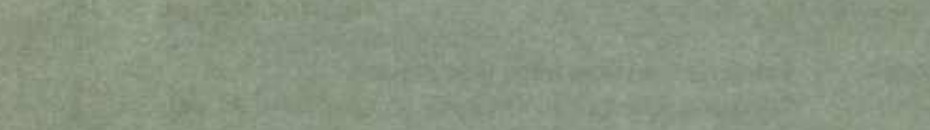
$4 \operatorname{lin}^{2}=2$

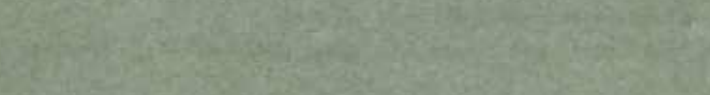

$$
\begin{aligned}
& \text { Shis }
\end{aligned}
$$

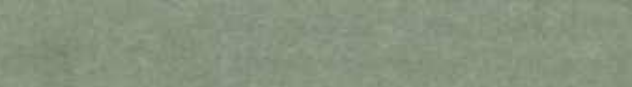

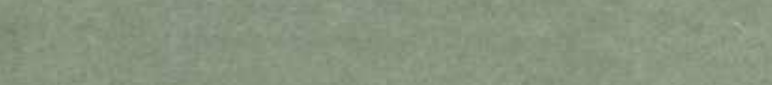

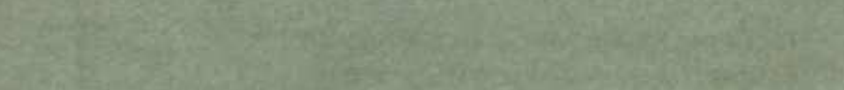

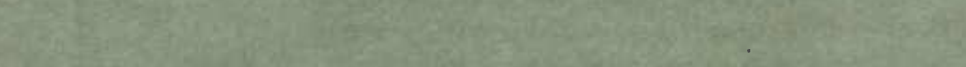

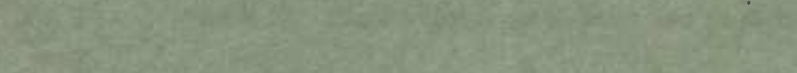


Chrysanthemum.

(Continued.)

Chrysanthemum, Slighted love.

Yellow.

Chrys. Indicum.

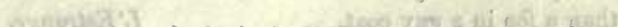

Eloquence glows on your lips,

When you swear that you 'll love me for cver. Moore.

Thy words had such a melting flow,

And spoke of truth so sweetly well,

They dropp'd, like lieaven's serenest snow,

And all was brightness where they fell! . . same.

Her heart all love, her soul all truth. . . . Dibdin.

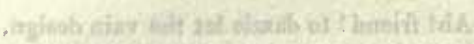

Still dash'd with blushes for her slighted lore.

Addison's Ovid.

Was it for this I loved him so,

And lavished hopes that brightly shone? . . C. G.

Did I not love him with the purest flame?

And give up friends and fortune for his sake? Shaw.

Love's summer flower, how soon thou art decayed-

Opening amid a paradise of sweets,

Dying with withered leaves, and cankered stem!

Gone-and the trusting heart which thou hast made

So green, so lovely, for thy dwelling place,

Left to desolation! . . . . L. E. L.

It may be sport to win a heart,

Then leave that heart to pine and die : Westmacott.

Clover, Red.

Industry.

Trifolium pratense.
If little labour, little are our gains:

Man's fortunes are according to his pains. Herrick.

\section{One alone}

May do the task of many, when the mind

Is active in it. . . . . . Sophocles' EEdipus.

Industrious wisdom often does prevent

What lazy folly thinks inevitable. Abdicated Prince.

Absence of occupation is not rest,

A mind quite vacant, is a mind distress'd. - Cowper.

The keenest pangs the wretched find,

Are rapture to the dreary void-

The leaflcss desert of the mind-

The waste of feelings unemploy'd. . . . Byron.

Like a coy maiden, ease, when courted most,

Farthest retires-an idol, at whose shrine

Who oft'nest sacrifice are favour'd least. . Cowper. 
Cocк's Сомв. Foppery. Affectation. The gaudy cock's comb, idly vain,

Celosia cristata.

Amaranthus.

Coxcombs are of all ranks and kind,

They 're not to sex, or age, confined,

Of rich, or poor, or great, or small,

'Tis vanity bescts them all. . . . . Gay.

The leopard's beauty, without the fox's wit, is no better than a fop in a gay coat. . . . L'Estrange.

Ah! friend! to dazzle let the vain design,

To raise the thought and teach the heart be thine. Pope.

Columbine, Purple. Resolved to win. This hand, I cannot but in death resign! - Dryden.

Think'st thou

That I could live, and let thee go,

Who art my life itself?-no-no. . . . . Moore.

To prevail in the cause that is dearer than life,

Or, crush'd in its ruins, to die! . . Campbell.

Columbine, Red. Anxious and trembling. A. canadensis.

How throbbed my fluttering pulse with hopes and fears.

Rogers.

Thrown into tumult, raptur'd or alarm'd! . . Young.

Hope and fear maintain eternal strife-

Where fleeting joy does lasting doubts inspire,

And most we question what we most desire. 1 . Prior.

$O$ ! soothe my soul to rest-

And calm the rising tumult in my breast.

Sophocles' Edipus Tyrannus.

\section{Answer.}

The rose is fairest when 'tis budding new,

And hope is brightest when it dawns from fears. Scott.

\section{Convolvulus. \\ Uncertainty.}

Convolvulus.
Hope and fear alternate sway'd his breast, Like light and shade upon a waving field, Coursing each other, when the flying clouds Now hide, and now reveal the sun. . . . Home. 


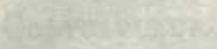

Ta

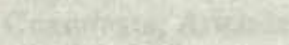

Tes

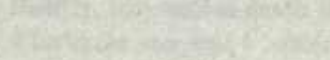

3.

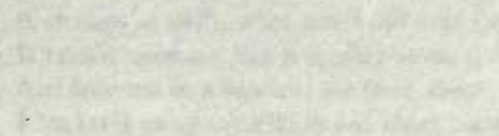

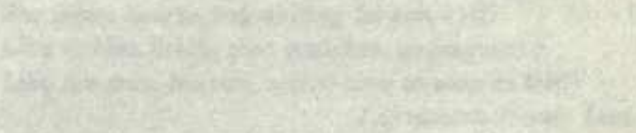

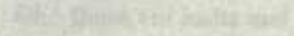

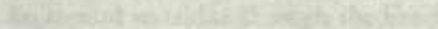

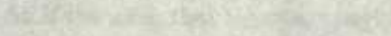

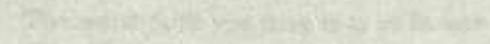

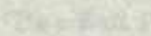

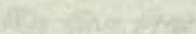

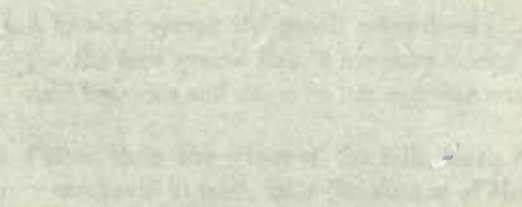




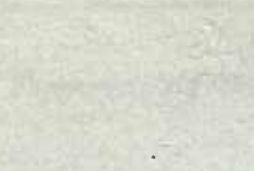


Convolvulus.

(Continued.)
For love pursues an ever devious race,

True to the winding lineaments of grace. . Campbell.

Coreopsis, Arkansa. Love at first sight. No warning of the approaching flame,

Coreopsis tinctoria.

Swiftly, like sudden death it came,

I lov'd the moment I beheld! . . . . Granville.

A change so swift, what heart did ever feel ?

It rush'd upon me like a mighty stream,

And bore me in a moment far from shore.

I 've lov'd away myself: in one short hour,

Already am I gone an age of passion. . . Dryden.

She seizes hearts, not waiting for consent,

Like sudden death, that snatches, unprepared;

Like fire from heaven, scarce seen so soon as felt.

Lansdown's Heroic Love.

Oh! there are looks and tones that dart

An instant sunshine through the heart;

As if the soul, that minute, caught

Some treasure it through life had sought! . Moore.

Thou com'st in beauty on my gaze at last, Image of many a dream in hours past ! . Halleck.

Answer.

Is it possiblc, that love should of a sudden take such hold ?. . . . . . . . . . Shaks.

The worst fault you have is to be in love-

'Tis a fault I would not change for your best virtue.

same.

\section{Cowsurp, Common.}

Primula veris.

\section{Winning grace.}

A soft subduing grace around her breathed.

$F$.

A lovelier nymph the pencil never drew;

For the fond graces form'd her easy mien,

And heaven's soft azure in her eye was seen. Hayley.

Fairer than the ghost of the hills, when it moves in a sun-beam at noon, over the silence of Morven.

Ossian.

Fair as the forms, that, wove in fancy's loom, Float in light vision round the poet's head. . Mason. 


\section{Crocus.}

Crocus.

\section{Cheerfulness.}

\section{Crocus.}

(20)

\section{Crown Imperial.} Majesty. Power.

Fritillaria imperialis.
Frame your mind to inirth and merriment, Which bars a thousand harms, and lengthens life. Shaks.

Then her mirth-oh! ' $t$ was sportive as ever took wing From the heart, with a burst, like the wild bird in spring.

Moore.

While her laugh, full of life, without any control

But the sweet one of gracefulness, rung from her soul. And where it most sparkled, no glance could discover, In lip, cheek, or eyes, for she brighten'd all over.

Like any fair lake that the breeze is upon,

When it breaks into dimples, and laughs in the sun.

same.

I cannot paint to thee the charm

Which thou hast wrought on me,

Thy laugh, so like the wild bird's song,

In the first bloom-touch'd tree. . . . L. E. $L$.

In his face sat meekness, heighten'd with majestic grace.

Denham.

Who paused to look again,

Saw more than marks the crowd of vulgar men. Byron.

The power of thought-the magic of the mind. same.

See, what a grace was seated on this brow :

Hyperion's curls; the front of Jove himself;

An eye, like Mars, to threaten and command;

A station like the herald Mercury,

New-lighted on a heaven-kissing hill;

A combination and a form, indeed,

Where every god did seem to set his seal,

To give the world assurance of a man! . . Shaks.

What peremptory eagle-sighted eye,

Dares look upon the heaven of her brow,

That is not blinded by her majesty? . . . same.

High on the circle of her brow enthron'd,

From each majestic motion darting awe,

Devoted awe ! till cherish'd by her looks

Benevolent, and meek confiding love,

To rapture soften'd all the soul. . . . Akenside.

His changing cheek, his sinking heart, confess

The might-the majesty of loveliness. . . Byron. 


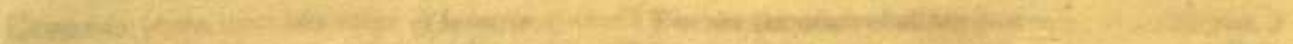

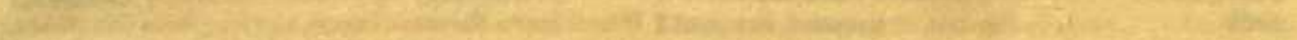

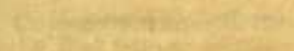

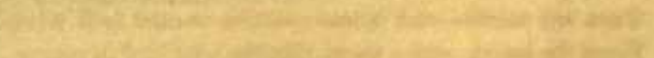

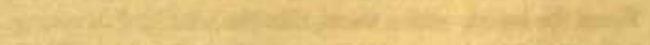

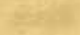

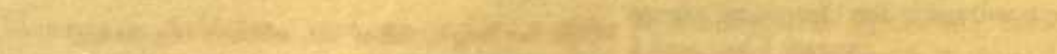

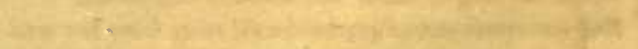

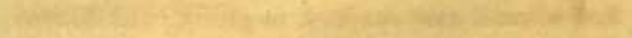

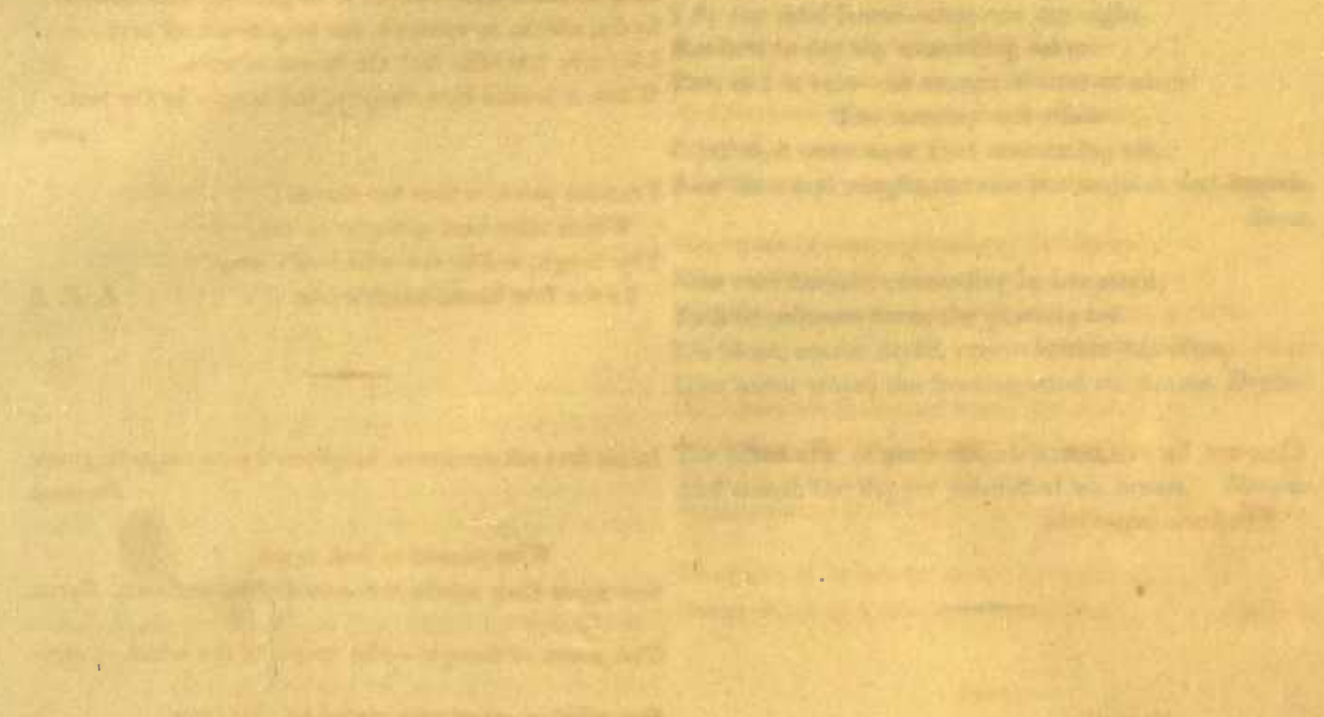

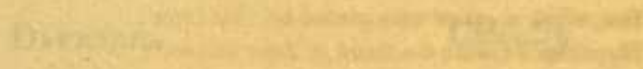

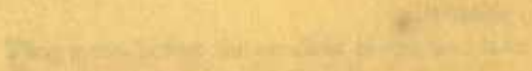

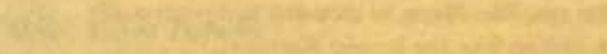

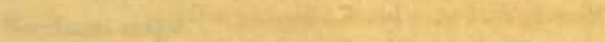

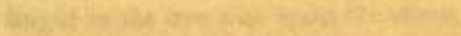

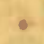

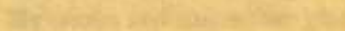

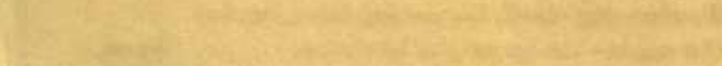

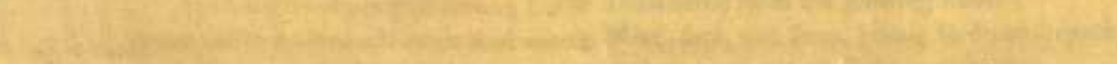

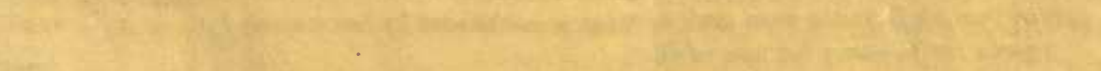

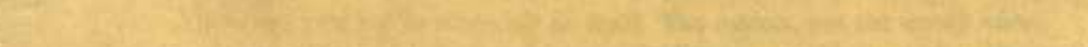

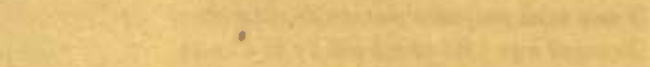

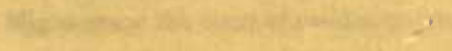

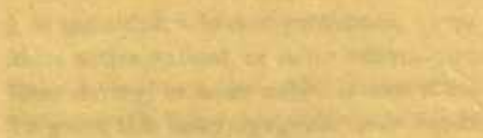
Thest

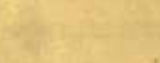


$\sqrt{3}$
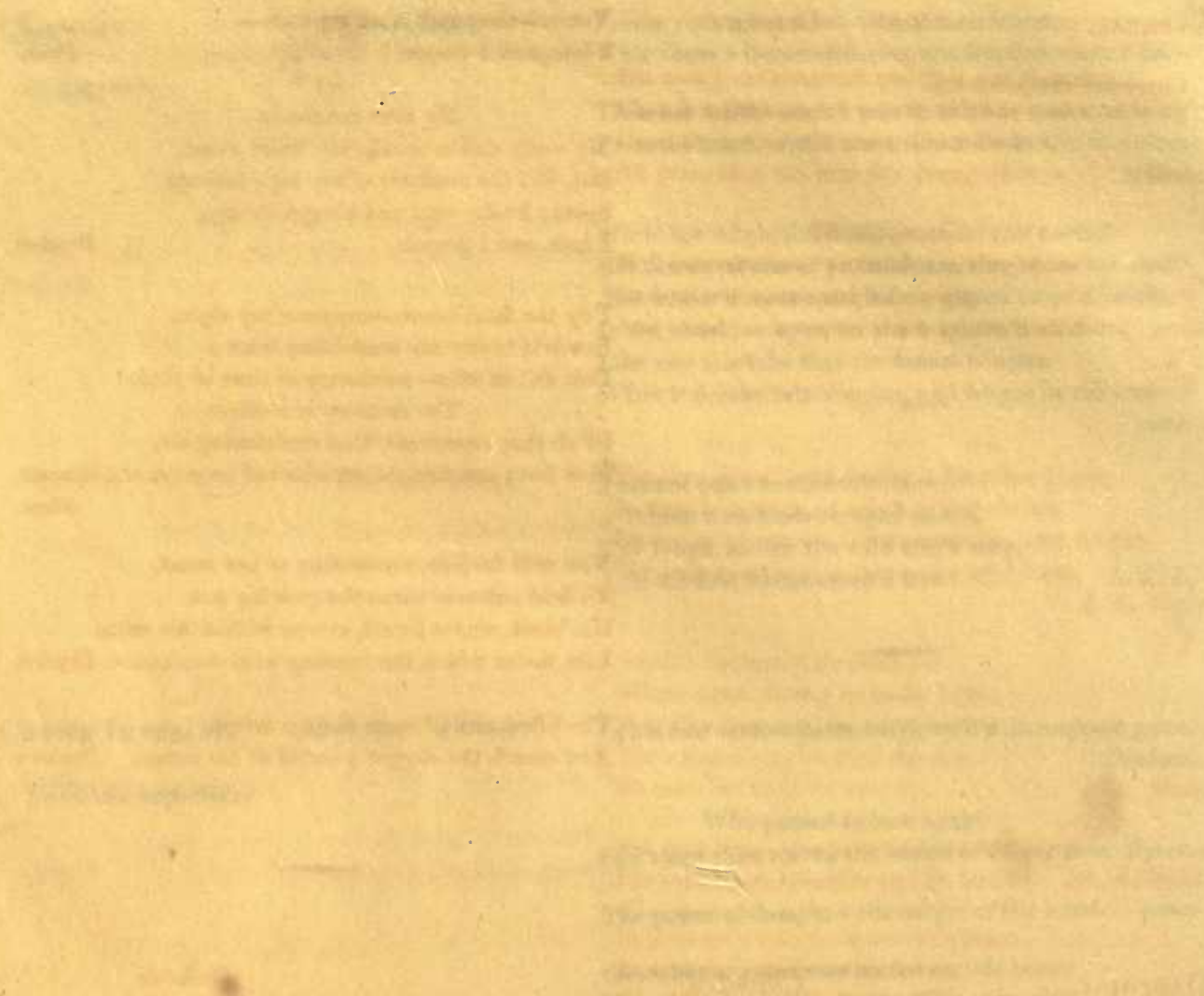

*

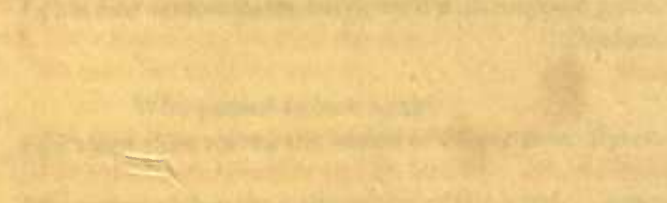

,

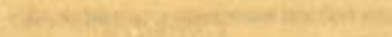

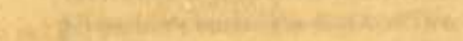

-

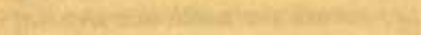

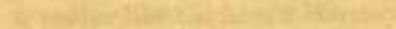

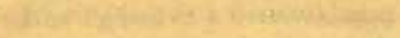

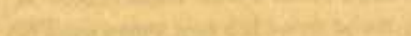

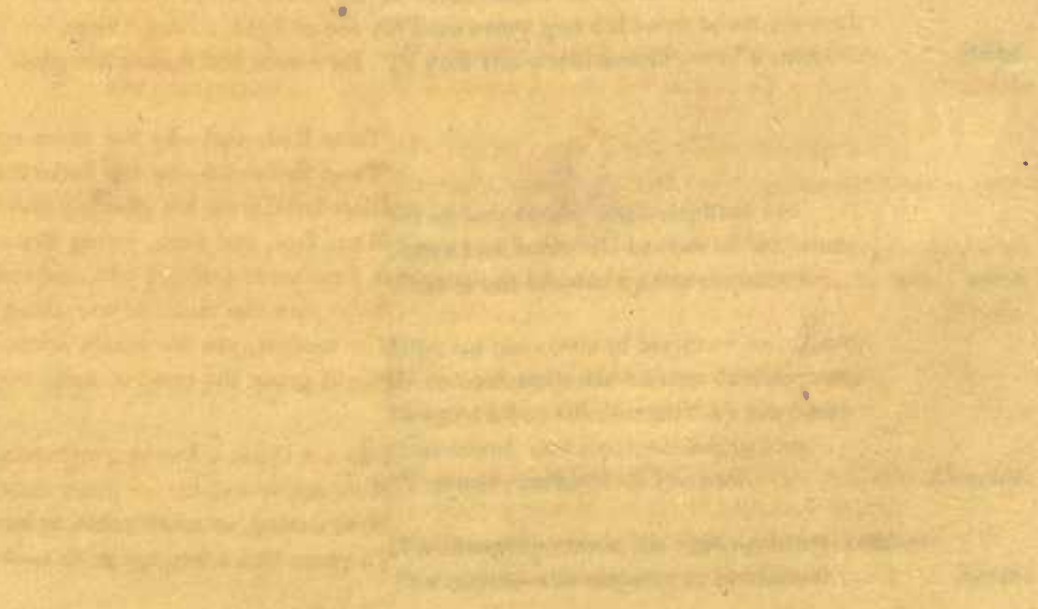

20 
Cypress.

Despair.

Cupressus sempervirens.

DAFFODIL.

Great Yellow Daffodil.

Narcissus major.
You are the cause of all my rare-

I love, and I despair ! . . . . . . Prior.

My eyes confess it.

My every action speaks my heart aloud.

But, oh! the madness of my high attempt

Speaks louder yet ! and altogether cry,

I love, and I despair. . . . . . Dryden.

I fly the fatal house-suppress my sighs, Resolv'd to dry my unavailing tears :

But, ah! in vain-no change of time or place

The memory can efface

Of all that sweetncss, that enchanting air,

Now lost ; and naught remains but anguish and despair.

Shaw.

Now cold despair, succceding in her stead,

To livid paleness turns the glowing red.

His blood, scarce liquid, creeps within his veins,

Like water which the freezing wind constrains. Dryden.

The lifted arm of mute despair arrest,

And snatch the dagger pointed at his breast. Durvin.

Chivalry.

Daffodils

That come before the swallow dares, and take

The winds of March with beauty. . . . . Shaks.

Bright as the bow that spans the storm,

In Erin's yellow vesture clad,

A son of light, a lovely form,

He comes and makes her glad. . . . Campbell.

'Twas Redmond-by the azure eye;

'Twas Redmond-by the locks that fly

Disordered from his glowing cheek;

Mien, face, and form, young Redmond speak.

A form more active, light, and strong,

Ne'er shot the ranks of war along;

The modest, yet the manly mien,

Might grace the court of maiden queen. . . Scott.

I do not think a braver gentleman,

More active-valiant, or more valiant-young,

More daring, or more noble, is now alive,

To grace this latter age with noble deeds. . . Shaks. 
Daffodil.

(Continued.)

Dahlia.

Dahlia.

For tver thine.

Answer.

But now I am returned, and that war thoughts

Have left their places vacant, in their rooms

Come thronging soft and delicate desires,

All prompting me how fair young Hero is. . . Shaks.

Most fair,-

Will you vouchsafe to teach a soldier terms

Such as will enter at a lady's ear,

And plead his love-suit to her gentle heart? same.

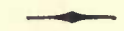

For ever thine! 'mid fashion's heartless throng, In courtly bowers, at folly's gilded shrine.

Smiles on my clieek, light words upon my tongue, My deep heart still is thine-for ever thine.

A. A. Watts.

Amidst the world, the only one

Whose light, among so many lights,

Was like that star, on starry nights

The seaman singles from the sky,

To steer his bark for ever by. . . . . . Moore.

For ever thine, whate'er this heart betide;

For ever thine, where'er our lot be cast. A. A. Watls.

In pleasure's dream, or sorrow's hour,

In crowded hall or lonely bower,

The business of my soul shall be,

For ever to remember thee!. . . . . Moore.

Beauty unknown to the possessor.
The beanty that is borne here in her face,

The bearer knows not of. . . . . . . Shaks.

,Tis beauty truly blent, whose red and whito

Nature's own sweet and cunning hand laid on. same.

Her eyes, her lips, her cheeks, her shapes, her featurcs, Seem to be drawn by love's own hands, by love

Himself in love. . . . . . . . . Dryden.

Is she not more than painting can express, Or youthful poets fancy when they love? . Rowe.

As lamps burn silent, with unconscious light,

So modest ease in beauty shines most bright;

Unaiming eharms with edge resistless fall, And she who means no mischief, does it all. 



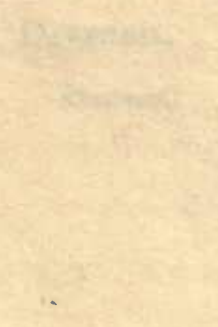

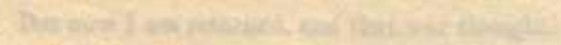

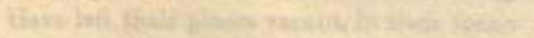

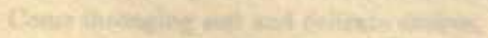

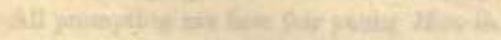

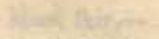

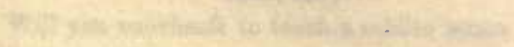

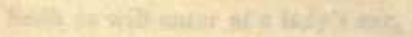

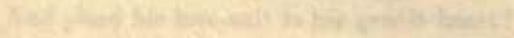

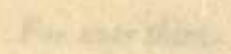

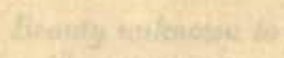

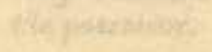

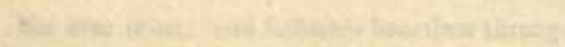

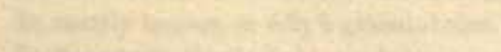

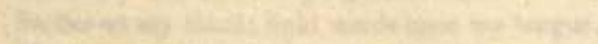

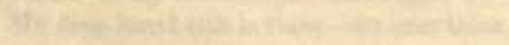

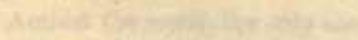

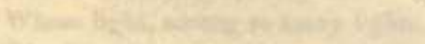

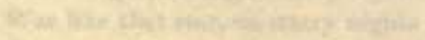

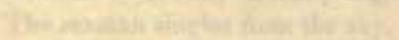

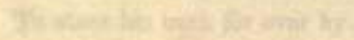

14:

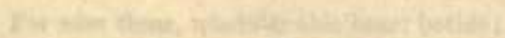

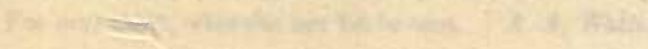

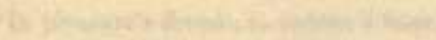

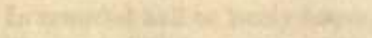

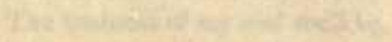

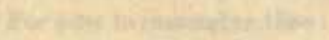

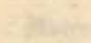

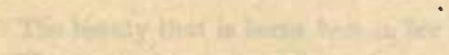

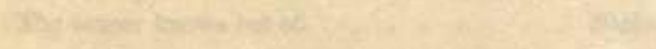

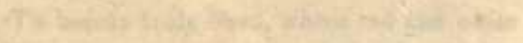

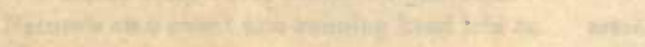

\section{.}

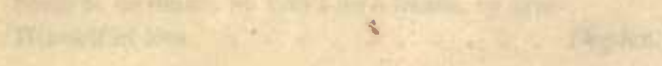

(1.20)

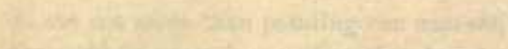

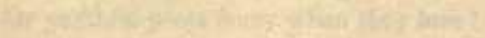




\section{DaISY, White.}

Bellis.
Innocence.

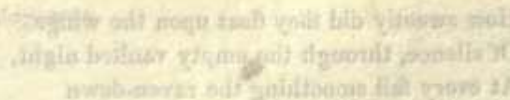

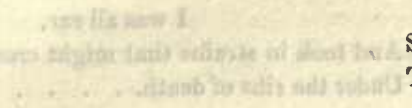

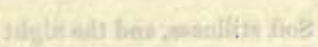
cosing

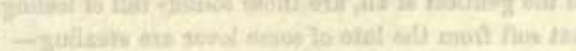

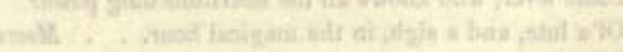

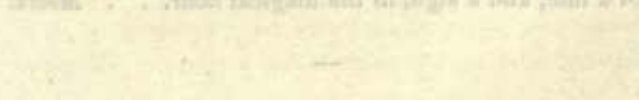

\section{Dandelion.}

Leontodon taraxacum.

\section{Coquetry.}

列

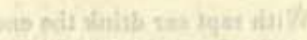


Dew Plant.

(Continued.)

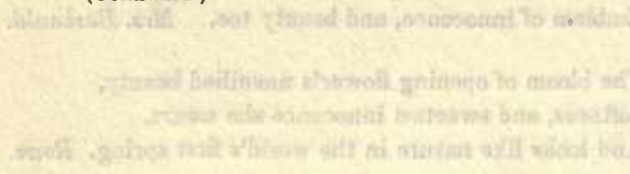

A soft and solemn-breathing sound

Rose like a stream of rich distill'd perfumes, .

And stole upon the air. . . . . . . Milton.

How sweetly did they float upon the wings

Of silence, through the empty raulted night,

At every fall smoothing the raven.down

Of darkness, till it smiled. . . . . . . . same.

I was all ear,

And took in strains that might create a soul

Under the ribs of death. . . . . . . . same.

Soft stillness, and the night

Become the touches of sweet harmony.j . . Shaks.

But the gentlest of all, are those sounds full of feeling,

That soft from the lute of some lover are stealing-

Some lover, who knows all the heart-touching power

Of a lute, and a sigh, in the magical hour. . . Moore.

"And yonder lattice, where thick vine-leaves Are canopy, a maiden leans-she has caught A shadow-and she sees a well known form Amid those trees, and with her hair flung back, She listens to his song- The song she loved.' "

With rapt ear drink the enchanting serenade, And, as it melts along the moonlight glade, To each soft note return as soft a sigh,

And bless the youth that bids her slumbers fiy. Rogers.

\section{Dogwoon Brossom. I am perfectly in- Cornus. different to you.}

Never did captive with freer heart

Cast off his chains of bondage. same.

Such love, by flattering charms betray'd,

Shall yet indignant soon rebel,

And, blushing for the choice he made,

Shall fly where gentler virtues dwell.

'Tis then the mind, from bondage free,

And all its former weakuess o'er,

Asserts its native dignity,

And scorns what folly prized before. . Cartwright.

\section{Answer.}

She gladly shunn'd, who gladly fled from her.

Shaks. 
Eglantine. I $\quad$ roound to heal. Now show the wound mine eyes have made in theo.

Shaks.

European Sweet Briar.

I will not cast away my physic,

Rosa rubiginosa.

But on those that are sick.

\section{Answer.}

If ever (as that ever may be near)

You mect in some fresh cheek the power of fancy,

Then shall you know the wounds invisible

That love's keen arrows make. . . . . same.

\section{Lady.}

Wise men ne'er wail their present woes,

But presently prevent the way to wail. . . Shaks.

I dare for once prescribe for your disease. Dryden.

I would cure you, if you would but call me Rosalind, And come every day to my cote, and woo me. Shaks.

\section{Rejoinder.}

Skill infinite-

Sweet practitioner, thy physic I will try. . . same.

\section{Elder.}

\section{Compassion.}

Sambucus niger. 
Everlasting.

(Continued.)
Thou wert a rainbow to my sight,

The storms of life before thee fled,

The glory and the guiding light,

That onward cheered, and upward led;

Thou wert my guiding light afar. . . Della.

There 's not an hour

Of day, or dreaming night, but I am with thee:

There 's not a wind but whispers of thy name;

And not a flower that sleeps beneath the moon,

But in its fragrance tells a tale

Of thee.

Proctor.

There's not a look, a word of thine,

My soul hath ere forgot;

Thou ne'er hast bid a ringlet shine,

Nor given thy locks one graceful twine,

Which I remember not! . . . . . Moore.

All nature fades extinct; and she alone

Heard, felt, and seen, possesses every thought,

Fills every sense, and pants in every vein. Thomson.
Fever Root.

Delay.

Eupatorium.

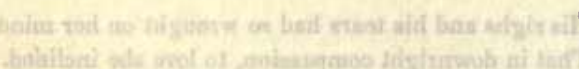
anat. M nod

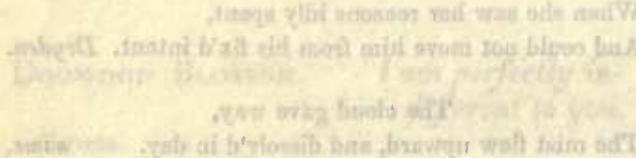

Fir.

Balm of Gilead.

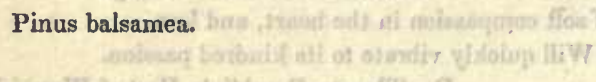

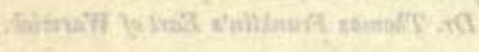

Why, how now, Orlando! where liave you been all this while? You a lover? An' you serve me such another trick, never come in nuy siglt more. . Shaks.

Nay, an' you be so tardy, come no more in my sight; I had as lief be woo'd of a snail. . . . . same.

Break an hour's promise in love? He that will divide a minute into a thousand parts, and break but a part of the thousandth part of a minute in the affairs of love, it may be said of him, that Cupid hath clapp'd him o' the shoulder, but I warrant him heart whole. . . same.

Ah! how much must that poor heart endure,

Which hopes from thee, and thee alone a cure! Bowles.

Years have not seen, time shall not see

The hour that tears my soul from thee. . . Byron.

And as age but makes the vine,

Whose young tendrils wander

Round the sapling stem, entwine

Fonder there and fonder-

So my breast for thee retains

The first love that bound it;

Time can only twine the chains thingugl 



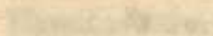

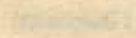

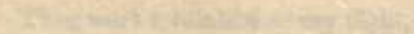

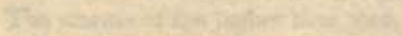

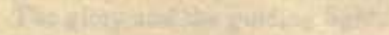

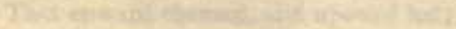

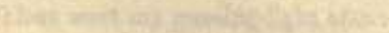

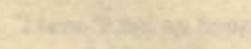

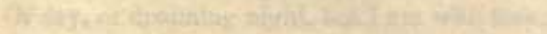

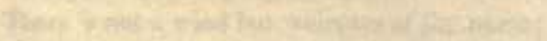

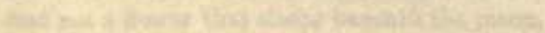

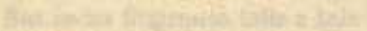

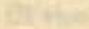

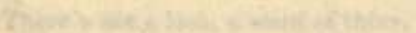

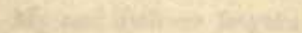

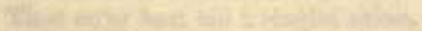

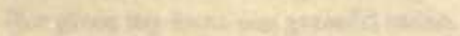

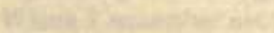

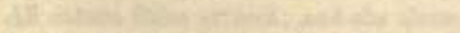

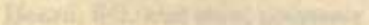

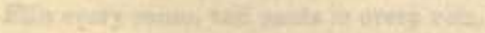


Fir. (Continued.)

Fox Glove. $A$ wish.

Digitalis.

Hopes, which ought not, like things of time, to cloy, And feelings time shall deepen-not destroy. Barton.

Oh ! that I were a glove upon that hand, That I might touch that cheek! . . . . Shaks.

Ah ! might I breathe my humble vow,

Might she too deign to lend an ear !

Elvira's self should then allow

That Armine was at least sincere.

Wild wish ! to dream the matchless maid

Would listen to a youth like me;

Or that my vows could e'er persuade,

Sincere and constant though they be ! Cartwright.

For myself alone,

I would not be ambitious in my wish;

Yet for you,

I would be trebled twenty times myself;

A thousand times more fair, ten thousand times more rich, That only to stand high in your account, I might in virtues, beauties, livings, friends, Exceed account! . . . Shaks.

\section{Fuchsia. Th' ambition in my love thus plagues itself.}

Love lies-a-bleeding. 
Fuchsia.

(Continued.)
This is the truth: his spirit wholly turn'd

To stern ambition's dream, to that fierce strife

Which leads to life's high places, and reck'd not

What lovely flowers might perish in his path. $L . E . L$.
Geranium, Apple. Present preference.

Pelargonium pomifragrans.

Emma with smiles receives his present flame;

But, smiling, will she ever be the same?

Beautiful looks are rul'd by fickle minds;

And summer seas are turn'd by sudden winds.

Another love may gain her easy youth :

Time changes thoughts, and flattery conquers truth.

Prior.

I know not what my future thoughts will be:

Poor woman's thoughts are all extempore.

Wise men, indeed,

Reforehand a long chain of thoughts produce;

But ours are only for our present use. . Dryden.

Never should man too confident assert,

Much less by oath should bind himself to aught;

For soon our judgments change, and one opinion

Destroys another. . . . Sophocles' Antigone.

With fame, in just proportion, envy grows;

The man that makes a character, makes foes. Young.

Great and good persons well may be

From guilt, but not from envy free. . . Barron.

Few have the fortitude of soul to honour

A friend's success, without a touch of envy.

Aschylus' Agamemnon.

Base envy withers at another's joy,

And hates that excellence it cannot reach. Thomson.

Envy doth invade

Works breathing to eternity; and cast

Upon the fairest piece the greatest shade. . Aleyn.

Envy will merit as its shade pursue;

But like a shadow, proves the substance true. Pope.

The great should have the fame of happiness,

The consolation of a little envy;

'Tis all their pay for those superior cares,

Those pangs of heart their vassals ne'er can feel.

Young. 


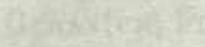

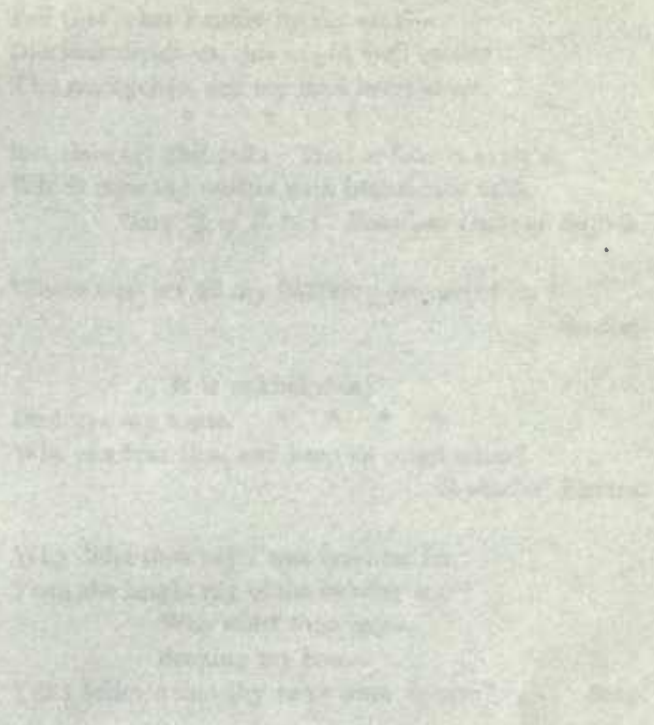

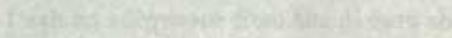

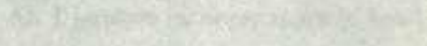

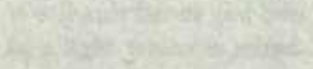

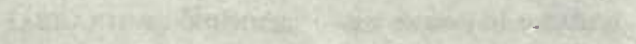




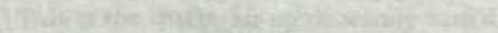

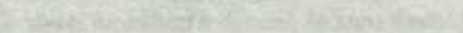

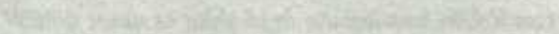

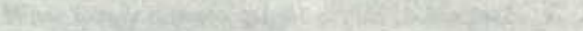

2.

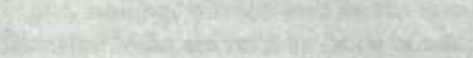

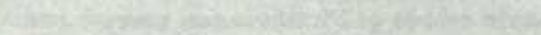

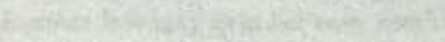

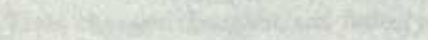

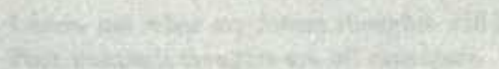

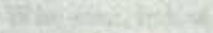

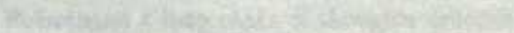

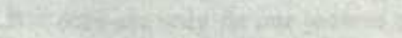

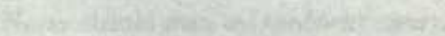

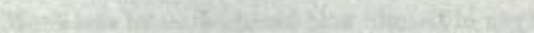

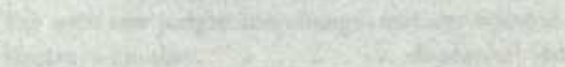

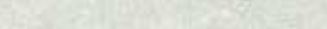

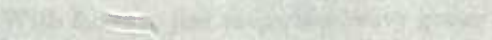

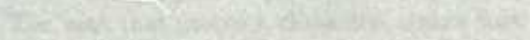

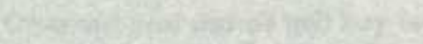

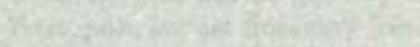

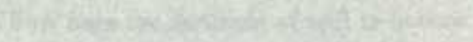

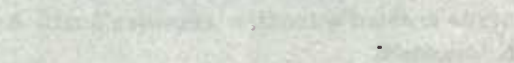

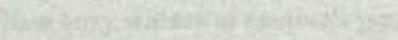

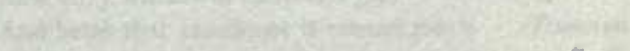

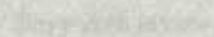

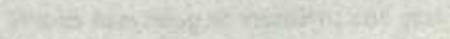

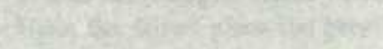

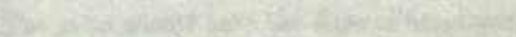

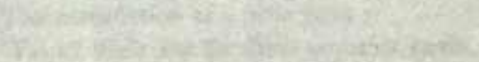

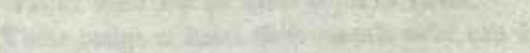


Geranium, Fish.

Pelargonium inquinans.
Disappointed expectation.

Let this

Tell thee what I suffer by thy stay-

Did seas divide us, this might well excuse

Thy negligence, and my fond heart abuse.

But thou art changed! That ardour is expir'd,

Which once thy wishes with impatience fir'd.

Mary Q. of F. to C. Brandon, Duke of Suffolk.

Where now are all my flatt'ring dreams of joy?

Smollet.

It is unkind delay

Destroys my hopes. * * * * *

Who can bear this, and keep an equal mind?

Sophocles' Electra.

Why didst thou say I was brighter far

Than the bright ray of the ev'ning star?

Why didst thou come,

Seeking my home,

Till I believ'd that thy vows were sincerc? . Song.

$I$ ask no vengeance from the powers above,

All I implore is, never more to love! . . Iyttelton.

Geranium, Ivy. Your hand for the next Be her my choice, who knows with perfect skill, quadrille?

Pelargonium peltatum.

When she should move, and when she should stand still;

Who, uninstructed, can perform her share,

And kindly half the pleasing burthen bear.

A nameless gracc does in her movements dwell,

Which words can ne'er express, or precepts tell.

'Tis such an air that makes her thousands fall

When Fielding dances at a birth-nigbt ball;

Smooth as Camilla she skims o'er the plain,

And flies, like her, through crowds of heroes slain.

S. Jenyns.

Answer.

We 'll knit hands and beat the ground,

In a light fantastic round. . . . . . Milton.

Geranium, Nutmeg. An expected meeting

The joys of meeting pay the pangs of absence;

Else who could bear it ? . . . . . Rowe.

P. odoratissimum. 


\section{Geranium.}

(Continued.)

The heavy hours are almost past,

That part my love and me;

My longing eyes may hope at last

Their only wish to see .....

Lyttelton.

\section{I go my love to meet-}

Oh ! may I find her as we parted last-

And may each future hour be like the past. - same.

Oh! how impatience gains upon the soul, When the long promised hour of joy draws near!

How slow the tardy moments seem to roll! Mrs. Tighe.

'Tis sweet to know there is an eye will mark

Our coming, and look brighter when we come. Byron.

Let fate frown on, so we part not ;

'Tis life where thou art, 'tis death where thou art not.

Moore.

\section{Geranium, Oak. Lady, deign to smile.}

Oh, where are the bright gleaming glances I miss?

Anon.

P. quercifolium.

Geranium, Rose.

Preference.

P. capitatum.
Do not blast my springing hopes,

That thy kind hand has planted in my soul! . Rowe.

Nor send me by thy frown from her I love,

Distant and sad; a banish'd man to rove. . . Prior.

What dangerous action, stood it next to death,

Would I not undergo for one calm look ? . Shaks.

Loose, now and then, a scatter'd smile,

And that I'll live upon. . . . . . . . same.

\section{Lady, I pray thee give}

One look whereon may absence live.

One word, upon my ear to dwell,

And then, sweet lady mine-farewell! . . L. E. $L$.

But thee I love, by love's own sweet constraint. Shaks.

\section{Admir'd Miranda!}

Indeed, the top of admiration: worth

What 's dearest to the world! full many a lady

I have eyed with best regard; and many a time

The harmony of their tongues hath into bondage

Brought my too diligent ears; but you-Oh, you,

So pcrfect and so peerless, are created

Of every creature best. . . . . . Shaks. 



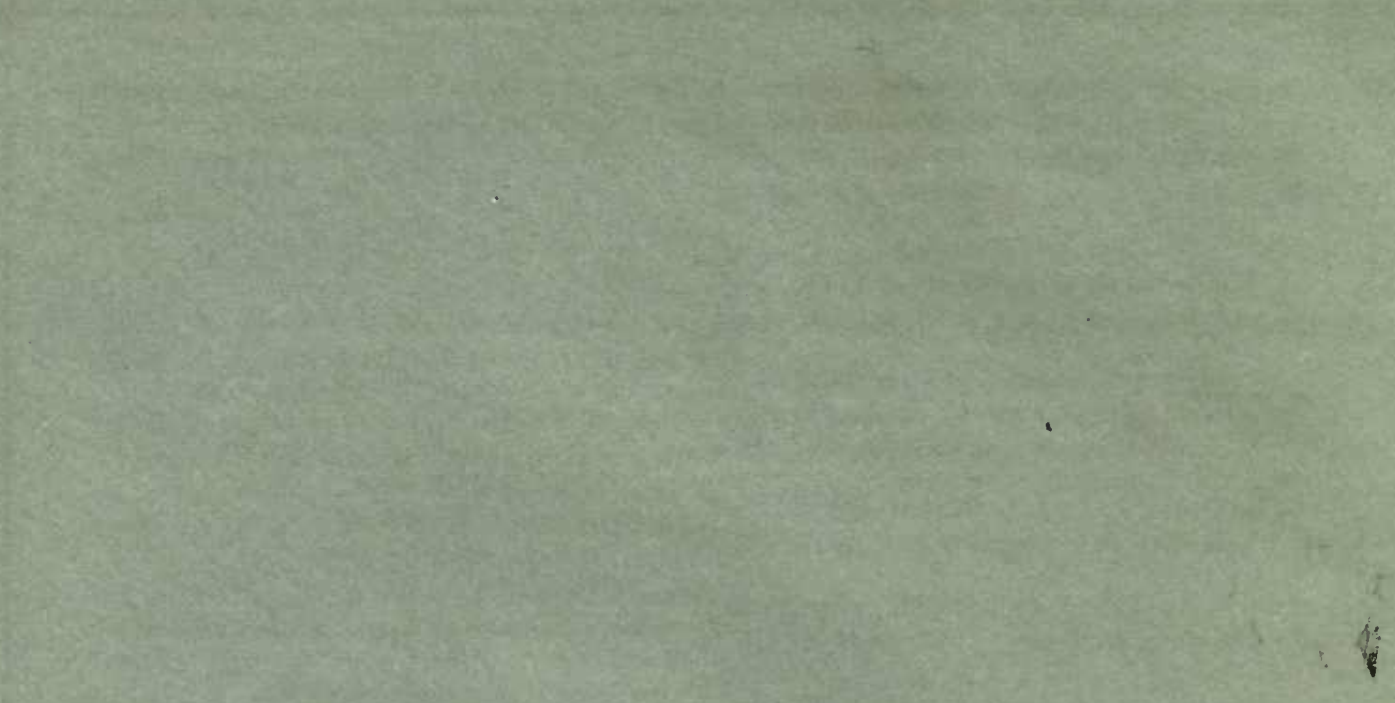


Geranium.

(Continued.)
And preferred in his heart the least ringlet that curl'd Down her exquisite neck, to the throne of the world.

Moore.

\section{Geranium, Silver Leaved. Recall.}

P. argentifolium.

Something since his going forth is thought of,

That his return is now most necessary. . . Shaks.
How angrily I taught my brow to frown,

When inward joy enforc'd my heart to smile.

My penanco is, to call * * * * back,

And ask remission for my folly past. . . . same.

'Tis not in language to impart

The secret meltings of my heart. Addison's Rosamond.

Fain would my tongue his griefs appease,

And give his tortur'd bosom ease. . . . . same.

If in thy soul thou 'st ever felt

Half what thy lips impassion'd swore. . . Moore.

If thou hast known

No other flame, nor falsely thrown

A gem away that thou hast sworn

Should ever in thy heart be worn. . . . . same.

Come, and remove doubts of my love;

But, if thou lov'st me not, como not to me.

Oh! if thy vow wearies thee now,

Though I may weep for thee, never come here. Song.

\section{Answer.}

Doubt thou the stars are fire;

Doubt that the sun doth move;

Doubt truth to be a liar;

But never doubt I love. . . . . . . Shaks.

\section{Gilly Flower.}

Bonds of Affection.

Cheiranthus incanus.

If this, he cried, bondage be,
Who would wish for liberty? . . . . Moore.

Oh! who the exquisite delights can tell, The joy which mutual confidence imparts? Or who can paint the charm unspeakable, Which links in tender bands two faithful hearts?

Mrs. Tighe's Psyche. 


\section{Gilly Flower.}

(Continued.)

\section{Golden Rod;}

or, Virgo aurea.

\section{Solidaga.}

Oh! the tender ties,

Close twisted with the fibres of the heart!

Which broken, break them, and drain off the soul

Of human joy, and make it pain to live. . . Young.

It is the secret sympathy,

The silver link, the silken tie,

Which heart to heart, and mind to mind,

In body and in soul can bind. . . . . . Scott.

Oh! if there be an clysium on earth,

$$
\text { It is this- }
$$

When two that are link'd in one heavenly tie,

Love on through all ills, and love on till they die.

Moore.

Encouragement.

Vivez: le sceptre d'or que vous tend cette main, Pour vous de ma clémence est un gage certain.

Racine's Esther.

Lady Easy. Pray, when you found you could not like him at first, why did you ever encourage him?

Lady B. Modish. Why, what would you have one do? for my part I could no more choose a man by my eye, than a shoe: one must draw them on a little to see if they are right to one's foot.

Lady $\boldsymbol{E}$. But I'd no more fool on with a man I could not like, than I'd wear a shoe that pinch'd me.

Lady B. Ay, but then a poor wretch tells one, he 'll widen 'em, or do any thing ; and is so civil and silly, that one does not know how to turn such a trifle as a pair of shoes, or an heart, upon a fellow's hands again.

Colley Cibber.

\section{Answer.}

Quelle voix salutaire ordonne que je vive, Et rappelle en mon sein mon ame fugitive?

Racine's Esther.

That word beams comfort ** a ray

That brightens through the melancholy gloom.

Aschylus. The Persians.

Blest be the hour, he cried, that happy hour,

When first I own'd my Delia's power. . . Lyttelton.

He found her kind, and soon believed her true. same. 


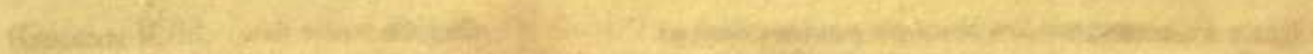
Shaverath

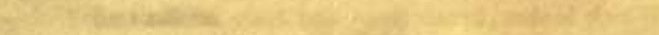

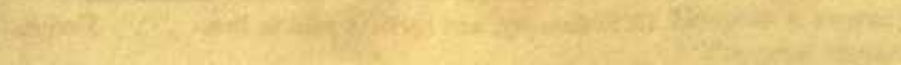

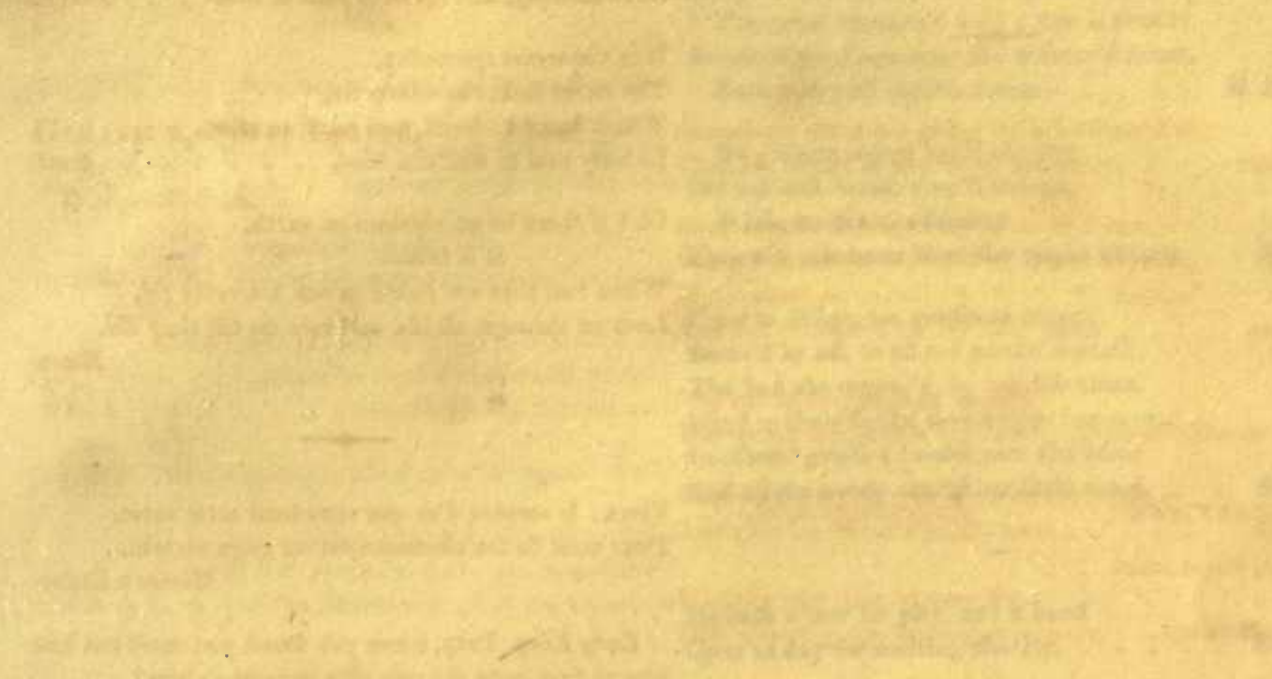

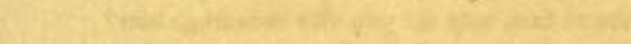

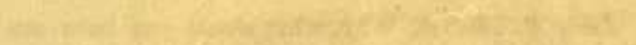

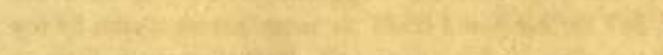

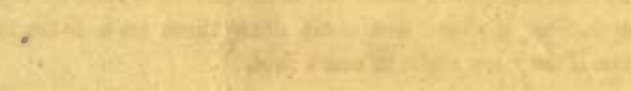

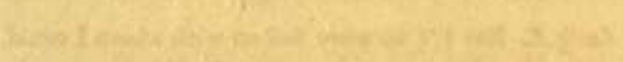

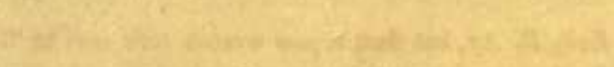

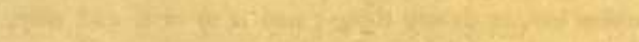

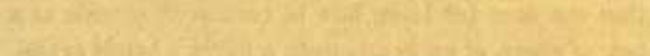
$3 x^{2}+3 y^{2}=12$

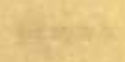

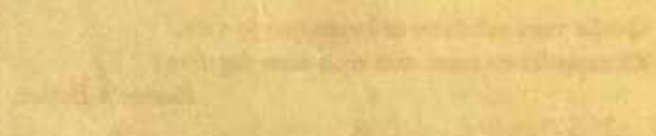

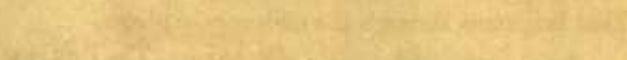

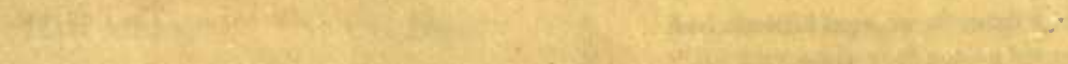

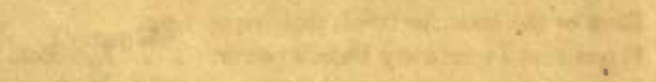

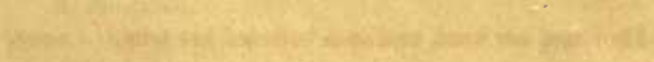

(25)

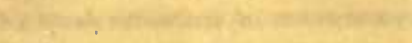

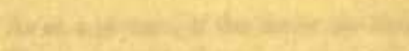

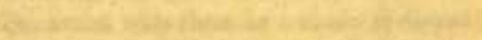

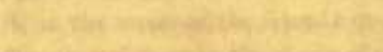

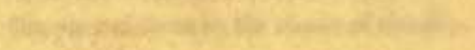




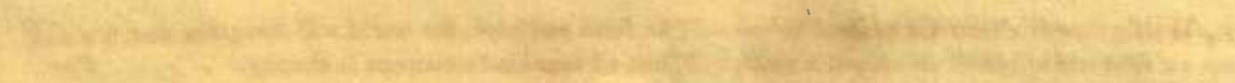

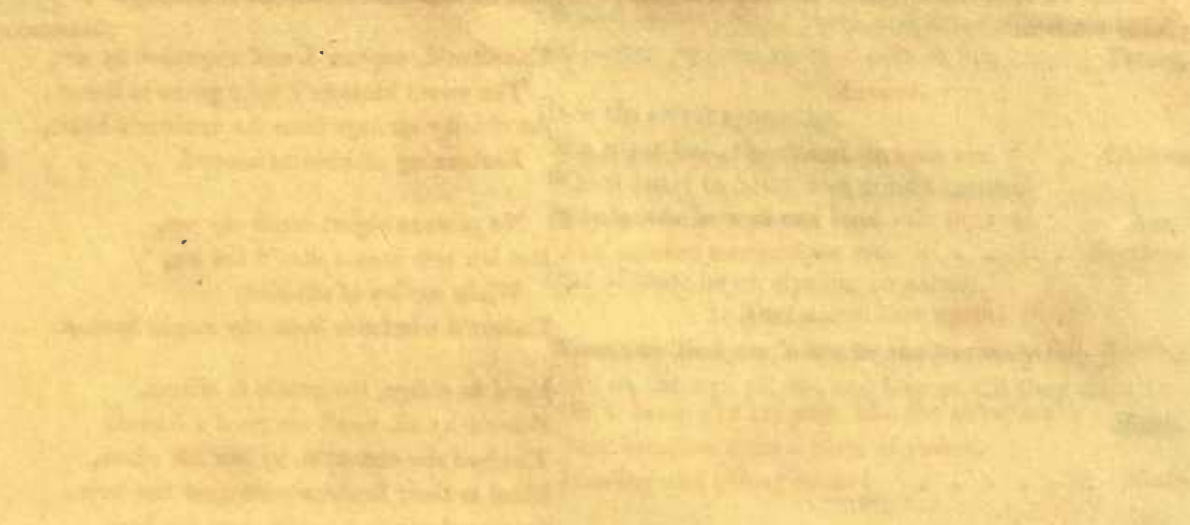

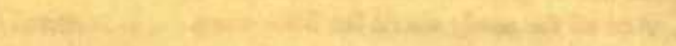

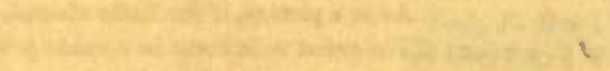

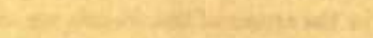

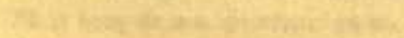
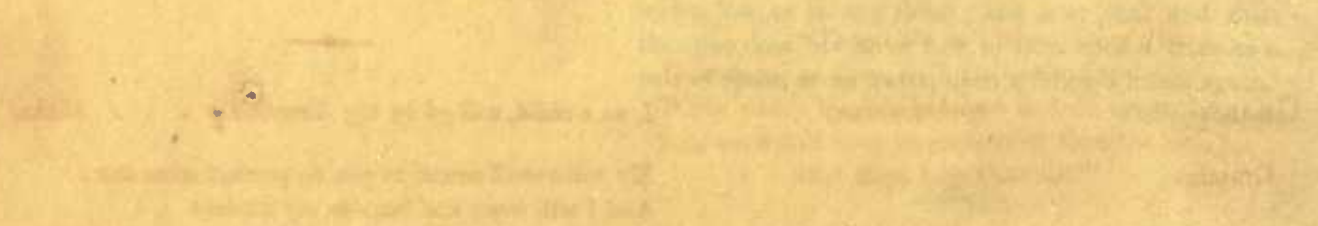

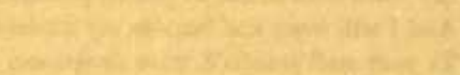

(12)

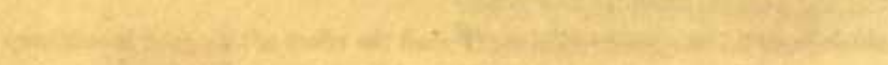

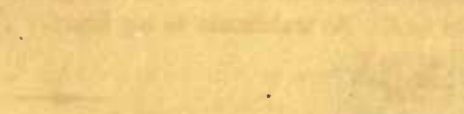

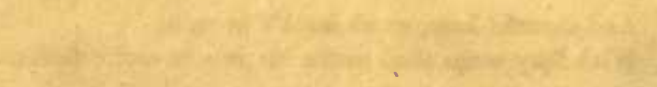

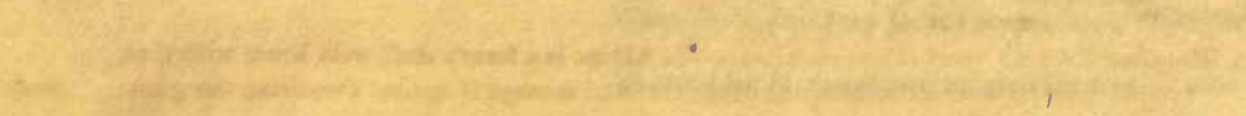




\section{GrAPE, Wild. \\ Charity.}

Vitis vinifera.

In faith and hope, the world will disagree, But all mankind's concern is charity. . . Pope.

Uncultur'd, unprun'd, and unguided by art,

The sweet blossom'd wild grape is found;

As charity springs from the untutor'd heart,

Embracing all objects around. . . .

B. L. L.

No piteous object could she see,

But her' soft bosom shar'd the wo,

While smiles of affability

Endear'd whatever boon she might bestow. . Shaw.

Fond to oblige, too gentle to offend,

Belov'd by all, to all too good a friend;

The bad she censur'd, by her life alone,

Blind to their faults, severe upon her own.

In others' griefs a tender part she bore,

And all the needy shar'd her little store. . . Anon.

He hath a tear for pity, and a hand

Open as day for melting charity. . . . . Shaks.

No harsh reflections let remembrance raise,

Forbear to mention what thou canst not praise. Prior.

As in a picture, if the faults abound,

The artist veils them in a shade profound;

So in the errors of the friends we see,

Oh, shroud them in tho shade of charity. ... Anon.

Grass. Submission.

Gramina.
I, as a child, will go by thy direction? . - Shaks.

My voice shall sound as you do prompt mine ear;

And I will stoop and humblo my intents

To your well practis'd, wise directions. . . same.

I shall the cffect of this good lesson keep

As watchman to my heart. . . . . . . same.

$\begin{array}{lll}\text { Hawthorn. } & \text { Hope. } & \text { And cheerful hope, so oft invok'd in vain, } \\ & \text { With fairy songs shall soothe his pensive ear. Collins. } \\ \text { Crategus. } & \text { Hope is a lover's staff, walk hence with that, } \\ \text { A. Mespilus. } & \text { And manage it against despairing thoughts. . Shaks. }\end{array}$

$\begin{array}{lll}\text { Hawthorn. } & \text { Hope. } & \text { And cheerful hope, so oft invok'd in vain, } \\ & \text { With fairy songs shall soothe his pensive ear. Collins. } \\ \text { Crategus. } & \text { Hope is a lover's staff, walk hence with that, } \\ \text { A. Mespilus. } & \text { And manage it against despairing thoughts. . Shaks. }\end{array}$

$\begin{array}{lll}\text { Hawthorn. } & \text { Hope. } & \text { And cheerful hope, so oft invok'd in vain, } \\ & \text { With fairy songs shall soothe his pensive ear. Collins. } \\ \text { Crategus. } & \text { Hope is a lover's staff, walk hence with that, } \\ \text { A. Mespilus. } & \text { And manage it against despairing thoughts. . Shaks. }\end{array}$

$\begin{array}{lll}\text { Hawthorn. } & \text { Hope. } & \text { And cheerful hope, so oft invok'd in vain, } \\ & \text { With fairy songs shall soothe his pensive ear. Collins. } \\ \text { Crategus. } & \text { Hope is a lover's staff, walk hence with that, } \\ \text { A. Mespilus. } & \text { And manage it against despairing thoughts. . Shaks. }\end{array}$

$\begin{array}{lll}\text { Hawthorn. } & \text { Hope. } & \text { And cheerful hope, so oft invok'd in vain, } \\ & \text { With fairy songs shall soothe his pensive ear. Collins. } \\ \text { Crategus. } & \text { Hope is a lover's staff, walk hence with that, } \\ \text { A. Mespilus. } & \text { And manage it against despairing thoughts. . Shaks. }\end{array}$

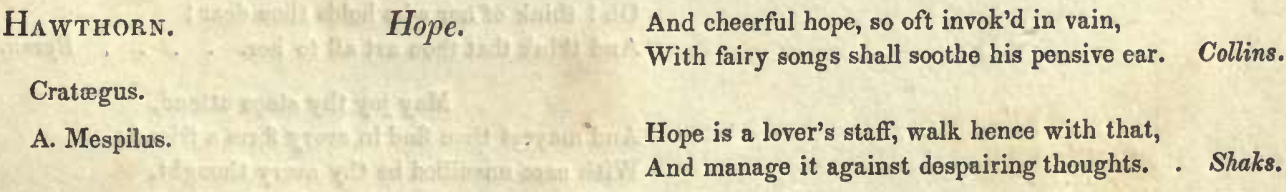




\section{HAWTHORN.}

(Continued.)

This bud of love, by summer's ripening breath,

May prove a beauteous flower, when next we meet.

Shaks.

\section{Answer}

I feel a dawn of joy break in upon me! . . Addison.

Thy words have darted hope into my soul,

And comfort dawns upon me. . . . Southern.

\section{Oh! speak that again!}

Sweet as the syren's tongue those accents fall. Southey.

Oh, it came o'er my soul, like the sweet south

That breathes upon a bank of violets,

Stealing and giving odour! . . . Shaks.

'Twas whisper'd balm, 'twas sunshine spoken! Moore.

I 'd live years of grief and pain,

To have my long sleep of sorrow broken

By sueh benigin, blessed sounds, again. . . same.

\section{Heart's Ease, Yellow and Purple. \\ Forget me not.}

Viola tricolor.
Though we should meet no more,

Sweet maid, forget me not. . . . . Anon.

Think of him whose prayer shall bless thee;

Think of him thy love had bless'd ! . . Byron.

He ne'er will forget the short vision that threw

Its enehantments around liim, while lingering with you.

Moore.

$$
\text { "Forget me not, when others gaze }
$$

Enamoured on thee, with the looks of praise.

When weary leagues between us both are cast, And each dull hour seems heavier than the last,

$\mathrm{Oh}$ ! then forget me not !'

\section{Answer.}

Remember thee, and all thy pains-

And all thy love for me !

Yes! while a breath, a pulse remains,

Will I remember thee ! . . . . Montgomery.

Oh ! think of her who holds thee dear !

And think that thou art all to her. . Byron.

May joy thy steps attend, And mayest thou find in every form a friend; With care unsullied be thy every thought, And in thy dreams of home, forget me not! . Song. 




\section{Heart's Ease, Purple.}

Viola tricolor.
You occupy my Neither rhyme nor reason can express how much ! thoughts.

Shaks.

My love for thee is such, as absence ne'er can quell.

Anon.

Dwelling deep in my shut and silent heart!

Byron.

And in

My soul, which flies to thee, her trust, her treasure-

As misers to their gold, while others rest.

Young.

Whilst love, by absence fed, without control

Tumultuous rushes on his soul.

Eschylus' Agamemnon.

HearT's Ease, Wild. Love in idleness. While idly I stood looking on,

Viola tricolor.

I found the effect of love in idleness ! . . . Shaks.

I looked, and looked, and still with new delight;

Such joy my soul, such pleasure filled my sight.

Dryden, from Chaucer.

Helen, I love thee; by my life I do;

I swear by that which I will lose for thee,

To prove him false, that says I love thee not.

Shaks.

And all the faith, the virtue of my heart,

The object, and the pleasure of mine eje,

Is on Helena.

same.

Whom I do love, and will do to my death.

same.

\section{HeLiotrope. Devotion.}

Heliotropium.

Gaze on my cheek,

And let its hue when thou art near, my heart's devotion speak,

Look on iny dim and tearful eye, my pale and rigid brow, And list my wild, unbidden sigh,- - what need of pledge or vow.

Anon.

I behold her

With adoration-feast my eye, while all

My other senses starve; and oft frequenting

The place which she makes happy with her presence,

I never yet had power, with tongue or pen,

To move her to compassion, or make known

What 'tis I languish for; yet I must gaze still

Though it increase my flame.

Massinger's Bashful Lover. 


\section{Heliotrope.}

(Continued.)
She was a form of life and light,

That seen became a part of sight;

And rose where'er I turn'd my eye,

The morning star of memory ! . . . Byron.

So turns the needle to the pole it loves

With fine librations quiv'ring as it moves. Darwin.

Her overpowering presence made you feel

It would not be idolatry to kneel. . . . . Byron.

\section{Answer.}

If you do love the maid-

Bend thoughts and wits to achieve her. . . Shaks.

Cross your meek arms, incline your wreathed brows,

And win the goddess with unwearied fows. Darwin.
HeLLEBore.

Helleborus.
Calumny. Scandal. Virtue itself 'scapes not calumnious stroke.

Shaks.

No might nor greatness in mortality

Can censure 'scape; back-wounding calumny

The whitest virtue strikes; what king so strong,

Can tie the gall up in the slanderous tongue? same.

On eagle's wings immortal scandals fly;

While virtuous actions are but born to die.

Harvey.

It is a busy talking world,

That with licentious breath blows like the wind,

As freely on the palace as the cottage. . . Rowe.

Nor do they trust their tongues alone,

But speak a language of their own;

Convey a libel in a frown,

And wink a reputation down. . . . . . Swift.

We must not stint

Our necessary actions, in the fear

To cope malicious censures. . . . . . . Shaks.

The silence often of pure innocence

Persuades, when speaking fails. . . . . same. 
5 
Hibiscus.

Venetian Mallow;

or, Flower of an hour.

Hibiscus trionum.
Delicate Beauly.

Oh, fairest flower, no sooner blown, but blasted.

Milton.

Beauty is but a vain, a fleeting good,

A shining gloss that fadeth suddenly;

A flow'r that dies when almost in the bud;

A brittle glass that breaketh presently;

A fleeting good, a gloss, a glass, a flow'r,

Lost, faded, broken, dead, within an hour. . Shaks.

But beauty how frail and how fleeting,

The bloom of a fine summer's day ;

While worth in the mind of my Phillis

Will flourish without a decay. . . . Burns.

What 's beauty?-call you that your own,

A flower that fades as soon as blown? . . . Gay.

Who trusts beauty, trusts the fading rose. . 'same.

Youth with rapid swiftness flies,

Beauty's lustre quickly dies.

Horace.

HoLty.

Am I forgotten?

Ilex.
And can thy promise to be mine,

$$
\text { Be e'er forgot? }
$$

If pity in that bosom dwell,

My fears, my jealous fears dispel,

Forget me not:

My life would waste in grief, sweet maid,

As wounded flow'rets droop and fade,

By thee forgot!

Thou bad'st me thy fond vows believe,

And can'st thou now my hopes deceive,

\section{Sweet maid!}

Oh! think upon those vows, dear maid,

When in the grove at eve we 've stray'd,

Deceive me not, my lovely maid.

Song.

$\mathrm{Oh}$ ! if she loves as I have loved,

She never can forget ! . . . . Bayly.

\section{Answer.}

Forget thee ! no never-among the light hearted,

Love may sink to decay, when the fond ones are parted.

But affection like ours is too deep and sublime,

To be chill'd in its ardour by absence or time.

I will not forget thee, till life's latest day

In the dark night of death shall have melted away.

Barbour. 
Holuy.

(Continued.)

Holtyноск.

Hollyноск, White.

Female Ambition.

A. $R$.

HONESTY ;

Sincerity.

or, Satin Flower.

Lunaria.
He loves me still !

And still my heart shall prove, How well it can those vows fulfil,

Which first repaid his love! . . Anon.

Ambition. Powerful source of good and ill : . . . Young.

That gallant spirit hath aspired the clouds. . Shaks.

Great souls

By nature half divine, soar to the stars,

And hold a near acquaintance with the gods. Rowe.

Souls truly great dart forward on the wing

Of just ambition, to the grand result. . . . Young.

Not by words

Would Theseus be distinguished, but by deeds

Illustrious. . . . . Sophocles' Edipus Coloneus.

\section{Ambition is at distance}

A goodly prospect, tempting to the view;

The height delights us, and the mountain top

Looks beautiful, because 'tis nigh to heaven;

But we ne'er think how sandy 's the foundation;

What storms will batter, and what tempests shake it.

Otway's Venice Preserved.

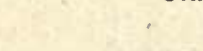





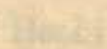

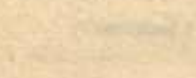

How thithese

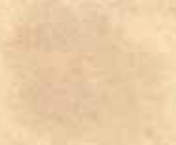

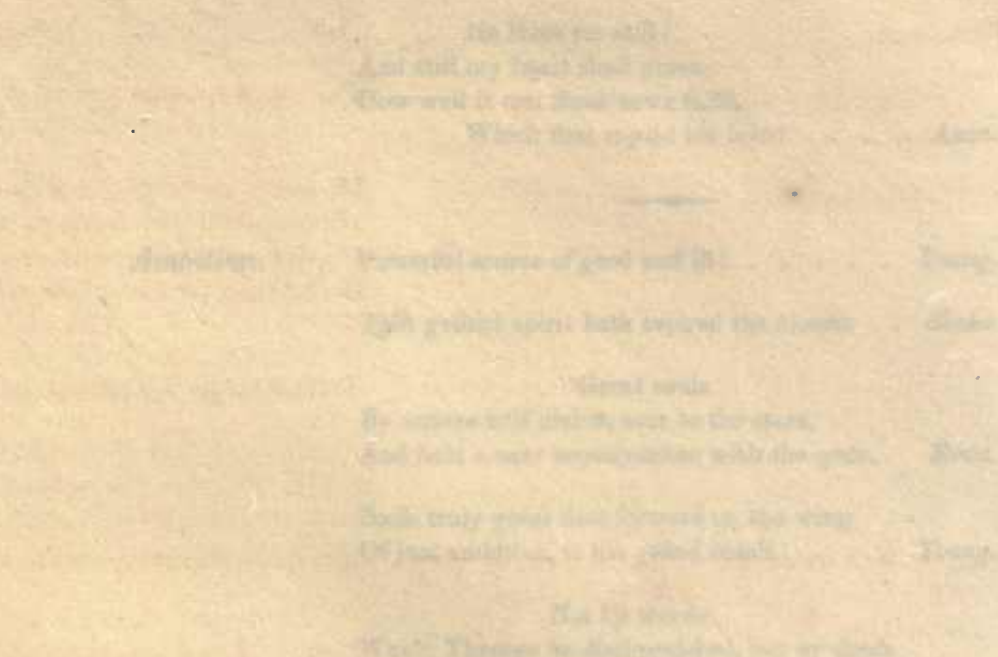

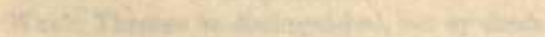

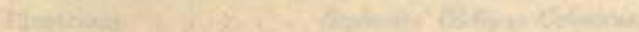

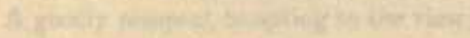

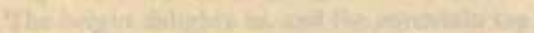

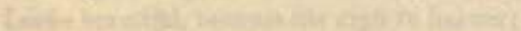

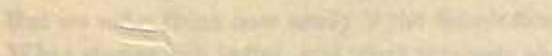

14.

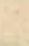

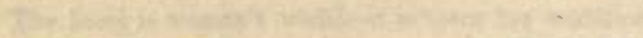

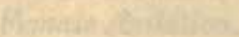

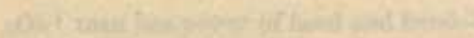

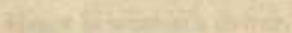

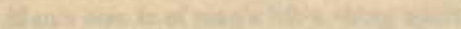

Mit.

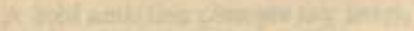

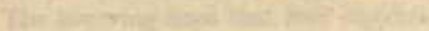

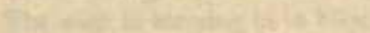

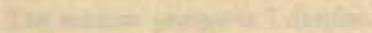

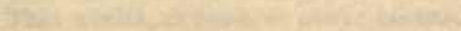

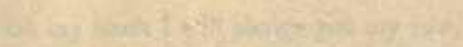

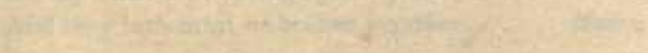

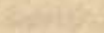

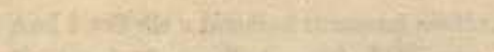

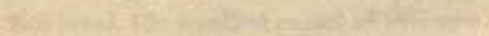


Honesty.

(Continued.)

\section{Answer.}

Thy words convince me; all my doubts are vanished.

Fschylus' Agamemnon.

His words are bonds, his oaths are oracles;

His love sincere, his thoughts immaculate;

His tears, pure messengers sent from his heart;

His heart, as far from guile, as heaven from earth.

Shaks.

Truth from his lips prevailed with double sway.

Goldsmith.

\section{Honey Flower.}

Melianthus.
Honey Flower.

Mourning Bride.

M.

\section{Honeysuckle, Coral. The colour of my fate.}

I have lost all.
Speak low, if you speak love.
And tell, with honey'd words, the tale of love.

Darwin.

How silver sweet sound lovers' tongues by night,

Like softest music to attending ears. . . . Shaks.

That voice was wont to come in gentle whispers,

And fill my ears with the soft breath of love.

Otway.

'Twas like the stealing

Of summer wind through some wreathed shell;

Each secret winding, each inmost feeling

Of all my soul, ecbo'd to its spell! . . . Moore.

Ours, too, the glance none saw beside;

The smile none else might understand;

The whisper'd thought of hearts allied;

The pressure of the thrilling hand. . . . Byron.

With whom, alas ! I fondly hoped to know

The humble walks of happiness below. - . Rogers.

With thee were the dreams of my earliest love;

Every thought of my reason was thine. . . Moore.

My soul's first idol—and its last. . . . . same.

Oh grief, beyond all other griefs, when fate

First leaves the young heart lone and desolate,

In the wide world, without that only tie,

For which it lov'd to live, or fear'd to die !

same.

The day too short for my distress; and night,

E'en in the zenith of her dark domain,

Is sunshine, to the colour of my fate. . . Young.

Lonicera sempervirens. 


\section{HoneysuCKLE.}

(Continued.)

\section{HoneysuCKLe.}

Lonicera.
Pierced through the heart with your stern cruelty !

Shaks.

Still thine own, its life retaineth-

Still must mine though bleeding beat! . . Byron.

I with grief have striven,

But find with each receding day,

The arrow deeper driven! . . . . C. G.

Deep in my breast the rosy tyrant dwells,

Piercing, with cruel aim, each poison'd dart-

And if my eye, my soul's sad torment tells,

It speaks the secret anguish of my heart. . . . Song.

$\mathrm{Oh}$, cruel! will no pang of pity pierce that heart!

Beattie.

We would consider of your suit,

And come some other time to know our mind. Shaks.

But lest you should not understand me well,

(And yet, a maiden hath no tongue but thought, )

I would detain you here some month or two,

Before you venture for me. . . . . . Shaks.

My choice is made-and I must you refuse. Dryden.

So much to win, so much to lose-

No marvel that I fear to choose. . . . . L. E. L.
If you oblige me suddenly to choose,

\section{Honeysuckle, Wild. Generous and} Azalea. devoted love.

Yet, let me say, what firmly I believe,

Love can be-ay, and is. I hold that love

Which chooseth from a thousand only one

To be the object of that tenderness

Natural to every heart; which can resign

Its own best happiness for one dear sake :

Can bear with absence; hath no part in hope,

For hope is somewhat selfish, love is not-

And doth prefer another to itself.

Unchangeable and generous : what, like love,

Can melt away the dross of worldliness;

Can elevate, refine, and make the heart

Of that pure gold which is the fitting shrine

For fire, as sacred as e'er came from heaven? $L . E . L$. 


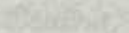

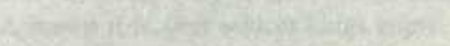

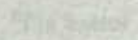

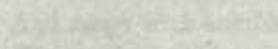

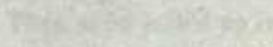

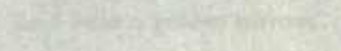

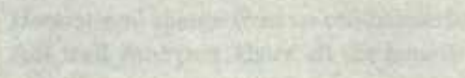

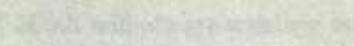

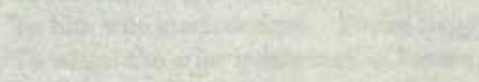

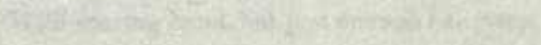

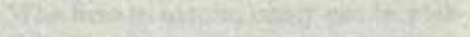

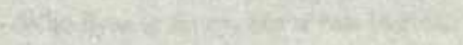

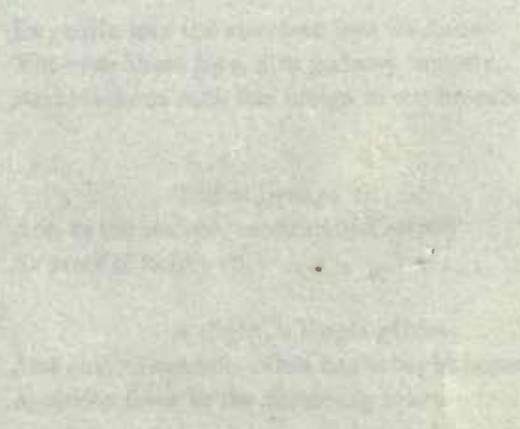




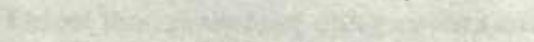
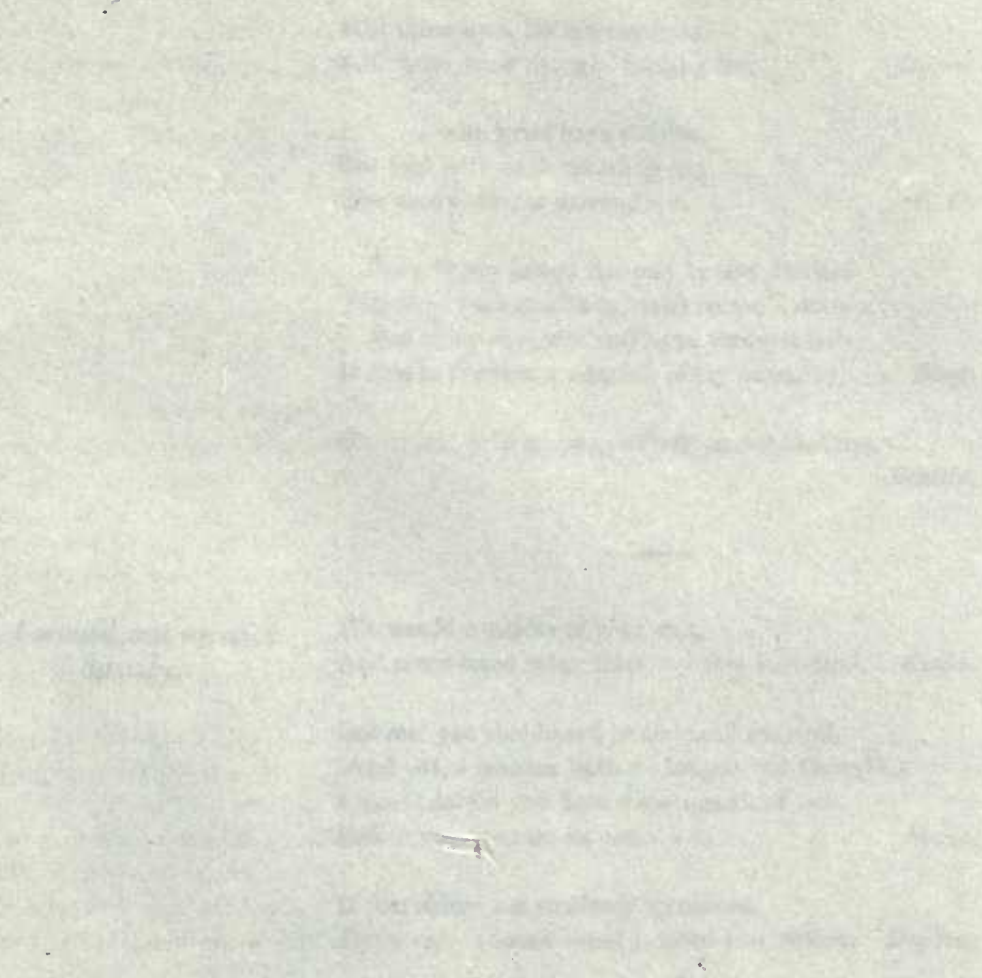

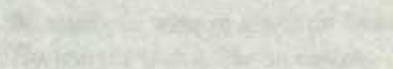

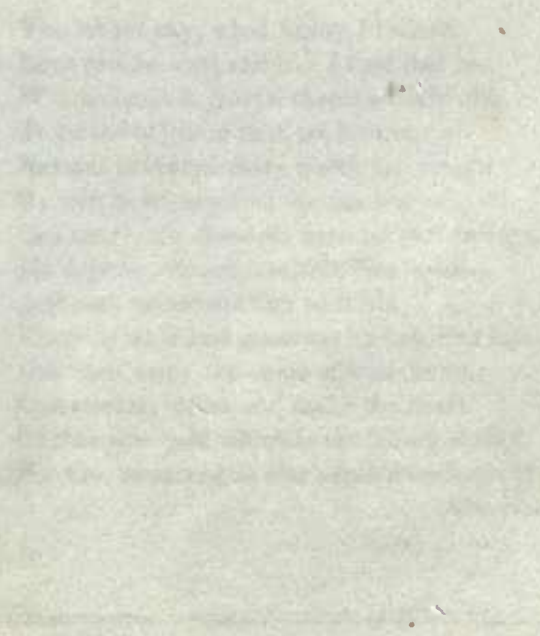




\section{HoneysuckLe.}

(Continued.)
Love, which nor defeated hope, nor baffled wile, Could render sullen, were she ne'er to smile, Nor rage could fire, nor sickness fret to vent On her one murmur of his discontent ;

Which still would meet with joy, with calmness part,

Lest that his look of grief should reach her heart;

Which nought remov'd, nor threaten'd to remove.

Byron.

\section{Houstonia.}

Houstonia cœrulea.

Hyacinth.

Hyacinthus.
Jealousy.

Content.

Contentment gives a crown

Where fortune hath deny'd it. . . . . Ford.

My crown is in my heart, not on my head;

Nor deck'd with diamonds, and Indian stones,

Nor to be seen : my crown is call'd content;

A crown it is, that seldom kings enjoy. . . Shaks.

'Tis better to be lowly born,

And range with humble livers, in content,

Than to be perk'd up in a glistering grief,

And wear a golden sorrow. . . . . same.

Honour and shame from no condition rise,

Act well your part, there all the lionour lies. Pope.

Much will always wanting be

To him who much desircs. Thrice happy he

To whom the wise indulgency of heaven,

With sparing hand, but just enough has given.

Covley.

Who lives to nature, rarely can be poor-

Who lives to fancy, never can be rich. . . Young.

Love, thou knowest, is full of jealousy ! . . Shaks.

In gentle love the sweetest joys we find-

Yet even those joys, dire jealousy molests,

And blackens each fair image in our breasts.

Lyitelton.

Trifles light as air

Are, to the jealous, confirmation strong

As proof of holy writ. . . . . . . Shaks.

A slight, a single glance, And shot at random, often has brought home A sudden fever to the throbbing heart. . . Young. 


\section{Hyacinth.}

(Continued.)

\section{HydRANGER.}

Hydrangea hortensis.

\section{Jasmine, White.}

Jasminum officinale.
Oh, how with one trivial glance,

Might she ruin the peace of my mind! . Shenstone.

\section{A boaster.}

One whom the music of his uwn vain tongue

Doth ravish, like enchanting harmony. . . . Shaks.

The lad of all sufficient merit,

With modesty, ne'er damps his spirit. . . Gay.

The breath of others raises our renown;

Our own, as surely blows the pageant down;

Take up no more than you by worth can claim,

Lest soon you prove a bankrupt in your fame.

Superior honour, when assumed, is lost. . . Young.
Amability.

More sweet, than the jassamine's flower !

What are pinks in a morn to compare?

What is eglantine after a shower? . . Shenstone.

You bear a gentle mind, and heavenly

Blessings follow such creatures. . . . Shaks.

Not only good and kind,

But strong and elevated was her mind.

- Lyttelton.

Still o'er my life preserve thy mild control,

Correct my views, and elevate my soul. • . Rogers.

And love, and gentleness, and joy impart. . Beattie.

\section{Answer.}

Not to delight thine eye alone design'd,

But touch, and calm, and elevate the mind.

\section{Jasmine, Yellow. Grace and Elegance.}

Bignonia sempervirens.

Sweet thoughts are mirror'd in her face,

And every motion is a grace. . . . C C***e.

Her grace of motion, and of look, the smooth

And swimming majesty of step and tread,

The symmetry of form and feature, set

The soul afloat, even like delicious airs

Of flute and harp. . . . . . Milman. 



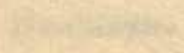

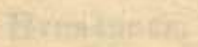

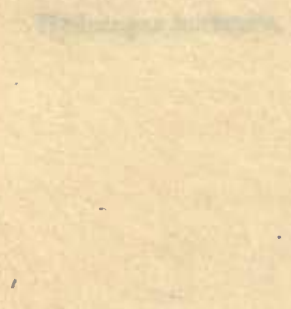

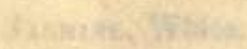

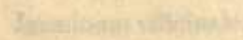

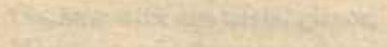

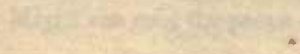

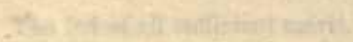

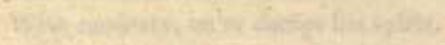

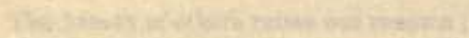

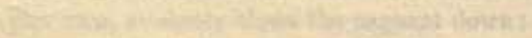

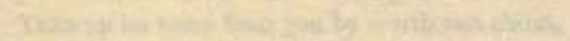

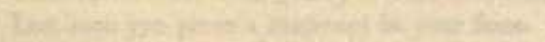

$\therefore 16$

7hoses

artatifin

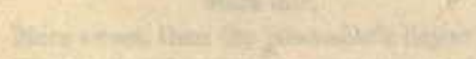

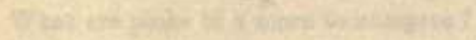

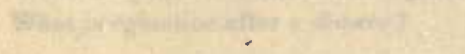

Basonatis

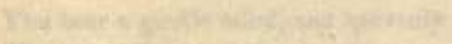

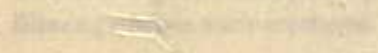

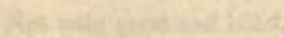

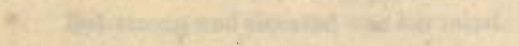

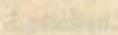

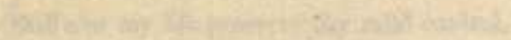

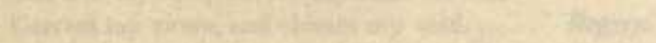

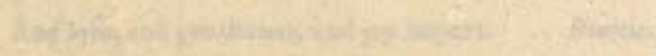

\section{Whiney}

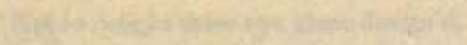

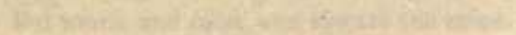

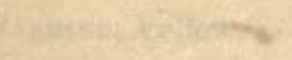

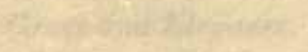

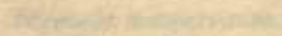

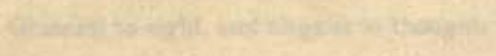

thases.

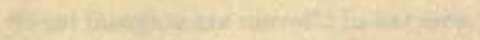

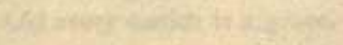

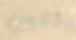


Jasmine, Yellow.

(Continued.)
Grace that with tenderness and sense combin'd

To form that harmony of soul, of face,

Where beauty shines the mirror of the mind.

Mason.

I have been often dazzled by the blaze

Of sun-like beauty; but till now ne'er knew

Perfected loveliness; all the harmonies

Of form, of feat ure, and of soul displayed

In one bright creature, as in thee, my love ;

In whom, beyond compare, her fairest work

Maternal nature hath summed all perfection.
Ice Plant.

Rejected addresses.

Mesembryanthemum crystallinum.
Alas ! my lord, if talking would prevail,

I could suggest much better arguments, Than those regards you throw away on me;

Your valour, honour, wisdom, praised by all :

But bid physicians talk our veins to temper,

And with an argument new-set a pulse ;

Then think, my lord, of reasoning into love. . Young.

Love is not in our power,

Nay, what seems stranger, is not in our choice :

We only love, where fate ordains we should,

And blindly fond, oft slight superior merit. . Frowde.

I cannot love him:

Yet I suppose him virtuous, know him noble, Of great estate, of fresh and stainless youth, In voices well divulg'd, learn'd, and valiant, And in dimensions, and the shape of nature, A gracious person: but yet I cannot love him. Shaks.

If of herself she will not love,

Nothing can move her. . . . . Sir J. Suckling.
JoNQUIL, Rush-leaved.

$I$ desire a return of affection.

Narcissus Jonquilla.
Dissolve me into ecstasies,

And bring all heaven before mine eyes! - . Milton.

The joy most like divine

Of all I ever dreamt or knew,

To see thee, hear thee, call thee mine ! . Moore.

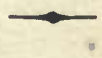

Tell thyself what I would say-

Thou know'st it, and I feel too much to pray. Dryden.

Iris.

I have a message for you. 
IRIS.

(Continued.)
She knew she was by him belor'd-she knew (For quickly comes such knowledge) that his heart Was darken'd with her shadow, and she saw That he was wretched, but she saw not all. - Byron.

\section{A lover's look}

Is his heart's Mercury. $O$ ! the eye's eloquence, Twin-born with thought, outstrips the tardy voice, Far swifter than the nimble lightning's flash, The sluggish thunder-peal that follows it.

George Coleman's Iron Chest.

IvY.

Matrimony.

Hedera.

\section{I have found}

One true companion, one dear soul is mine, Whose converse still doth soothe, arouse, refine.

Howitt.

One sacred oath has tied our loves! . . Prior.

Say, shall I love the fading beauty less,

Whose spring-tide radiance has been wholly mine?

No-come what will, thy steadfast truth I 'll bless ;

In youth, in age, thine own-for ever thine.

A. A. Watts.

Blest in a wife whose beauty, though so rare,

Is the least grace of all that round her wait.

Edwards.

The pure, open, prosperous love,

That, pledg'd on earth, and seal'd above,

Grows in the world's approving eyes,

In friendship's smile, and home's caress ;

Collecting all the heart's sweet ties

Into one knot of happiness. . . . . . Moore.
LABURNUM。 Pensive beauty. Cytisus laburnum.
Fair was her form; but who can hope to trace The pensive softness of her angel face? . Rogers.

When pensive, it seem'd as if that very grace, That charm of all others, was born with her face.

Moore.

\section{Pensive grace}

Was in her every motion, and her look Had something sacred in it, that declared How pure the spirit in that form ensbrined, Like light that dwelleth in the diamond gem. S. P.C. 



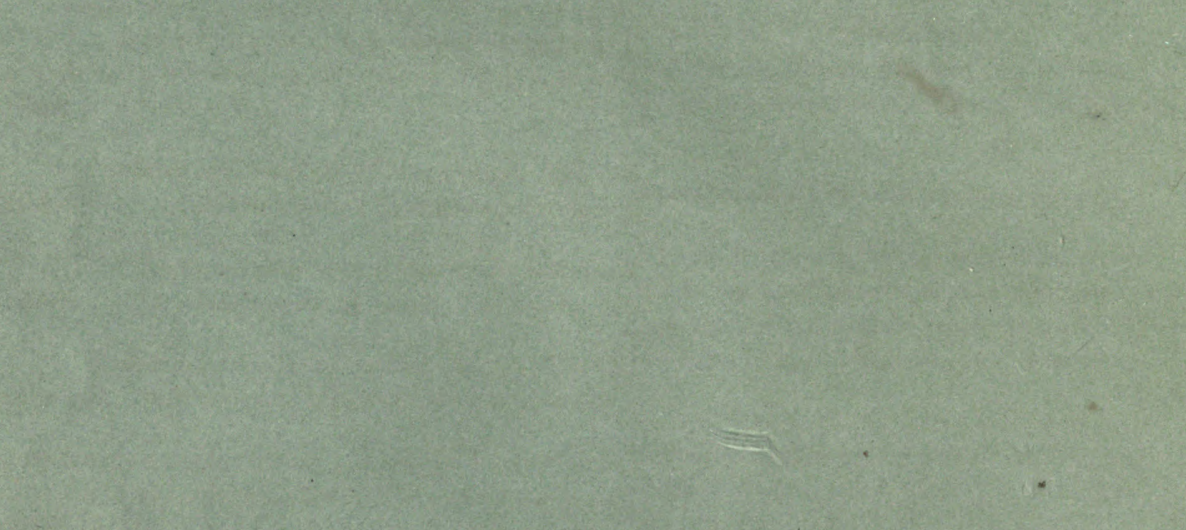




\section{LABURNUM.}

(Continued.)
There was a soft and pensive grace,

A cast of thought upon her face,

That suited well the forehead high,

The eye-lash dark, and downcast eye;

The nild expression spoke a mind

In duty firm, composed, resigned. . . . . Scott.

\section{LADY'S SLIPPFR.}

Cypripedium.
Capricious beauty.

Fair Cypripedia, with successful guile,

Knits her smooth brow, extinguishes her smile.

Darwin.

When angry-for ev'n in the tranquillest climes,

Light breezes will ruffle the blossoms sometimesThe short passing anger but seem'd to awaken

New beauty, like flowers that are sweetest when shaken.

Moore.

Say that she frown; I 'll say she looks as clear As morning roses newly wash'd in dew. . . . Shaks.

No, not the bow which so adorns the skies, So glorious is, or boasts so many dyes. . . Waller.

She will, and she will not, she grants, denies,

Consents, retracts, advances, and then flies. Granville.

Come, come, 't will not do ! put that purling brow down; You can't, for the soul of you, learn how to frown.

H. K. White.

\section{LAgerstremia, Indian.}

L. Indica.
Eloquence. [ Every word he speaks is is a syren's note To draw the careless hearer. $]$. . . . Beaumont.

Celestial raptures flowed in every word,

In every motion, kindling warmth divine,

To seize who listen'd. . . . . . . Akenside.

Whose words all ears took captive. . . . . Shaks.

With an eloquence-not like those rills from a height

Which sparkle, and foam, and in vapour are o'er,

But a current that works out its way into light, Through the filtering recesses of thought and of lore.

Moore.

So sweet and voluble is his discourse,

That aged ears play truant at his tales,

And younger hearings are quite ravished. . . Shaks. 
LAGERSTRAMIA.

(Continued.)

From her sweet lips smouth elocution flows.

Gay.

Gaze as we learn, and as we listen, love. . Darwin.

Whose gentle lips persuade without a word,

Whose words, e'en when unmeaning, are ador'd.

Moore.

'Tis not the powerful arm,

But soft enchanting tongue, that governs all.

Sophocles' Philoctetes.

- To listen to her, is to seem to wander

In some enchanted labyrinth of romance,

Whence nothing but the lovely fairy's will

That wove the spell, can extricate the wanderer. Scott.

LARKSPUR.

Lightness.

For unto knight there is no greater shame,

Than lightness, and inconstancy in love. . . Spencer.

Delphinium.

Men's fancies are more giddy and unfirm,

More longing, wavering, sooner lost and won,

Than women's are. . . Shaks.

He wears his faith but as the fashion of his hat,

It ever changeth with the next block. . . . . same.

No woman can endure a recreant knight. . Dryden.

They know how fickle common lovers are;

Their oaths, and vows, are cautiously believed,

For few there are, but have been once deceived. same.

Larkspur, Pink.

Fickleness. Ladies whuse love is constant as the wind. - Young.

D.

We in vain the fickle sex pursue,

Who change the constant lover for the new. Prior.

Of constancy no root infix'd,

That either they love nothing, or not long. same.

Inconstant as the passing wind,

As winter's dreary frost unkind ;

To fix her, 'twere a task as vain

To count the April drops of rain. . . . Smollet.

She was fair-and my passion begun;

She smiled-and I could not but love;

She is faithless-and I am undone. . . . Shenstone. 


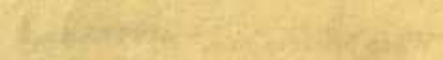

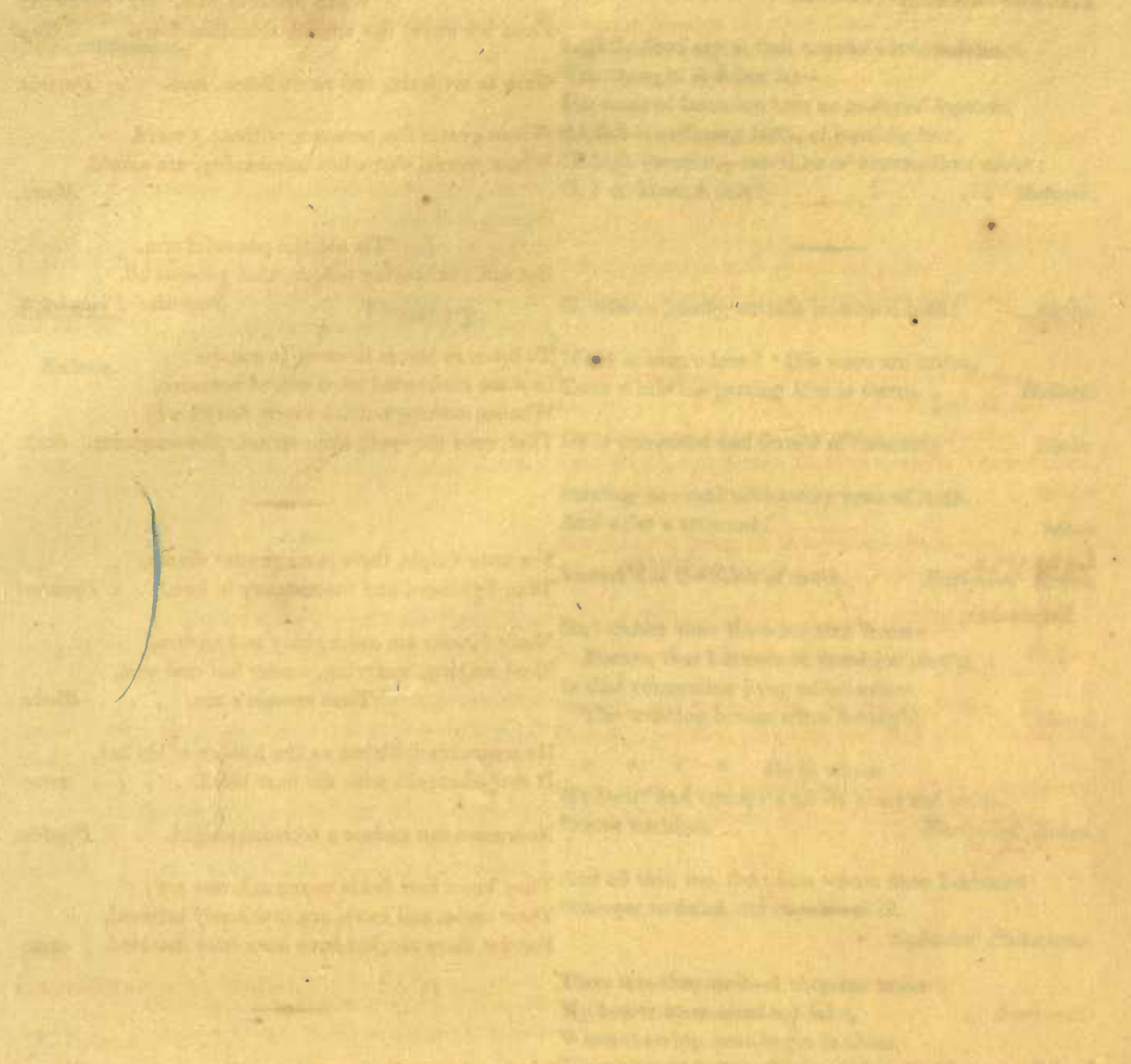

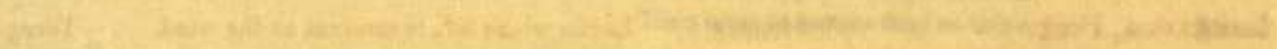

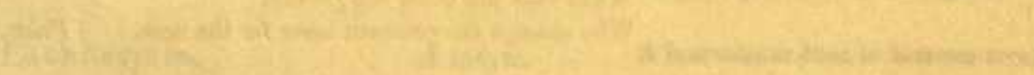

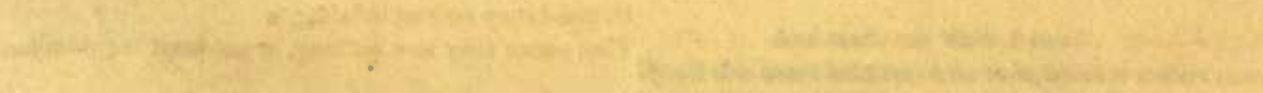

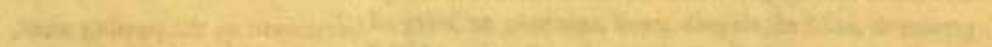

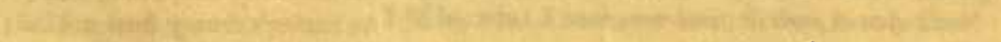

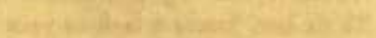

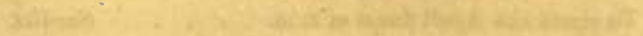

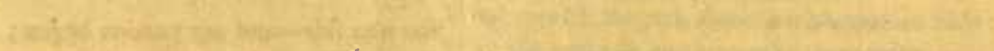

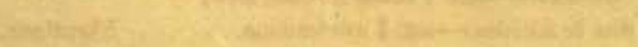




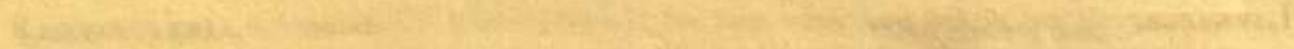

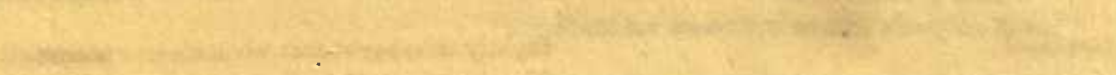

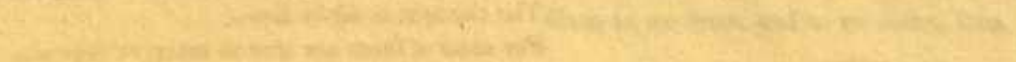

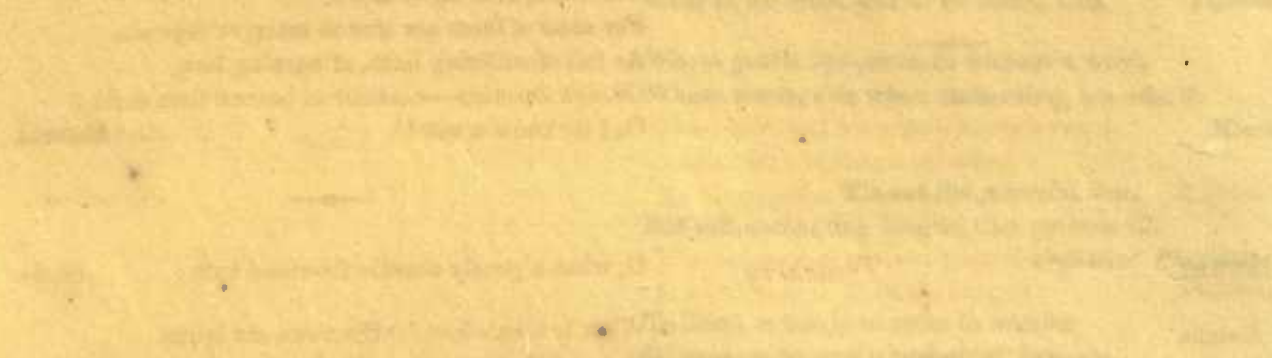

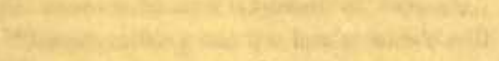

In the

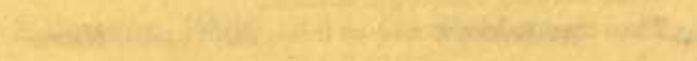
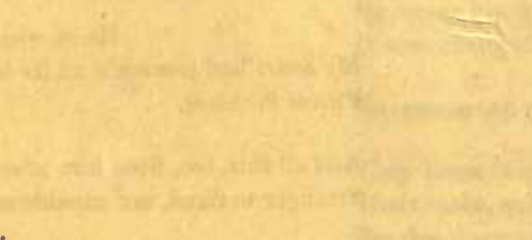

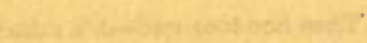

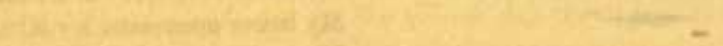

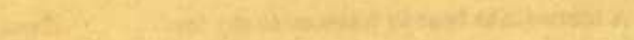

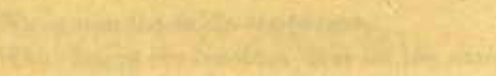

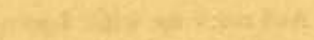

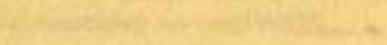

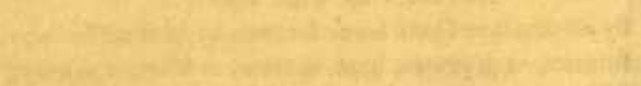

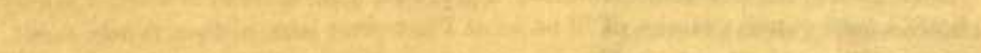

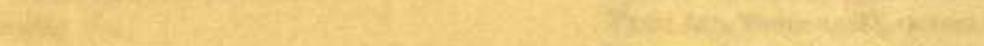

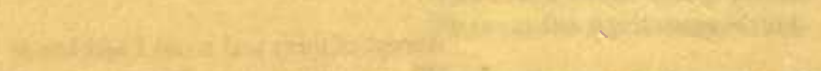

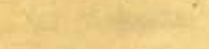

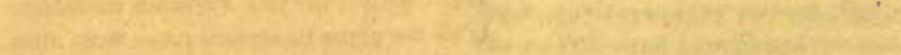




\section{LARKSPUR.}

(Continued.)

LAUREL.

Kalmia.

\section{Laurustinus.}

A token.

Viburnuın tinus.
Answer.

Lightly thou say'st that woman's love is false, The thought is falser far-

For some of them are true as martyrs' legends, As full of suffering faith, of burning love, Of high devotion-worthier of heaven than earth;

$\mathrm{O}, \mathrm{I}$ do know a tale! . . . . . . Maturin.

Treachery. $\quad$, what a goodly outside falsehood hath! . . Shaks.

What is man's love? His vows are broke,

Even while his parting kiss is warm. . . Halleck.

He is composed and fram'd of treachery ! . . Shaks.

Stealing her soul with many vows of faith,

And ne'er a true one ! . . . . . same.

Vanish'd is the faith of oaths. . . Euripides' Medea.

Oh! colder than the wind that freezes

Founts, that but now in sunshine play'd,

Is that congealing pang which seizes

The trusting bosom when betray'd. . . . Moore.

* * * * He in whom

My heart had treasur'd all its boast and pride,

Proves faithless. . . . . . Euripides' Medea.

And all this, too, from him whom once I deemed

Stranger to fraud, nor capable of ill.

- Sophocles' Philoctetes.

Then fare-thee-well-I'd rather make

My bower upon some icy lake,

When thawing suns begin to shine,

Than trust to love so false as thine. . . . Moore.

A laurustinus bear in blossom to my love. . Anon.

And mark me while I vow,

By all this heart hath borne for thee, by all it suffers now, In grief, or gladness, hope, despair, in bliss, or misery, I 'll be, what I have ever been, to thee, to only thee !

Moore.

Accept of this ; and could I add beside

What wealth the rich Peruvian mountains hide;

If all the gems in eastern rocks were mine,

On thee alone their glittering pride should shine.

Lyttelton. 
Laurustinus.

(Continued.)

She knew whose hand had gathered them, she knew Whose sigh and touch were on their scent and hue.

Pickersgill.

LAVENDER.

Distrust.

Lavandula.

\section{Lemon Blossom.}

Citrus limon.

\section{Discretion.}

And from the precipice's brink retire,

Afraid to venture on so large a leap. . . Dryden.

Press me not, 'beseech you so ;-

There is no tongue that moves, none, none i' th' world, So soon as yours, could win me. . . . . Shaks.

His air, his voice, his looks, and honest soul, Speak all too movingly in his behalf,

I dare not trust myself to hear him talk. . Addison.

Our separate fortune

Shall keep us both the safer. . . . . . same.

She will not stay the siege of loving terms,

Nor bide the encounter of assailing eyes. . . same.

Prudent, lest from her resolution rais'd. . . Milton.

So far hath discretion fought with nature. . Shaks.

\section{LICHEN.}

Solitude.

Tree Moss.
Wisdom's self

Oft seeks to sweet retired solitude ;

Where, with her best nurse, contemplation,

She plumes her feathers, and lets grow her wings,

That in the various bustle of resort

Were all too ruffled, and sometimes impair'd. 


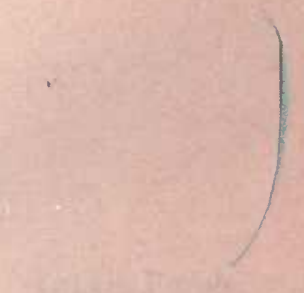




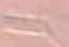




\section{LICHEN.}

(Continued.)

No, 'tis not here that solitude is known, Through the wide world he only is alone Who lives not for another. . . . . Rogers.

There is a pleasure in the pathless woods, There is a rapture in the lonely shore, There is society, where none intrudes, By the deep sea, and music in its roar.

I love not man the less, but nature more, From these our interviews, in which I steal From all I may be, or have been before, To mingle with the universe, and feel What I can ne'er express, yet cannot all conceal.

Byron.

If from society we learn to live,

'Tis solitude should teach us how to die;

It hath no flatterers ; vanity can give

No hollow aid; alone-man with his God must strive.

same.

\section{Lilac, Purple.}

Syringa.
The first emotions of love.

Methinks I feel this youth's perfections

Steal with an invisible and subtle stealth, To creep in at mine eyes. Well, let it be! . Shaks.

Love, where he gets possession, his first work

Is to dig deep within a heart, and there

Lie hid, and, like a miser in the dark,

To feast alone.

Dryden.

The yielding smile that 's half supprest,

The short quick breath, the trembling tear,

The swell tumultuous of the breast,

In Armine's favour all appear. . . . Cartworight.

How beautiful she look'd ! her conscious heart Glow'd in her cheek, and yet she felt no wrong.

Byron.

Lilac, White.

Syringa vulgaris.
Youth.

A lovely being scarcely form'd or moulded,

A rose with all its sweetest leaves yet folded.

Byron.

Now is the morning of thy years,

And all is joy before thee! . . . B. Chester.

Glad spirits sparkled in Narcissa's eyes,

And made youth younger, and taught life to live.

Young. 
Licac.

(Continued.)
Thou art now in thy dreaming time:

The green leaves on the bough;

The sun-shine turning them to gold

Are pleasures to thee now.

L. E. L.

To a young Poetess.

Thy hands are fill'd with early flowers,

Thy step is on the wind;

The innocent and keen delight.

Of youth is on thy mind;

That glad fresh feeling that bestows

Itself the pleasure which it knows,

The pure, the undefined. . . . . same.

His years but young, but his experience old;

His head unmellow'd, but his judgment ripe.

Shaks.

Though few his years, the west already knows

Young Azim's fame. . . . . . . Moore.
Licy, White.

Lilium candidum.

Purity and sweetness. Every thing about her resembles the purity of her soul.

Law.

Around her shone

The light of love, the purity of grace,

The mind, the music breathing from her face;

The heart whose softness harmonized the whole;

And, oh ! that eye was in itself a soul! . . Byron.

Her form was fresher than the morning rose,

When the dew wets its leaves; unstain'd and pure

As is the lily, or the mountain snow. . . Thomson.

I saw her coral lips to move,

And with her breath she did perfume the air.

Sacred, and sweet, kas all I saw in her. . . Shaks.

With looks too bright and beautiful for such a world as this. . . . . . Author of Sol. Hours.

Innocence shines in the lily's bell,

Pure as a heart in its native heaven. . . Percival.

Ye lilies, bathed in morning dew,

Of purity, and innocence renew

Each lovely thought. . . . Bernard Barton. 


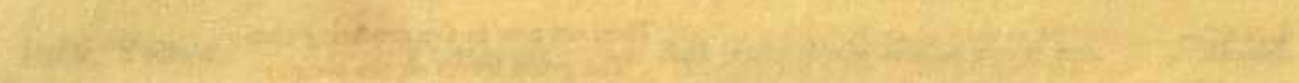

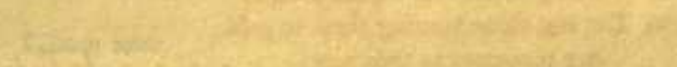

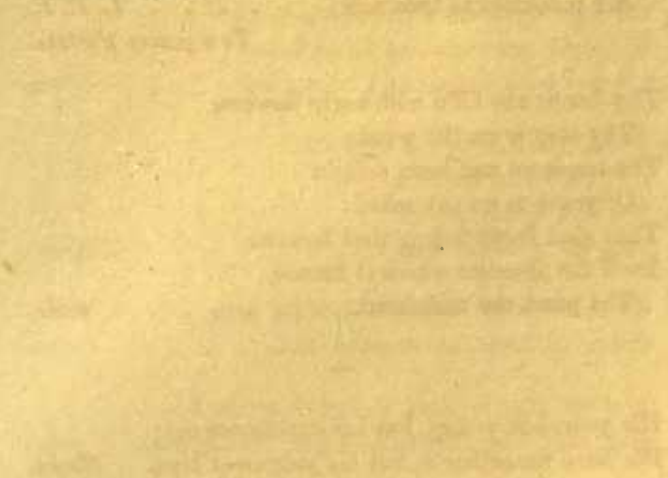

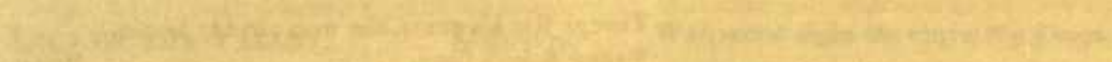
34tont?

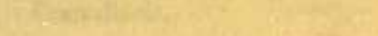

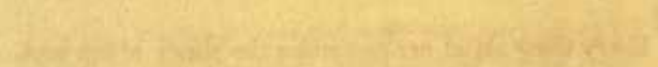

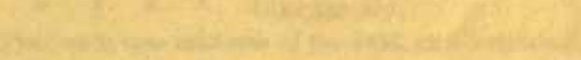

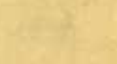

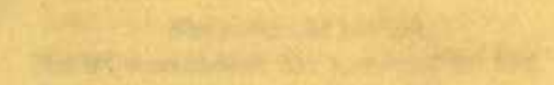
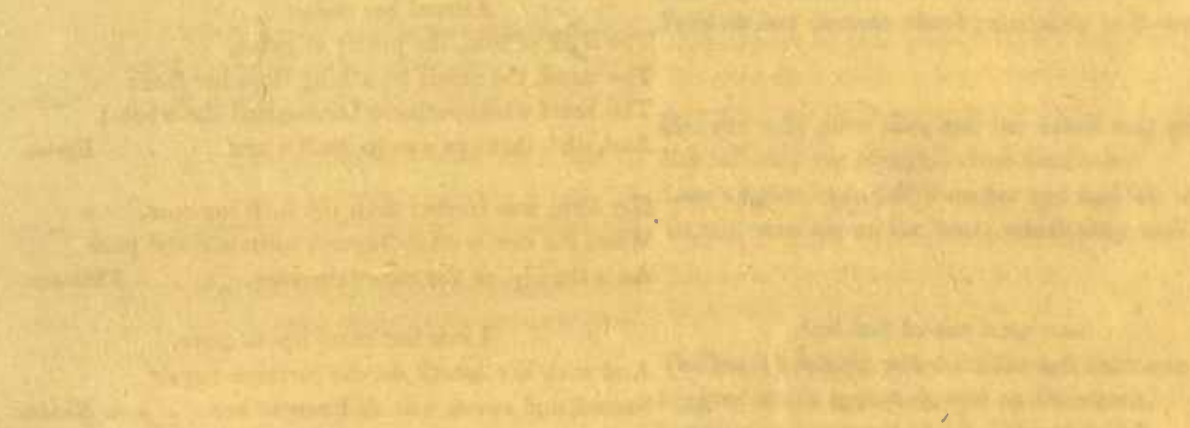


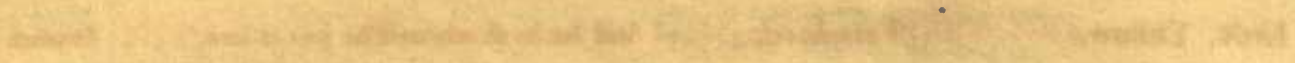

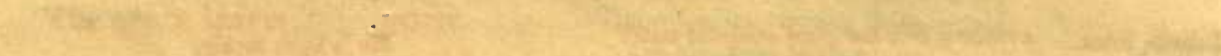

verien

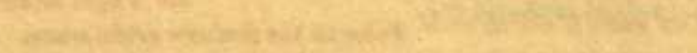

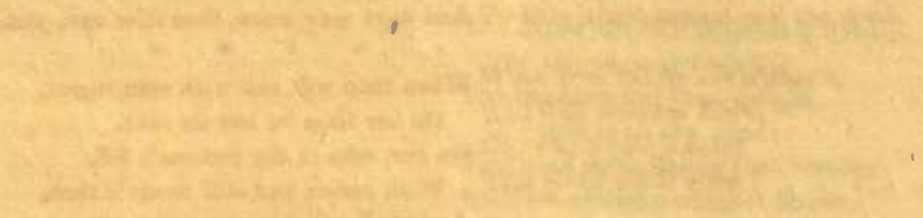

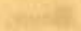

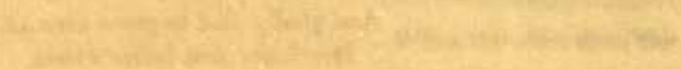

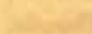

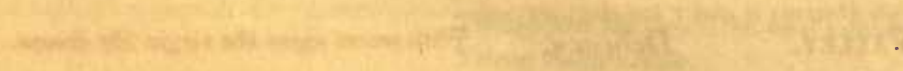

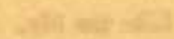

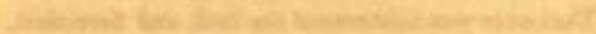

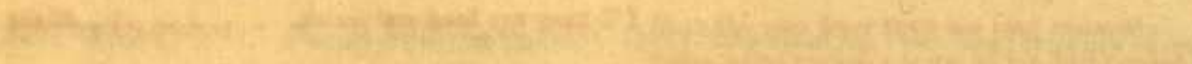

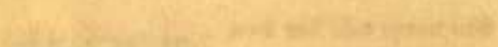

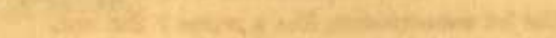

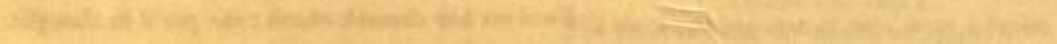

(2)

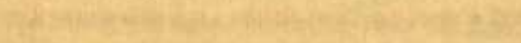

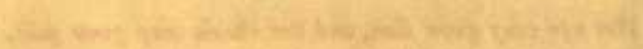

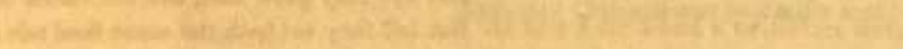

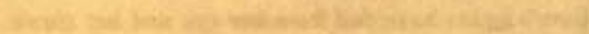

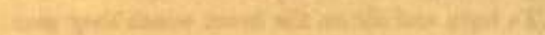

Ans -3

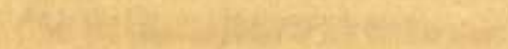

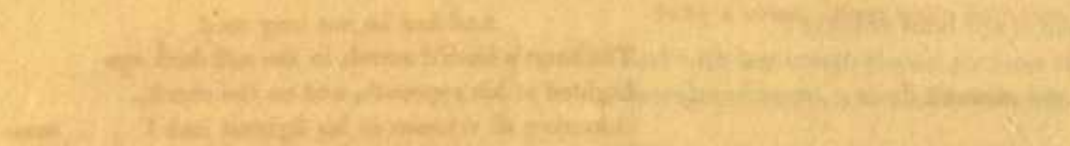

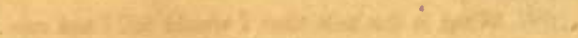

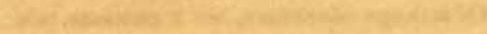

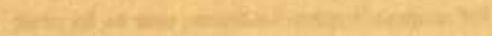

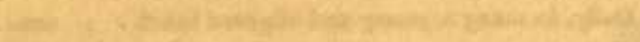

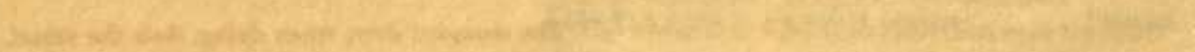

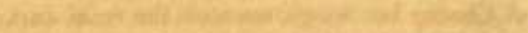

Be 74 -

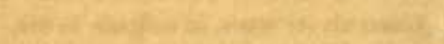

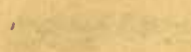




\section{Liny, Yellow. Falsehood.}

Lilium lutea.

\section{LiLy of the VaLLey.}

Convallaria.
Delicacy.

With secret sighs the virgin lily droops. . Darwin.

\section{* * * * Like the lily,}

That once was mistress of the field, and flourished,

I'll hang my head and perish. . . . . . Shaks.

She never told her love,

But let concealment, like a worm i' the bud,

Feed on her damask cheek; she pin'd in thought.

same.

Her eye may grow dim, and her cheek may grow pale, But tell they not both the same fond tale?

Love's lights have fled from her eye and her cheek

To burn and die on the heart which they seek.

L. E. L.

And had he not long read

The heart's hush'd secret, in the soft dark eye

Lighted at his approach, and on the cheek,

Colouring all crimson at his lightest look? . . same.

What is the tale that I would tell ? not one

Of strange adventure, but a common tale

Of woman's wretchedness; one to be read

Daily, in many a young and blighted heart. . same.

The wounded dove, when dying, feels the smart,

Closing her wings, conceals the cruel dart :

So love, abandon'd, flies from every eye,

Conceals its woes, in solitude to die. . . Irving. 
Locost, Affection beyond the In his grave assure thyself my love is buried. Shatk.

The green leaves. grave.

Robinia.

Pseudo Acacia.
Time tempers love, but not removes,

Mure hallow'd when its hope is fled;

Oh! what are thousand living loves,

To that which cannot quit the dead. . . Byron.

When true hearts are wither'd,

And fond ones are flown,

Oh, who would inhabit

This bleak world alone? . . . . . Moore.

Wlien the stcm dies, the leaf that grew

Out of its heart, must perish too. . . . . same.

The tear that is shed, though in secret it roll,

Shall long keep his memory green in my soul. same.

Sorrow ends not when it seemeth done. . . Shaks.

\section{Lotos Flower.}

The Water Lotos.

Here the poor lover than has long endured Some proud nymph's scorn, of his fond passion cured.

Shaks.

This weak impress of love, is as a figuro

Trenched in ice; which, with an hour's heat,

Dissolves to water, and doth lose his form. . . same.

At first I did adore a twinkling star,

But now I worship a celestial sun.

Unheedful vows may liecdfully be broken. . . same.

So the remembrance of my former love

Is by a newer object quite forgotten. . . . same.

\section{Answer.}

Some witchery seems to await you ! . . Moore.

Are you not Lysander?

I am as fair now, as I was erewhile. . . . Shaks.

Read over Julia's heart, thy first best love,

For whose dear sake thou didst then rend thy faith

Into a thousand oaths : and all those oaths

Descended into perjury. . . . . . . same.

She dreams of him that has forgot her love. - same.

But you,

"In all, save form alone, how changed !" . . Byron. 



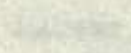

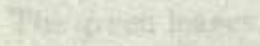

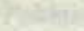

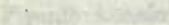

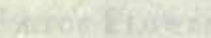

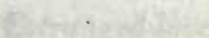

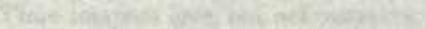

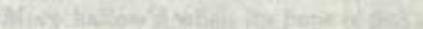

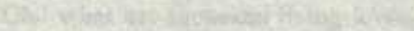

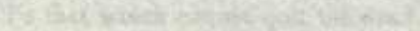

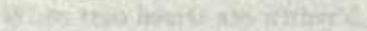

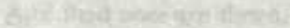

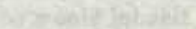

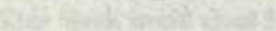

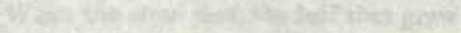

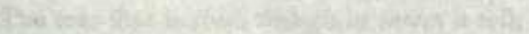

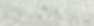

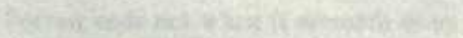

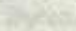

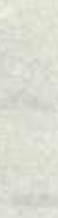

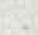

2014.

$\tan x^{2}=$

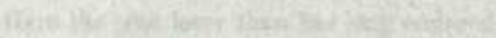

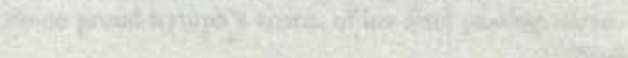

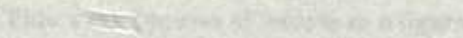

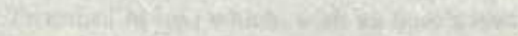

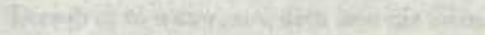

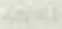

W.

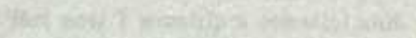

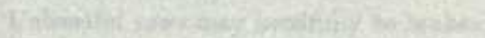

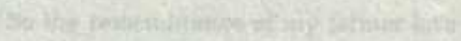

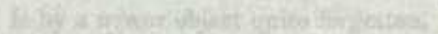

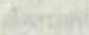

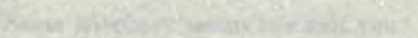

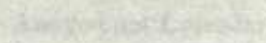

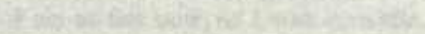

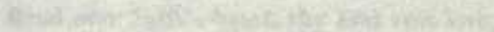

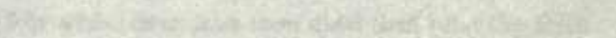

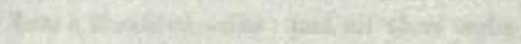

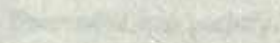

\section{.}




\section{Lotos Flower.}

(Continued.)

Lovers, and madmen, have such seathing brains,

Such shaping fantasies, that apprehend

More than cool reason ever comprehends. . Shaks.

To nurse strange doubts, and groundless fears.

Mrs. Barbauld.

\section{Lotos Lear.}

Lotos.

\section{Recantation.}

36 Wherefore doth Lysander

Deny your love, so rich within his soul?" . . Shaks.

Have I not managed my contrivance well

To try your love, and make you doubt of mine?

Dryden.

Hence then for ever from my Emma's breast, (That hcaven of softness, and that seat of rest,) Ye doubts and fears, and all that know to move Tormenting grief, and all that trouble love, Scatter'd by winds recede, and wild in forests rove.

Prior.

Hear, solemn Jove! and, conscious Venus, hear ! And thou, bright maid, believe me whilst 1 swear; No time, no change, no future flame, shall move 'The well-plac'd basis of my lasting love. . . same. And here to pledge my vow, I give my hand. Shaks.

LOVE IN-A-MIST.

Nigella damascena.
Perplexity.

Love in these labyrinths his slave detains! . Pope.

Perplexity and doubt distract my thoughts.

Eschylus' Agamemnon.

In such a maze of love my thoughts are lost.

Addison's Ovid.

Long, long held by a spell too dear,

Thy smile has kept thy loiterer here.

Almost it seem'd enough for me,

Of heaven, to only gaze on thee;

But love lights high and gallant thought,

A rich prize must be dearly bought. . . L. E. $L$.

And must I go-" Without the hope

My foolish heart still clings to, though that hope

Is like the opiate which may lull awhile,

Then wake to double torture ?" . . . . .s same. 
LOVE IN-A-MIST.

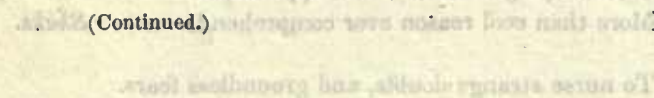

I. WT.

\section{Love lies-A-BLeEDing. Hopeless, not heartless.}

Amaranthus caudatus.
Without a word, a look of tenderness,

To be called up, when, in his lonely hours

He would indulge in weeping. . . . Rogers.

The dead will soon forget, and I

Shall soon be with the dead. . . . . Anon.

I had not lived till now, could sorrow kill!

Death shuns the wretch, who fain the blow would meet.

Byron.

$\underset{*}{\text { Ambition's dreams I 've seen depart; }}{ }_{*}$

Have felt of love the venom'd dart

When hope has flown. . . . . . Scott.

Oh! had we never, never met,

Or could this heart e'en now forget

How link'd, how bless'd we might have been,

Had fate not frown'd so dark bctween. . . Moore.

Now farewell!

Thou that hast been, what words may never tell.

Hemans.

His friends beheld, and pitied him in vain,

For what relicf can ease a lover's pain? . Darwin.

\section{LUPINE.}

Imagination.

Where beams of warm imagination play. . Pope.

Lupinus.

And the wild sparkle of his eye seem'd caught

From high, and lighten'd with electric thought.

Byron.

O'er all bright fancy's beamy radiance shone. Ogilvie.

Bright-ey'd fancy hov'ring o'er,

Scatters from her pictur'd urn,

Thoughts that breathe, and words that burn. - Gray.

Do what he will, he cannot realize

Half he conceives-the glorious vision flies.

Go where he may, he cannot hope to find

The truth, the beauty, pictured in his mind. . Rogers.

\section{But beyond}

This energy of truth, whose dictates bind Assenting reason, the benignant sire, To deck the honour'd paths of just and good,

Has added bright imagination's ray. . . Akenside. 


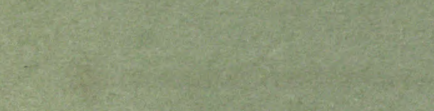

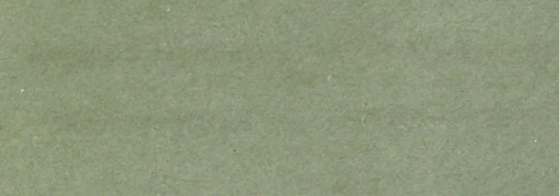

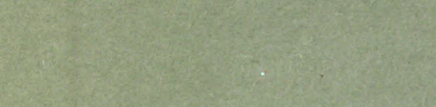




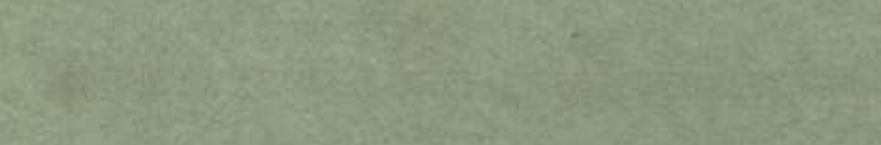

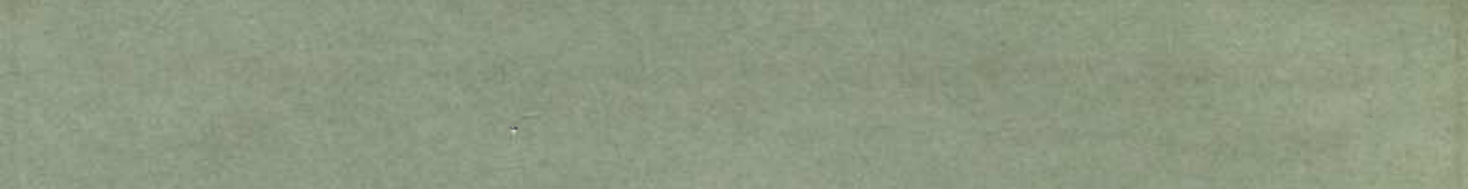

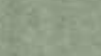

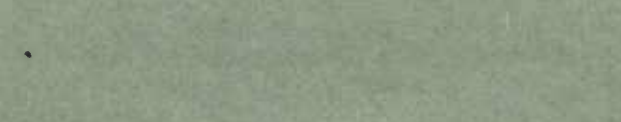

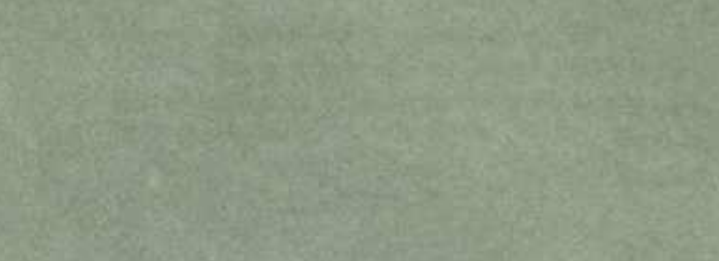

The

Dit

(3)

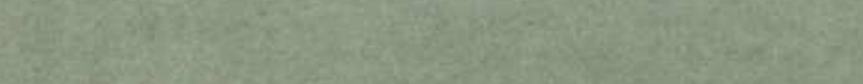

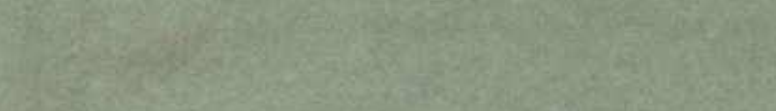

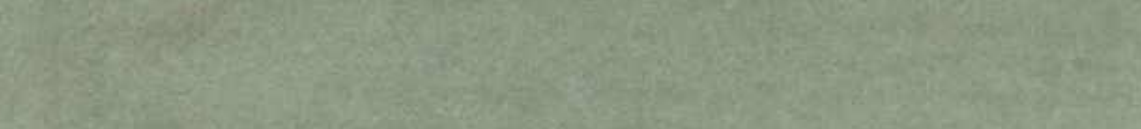

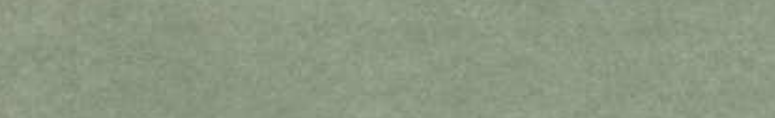

Fen

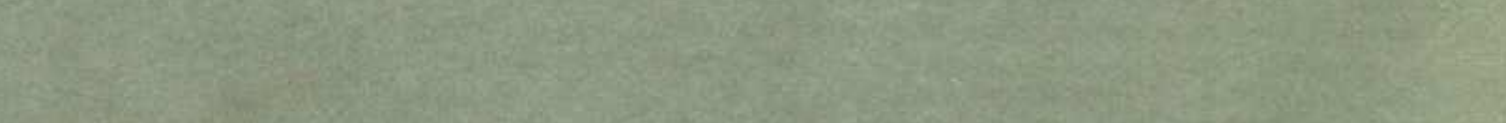

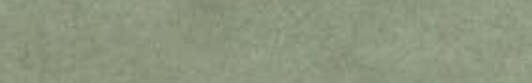

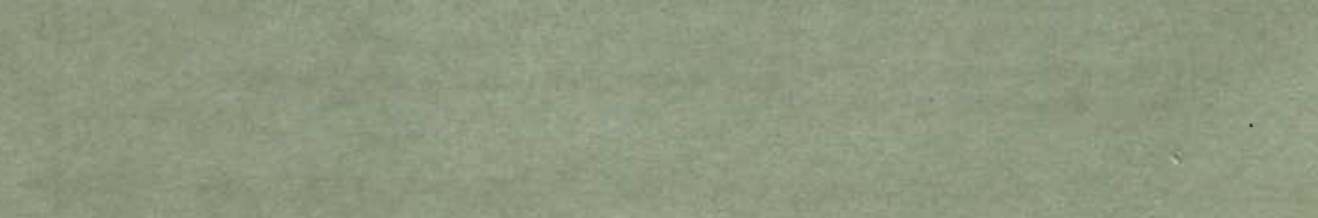

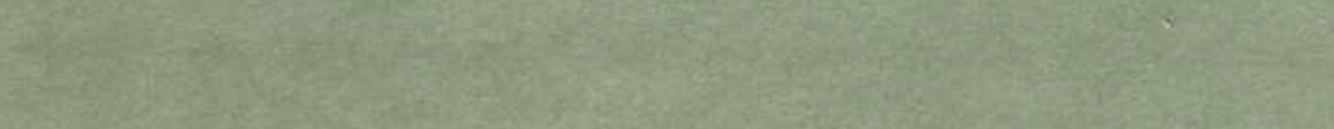


Magnolia, Swamp. Persererance. Urge your success, deserve a lasting name,
She 'll crown a grateful and a constant flame

Magnolia glauca.

Roscommon.

Glory, like time, progression does require;

When it does cease t' advance, it does expire.

Earl of Orrery.

Perseverance, dear my lord,

Keeps honour bright. To have done, is to hang

Quite out of fashion, like a rusty nail

In monumental mockery.. . . . . . . Shaks.

The life of fame is action, understood

That action must be virtuous, great, and good.

Johnson's Clorinda.

This, in the presage of my thoughts that flow

Benevolent to thee, have I proposed;

And all, we trust, shall be successful to thee.

AEschylus. The Persians.

Marigold.

Cruelty.

Calendula.
Love make his heart of flint whom thou shalt love, And may thy fervour, like my passion, be Plac'd in contempt! Farewell, fair cruelty! . Shaks.

And thou, forsworn, thou, cruel as thou art, If Emma's image ever touch'd thy heart,

Thou sure must give one thought, and drop a tear To her whom love abandoned to despair. . Prior.

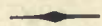

Marvel of Peru. Timidity. Mirabilis. With downcast eyes, and modest grace, For well she knew I could not choose But gaze upon her face. . . . . . Coleridge.

With easy smiles dispell' $\alpha$ the silent fear That durst not tell me what I died to hear. . Prior.

For slie was timid as the wintry flower, That, whiter than the snow it blooms among, Droops its fair head, submissive to the power Of every angry blast which sweeps along.

Mrs. Tighe's Psyche.

He is one, with

More of soul in his face, than words on his tongue.

Wordsworth. 
Marvel of Peru.

(Continued.)

\section{Meadow Saffron. My best days are past.}

Colchicum autumnali.
Silent when glad; affectionate, though shy. . Beattie.

The half suppress'd glance of an eye admiring,

The tremulous rays of an evening sky,

The startled fawn from the hunter retiring,

The fluttering light of a taper expiring-

Apt emblems afford of timidity. . . . $E^{* * * t}$.

'Tis greatly wise to know before we 're told,

The melancholy news that we grow old. - Young.

Nought treads so silent as the foot of time;

Hence we nistake our autumn for our prime. . same.

We see time's furrows on another's brow. . same.

Peace and esteem is all that age can boast. . same.

'Tis greatly wise to talk with our past hours,

And ask them what report they bore to heaven;

And how they might have borne more welcome news.

Their answers form what men experience call. same.

\section{Age should}

Walk thoughtful on the silent, solemn shore

Of that vast ocean it must sail so soon,

And put good works on board, and wait the wind

That shortly blows us into worlds unknown. . same.

\section{Mignonette. Your qualities surpass your loveliness. \\ Reseda odorata.

$$
\text { your loveliness. }
$$

Charms strike the sight, but merit wins the soul.

Pope.

Some forms, though bright, no mortal man can bear,

Some, none resist, though not exceeding fair. Young.

\section{Beauty dwells}

There most conspicuous, even in outward shape,

Where dawns the high expression of a mind.

Akenside.

Mind, mind alone, (bear witness, earth and heaven!)

The living fonntains in itself contains

Of beauteous and sublime: here hand in hand,

Sit paramount the graces : here enthron'd,

Celestial Venus, with divinest airs,

Invites the soul to never-fading joy. . . . . same. 



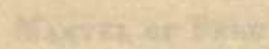

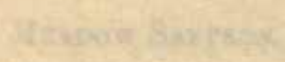

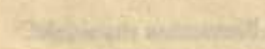

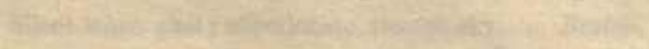

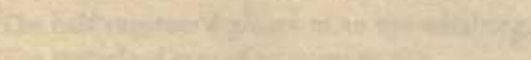

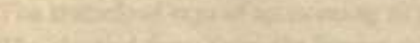

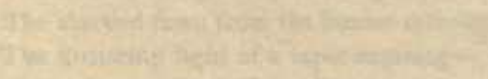

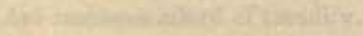

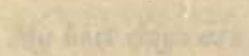
stetis
201

antistix:

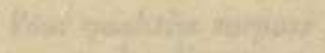

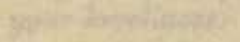

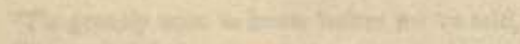

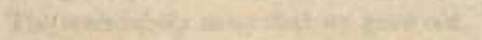

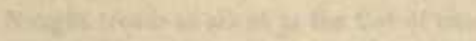

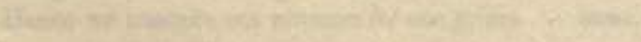

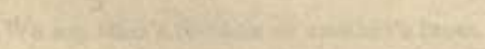

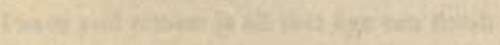

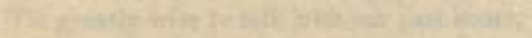

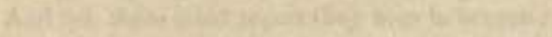

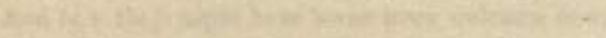

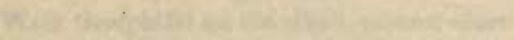

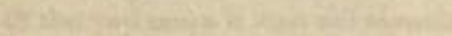

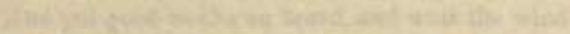

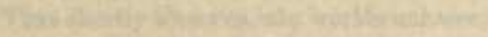

$x^{2}+x^{2}+5$

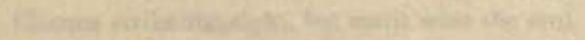

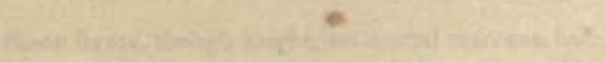

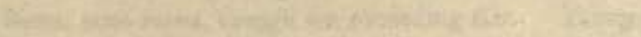

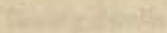

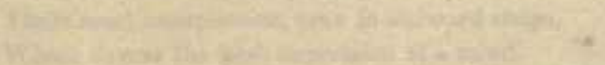

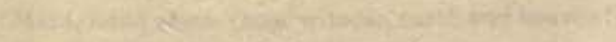

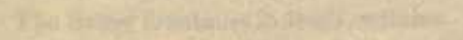

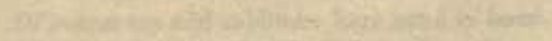

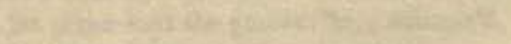

+

4 


\section{Mignonette.}

(Continued.)

There was that in her dark, bright, joyous eyes,

And in the expression of her speaking face,

Where, 'mid the graces, dwelt pcrpetual smiles-

And the pure light that evermore pours out

From the mind's fountain-that demanded more

Than the cold name of beauty, which may be

The attribute of beings whom no ray

Of intellect illumines, and no charm

Of loveliness invests. . . . . . . S. P.C.

Such charms would fix

Inconstancy itself: her unmixed virtues,

Ev'n if her beauty fail'd, would soon subdue

The rebel heart, and you would learn to love her.

Dr. Thomas Franklin's Earl of Warwick.

\section{Mimosa.}

Sensitive Plant.

Mimosa.
Sensitiveness.

I cannot bear that alter'd brow ! . . . . F

My misery can scarce be more complete! . . Byron.

Oh ! would it were my lot,

To be forgetful, as I am forgot! . . . . same.

Upon my lute there is one string

Broken;-the chords were drawn too fast;

My heart is like that string-it tried

Too much, and snapt in twain at last. . . . Anon.

\section{Mock Orange. Counterfeit.}

Philadelphus coronarius.
You have beguil'd me with a counterfeit, * * which being touch'd and tried, Proves valueless: you are forsworn, forsworn. Shaks.

Idiots only may be cozen'd twice;

Once warn'd, is well bewar'd. . . . . Dryden.

Now my love is thaw' $\mathrm{d}$;

Which, like a waxen image 'gainst a fire, Bears no impression of the thing it was. . Shaks.
Moss.

Musci.
Recluse.

You subject yourself to solitariness, the sly enemy that doth most separate man from well doing. Sidney.

In solitude

What happiness? Who can enjoy alone, Or, if enjoying, what contentment find ? . Milton. 
Moss.

(Continued.)

With none to bless us, none whom we can bless, None, that with kindred consciousness endued, If we were not, would seem to smile the less ! This is to be alone;-this, this is solitude. . Byron.

And say, without our hopes, without our fears, Without the home that plighted love endears, Without the smile from partial beauty won, Oh! what were man?-a world without a sun.

Campbell.

Short retirement urges sweet return. . . Milton.

\section{Myrtle. Love positive.}

Myrtus.
I court others in verse, but love thee in prose !

They have my whimsies, but thou hast my heart.

Prior.

On your hand, that pure altar, I vow,

Though I 've looked, and have liked, and have left-

That I never have loved-till now. . . M. G. Lewois.

By those tresses unconfined,

Woo'd by "every gentle" wind ;

By those lids whose jetty fringe

Kiss thy soft cheek's blooming tinge;

By those wild eyes, like the roe,

Ah ! hear my vow before I go-

My dearest life, I love thee!

Can I cease to love thee? - no !

Zoe mou 8-as agapo. . . . . . . B Byron.

Yes, it is love-if thoughts of tenderness,

Tried in temptation, strengthen'd by distress,

Unmov'd by absence, firm in every clime,

And yet-oh, more than all !- untir'd by time.

same.

\section{Answer.}

The myrtle bough bids lovers live. . . . . Scott.

\section{Narcissus, Poetic. Egotism and self love.}

Narcissus poeticus.

Nor knew, fond youth! it was himself he lov'd.

Addison's Ovid.

His duty 'tis to love himself alone-

Nor cares, though mankind perish, if he smiles. Young.

And he, the light and vain one, for him there never wakes

That love, for which a woman's heart will beat until it breaks. . . . . . . L. E. L.

The selfish heart deserves the pain it feels. . Young. 



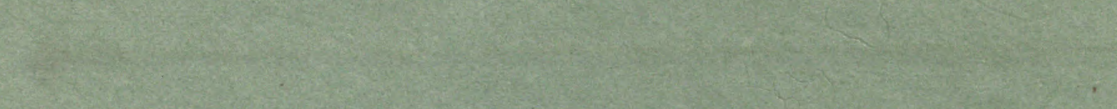

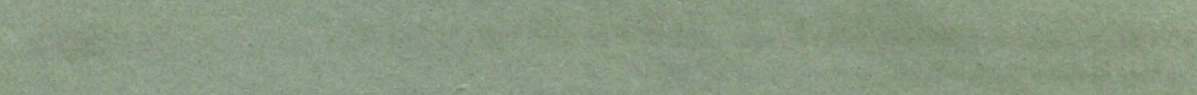

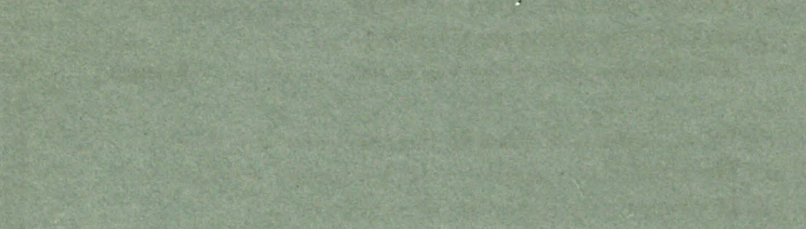

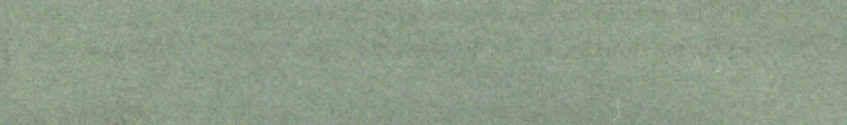

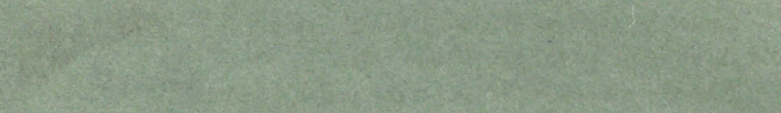

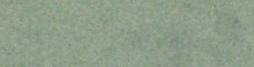

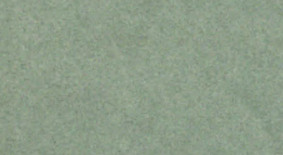

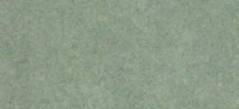

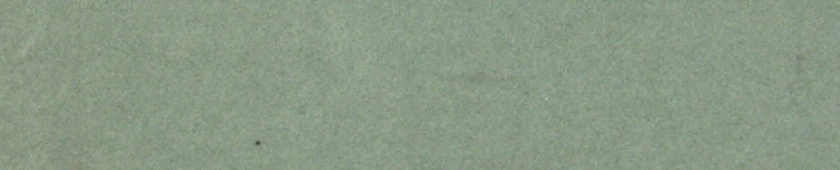

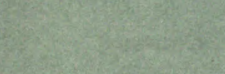

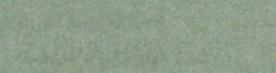

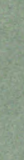

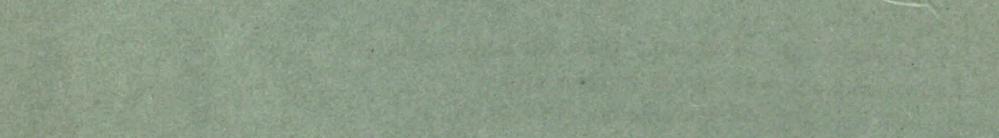

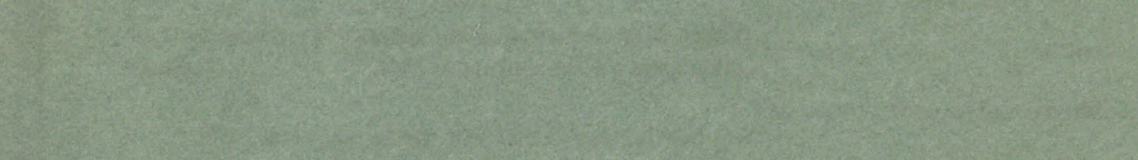

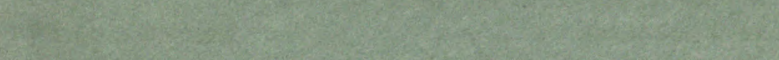

$x+\frac{1}{20}$

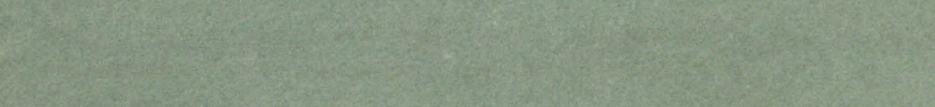

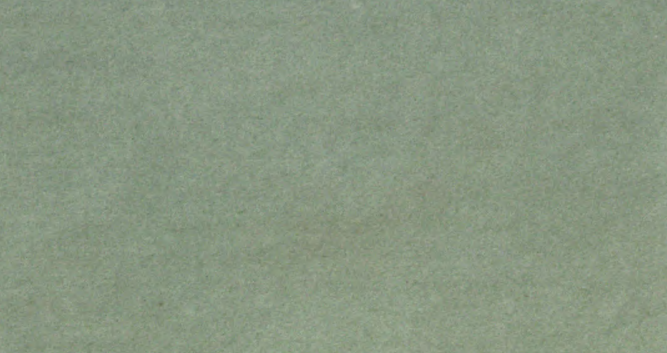

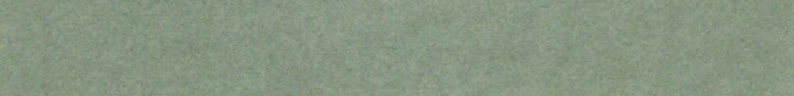

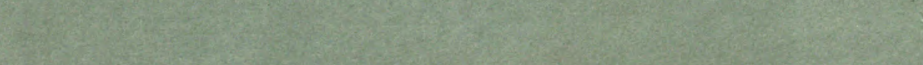

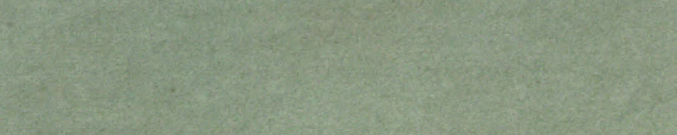

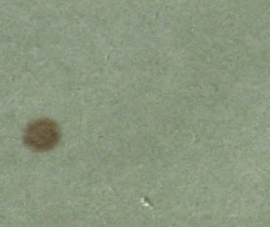


Nasturtium. $\quad A$ warlike trophy.

Indian Cress.

Tropœolum major.
In war excelling, as in peace. . . . Horace.

This, to the hero, when his sword

Has won the battle for the free-

The thanks of millions yet to be! . . Halleck.

Bring flowers, to strew in the conqueror's path-

He hath shaken thrones with his stormy wrath!

He comes with the spoils of nations back;

The vines lie crush'd in his chariot's track;

The turf looks red where he won the day;

Bring flowers, to die in the conqueror's way. Hemans.

Crown ye the brave! crown ye the brave !

As through your streets they ride,

And the sunbeams dance on the polish'd arms

Of the warriors side by side ;

Shower on them your sweetest flowers,

Let the air ring with their praise. . . . same.

\section{Answer.}

Conld deeds my heart discover, Could valour gain your charms,

I'd prove myself a lover,

Against a world in arms. . . . . Old song.

Most fair! thus low before you,

A prostrate warrior view,

Whose sole delight and glory

Are centred all in you.
Nettle.

Slander.

Urtica.
T'Tis slander,

Whose edge is sharper than the sword; whose tongue Outvenoms all the worms of Nile. . . . Shaks.

Soft buzzing slander; silky moths, that eat

An honest name. . . . . . . Thomson.

The man that dares traduce, because he can

With safety to himself, is not a man. . . Covper.

Those who murder fame

Kill more than life destroyers. . . . Savage.

Slander meets no regard from noble minds;

Only the base believe, what the base only utter.

Beller's Injured Innocence. 


\section{Night Shade.}

Scepticism.

Solanum Nigrum,

or, Atropa belladonna.

Ah me ! the laurel'd wreath that murder rears,

Blood-nurs'd and water'd by the widow's tears,

Seems not so foul, so tainted, and so dread,

As waves the night-shade round the sceptic head.

Camplell.

But you are learn'd; in volumes deep you sit.$$
\text { * }
$$

Your learning, like the lunar beam, affords

Light, but not heat; it leaves you undevout,

Frozen at heart, while speculation shines. . Young.

A fugitive from heaven and prayer,

He mock'd at all religious fear,

Deep scienc'd in the mazy lore

Of mad philosophy. . . Horace. Ode XXXIV.

A foe to God, was ne'er true friend to man. Young.

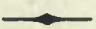

\section{OAK Lear.}

\section{Bravery.}

Quercus.
The manly oak ! the pensive yew,

To patriot, and to sage, be due.

Scott.

And for his meed was brow-bound with the oak.

Shaks.

He comes the third time home with oaken garland.

same.

\section{It is held}

That valour is the chiefest virtue, and Most dignifies the haver : if it be, The man I speak of, cannot in the world

Be singly countcrpoised. . . . . . same.

Not to the sanguine field alone,

Is valour limited: she sits serene

In the deliberate council, sagely scans

The source of every action; weighs, prevents, provides, And scorns to count her glories from the feats

Of brutal force alone. . . . . . Smollet.

\section{By his light,}

Did all the chivalry of England move

To do brave acts; he was indeed the glass

Wherein the noble youth did dress themselves. Shaks.

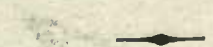

Avena.

Music resembles poetry : in each

Are nameless graces, which no methods teach,

And which a master's hand alone can reach ! Pope.

Music. 


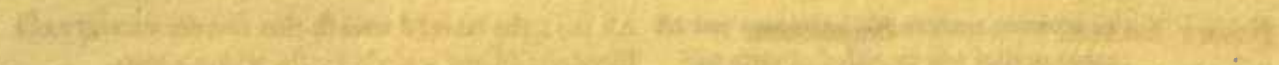

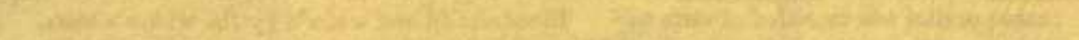

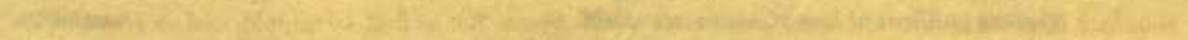

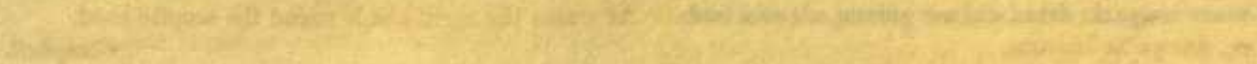

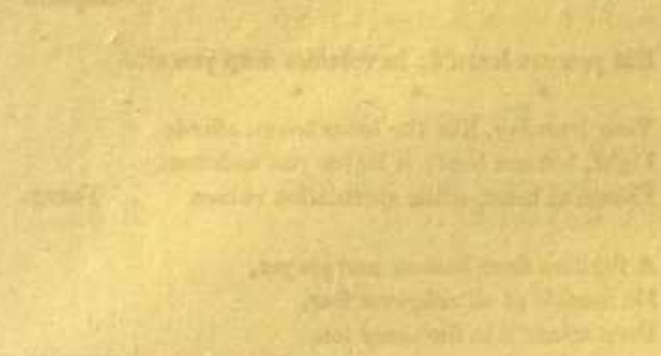

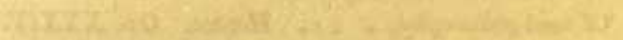

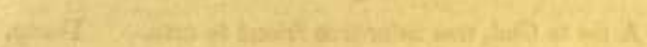

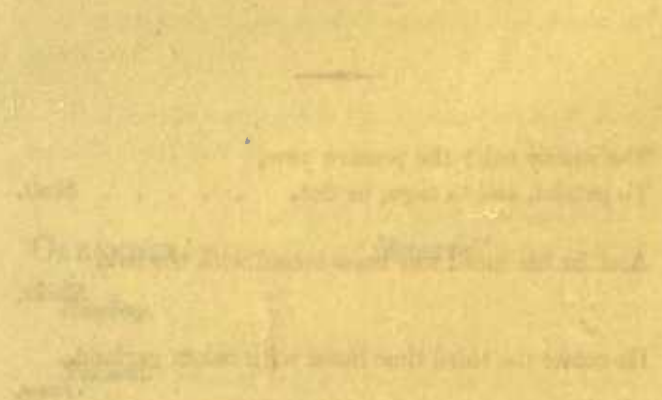

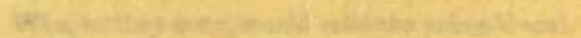

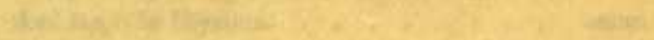

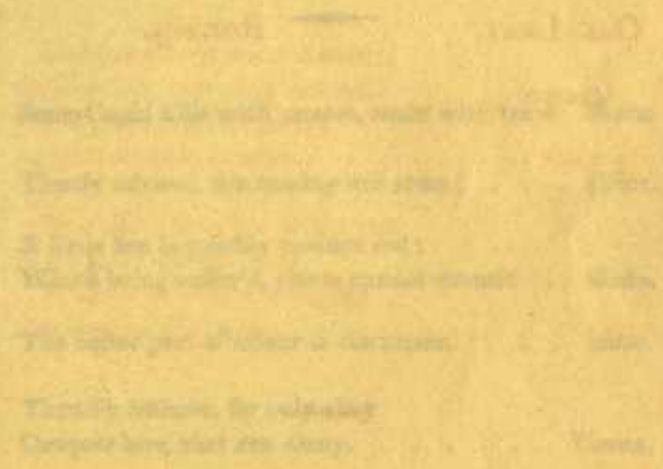

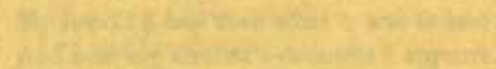

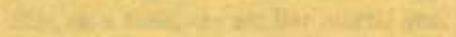

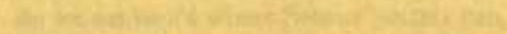

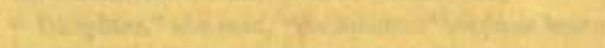

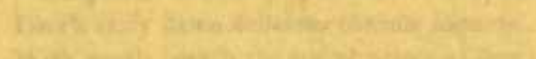

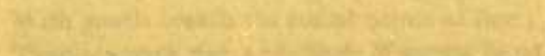

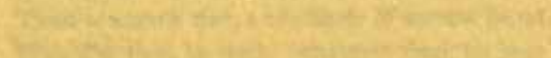

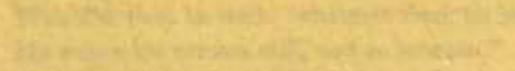

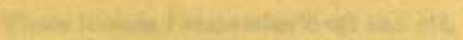

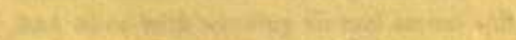

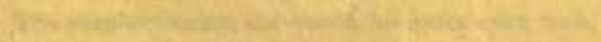

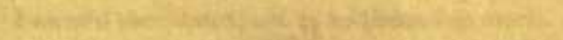

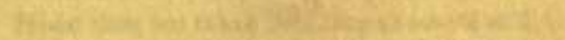

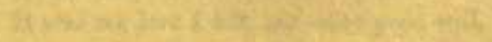

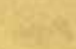

$+$ 


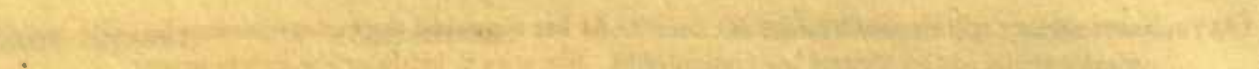

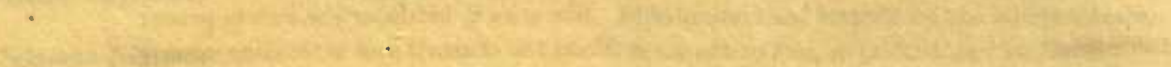

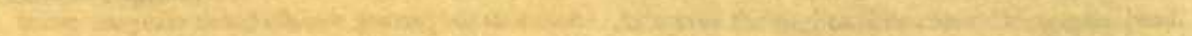

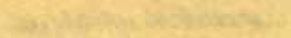

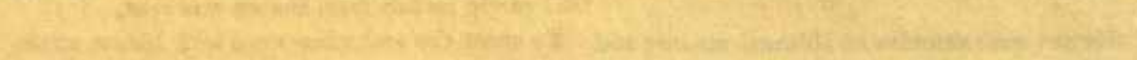

(4) 158

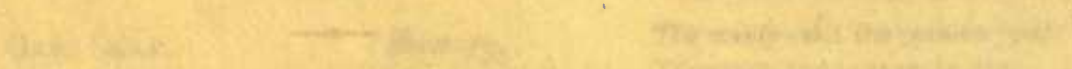

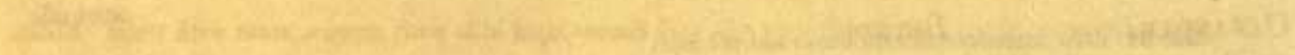

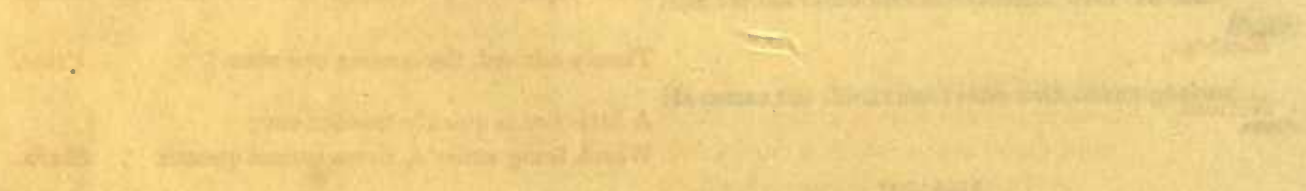

$$
\begin{aligned}
& \text { W. }
\end{aligned}
$$

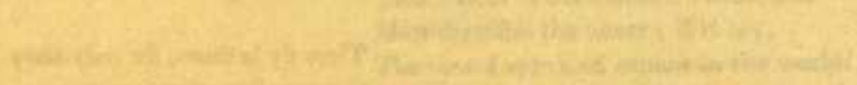

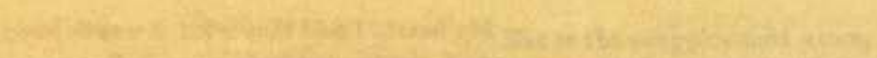

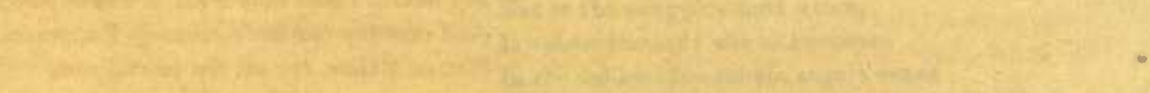

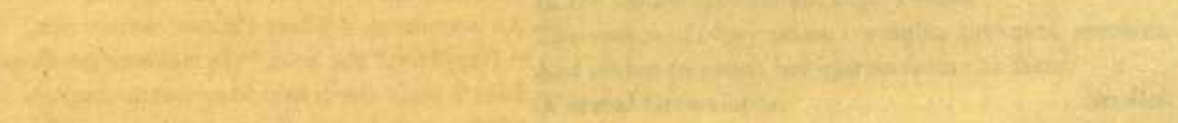

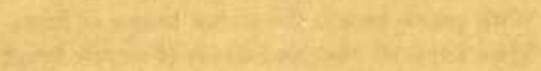

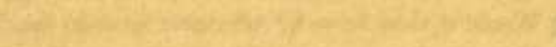

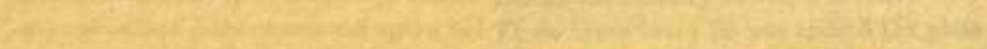

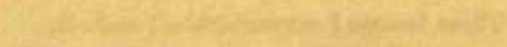

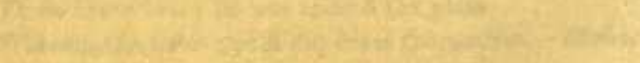

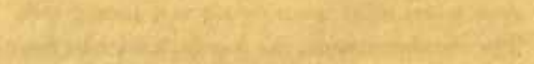

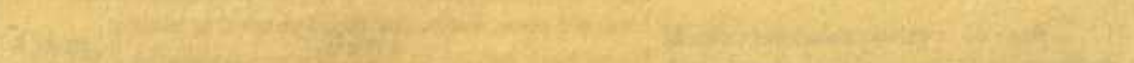
aid 
OATS.

(Continued.)
At her command the various passions lie;

She stirs to battle, or she lulls to peace;

Melts the charm'd soul to thrilling ecstasy,

And bids the jarring world's harsh clangour cease.

$\mathrm{Oh}$ ! surely melody from heaven was sent,

To cheer the soul when tired with human strife,

To soothe the wayward heart by sorrow rent,

And soften down the rugged road of life.

H. $K$. White.

Can any mortal mixture of earth's mould

Breathe such divine enchanting ravishment?

Sure something holy lodges in that breast,

And with these raptures moves the vocal air

To testify his hidden residence. . . . Milton.

Who, as they sung, would take the prison'd soul,

And lap it in Elysium.

same.

\section{Oleander.}

Rosebay.

Nerium.
Bezvare!

Some Cupid kills with arrows, some with traps

Timely advised, the coming evil shun! . . Prior.

A little fire is quickly trodden out;

Which being suffer'd, rivers cannot quench. '. Shaks.

The better part of valour is discretion. . . same.

Then fly betimes, for only they

Conquer love, that run away. . . . . Carew.

My heart! I told thee what it was to love; And now my mother's counsels $I$ approve.

She, on a time, ere set her mortal sun,

As we convers'd where Peneus' waters run,

" Daughter," she said, "to maidens' heedless hearts

Love's early dawn delicious charms imparts :

With gentle breath the traitor comes at first;

Then tempests rise, and clouds of sorrow burst.

Would'st thou be well? whatever form he bear,

He wears his arrows still, and so beware!"

These lessons I remember'd oft and oft,

And when with winning air and accent soft

The shepherd came, lis words, his looks were such,

I warn'd thee, heart, not to be pleased so much.

Hadst thou but taken heed, nor answer'd still

It was not love I felt, but mere good will, 
Oleander.

(Continued.)
Nor idly sported with his lambent fires,

His quiet joys, and innocent desires,

Thou hudst not found, when it was all too late,

The dart of love is often that of fate.

Ah silly, silly heart! I told thee so;

But I will school thee yet to hide thy wo.

Moliere. Translated by $C^{* * *}$.

What could I more ?

I warn'd thee, I admonish'd thee, foretold

The danger, and the lurking enemy

That lay in wait. . . . . . Milton.
Otive.

Peace.

Olea.
I hold the olive in my hand: my words are as full of peace, as of matter. . . . . . Shaks.

Our peace shall stand as firm as rocky mountain.

same.

Sweet peace, who long hath shunn'd my plaintive lay, Consents at length to bring me short delight. Collins.

If after tempest come such calms,

May the winds blow till they have waken'd death !

Shaks.

* *. * * * welcome as day

After a night of storms, with fairer beams

Returning; welcome as the liquid lapse

Of fountain to the thirsty traveller.

Aischylus' Agamemnon.

\section{Orange Blossom. Your purity equals your loveliness.}

Citrus aurantium.

\section{Nought can be diviner}

Than the blue meaning of those soft spring eyes-

Young, vernal-looking,-filled with vernal life;

Whose peace surpasscth all we know of strife,

Telling of thoughts all pure and bright within,

Untouched by sorrow, unalloyed by sin. . . . Anon.

There are creatures yet who bless

This earth with so mueh loveliness,

As if they had escaped the blight,

The first transgression shed o'er all,

And still preserved the souls's pure light,

Undimm'd, unfaded from the fall.

Or were some young bright spirits strayed

From their own far-off world of bliss,

In beauty's loveliest charms array'd,

To make a paradise of this. . . . S. P.C. 
Orange Blossom.

(Continued.)

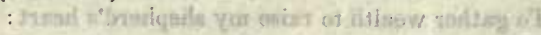

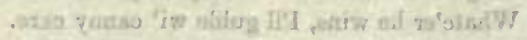

Ox Eye.

Patience.

Buphthalmum.

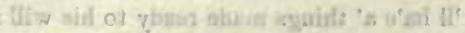

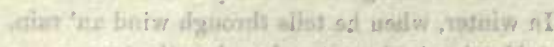

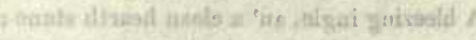

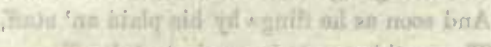

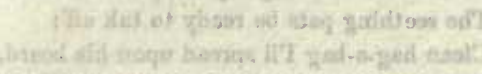

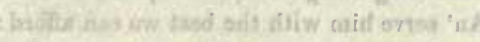

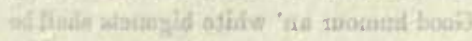

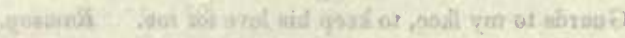
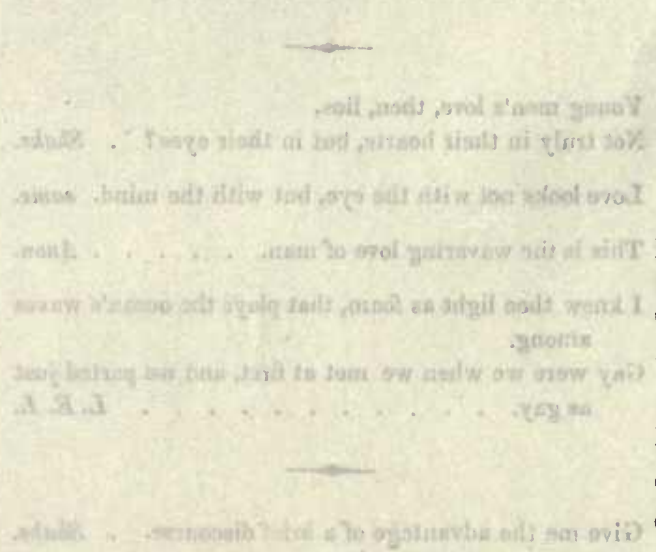

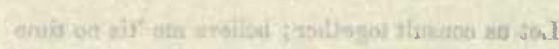

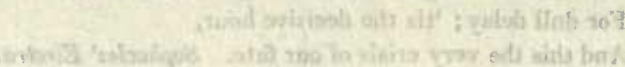

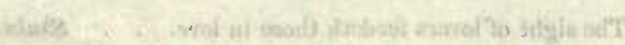

Parstey. Useful Knowledge.

Apium.
No pearl ever lay. under Oman's green water, aw, 1 a 4 More pure in its shell than thy spirit in thee. . Moore.
With patience calm the storm,

While we bethink a means to break it off. . Shaks.

Ah me ! for aught that ever I could read,

Could ever hear by tale or history,

The course of true love never did run smooth. . same.

True lovers have been ever cross'd,

Then let us teach our trial patience;

Because it is a customary cross,

As due to love, as thoughts, and dreams, and sighs,

Wishes, and tears, poor fancy's followers. . . same.

'Tis hard : but patience must endure,

And soothe the woes it cannot cure.

Horace. Ode $\mathrm{XXV}$.

To bear, is to conquer our fate. . . . . Campbell.

\section{Answer.}

Had it pleas'd Heaven to try me with affliction-

Steep'd me in poverty to the very lips;

Given to captivity me and my utmost bopes;

I should have found in some part of my soul

A drop of patience-

But there where I have garner'd up my heart;

Where either I must live, or bear no life;

The fountain from the which my current runs,

Or else dries up; to be discarded thence! . . Shaks.

Exiled from all my soul holds dear !

Life bath no torture so severe. . . Euripides' Medea.

Patience says, 'tis past her cure! . . . Shaks.

He ordain'd a lady for his praise,

Generally praiseful; fair and young, and skill'd in housewiferies. . . . . Chapman. Iliad.

And ay she wrought her mammy's wark,

And ay she sang sae merrilie;

The blythest bird upon the bush

Had ne'er a lighter heart than she. . . Burns.

A bonny lass, I will confess,

Is pleasant to the e'e,

But without some better qualities

She's no a lass for me. . . . . . . . same. 


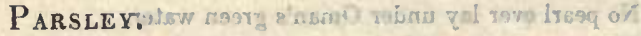

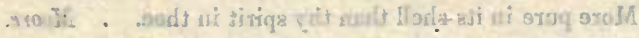
(Continued.)

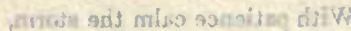
แล่ามี่อ

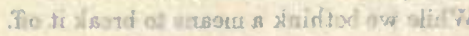

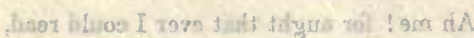

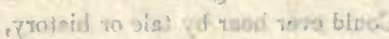
sixns

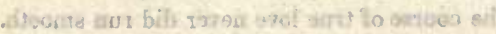

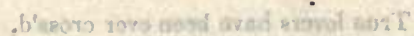

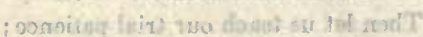

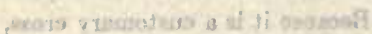

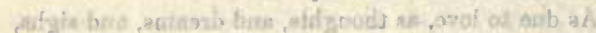
.3959

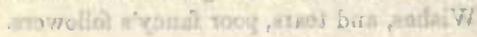

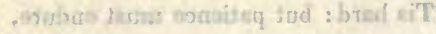

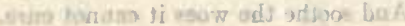
Passion Flower.

- Visdyation

Passiflora.

Susceptibility.

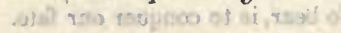

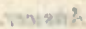

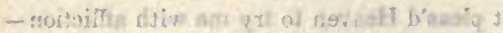

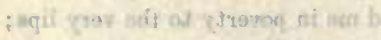

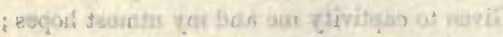

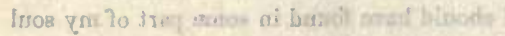

-asesisey to quobi $\mathrm{A}$

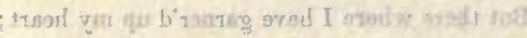

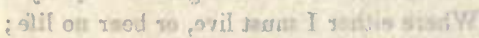

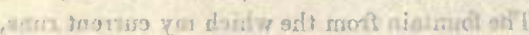

PeA, Everlasting. An appointed meeting.

Lathyrus latifolia.

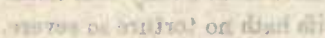

Let us consult together; beliere me 'tis no time

For dull delay; 'tis the decisive hour,

And this the very crisis of our fate. Sophocles' Electra.

The sight of lovers feedeth those in love. . . Shaks.

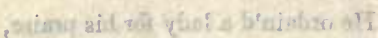

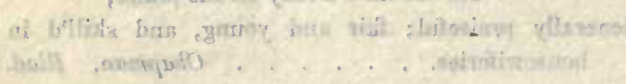

Come you this afternoon.

\section{Answer.}

To know our pleasure in this case. . . . Shaks.

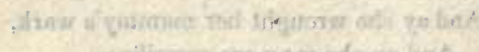

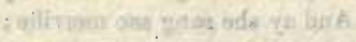

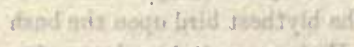

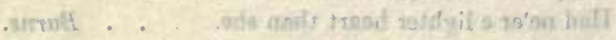

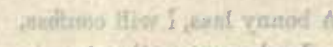

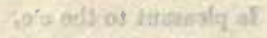

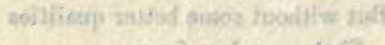

By all the pretty oaths that are not dangerous, If you come one minute behind your hour, I will think you the most pathetical break-promise, And the most hollow lover, that may be chosen Out of the gross band of the unfaithful. . . same. Lovers ever run before the clock. . . . . same. Lovers break not hours, except it be To come before their time. . . . . . same. 


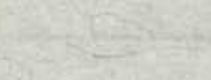
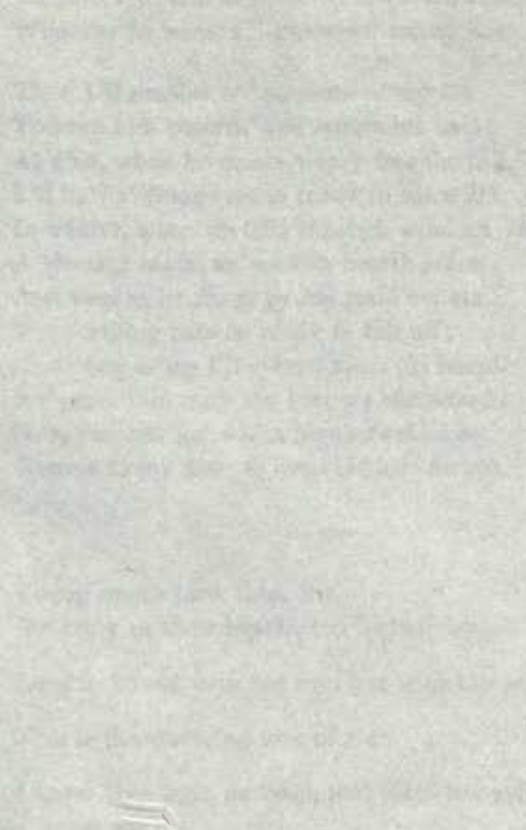

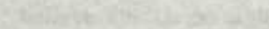

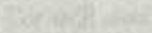

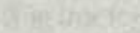

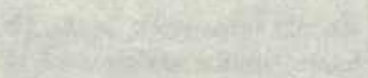

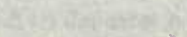


PEA, Sweet. PEst Departure. Parting strikes poor lovers dumb. ... Thaks.

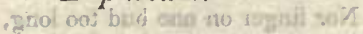

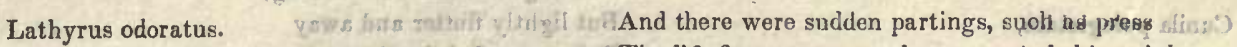

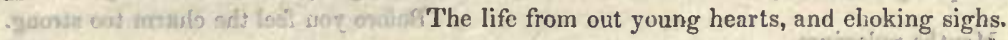

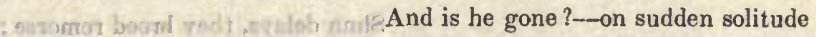

How oft that fearful question will intrude!

'Twas but an instant past—and here he stood! same.

I 'll think it but a fond conceit;

It cannot be that thou art gone ! . . Coleridge.

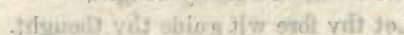

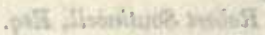

Think'st thou that she, whose only light,

In this dim world, from thee hath shone,

Could bear the long and cheerless night,

That must be hers when thou art gone? . Moore.

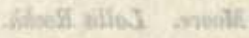

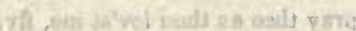

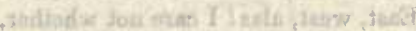

How can I live without thee, how forego

Thy sweet converse and love ? . . . Milton.

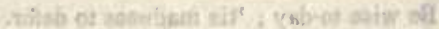

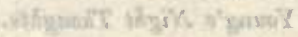

* * * There is no living, none,

If Bertran be away. . . . . . . . Shaks.

Peach Blossom. I am your captice. I strove not to resist so sweet a flame,

But gloried in a happy eaptive's name.

Amygdalus persica.

Nor would I now, could love permit, be free !

Lyttelton.

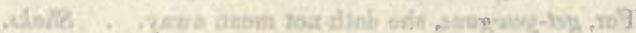

My heart with love is beating,

Transported by your eyes;

Alas ! there 's no retreating,

In vain a captive flies. . . . . Old Song.

I ne'er saw excellence in woman-kind

Till now, and yet, discern'd it at the first :

Perfection is discover'd in a moment,

He that ne'er saw the sun before, yet knew him.

Dryden.

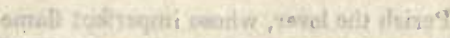

swevathe If

And bless the silken fetter. . . . . . Moore.

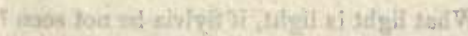

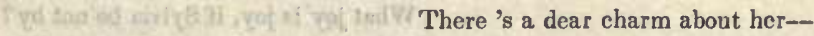

'Tis a heart so kind and warm,

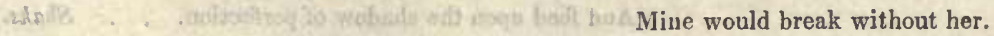

Never

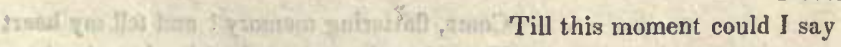

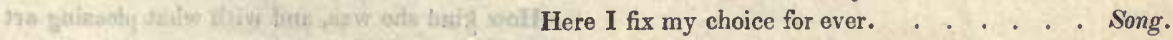

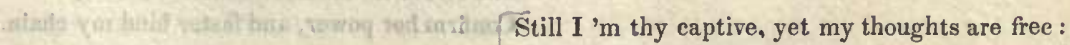

To be love's bond-man, is true liberty.) . . Marston. 


\section{Pennyoyat. Flee away! datare of danger! never stay \\ Nor linger on one bud too long, \\ Cunila pulegioides, \\ But lightly flutter and away \\ or, Menthe pulegium. \\ Before you feel the charm too strong.}

Hon. Charles Phipps.

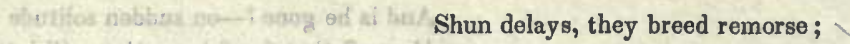

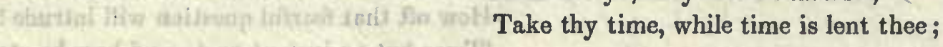

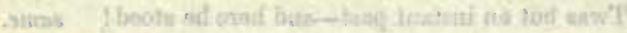

Sober speed is wisdom's leisure,

After wits are dearly bought,

Let thy fore wit guide thy thought.

Robert Southwell, Esq.

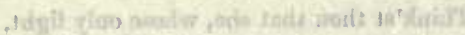

Then, Hafed, as thou lov'st me, fly,

I pray thee as thou lov'st me, fly,

East, west, alas! I care not whether,

So thou art safe.

Moore. Lalla Rookh.

Be wise to-day ; 'tis madness to defer.

Young's Night Thoughts.

Peony. Anger. A Frown.

Pæonia.

If she do frown, 'tis not in hate of you-

But rather to beget more love in you.

If she do chide, 'tis not to have you gone-

Take no repulse, whatever she doth say;

For, get-you-gone, she doth not mean away. . Shaks.

Periwinkle, Blue. Pleasures of Memory. Still the fond lover views his absent maid. . . Rogers.

Vinca minor:

And, to his eye,

There is but one beloved face on earth, !. . Byron.

Perish the lover, whose imperfect flame

Forgets one feature of the nymph he lov'd. Shenstone.

What light is light, if Sylvia be not seen ?

What joy" is joy, if Sylvia be not by?

Unless it be to think that she is by,

And feed upon the shadow of perfection. . . Shaks.

Come, flattering memory ! and tell my heart

How kind she was, and with what pleasing art

She strove its fondest wishes to obtain,

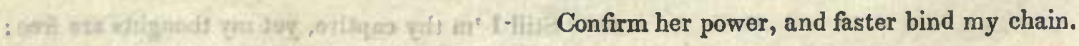

Lyttelton. 

Periwinkle, White. Pleasing reminis- Somo little friendship formed, and cherished here.

Vinca minor.

cences.

Rogers.

So turn our hearts, where'er we rove,

To those we 've left behind us. . . . . Moore.

Often, like the evening sun, comes the memory of former times o'er my soul. . . . . . Ossian.

The memory of joys that are past, is like the music of Caryl, pleasant and mournful to the soul. . same.

Phlox. Unanimity.

Phlox.
There are two hearts whose movements thrill In unison so closely sweet !

That pulse to pulse responsive still,

They both must heavo-or cease to beat. . Barton.

There are two suuls whose equal flow

In gentle streams so calmly run,

That when they part-they part!-ah, no !

They cannot part-those souls are one. . . same.

Each was the other's mirror, and but read

Joy sparkling in their dark eyes, like a gem;

And knew such brightness was but the reflection

Of their exchanging glances of affection. . Byron.

Oh! happy, happy lovers !

Happy youth, and happy maid-

When tremblingly each heart discovers

All its love by love repaid. . . . . . Old Song.
Pine, Black Spruce Fir.

Pity.

Pinus nigra.
A crown of pine upon his head he wore;

And thus began her pity to implore. . Dryden's Ovid.

Is there no pity sitting in the clouds,

That sees into the bottom of my grief? . . Shaks.

Where first my shipwreck'd heart was lost,

I may once more repeat my pain;

Once more in dying notes complain

Of slighted vows and cold disdain. . . . . Prior.

As love can exquisitely bless,

Love only feels the marvellous of pain;

Opens new views of torture in the soul,

And wakes the nerve where agonies are born. Smollet. 
Pine, Black Spruce Fir.

(Continued.)
Let soft compassion touch your gentle mind.

Pope's Ovid.

Can a bosom so gentle remain

Unmov'd, when her Corydon sighs? . . Shenstone.

Could my griefs speak, the tale would have no end.

Otway.

\section{Answer.}

Your cause doth strike my heart

With pity. . . . . . . . . Shaks.

And pity still foreruns approaching love,

As lightning does the thunder. . . . . Dryden.

Love was in the next degree:

'Twas but a kindred sound to move,

For pity melts the mind to love. . . . . same.

\section{Pine, Pitch. Time and philosophy. P. rigida.}

So subtle, and so swift I fly,

Love 's not more fugitive than I! . . . Gay.

Youth is not rich in time; it may be poor.

Part with it as with money, sparingly; pay

No moment, but in purchase of its worth;

And what its worth, ask death-beds; they can tell.

Part with it as with life, reluctant; big

With holy hope of nobler time to come. . . Young.

Time's use was doom'd a pleasure, waste, a pain-.

That man might feel his error if unseen,

And feeling, fly to labour for his cure;

Not blund'ring split on idleness for ease.

Life's cares are comforts; such by Heaven designed;

He that hath none, must make them, or be wretched.

same.

Time, which all things else removes,

Still heightens virtue and improves. . . . Gay.

Farewell! whatever be my lot,

While feeling burns within my breast,

Although by thee, perhaps, forgot,

On thee remembrance oft will rest.

In pleasure's time, my heart will say,

Though brightly move these moments by-

Yet far less bright and bless'd are they,

Than those I knew when thou wert nigh. 


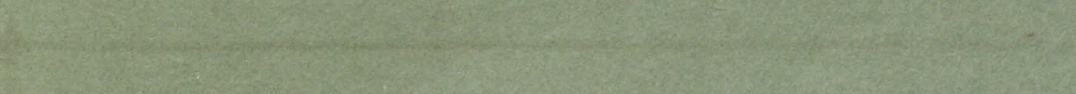

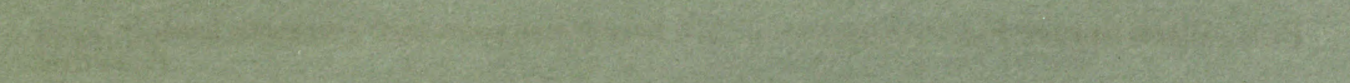

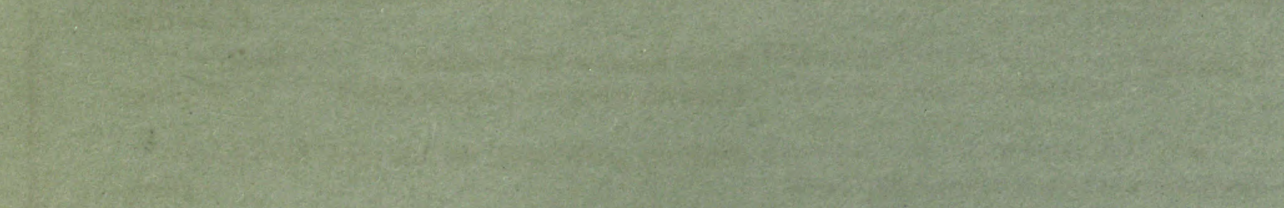

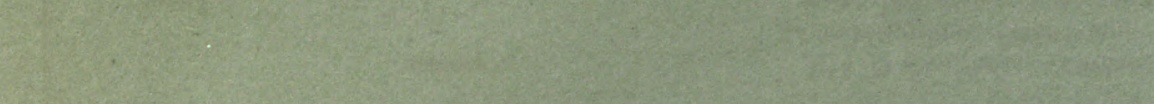

2.

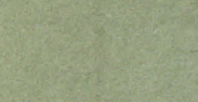

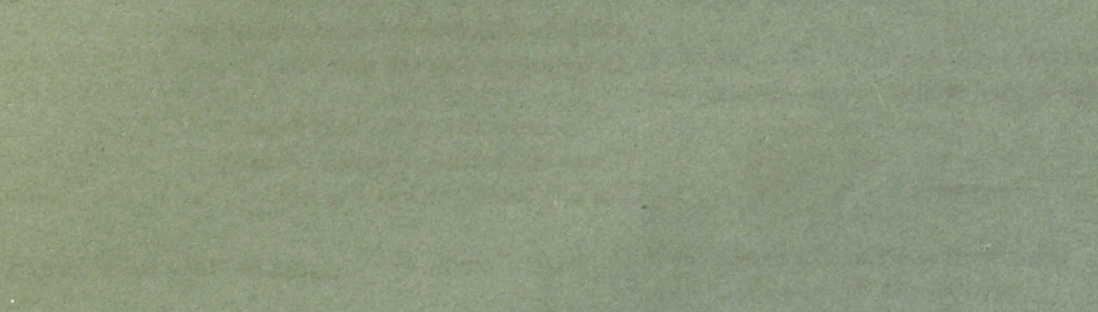

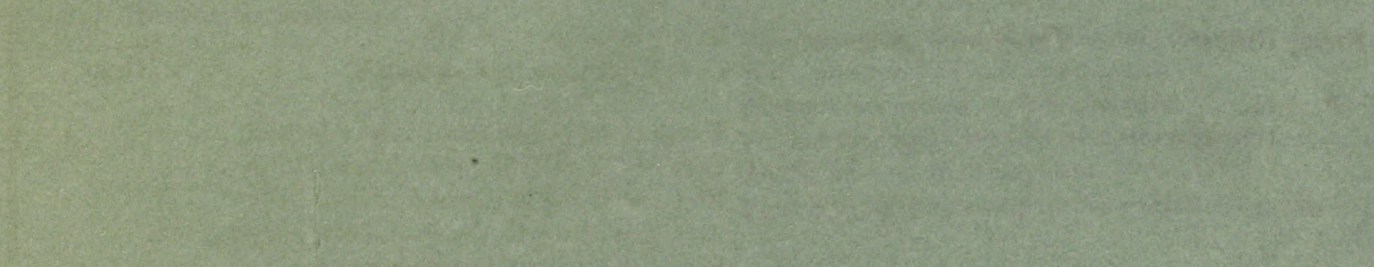

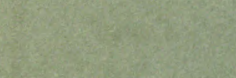

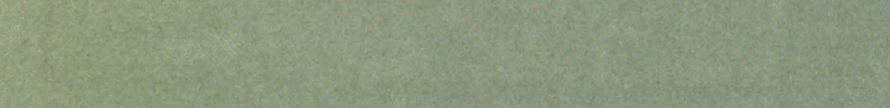

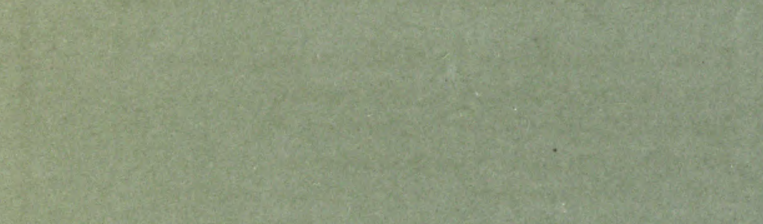


Pine, Spruce.

(Continued.)
And oft in sorrow's lonely hour,

Thy memory on my soul will steal,

Like musie's strain, with magic power

To chase away each thought of ill.

Farewell! may sorrow never thrill

That breast, where truth and peace reside,

But unprofaned by anguish still,

May all thy hours in sweetness glide.

R. $R * * * * * l$.

Farewell! for I must leave thee,

I weep my last adieı. . . . . . . Song.

Farewell !-In that word-that fatal word-howe'er

We promise-hope-believe-there breathes despair.

Byron.

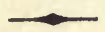

Pink, The Carnation. Woman's love.

Dianthus caryophyllus.
Yes, woman's love is free from guile, And pure as bright Aurora's ray. . . G. P. Morris.

$\widehat{O h}$ ! where on the earth is the truth that may vie, With woman's love and long constancy?

Absence but makes her love the more,

For her thoughts then feed on their own sweet store.

And is not hers the heart alone

That hath pleasure and pride, in a prize, when won?

L. E. t.

Alas, the love of woman! it is known

To be a lovely and a fearful thing;

For all of theirs upon that die is thrown,

And if 'tis lost, life has no more to bring

To them, but mockeries of the past alone. . Byron.

It is a fearful thing

To love as I love thee; to feel the world-

The bright, the beautiful, joy-giving world-

A blank without thee. Never more to mo

Can hope, joy, fear, wear different seeming. Now,

I have no hope that docs not dream for thee;

I have no joy, that is not sbared by thee;

I have no fear, that does not dread for thee.

All that I once took pleasure in-my lute,

Is only sweet when it repeats thy name;

My flowers, I only gather them for thee;

The book drops listless down, I cannot read,

Unless it is to thee; my lonely hours

Are spent in shaping forth our future lives,

After my own romantic fantasies.

He is the star round which my thoughts revolve

Like satellites. . . . . . . . . L. E. L. The Ancestress. 
Pink, Indian, single.

Dianthus chinensis.

\section{PInK, Mountain.}

Dianthus cæsius.

Aspiring.

Fain would I climb-

But that I fear to fall.

\section{Answer.}

If you do fear-

Then do not climb at all! . . Queen Elizabeth.

Who has assay'd no danger, gains no praise. . Prior.

The wise and active conquer difficulties

By daring to attempt them. . . . . Rowe.

And fearless minds climb soonest unto crowns. Shaks.

Our doubts are traitors-

And make us lose, by fearing to attempt,

The good we oft might win. . . same.

Thou wilt not take the trouble to be blest. . Young.

Pink, Red, double. Pure and ardent

Dianthus rubeus.

\section{love.}

He loves you with such a pure and boly fire

As will not, cannot, but with life expire! . . Dryden.

Thou loved beyond what verse or speech can tell!

Beattie. 



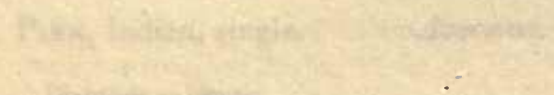

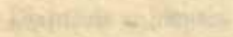

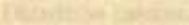

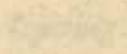

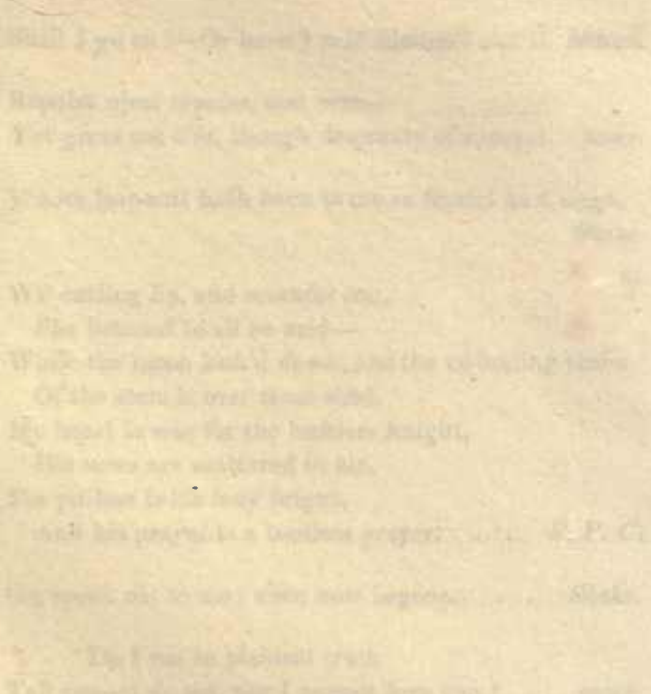

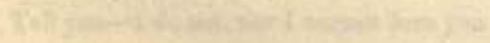

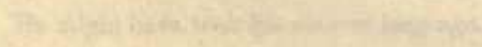

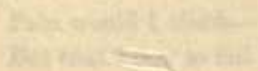

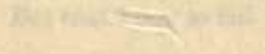

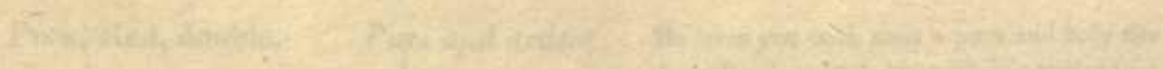

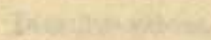

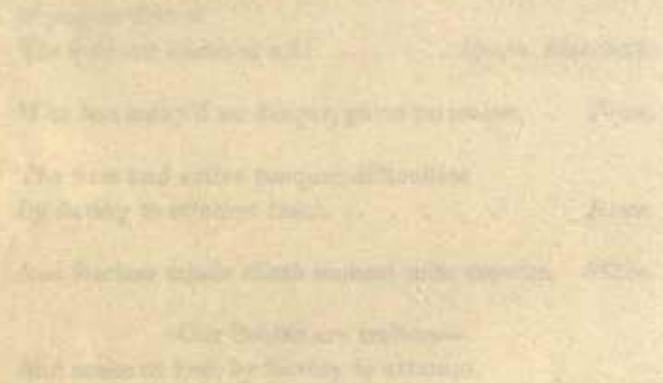

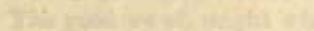

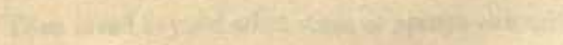


Pink, Red, double.

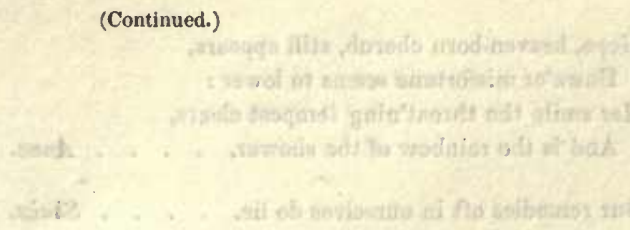

I will send the pink, the emblem of my dear,

For she 's the pink of womankind, and bloons without a peer. . . . . . . . Burns.

'Tis a token of all the heart can keep

Of holy love, in its fountain deep. . . . . Anon.

This pink is one of Cupid's carriers. . . . Shaks.

Oh, tell her that my virtuous flame

Is, as her spotless soul, refin'd. . . Thomson. Song.
Prnk, Variegated.

Refusal.

Dianthus variegatus.

Pink, White.

Ingenuousness.

Dianthus albus.
Too much, Alexis, I have heard-

But you shall prumise, ne'er again

To breathe your vows, or speak your pain... . Prior.

Take my esteem, if you on that can live;

For frankly, sir, 'tis all I have to give. . . Dryden.

It is not virtue, wisdom, valour, wit,

Strength, comeliness of shape, or amplest merit,

That woman's love can win. * * *

But what it is, hard is to say, harder to hit. . Milton.

Whate'er the emotions of her heart,

Still shone conspicuous in her eyes-

Stranger to every female art,

Alike to feign, or to disguise. . . . Shavo.

Heart on her lips, and soul within her eyes. . Byron.

If tenderness touch'd her, the dark of her eye

At once took a darker, a heavenlier dye,

From the depth of whose shadow, like holy revealings

From the innermost shrine, came the light of her feelings.

Moore.

Each beauty of her mind and face,

Was brighten'd by some sweet peculiar grace !

How eloquent in every look-

Through her expressive eyes, her soul distinctly spoke.

Lyttelton.

And the soft language of the soul

Flow'd from her never-silent eye. . . . Cartwright. 
Pleurisy Root ; Cure for the heart- The miserable have no other medicine, but only hope. ache.

Shaks.

or, Swallow Wort.

Asclepias.
Hope, heaven-born cherub, still appears,

Howe'er misfortune seems to lower:

Her smile the threat'ning tempest clears,

And is the rainbow of the shower. . . . Anon.

Our remedies oft in ourselves do lie. . . . Shaks.

Wise men ne'er sit and wail their loss,

But cheerly seek how to redress their harms. . same.

You may be pleased to catch at my intent. . same.

Polyantros, Lilac coloured. Confidence. Be as just and gracious unto me,

Primula.

As I am confident and kind to thee. . . . . same.

Let mutual joys our mutual trust combine,

And love, and love-born confidence, be thine! Dryden.

Thou knowest how fearless is my trust in thee.

L. E. L.

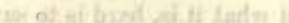

Polyanthos, Crimson heart.

The heart's mystery.

Prinula.
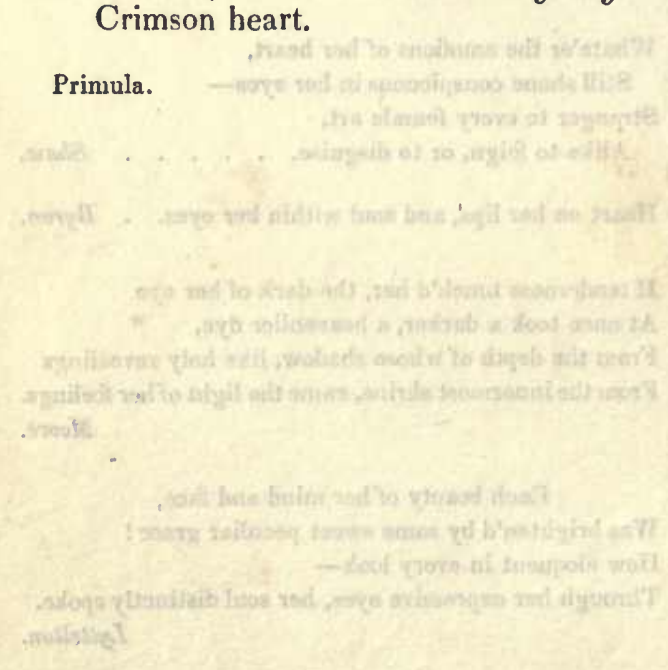

Ahenetra:

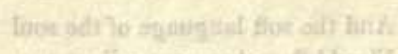

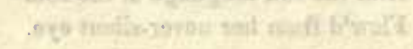

The love-sick cowslip that head inclines

To hide a bleeding heart. . . . . . Hurdis.

The rath primrose that forsaken dies.

Milton's Lycidas.

The heart hath its mystery, and who may reveal it;

Or who ever read in the depths of their own,

How much we never may speak of, yet feel it,

But even in feeling it, know it unknown? - L.E. $L$.

A Night in May.

* * * * None knew

If she had loved; but always did her song

Dwell on love's sorrow-

She had a strange sweet voice, the maid who sang-

"Sleep, beart of mine-

Why should love awake thee?

Like yon closed rose-bud,

To thy rest betake thee.

Waken, heart, of mine!

From such dangerous sleeping;

Love's haunted visions

Ever end in weeping." . . . . L. E. L.

The Ancestress. 


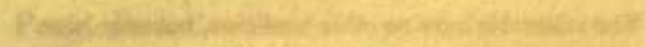

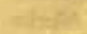
astivitore

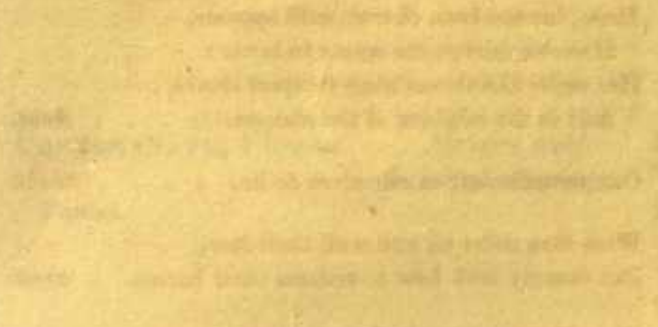

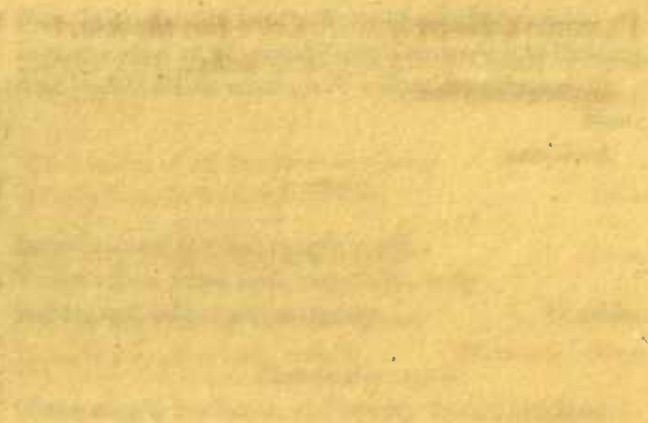

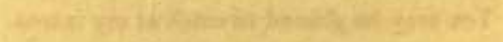

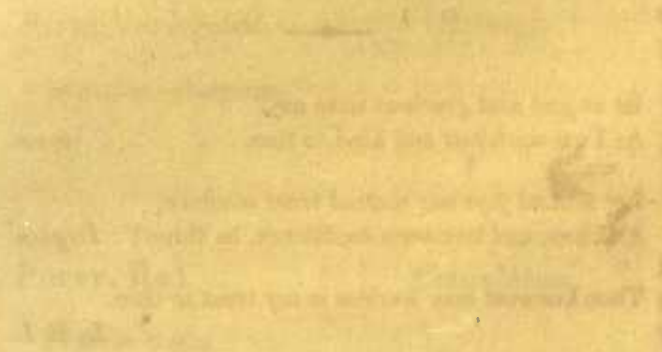

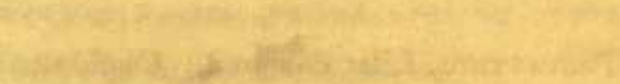

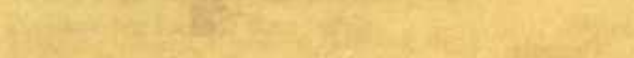

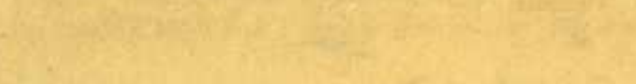

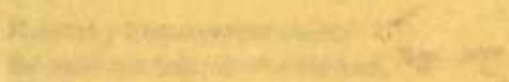

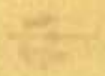

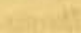

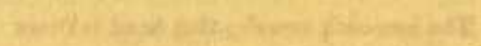

H.

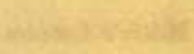

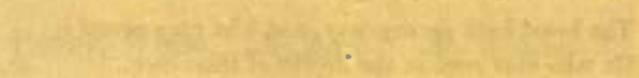

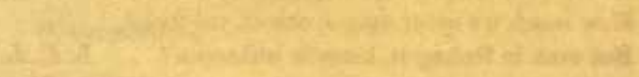

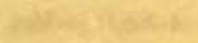

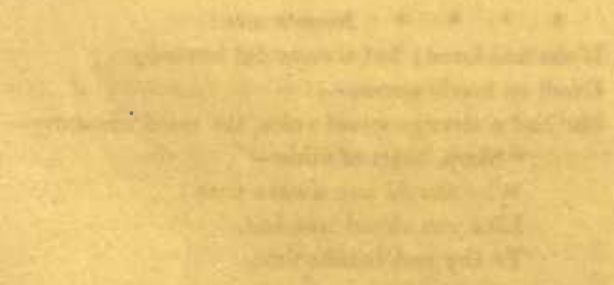
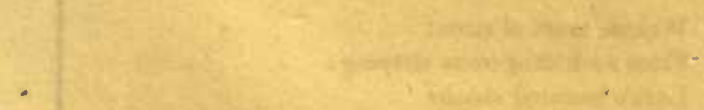

$$
\text { . }
$$

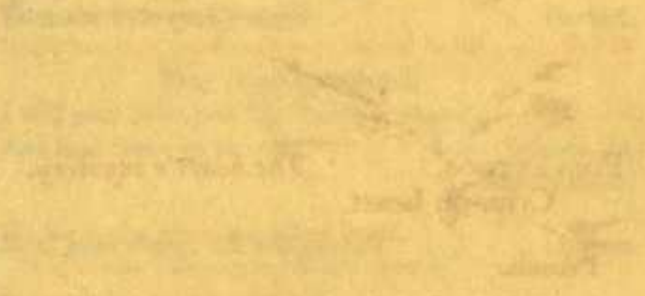

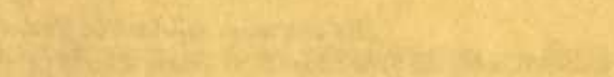

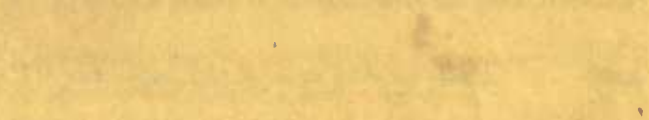

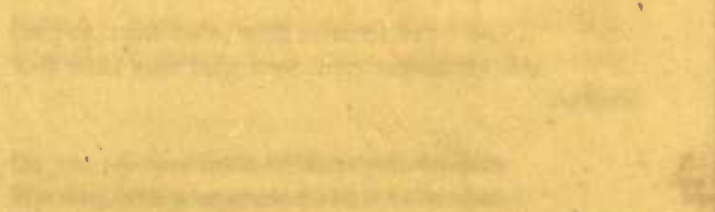

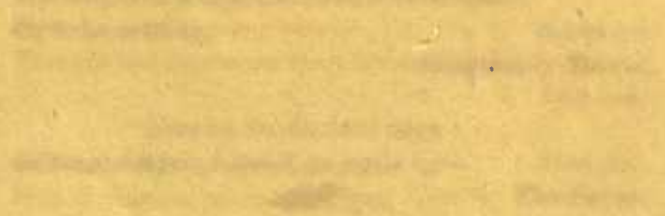

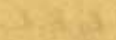

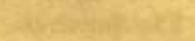

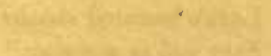

24 


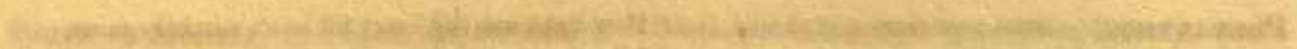

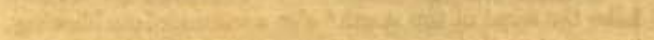

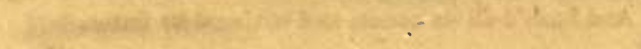
(n) $x$

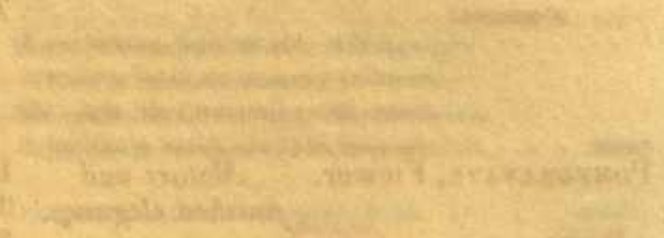

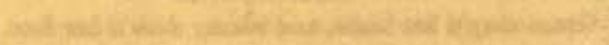
$(x+3)$

Nat is bi

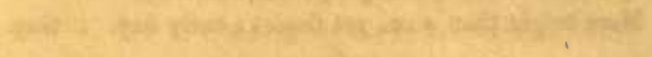

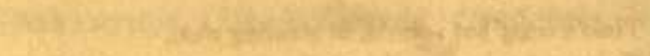
whate

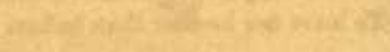

a

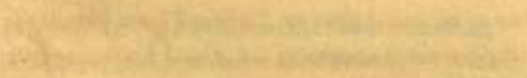

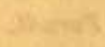

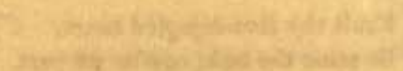

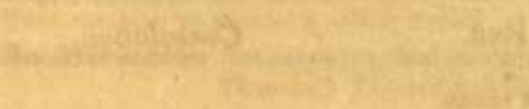

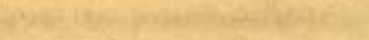
$x=$

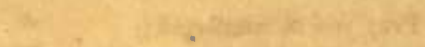

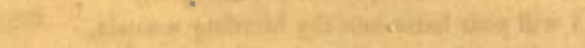

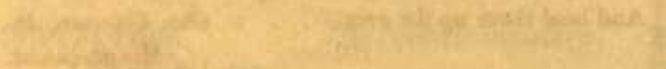

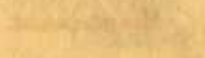

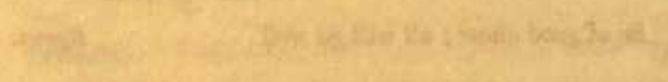

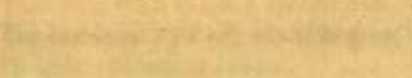

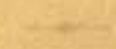

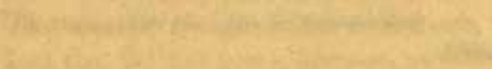

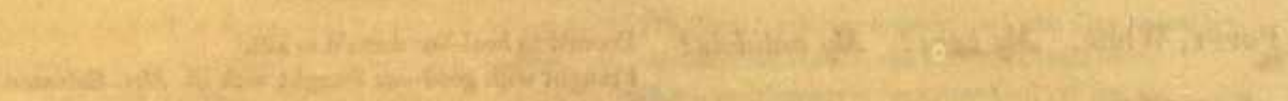

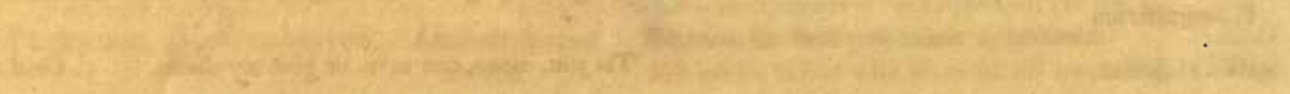

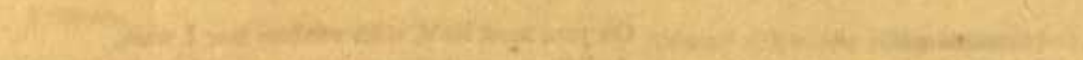

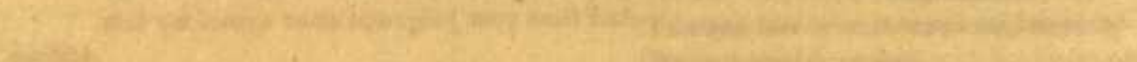
$30+2=15$

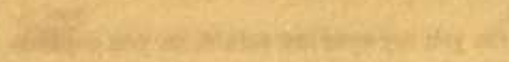

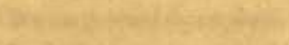

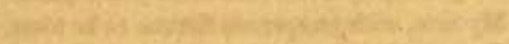

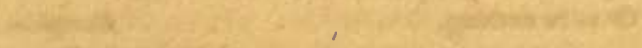

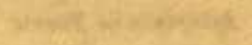

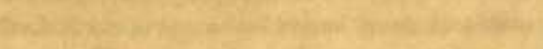

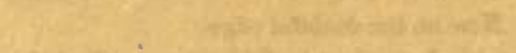

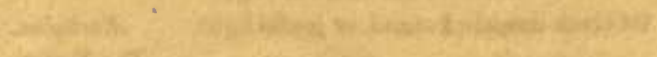
tertats actis

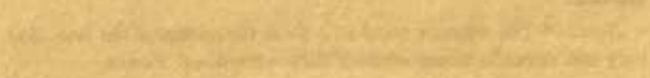


(Continued.)

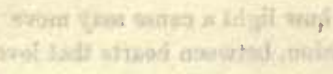

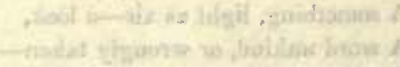

\begin{abstract}
Pomegranate, Flower. Mature and finished elegance.
\end{abstract} Punica.
Polyanthos.

How light was thy heart till love's witchery came, Like the wind of the south* o'er a summer lute blowing, And hush'd all its music, and wither'd its frame.

Moore.

Impatient nature had taught motion

To start from time, and, cheerfully, to fly

Before, and seize upon maturity. . . . Crashaw.

Mature she was-

Grace shap'd her limbs, and beauty deck'd her face.

Prior.

Sylvia 's like autumn ripe, yet mild as May,

More bright than noon, yet fresh as early day. . Gay.

Time's wing but seem'd, in stealing o'er,

To leave her lovelier than before. . . . Moore.

Exalt thy love-dejected heart;

Be mine the task, or e'er we part,

To make thee gricf resign. . . . . . Parnell.

Pray you be comforted;

I will pour balm into thy bleeding wouuds, And heal them up for ever. . . Geo. Coleman, Jr. Mountaineers.

Be of good cheer; all will go well. . . . Byron.

Poppr, White. My bane! My antidote! P. somniferum.

oom'd to heal-or doom'd to kill,

Fraught with good-or fraught with ill. Mrs. Robinson.

'Tis you, alone, can save, or give my doom. . . Ovid.

On you, most lov'd, with anxious fear I wait, And from your judgment must expect my fate.

Addison.

On you my eyes are turn'd, on you depends

My fate, with prosperous fortune to be blest,

Or to be nothing. . . . . . . Euripides.

Iphigenia in Tauris.

Now on the doubtful edge

Of black despair I stand, or joyful light. Aschylus.

The Furies.

Note.- The Samoor wind so softens the strings of the lute, that they can never be tuned while it lasts.-Stephens' Persia. 
$\begin{array}{ll}\text { Pride of China. } & \text { Dissension. wast how light a cause may move } \\ \text { Dissension, between hearts that lo }\end{array}$

Dissension, between hearts that love ! . Moore.

Melia azedarach.

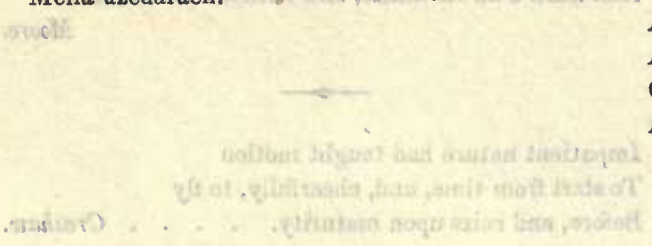

A something, light as air-a look,

A word unkind, or wrongly taken-

Oh! love, that tempest never shook,

A breath, a touch like this, hath shaken. . . same.

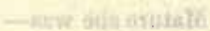

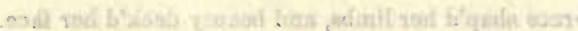

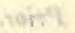

Primrose, Evening. Inconstancy.

Enothera.

\section{Whate. . .}

\section{Answer.}

Though light cause may move

Dissensions between hearts that love,

Is it not true, a cause as light,

May sever'd hearts again unite

In truer, kindlier, harmony,

Than felt before? . . . . Anon.
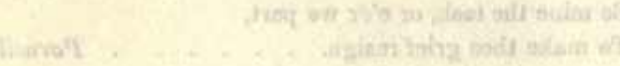

Is there, kind heaven ! no constancy in man?

No steadfast truth, no generous fixed affection,

That can bear up against a selfish world?

No, there is none.

Thomson's Tancred and Sigismunda.

\section{Wero man}

But constant, he were perfect : that one error

Fills him with faults; makes him run through all sins : Inconstancy falls off, ere it begins. . . . . same.

Oh! swear not by the moon, th' inconstant moon, That monthly changes in her circled orb;

Lest that thy love prove, likewise, variable.

Shaks.

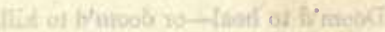

Primrose, Rose coloured. Unpatronised Primula.
Be thou the first true merit to befriend,

His praise is lost who waits till all commend. - Pope.

Ah me! full sorely is my heart forlorn,

To think how modest worth neglected lies;

While partial fame doth with her blasts adorn

Such deeds alone, as pride and pomp disguise, Deeds of ill sort, and mischievous emprisc.

Shenstone.

But own I must, in this perverted age,

Who most deserve, can't always most engage;

So far is worth from making glory sure,

It often hinders what it should procure. . . Young.

Unrivall'd as thy merit, be thy fame! . . . Tickell. 


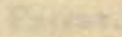

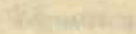

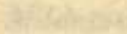

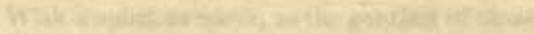

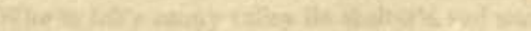

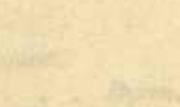

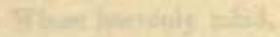

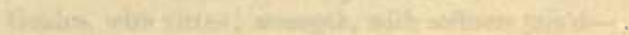

wath

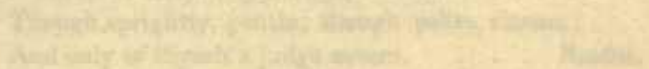

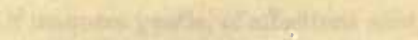

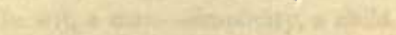

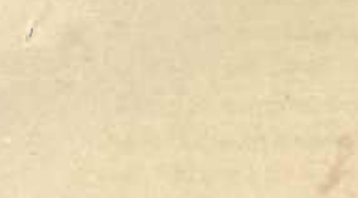

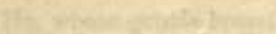

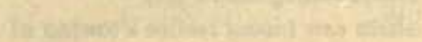

Q10ancent:

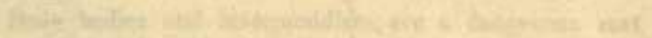
4.

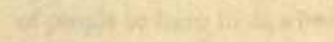

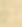

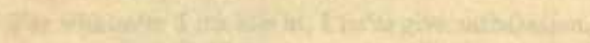

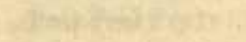

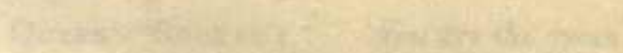

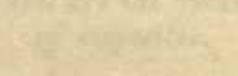

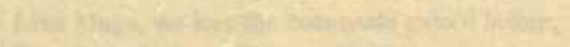

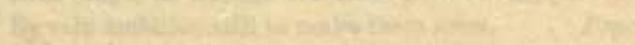

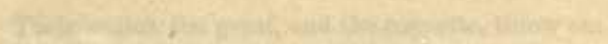

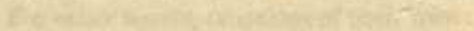

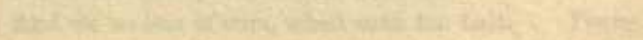




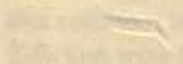

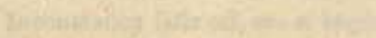

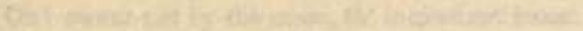

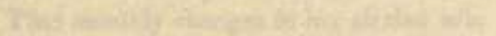

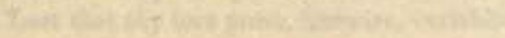




\section{Privet.}

Mildness.

Ligustrum.

With a spirit as meek, as the gentlest of those Who in life's sunny valley lie shclter'd and warm.

Moore.

She was a soft landscape of mild earth, Where all was harmony, and calm and quiet,

Luxuriant, budding. . . . . . Byron.

Whose heavenly mind,

Genius, with virtue; strength, with softness join'dWith meek simplicity, and joy of heart;

Though sprightly, gentle; though polite, sincere;

And only of thyself a judge severe. . . Beattie.

Of manners gentle, of affections mild,

In wit, a man-simplicity, a child. . . . Pope.

$\mathrm{He}$, whose gentle breast

In nature's softest mould was made. . . Langhorne.

Busy body.

Quamochit.

\section{Ipomœa.}

\section{Queen's Rocket; \\ or, Dame's Violet.}

Hesperis matronalis.
You are the queen of coquettes.
Busy bodies and intermeddlers, are a dangerous sort of people to have to do withal.

L'Estrange.

\section{Answer.}

Because I take an interest in other people's business, I 'm hubb'd, and scrubb'd, and rubb'd, and drubb'd, Until I fecl a dizziness;

Which makes me vow, I 'll never do a kind or worthy action,

For whatso'er I meddle in, I ne'er give satisfaction.

Poor Paul Pry!!

Like kings, we lose the conquests gain'd before,

By vain ambition still to make them more. Pope.

Their smiles, the great, and the coquette, throw out For other hearts, tenacious of their own:

And we no less of ours, when such the bait. . Young.

The vain coquette each suit disdains,

And glories in her lover's pains-

With age she fades, each lover flies,

Contemn'd, forlorn, she pines and dies. . . Gay. 


\section{Ragged Robin;}

or, Meadovo Lychnis.

Flos cuculi.

Wit.

With Cupid's arrow, she hath Dian's wit. . . Shaks.

Her words do show her wit incomparably. - same.

With her mien she enainours the brave;

With her wit she engages the free;

With her modesty pleases the grave;

She is every way pleasing to me. . . Shenstone.

Illum'd by a wit that would fascinate sages,

Yet playful as Peris just loos'd from their cages.

Moore.

My heart would you hit,

Tip your arrow with wit,

And it comes to my heart with a twang.

I am rock to the handsome and pretty,

Can only be touch'd by the witty;

And beauty will ogle in vain:

The way to my heart 's through my brain. . Garrick.

\section{Ranunculus.}

Ranunculus.
I am dazzled by your charms.

\section{Rocket.}

Hesperis.
Rivalry.

(IItran

Bright as the sun, her eyes the gazers strike. - Pope.

Who sees the heavenly Rosaline, That, like a rude and savage man of Inde, At the first opening of the gorgeous east, Bows not his vassal head, and, strucken blind, Kisses the base ground with obedient breath?

Shaks.

Oh, I have known a brighter charm

Than Flora's region e'er contain'd-

A piereing radianee that could warm

The heart which never beauty claim'd.

And this was in a maiden's fuce,

Where mantled beauty's gayest dress;

She was so sweet-so wildly fair,

Methought perfection centr'd there. . . . $S^{* *} n$.

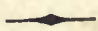

Oh, love ! thou sternly dost thy power maintain, And wilt not bear a rival in thy reign,

Tyrants and thee all fellowship disdain. . . Dryden.

Love, well thou know'st, no partnership allows;

Cupid, averse, rejects divided vows. . . . Prior.

Friendship is constant in all other things,

Saving the office and affairs of love :

Therefore all hearts in love use their own tongues,

And trust no agent; for beauty is a witch

Against whose charms faith melteth into blood. Shaks. 



\section{Rocket.}

(Continued.)
I saw them, hand in hand, walk o'er the mead: Would my closed eye had sunk in endless night, Ere I was doom'd to bear that hateful sight! Where'er they pass'd, be blasted every flower !

Lyttelton.

Say, thou inconstant, what has Damon done, To lose the heart his tedious pains had won? Tell me what you in my rival find, Against whose power no ties have strength to bind? Has he, like me, with long obedience, strove To conquer your disdain, and merit love? Has he, with transport, every smile ador'd, And died with grief at each ungentle word? Ah, no ! the conquest was obtain'd with ease ; He pleased you, by not studying to please : His careless indolence your pride alarm'd; And had he lov'd you more, be less bad charm'd.

Lyttelton.
Rose, Austrian.

Rosa bicolor.

\section{Thou art all that's} lovely.

\author{
Rose, Bridal ; \\ Happy love. \\ or, Rose-leaved Bramble.
}

Rubus rosæfolius.
Bright as the blush of rising morn! . . Darwin.

Light as the angel shapes that bless

An infant's dream, yet not the less

Rich in all woman's loveliness . . . . Moore.

Loveliest of women! Heaven is in thy soul;

Beauty and virtue shine for ever round thee,

Brightening each other! Thou art all divine. Addison.

Thou art so fair, so excellently fram'd,

There is such mind in thy soul-breathing eye,

As if its pure home in heaven it claimed,

And thence alone could draw its witchery;

Thy voice hath such a soothing melody,

And on thy lightest thought such magic plays,

Like a bright fountain on the gladden'd sky-

Methinks, as on thy perfect form I gaze,

In peace should be thy paths, in pleasantness thy ways.

C.M.M
To feel that we adore, to such refined excess,

That though the heart would break with more,

It could not do with less. . . . . Moore.

My soul hath her content so absolute,

That not another comfort like to this,

Succeeds in unknown fate. Shaks. 
Rose.

(Continued.)
Thou art more happy, Oh, my soul! than speech

Knows to express: what shall I say, 'tis all

Surpassing wonder and the power of words. Euripides.

Iphigenia in Taurus.

She is mine own :

And I as rich in having such a jewel,

As twenty seas, if all their sand were pearls,

The water nectar, and the rocks pure gold. . . Shaks.

My true love is grown to such exeess,

I cannot sum up half my sum of wealth. . . . same.

There's beggary in love that can be reckon'd. . same.

Bring flowers, fresh flowers, for the bride to wear !

They were born to blush in her shining hair.

Bring flowers, for the locks of the fair young bride.

Hemans.

\section{Rose, Burgundy. Unconscious beauty.} Rosa parbifolia.

\section{Rose, Cabbage. \\ The ambassador of love.}

Rosa capitatum.
Doubts the beauty, which she doubts alone,

Which dazzles every eye, except her own. . Hayley.

Around her shone

The nameless charms, unmark'd by lier alone. Byron.

O'er her warm cheek the blush of beauty swims.

Shaks.

The bloom that open'd on her face

Well seem'd the emblem of her mind,

Where snowy innocence we trace,

With blushing modesty combin'd. . . Cartwright.

\section{Go, fragrant rose, and deck the lovely breast}

Of her whose image ever divells in mine,

And in thy fair abode supremely blest,

With balmy sweets repay the bliss divine. - Anon.

Go, rose-my Chloe's bosom grace-

How happy should I prove,

Might I supply that envied place,

With never-fading love ! . . . . Gay.

\section{Answer.}

Yet I have not seen

So likely an ambassador of love :

A day in April never came so sweet,

To show how costly summer was at hand,

As this fore-spurrer comes before his lord. . . Shaks. 

$+\frac{1}{3}$

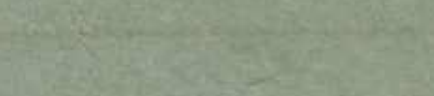

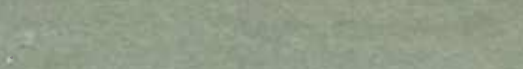

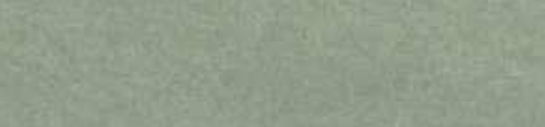$$
\text { cisters }
$$

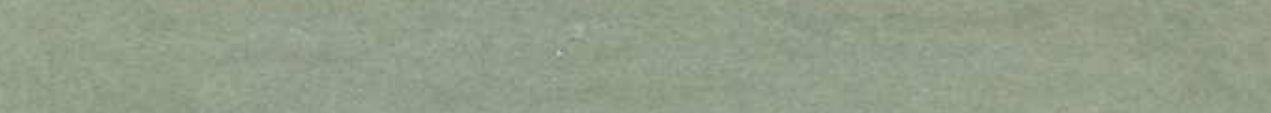

$9 x^{2}+\frac{2}{2}$

125.

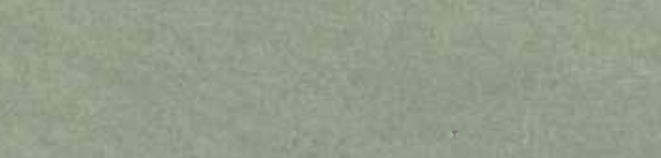

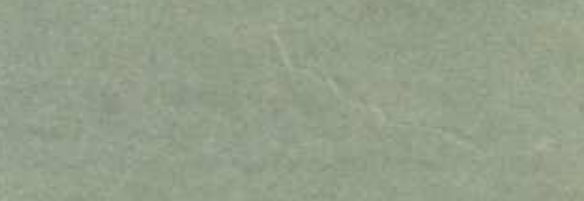

unisy

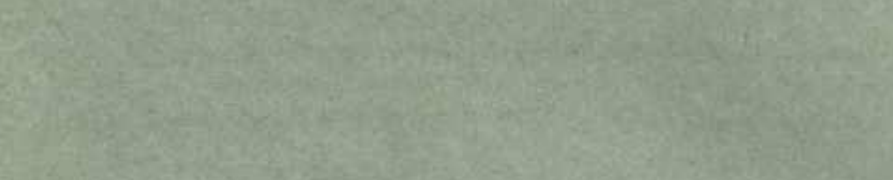

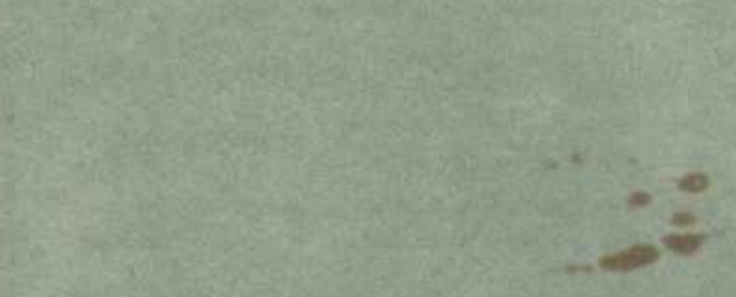

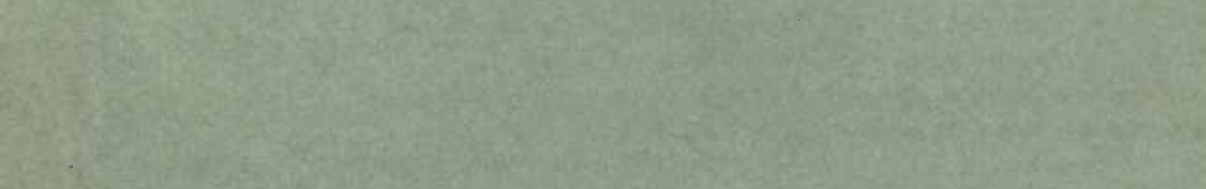

$$
206 x+3 x^{2}
$$

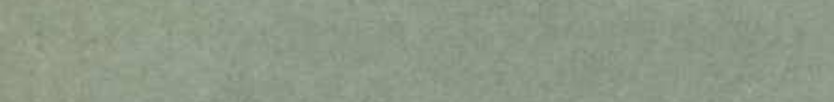

(2)

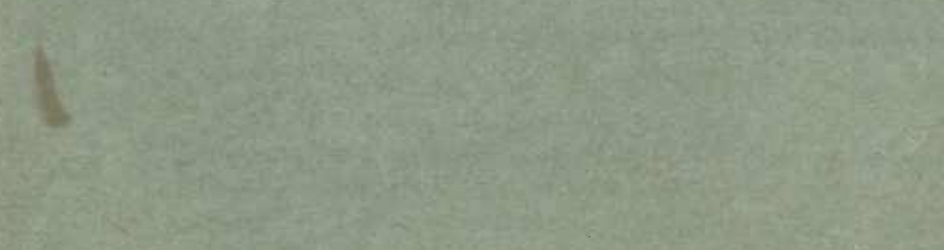


Rose, Daily. That smile I zoould Smiling she seem'd, and full of pleasing thought. aspire to!

Rosa quotidiana.

The pleasant hour

Dryden.

Only wants thy smile to bless it. . . . Anon.

Who will, may pant for glory and excel,

Her smile his aim, all higher aims farewell! . Cowper.

Oh : let me only breathe the air,

The blessed air, that 's breath'd by thee,

And whether on its wings it bear

Healing, or death, 'tis sweet to me. . . Moore.

Smiles from reason flow-and are of love the food.

Milton.

Answer.

Know, smiler, at thy peril thou art pleas'd,

'Thy pleasure is the promise of thy pain,

'The fancied med'cine heightens the disease. Young.

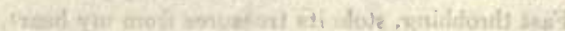

Rose, Damask.

Freshness.

Rosa damascena.

1.

\section{Rose, Deep red. Bashful shame.}

I have marked a thousand blushing apparitions

To start into her face; a thousand innocent shames

In angel whiteness bear away those blushes.

Shaks.

From every blush that kindles in thy cheeks,

Ten thousand little loves and graces spring

To revel in the roses. . . . . . . . Rowe.

The crimson glow of modesty o'erspread

Her cheek, and gave new lustre to her charms.

Dr. Thos. Franklin.

Still, from the sweet confusion, some ncw grace

Blush'd out by stealth, and languish'd in her face.

Eusden's Ovid.

So sweet the blush of bashfulness,

Even pity scarce can wish it less ! . . . Byron. 


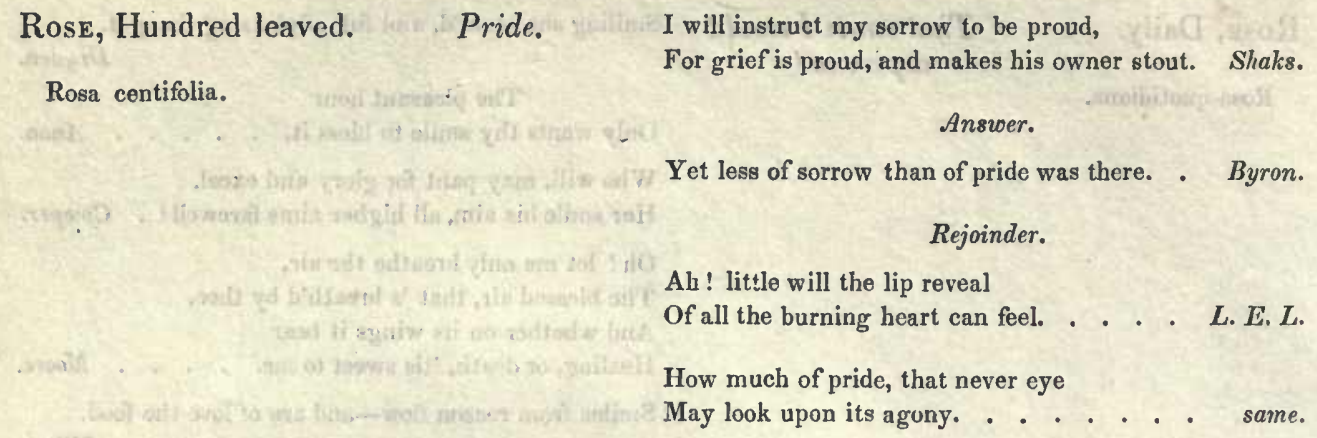

Rose, Maidens' Blush. If you do love me, I do betray myself with blushing ! . . . . Shaks.

\section{Rosa rubor virginea.} you will find me out.

Confusion thrill'd me then, and secret joy,

Fast throbbing, stole its treasures from my heart,

And mantling upward, turn'd my faco to crimson.

Brooke's Gustavus Vasa.

I blush to think what I have said-

But fate has wrested the confession from me.

Go on, and prosper in the paths of honour :

Thy virtue will excuse my passion for thee,

And make the gods propitious to our love. . Addison.

And yet, what need I blush at such a choice?

I love a man whom I am proud to love. . . Dryden.

Rose, Moss, full blown. Superior merit.

Rosa muscosa.
Behold the first in virtue, as in face!

In praise so just, let every voice be raised. . . Pope.

Oh ! what perfections must that virgin share,

Who fairest is esteen'd, where all are fair ! . Prior.

The virtuous Marcia towers above her sex:

True she is fair-oh, how divinely fair !

But still the lovely maid improves her charms

With inward greatness, unaffected wisdom,

And sanctity of manners. Cato's soul

Shines out in every thing she acts and speaks;

While winning mildness and attractive smiles

Dwell in her looks. . . . . . . Addison.

\section{She is one}

For whom a life were a small sacrifice,

Aye, to be deemed as nothing! . . S.P.C.

How could my tongue

Take pleasure, and be lavish in thy praise ! 
Rose.

(Continued.)

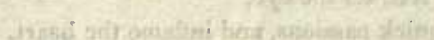
Bakian all'

nuimad?
How could I speak thy nobleness of nature :

Thy open, manly heart, thy courage, constancy, And inborn truth, unknowing to dissemble!

Rowe.

And, in a word, (for far behind his worth

Come all the praises that I can bestow,)

$\mathrm{He}$ is complete in feature and in mind,

With all good grace to grace a gentleman.

He is worthy for an empress' love,

As meet to be an emperor's counsellor.

- Shaks.

\section{Rose-bud, Moss. Confession.}

Rosa muscosa.

Well did I mark the new-born passion grow, Which my heart beat responsive at perceiving.

\section{I know not why}

I love this youth; and I have heard you say, Love's reason's without reason. . . . . Shaks.

As letters some hand has invisibly trac'd,

When held to the flame will steal out to the sight;

So, many a feeling that long seem'd effac'd,

The warmth of a meeting like this brings to light.

Moore.

\section{Answer.}

A light comes o'er me from those looks of love,

Like the first dawn of mercy from above. . . same.

In the mild eyes that shone before him,

Beaming that blest assurance, worth

All other transports known on earth,

That he was loved-

Oh! in this precious hour he prov'd

How deep, how thorough-felt the glow

Of rapture, kindling out of wo. . . . . . same.

Rose, Multiflora.

Grace.

R. M.

or, Bramble flowered Chinese Rose.
Grace was in all her steps, heaven in her eye,

In every gesture dignity and love. . . Milton.

Heavens! with what grace she mov'd, Who could have seen her then, and not have lov'd?

Lyttelton.

With smooth step

Disclosing motion in its every charm. . Thomson.

Each look, each motion, wak'd a new-born grace,

That o'er her form its transient glory cast. . Mason. 
Rose, Multiflora. (Continued.)
All the wonders of external grace, A person finely turn'd, a mould, a face, Where, union rare, expression's lively force, With beauty's softest magic holds discourse, At tract the eye,

Rouse the quick passions, and inflame the heart.

Churchill.

Melinda! formed with every grace complete, Yet these neglecting, above bcauty wise.

Thomson.
Rose, Mundi. Variety.

Rosa versicolor.

Skilled alike to dazzle and to please.

Each look, cach motion, waked a new-born grace,

That o'er her form its transient glory cast.

Some lovelier wonder soon usurped the place, Chas'd by a charm still lovelier than the last.

Mason.

That loveliness, ever in motion, which plays

Like the light upon autumn's soft shadowy days,

Now here, and now there, giving warmth as it flies

From the lips to the cheek, from the cheek to the eyesNow melting in mist, and now brealking in gleams;

Like the glimpses a saint hath of heav'n in his dreams.

Moore.

She stood as stands a rainbow in a storm,

Changing its hue with bright variety,

But still expanding lovelier o'er the sky,

Howe'er its arch may swell, its colours move,

The cloud-compelling harbinger of love. . . Byron.

As sun-shine dwells upon the summer wave,

Changing for ever, yet for ever bright.

S. P. C.

New beauties rise with eacli revolving day.

Thomson.

Rose, Musk cluster.

Charming.

Rosa muschata.
Where the power that charms us so,
In the soul, or in the eye? . . . Waller.

Behold a nymph with ev'ry virtue graced, Minerva's head on Venus' shoulders placed !

Here's beauty, mental, moral, and divine, To charm the lover, and his thoughts refine.

Anon.

What's fernale beauty, but an air divine, Through which the mind's all gentle graces shine? They, like the sun, irradiate all between,

The body charms, because the soul is seen. Young.

With artless grace, and native ease she charms. 


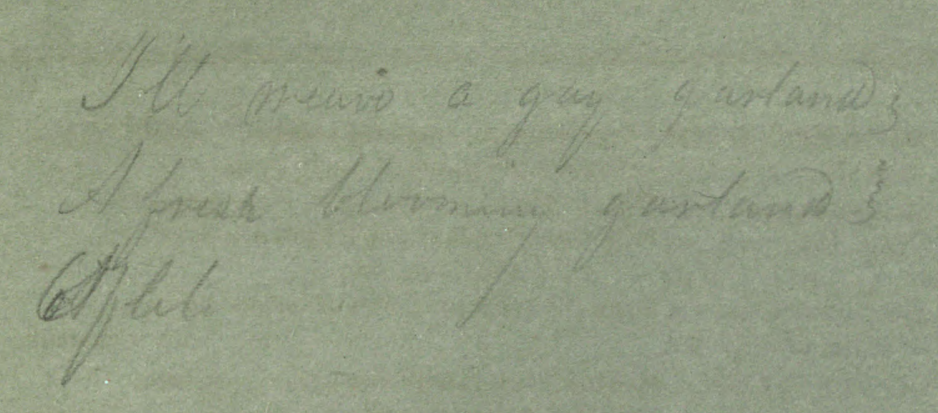




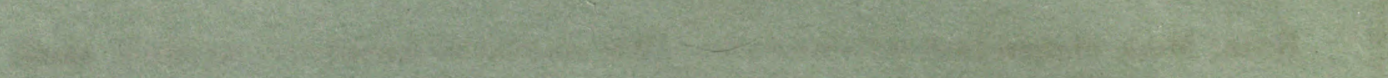

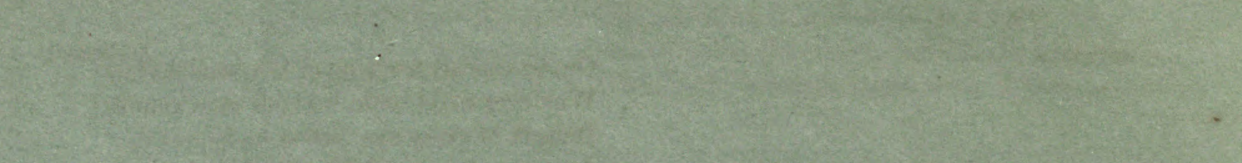

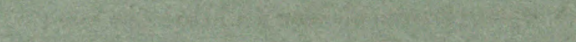

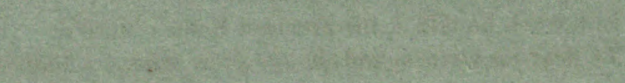

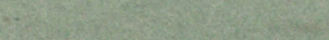

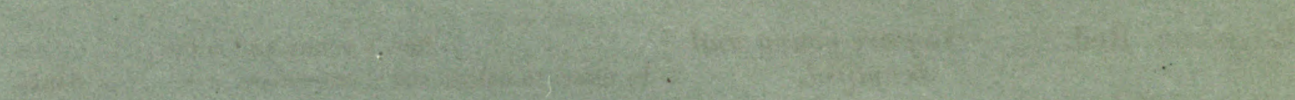

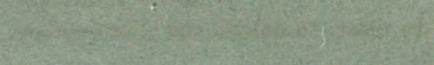

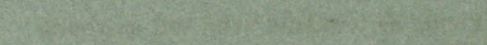

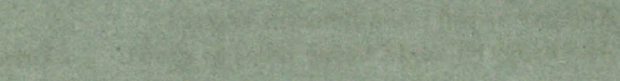

ait

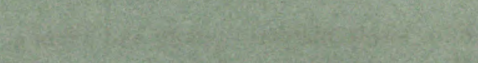

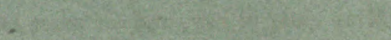

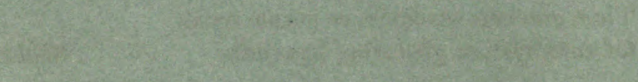

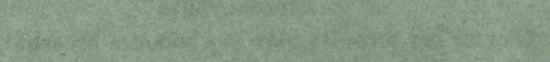

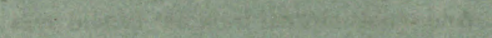

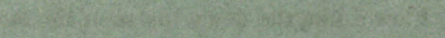

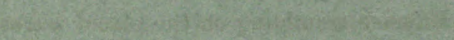

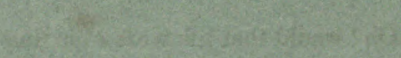

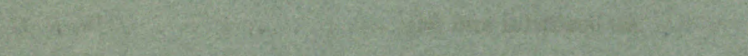

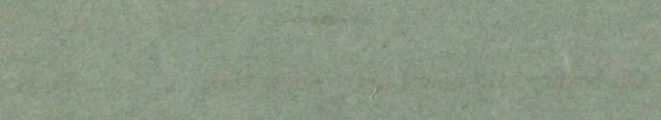

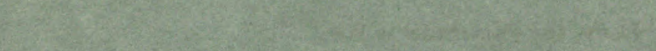

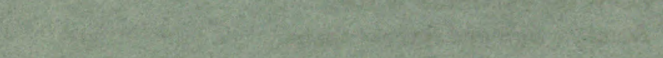

2.

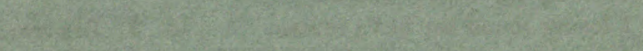

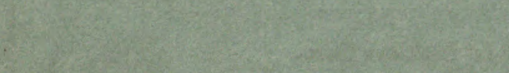

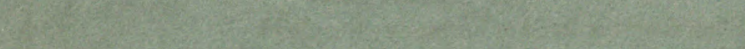

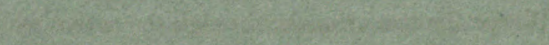

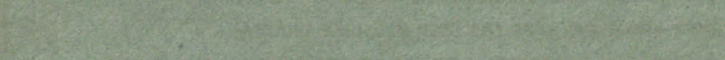

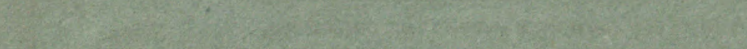

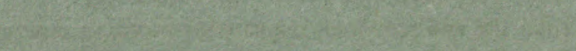

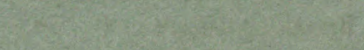

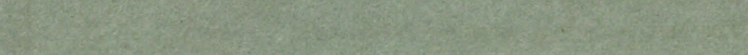

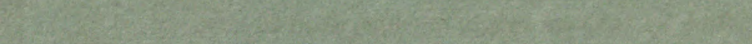

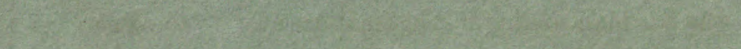
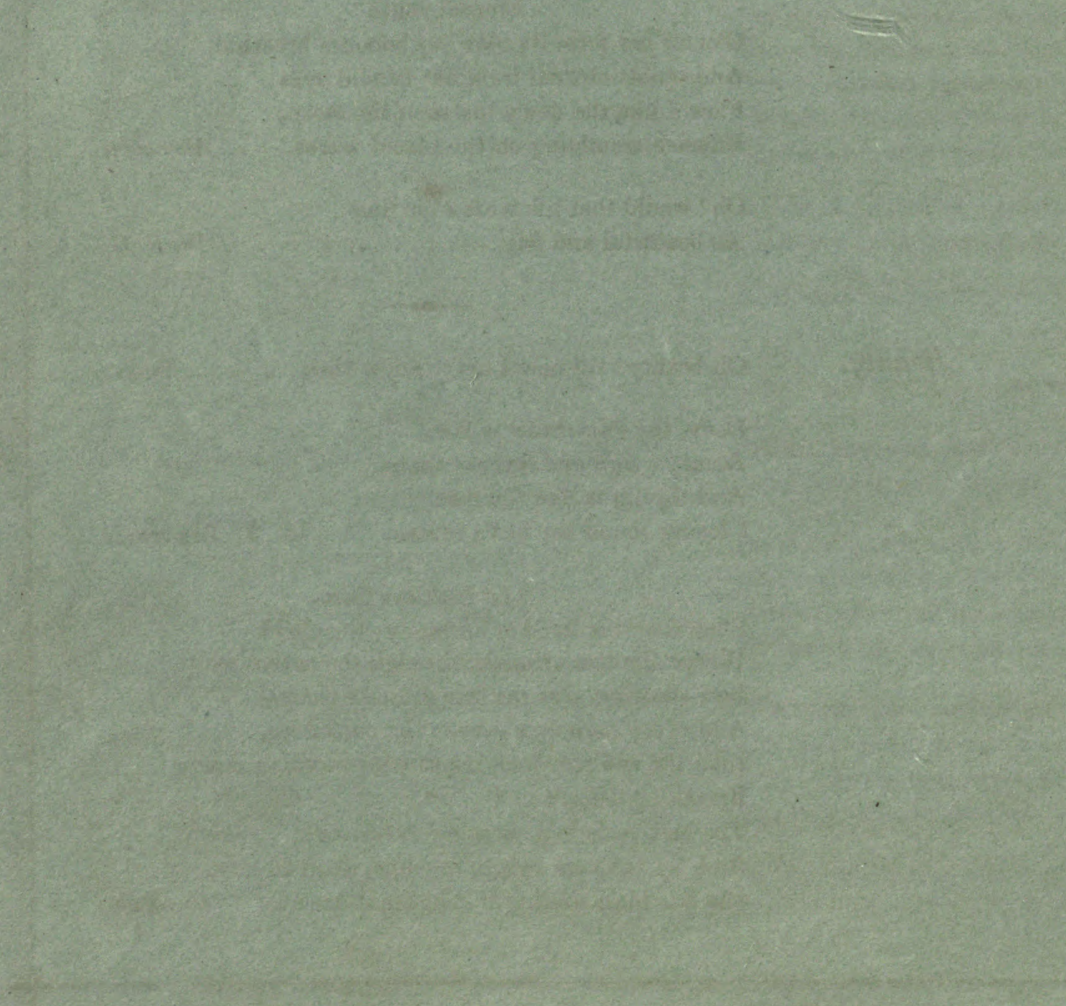
Rose, Musk cluster.

(Continued.)

Rose-Bud, Red. You are young and
beautiful.

Who can resist her charms? . . . Young.

Oh, he was all made up of love and charms :

Whatever maid could wish, or man admire;

Delight of every eye; when he appear'd,

A secret pleasure gladden'd all that saw him;

But, when he talk'd, the proudest Roman blush'd

To hear his virtues, and old age grew wise. Addison.

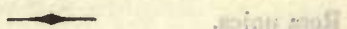

She 's young and fair-

In these, to nature she 's immeriate heir. . . Shaks.

Young as beautiful ! and soft as young !

And gay as soft! and innocent as gay!

And happy [if aught happy here] as good! Young.

In youth's fresh bloom with beauty crown'd.

Eschylus' Agamemnon.

Fair, lovely maiden-young and affable,

More clear of hue, and far more beautiful

Than precious sardonix, or purple rocks

Of amethyst, or glistering hyacinth. . . Shaks.

\section{Eternal youth}

Nofic $10.9 \mathrm{~T}$

O'cr all her form its glowing honours brcath'd,

And smiles eternal from her candid eyes

Flow'd like the dewy lustre of the morn,

Effusive trembling on the placid waves. Akenside.

Oh! would that life were ever thus

As beautiful and gay. . . . . . W. B. G.

Rose, Red, full blown. Beauty.

Rosa rubrifolia.
Oh beauty ! till now I never knew thee. . . Shaks.

Lady, thy lofty brow is fair,

Bcauty's sign and seal are there.

And thy lip is like the rose,

Closing round the bee's repose. . . S. T. Lawrence.

The faultless form,

Shap'd by the hand of harmony; the cheek

Where the live crimson, through the native white

Soft-shooting, o'er the face diffuses bloom,

And every nameless grace; the parted lip,

Like the red rose-bud, moist with morning dew,

Breathing delight;

The look resistless, piercing to the soul,

And, by the soul inform'd, wlen, drest in love,

She sits high-smiling in the conscious eye.

Thom son. 
Rose, Red.

(Continued.)
The brightness of her cheek would shame the stars, As daylight doth a lamp! her eye in heaven Would through the airy region stream so bright, That birds would sing, and think it were not night.
Rose, Unique.

Rosa unica.
Rose-Bud, White.

Rosa alba.

\section{$A$ heart that is ignorant of love.}

Mine, is the freedom of the soul,

And mine, the unconquer'd will. . . . . Dale.

Do not disturb our calm, oh love ! . . . Moore.

$\Rightarrow \quad$ By love, the young and tender wit

Is turn'd to folly; blasting in the bud,

Losing his verdure even in the prime,

And all the fair effects of future hopes. . . . Shaks.

$$
\text { No-let me be }
$$

"In maiden meditation, fancy free !" . . same.

All its joys and pains to others I resign,

Be the vacant heart, the careless bosom, mine! Moore.

From love's weak childish vow I live unharm'd.

Shaks.

Rose, White.

Rosa alba.
I am worthy of you.

all this heart hath borne for thee,

By all it suffers now. . . . . . . Anon.

My suff'rings for you make your heart my due.

Dryden.

Take then this flower--

The perfume of its faded leaves, triumphant o'er decay, May whisper of my changeless love, when I have pass'd 


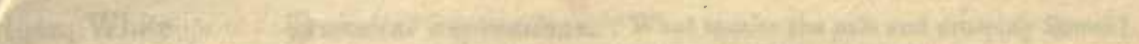

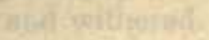

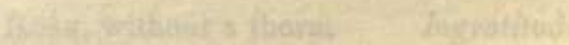

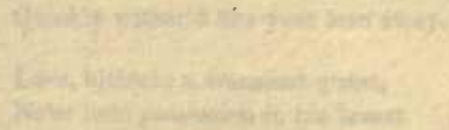

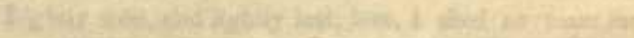

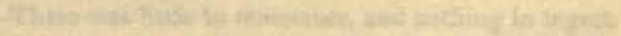

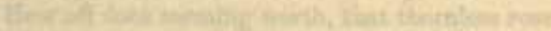

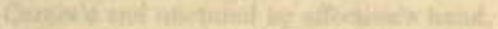

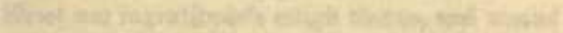

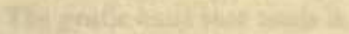

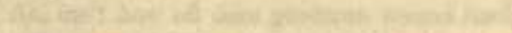

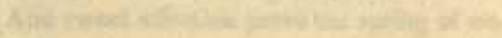

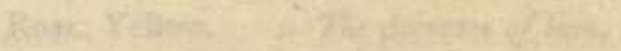

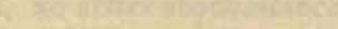
(15)

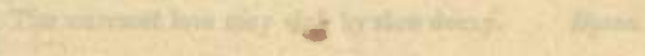

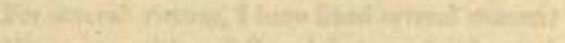

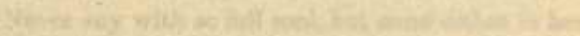

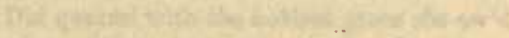

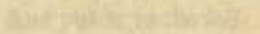




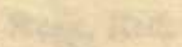

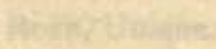

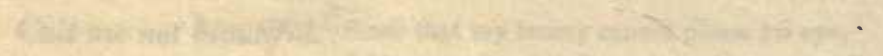

terat $x+5=$

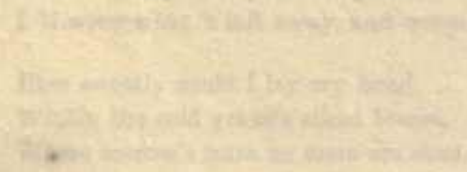

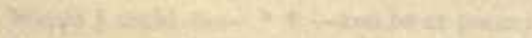

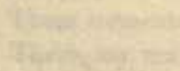

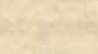

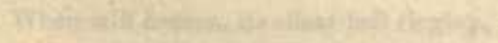

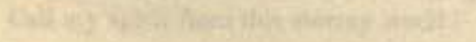

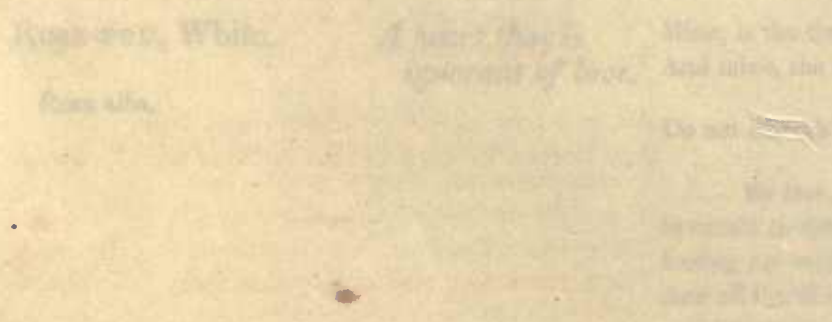

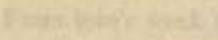

$4 x^{2}+4 x^{2}=$ 
Rose, White Transient impressions. What speaks the pale and drooping flower? and withered.

Of joy that withers in an hour! . . . T. Dale.

Quickly wither'd like your love away. . . Anon.

Love, hitherto a transient guest,

Ne'er held possession in his breast. . . . Swift.

Lightly won, and lightly lost, love, I shed no tears for thee ;

There was little to remember, and nothing to regret.

L. E. L.

I have no parting sigh to give,

So take my parting snile.

same.

Rose, without a thorn. Ingratitude.

Rośa inermis.

Rose, Yellow.

Yellow Sweet Briar.

The decrease of love, on better acquaintance.

Rosa lutea.
If there be a crime

Of deeper dye than all the guilty train Of human vices, 'tis-ingratitude.

Dr. Thomas Franklin's Earl of Warwick.

How oft does seeming worth, that thornless rose, Caress'd and nurtured by affection's hand, Shoot out ingratitude's rough thorns, and wound The gentle hand that tends it. . . . S. P. C.

Ah, me ! how oft does goodness wound itself, And sweet affection prove the spring of wo.

Shaks.

The warmest love may sink by slow decay. . Byron.

For several virtues, I have liked several women; Never any with so full soul, but some defect in her Did quarrel with the noblest grace she ow'd, And put it to the foil. . . . . . Shaks.

Rose, York and Lancaster. War. Such war of white and red within her cheeks. Shaks. Rosa versicolor.

There is a white cloud o'er the moon, its form Is very light, and yet there sleeps the storm;

It is an omen, it may tell the fate Of love known all too soon, repented all too late.

Thomson's Masquerade.

A chase of idle hopes and fears,

Begun in folly, closed in tears. . . . Byron.

The beacon sign of inward strife,

Was that cheek's flushing red. L. E. L. 
Rose, York and Lancaster.

(Continueds)
That proud heart had been given to one

Who sought it not to win-

And now she only strove to hide

The burning shame within. . . . L. E. L.

Rose, Campion. Only deserve my love. Our hearts ne'er bow but to superior worth;

And never fail of their allegiance there. . . Young.

Agrostemma.

Rosemary.

Rosmarinus officinalis.

Rue.

Ruta graveolens.
Remembrance. Keep this remembrancc for thy Julia's sake. . Shaks.

She sent him rosemary, to the intent that he should hold her in remembrance. . . . . . Drayton.

\section{Answer.}

She placed it sad, with ncedless fear,

Lest time should shake my wavering soul-

Uneonscious that her image there

Held every sense in fast control. . . . Byron.

$$
\text { Oh! only those }
$$

Whose souls have felt this ono idulatry,

Can tell how precious is the slightest thing

Affection gives and hallows! A dead flower

Will long be kept, remembrancer of looks

That made each leaf a treasure.

L. E. L.

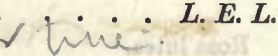

She I love, or laughs at all my pain,

Or knows her worth too well, and pays me with disdain.

Dryden.

Disdain and scorn ride sparkling in her eyes,

Misprizing what they look upon. . . . Shaks.

$\mathrm{Oh}$ ! to be in love, where scorn is bought with groans ; coy looks

With heart-sore sighs; one fading moment's mirth,

With twenty watchful, weary, tedious nights! same.

\section{Answer.}

Can this be true?

Stand I condemn'd for pride and scorn so much ?

Contempt, farewell ! and, maiden pride, adieu !

No glory lives behind the back of such. 


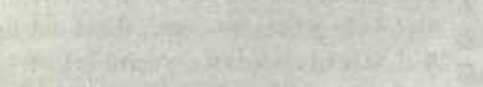




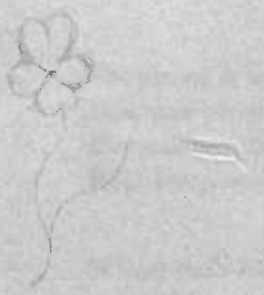


Rue.

\section{(Continued.)}

SAGE.

Domestic Virtues.

Salvia officinalis.

\section{Scabious, Dark purple.}

Unfortunate altachment.

Scabiosa atro-purpurea.
And, Benedict, love on, I will requite thee,

Taming my wild heart to thy loving hand;

For others say thou dost deserve, and I

Believe it better than reportingly. . . . Shaks.

\section{Nothing lovelier can be found}

In woman, than to study household good;

And good works in her husband to promote.

Milton.

A woman's noblest station is retreat :

Her fairest virtues fiy from public sight;

Domestic worth-that shuns too strong a light.

Lyttelton.

Domestic happiness, thou only bliss

Of paradise, that hast surviv'd the fall !

Thou art the nurse of virtue; in thine arms

She smiles, appearing, as in truth she is,

Heav'n-born, and destin'd to the skies again. Cowper.

To give society its highest taste;

Well-order'd home man's best delight to make;

And, by submissive wisdom, modest skill,

With every gentle, care-deluding art,

To raise the virtues, animate the bliss,

And sweeten all the toils of human life:

This be the female dignity and praise. . . Thomson.

I 've heard my honest uncle often say,

That lads should a' for wives that 's virtuous pray;

For the maist thrifty man could never get

A weel-stor'd room, unless his wife wad let.

Allan Ramsay.

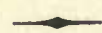

Oh, love ! how are thy precious, sweetest moments

Thus cver cross'd, thus vex'd with disappointments !

Rowe's Ulysses.

Such is the posie love composes;

A stinging nettle mixed with roses. . . . Brown.

Have blissful thoughts allur'd thee on,

And faded when most fair?

The look-the tone of bliss is gone,-

Love has been there. . . . . . T. Bayley.

The maid that loves,

Goes out to sea upon a shattered plank,

And puts her trust in miracles for safety. . Young.

Ah, Zelica ! there was a time when bliss

Shone o'er thy heart from every look of his;

When but to see him, hear him, breathe the air

In which he dwelt, was thy soul's fondest prayer ! 
Scabious.

(Continued.)

Scarlet Lychnis.

Lychnis chalcedonica.
When round him hung such a perpetual spell, Whate'er he did, none ever did so well.

Too happy days! when, if he touch'd a flower Or gem of thine, 'twas sacred from that hour ; When thou didst study him, till every tone,

And gesture, and dear look, became thy own.

Sun-beam'd eyes. Her glance, how wildly beautiful. . . B Bron.

Soul beam'd forth in cvery spark

That darted from beneath the lid,

Bright as the jewel of Giamschid. . . . . same.

In her two eyes two living lamps did flame,

Kindled above, at the heavenly light,

And darting fiery beams out of the same,

So passing pearceant, and so wondrous bright,

That quite bereav'd the rash beholders of their sight.

Spencer.

And then her look-Oh, where 's the heart so wise, Could, unbewilder'd, meet those matchless eyes?

Quick, restless, strange, but exquisite withal,

Like those of angels. . . . Moore.

So by thy bright eye's glowing bearn,

I court, as it were, my undoing ;

And although but to torture they gleam,

I knowingly rush to my ruin. . . . . same.

Thus the moth round a tremulous light,

With quivering wing still will turn,

And merely because it is bright,

Although once he has felt it can burn. . . same.

And see the danger which we cannot shun. Dryden.

SNap Dragon.

Antirrhinum.

\section{Presumption.}

Minds somewhat raised

By false presumptuous hope! . . . . Milton.

Answer.

With looks that asked, yet dared not hope relief.

Rogers.

$I$ was indeed delirious in my heart,

To lift my love so lofty as thou art.

That thou wert beautiful, and I not blind,

Hath been my sin;

Tolove too much-has been the only art I used. 


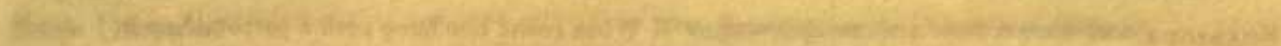
Wh

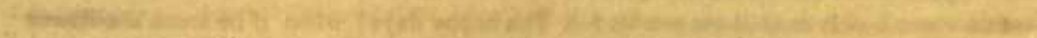

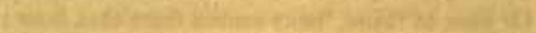

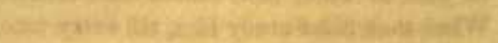

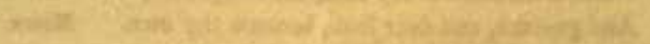

(5)

ynity

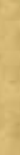 \\ 4} $2 x=\frac{1}{20}$

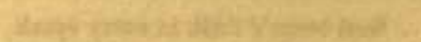

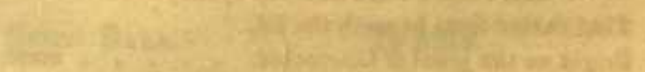

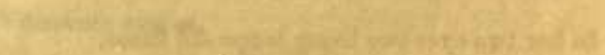

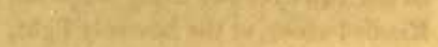

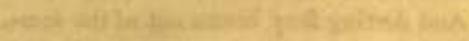

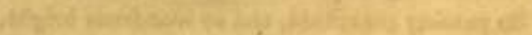

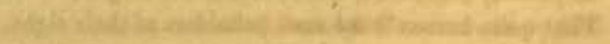
25ang

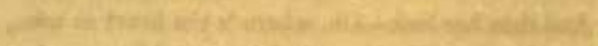

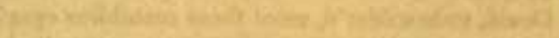

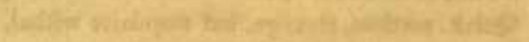
(4)

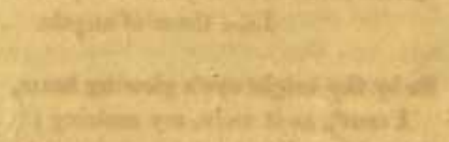

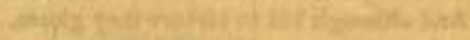

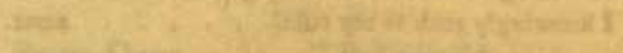

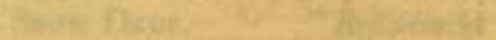

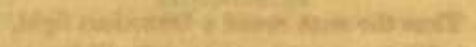

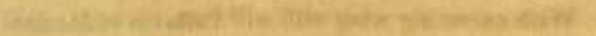

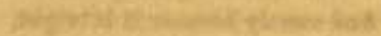

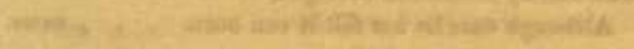
and 8 .

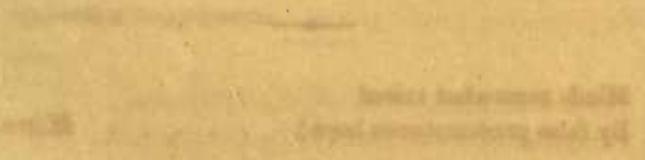

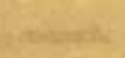
Mneger

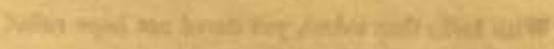

(1.) whely

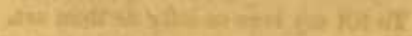

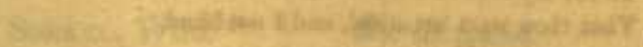

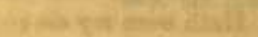

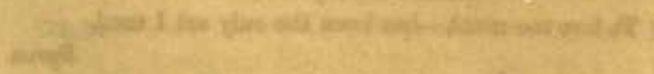

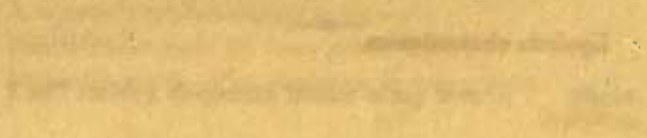

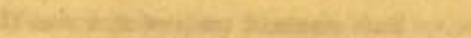

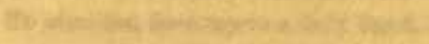

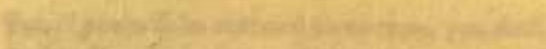

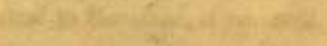

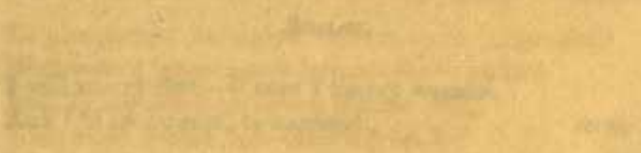

thentat

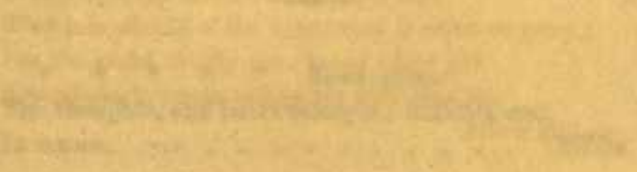


7.

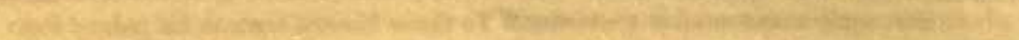

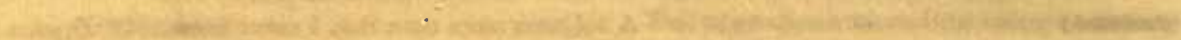

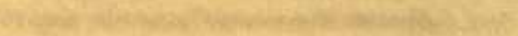

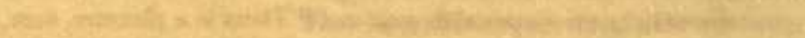

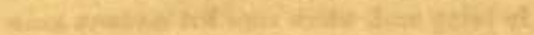

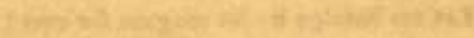

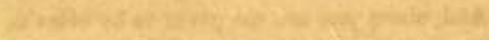

15y

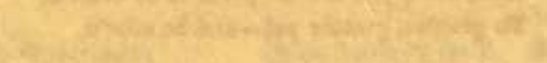

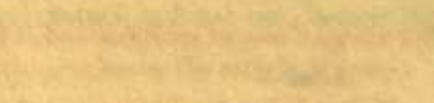

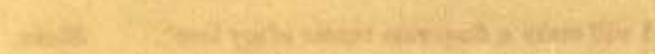

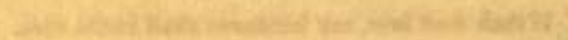

$\operatorname{lin}$

$+r^{4}$

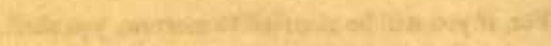

a.

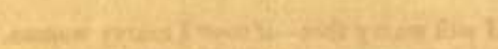

ans

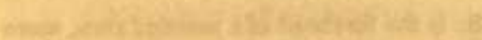

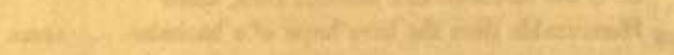

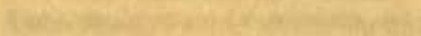

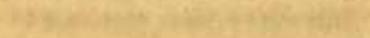

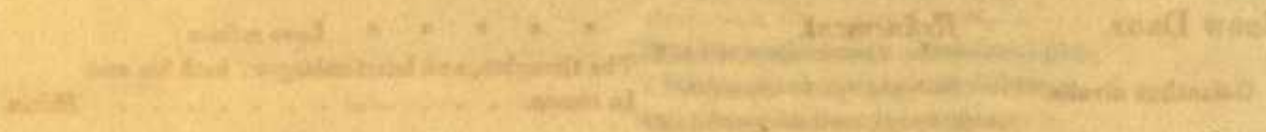

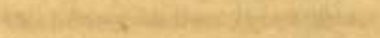

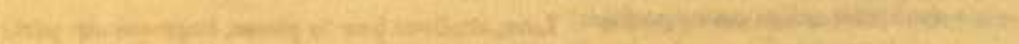

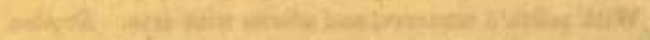

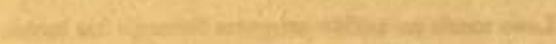

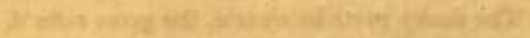

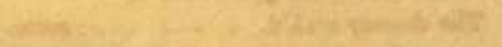

(14.

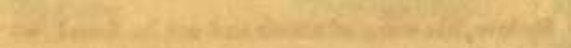

aver

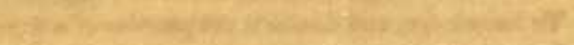

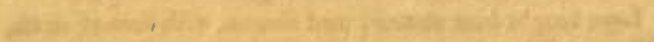

seys

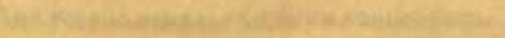

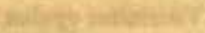

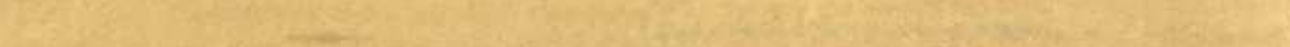

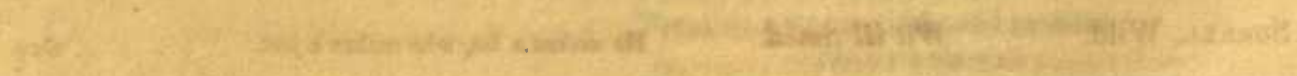

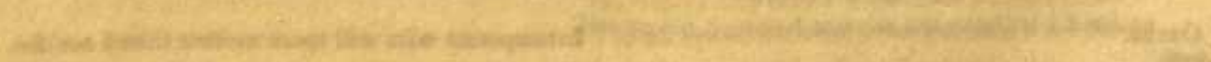
monusas 


\section{Snap Dragon.}

(Continued.)

\section{SNow BaLl.}

To bind.

Viburnum opulus.

\section{SNOW Drop. \\ Refinemsnt.}

Galanthus nivalis.

Sorrel, Wild.

Wit ill timed.

Oxalis.
If 'tis presumption for a wretch condemned,

To throw himself beneath his judges' feet :

A boldness more than this, I never knew. - Dryden.

There is a pleasure, sure,

In being mad, which none but madmen know !

Let me indulge it : let me gaze for ever !

And, since you are too great to be belov'd,

Be greater, greater yet-and be ador'd. . . . same.

I will make a desperate tender of my love ! . Shaks.

If thou dost love, my kindness shall incite thee

To bind our loves up in a boly band. . . . . same.

For, if you will be married to-morrow, you shall ;

And to Rosalind, if you will. . . . . . . same.

\section{Answer.}

I will marry theo--if ever I marry woman,

And I'll be married to-morrow. . . . . . same.

So is the forehead of a married man, more

Honourable than the bare brow of a bachelor. . same.

* * * * * Love refines

The thoughts, and heart enlarges; hath his seat

In reason. . . . . . . . . . Milton.

Love, studious how to please, improves our parts

With polish'd manners, and adorns with arts. Dryden.

Love made an active progress through his mind, The dusky parts he clear'd, the gross refin'd,

The drowsy wak'd. . . . same.

By love, his want of words and wit he found,

That sense of want prepared the future way

To knowledge, and disclos'd the promise of a day.

Love taught him shame; and shame, with love at strife, Soon taught the sweet civilities of life. . . . same.

He makes a foe, who makes a jest. . . . . Gay.

Intemperate wits will spare neither friend nor foe.

L'Estrange. 
Sorrel, Wild.

(Continued.)
The world's large tongue

Proclaims you for a man replete with mocks;

Full of comparisons, and wounding flouts;

Which you on all estates will execute,

That lie within the mercy of your wit. . . Shaks.

Wit, how delicious to man's dainty taste!

'Tis precious as the vehicle of sense;

But, as its substitute, a dire disease.

Pernicious talent ! flattered by the world,

By the blind world, which thinks the talent rare.

Young.

Wit, makes an enterpriser; sense, a man. . . same.

Wit, widow'd of good sense, is worse than nought;

It hoists more sail to run against a rock. . . same.

\section{Speedwelr. Female fidelily.}

Verouica.
Oh ! woman's love 's a holy light,

And when 'tis kindled, ne'er can die,

It lives, though treachery and slight.

To quench the constant flame may try.

Like ivy, where it grows 'tis scen

To wear an crerlasting green :

Like ivy, too, 'tis found to cling ,

Too often round a worthless thing. . . . Anon.

Pure, as the snow the summer sun

Never at noon hath look'd upon-

Deep, as is the diamond wave,

Hidden in the desert cave-

Changeless, as the greenest leaves

Of the wreath the cypress weaves-

Hopeless, often, when most fond-

Without hope or fear beyond

Its own pale fidelity-

And this woman's love can be. $\quad . \quad$ L. E. L.
SpIDER Wort. I esleem, but do not
love you.

Tradescantia virginica.

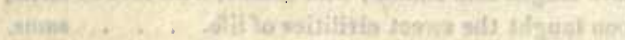

Oh, do not talk to me of love,

"Tis deepest cruelty to me-

Why throw a net around the bird,

That might be happy, light, and free? . Westmacott.

There is in love a ceaseless vestal flame,

Oh, surely this is not what thou wouldst claim;

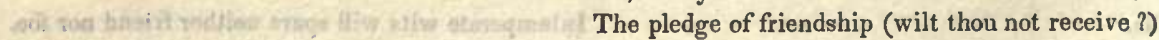

Is truly yours-'tis all my heart can give. . . $S^{* *} n$. 


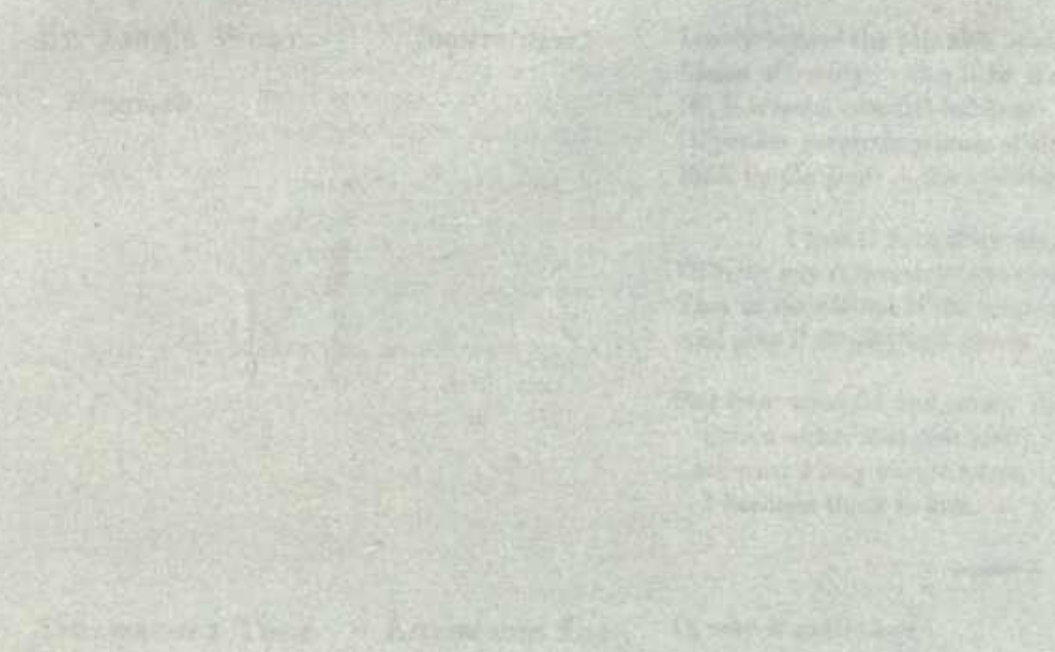


Stak of Bethlehem. Reconcilintion. Love quarrels oft in pleasing concord end. Milton.

Ornithogalum.

I would have my love

Angry sometimes, to sweeten off the rest of her behaviour.

B. Jonson.

And well do vanish'd frowns enhance

The charm of every brighten'd glance ;

And dearer seems each dawning smile,

For having lost its light awhile. . . . Moore.

The short passing anger but seem'd to awaken

New beauty, like flowers that are sweetest when shaken.

same.

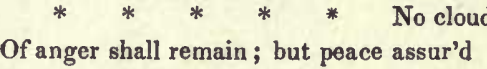

And reconcilement. . . . . . . Milton.

Sr. JoHn's Wort. Superstition.

Hypericum.
Lovely beyond the painter's brightest dream,

Vision of beauty ! Can it be of earth-

$\mathrm{Or}$, is it some celestial habitant

Of yonder gorgeous palaces of air,

Built by the genii in the evening sky? . S. P. C.

I took it for a fairy vision

Of some gay creatures of the element,

That in the colours of the rainbow live,

And play i' th' plighted clouds. . . . . Milton.

Say from what far and sunny shore,

Fair wonder, thou dost rove ;

Lest what I only should adore,

I heedless think to love. . . . . . $C^{* * * *}$.

\section{Strawberry Tree. Esteem and Love.}

Arbutus.
$\mathrm{O}$, why is gentle love

A stranger to that mind,

Which pity and esteem can move,

Which can be just and kind. . . . . Lyttelton.

Love is not love,

When it is mingled with respects, that stand

Aloof from the entire point. . . . . Shaks.

Friendship, when we ask for love, is like the fragrance of remote flowers, that faintly touches the senses; or, like the beams of the chaste moon that gives us light, but yields not warmth. . S. Johnson.

I do love you more than words can wield the matter.

A love that makes breath poor, and speech unable.

Shaks. 
Strawberry Tree.

(Continued.)

And long experience of your goodness-

What then was passion, is my judgment now.

Through all the several changes of your life,

Confirm'd and settled in adoring you.

Haynes' Fatal Mistake.

For all true love is grounded on esteem.

Buckingham.

Sumach, Venice. Splendour.

Rhus cotinus.
To splendour only do we live?

Must pomp alone our thoughts employ?

All, all that pomp and splendour give,

Is dearly bought with love and joy!

- Cartwright.

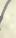

Can wealth give happiness ? look round and see

What gay distress! what splendid misery!

I envy none their pageantry and show,

I envy none the gilding of their wo. . . Young.

No flocks, nor herds, nor stores of gold,

Nor house, nor home have $I_{\text {, }}$

If beauty must be bought and sold,

Alas ! I cannot buy! . . . . . Old song.

\section{Answer.}

Truth, the sunshine of the breast,

Were Armine's wealth, were Armine's famc.

Cartwright.

No wealth nor pow'r had he,

Wisdom and worth were all he bad,

But these were all to me! . Goldsmith.

Merit like his, the fortune of the mind,

Beggars all wealth.

Thomson's Tancred and Sigismunda.

I feel I love him, and, in that word are contained birth, fame, and riches. . . . O'Keefe. Wild Oats.

$\mathrm{Oh}$ ! if gold could win his heart,

I should from the search depart. . . . L. $E$. $L$.

"What can wealth be to that young heart

Which has a mine of treasure in its own fresh feelings?"

same.

Sun Flower, Dwarf. Your devout adorer. Oh ! the heart that has truly lov'd never forgets,

But as truly loves on to tlie close;

Helianthus indicus.

As the sun-flower turns on her god, when he sets,

The same look which she gave when he rose.

Moore. 
the 20.0.

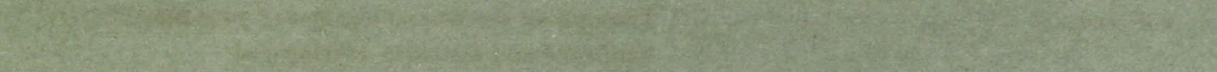

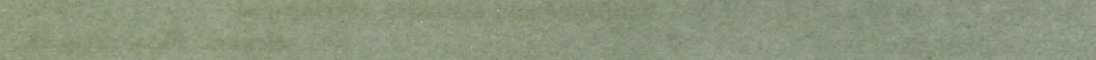

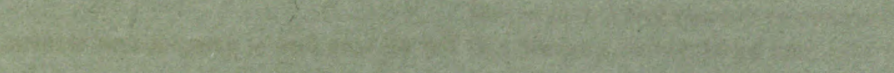

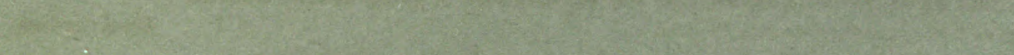

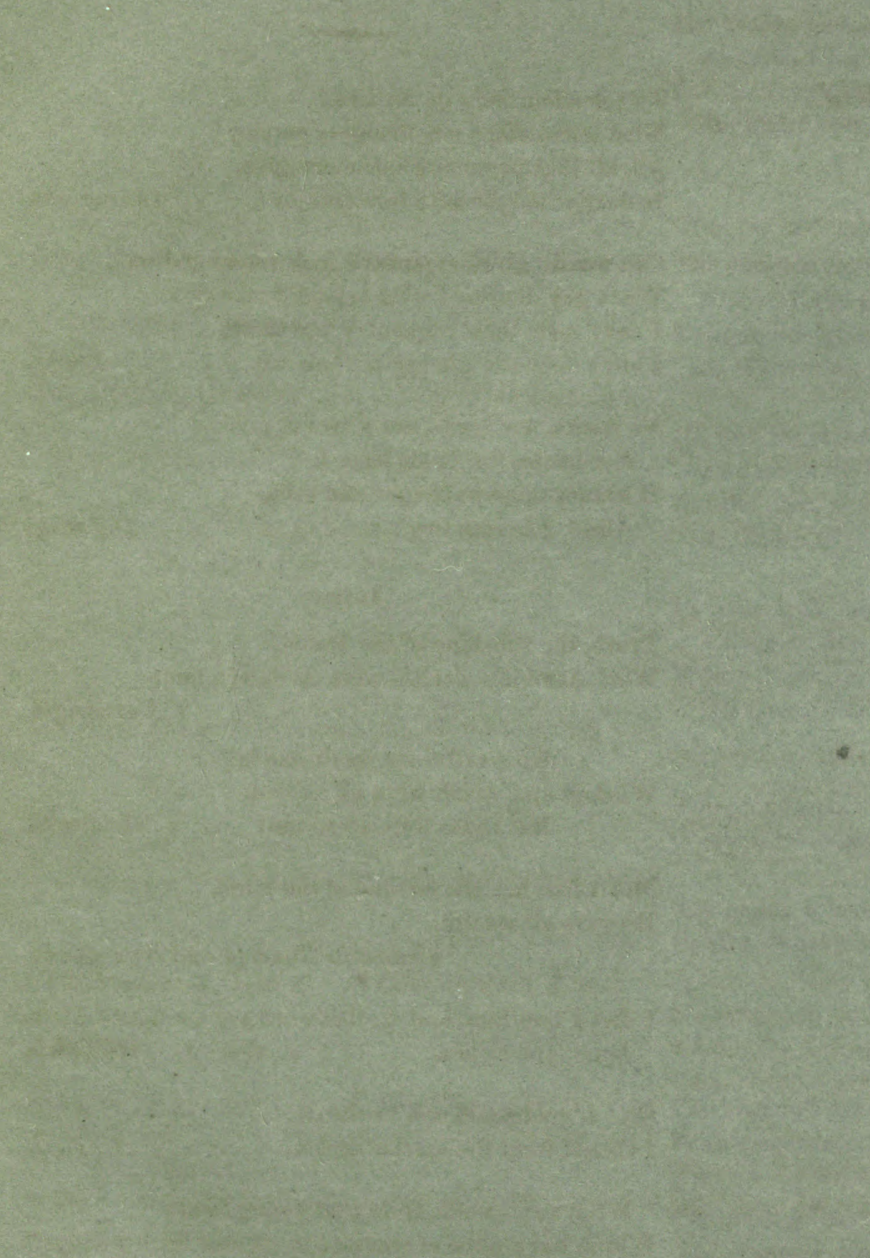

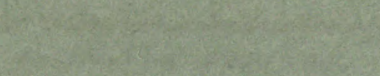

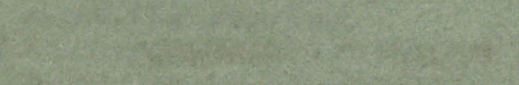

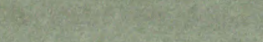

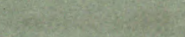

(n)

-

(

-

(.).

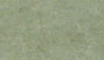

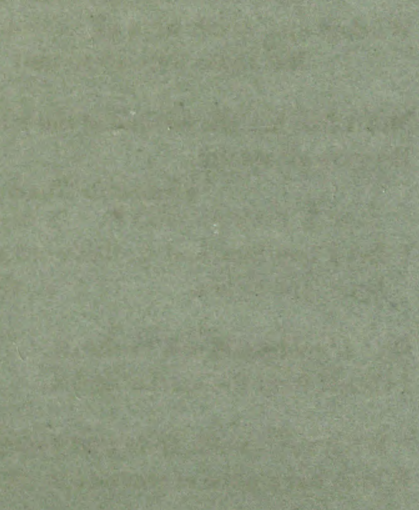

(6)

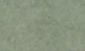

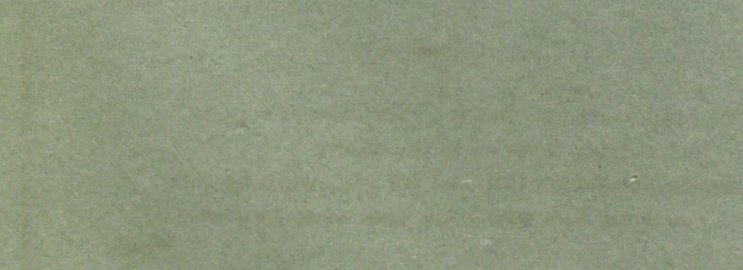

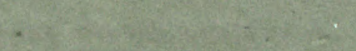

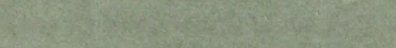

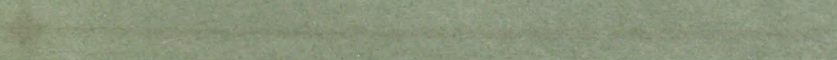




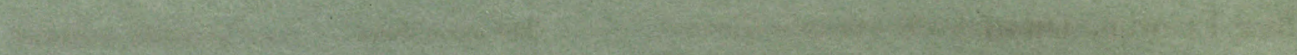

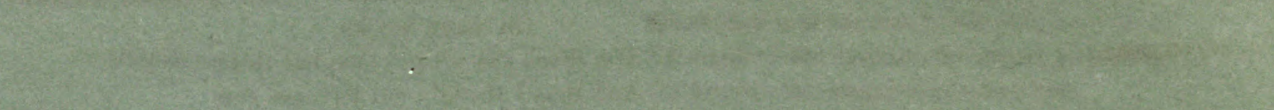

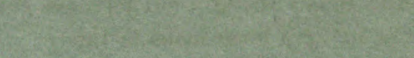

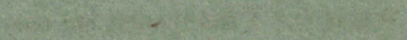

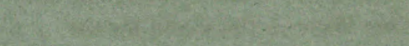

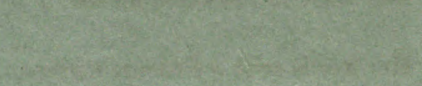

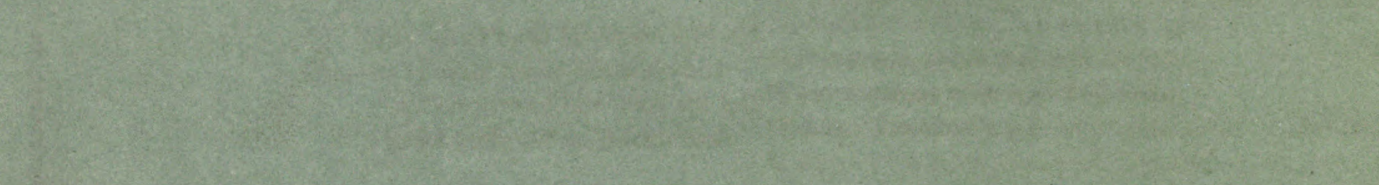

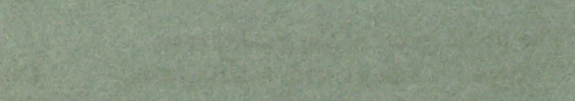

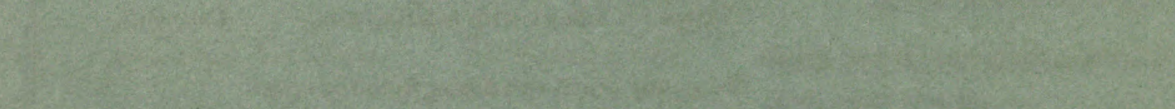

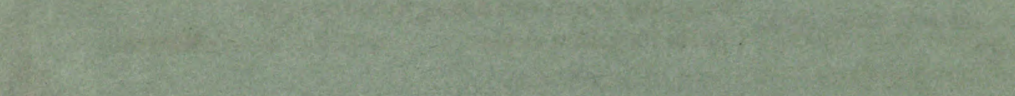

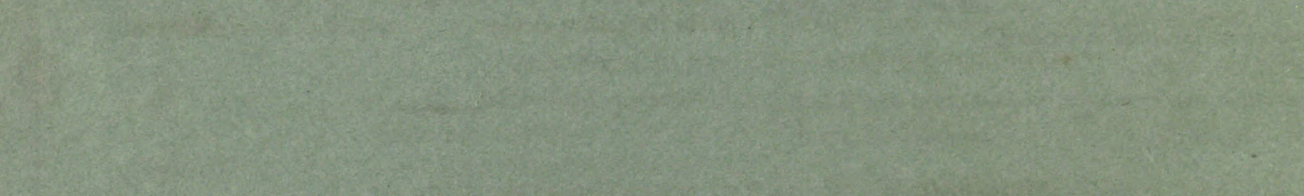

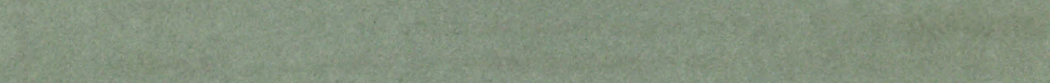

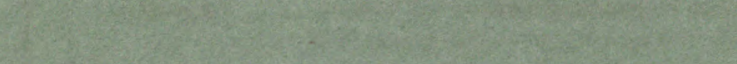
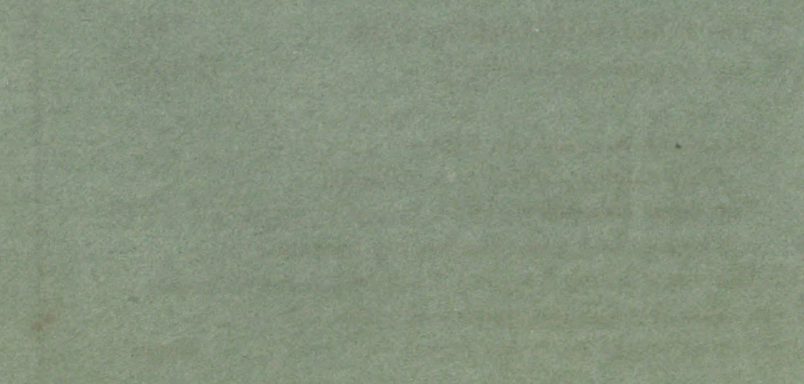


\section{Sun Flower, Dwarf.}

(Conlinued.)

\section{The moon looks}

On many brooks,

The brook can see no moon but this :

And thus I thought our fortunes run,

For many a lover looks to thee :

While, oh ! I feel there is but one,

One Mary in the world for me. . . . . Moore.

Her words such a pleasure convey,

So much I her accents adore,

Let her speak, and whatever she say, Methinks I should love her the more.

Shenstone.

Sun Flower, Tall. Pride. Haughtiness. The sun-flower, with gaudy display, Above all the garden around

Helianthus annuus.

Exhibits his golden array,

As if scorning to spring from the ground.

He lifts his proud head to the sky,

And seeks the broad blaze of the day,

But the poet, and lover, pass by,

And turn from his glory away:

In some spot, more sequester'd, to find

A delicate flower of the morn,

Whose fragrance and beauty combin'd,

His bower and his bosom adorn. . . . B. L. L.

The proud giant of the garden race,

O'ertops his fellows with aspiring aim. . Churchill.

The gaudy orient sun-flower from the crowd

Uplifts its golden circle. . . . . Maturin.

Sweet Briar. Simplicity.

Rosa suaveolens.
Fair nature's sweet simplicity

With elegance refined. . . . . . Iyttelton.

The feeling heart, simplicity of life,

And elegance, and taste. . . . . . Thomson.

So artless, so simple, so wild-

Thou emblem, said I, of my Phillis,

For she is simplicity's child.

The rose-bud's the blush of my charmer,

Her sweet balmy lip when 'tis prest;

How fair and how pure is the lily,

But fairer and purer her breast. . . . Burns. 
Sweet Briar.

(Continued.)
Beautiful one! Thy look and tone

Of witchery are nature's own-

Like light from heaven, thy magic glance-

Thy voice, the harp's wild utterance,

When touch'd at eve by some spirit's hand,

It breathes the notes of the better land. - S. P.C.
Sweet William.

Finesse.

Dianthus barbatus.
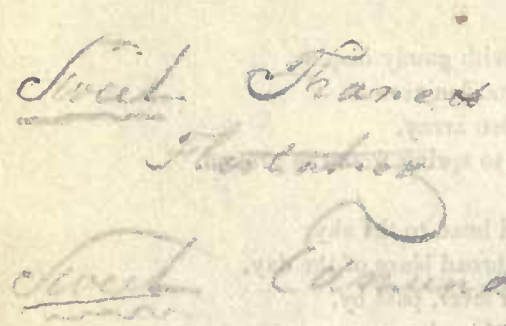

Griefs, alas! that may not speak,

Earn poor relief by feigning. . . . . B. Chester.

Many a withering thought lies hid, not lost,

In smiles, that least befit who wear them most. Byron.

So the cheek may be ting'd with a warm sunny smile,

Though the cold heart to ruin runs darkly the while.

Moore.

An outward firmness, whate'er lurk'd below.

L. E. L.

Her cheek was red, but who could know

'Twas flushing with the strife below?

Her eye was bright, but who could tell

It shone with tcars she strove to quell?

Ah ! who could think that all so fair

Was semblance, and but misery there ? . . same.

This perturbation smooth'd with outward calm. Milton.

Syringa, Carolina. Disappointment.

Bright blown hopes dispersed in air! $V^{-} \cdot$ M. I. I.

That keep the word of promise to our ear,

And break it in our hope. . . . . . Shaks.

Thus ever fade my fairy dreams of bliss ! . Byron.

Oh ! ever thus, from childhood's.hour,

I've seen my fondest hopes decay. . . . Moore.

'Tis ever.thus, 'tis ever thus, when hope has built a bower,

Like that of Eden, wreath'd about with ev'ry thornless flower,

To dwell therein securely, the self-deceiver's trust,

A whirlwind from the desert comes-and all is in the dust. . . . . . . . . Anon.

I clasp'd the phantoms, and I found them air.

Oh ! had I weigh'd it ere iny fond embrace,

What darts of agony had miss'd my heart. . Young. 



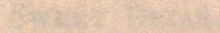

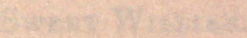

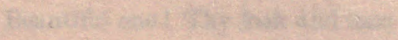

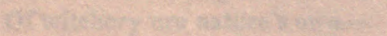

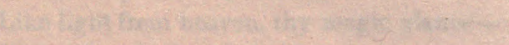

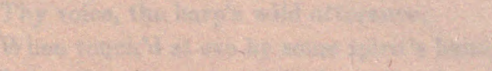

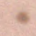
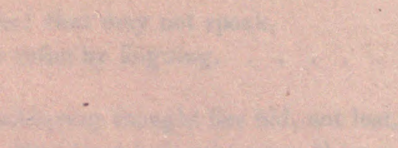
Thistle.

\section{Misanthropy.}

Carduus.

He ponders on the world $\longrightarrow$ abhors the whole! Rogers.

$\mathrm{Oh}$ ! that the desert were my dwelling place,

That I might forget all the human race! . Byron.

He sought in solitude to lose his cares;

Relief in solitude he sought in vain,

It serv'd, like music, but to feed his pain. . . . Gay.

\section{Thorn Apple. Deceitful charms.}

Datura stramonium.

Ah! that deceit should steal such gentle shapes.

Shaks.

Are words, then, only false? are there no looks

Mute, but most eloquent ? . . . L. E. L.

That mute eloquence which passes speech. . Rogers.

\section{Mine eyes}

Were not in fault, for she was beautiful ;

Mine ears, that heard her flattery; nor mine heart,

That thought her like her seeming; it had been vicious

To have mistrusted her. . . . . . . Shaks.

Ah, how have I deserv'd, inhuman maid !

To have my faithful service thus repaid?

Were all the marks of kindness I receiv'd

But dreams of joy, that charm'd me and deceiv'd?

Or, did you only nurse my growing love,

That with more pain I might your hatred prove?

Lyttelton.

'Тнуме.

Activity.

Thymus.
Tuberose.

Polianthes tuberosa.
Le plus loin, le plus cher.
I would chide hasty-footed time for parting us. Shaks.

But now the moments bring

The time of parting, with redoubled wing. . Byron.

Ah! never does time travel faster,

Than when his way lies among flowers.j. . Moore.

For things.so heavenly have such fleetness. . same.

As I listened to thee,

The happy hours pass'd by us unperceived,

So was my soul fix'd to the soft enchantment.

Rowe's Tamerlane.

How love can trifle with itself!

Fie! fie! how wayward is this foolish love!. Shaks.

It so falls out,

That what we have, we prize not to the worth

Whiles we enjoy it; but, being lack'd and lost, 
'T'uberose.

(Continued.)

Why, then, we rack the value: then, we find

The virtue that possession would not show us Whiles it was ours. . . . . . . Shaks.

What our contempts do often hurl from us, We wish it ours again. . . . . . same.

Mysterious love, uncertain treasure,

Hast thou more of pain or pleasure?

Endless torments dwell about thee,

Yet who would live, and live without thee?

Addison's Rosamond.

By all the token flowers that tell

What words can never tell so well. . . . Byron.

Every thing seems drear without thee !. . Moore.

\section{T'ulip, Red.}

A declaration of love.

Tulipa.

Tulip, Yellow.

Hopeless love.
Who could refrain, that had a heart to love, And courage to make his love known? . . Shaks.

No wonder that iny heart was moved,

'Twere marvel, if I had not loved. L. E. $\boldsymbol{L}$.

What should I say,

Or how begin the strain?

These passions how contain,

That in my throbbing breast tumultuous spring ?

\section{Aschylus. The Choephora.}

Thou-thou hast metamorphos'd me;

Made me neglect my studies, lose my time,

War with good counsel, set the world at nought,

Made wit with musing, weak, heart-sick with thought.

Shaks.

\section{In mine, survey}

A heart that 's yours alone;

Long has it own'd Elvira's sway,

Though long unnotic'd and unknown. . Cartwright.
and 40

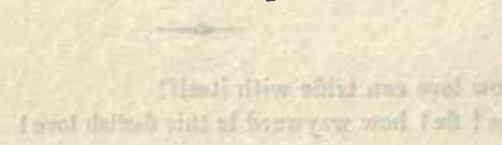
The maid that ev'ry beauty shar'd ?
Her Armine saw; he saw; he lov'd;
He lov'd-alas ! and he despaired. . . Cartwright.
I know thou doom'st me to despair,
Nor wilt, nor canst relieve me;
But, ah, Eliza, hear my prayer,-
For pity's sake forgive me! . . . . . Burns.

What youth so cold could view unmov'd 


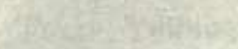
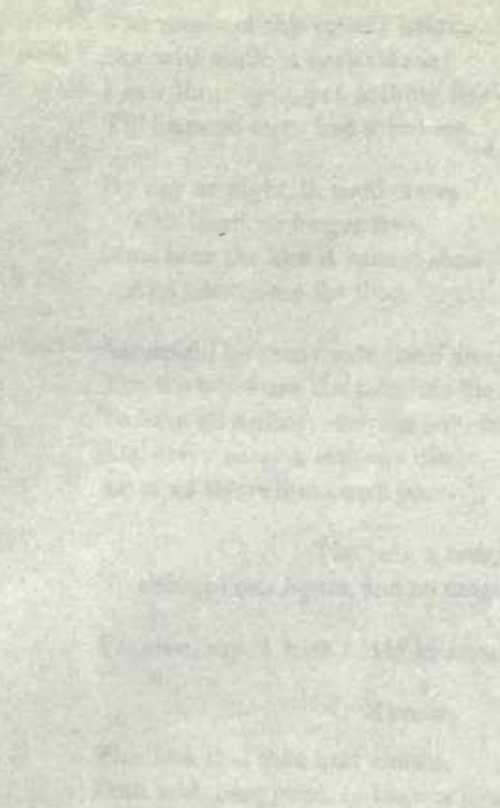

264 and 


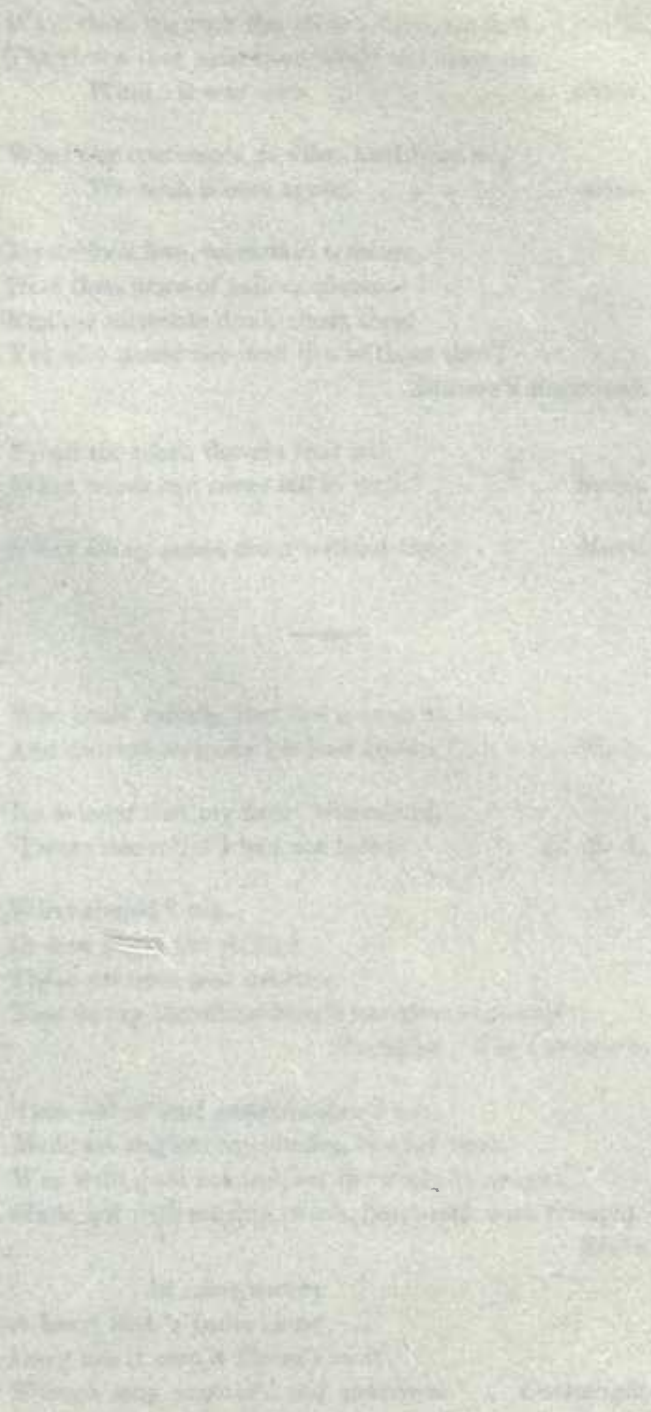


Tulip, Yellow. (Continued.)
The music of thy voice I heard,

Nor wist while it enslav'd me;

I saw thine eyes, yet nothing fear'd,

Till fears no more had saved me.

Burns.

By day or night, in weal or wo,

This heart no longer free,

Must bear the love it cannot show,

And silent ache for thee. . . . . . Byron.

Successful love may sate itself away,

The wretched are the faithful; 'tis their fate

To have all feeling, save the one, decay,

And every passion into one dilate,

As rapid rivers into ocean pour. . . . . . same.

The pain I bear,

No thought can figure, and no tongue declare. Prior.

I cannot, nay, I wish not to be cured. . . . Dryden.

\section{Answer.}

This love that thou hast shown,

Doth add more grief, to too much of mine own.

Shaks.

Thy piercing griefs,

Bewailing thus the miseries of thy fate,

Strike deep; they wound me to the very soul.

Aschylus' Agamemnon.

Those tears may tell thee while they start,

How all thy griefs endear thee. Song by W. Smyth.

\section{Tulip Tree, Blossom. Rural happiness.}

Liriodendron tulipifera.
What happiness the rural maid attends, In cheerful labour while each day she spends ! She gratefully receives what Heaven has sent, And, rich in puverty, enjoys content.

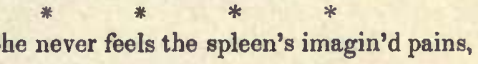

Nor melancholy stagnates in her veins ;

She never loses life in thoughtless ease,

Nor on the velvet couch invites disease;

Her home-spun dress in simple neatness lies, And for no glaring equipage she sighs :

No midnight masquerade her beauty wears, And health, not paint, the fading bloom repairs.

Gay.

The spleen is seldom felt where Flora reigns;

The low'ring eye, the petulance, the frown, And sullen sadness, that o'ershade, distort, And mar the face of beauty, when no cause 
Tulip Tree, Blossom.

(Continued.)
For such immeasurable wo appears,

These Flora banishes, and gives the fair

Sweet smiles, and bloom less transient than her own.

Cowper.

$O$, friendly to the best pursuits of man,

Friendly to thought, to virtue, and to peace,

Domestic life in rural pleasures past. . . . same.

You who the sweets of rural lifo have known,

Despise the ungrateful hurry of the town. . Gay.

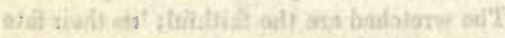

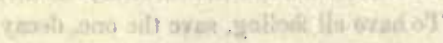

Venus' Looking-glass. Flattery.

Campanula speculum.

Thy words were courtly flattery, such sink like morning dew,

But, oh! love takes another tone, the tender and the true. . . . . . . . L.E. L.

I 'll mark no words that smooth-faced wooers say.

Shaks.

Think'st thou I am so shallow, so conceitless,

To be seduced by thy flattery,

That hast deceived so many with thy vows?

Shaks.

\section{Answer.}

Think not I flatter, for I swear I do not. . . same.

Yet sure whene'er the praise is just,

One may commend, without disgust.

If 'tis offence, such truths to tell,

Why do your merits thus excel . . . . . Gay.

\section{VERBENA;}

or, Vervain.
Sensibility, how charming,

Thou, my friend, canst truly tell;

But distress, with horrors arming,

Thou hast also known too well!

Dearly bought, the hidden treasure,

Finer feelings can bestow !

Chords that vibrate sweetest pleasure,

Thrill the deepest notes of wo. . . . Burns.

Where glow exalted sense, and taste refin'd,

There keener anguish rankles in the mind;

There feeling is diffus' $d$ through every part;

Thrills in each nerve, and lives in all the heart.

Hannah More.

The heart that is soonest awake to the flowers, Is always the first to be touch'd by the thorns. Moore. 

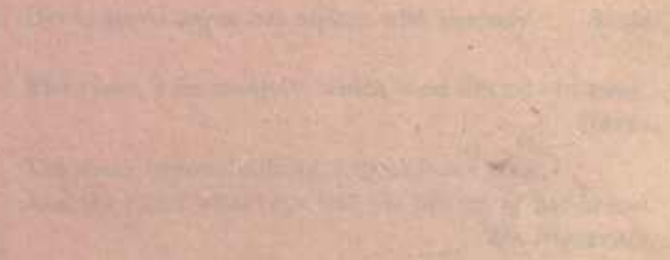


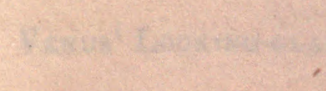

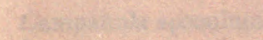

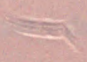

$x^{2}+24=$

$x^{2}$

$\operatorname{lin}^{2}$ 
Violet, Blue.

Love.

Viola odorata.
For thee I 'll lock up all the gates of love. . . Shaks.

Love, then, hath every bliss in store:

'Tis friendship, and 'tis something more.

Not to know love, is not to live. . . . . . Gay.

Love is a celestial harmony

Of likely hearts, composed of stars' consent,

Which join together, in sweet sympathy,

To work each other's joy and sweet content. Spencer.

Endearing strife,

That carries friendship to her noon-tide point,

And gives the rivet to eternity. . . . Young.

What can earth produce but love

To represent the joys above. Anon.

A woman's love, deep in the heart,

Is like the violet flower,

That lifts its modest head apart

In some sequester'd bower. . . . . . Anon.

Unhappy fate of doubtful maid!

Her tears may fall, her bosom swell,

But even to the desert shade

She never must her secret tell. . . . W. Smyth.

The love-sick violet, and primrose pale,

Bow their sweet heads, and whisper to the gale.

Darwin.

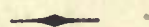

Sweet as spring-time flowers! . . . Shaks.

The blushing beauties of a modest maid.

Dryden's Ovid.

Her looks do argue her replete with modesty.

Shaks.

The violet 's for modesty, which weel she sets to wear.

Burns.

The meek mountain daisy, with delicate crest,

And the violet whose eye told the heaven of her breast.

Mrs. Sigourney.

The modest virtues mingled in her eyes-

Still on the ground dejected, darting all

Their humid beams into the blooming flowers.

Thomson.

And such, methought, whilst bending to the stem, Is modest virtue's pure and simple gem; 
VIOLET, White.

(Continued.)

\section{Virgin's Bower.}

Filial love.

Clematis.

\section{Wall Flower. Fidelity in misfortune.}

Cheiranthus cheiri.
No ostentatious wish to seek for praise, But still retiring from the public gaze, It spreads its sweet beneficence around, And, by the fame it shuns, can but be found.

H. $K$. White.

My mother ! at that holy name,

Within my bosom there's a gush

Of feeling, which no time can tame,

A feeling, which, for years of fame,

I would not, could not crush. . . . G. P. Morris.

Can I forget thy cares, from helpless years-

Thy tenderness for me? An eye still beam'd

With love? A brow that never knew a frown?

Nor a harsh word thy tongue? . . . Thomson.

Can I ever cease to be

Affectionate and kind to thee,

Who wast so very kind to me?

My Mother!

Oh, no! the thought I cannot bear,

And if God please my life to spare,

I hope I shall reward thy care,

My Mother!. . Anon.

And may reproach transmit my name abhorr'd

To latest time-if ever thought was mine

Unjust to filial reverence-filial love.

"My Father!" . Mallet.

Ne'er in his woes

Will I forsake whom my soul holds most dear.

Aschylus. The Persians.

Thy rise of fortune did I only wed,

From its decline determin'd to recede?

Did I but purpose to embark with thee

On the smooth surface of a summer's sea,

While gentle zephyrs play in prosp'rous gales,

And fortune's favour fills the swelling sails;

But would forsake the ship, and make the shore,

When the winds whistle, and the tempests roar?

No, Henry, no: one sacred oath has tied

Our loves; one destiny our life shall guide,

Nor wild, nor deep, our common way divide! Prior.

Friendship has a power

To soothe affliction in her darkest hour. $H$. K. White. 
$\frac{1}{2}$

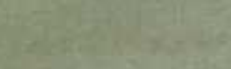

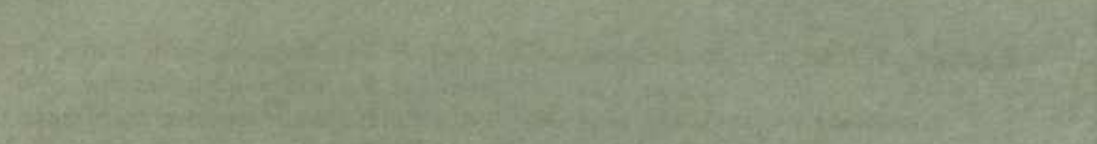

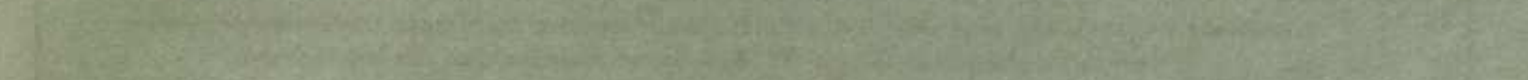

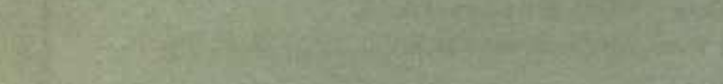

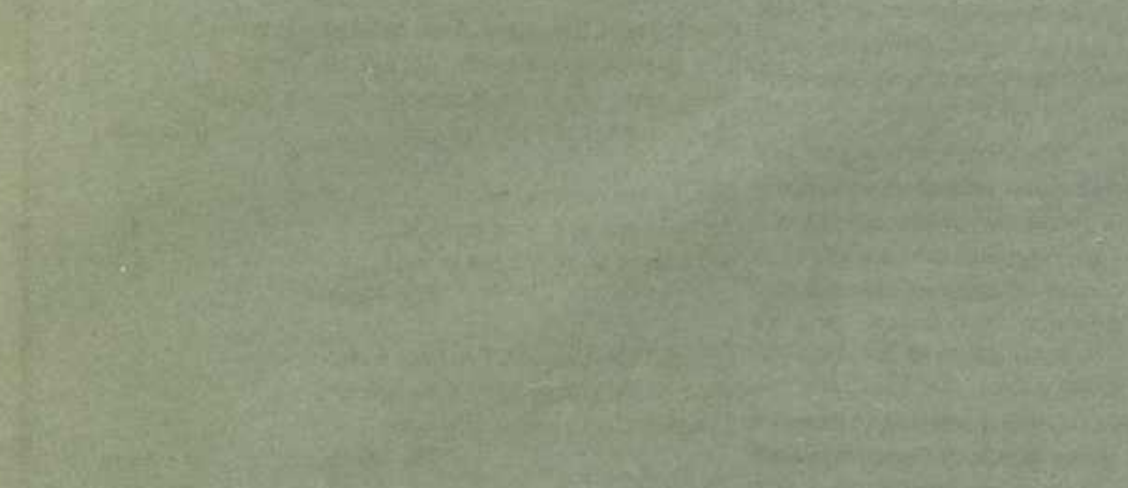

$\cos 2 x$

9.

78

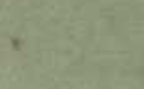

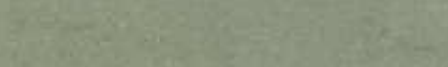

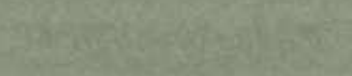


$\frac{1}{4}$

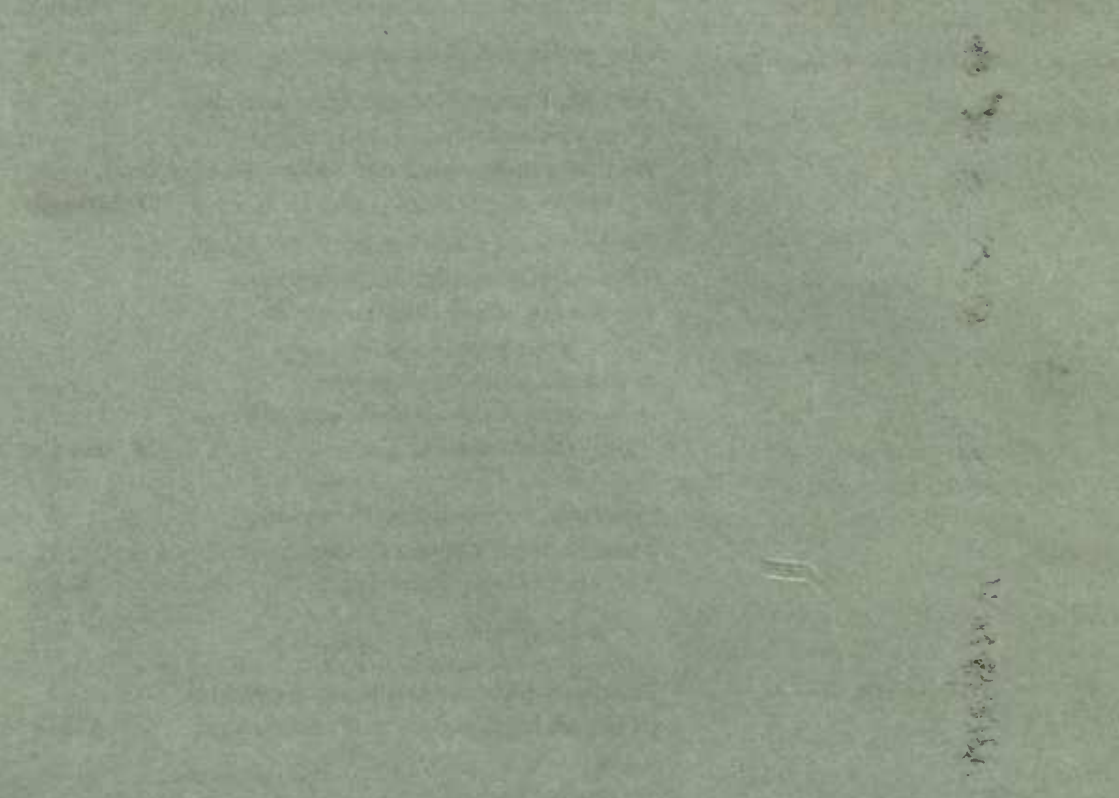

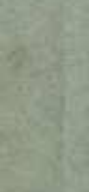

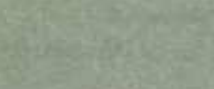

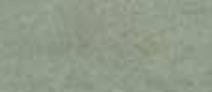

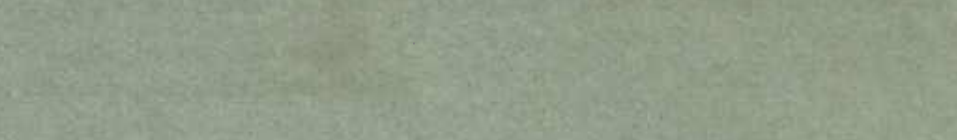

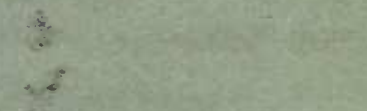

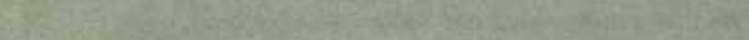

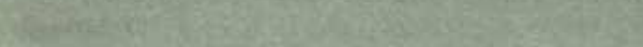

$\frac{3}{2}$

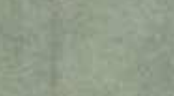

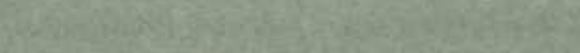

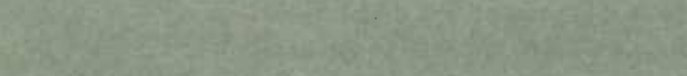

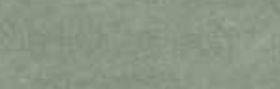

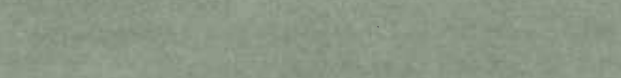

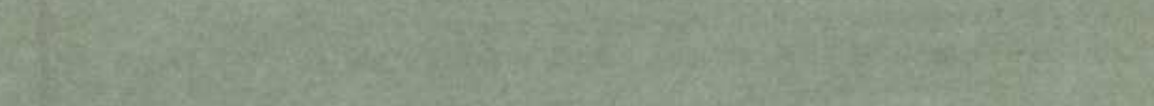

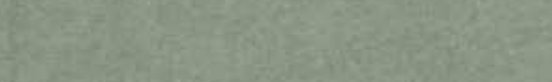

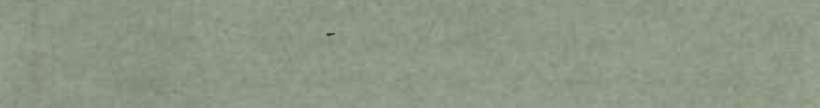

3.7.

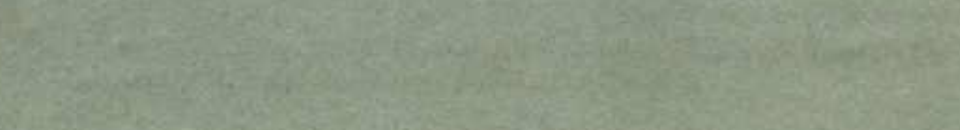

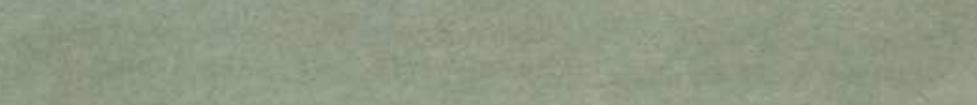

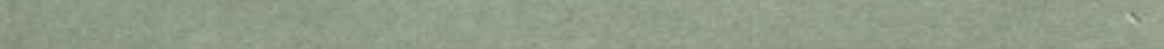


Wall Flower.

(Continued.)

Adhering in the adverse hour,

Like fidelity's own flower,

That over ruins long grown grey,

Throws its colours bright and gay. . . Mrs. H. S.

In adverse hours the friendship of the good

Shines most; each prosperous day commands its friends. Euripides' Hecuba.

\section{WeEPING WiLlow.}

Salix babylonica.

Forsaken.

Prevent his falsehood, and forsake him first. - Philips.

Change thou the first, nor wait thy lover's flight. Prior.

Ah ! little marvel in such clime and age,

That we should daily hear that love is fled,

And hope grown pale, and lighted feelings dead.

Pickersgill.

For love is oft a fatal spell,

That sweetly soothes but to betray-

Let not the soft enchantment wile

Your heart away.

A garland of the cypress tree,

Or weeping willow-wreatl, may well

Its emblem be. . . . . . . J. Malcolm.

Some day, perhaps, thou 'lt waken

From pleasure's dream to know

The grief of hearts forsaken ! . . . . Moore.

\section{Wheat. Prosperity.}

Triticum.

WOODBINE, The variegated leaf.

Lonicera.
Prosperity puts out unnumber'd thoughts

Of import higl, and light divine, to man. . . Young.

$$
\text { * * * * Who feels no ills, }
$$

Should, therefore, fear them ; and, when fortune smiles, Be doubly cautious, lest destruction come

Remorseless on him, and he fall unpitied.

Sophocles' Philoctetes.

When most the world applauds you, most beware;

'Tis often less a blessing than a snare.

Distrust mankind-with your own heart confer;

And dread even there to find a flatterer. . Young.

Beware what earth calls happiness; beware

All joys, but joys that never can expire;

Who builds on less than an immortal base,

Fond as he seems, condemns his joy to death. . same.

Their love in early infancy began,

And rose as childhood ripen'd into man. . . Dryden.

Thanks to my stars, I have not rang'd about

The wilds of life, ere I could find a friend: 
WOODBINE.

(Continued.)

- Yarrow.

Achillea millefolium.
Nature first pointed out my brother to me,

And early taught me, by her sacred force,

To love thy person, ere I knew thy merit,

Till what was instinct grew up into friendship.

Ours has severest virtue for its basis,

And such a friendship ends not but with life. Addison.
To cure.

$\longrightarrow$
Hear, what from love unpractis'd hearts endure, From love,-the sole disease thou canst not cure.

Pope.

Ah, luckless day ! when first with fond surprise

On Delia's face I fix'd my eager eyes !

Then in wild tumults all my soul was tost :

Then reason, liberty, at once were lost :

And every wish, and thought, and care, was gone,

But what my heart employ'd on her alone. Lyttelton.

Ye, that witness the woes I endure,

Let reason instruct you to shun

What it cannot instruct you to cure. . Shenstone.

And soothe the pains thou know'st not how to curc.

Lyttelton.

If there is on earth a cure

For the sunk heart-'tis this-day after day

To be the blest companion of thy way;

To hear thy angel eloquence-to see

Those virtuous eyes for ever turn'd on me;

And in their light, rechasten'd silently,

Like the stain'd web that whitens in the sun,

Grow pure by being purely shone upon. . . Moore.

\section{ZinNIA.}

Absence.

Zinnia multiflora.
How blessings brighten as they take their flight !

Now I know

Young.

What it is to admire and to love,

And to leave her we love and admire. . Shenstone.

I priz'd ev'ry hour that went by,

Beyond all that had pleas'd me before;

But now they are past, and I sigh;

And I grieve that I priz'd them no more. . . same.

All flowers will droop in absence of the sun

That wak'd their sweets. . . . . Dryden.

Love reckons hours for months, and days for years,

And every little absence is an age. . . . same.

L'absence est à l'amour ce qui est au feu le vent,

Il éteint le petit, il allume le grand. . . Rousseau. 


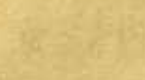

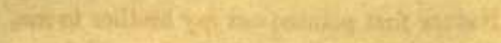

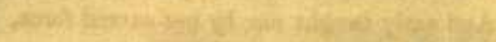

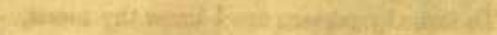

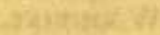

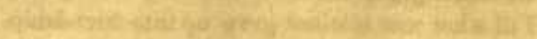

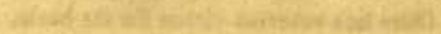

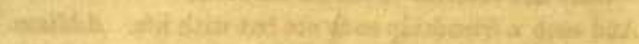

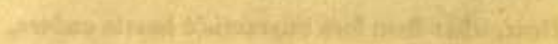

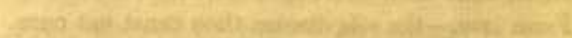
20.7.

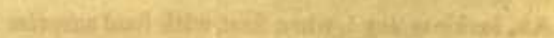

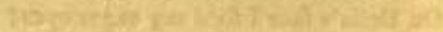

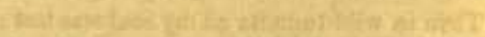

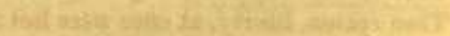

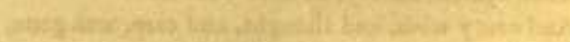

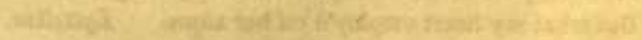

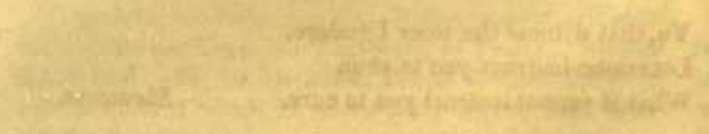

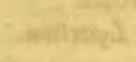

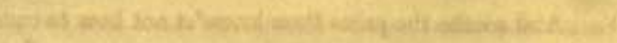

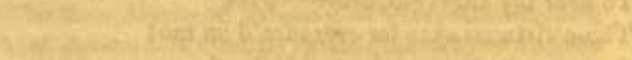

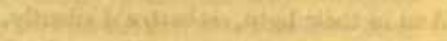

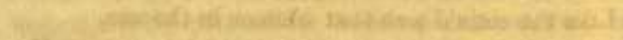

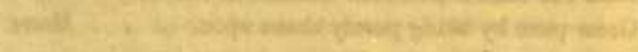

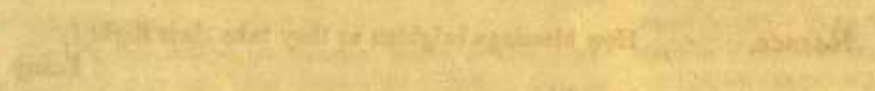

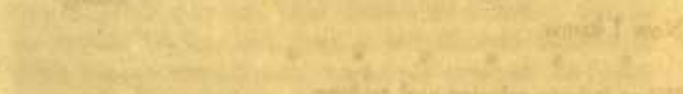

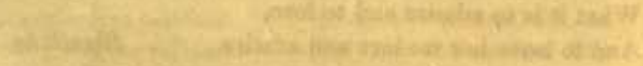

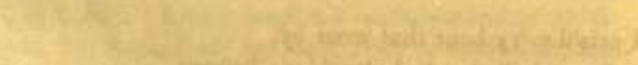

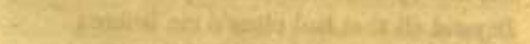
.

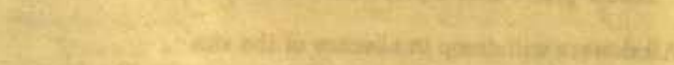
and

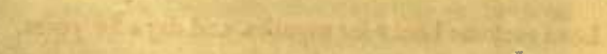

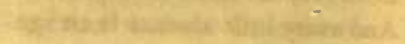

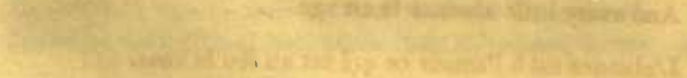

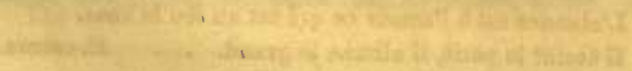


bi

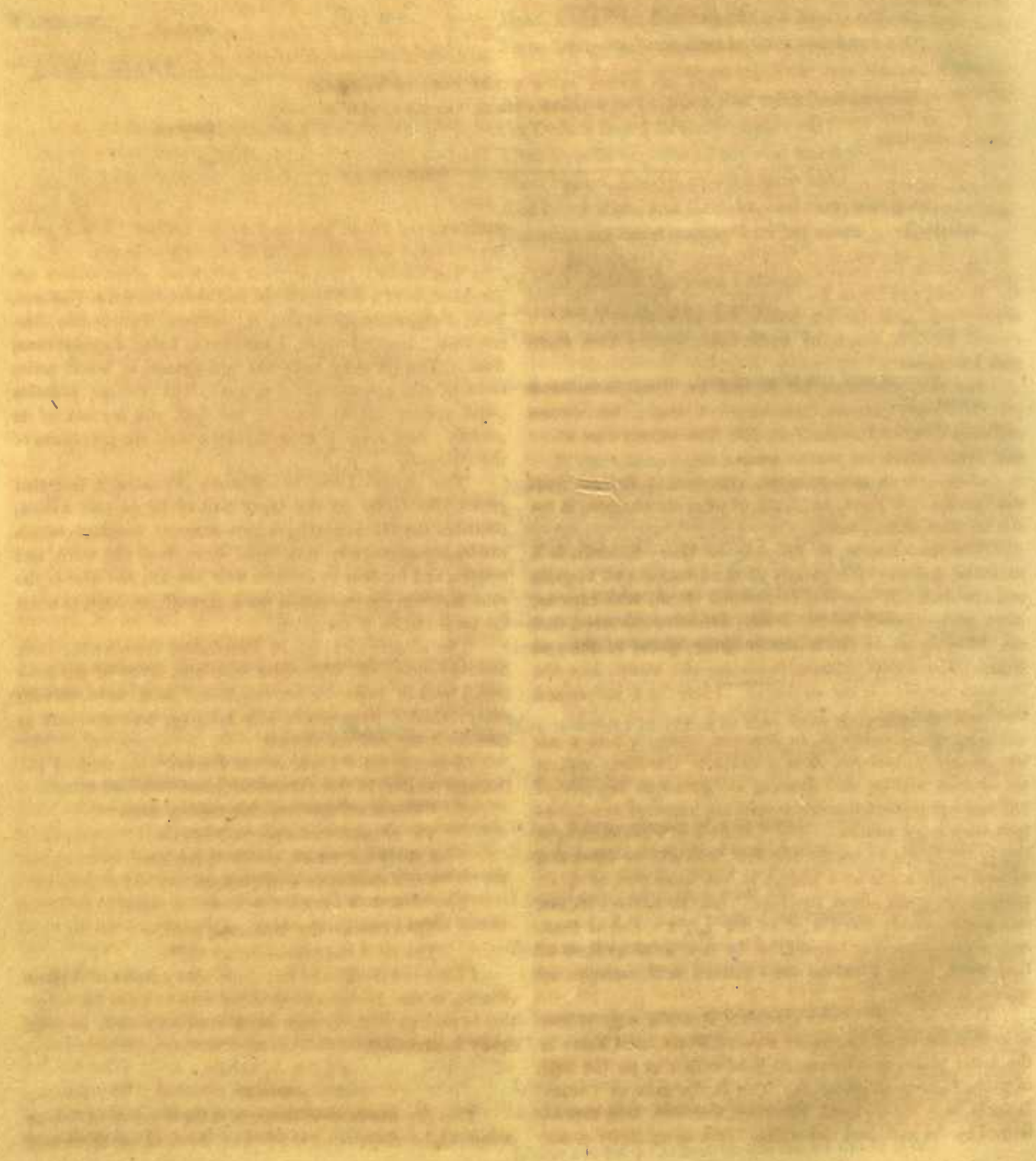




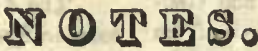

WITNESS THE SPRIGHTLY JOT, WHEN AUGHT UNKNOWN STRIKES THE QUICK SENSE, AND WAKES EACH ACTIVE POWER TO BRISKER MEASURES.

Akenside.

AND ALL ABOUT GREW EVERY SORT OF FLOWER

TO WHICH SAD LOVERS WERE TRANSFORMED OF YORE.

Spencer.

ACACIA.

Robinia.

Robinia, commemorates John Robin, botanist to Henry the Fourth, and Louis the Thirteenth, of France. He was found fault with for his selfish love of flowers; the more curious kinds of which, he would rather destroy, than share with his friends.

His son, Vespasian Robin, and De Theis, introduced into the French gardens, from American seeds, that species of Robinia, called Pseudo Acacia, by Tournefort; who, under that name, founds the present genus.

Acacia, is an ancient name, (Gr. uxaxta) derived from the Greek axk, a point, or $a \times \propto \zeta^{\circ}$, to point or sharpen, in reference to its thorny habit.

The Rose Acacia, R. Hispida, or Hairy Robinia, is a native of America, particularly of the monntains of Virginia and Carolina. It is a very ornamental shrub, with copious, large, pink-coloured papilionaceous blossoms, enhanced, like the Moss Rose, by the bristly covering of the stalks and calyx. The leaves pinnate, with an odd leafet, like the common locust. It has no thorns. There is a taller, and less hisped yariety.

The Pscudo Acacia, or common locust, is also a native of North America, from Canada to Carolina: and, in the months of May and June, it is laden with bunches of white sweet-scented flowers, resembling those of the laburnum in size and position. The foliage is of a beautiful light green, consisting of many elliptical, opposite or alternate, stalked leaflets. It is a large and handsome tree, of quick growth; beginning, from the third year, to convert its sap into perfect wood, which is of so fine a grain, and so hard, as to be substituted by turners for the box, in many sorts of light work. The branches are liable to be shivered off by autumnal storms.

There is a very thorny species of Robinio, with yellow flowers, a native of Siberia, as also of Pekin, in China: in the latter place, it is frequently fixed with clay on the tops of walls, to keep off intruders. This $\boldsymbol{R}$. Spinosa, or Thorny Robinia, is a shrub, much branched, and with long thorns, formed by the hardcned foot-stalks. It is quite hardy in our gardens, and would be excellent for hedges. The leaflets are oblong, wedge-shaped, hardly an inch in length.

The Oriental Acacia, from which our green-houses are furnished, is of a different class and order from the Robinia, being Polygamia Monocia; or, perhaps, Polyandria Monogynia. Natural order, Lomentacæ, Linn. Leguminosæ, Juss. The flowers have the appearance of small tufts; some of the species very fragrant. The foliage presents great variety in the form of the leaf, and manner of its growth. And some of them have the sensitive properties of the Mimosa.

The Acacia Vera, or Mimosa Nilotica, a tree that grows abundantly on the sandy soil of Egypt and Arabia, furnishes the Gum-Arabic, a pure concrete mucilage, which exudes, spontaneously, in a liquid state, from the trunk and boughs, and hardens by contact with the air, and heat of the sun: incisions are sometimes made through the bark, to assist the transudation of the juice.

The Acacia Arabica, or East-Indian Gum-Arabic tree, besides yielding this wholesome mucilage, is one of the most useful trees in India, for its tough and hard wood, serving many valuable purposes in ship building, \&c.: the bark is used for dying, and making ink.

Moore, in his "Light of the Harem," has noticed the Oriental Acacia, in these beautiful lines:

"Our sands are bare, but smiling there

Th' Acacia waves her yellow hair.

Lonely and sweet, nor lor'd the less

For flowering in a wilderness.

Then come,-thy Arab maid shall be

The lov'd and lone Acacia tree."

I have not designated any particular species of Yellow Acacia, in the Dictionary, from my wish to leave the selection to such as might chance to be most cultivated, or most easily commanded.

\section{FLOS ADONIS. Adonis.}

That this flower owes its name to the favourite of Venus, is not to be disputed; but whether the Goddess of Beauty 
changed her lover into this plant, or the Anemone, would be difficult to decide,--since the Linnzan system of dividing plants into families, did not exist when the Gods and Goddesses made love upon earth: and previous to the time of the Swedish botanist, the $A$ donis was considered to be one of the Anemonies, which it greatly resembles, and is of the same class and order.

Flos (L) a flower, a bloom, a blossom.

Look, in the garden, blooms the Flos Adonis,

And memory keeps of him who rashly died,

Thereafter changed by Venus, weeping, to this flower. Inonymous. Garland of Flora.

Ovid certainly designates the Anemone, as being the subject of this metamorphosis:

"Then on the blood, sweet nectar she bestows,

The scented blood in little bubbles rose:

Little as rainy drops, which fluttering fly,

Borne by the winds along a low'ring sky.

Short time ensu'd, till where the blood was shed,

A fiower began to rear its purple head:

Such as on punic apples is reveal'd,

Or in the filmy rind but half conceal'd.

Still here the fate of lovely forms we see,

So sudden fades the sweet Ancmone.

The feeble stems, to stormy blasts a prey,

Their sickly beauties droop and pine away.

The winds forbid the flow'rs to flourish long,

Which owe to winds their names in Grecian song."

Eusden's Ovid.

Great quantities of the Adonis Autumnalis are annually carried to the London market, and sold by the name of Red Morocco and Pheasant's Eye. And, in the time of Gerard, (a surgeon, and famous herbalist in the reign of Queen Elizabeth, chief gardener to William Cecil, Lord Burleigh, who was himself a great lover of plants, and had the best collection of any nobleman in the kingdom,) the country people called it "Red Cannomile"-the London women, "Rosearubie." It is an annual, flowering from May to October. Its characters are, that the calyx is a fiveleaved perianthium, and the leaflets are obtuse, concave, a little coloured and deciduous; the corolla has from five to fifteen, but most commonly eight,-oblong, obtuse, shining, petals. The stamina consist of very short filaments, and the antheræ are oblong and inflex: the pistulum has numerous germs collected in a head, no styles, and acute reflex stigmas: no pericarpium; an oblong, spiked receptacle: seeds numerous, irregular, angular.

\section{ALMOND.}

Amygdalus.

Amygdalus, in gardening, applies to the Almond, Peach, and Nectarine trees.

Amygdala, Latin for an Almond tree.

Amygdaline, English, resembling slmonds.

Almond, (English) Almendra, (Spanisb) Amande,
(French) derived by Menage from amandala, a word in low Latin-see Johnson.

The Almond is the earliest tree that puts forth its blossoms in Syria, and is hence regarded as the emblem and pro. mise of a fruitful season: its snow-white blossoms appear on the bare branches, unaccompanied by leaves.

"Mark well the flowering almond in the wood;

If odorous blooms the bearing branches load,

The glebe will answer to the sylvan reign,

Great heats will follow, and large crops of grain.

But, if a wood of leaves o'ershade the tree,

Such, and so barren will the harvest be;

In vain the hind shall vex the threshing floor,

For empty straw and chaff will be thy store."

Dryden's Virgil.

It is the emhlem of Hope:

"The Hope, in dreams of a happier hour

That alights on misery's brow,

Springs out of the silvery almond flower,

That blooms on a leafless bough."

Moore.

We presume that Aaron's rod was taken from the A]mond tree:

"And behold, the rod of Aaron, for the house of Levi, was budded, and brought forth buds, and bloomed blossoms, and yielded almonds." (Numbers xvii. 8.)

The common almond, $\mathcal{A}$. Communis, has leaves resembling those of the peach, but the lower serratures are glandular; they proceed from buds both above and below the flowers, and not, as in the peach, from the ends of the shoots above, and not below the flowers. The form of the flowers is not very different, but they usually come out in pairs, and vary more in their colour, from the fine blush of the apple-blossom, to a snowy whiteness. The chief obvious distinction is in the fruit, which is flatter, with a coriaceous, or lesther-like covering, instead of the rich pulp of the peach and nectarine, opening spontaneously when the kernel is ripe.

It is a native of Barbary-much cultivated in Italy and the south of France. It is common in China, and most of the eastern countries. According to Miller, the $\mathcal{A}$. Communis is cultivated more for the beauty of its flowers than for its fruit; of which there are two varieties, the sweet and the bitter; which often arise from the fruit of the same tree: the fruit is good while fresh, but will not keep long.

It is the fruit of the $A$. Duleis, or Jordan A., which is preferred in commerce. This has a tender shell, and a large sweet kernel. The leaves are broader, shorter, and grow much closer than those of the common sort, and their edges are crenate. The flowers are very small, and of a pale colour, inclining to white. The trees bave been often raised from the nut, which is imported.

The A. Pumila, double-flowering dwarf-almond, is a shrub of two or three feet bigh, smooth branches, and dark purple. Leaves veined-wrinkled, or lanceolated, and double serrated. Flowers, generally two in a bud and sessile. Caly $x$ reddish; petals emarginato, red, longer than the 
tube of the calyx: filaments paler; germ and style pubescent at bottom; stipules linear and very deeply serrate. Its native country Africa.

\section{ALTH无A.}

Hibiscus Syriacus.

Hibiscus, a name given by Linnæus to designate a genus of the Mallow tribe, which had hitherto received only barbarous, or ill-constructed appellations.

The Greek word $\$ 3 \_\sigma \times s$, from which it is derived, is translated "a species of wild or woodland IMallow-Althæa."

Althxa-Greek $\approx \lambda \vartheta_{x+\infty}$, from the Gr. $\alpha \lambda \vartheta_{\omega}$, or $\alpha \lambda \vartheta_{\alpha i v \omega}$, to heal, a remedy, from its many excellent qualities. The A. Officinalis, common Marsh Mallow, a perennial plant of about three feet high; the whole herb clothed with a very soft wool or velvet; purple flowers; leaves simple, undivided, angular, and cottony, alternate, serrated: is a native of temperate climes, and has been used medicinally in all countries.

The Hibiscus Syriacus, popularly called Althæa frutex, is a native of Syria and Carniola; a hardy shrub in our gardens, growing to the height of a small tree; leaves ovate, somewhat wedge-shaped, three-lobbed, cut, smooth; calyx double, the outer permanent, consisting of about eight leaves, as long as the inner; the blossoms are handsome, rose coloured, with a crimson eye: liable to variations in colour, and sometimes double; scentless. It is, perhaps, the last shrub that comes into leaf with us, and one of the latest flowering.

The fable of Althæa and her unfortunate son, being read in my hearing, at the time that the shrub Althrea was in bloom, and finding that it had been overlooked in the assemblage of speaking flowers, I determined to introduce it, if possible, and the fate of the poor youth who bad lost his life, in consequence of his love for the beautiful nymph Atalanta-his consuming away, as the fatal brand was burned-by the power of association, suggested the emblem of "Consumed by Love."

Aloe $L$, Greek « «о\%.

\section{ALOE.}

All Aloes are natives of hot climates; the Cape of Good Hope, \&cc. Some of the species furnish the stimulating bitter medicine of our shops, which is made by boiling the leaves to a suitable consistency, and exposing the decoction to such heat as will evaporate its fluid parts. The Africans make ropes of the leaves, which are not apt to rot in the water; fishing lines, bow strings, \&c., and manufacture it into stockings, hammocks, \&cc.

The tree Aloe, Aloe Dichotoma, growing on the mountains of the Cape of Good Hope, with an erect stem, two fathoms high, and as thick as a man's leg, is hollowed out by the natives to make quivers for their bows. Several of the species are nsed for hedges. The A. D. has leaves sword-shaped, and serrate; flowers paniculate; corolla monopetalous.

Our green-houses abound with the Aloes of diminutive growth. The flower of the Aloe has no calyx: corolla one- petalled, erect; border spreading and small; nectarious at the bottom; seeds angular; leaves fleshy.

Among the Mahometans, and particularly in Egypt, the Aloe is a kind of symbolic plant, and dedicated to the offices of religion. Pilgrims, on their return from Mecca, suspend it over their doors, as an evidence of their having performed that holy journey. The superstitious imagine that it has the virtue of keeping off evil spirits from their houses. Even the Christians and Jews of Cairo, hang it over their doors for this purpose.

The Aloe was used by the ancients in embalming bodies. Of this Aloes, interpreters understand that to have been which Nicodemus brought to embalm the body of our Saviour. John xix. 39.

\section{AMARANTH.}

Amaranthus.

Amaranthus, L.-Greek apxpartos, formed from $\propto$,

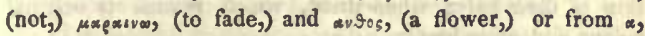
not, and $\mu x \rho_{x / v}$, to fade-unfading, ever fair, ever young.

Milton mentions this flower as forming the diadem of the angels:

"With solemn adoration down they cast

Their crowns inwove with Amaranth and gold;

Inmortal Amaranth, a flower which once

In Paradise, fast by the trec of life,

Began to bloom; but soon, for man's offence,

To Heaven remov'd, where first it grew, there grows

And flowers alof, shading the fount of life;

And where the river of bliss, through midst Heaven

Rolls o'er Elysian flowers her amber stream;

With these, that never fade, the spirits elect

Bind their resplendent locks, inwreath'd with heams."

The Amaranth has been placed among the funereal flowers. Homer has described the Thessalians as wearing crowns of Amaranth at the funeral of Achilles. Milton, also, in his Lycidas, classes it among the flowers "that sad embroidery wear:"

"Bid Amaranthus all his beauty shed,

And daffodillies fill their cups with tears,

To strew the laureate hearse where Lycid lies."

The unfading nature of the flower, we may suppose, the emblem of lasting grief, the immortality of the soul, \&c.

The Amaranth has no corolla: the calyx is coloured, five or three-leaved, permanent; the leaflets lanceolate and acute: native of Asia, Africa, and America.

The A. Tricolor, native of the Fast Indies, is admired on account of the variegated colours of its leaves, resembling, as Gerard tells us, the splendid and beantiful feathers of a parrot, with its stripes of red, yellow, white, green, \&c.

There are several American species. The Prince's Feather, $A$. Hypochondriacus, is a native of Virginia, as are several others. The leaves of most of the species of 
Amaranth are used in hot countries as culinary plants, but are not equal to the spinach, which they somewhat resemble.

The greater number of species are annuals.

\section{GLOBE AMARAN'TH. \\ Gomphrena.}

Gomphrena, a name adopted by Linnæus, from Dalechamp, and which is perverted from the Gomphrena of Pliny. Linnæus made it classical, by an allusion to Gomphos, $\alpha$ nail, wedge, or club-applied to the round head of flowers.

The Gomphrena of the ancients, is supposed to be the Amaranthus tricolor, from the description given of it by Pliny. By the transposition of a letter, this name became Gomphrena, in some old writers, in which form it was adopted by Linnæus.

Gomphrena comes under the denomination of Everlasting, or Amaranthus, on account of the permanent nature of their calyx when dried, which retains its original colour and splendour.

The G. Globosa is a native of India $\rightarrow$ an annual. $C a$ lyx coloured; the outer, of three unequal leaves; inner, in five deep segments. Corolla cylindrical, of one petal, the length of the inner calyx; its margin equally five-cleft, spreading, bearing the stamens at its orifice. Filaments five, short, inserted into the orifice of the corolla, betwixt its segments; anthers erect, roundish, closing the mouth of the corolla. Pist. German ovate, pointed, superior; styles short, cohering at their base; stigmas simple, obtuse, scarcely reaching to the stamens. Seed large, roundish, with an oblique point.

The Globe Amaranth offers several varieties-white, purple, speckled with gold, and variegated. They resemble heads of clover, in the form of their flowers.

The late flowering variegated $G . A$. are called Bachelor $\&^{\prime}$ Buttons, in America, according to the Encyclopedia.

\section{AMARYLLIS.}

Amaryllis, derived either from the name of a shepherdess, mentioned by Theocritus and Virgil, or from the Greek $\alpha \mu \alpha \rho \gamma_{\mu \alpha}$, or $\alpha \mu x \rho \cup \gamma \eta$ splendour-from $\approx \mu x \rho v \sigma \sigma \omega$, to shine, glitter, sparkle, flash-the Lilio-Narcissus of Tournefort.

"Amaryllis Formosissima, most beautiful Amaryllis, hangs its nodding bell obliquely towards the horizon, and as its stem is slender, turns, like a weathercock, from the wind; and thus, very effectually, preserves its inclosed stamens and anthers from the rain and cold-affording an agreeable example of art in the vegetable economy."

See Darwin.

"When Heaven's high vault condensing clouds deform,

Fair Amaryllis flies the incumbent storm;

Seeks, with unsteady step, the shelter'd vale,

And turns her blushing beauties from the gale."

Darwoin.

It received the name of Jacobea Lily, because some imagined that they discovered in it, a likeness to the badge of the order of the knights of the order of St. James, in Spain.

R. Encyclopedia.

It is a native of South America. The flowers are produced from the sides of the bulbs, are large, and of a deep red.

The caly $x$ is a spathe, undivided; corolla two lipped, nodding, deeply six-parted, stamens snd pistils bent down.

There are many species of the Amaryllis, with various coloured flowers, purple, yellow, \&c. The yellow, $\mathcal{A}$. Iutea, a smaller variety, seldom rising more than three or four inches high, is a native of France, \&c., very hardy, flowering late, generally in September.

A. Sarniensis, Guernsey Lily, is a splendid species. The number of flowers is commonly from eight to twelve, and the circumference of each about seven inches; the corolla, in its prime, has the colour of a fine gold tissue, wrought on a rose-coloured ground, and when it begins to fade, it is pink: in full sunshine, it seems to be studded with diamonds; but by candle-light, the specks or spangles appear more like fine gold-dust: when the petals are somewhat withered, they assume a deep crimson colour. This beautiful plant is a native of Japan, and has long been naturalized in Guernsey, whence the roots are sent to most parts of Europe.

\section{AMBROSIA}

Ambrosia, formed of the two Greek words, * (not) and Beoros (human) signifying divine, immortal; because it rendered those who fed on it, immortal; or, because it was the food of the immortals.

"The imaginary food of the gods, from which every thing eminently pleasing to the smell and taste, is called Ambrosia."

Johnson.

Thus, while God spake, ambrosial fragrance fill'd

All Heaven, and the olessed spirits elect

Sense of new joy ineffable diffused.

Milton.

To farthest shores th' ambrosial spirit flies, Sweet to the world, and grateful to the skies.

Pope.

Ambrosia for to fesst the appetite,

Or flowery odour mix'd with spicery.

G. Fletcher.

Here is beauty for the eye;

For the ear sweet melody;

Ambrosiack odours for the smell.

B. Johnson.

The general character of Ambrosia, is a common oneleafed calyx; corolla of the male compound, uniform, and bemispherical; (no corolla to the female) the proper, onepetalled, funnel-shaped; the stamina have very small filaments, anthers erect, parallel, and acuminate; pistillum of the length of the stamens, stigma membranous; a common receptacle, scarcely any, naked. Female flowers, below the males, doubled; one-leafed calyx; the pistillum a germ ovate, in the bottom of the calyx; style filiform, of the same length with the calyx, two stigmas; seed single and roundish. 
There are five species enumerated: one, a common annual weed of North America, $\mathcal{A}$. Gigantea inodora, growing often eight or ten feet high, spreading out into many branches; the flowers are not more conspicuous than those of hemp. The sort common in gardens has three lobed leaves.

The A. Maratima, rises about two feet, with multifid leaves; which, when handled, emit a strong odour: spikes solitary, hairy and subsessile; native of Cappadocia, Tuscany, and the country of Nice, on sandy shores.

\section{AMERICAN STARWORT Aster Tradescanti.} radiated.

Aster, L. from the Greek asтn६, a star, the flower being

Botanists have named this species of Aster in compliment to the memory of John Tradescant, one of the fathers of Natural History in England; as well as one of the earliest cultivators of exotic plants in that country. He was appointed chief gardener to king Charles the First. His son, of the same name, visited Virginia, in 1633, and carried back with him several new plants, of which this was one.

It obtained the more familiar name of Michaelmass" Daisy, from its flowering about that aeason of the year, and the corollas being radiated, and nearly of the size of the common Daisy.

There are two varieties, viz: the dwarf and tall starwort. The common Michaelmass Daisy grows from three to five feet high. The leaves of both are radical, about four inches long, like those of willow; ray varies from white to purple, consisting of many florets. The dwarf variety produces smaller Ilowers, of a dark purple.

North America abounds in Asters of every variety of hue.

\section{ANEMONE.}

\section{(See Note on Adonis.)}

Anemone, Greek avousvs, from avouos, the wind, because the flower is supposed not to open except the wind blows on it; or, because it grows in situations much exposed to the wind.

And coy Anemone that ne'er uncloses

Her lips until they're blown on by the wind.

Hor. Smith.

Heathen mythology informs us that Adonis wss killed by a wild boar, while engaged in the chase of that furious animal; and that his blood, which was shed upon the ground, was, by Venus, changed into the flower Anemone, which has ever since retained the colour of blood.

By this the boy that by her side lay killed, Was melted like a vapour from her sight; And in his blood, that on the ground lay spilled, A purple flower sprung up chequered with white.

Shaks.

- Michaelmass, Michael and Mass. The feast of the archangel Michael, celebrated on the 29th September.
The Anemone Vernalis is a native of the mountains, and barren sands in Sweden, Germany, and Switzerland. Leaves pinnate; flovers red without, and white within.

It has been made the emblem of anxious expectation:

"All wan and shivering in the leafless glade,

The sad Anemone reclin'd her head;

Grief on her cheeks had paled the roseate hue,

And her sweet eye-lids dropp'd with pearly dew.

Breathe gentle air! from cherub lips impart

Thy balmy influence to my anguish'd heart;

Thou whose soft roice calls forth the tender blooms,

Whose pencil paints them, and whose breath perfumes.

And give my ivory petals to expand.

To her fond prayer propitious zephyr yields,

Sweeps on his sliding shell through azure fields,

O'er her fair mansion waves his whispering wand,

And gives her ivory petals to expand."

Darroiñ.

The Anemone has, properly, no calyx; but two or three sets of petals, three in a set, somewhat oblong, which are folded over the stamens and pistils in a singular and beautiful manner. It differs from the Ranuncnlus, in not having a melliferous pore on the claw of each petal. The stamina have numerous filaments, half the length of the corolla; anthers twin and erect; the pistillum has numerous germs in a head; styles acuminate, and stigmas obtuse; no pericarpium; receptacle globular or oblong, hollowed and dotted; numerous seeds, acuminate, retaining the style. It is said to expand its flower only in fine weather, and to close them on the approach of rain.

"Anemone, that shuns the impending shower."

Evans.

And hails with kindling smiles the genial skies.

Darwin.

The flowers of the Anemone are of various colourswhite, blue, purple, yellow, crimson, scarlet, peach-blossom, \&cc.

Anemone now robed in virgin white,

Now blushing with faint crimson.

Gisborne.

"See yon Anemonies their leaves unfold, thic , th in With rubies flaming, and with living gold."

The lily, or purple bell

Of Persian wind-flower.

Maturin.

The American Wild Anemone is very delicate and fragile, and soon withers after being cropped.

"Youth, like a thin Anemone, displays

His silken leaf, and in a morn decays."

Sir Wm. Jones. 


\section{ARBOR VIT 压.}

\section{Thuja.}

Thuja, L. Greek ousov, buis, or tus; which is derived from sues, to perfume.

Arbor Vitæ, L. from Arbor, a tree, and Vita, of life. The tree of life.

Thuja, the name of a tree, whose very durable wood served, according to Theophrastus, to make images. Its roots, in particular, being curiously twisted or veined, were used for the most valuable ornamental works. This plant was probably the Juniperus Oxycedrus, very common throughout Greece and the Archipelago, of which Mr. Hawkins is of opinion that the most ancient statues were made. Our present genus of Thuja has nothing in common with this classical plant, except being an aromatic evergreen tree of the same natural order, with very durable wood; but it is not a native of Greece or the Levant. Rees' Encyclopedia.

The species cultivated are, the American Arbor Vitæ, Thuja Occidentalis, called White Cedar; and the Chinese Arbor Vitæ, Thuja Orientalis. In the first of these species, there are great varieties; as the American sweet-scented, and the variegated-leaved-native of North America, from Cana$\mathrm{da}$ to the mountains of Virginia and North Carolina. It is rather. scarce in the Southern States, and only found on the steep banks of mountain torrents.

The Thuja Occidentalis is an evergreen tree of humble growth, much branched, very different from most others in the compressed vertical aspect of its younger shoots, and their closely imbricated leaves, which are small, obtuse with \& point, smooth; those of two opposite rows compressed and keeled; the intermediate ones flat, with a glandular point or cell of resin, at the back. The flowers appear in May, and are small, solitary, terminal; the males yellowish, and most abundant. Cones ripened the following year, drooping, about the size of a filbert kernel, consisting of about half a dozen las, smooth, coriaceous scales. The odour of the bruised plant is aromatic, but not agreeable. The voood is not hard, but tough, and extremely durable.

Thuja Orientalis, is a native of rocky and mountainous situations in China and Japan. It is a hardy evergreen in our gardens, flowering at the same time with the former. The very copious and crowded young branches are more erect, more slender, and rather less compressed than those of the former, and the leaves are furrowed, without any resinous dot. The young branches two edged; leaves imbricated in four furrows, compressed, ovate, somewhat rhomboid, with a central furrow. Inner scales of the cone obtuse, and remarkably hooked, with a recurved dorsal point.

\section{AURICULA.}

Primula Auricula.

Primula, a name given to the Primrose, as the first offering of Spring, (from Primus,) and retained by Linnæus for the genus to which that favourite flower belongs; though, as he rcmarks in some parts of his writings, there are plants, in various countries, more strictly, entitled to such an appellation.

Auricula, In the outside, the flap of the ear; from areris,
L. the ear. That species of Primrose, called from the shape of its leaves, Bear's ear.

The Auricula is considered in the Linnæan system as a species of Primula. The varieties of the Auricula are extremely numerous, as every year produces a great number of flowers, different in shape, size, and colour; in the leaves, also, there is great variety, so that the experienced florist can distinguish the particular sorts by that means.

The Flora Historica tells us, that it is a native of the icy summits of the Alps: that it is a plant on which Nature plays her frolics, and loves to paint in all the varieties of whimsicality and diversity of rich hues. Nature has guarded these delicate flowers from the scorching heat of the sun's rays, by sprinkling them with a fine powder, and the leaves of most of the kinds of Auricula are kept cool by the same wise precaution.

\section{Auriculas enrich'd}

With shining weal o'er all their velvet leaves.

\section{See}

Thomson.

Where rayed in sparkling dust, and velvet pride,

Like brilliant stars arranged in splendid row,

The proud Auriculas their lustre show.

Kleist.

The acme of the florist's ambition is to procure the $A u$ ricula of a glowing scarlet, or deep crimson, edged with green.

The Primula Auricula, garden Auricula, or Bear's ear, is the origin of all the fine powdered garden Auriculas; it has, in a wild state, much less powdery leaves, whose edges are partially, but often coarsely, serrated; their form broadly and obtusely obovate. Stalk many-flowered, about the length of the foliage. The flowers are small, yellow, occasionally purple, or red, as usually seen in gardens. Their scent is grateful and peculiar.

\section{BACHELOR'S BUTTON. Lychris Dioica.}

(See note on Scarlet Lychnis.)

Dioica Flores, or Diœcious flowers, have stamens in one individual, and pistils in another, on separate plants of the same species.

Bachelor's Button-Bachelor, a word of very uncertain etymology. Junius derives it from the Gr. $\beta \approx x s \lambda_{0}$, foolish. Menage, from bas chevalier, a knight of the lowest rank. - The most probable derivation seems to be from bacca laurus, (L) the berry of a Laurel or Bay; Bachelors being young, are of good hopes, like laurels in the berry.

Johnson.

Lychnis Dioica-red or white field campion, flowers dicecious; fruit of one cell; crown of each petal four-cleft. There is a blush-coloured variety, otherwise most like the white; but more evanescent.

The red flowering kind, L. Diurna, is a very common plant throughout Europe, in hedges and shady bushy places, in the spring. The white, L. Vespertina, so called from its evening fragrance, is a stronger plant, usually found in 
fields or open situations, in summer. The roots perennial; plant hairy, and somewhat viscid, two or three feet high; leaves ovate or lanceolate, hairy; limb of each petal cloven half way down, generally with two small acute lobes; its crown consisting of two obtuse central teeth, and two acute lateral ones.

\section{BALM.}

\section{Melissa.}

Melissa, from Melissa, the Greek name of a Bee; or, rather, as that name itself, like the ancient proper names Melissa and Melissus, also originated from Meli, the Greek for honcy, because of the abundant and excellent honey of the flowers of this herb, for which bees are said greatly to frequent them.

Rees' Encyclopedia.

Balm, E.-French Baume, a contraction of balsam, which is an aromatic substance, flowing from certain plants.

The Melissa Officinalis, Common Balm, has a pleasant scent, somewhat like the lemon, and has been denominated "Melissa odore citri," for this reason. It was formerly esteemed of great use in all complaints proceeding from a disordered state of the nervous system. As a tea, it is well known to be a grateful diluent drink in fevers, either by itself, or acidulated with lemon.

Balm is too generally known to require a botanical description.

\section{BALSAM.}

\section{Impatiens.}

Impatiens, so called from the great elasticity of the sutures of its seed ressel, which is completely impatient of the touch; curling up with great velocity, and scattering round the seeds. From this remarkable circumstance, it has obtained the English appellation of "Touch-me-not."

It is a native of the East Indies, China, and Japan. It has the advantage of retaining all its splendour and freshness during the drought of the hottest months. Contrary to the nature of plants, in general, it droops in the cool of the night, whilst it erects itself in the heat of day, which causes most other plants to fade. In watering these plants, care should be taken not to sprinkle or wet the foliage; and it is recommended to save the seeds from the principal stem only, and not from the collateral branches.

General character of Impatiens: Perianth very small, of two roundish, pointed, equal leaves, coloured, deciduous. Corolla five-petalled, irregular; the upper petal roundish, flat, slightly trifid, making a sort of upper lip; lower pair very large, obtuse; intermediate pair opposite, rising from the base of the upper petal; nectary receiving, like a hood, the base of the flower.

The generic name of Impatiens, has suggested the emblem of Impatience; but the Turks represent ardent love by this flower.

\section{SWEET BASIL.}

\section{Ocimum Basilicun.}

Ocimum L. the wxıнor of the Greeks. Etymology un-

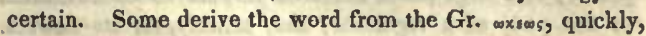

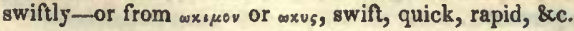

The Ocimum Basilicum, or Common Sweet Basil, is a native of India and Persia; and may be placed among the hardy annuals. The leaves ovate, peculiarly smooth and cool to the touch, and if not too much bruised, exhale a delightful fragrance. The calyz is remarkably hairy; the flowers violetcoloured, varying in colour, sometimes only spotted with purple.

Basil, E.-French basilic-Latin basilico-Greek

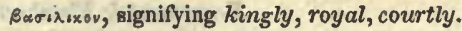

Several of the species of the Ocimum are held in superstitious veneration by the Hindoos, and are used in their religious ceremonies. The species most in estimation at Calcutta, is known by the general name of Toolsey. The whole genus is valued for their fragrant, aromatic, and sweet scent; which, in some instances, resembles the nutmeg, clove, citron, and fennel.

That which is used in French cookery, rises about ten inches high, sending out opposite four cornered branches from the very bottom. Leaves ovate, narrowing gradually towards each end in acute points, indented on their edges. The whole plant hairy, and has the odour of cloves.

\section{BAY TREE.}

Laurus.

Laurus, the ancient Latin name of the Bay Tree, for which it is retained by modern botanists, and along with which it now comprebends a great number of species, constituting one of the noblest genera in the whole regetable kingdom. The origin of the word is now lost in the obscurity of antiquity: and whether etymologists derive it from lavo, to wash, or from laus, praise or honour, we have not the satisfaction to know.

Bay, E.-In Spanish Baya, is a berry, the fruit of the laurel. Greek $\beta_{x w 0 v}$, a branch of the palm tree. It was used in the ancient purifications. Ainsworth.

What is now called Bay, was formerly called Laurel, which has introduced some confusion.

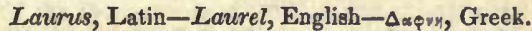

Daphne, so famous for her modesty, was transformed into the Laurel, or Bay tree, which is always flourishing and pure. Apollo, her lover, crowned his head with the leaves, and ordained that for ever after, the tree should be sacred to him. He says of the tree, after the metamorphosis:-

\section{Because thou canst not be}

My mistress, I espouse thee for my tree: Be thou the prize of honour and renown; The deathless poet, and the victor crown. Thou shalt the Roman festivals adorn, And, after poets, be by victors worn.

Secure from thunder, and unharm'd by Jove, Unfading as th' immortal pow'rs above: And as the locks of Phebus are unshorn, So shall perpetual green thy brows adorn. The grateful tree was pleas'd with what he said, And shook the shady honours of her head:

Dryden's Ovid. 
The Bay has had ascribed to it the property of resisting lightning:

There bays still grow, (by thunder not struck down,)

The victor's garland, and the poet's crown.

W. Brovone.

Low at your sacred feet our poor muse lays

Her, and her thunder-fearless bays.

\section{Beaumont \& Fletcher.}

The Laumus Nobilis, or Sweet Bay, is decided to be the Daphne of Dioscorides; and, consequently, the classical Laurel of the ancients. It is still called by the same name among the modern Greeks. It is a native of Asia and Europe. There are many species of it, some of them indigenous in America.

The L. Nobilis is a tree of slow growth. Leaves stalked, lanceolate, veiny, finely reticulated, evergreen, aromatic: flowers four-cleft, dicecious, in short axillary clusters, of a pale yellow, borne only by old trees: no calyx.

The Laurel only to adorn

The conqueror, and the poet.

Drayton.

The Laurel meed of mighty conquerors, And poets sage. Spencer's Fairy Queen.

The triumphal crown of the Romans, was made of branches of Laurel, or Bay tree, and given to a General who had gained a battle, or conquered a province, and who was worthy of the honour of a triumph:

\section{Unchallenged, let the warrior wear}

The Laurel in his gory hair.

J. H. Wiffin.

Triumphant Laurels seem to grow

No where so green as on his brow.

Butler.

In the genus Laurus, are found the Cinnamon tree, or I. Cinnamonum, whose bark furnishes the spicy aromatic Cinnamon of our shops. It is a native of Ceylon, an island of the East Indies.

The L. Camphora, or Japan Camphor tree, of this genus, is that from which the best camphor is procured. This is found in perpendicular veins, near the centre of the tree, or concreted in the knots of the wood. There is a grosser sort prepared from the roots, which is afterwards refined by a chemical process, into the transparent resin used in medicine. The Camphor tree, in its general character, is nearly related to the Red Bay of America; so similar in appearance, that, at a little distance, they are easily confounded.

The $\boldsymbol{L}$. Cassia, or Cassia-bark tree, celebrated from all antiquity, belongs to this fámily: native, also, of the East Indies. It is noticed in the. Old Testament, Ps. xiv. 7, 8. It resembles the Cinnamon in its aromatic, fragrant bark.

$\boldsymbol{L}$. Sassafras, American Sassafras tree, is also of this genus. It was among the first trees of America which became known to the Earopeans, on account of its medicinal virtues.
L. Caroliniensis, American Red Bay, is another species, abundant in the Southern States, where it attains the height of from sixty to seventy feet, and from fifteen to twenty inches in diameter. The leaves are about six inches long, aiternate, oval-acuminate, whitish, or glaucous, on the lower surface, and evergreen. They resemble, in odour, those of the Sweet Bay, L. Nobilis, and may be employed in cookery. The fruit, or seed, is very similar to those of the Sassafras, of a dark blue colour.

\section{BELVIDERE. \\ Scoparia. Dulcis. \\ A. Veronica.}

Veronica, an old but not classical name. Its common etymology is between the Greek and Latin, from Verus, or rather Vera, true, and the Greek s"xwr, a figure; and this, illiterate and barbarous as it is, has the sanction of the superstitious legend of St. Veronica, whose handkerchief is recorded to have received the impression of our Saviour's face, as he used it in bearing his cross to the place of crucifixion.

Veronica is abbreviated from Vericonica, of Vera-icon q. d. true image. Veronicas, in commerce, are imitations of that celebrated original one, preserved with great veneration at St. Peter's, in Romc; and imagined, by some, to be the handkerchief laid over our Saviour's face in the sepulchre.

Ambrosinus says, the word Veronica is German, and originated in the druggists' shops of that country. He favours the idea of its being corrupted from Vetonica, our Betonica, or Betony.

Belvidere, E., from the Latin bellus, fine, and video, to see.

Scoparia, from the Latin Scopæ, a broom, because the plant is used in the West Indies for making brooms.

Scoparia Dulcis, Sweet Scoparia. The leaves have a sweet taste like liquorice, whence its name of Wild Liquorice, or Sweet Weed, by which it is known in Jamaica. Sloane says, that three spoonfulls of the expresscd juice of these leaves, taken evening and morning, for three days, is counted an infallible remedy for any cough. It has long been known in our green-houses as an annual of no great beauty. It blossoms throughout the summer: the stem is very bushy, angular: leaves stalked, an inch long, light green, smooth, coarsely and bluntly serrated, tapering at the base: flowers small, white: corolla wheel-shaped, deeply four-cleft; numerous axillary, solitary, on short slender stalks: calyx in four deep equal segments.

\section{BIRD'S-FOOT TREFOIL Lotus.}

\section{(See Lotos.)}

Lotus, or Lotos, a name applied to several herbaceous plants, essential to the maintenance of domestic cattle in countries sparingly furnished with grass.

For Trefoil, see clover.

There are several species of the Bird's-foot trefoil noticed under the article Lotus. The square podded Lotus siliquosus, with large lemon-colonred flowers-once cultivated for the pods as a regetable; and, latterly, for its flowers. Roots perennial. 
The Crimson-winged Pea, or L. Tetragonolobus, is a hardy annual, with deep erimson velvety flowers. The pods, also, esculent. This species has been celebrated, as having first called the attention of Linnass to the sleep of the plants. He observed its flowers to close up in the evening, and open again in the morning.

Common Bird's-foot Trefoil, L. Corniculatus, usually found in open grassy pastures, where it is conspicuous in the Autumn, with flowers of a golden yellow, more or less stained or striped with dark red: the stem clothed with closepressed hairs: pod or seed-vessel of a shining brown or copper colour: roots perennial-has been recommended for fodder and hay, by the name of Milk-vetch.

The essential character of this genus, is Legume cylindrical, straight, wings cohering longitudinally above: calyx tubular; filaments dilated upwards: corolla papilionaceous.

\section{BOX.}

\section{Buxus.}

Buxus, L. from the Greek $\pi v \xi เ \xi$, a box, and $\pi v \xi \circ$, the tree. Sax. box.

The Box, sacred to Cybele, because the pipes used in her sacrifices were made of it.

(See Tooke's Pantheon.)

The Arborescent Box, or Buxus Arborescens, (Sempervirens, Linn.) a shrubby tree, from twelve to sixteen feet high; is a native of most parts of Europe, from Britain sonthward, and in the temperate parts of Asia and America. It was much admired by the ancients, on account of its being easily clipped into the shape of animals, and other fantastic appearances. The younger Pliny gives a florid description of the pleasure grounds at one of his country seats; in which, among other curious devices, the letters of his own name, and of other words, were orderly expressed in rows of shorn box.

The Dwarf Box, or Buxus Suffruticosa, never rises to a greater height than about three feet, and grows in thick, much-branched tufts. It is found wild in many parts of France, by the road sides, about villages, and in stony, waste places, and is said to be truly indigenous.

It is used in gardening, to divide beds from the walks of flower-gardens, and has great durability.

R. $\boldsymbol{E}$.

The Box is too well known to require a botanical description.

\section{BROOM.}

Genista.

Genista, either from Genu, a knee-in allusion to the bending of the twigs; or from Geno, to produce: because it grows wild in abundance. Not a very clear etymology.

Rees' Encyclopedia.

Broom, E.-Sax. brum, so called from its being made into brooms to sweep with.

Genista, Green-weed, Dwarf Broom, Scotch Broom, \&c. A genus of shrubs almost entirely European, with tough angular stems and branches, either ternate or simple leaves, and yellow flowers: calyx a perianth inferior, of one leaf, small, tubular, two-lipped, the upper lip with two teeth, lower

*Corniculatus, Latin-Horned, like the Moon. Ainsworth. with three. Corolla papilionaceous, standard oblong, bent backwards from the rest of the flower.

Sweet blooms Genista in the myrtle shade, And ten fond brothers woo the haughty maid.

Darwin.

In allusion to the ten stamens being united at the bottom into one brotherhood, and with the single pistil inhabiting the same flower.

In France, the Broom is regarded as the emblem of Humility. Garland of Flora.

The Encyclopedia states, that the term Plantagenet has given infinite perplexity to the etymologists and antiquarians. It is allowed to have belonged to the house of Anjou; and was brought to the throne of England by Henry the Second, where it was preserved by his posterity, till the time of Henry the Eighth, a space of above four hundred years.

Skinner tells us that "the house of Anjou derived the name Plantagenet from a prince thereof, who having killed his brother, to enjoy his principality, afterwards repented, and made a voyage to the Holy Land to expiate his crime; disciplining himself every night with a rod made of the plant Genet, Genista, broom." And we are told, elsewhere, that he became nick-named Planta-genet, from the use he had made of the Broom, or Genista.

Lemon, in his English Etymology, says: "It is very observable, that fourteen princes of the family of Plantagenet have sate on the throne of England for upwards of three hundred years, and yet very few of our countrymen have known either the reason of that appellation, or the etymology of it: but history tells us, that Geofry, earl of Anjou, acquired the surname of Plantagenet from the incident of his wearing $a$ sprig of Broom in his helmet, on a day of battle. This Geofry was second husband to Matilda, or Maud, empress of Germany, and daughter of Henry I., of England: and from this Plantagenet family were descended all our Edwards and Henrys."

Of the Broom there are three varieties-the yellow, violet, and white flowering.

Their groves of sweet myrtle let foreign lands reckon, Where bright beaming summers exalt the perfume; Far dearer to me yon lone glen $\sigma^{\prime}$ green breckan, W'' the burn stealing under the lang yellow broom.

The wilding broom as sweet, which gracefully

Flings its long tresses, waving in yellow beauty. Landon.

The humble Broom and osiers have their use, And shade for sheep, and food for flocks produce.

Dryden.

The broom and the furze are perpetually associated. They both bear papilionaceous flowers. The furze is sometimes called, by botanists, Genista Spinosa, and also Ulex Europceus, provincially Whin or Gorse. This grows abundantly in England: and it is recorded of Linnæus, that when he visited England, in 1736, he was so much delighted with the golden bloom of the furze, which he then saw for the 
first time, on a common near London, that he fell on his knees, enraptured at the sight. He conveyed some of the plants to Sweden; and he complains in Hort. Upsal, 212, that he could never preserve it in his garden, through the winter.

Of the furze, the common yellow and the white, are ranked under the head of evergreens.

\section{Here the furze}

Enriched among its spines, with golden flowers, Scents the keen air. Charlotte Smith.

The gorse is yellow on the heath, The banks with speedwell flowers are gay.

Same.

The purple heath, and golden broom, Which scent the passing gale.

Montgomery.

\section{BUTTER CUP.}

\section{Ranunculus. Acris.}

Ranunculus, derived from $R a n a$, and means a little frog. It is possible that the divisions of the leaves may have suggested the idea of a frog's foot, which supposition is confirmed by the English name Crow-foot.

It is an extensive and varied herbaceous genus: the seed, in no instance, ever producing two flowers alike, or one similar to the parent plant. The prevailing colour of the flower is yellow; yet it embraces all colours, from black down to white: blue is one of its most rare colours.

Tle plants of Ranunculus have a caustic and burning quality, injurious to men and cattle; particularly sheep: and it was with one kind of Ranunculus that the ancients poisoned their arrows.

The essential mark of this genus, consists, according to Linnæus, in the nectary; the rest of the parts being uncertain. The nectary, in some species, is a naked pore; in some, it is bordered with a cylindrical margin; in others, closed with a notched scaie.

Its general character is that of a perianth, of five ovate, concave, somewhat coloured, deciduous leaves: corolla of five petals, obtuse, polished; with small claws: nectary a cavity in each petal, just above the claw.

The Ranunculus Acris, Butter-cup, or King-cup, is a native of meadows and pastures, flowering from May to August. Called Butter-cup, from blooming at the season when the best butter is made. The double-flowered variety is frequent in gardens.

And fairies now, no doubt, unseen,

In silent revels sup;

With dew-drop bumpers toast their queen, From crow-flower's golden cup.

Clare.

Let weeds, instead of butter-flowers, appear, And meads, instead of daisies, hemlock wear.

Gay.

Bright flowing king-cups promise future wealth. Garland of Flora.

\section{CALLA AETHIOPICA.}

Arum Fthiopicum.

Arum, supposed to be derived from a Greek word os $\alpha$, signifying injury. I suppose from the acrimonious quality of the root, which, if cut in slices, and applied to the skin, will blister the part.

The $\mathcal{A}$. Maculatum, or common Arum, is the only species indigenous in Britain, and is used medicinally. Its medicinal efficacy resides wholly in the active volatile matter, which is completely dissipated by drying, or the application of heat, so as to leave the root a bland farinaceous aliment.

There is a species, Arum Virginicum, Virginian Arum, which grows wild in wet places in Virginia, Carolina and Pennsylvania, \&c., of which the savages are said to be very fond. They boil the spadix, with the berries, and devour it as a great dainty. There are several species of the Arum indigenous in America.

Calla, is derived, according to some authors, from the Greek $x x_{\lambda \lambda \circ \varsigma}$, beauty. According to Professor Martyn, from $x \approx \lambda \lambda \approx \approx 0 \%, \mathrm{Gr}$., the wattles of a cock.

The Calla Ethiopica-Ethiopian Calla, Cuckoo-pint, Wake-robin, Dragon-plant, Friar's-cowl, Eve's-apron, all English names applied to it, is a species of Arum-a native of the cape of Good Hope. The flower is beautiful. Its alabaster white calyx expands into so elegant a vase-like shape, that Flora seems to have intended it for the hand of Hebe, when she presents the imperial nectar to Jove. This vegetable cup also pours out an. agreeable perfume from its graceful and beautiful horn. Its appearance, in a group of plants, reminds us of a beautiful antique lamp for burning incense; which illusion the flame-coloured spadix, arising out of the centre of the white calix, considerably increases. It has arrow-shaped leaves, clustering from the root, eight or nine inches long, of a shining green, ending in a point, which turns backwards on petioles more than a foot long, furrowed, and sheathing at their base. The white spathe, a little fleshy, twisted at the bottom, but spread open at the top, suddenly contracting, and ending in a point. The spadix yellowish, cylindrical, about half the length of the spathe. Stamens above, pistils below, set so closely together, that they are not easily distinguished. 'The seeds are roundish, darkbrown and smooth.

\section{CALYCANTHUS FLORIDUS. \\ Carolina Allspice; or \\ Sweet-scented Shrub.}

Calycanthus, from the Greek $x \times \lambda \cup \xi$, calyx; and av9०5, a flower. So called, because the calyx resembles a corolla. Linnæus gives the flower no corolla, but a calyx with many divisions in two concentric ranks, all resembling petals.

Jussieu observed, that the inner rank probably consists of petals. A shrub three or four feet high: stem irregularly branched; covered with a brown aromatic bark. Leaves opposite, egg-shaped: flowers of a dusky purple; the pctals incurved at the top. A native of Carolina. The seeds are thought to be poisonous to dogs and foxes.

\section{CAMEIIIA JAPONICA.}

Japan Rose.

Camellia, so named in honour of Geo. Joscph Kamel, a 
Jesuit, whose name has been Latinized into Camellus; author of Syllabus Stirpium, \&cc., annexed to the third volume of Ray's Historia Plantarum.

Camellia Japonica-a lofty, large, evergreen tree: leaves alternate, egg-shaped, acute, shining on both sides, thick and stiff, paler green beneath, on short leaf-stalks. Flewers large and beautiful, in the form of the rose: those raised in Europe, of a lively red; but in their native country, they exhibit a variety of colours. Its flowers readily become double, in which state they often occur in Chinese paintings. A native of China and Japan-introduced into England, before 1742, by Robert James, Lord Petre.

As Venus wander'd 'midst the Italian bower, And mark'd the loves and graces round her play;

She pluck'd a musk-rose from its dew-bent spray,

"And this," she cried, "shall be my favourite flower;

For o'er its crimson leaflets I will shower

Dissolving sweets to steal the soul away;

That Dian's self shall own their sov'reign sway,

And feel the influence of my mightier power."

Then spoke fair Cynthia, as severe she smiled,-

"Be others by thy amorous arts beguiled;

Ne'er shall thy dang'rous gifts these brows adorn;

'To me more dear than all their rich perfume

'The chaste Camellia's pure and spotless bloom,

That boasts no fragrance, and conceals no thorn." Wm. Roscoe, Esq.

\section{CANTERBURY BELL.}

\section{Campanula. Medium.}

Campanula, Latin, for a little bell.

Root biennial. The plant decays after having matured its seeds. The seeds should be sown in the spring and transplanted in the autumn, preparatory to its flowering the following year.

Stem two feet high. Root-leaves narrowed at the base into long leaf-stalks, slightly scolloped, hairy, harsh to the touch. Stem-leaves oblong, scolloped. Flovers blue, purple, or white, large-Monopetalous.

Native of woods on the continent of Europe.

\section{CAPE, JASMINE.}

\section{Gardenia. Florida.}

Gardenia, so named by Ellis, in honour of his able friend and correspondent, Dr. Alexander Garden-an eminent botanist and zoologist-a Scotchman, who settled at Charleston, S. C., in 1752: a correspondent, also, of Linnæus. During the political disturbances in America, he, being a loyalist, took refuge in Europe; and, in 1761, he was elected a member of the Royal Academy of Upsal.

The original idea and character of this genus are taken from the $G$. Florida, first carried to England by Captain Hutchinson, in full bloom, from the Cape of Grood Hope. Gordon, the nursery-man, having obtained layers, propagated it so successfully, as to have gained more than five hundred pounds by the produce. The flowers are always double, like those of the original shrub; with only imperfect traces of anthers: but many specimens, with single flowers, have been brought from the East Indies, where it grows wild, as well as in China and Japan.

Stem shrubby, three or four feet high: leaves opposite, on short stalks, elliptical, bluntly pointed, entire, smooth, veiny, evergreen. Flowers solitary, of the size and aspect of a double $\mathcal{N}$ arcissus Poeticus, (which is the largest of the white kinds, with a crimson border on the cup of the nectary,) with a sweet and very powerful scent, resembling the flavour of ginger.

\section{CARDINAL'S FLOWER.}

\section{Lobelia. Cardinalis.}

Lobelia, so called in honour of Matthias de Lobel, or L'Obel, a botanist, contemporary with Clusius, whose wooden cuts, for the most part, re-appeared in his works. He was, at one time, physician to the illustrious Prince of Orange, and to the States of Holland. Born at Lisle, in Flanders, in 1538. He removed to England before the year 1750 , and was appointed botanist and physician to James the First, of England. He had, at one time, the superintendence of Lord Zouch's garden, at Hackney, during the latter part of the reign of Queen Elizabeth. He was one of the contributors to a work entitled the Adversaria, dedicated to Queen Elizabeth. The aim of the authors of this work, was to investigate the botany and materia medica of the ancients; and especially of Dioscorides. In the decline of life, he lived at Highgate; and dicd in 1616-aged 78.

The Cardinal's flower, Lobelia Cardinalis, was introduced into Great Britain in the reign of the First Charles; whose herbalist, Parkinson, mentions it as a "brave plant." We presume it was called Cardinal's flower on account of the bright red colour of the corollas. It is a native of North America, growing by the sides of rivers and ditches. Its roots perennial; stems three feet high, leafy: flowers rich, and vivid scarlet.

The L. Fulgens, Refulgent Lobelia; and the L. Splendous, Shining Lobelia, are still more brilliant: they are Mexican plants; and when cultivated with care, the crimson flowers assume a degree of magnificence scarcely surpassed by any other plant.

The foliage of the Splendid, or Shining Lobelia, is marked with dashes of a rich puce colour; which, together with the claret coloured flower-stalks, adds greatly to the beauty of the plant. The stems from five to six feet high.

The Blue Lobelia, much used in medicine, grows abundantly in the middle and southern states of North America, in moist grounds. The stem erect, (not branched, like the $I$. Inflata,) rather hairy, from one to three or four feet high; leaves ovate, lanceolate, unequally serrate; raceme leafy; calyx, hairy, with sinuses reflexed; flowers, large, bright blue, on short peduncles. Every part of the plant abounds with a milky juice, and has a strong, disagreeable odour. The root, which is the part used in medicine, resembles tobacco in taste, and is apt to excite nausea. It flowers all the summer.

\section{CATCH FLY.}

Silene.

Silene, a name given to this genus by Linnæus, in allu- 
sion to the viscid moisture of its stalks, under the flowers of this plant, by which flies of the smaller kind are entrapped: a curious contrivance of Nature, to prevent various insects from plundering the honey, or devouring the seed. The

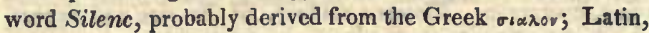
saliva. De Theis deduces it more directly from the drunken god Silents, whose name he supposes to have a similar origin:

The fell Silene, and her sisters fair,

Skill'd in destruction, spread the viscous snare.

Haste, glittering nations, tenants of the air,

$\mathrm{Oh}$, steer from hence your viewless course afar!

If with soft words * * * *

The three dread syrens lure you to their toils,

Limed by their art, in vain you point your stings,

In vain the efforts of your whirring wings!

Darwin.

The general character of this genus is, a calyx of one leaf, swelling; petals five; with erect, narrow claws, the length of the calyx; bordered with a membrane, capsule superior, imperfectly three celled, bursting at the top; seeds numerous, kidney-shaped, attached to a central receptacle.

There are varieties of pink-whitc, purple, and variegated flowers. They are hardy, herbaceous, annual and perennial plants.

\section{CEDAR.}

Juniperus.

Juniperus, an ancient Latin name; of whose meaning or derivation, no account is given.

The Juniperus Virginiana, Virginian Juniper, or Red Cedar-native of North America, the West India islands, and Japan. The wood of this tree is celebrated for its powerful fragrance, and for resisting the attacks of insects; being the well known red cedar used in lead pencils, \&cc. It is the most common of its genus in the United States. The foliage is evergreen, numerously subdivided, and composed of small sharp scales, enchased in one another. The flowers are small and inconspicuous: no corolla, only a calyx. The seeds are small, ovate berries, bluish when ripe, and covered with a white exudation. From these berries the spirituous Gin is prepared.

\section{CHINA ASTER; or, STARWORT. Aster Chinensis.}

(For Aster, see American Starwort.)

The Chinc Aster has the largest and handsomest flowers of any of this genus. Flowers, single and double, white, blue, purple, red, and variegated, blue and white. Height from eighteen inches to two feet; a well known annual piant. Lcaves ovate, angular, toothed, petioled; calyx expanding, leafy, terminal; disk yellow, floscules of the roy, broad and long; seeds ripened in autumn.

\section{CHINESE CHRYSANTHEMUM.} Chrysanthemum Indicum.

Chrysanthemum, from Chrusos, the Greek for gold, and Anthos, a flower-a generic name given to these plants, because the species most familiar to the Greeks produced flowers of a gold colour. This shows the error of forming the gencric name of plants from the colour, when the same species may present all the colours of the rainbow.

The Indian, or Chinese Chrysanthemum, was introduced into Europe as early as $\mathbf{1 7 6 4}$. There are already thirty varieties of it. It may now be considered a hardy perennial plant. The varieties differ in the shape of their leaves; some having their serratures much deeper cut than others. The greater number have an odour resembling that of the chamomile flower. Stem somewhat woody, two or three feet high, much branched: leaves alternate, and serrated; upper surface deep green; lower, soft to the touch, and clothed with a slight down: flowers large, solitary, terminating the branches: calyx common, hemispherical, imbricated: corolla compound, radiated: receptacle naked.

\section{CLOVER RED. Trifolium.}

Trifolium, the Triphullon of the Greeks-Trefle of the French; from which last is more immediately derived our Trefoil: names, all expressive of the same idea, of three leaves, or leaflets, growing on one stalk.

Clover, E. more properly claver. Dutch klaver. The word is no doubt from the Saxon word clof fr, to cleave, from the appearance of the cloven leaves.

Johnson.

Clover-grass-Saxon clafer-voyrt, clover-wort. Dutch klaver. The D. word signifies $a$ club. The name signifies club-grass, club-2oort. Latin clava, a club, from its flower.

Webster.

The desert with sweet claver fills,

And richly shades the joyful hills.

Sandys, see Johnson.

The different species of Trefoil always contract their leaves at the approach of a storm: hence these plants have been termed the husbandman's barometer.

To live in clover, is to live luxuriously, or in abundance.

The purple or red Trefoil, or Clover $T$. Pratense, with terminal spikes of numerous flowers, their petals united at the base, and combined with the flaments: calyx hairy, ten. ribbed, much shorter than the corolla; a swect but faint scent; blooms all the summer through, from May to September: affording an abundant return of profit to those who have the industry to attend properly to its cultivation. It is a well known biennial, perennial plant, of the artificial grass kind, whose roots are apt to decay after they have perfected their seed; it is, therefore, necessary to be diligent in cropping, or mowing it, when it begins to flower: the roots then send up new shoots, whereby the plant is continued longer than it would naturally do. One acre of red or broad clover will go as far in feeding cattle, as three or four of natural grass. The best clover-seed is that where the purple colour chiefly prevails.

Pliny designates clover as the sweet and honeyed Lotus. "The field clover that grew in Campagne, about Rome, the bees, you know, are very fond of it." 

Trefoil.

Shamrock, is the Irish name for three-leaved grass, or

Saint Patrick, (the tutelar saint of Ireland,) is said, while preaching to the pagan Irish, to have used the Trefoil, or Shamrock, to explain the doctrine of the Trinity; which so operated on their conviction, that a sprig of this grass is ever since worn by the Irish, on the anniversary of the saint, commemorative of the event.

The order of St. Patrick, was instituted by George III., in 1783. The badge of this order is a saltier red, on a field azure, surrounded with a Shamrock, or Trefoil vert, charged with three imperial crowns, or within a garter; on which is the motto quis separabit_- who shall separate them." The whole is surrounded by a star of silver, with eight points; all which is embrojdered, and worn on the outer garment of the knights of the order.

\section{CRESTED AMARANTH; or, COCK'S COMB. Celosia Cristata.}

Celosia, the generic name of this singular plant, is derived from the Greek $x y \lambda \lambda_{10}$, brilliant, or $x y \lambda s w$, to entice, or enchant. The English name Cock's comb, and the French Crete de Coq, is given on account of the resemblance which the crested head, or mass of flowers, bears to the crest, or comb of a cock.

It is a native of Asia: cultivated to such perfection in Persia, China, and Japan, that the crests, or heads of the flowers, are said to be frequently a foot in length and breadth.

It is an annual plant, with angular, striated stems: leaves alternate, acute, narrowed into a petiole at the base, sometimes a little curved: flowers so pumerous and small, and so closely set together, on an irregular, flattish surface, as to look more like a piece of rich velvet, than a vegetable substance, sometimes branched at the base. The form of the crests are so variable as seldom to give two of the same shape. The colours, orange-yellow, bright red, purple, white, and sometimes varjegated.

\section{COLUMBINE.}

\section{Aquilegia.}

Aquilegia, from Aquila, an Eagle; the nectaries being fancied to resemble an Eagle's talon.

Columbine, from Columba, a Pigeon-from a supposed resemblance the same parts of the flower bear to the head of a Pigeon.

Some etymologists are of opinion, that the name of Aquilegia is given to this plant, because the leaves, when not fully expanded, collect and gather a great deal of rain water.

Darwin tells us that in Aquilegia (or Columbine) the nectary is imagined to be like the neck and body of a bird, and the two petals standing upon each side to represent wings, whence its name of Columbine, as if resembling a nest of young pigeons fluttering whilst their parent feeds them. [See his note upon Lonicera.]

The roots are perennial. Flowers of various colours, purple, blue, red, white, \&c.
The dark blue or purple-flowered, $\mathcal{A}$. vuigaris, common Columbine, about three feet high, is of European growth.

The $\mathcal{A}$. Canadensis, red flowering Columbine, is a native of North America, from Canada, to Carolina: and was carried from Virginia to Europe by Tradescant. It is a more graceful and delicate plant than the purple. Its very slender stems are reddish. Corollas, yellow within, and red without. Lower leaves biternate, irregularly divided, the extreme lobes blunt; the upper lobes simply ternate, toothed, or perfectly entire: the uppermost, simple, lanccolate, acuminate.

\section{CONVOLVULUS; Or, Bind Weed.}

Convolvulus, perhaps from Convoivo, to wrap or wind about, to envelope, to encompass-as many of the species are twining.

Indigenous in Europe, America, and the Indies.

The Convolvulus opens and closes its monopetalous flower with folds similar to those of a parasol, and are never expanded at night, or in wet weather, in order that the anthers and stigma may be guarded from the humidity of the air.

Convolvulus, expand thy cup-like flower,

Graceful in form, and beautiful in hue!

Barton.

"Flowers, which shrinking from the chilly night, Droop and shut up; but, with fair morning's touch

Rise on their stems, all open and upright."

The character of this genus is a five-cleft calyx, bell, or funnel-shaped corolla, plaited border generally spreading, more or less five lobed. Leaves, heart-shaped.

\section{ARKANSA. COREOPSIS.} Coreopsis tinctoria.

Coreopsis, from the Greek xogıs, a bug, and orsus, appearance; alluding to a fancied resemblance between the seed and an insect.

Tinctoria, from the Latin tinctura, a colour or dye.

Arkansa, indicates the situation from whence it was taken by Professor Nuttall.

Mr. Pastie of the Royal Academy of Sciences of Paris, advances the new hypothesis, that it is of more consequence (in a medical point of view) to know the exact natural situation of a plant, than knowing the genus. He observes, that, all plants which grow on high cold grounds have a tonic and stimulating power, whilst those are found to have a contrary quality, which are natives of opposite situations.

(See Maun's Botany.)

The Arkansa Coreopsis, is a very pretty slender growing annual, of from two to three feet high. Flowers terminal. Petals wedge-shaped, generally three-toothed at the point, the middle tooth longest, and often notched, of a bright golden colour, with a dark crimson spot at the base. Florets of the disk black-purple; but the styles and stigma being yellow, occasion the outer rim, when the florets are expanded, to appear yellow. 


\section{COWSLIP.}

Primula. Veris.

(See Primrose.)

Primula veris, sulphur coloured Cowslip.

Called Coroslip, as some think, from their odour resembling the breath of a cow; - or, perhaps, from their growing much in pasture grounds, and often meeting the cow's-lip.

Johnson.

The blossoms of the $\boldsymbol{P}$. veris (or common European Cowslip) communicate their aromatic fragrance, and narcotic quality, to made wines, which thence have a resemblance to the Muscadel wines of the south of France.

\section{For want of rest,}

Lettuce and Couslip wine: probatum est.

Pope.

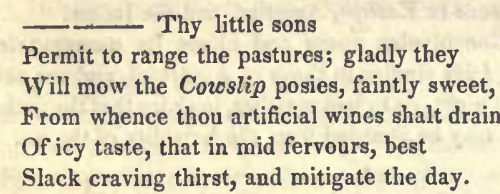

Philips.

The flowers of the Cowslip are frequently mixed with tea, to give it a flavour. The leaves were formerly eaten in sallad.

Flora Historica.

How cheerful along the gay mead

The Daisy and Cowslip appear.

Milton.

Pale Primrose, in whose cup

The pearly dew glitters.

B. Barton.

The uncommon beauty of the American Coroslip, or Meadia, occasioned Linnæus to give it the generic name of Dodecatheon, and Dr. Mead to affix his name to it.

Dodecatheon, is derived from two Greek words signifying twelve and $a$ divinity. An old name for the Cowslip, supposed to signify the twelve heathen gods. Or, as some suppose, to allude to the twelve Cæsars, who were commemorated in the circle of twelve flowers, or thereabouts, composing its umbel. The idea is rather far-fetched, and the Cæsars, for the most part, were unworthy of any such elegant commemoration. However this may be, Linnæus retained the appellation for a new genus, akin to the Covslip, which had been called Meadia, after Dr. Mead, a name, which Linnæus rejected as unworthy for generic, though he preserved it in the specific one.

The only species described is the Meadia, which is a native of Virginia. A hardy perennial, that bears the severest cold, flowering in June. When it was first sent to England, it was raised from the seed, by Mr. Peter Collinson, and the leaves proved so like those of the lettuce, that he apprehended some mistake, till the beautiful flowers came forth.

\section{CROCUS.}

Crocus, a Latin name, translated by Ainsworth, "Saffron;" also "the yellow chives in the midst of flowers."
Saffron, the xeoxos of the Greeks-Crocus, of the Latin-Zaffaran, or Zah afaran, of the Arabians, (from which last, according to Skinner, comes its English name of Saffron,) and Carcom, of the Hebrews, who held it in much estimation. It has been greatly celebrated in ancient times, both by physicians and poets.

We are told that the Saffron of the shops, is the odorous aromatic stigmas of the Crocus sativus, or officinalis, a native of Grece, and Asia Minor. Which, since its introduction into England, has been called Saffron-IValden, because formerly cultivated chiefly near or about the town of Walden.

It is mentioned in Solomon's Song, iv. 14.

Fabulous history derives the name Crocus, from a youth of that name, who was consumed by the ardour of his love for the nymph Smilax, and, afterwards, changed into the flower bearing his name.

Crocus, and Smilax,* may be turn'd to flow'rs, And the Curêtèsł spring from bounteous show'rs, I pass a hundred legends, stale as these, And, with swcet novelty, your taste will please.

Eusdcn's Ovid.

The Crocus is one of the earliest spring flowers.

There is, also, an autumnal variety. The colours of the flowers are purple, yellow, white, \&c.

Fair handed Spring unbosoms every grace, Throws out the Snow drop, and the Crocus first.

Thomson.

The general character of Crocus is a spathe transpareatly membranous, one or two-leaved. Corolla monopetalous, funnel-shaped; tube very long, six-parted, superior; border with six ovate oblong, nearly equal divisions.

\section{CROWN IMPERIAL. \\ Fritillaria Imperialis.}

Fritillaria, from fritillus, which some take for a chessboard, and which, in that sense, alludes to the chequered nature of the petals.

Fritillus, however, is used by Juvenal and Persius for a dice-box, and is supposed to have expressed the rattling sound of the dice.

Fritillus -A dice-box to throw dice out of.

Ainsworth.

The common Fritillaria, or chequered lily, F. Meleagris, is regularly chequered with purple, or with different whites.

Note* Smilax was also changed into a plant of the same name, said by the ancients to be the $\boldsymbol{Y}$ ew $T$ ree-she having pined away for thelore of Crocus.-Modern botanists give Smilax as the generic name of a family of plants, in which the Medicinal Sarsaparilla, or Smilax Sarsaparilla, is included.

† Curetes, a people of Crete, who, according to Ovid, were produced from rain. They were also called Corybantes-and were entrusted with the education of Jupiter-and, afterwards, made priests and favourite ministers of Rhea, or Cybele. 
The Fritillaria is a native of Persia, and was, for some time, called in Europe Lilium Persicum, but, as there was already another Persian lily growing in the European gardens, it was changed to Corona Imperialis, or Crown Imperial, by Alphonsus Paucius, Physician to the Duke of Florence. This title appears to have been adopted in all the European languages.

Modern botanists have since bestowed the name of Fritillaria on a family of plants, of which this is, from its noble deportment and brilliancy of colouring; considered the sovereign.

"'The Lily's height bespoke command,

A fair imperial flower;

She seem'd design'd for Flora's hand,

The sceptre of her power."

The F. Imperialis has a large scaly bulb root-Herb of very quick growth, foetid, two or three feet high, succulent or juicy, of a fine shining green, consisting of a thick, simple, straight, leafy stem. Leaves scattered, linear-oblong, twisted. Flowers a circle of tulip-shaped corollas turned downwards, which have the appearance of so many gay bells, the stigma answering for the clapper; the whole being crowned by a coma, or tuft of green leaves, gives it a singular and agreeable effect. The colours most admired are the orangc, lemon, and brilliant red.-There is a variety with variegated leaves, and one with a red stem.

But to breathe fragrance on the morn,

Proud gorgeous flower, was never thine.

Then heed ye not the dazzling gem

That gleams in Fritillaria's diadem.

Fables of Flora.

\section{COMMON CYPRESS.}

Cupressus sempervirens.

Cupressus, from two Greek words, sum to produce, and $\tau x$ cros equal, alluding to the regularity of its branches.

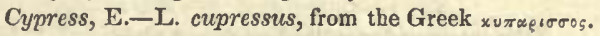

Or, according to Ovid, from Cyparissus, a Youth beloved by Apollo, who, in grief at having inadvertently killed the favourite stag of his friend, requested of the Gods, that his mourning might be made perpetual, and was by Apollo changed into a Cypress Tree, the branches of which were ulways used at funerals.

Himself he would have slain thro' desp'rate grief:

What said not Phœbus, that might yield relief!

To cease his mourning, he, the boy desir'd,

Or mourn no more than such a loss requir'd.

But he, incessant griev'd: at length address'd

To the superior pow'rs a last request;

Praying, in expiation of his crime,

Thenceforth to mourn to all succeeding time.

Apollo sad look'd on, and, sighing, cry'd

Then, be for ever, what thy pray'r imply'd;

Bemean'd by me, in ethers grief excite;

And still preside at ev'ry fun'ral rite.

Congreve's Ovid.
Amid the throng of this promiscuous wood, With pointed top, the taper Cypress stood; A tree, which once a Youth, and heav'nly fair, Was of that deity the darling care, Whose hand adapts, with equal skill, the strings

To bows with which he kills, and harps to which he sings.

Congreve's Ovid.

"The Cypress is the emblem of mourning." Shaks.

The Cypress, that darkly shades the grave, Is sorrow that mourns its bitter lot.

Percival.

On account of the gloomy hue of its leaves, especially in winter, it was esteemed by the ancients a suitable ornament of their burial places.-It was held sacred to Plute and Proserpine.

The common European Cypress, C. sempervirens, has two varieties, the pyranjidal, and sproading, or horizontal. It is snid to be a long-lived tree.-According to an assertion of Pliny's, there were, in his time, cypress trees growing at Rome, which were more ancient than the city itself.-We are told, that the gates of St. Paul's church at Rome, made of cypress-wood, had lasted from the time of Constantine, 1100 years, as fresh as new, when Pope Eugenius IV, ordered gates of brass in their stead. Many of the chests which enclosed the Egyptian mummies, are made of Cypress, affording a decisive proof of its almost incorruptible nature. The wood is capable of a fine polish, and, being fragrant, it is esteemed for some species of light cabinet work.-Its little branches are quadrangular. Leaves imbricated in four rows, obtuse, depressed, convex; strobiles globular; scales awnless.

The American species of this genus in most estimation is the C. Disticha, Deciduous Cypress-sometimes called Bald Cypress. It is one of the largest trees in North America, being found, sometimes, seventy feet high, thirty feet in circumference at the surface of the ground, and twentysix, at the height of six feet. Its branches extend almost horizentally. Leaves acute, in two rows, and very near together on the little branches, whence they have been compared to the leaves of Acacia. Cones larger, with stronger scales than those of the common Cypress. Its wood is light, fine grained, and, after being exposed to the light, of a reddish colour, and very durable. Delaware, may be assumed as its northern boundary. East Florida abounds in it. Cypress shingles are in great estimation, and are said to last forty years.

\section{DAFFODIL. \\ Great Yellow Daffodit. \\ Narcissus Major.}

(For Narcissus, see note on that flower.)

Daffodil-supposed, by Skinner, to be corrupted from Asphodelus. And Asphodelus is defined by Ainsworth, to be the Daffodil of two sorts, white and ycllow.

The Flora Historica tells us that "this flower was evidently considered a kind of Lily by early writers, and we are of opinion that the name is a corruption of Dis's Lily, as 
it is supposed to be the flower dropped from the chariot of that god in his flight with Proserpine."

Shakspeare, in his Winter's Tale, alludes to this story, as well as to the early season in which the Daffodil appears.

\section{"O Proserpina}

For the flowers now, that frighten'd, thou let'st fall

From Dis's wagon; Daffodils,

That come before the swallow dares, and take

The winds of March with beauty."

Drayton, in his Pastorals, makes Daffodillies and $L i$. lies the same:-

See that there be stores of lilies,

(Called by shepherds, daffodillies.)

The Daffodil, and Jonquil, are varieties of the Narcissus, though the names are often used indiscriminately.

Narcissus Major, is a native of Spain. Common, with double flowers in gardens-rarely seen single. It is the largest of the genus, and has the most magnificent flowers, bearing its fine golden chalice, amidst petals of the same colour, on a stalk two feet high. Cup of the nectary bellshaped, erect, the length of the oblong oblique petals; its margin spreading, lobed, (divided) and crisped. Leaves, twisted, somewhat glaucous.

\section{DAHLIA. Dahlia.}

Dahlia, named by the late Professor Cavanilles, in honour of Andrew Dahl, a Swedish botanist, author of a little volume of botanical observations.

There are several species of Dahtia, all natives of mountainous parts of the Spanish settlements in South America. Their flowers are large and handsome, something like those of a Sun-flower, but the rays mostly red, or purple, like the China-Aster, and likewise variable in this respect. The herbage is coarse and rank, with compound leaves.

It is an autumnal flower; first introduced into Fingland by Lady Bute, who procured it from Madrid in the same year that it had arrived from America-but lost sight of till reintroduced by Lady Holland, in the year 1804. The first introduction marked the year when France became revolutionized, the second, that which saw Napoleon made Emperor of the French nation.

By cultivation these flowers have had their petals doubled and quadrupled, until they have become as full as the China-Aster, whilst their colours have been even more increased than their petals.

Gen. cha. a double Calyx; the outer of many leaves. Corolla, radiant, compound, its rays equal in number to the segments of the calyx; ovate, three-toothed; receptacle chaffy; stigmas downy.

\section{DAISY.}

\section{Bellis.}

Bellis, Latin-formed from bellus, pretty or handsome. English, Daisy.
Fabulous history informs us that it owes its origin to Belides, grand daugliter to Danaus, one of the rymphs called Dryads, that presided over the meadows and pastures, in ancient times.

Belides, whilst dancing on the grass with Ephigeus, (a rural Deity, whose suit she encouraged,) attracted the admiration of Vertumnus, (the Deity who presided over the spring and orchards,) and to escape from him she was transformed into the humble plant bearing her name.

Chaucer affirms that the fair queen Alceste, (wife of Admetus, king of Pheræ, in Thessaly,) who sacrificed her own life to preserve that of her husband, was, for this admirable proof of unbounded affection, transformed into this beautiful flower, the Daisy.

The English name of Daisy is derived from a Saxon word, meaning Day's eye, in which way it is written by Ben Johnson. And Chaucer calls it the "ee of the daie." No doubt from the habit of the flower of closing its petals at night; which it also does in rainy weather.

Star of the mead! sweet daughter of the day, Whose opening flower invites the morning ray. From thy moist cheek and bosom's chilly fold, To kiss the tears of eve, the dew-drops cold.

$$
\text { Sweet Daisy. }
$$

Leyden.

When smitten by the morning ray,

I see thee rise alert and gay,

Then cheerful flower! my spirits play

With kindred gladness:

And, when at dark, by dews opprest, Thou sink'st, the image of thy rest

Hath often eased my pensive breast Of careful sadness.

Wordsworth.

The little daizie, that at evening closes.

Spencer.

O'er waste and woodland, rock and plain,

Its humble buds unheeded rise;

The rose, has but a summer reign, The daisy, never dies.

James Montgomery.

The gen. cha. of the Daisy, is, a common calyx; Corolla, compound radiate; corollules, tubular, numerous in the disk.

\section{DANDELION.}

\section{Leontodon taraxacum.}

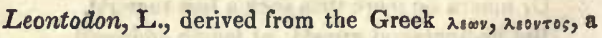
lion, and $\diamond \delta u_{5}$, a tooth, and so called from a similarity in the shape of its jagged leaves to the teeth of a lion.

The English name Dandelion, which is a corruption of dent de Lion, is expressive of the same idea, and might, possibly, have given rise to its botanical name.

8.7 The specific name, Taraxacum, or Taraxacon, is a name used by the Arabians, supposed by Ambrosini to have been derived from the Greek $\tau_{\rho} \omega \xi_{4} \cdot \mu \circ$, eatable, because the plant to which it was applied (our Dandelion, or something 
nearly akin to it) was used for food. De Theis deriyes it from the Greek $\tau$ *s*orw, to move, or trouble.

Leontodon taraxacum, or common Dandelion, is esculent-its leaves, when blanched, have the taste of endive, and, boiled, in their green state, is an excellent and wholesome vegetable. At Grottingen, the roots are roasted, and substituted for coffee.

The leaves, roots, flowers, and juice of dandelion, have all been employed for medicinal purposes.

It is one of the plants that may be most certainly depended on as to the hour of opening and closing its flowers. Flora's best time-piece. The flowers of this habit are styled by Linnæus the Horologne, or watch of Flora.

"Leontodons unfold,

On the swarth turf, their ray-encircled gold;

With Sol's expanding beam the flowers unclose,

And rising Hesper lights them to repose."

She, enamoured of the sun,

At his departure hangs her head and weeps,

And shrouds her sweetness up, and keeps

Sad vigils like a cloistered nun,

'Till his reviving ray appears,

Waking her beauty, as he dries her tears.

Moore.

Thus in each flower and simple bell,

That in our path betrodden lie,

Are sweet remembrancers, who tell

How fast their winged moments fly.

Charlotte Smith.

The dandelion blooms earyy in the spring, and continnes throughout the summer.

"Nor yet alone to full-robed spring confined,

Around her brow the crown of flame they bind,

But scattered still o'er summer's tawny vest,

Their lingering sweets regale the insect guest."

The Dandelion, has terminal, golden-coloured flowers. A double calyx, imbricated, oblong. Corolla, compound, imbricated, uniform; florets numerous, equal, each of one petal, with five teeth. Receptacle naked, dotted. Down stalked, hairy. Leaves radical, toothed, smooth.

\section{DEW PLANT.}

Mezembryanthemum.

(See Ice Plant.)

There are more than fifty Fig Marygolds, or Mezembryanthemums, cultivated. Some of them have less of the frosted appearance noticed in the Ice plant-and are called Dew plants-appearing moist, and cool, as if wet with dew.

The M. Barbatus, Trailing Bearded Fig Marygold, is one of those most common in green-houses, and even in the garret window of many an humble collector. It throws out its trailing stems over the flower-pot, bearing a very small bright reddish purple flower. Leaves remote, somewhat ovate, tumid, flattish above. Branches smooth, slender, straggling. Calyx, five cleft. Petals numerous, linear, cohering at the base.

The $\mathcal{M}$. Hispidum, is another of the Dew plants.Leaves cylindrical, blunt. Branches hairy. Flowers larger than the last, and of the same colour.

It will be observed that no particular species has been designated, thereby giving a wider field for selection, when the plant is to be used.

\section{DOGWOOD.}

\section{Cornus.}

Cormus, from the Greek x horny toughness of the wood.

Ainsworth defines Cornus, 1. The cornel tree, called the dog-tree, or wild cherry.

Johnson-Dogroood, a species of cornelian cherry.

There are several varieties indigenous in North America. That designated as belonging to Virginia - C. florida, or Yirginia Dogwood, grows to the height of from ten to twenty feet. Leaves opposite, egg-shaped, acuminate, green above, glaucous beneath, petioled. Flovers small, yellow; leaves of the involucre two inches broad or more, greenish white, sometimes rose-coloured, resembling petals, a little tomentous, ending in a short point, and appearing as if nipped almost double near the tip, which makes them seem emarginate and heart-shaped; peduncles one-flowered, forming close lateral and terminal umbels.

\section{EGLANTINE, English.-EGLANTERIA, Latin.} European Sweet-Briar.

Rosa mubiginosa.

(For Rosa, see Austrian Rose.)

"Eglanteria, corrupted from the French Eglentier, or Eglantier, of whose derivation we are ignorant.

Lamarck's Flora Françoise, has been examined in vain, for the derivation, or meaning of the word Eglantier. And we perceive that he has taken the orange coloured variety of Rosa lutea, or Austrian Rose, for Linnæus' rubiginosa, or European Sweet Briar.

We retain the name of Rosa rubiginosa for our European Sweet Briar, as being indisputably certain, peculiarly expressive, and now sanctioned by Jacquin, Roth, IVilldenow, indeed, by general use." Rees' Enc.

Skinner, who has just been examined, offers the following etymology: "Eglantine, Belgic Eghelentier, Franco. Gallic, Esglantier, Aiglantier, Anglantine, Cynosbatus, [the eglantine] the wild rose. Minsher, I know not how well, derives it from the Latin and Greek, Echinus, (an urchin, or hedge-hog: a sea-urchin, being a kind of crab-fish, with prickles instead of feet: also the rough prickly shells of chesnuts) because it is thorny. I prefer, rather, to derive it from the Latin Aculeus, (a prickle, as in thorns, herbs, burs, hedgehogs, \&cc.) as it were, Aculeantinus (prickly) for it is defended by many thorns. It may also be speciously derived from the Belgic Eghel, a hedge-hog; but it returns to the same point, for this undoubtedly takes its rise from the Latin, Aculeus (a prickle, \&cc.) and this animal is, in truth, furnished by nature with prickles."

Lemon, after quoting, in part, this etymology of Skin- 
ner, adds, "So near was the Doctor to the true origin of this word that he would not see it; for aculeus is, undoubtedly, derived from (the Greek word) $\alpha \times y$, or $s \times n$, (in Latin,) acies (the sharp edge, or point of any thing, whence a cus (a needle,) acutus (sharp) aculeus (a prickle) sharp pointed, like a needle: the Sweet Briar, therefore, seems to have received its name of Eglontine, from the sharpness of its thorns."

Rubiginosa, one of its meanings is florid.

The common Sweet Briar Rose, or Eglantine, has flowcrs of a sweet scent, and a full and uniform pink colour: occasionally double, and sometimes pale, or whitish. The stem branched, about a yard high, with copious, broad, strongly hooked prickles, of a pale brown, all over its green branches. Leaflets five or seven, of a roundish, elliptical figure, with strong, double, glandular serratures; their upper surface bright green, slightly hairy; the under, clothed with reddish viscid glands, and delightfully fragrant. Fruit, scarlet, internally mealy and insipid.

There is a small-flowered Sweet Briar, R. Micrantha, with paler flowers, and smaller, the least of all the British Roses, that is sometimes mistaken for the $\boldsymbol{R}$. Rubiginosa.

Poetry is full of the fragrance of the Eglantine.

Come, gentle air,

And with the jasmine's breath divine,

Convey the woodbine's rich perfume,

Nor spare the sweet-leafed eglantine.

Smith.

No, nor the leaf of Eglantine, whom not to slander, Out-sweeten'd not thy breath.

Shaks.

And the fresh eglantine exhaled a breath, Whose odours were of power to raise from death.

Dryden's Chaucer.

\section{ELDER.}

Sambucus nigra.

Sambucus, L. from the Greek $\sigma \propto \mu \beta u x y$, an instrument of music, in the construction of which, this tree is used, on account of its hardness; so says De Theis.

(See Rees' Encyclopedia.)

Elder, E., German holder, or hohlunder. It seems to be named from hollowness.

Webster.

The common Elder, S. Nigra, is a low bushy tree or shrub, with smooth pithy branches. Leaves opposite, unequal, pinnate; leaflets generally five, smooth. Stipules, scarcely any. Cymes, terminal, in five principal branches, many flowered. Flowers, milk-white, fragrant, generally stalked. Stamens divaricated. Berries globular, dark purple, sweetish, but unpleasant in the crude state. This tree is, as it were, a whole magazine of physic to rustic practitioners. The inner bark, flowers, leaves, berries, all have their peculiar medicinal virtues.

The Sambucus niger, very abundant in the United States.

\section{EVERLASTING}

\section{Gnaphalium.}

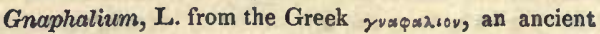
Greek name; from $\gamma v x p_{x} \wedge c v$, soft down or wool, alluding to the wooliness of the herbage.
The Latins called it Gnaphalium, from the downy or cottony nature of the leaves or stalks, which they collected to fill their couches and matresses, instead of wool or flocks. Pliny tells us that it was also called Chamozelon, which signifies low or ground cotton; and it was sometimes named $\mathscr{A l}$ binum, from the whiteness of the leaves and stalks.

The American Everlasting, or Eternal Flower, G. margaritaceum, has white flowers. It also grows wild, in Wales, and is there used to adorn the graves of the departed; elegantly alluding to immortality, by the unfading nature of its flowers, and to spotless purity by their snowy whiteness.

The Everlasting flower which the French call Immortelle, the G. orientale - is in such demand in Paris, ever since the hill of Pere la Chaise has been converted into a cemetery, for that city, as not only to give employment to many hands in its cultivation, but numerous families are regularly occupied, and entirely supported by forming these flowers into garlands and crosses, which are offered for sale near the entrance of burial grounds.

It is stated to be a native of Africa, therefore improperly called G. orientale. Gerard styles it Golden Mother Wort, or cud-weed. And he describes the flowers as standing "on the top of the stalkes ioined togither in tuftes of a yellow colour, glittering like gold, in forme resembling the scalie flowers of Tansie."

The ancients crowned the images of their gods with garlands made of these flowers, and, hence, they were frequently called God's flowers. In Spain, and Portugal, they are still used to decorate the altars, and images of saints.

As an ornament for the saloon, or head dress, the $G$. orientale is, in modern times, frequently dyed of various colours.

The general character of the flowers of this genus, is, a common Calyx, imbricated, its inner seales rounded, scariose, coloured. Corolla compound; florets of the disk, funnel-shaped, in five equal reflexed marginal segments. $R e$ ceptacle, naked.

\section{FEVER ROOT. Eupatorium.}

Eupatorium, from Mithridates, surnamed Eupator, who is reported to have brought this plant into use, as a counter poison. He was the seventh king of that name who reigned over the province of Pontus in Asia Minor. His ambition and cruelty raised up many enemics; and his babit was, by drinking antidotes against poison, to fortify his constitution against their attempts to destroy him.

Eupatorium, is a large genus chiefly, though not entirely, American. Roots perennial. Stems sometimes shrubby. Leaves opposite, mostly simple, and strongly serrated. Flow. ers corymbose, terminal, numerous, white, bluish, or reddish. Whole plant, roughish, bitter, or aromatic.

Several of the American species are esteemed, on account of their aromatic and bitter qualities. Among these are E. Sessitifolium, E. Perfoliatum, and E. Aromaticum.

\section{BALM OF GILEAD FIR.}

Pinus Balsamea.

(For Pinus, see Pine.)

Pinus balsamea, is a native of Canada, Nova Scotia, 
New England, and the Alleghany Mountains, in high cold situations. Leaves solitary, flat, imperfectly two-ranked. Cones cylindrical, erect, with short pointed scales, when full grown, of a beautiful violet hue, and exuding a plenty of candied turpentine, or balsam, as does the trunk when wounded Its fragrant exudation is the well known Canada balsam, which some quacks celebrate as Balm of Gilead.

The stamens and pistils of all cone-bearing plants are in separate flowers, either on the same, or on different plants; they produce resins, and many of them are supposed to supply the most durable timber, as the Cypress and Cedar.

Venice-Turpentine is obtained from the larch. Sandarach from the common Juniper; and Incense from a juniper with yellow fruit.

[See Darwin's Notes to Loves of the Plants.]

\section{FOX GLOVE. Digitalis.}

Digitalis, from Digitale, the finger of a glove. The name given first by Fuchsius, and hence the plant is called Digitaiis Fuchsii.

The D. purpurea, or Purple British Fox-glove, is the species best known. It grows in various parts of Europe. The Root is biennial. Stem erect, about three or four feet high. Leaves large, ovate, crenate, downy. Flowers numerous, in a long simple spike, large, crimson, sometimes white, elegantly sprinkled with eye-like spots within. It is a dangerous plant, from its strongly narcotic power-yet a valuable medicine in careful hands.

The Fox-glove on fair Flora's hand is worn,

Lest while she gathers flowers she meet a thorn.

\section{FUCHSIA.}

Fuchsia, so named by Plumier, in honour of Leonard Fuchsius, a distinguished German Physician and Botanist, particularly celebrated for his figures of plates. Born, at Wembding in Bavaria, in 1501.

The species chiefly cultivated, are the $F$. Coccinea, a native of Chili, S. A. It is a shrub of from three to six feet high, smooth in all its parts, and much branched. Leaves, two or three, rarely four, together; an inch or more in length, rather distantly toothed; pale and shining beneath. Calyx scarlet. Petals violet, obovate, and blunt. Stamens, and style scarlet, hanging far out of the flower. Berries dark purple. The young branches and leaves have the veins tinged with a fine crimson colour. Although a greé -house plant, it will bear the open garden in a well sheltered situation.

The F. Triphylla, or three-leaved Fuchsia, is a native of the West Indies: an herbaceous plant of more diminutive growth. Leaves three together in a whorl. The Calyx about an inch and a half long, scarlet, as well as the petals. Berrics almost globular, and rather larger than a common black Currant.

\section{GERANIUM.}

Pelargonium.

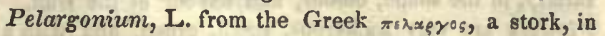
allusion to the beak of the fruit, resembling the bill of that bird, as well as to preserve an analogy with the Geranium, or Crane's Bill; the Greek word ripzvos, signifying a Crane.

Pelargonium, embraces what are commonly known by the appellation of African Geraniums, and which, doubtless, constitute a genus clearly distinguished from the European and American Geranium, by the irregularity of the flower, and its tubular nectary, to say nothing of the number of stamens.

It is the African Geranium, that is most generally cultivated in our green-houses, for the beauty of its flowers, and fragrance of its foliage.

The Crane's Bill Geranium, is of the same Class and Order as Pelargonium, except'that it has 10 stamens, Decandria, instead of 7, Heptandria.

The only Crane's Bill Geranium, introduced into this collection, is the Geranium Maculatum, or Spotted Crane's Bill.-An American plant of such highly medicinal virtues, as to recommend it to our attention, and which ought to be in every garden, being esteemed the best known styptic in the whole Materia Medica; having produced wonderful cures when applied to wounded or ruptured blood-vessels. It has not much beauty to recommend it, yet its retiring and modest worth, so generally overlooked in the gay saloon, may well be supposed to excite something like envy of its more favoured rivals.

The G. Maculatum may be found abundantly in our meadows and woods. The one with purple flowers, has downy leaves, with five lobes or scollops, and these divided into small indentures. The leaves of the blue, are wrinkled and divided deeply into many parts or fingers. The stalks supporting the delicate blue flowera, are long and slender, from six inches to a foot high. They, both, have a flower with a single cup, or Calyx, of five leaves. Corolla of five petals; ten stamens alternately longer and shorter; one pointal, terminated by five stigmas. Fruit, five dry berries furnished with a bill, each, containing a single seed, crowned with a tail or awn, which rolls up in a spiral form, when the seed becomes ripe. The root, which is the part used medicinally, is generally crooked and knotty, blackish or reddish on the outside, with a roughish taste, and aromatic flavour.

Hemlock-leaved, and Musk Crane's Bill, of this genus, have but five stamens.

The general character of the Pelargonium, is a Perianth, inferior, in five deep, oblong, permanent segments, the uppermost elongated at the base into a nectariferous tube, running down the flower-stalk. Petals five, irregular, oblong, spreading, longer than the calyx. Filaments ten, unequal, three of them, rarely five, abortive. Fruit beaked, of five aggregate capsules, each tipped with a long spiral awn, bearded on the inside. The foliage of the different species is too varied and multifarious for description, and too well known to require it. We will therefore take our leare of

$$
\text { Genteel Geranium, }
$$

With a leaf for all that come.

Hunt.

GILLY FLOWER.

Cheiranthus. Incanus.

Cheiranthus, from the Arabic keiri, altered by Linnæus 
into a name with a Greek form, from the Greek zic , a hand, and $\alpha$ \%o 5 , a flower.

Incanus, from the hoary white of its branches.

Gilly-Flower, either corrupted from July-flower, or from the French giroflée.

(See Johnson.)

In July come gilly-flowers of all varietiés.

Bacon.

The Gilly-Flower is a native of the sea coast in France and Spain. Cultivation has produced numerous varieties; the principal ones are Queen's stock gilly-flower, with bright red, or carmine coloured flowers, and the Brompton stock, . with large purple flowers, and the white stock; there are also other varieties, as the variegated stock, \&c.

The Root perennial, sometimes biennial. Stem, from 15 to 15 inches high, branched, hoary. Leaves, scattered, long, soft, clothed with a short down. Flowers, sweet scented, four petaled, cruciform; petals roundish, longer than the calyx; claws, length of the calyx. The calyx, a four-leaved perianth.

The Stock Gilly-Flower, and Wall-Flower, are of the same genus.

Fair is the gilly-flow'r of gardens sweet,

Fair is the marigold, for pottage meet.

Gay.

And la vish stock, that scents the garden round.

Thomson.

\section{GOLDEN ROD, or VIRGA AUREA.}

Solidago.

Solidago, from solido, to make firm, and partlcularly to heal a wound. From its reputed efficacy in healing wounds, and other medicinal properties, it ranked among the most expensive drugs, about the middle of the sixteenth century, though not much in repute in modern times.

Fifty-one American species have been ascertained. There is but one indigenous to Great Britain, but this is subject to many varieties. They are all perennial, mostly herbaceous.

The flowers yellow, with very fow exceptions.

"In golden armour glorious to behold."

Several species of the Tree Golden Rod, have been brought from St. Helena, with white flowers.

"Nor shines the silver Moon one half so bright

Through the transparent bosom of the deep."

The name "Golden Rod, or Virga Aurea," suggested the emblem, as well as the illustrations attached to the flower; as also, the following note from the first edition of Flora's Dictionary.

"Le Gendre tells us, that in the first race of the French Kings the sceptre was a golden rod, almost always of the same height with the king who bore it, and crooked at one end, like a crozier." The sceptre is an ensign of royalty, of greater antiquity than the crown.
Mercury's famous Caduce, or Wand, is called Virga. That Wand, which was supposed to possess the power of deciding controversies, composing differences, raising the dead, \&c.

The Caduceus found on medals, is a common symbol, signifying good-conduct, peace, and prosperity. The rod expresses power, the two serpents, prudence, the wings, diligence.

\section{GRAPE VINE.}

Vitis Vinifera.

Vitis, a Vine, usually derived from vieo, to bind with twigs, to hoop, to bend, to tie up-in allusion to the flexibility of its branches. "De Theis traces it to the Celtic Gwid, a tree or shrub, as being the chief, or best of trees. Gwin, is the name for wine, in the same language; from whence comes, evidently enough, the Greek word for wine owvos, Latin Vinum, English Wine." Rees' Enc.

The specific name Vinifera, L. is from Vinea, a vine, or Vinum, wine.

The English name Grape, is from the root of grab, gripe, and signifies primarily a cluster or bunch. Welsh grab, a cluster, a grape. French grappe de raisin, a bunch of grapes.

Webster.

Bacchus, the God of Wine, who first taught the use of the Vlne, is represented crowned with $V_{i n e}$ and Ivy leaves.

According to Pliny, he was tho first who ever wore a crown.

The Fig-tree, Ivy, and Yew-tree, were also sacred to him.

Let dimpled mirth his temples twine,

With tendrils of the laughing vine.

Scott.

According to Plutarch, the Grape Dine'sprang from the blood of the Giants, who having made war on the Gods, had perished in battle. The Egyptians never drank wine; they held the liquor to be the blood of the giants; nor did they offer it in libations, thinking it odious to the Gods.

[See Beloe's Herodotus, Euterpe.]

Nor were the Gods, themselves, more safe above;

Against beleaguer'd heav'n the Giants move.

Hills pil'd on hills, on mountains mountains lie,

To make their mad approaches to the sky.

Till Jove, no longer patient, took his time

Travenge, with thunder, their audacious crime;

Red lightning play'd along the firmament,

And their demolish'd works to pieces rent.

Singed with the flames, and with the bolts transfix'd,

With native earth, their blood the monsters mixt.

Dryden's Ovid.

The 'Vitis Vinifera, or common Grape Vine, is found naturalized at least, in most parts of the more temperate climes of the globe. The cultivated Vine, sports an endless variety, in the shape, colour, and flavour of the fruit. The Flotoers are very numerous, small, green, and with a fragrance resembling that of the Mignonette. 


\section{GRASS.}

Gramen, or Gramina.

The Latin word gramen is supposed to be derived from gradiens, going or proceeding along, in allusion to the great increase of many of these plants by their creeping roots. Linnæus has remarked that "Grasses are the most general of plants, constituting almost a sixth part of all the vegetables on our globe."

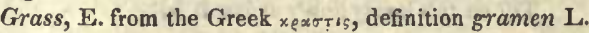
(grass) foenum L. (hay.) Hence (says Schrevelius) the English word grass. This Greek word xenбtเ5, is also put as a theme, or etymon, that is, an original, and not a derivative, nor compound word. Schrevelius adds, it is the same as grastis, and defines grastis, gramen (L.) deriving it from rexw (Gr.) because it is the food of cattle.

The verb $\gamma_{5} \times$ (Gr.) is defined to eat, and is conjugated

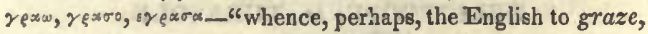
to feed on herbs."

The creeping roots of grasses, or gramina, are mostly fibrous, rarely tuberous, or bulbous. They consist of numerous joints and knots, each of which has its bud, capable of producing a new stem, and the more they are separated by the heavy trend of cattle, the more they multiply. The more their herbage is cropped, the better they thrive, and extend themselves the more under ground. In confined and woody places they scarcely creep, but grow erect. The Author of Nature has protected these plants, by giving them such hard stems, while they are perfecting, their seed, that cattle cannot readily attack them in that state.

Some species of grass, which, in moist situations, emit fibrous roots alone, will, in more uncongenial and dry ones, form builbs, whereby a reservoir of nutriment is secured against the occurrence of an irregular supply of the juices for its sustenance.

The roots of large irees, also, in unpropitious situations, have been observed to vary their natural mode of growth, most materially, in conformity with their need of nourishment.

There are upwards of three hundred species of Grasses -in which are included the Rye, Barley, Wheat, Oat, \&c. They are distinguished by their narrow tapering leavestheir cylindrical or hollow stems, which are jointed, or separated into distinct portions by knots.

They were first divided into Corn and Grasses, but the former differ from the latter, merely, in the greater size of their seeds, which compose the basis of our aliment, as the smallest of the grass-seeds nourish small birds.

The Roman crown of grass or herbs found on the ground in the place besieged, was given by common consent of the soldiers, to generals who had delivered a Roman army besieged by the enemy, and obliged him to decamp. It was called Corona Graminea obsidionalis.

About his temples grass they tie,

Himself that so behaved,

In some strong siege by the enemy

A city that had saved.

Drayton.

In Herodotus, we find Grass the symbol of Submission.
"Amongst the ancient Nations of the West, to show that they confessed themselves overcome, or that they surrendered at discretion, they gathered some Grass, and presented it to the conqueror. By this action they resigned all the claims they possessed to their country. In the time of Pliny, the Germans still observed this custom.

(See note to 4 Book, Melpomene.)

\section{HAWTHORN \\ Cratægrus. \\ A. Mespilus.}

Mespilus, from the Greek $\mu_{\varepsilon \sigma \pi \iota \lambda \eta}$, the Medlar tree.

Hawothorn, from the Saxon hog-thorn, or hedge-thorn, a species of Medlar; the thorn that bears haros; the whitethorn.

(See Johnson and Webster.)

Cratægus, from the Greek xparaıros, definition the wild service tree.

In conmencing our examination of this plant, we are referred to Cratægus, for a description of the Hawthorn. Under this article there are several species described, which are, also, to be found under the article Mespilus, to which we are referred for the Class, Order, \&c. Mespilus, is therefore (as I understand it) the generic name, embracing all the varieties of Medlar and Harothorm; and Cratrgus confined to the Harothorn.

The Mespilus is native to America, and Europe, and varies, in height, from a shrub, to a tall tree. That which produces the smallest leaves is preferred for hedges, because its branches grow : close together. The thorns of the whole genus are long and sharp.

"The Cratægus of Linnæus, is distinguished from his Mespilus, solely by the former having but two styles, and, occasionally, on the same tree some flowers with but one; while the latter has five." They are sometimes mentioned as the same tree.

Men have gather'd from hawthorn's branch

Large medlars, imitating crowns.

Phillips.

The fruit of the Medlar is said to be eatable only when age or decay has mellowed it.

\section{Rotten ere half ripe,}

And that's the right virtue of the medlar.

Shaks.

Haw, the berry, or seed of the havethorn, is also noticed.

The seed of the bramble with'kernel and havo.

Tusser.

Store of havos and hips portend cold winters.

Bacon.

The fruit of the Medlar, is generally brown, or reddish; that of the Harothorn, scarlet, yellow, or red. The flowers of both, white; sometimes doubled in the Hawthorn, and rose coloured; as in the common Hawthorn, Cratægus Oxycanthus.

Now hawthorns blossom, now the daisies spring.

Pope.

The havothorn whitens. Thomson. 


\section{HEART'S EASE. \\ Viola Tricolor.}

(For Viola, see $V$ iolet.)

Viola tricolor, or Pansy Violet, from the French pensee, thought.

And there are Pansies, that's for thoughts.

Shaks. Hamlet.

And thou, so rich in gentle names, appealing

To hearts that own our nature's common lot;

Thou, styl'd by sportive fancy's better feeling,

"A thought," "the Heart's Ease," or "Forget me not."

Barton.

And faith that a thousand ills can brave,

Speaks in the blue leaves, Forget me not.

Percival.

The glowing violet.

And the Pansy freakt with jet;

The $V$. Tricolor, is a beautiful variety of the violet, differing from it, in the variety of its colouring, the petals being chiefly yellow, variegated with black and purple. Its fragrance is very inferior, and too weak to be regarded in a single flower. It is a native of Europe, North America, \&c. The root is annual, but it renews itself readily from the scattering seeds, so as to keep up a continual bloom all the year; even in the depths of winter, in a warm situation, it may be seen beautifully contrasted with the white snow, which surrounds it.

There are many varieties of the blue and purple Heart's Ease to be found all over North America. I cannot forbear giving in the Bard's own beautiful language the fanciful origin of its colour.

\section{I saw}

Flying between the cold Moon and the Earth, Cupid all arm'd; a certain aim he took

At a fair vestal, throned by the west;

And loos'd his love-shaft smartly from his bow,

As it should pierce a hundred thousand hearts:

But I might see young Cupid's fiery shaft

Quench'd in the chaste beams of the wat'ry Moon;

And the Imperial vot'ress passed on,

In Maiden meditation, fancy free.

Yet mark'd I where the bolt of Cupid fell:

It fell upon a little western flower,

Before milk-uohite; now purple with Love's wound,

And Maidens call it Love in Idleness.

The juice of it, on sleeping eye-lids laid,

Will make or Man or Woman madly doat

Upon the next live creature that it sees.

Shaks. Mid. N. Dream.

In gardens oft a beauteous flow'r there grows,

By vulgar eyes unnoticed, or unseen-

In sweet security it humbly blows,

And rears its purple head to deck the green.
This Flower, (as Nature's Poet sweetly sings,)

Was once milk-white, and Heart's Ease was its name, Till wanton Cupid poised his roseate wings

A vestsl's sacred bosom to inflame.

With treacherous aim the God his arrow drew,

Which she with icy coldness did repel-

Rebounding thence, with feathery speed it flew, Till on this lovely flow'r at last it fell.

Heart's Ease no more the wand'ring shepherd found, No more the Nymphs its snowy form possess-

Its vohite now changed to purple, by Love's wound, Heart's Ease no more, 'tis "Love in Idleness."

Mrs. R. B. Sheridan.

\section{HELIOTROPE; or, TURNSOLE.} Heliotropium.

Heliotropium, L. from the Greek $\lambda_{\lambda \iota \circ g}$, the sun, and $\tau \varrho \iota \pi s$, to turn, "because," says Dioscorides, "it turns its leaves round with the declining sun."

This flower has been confounded with the Helianthus, or Sun-flower, but is of $\mathrm{s}$ different genus. Both have had ascribed to them the property of turning towards the sun, and following his course round the horizon. A property not confined to these flowers alone, as other plants do the same, in a more or less degree, particularly when confined in a room, turning the shining surface of their leaves, and bending their whole branches to catch the light.

It is surprising that two flowers so unlike, as the SunFlower and Heliotrope, should ever have been mistaken for each other. The blossoms of the Sun-Flower are too well known to need a description here; those of the Heliotrope, are very small, delicate, fragrant blossoms, generally of a faint purple colour, or white, sometimes red, and bluish white. It is made to be yelloro, and confounded with the Sun-flower in the following lines-

What yellow, lovely as the golden morn, The lupine, and the heliotrope adorn.

Brovone.

The snowy rose is there

A silver moon, the heliotrope a Sun!

Andrein's Adam.

The fabulous account of the origin of the Heliotrope, is, that Clytia (daughter of Oceanus) being deserted by Apollo, with whom she was enamoured, pined away, and was changed into a flower commonly called sun-flower, which still turns its head towards the Sun, in his course, as in pledge of her love. Ovid says of her-

All day, all night, in trackless wilds, alone She pin'd and taught the list'ning rocks her moan. On the bare earth she lies, her bosom bare,

Loose her attire, dishevell'd is her hair.

$$
\text { * * * * }
$$

She turn'd about, but rose not from the ground, Turn'd to the Sun, still as he roll'd his round: 
On his bright face hung her desiring eyes,

Till fix'd to earth, she strove in vain to rise.

Her looks their paleness in a flow'r retain'd,

But here and there, some purple streaks they gain'd.

Stiil the lov'd object the fond leaves pursue,

Still move their root, the moving Sun to view,

And in the Heliotrope the Nymph is true.

Eusden's Ooid

The Heliotrope is a native of warm climates; growing in India, Peru, the West Indies, South of Europe, \&c. With us, it is a green-house plant of the ehrubby, and herbaceous kinds, with annual, and biennial roots. Calyx of one leaf, tubular, with five segments, permanent. Coroll $a$ of one petal, salver shaped, five cleft, with intermediate teeth: its mouth without valves. Seeds naked.

\section{HELLEBORE. Helleborus.}

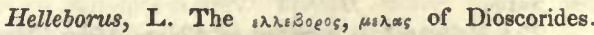
The name most probably derived from ${ }_{s i s}$ (Gr.) to kill, and Ropa, food, or fodder, in allusion to the poisonous qualities for which it has been famous throughout antiquity. (According to Bergeret, it is derived from the river Eleborus.)

The Black Hellebore was used by the ancients to purify their houses, and to hallow their dwellings. By strewing or perfuming their apartments with this plant, they believed that evil spirits would be expelled or driven away.

By the witches' tow'r

Where Hellebore and hemlock seem to weave

Round its dark vaults a melancholy bow'r,

For spirits of the dead at night's enchanted hour.

Campbell.

We find it, in the Materia Medica, prescribed for hypochondria and mania. Burton notices it in his "Anatomy of Melancholy."

"Borage and Hellebore fill two scenes,

Soveraigne plants to clear the reins

Of melancholy, and cheer the heart

Of those black fumes which make it smart;

To clear the brain of misty foge,

Which dull our senses, and soul clogs;

The best medicine that ere God made

For this malady, if well assaid.”

Dainty young thing

Of life! Thou vent'rous flower

Who growest through the hard, cold bower, Of wintry spring.

Thy fancied bride

The delicate snow-drop keeps

Her home with thee; she wakes and sleeps Near thy true side.

J. R. Prior.

It should never be allowed a place in the kitchen garden, since fatal accidents have arisen from mistaking its root for that of the horse radish.

The $\boldsymbol{H}$. Niger, or Christmas rose, blooms in mid-winter, and few plants are more elegant. The flower is something like the dog-rose-white on first opening, afterwards with a blush of pink, and finally greenish. The foliage a dark and shining green; leaves pedate, luxuriant. The root perennial, externally very dark-consisting of a roundish head, about the size of a nutmeg; from which short, articulated bunches arise, sending out numerous corrugated fibres, about the thickness of a straw, from a span to a foot in length, deep brown outside, white or yellow within, and of an acrid nauseous taste. shrub.

Native of the south of Europe. In our gardens a hardy

The Hellebore Officinalis, the true Hellebore of the ancients. The roots very like the $\boldsymbol{H}$. Niger-the leaves twice the breadth, and truly pedate. The flower-stalks do not rise above the leaves, but are branched, bearing five or six drooping, concave, white flowers, turning purplish as they fade. Corolla deciduous.

The North American $H$ Trifolius, or small three-leafed Hellebore, with twice ternate leaves, and green flowers, is a very pretty plant.

The $\boldsymbol{H}$. Hyemalis, Winter Hellebore, or Yellow Winter Aconite, a little herbaceous plant, with a yellow flower, whose petals are deciduous: native of Germany, Switzerland, and France; common in our gardens, and forming a beautiful contrast with the snoro drop which blooms about the same time.

We are told that the powder of Black Hellebore given as snuff, has cured discases of the eyes; particularly that called $\mathcal{N}$ yctalopia, in which the eyes become periodically dim, usually from sunset till sunrise the next morning.

Of this plant Juvenal sarcastically observes:

"Misers need a double dose of Hellebore."

Bright as the silvery plume, or pearly shell,

The snow-white rose, or lily's virgin bell,

The fair Helleborus attractive shone,

Warm'd every sage, and every shepherd won.

Darwin.

\section{HIBISCUS. \\ Venetian Mallow, or Flower of an Hour. Hibiscus Trionum. \\ (For Hibiscus, see Althsea.)}

The specific name Trionum. There is a ressov in Theophrastus, said to be one of the Mallow tribe; like the Hibiscus in question, whose leaves, having three lobes, are supposed to sanction the present application of this name.

Rees' Encyclopedia.

The species constituting the genus Hibiscus, are a numerous tribe of the largest and finest plants of the Malvaceous order.

The Hibiscus Trionum, beautiful Venetian Mallow, or Flower of an Hour, is a European species, and one of the few that are annual. It is commonly cultivated for the elegance of its flowers, which are large, sulphur coloured, with 
five purple external stripes, and a violet eye, beautifully contrasted with the yellow anthers. The purple hairy stigmas, too, are remarkaole; as well as the bladdery hisped inner calyx. It has a double caly $x$-the outer permanent, inner of one leaf, cup-shaped, five cleft half way down, permanent. Petals five, narrow at the base, spreading. Leaves in three deep divisions, cut, somewhat pinnatifid.

There is a plant of mildest hue, Whose modest visage charms the eye, Which blooms as fair as tho' it grew Beneath a purer, holier sky.

\begin{abstract}
As mellow as the Moon's soft beam
On ocean's mirror'd breast arrayed,

Swifter it passes than a dream,

And blossoms-only but to fade.
\end{abstract}

Thus Beauty lights the Maiden's face,

With all her mildest-chastest rays,

When searing age comes on apace,

And leaves no mark of former days.

\section{HOLLY.}

Ilex.

Ilex appears to be an original Latin word. Johnson derives the name Holly from Holegn, Saxon, for a Tree. Webster from Holegn, (Saxon,) the Holm tree, of the genus Ilex. Ainsworth defines Ilex to be "a kind of oak tree, called by some Holm: the Scarlet Oak, the Holm Oak."

Skinner suggests that the Saxon for Holly, Holegn, is compounded of $\mathrm{Hol}$, all; and Erge, sharp point, because it is all sharpened, or pointed with thorns.

The Ilex of the Latin has become, in the Italian, Elice. See Baretti's Dictionary.

The Holly is a beautiful evergreen tree, several species of which are abundant in North America. It also grows in many parts of Europe, Japan, \&c. There is one species, native of West Florida, called South Sea Tea, the Ilex Vomitoria, held in great estimation by the Indians, who make a tea of the leaves, and account it very wholesome: and it is almost the only physic they use in those parts. The plant is supposed to be the same with that of Paraguay, where the Jesuits make a great revenue from the leaves.

The Holly is a tree of singular beauty, sometimes rising to the height of twenty or thirty feet, with shining prickly leaves and white flowers, which grow in clusters round the branches, and are succeeded by berries of a bright ocarlet colour, containing four very bard seeds. The leaves form a grateful food to many animals: but Nature has armed them for self-defence against these depredators, in their sharp prickles. And it is curious to observe, that the thorny leaves only grow on the lower part of the tree, where they are most liable to be destroyed; and that those above, out of the reach of horses and cattle, have smooth leaves, as if conscious that there they might repose in safety.

Four of the giant brood with Hex stand, Each grasps a thousand arrows in his hand;
A thousand steely points on every scale, Form the bright terrors of his bristly mail.

Darwin.

The bark of the common Holly, I. aquifolium, when fermented and then washed from the woody fibres, constitutes the common bird lime, a material somewhat similar to the elastic gum, or Indian rubber.

\section{HOLLYHOCK, or ROSE-MALLOW. Alcea rosea.}

Alcea, from the Greek $A_{\lambda \times y}$, strength, aid, on account of its reputed medicinal properties, for which it was formerly held in great esteem.

Ainsworth defines Alcea, a kind of wild Mallow; marsh mallow.

Hollyhock, its derivation may be traced to the Saxon language; the old name of Holyoak, being the same as Holihec, Saxon.

The Hollyhock is a native of China, Africa, Madras, Istira, Siberia, \&c. Pliny speaks of this flower in the fourth chapter of his twenty-first book, where he describes it as a rose growing on stalks, like a mallow. The colour of the flowers is accidental, and the double flowers are only varieties proceeding from culture. It is an autumnal flower of which the Bees are fond.

From the nectaries of Hollyhocks

The humble Bee, e'en till he faints, will sip.

H. Smith.

The flowers of this genus have a double Calyx, each oneleafed, the outer, cut half way into six parts, permanent, and very spreading; the innor, cut half way into five parts, larger, and permanent. The Corolla consists of five spreading petals, coalescing at their base. This description is of the single flowered. Seed flat, kidney-shaped.

\section{HONESTY, or SATIN FLOWER. \\ Lunaria.}

Lunaria, from Luna, the Moon, so named on account of the broad orbicular shape of its silique, and its silvery semitransparent nature, which discovers those seed-vessels that contain seed, from such as have none; from which last, it derives its English name of Honesty.

Ainsworth defines Lunaria to be Moon-Wort, a kind of herb used by old women for love-potions.

It was in high repute among the credulous of former ages, as a bewitching, or enchanting herb. And we learn from Chaucer that Lunaria was one of the plants used in incantations.

Then sprinkles she the juice of rue

With nine drops of the midnight dew,

From Lunary distilling.

Drayton's Nymphia.

Enchanting Lunary here lies,

In eorceries excelling.

Drayton.

This genus of plants is herbaceous, annual, biennial, 
and perennial. Natives of Germany, Switzerland, \&c. They sometimes grow to the height of three or four feet. Flowers, crimson, lilac, \&c. Sometimes fragrant. Corolla, cruciform, of four equal, large, undivided, obtuse petals, as long as the Calyx, each tapering down into a claw of the same length. Calyx, of four ovate oblong cohering leaves, of which two opposite ones are pouched, or bagged at the base.

\section{HONEY FLOWER.}

\section{Melianthus.}

Melianthus, L. from the Greek $\mu \in \lambda_{t}$, honey, and $\alpha \nu \vartheta_{0 \xi}$, a flower, so named from the abundance of honey which flows from M. Major, in particular, which, if shaken whilst in flower, distils a shower of nectar.

There are only three spccies noticed in the Encyclopedia. The M. Major, with flowers in a long spike, springing from between the lcaves towards the top of the stalks, of a brown, or chocolate colour. The M. Minor, flowers, six or eight in a cluster, very ornamental, variegated with green, yellow, and red, or pink. And the $\mathcal{M}$. Comosus, flowers, in pendant clusters, on short stalks, of a yellow colour. These are all natives of the Cape of Good Hope. Roots perennial: growing to the height of from three to four feet.

\section{HONEYSUCKLE; or, WOODBINE.}

\section{Lonicera.}

Lonicera, so named by Linnæus, in honour of $\mathcal{A} d a m$ Lonicer, an old physician and naturalist, who lived about the middle of the sixteenth century: lorn at Marburg, 1528, lived at Frankfort, and died at the age of fifty-eight. He published two volumes, folio, in Latin, upon the Materia Medica; and a German Herbal, with wooden cuts, which are occasionally to be met with rudely coloured.

The English name Honeysuckle, is called, in Latin, Caprifolium; first definition in Johnson, Woodbine, the plant. 2d. The flower, or blossom, of the Woodbine."Woodbine that beareth the Honeysuckle."

\section{"A Honeysuckle}

The amorous Woodbine's offspring."

(See Johnson.)

Caprifolium is derived from the Latin Caprea, a branch that putteth forth tendrils; and folium, a lcaf.

Caprea, also signifies a roe, $a$ deer, a gazelle. Tho French name for the Lonicera Caprifolium, is Chcorefeuille, said to be derived from the Latin Caper, or Capra, a goat; and folium, a leaf. We are also told that goats are remarkably fond of the leaves of the Honeysuckle.

Woodbine-Latin, Pcriclymenon; English, Honeysuckle.

(See Johnson.)

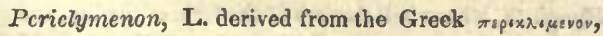
from $\pi \varepsilon \varrho_{\imath}$, about, and $x v \lambda_{s \omega}$, to roll around.

I. Caprifolium, in the Encyclopedia, designates a species called Pale perfoliate Honeysuckle, native of Great Britain. Leaves deciduous; the uppermost united and perfoliate. Flowering in May or June, in England. Stem shrubby, woody, turning. Branches nearly opposite, round, smooth. Almost all the leaves are combined, elliptical, obtuse, entire, smooth, rather glaucous beneath; the upper ones in united perfoliate pairs, somewhat orbiculate accompanying the flowers. Flowers in whorls, ringent, terminal, spreading, yellowish, with a flesh-coloured tube, very fragrant. Berries of an orange red, crowned by the almost entire calyx.

L. Periclymenon, Common Honeysuckle, or Woodbine, native of Europe, flowering in June, July, and occasionally in the Autumn. Stem and branches similar to the last. Leaves opposite, on very short foot-stalks, elliptical, entire, sometimes pubescent, glaucous beneath. Flowers in a terminal head, spreading in a radiate manner, yellowish-white, and blush-coloured, very fragrant, and particularly so, early in the evening. Berries red, crowned with a five-toothed calyx, bitter, with a sweetish flavour.

A remarkable variety sometimes occurs with sinuated, variegated leaves, called the Oak-leaved Honeysuckle.

The flowers of the genus Lonicera, have five-cleft calyx. Corolla of one petal, tubular; tube oblong, gibbous; limb in five revolute segments, one of which is more deeply separated.

A Honeysuckle on the sunny side,

Hung round the lattices its fragrant trumpets.

Copious of flowers, the Woodbine pale and wan,

But well compensating her sickly looks

With never cloying odours, early and late.

Cowper.

The Wild Honeysuckle, Azalea, is a splendid genus of shrubs, abundant in North America : to be found, also, in the East Indies.

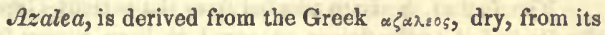
growing in a dry soil. Its flower resembles that of the Honeysuckle, or Lonicera, but is much larger and richer in its hues. Some of the species are delightfully fragrant. $\mathcal{N} a$ tural order different from Lonicera, as will be seen in Glossary.

\section{HOUSTONIA.}

Named by Linnæus after Dr. William Houston, F. R. S., resident for several years in the West Indies. He visited the Spanish Main, from whence he sent various seeds to Europe, between the years 1728 and 1732. Some engravings of flowers, by his own hand, were purchased by Sir Joscph Banks, who printed and liberally distributed an edition of them.

There are several varieties of the Houstonia, natives of North America-as the H. Cærulea, H. Purpuria, \&c.: a genus of pretty little delicate plants that cover our fields in the early spring, with their small brilliant pale blue, or almost white flowers, with a yellow eye, jasmine like, but scentless; produced all the summer long. Each flower grows on a slender, simple, naked, smooth stalk, only a few inches high. The perianth half superior, of four small upright permanent teeth. Corolla of one petal, funnel-shaped; tube much longer than the calyx, cylindrical, slightly dilated at the top; limb in four deep, roundish or elliptical spreading segments. 
Leaves from half an inch to an inch long, entire, smooth, rough-edged, rather acute; the radical ones obovate, stalked; stem-leaves opposite, much narrower; roots fibrous and perennial. If the least attention be paid, it flowers perpetually. It bas been transplanted to the European green-houses; but with us it is so common and so abundant, that it is left in quiet possession of its native fields, where it flourishes in unambitious contentment.

Its four-cleft petal forms a Maltese cross, and its yellow anthers, also, form a cross in the centre, looking like a tiny drop of gold set in pearls.

How often, modest flower,

I mark thy tender blossoms, when they spread,

Along the turfy slope, their starry bed,

Hung heavy with the shower.

Percival.

Sweet flower, thou tell'st how hearts

As pure and tender as thy leaf, -as low

And humble as thy stem, will surely know

The joy that peace imparts.

Same.

The popular names of Houstonia, are Droarf Pink, Bluets, Innocence, and sometimes American Daisy, (although it has none of the botanical characteristics of the Bellis,) from its humble growth, its simple beauty, and general diffusion over the United States, covering and adorning our fields, as does the European Daisy in its own climate, and like it, an endeared little flower, and universal favourite.

\section{HYACINTH.}

\section{Hyacinthus.}

Hyacinthus, a name adopted from the ancient Greeks, who applied it to the flower supposed to have sprung from the blood of Hyacinthus, son of Amyclas, founder of the city of Amyclæ. He was a favourite with both Apollo and Zephyrus, but his preference of the Sun to the Winds, excited the jealousy of Zephyrus, who caused his destruction, by sending a puff of wind to change the course of a quoit thrown by Apollo, so as to fall upon the head of the young Hyacinthus and deprive him of his life.

He was afterwards changed by Apollo into a flower bearing his name.

You when alive, were Phœbus' darling boy;

Yet this he gave; as of as wintry rains

Are past, and vernal breezes soothe the plains,

From the green turf, a purple flow'r you rise,

And with your fragrant breath perfume the skies.

Thy name my lyre shall sound, my verse shall tell;

And to a flow'r transform'd unheard of yet,

Stamp'd on thy leaves, my cries thou shalt repeat.

The time shall come prophetic I foreknow,

When join'd to thee, a mighty chief* shall grow

And with my plaints his name my leaf shall show.

* Ajax.
While Phœbus thus the laws of fate reveal'd,

Behold the blood which stain'd the verdant field,

Is blood no longer; but a flow'r full blown,

A lily's form it took; its purple hue

Was all that made a difference to the view.

Nor stopp'd he here; the god upon its leaves,

The sad expression of his sorrow weaves;

And to this hour the mournful purple wears

$A i, A i$, inscrib'd in fun'ral characters.

Ozill's Ovid.

Another fabulous account of the flower, is, that it sprung from the blood of Ajax Telamonius, who slew himself in a rage, when the arms of Achilles were adjudged by the Greeks to his rival, Ulysses. And it is described by Ovid, as a purple flower in this instance, also.

The fruitful blood produc'd a flower which grew

On a green stem, and of a purple hue:

Like his, whom unaware, Apollo slew:

Inscribed in both, the letters were the same,

But those express the grief, and these the name.

[See Dcath of $A j a x$.

As poets feign'd-from Ajax streaming blood

Arose, with grief inscribed, a mournful flower.

Young's Night Thoughts.

$O$ tell in what delightful region springs

The flow'r that bears inscrib'd the names of kings."

Virgil's Eclogrues.

Great differences have arisen amongst commentators concerning this plant of the ancients, which we cannot presume to settle, but there seems no paramount authority for the application of the name in question to our common garden Hyacinth. [See Rees' Encyclopedia.

The garland of Flora tells us that the classical flower, is a species of Martagon Lily, and decides it to be the red Martagon lily-quoting Martyn, as observing "that most Martagons are marked with many spots of a darker colour than the flower itself; which often run together so as to form the letters $\mathcal{A} i$-as the ancient hyacinth is represented."

I have searched in vain for the origin of the word Martagon; all that I can find said of it, is, that Gerard, who wrote in 1596, in speaking of a lily brought "many daies iourneis beyond Constantinople," which he calls Lilium Bizantinum, "the red lilie of Constantinople," tells us, that he had two other smaller kinds of lilies growing in his garden, which, at that time, bore the name of Martagon, which seems to have been given to these kinds of lilies by Matthiolus.

The Martagon, is elsewhere represented as a species of lily red or yellow, with dark spots, or blotched. Flowers pendulous, or hanging downwards. This agrees with the Hyacinth, whose bell flowers of the form of the lily, and only inferior in size, are suspended by a short peduncle, or flower stalk. The Martagon lily has a disagreeable scent, but the Hyacinth a deliglitful odour.

*From Pitt's Virgil " of Kings-The flower here meant is the Hyacinth, which, as it is said to spring from the blood of Ajax, was marked $\mathcal{A}$. I." 
Now tell your story, hyacinth; and show

$\mathcal{A i}, \mathcal{A i}_{i}$, the more amidst your sanguine wo. Calendar of Nature, $G$. of $F$.

"Or that red flower whose lips ejaculate Wo." Garland of Flora.

Csmus," reverend sire, went footing slow, His mantle hairy, and his bonnet sedge, Inwrought with figures dim, and on the edge, Like to that sanguine flower, inscribed with wo. Milton's Lycidas.

The Martagon, of classic honours vain, Bears on his brow the gory spotted stain. Still darkly graved on each returning bloom The moans of Phobus, and the Hero's doom.

Dr. Evans.

The Flora Historica remarks that "some authors suppose the red Martagon lily to be the poetical Hyacinth of the ancients, but this is evidently a mistaken opinion, as the azure colour would decide-and a blue Martagon will be sought in vain.-Pliny describes the Hyacinth, as having a sword grass leaf, and the scent of the grape flower, which agrees with the Hyacinth, but not with the Martagon." Upon the whole, it appears to be an affair not easily decided.

The drooping pendulous growth of the Hyacinth is alluded to in the following lines:

The melancholy hyacinth, that weeps

All night and never lifts an eye all day.

Hurdis.

The languid hyacinth who wears

His bitter sorrow painted on his bosom.

G. of Flora.

And for their grateful perfume, we haveThere were

Hyacinths, with their graceful bells,

Where the spirit of odour dwells.

Landon, G. F.

Breathe o'er the hyacinth bells

Where, every summer, odour dwells.

L. E. L.

The sad blue, or purple colour, is noticed by Percival.

"A hyacinth lifted its purple bell

From the slender leaves around it;

It curved its cup in a flowing swell,

And a starry circle crowned it;

The deep blue tincture that robed it, seem'd,

The gloomicst garb of sorrow,

As if on its eye no brightness beamed,

And it never in clearer moments dreamed,

of a fair and calm to-morrow."

* The poetical name of the river Cam, on which Cambridge stands.
The colours for mourning are varions, in different countries; and for each there is an assigned reason.

In Europe, the ordinary colour for mourning is blackdenoting the privation of life; as being the privation of light.

In Turkey blue or violet denotes mourning. Blue, as expressing the happiness which it is hoped the deceased enjoy; and purple, or violet, sorrow on the one side, and hope on the other, as being a mixture of black and blue. Kings and Cardinals always mourn in purple.

In China, it is rohite; supposed to denote purity.

The ancient Spartan and Roman Ladies mourned in white; and the same colour obtained formerly in Castile, on the death of their Princes. The last time it was used was in 1498, at the death of Prince John.

In Egypt, yellow is the mourning colour, denoting that death is the end of human hopes; as leaves when they fall, and flowers when they fade, become yellow.

In Ethiopia, brown, the emblem of mourning, denotes the earth, whither the dead return.

The memory of the lamented Hyacinthus was kept alive by annual solemnities called Hyacinthia, celebrated at Amyclæ in Laconia, which lasted three days. The first day was devoted to mourning for Hyacinthus, the other two were spent in games and festivals in honour of Apollo, and in allusion to the fabulous origin of this favourite flower, by the death of the youth, while Apollo was engaged in one of these games.

Nor are the Spartans, who so much are fam'd

For virtue, of their hyacinth asham'd;

But still with pompous wo, and solemn state,

The hyacinthian feasts they yearly celebrate.

Ozill's Ovid.

The English Hyacinth, non scriptus, commonly called harebell, from the bell-shape of its flowers, and from its being found so frequently in those thickets most frequented by hares, is of a clear blue, occasionally seen with a pure white corolla. It has been scarcely less celebrated than the poetic hyacinth. Shakspeare's magic pen is alone sufficient to give it the stamp of celebrity.

\section{With fairest flowers}

Whilst summer lasts, and I live here, Fidele, I'll sweeten thy sad grave: thou shalt not lack

The flower that's like thy face, pale Primrose, nor

The azure harebell, like thy veins.

Shaks.

In the lone copse, or shady dell,

Wild cluster'd knots of harebells blow.

Char. Smith.

The harebell, for her stainless azured hue,

Claims to be worn by none but those are true.

W. Browne.

Dioscorides tells us, that the root of this flower will procure hair on bald, and beardless men.

The cottage children call it blue bell. 
Bluebell! how gayly art thou dreat,

How neat and trim art thou, sweet flower;

How silky is thy azure vest,

How fresh to flaunt at morning's hour! Mrs. Robinson.

Gerard calls this plant blue barebell, or English Jacint, which is evidently from the French Jacinthe. The term non scriptus, was applied by Dodonæus, because it had not the $A i$, $A i$, on the petals, and, therefore, could not be the Hyacinthus Poeticus.

F. Historica.

The garden Hyacinth, $\boldsymbol{H}$. Orientalis, has numerous varieties, all without a Calyx. Corolla of one petal, bell-shaped; limb in six reflected segments. Nectary three pores near the summit of the germen. Frequently doubled.

\section{HYDRANGER; or, CHINESE GUELDER ROSE.}

\section{Hydrangea Hortensis.}

Hydrangea, L. from the Greek usoo , water, and arrasov, a vessel; in allusion to the pitcher-like shape of the seed vessels.

The specific name Hortensis, L. pertaining to, or growing in gardens.

A native of the East-cultivated in the gardens of China and Japan, from whence it was introduced into England, by Sir Joseph Banks, in 1790.

This plant is nearly allied to Viburnum and Sambucus. Soon after its introduction into England, it was observed that some of the plants produced flowers of a fine blue colour, from cuttings taken from the rose coloured varieties. Some conjectured it was caused by oxyd of iron; others, that it originated from salt, or saltpetre, being accidentally mixed in the earth. It was also observed, that a cutting from the rose coloured variety, that had been planted in the soil of the heathy common, mixed with a portion of turf ashes, produced blue flowers. The owner of this plant, a poor cottagewoman, refused ten guineas for it, being unwilling to part with a plant that had been reared by a child whom she had lost; but she gladly sold cuttings from it, all of which produced flowers of the original rose colour, having been planted in common garden soil.

In our own country, the rose-coloured Hydranger has been made to bear blue flowers, when fed with marsh mud, as has been tested a few miles below Annapolis, on Backriver.

We find this flower made emblematical of a boaster, whose vaunting words resemble the abortive flowers-large and showy, without being followed by suitable results.

Flowers in clusters, terminal, of a beautiful rose-colour, inodorous, green when young, as well as in decay. Corolla of five petals, equal, roundish, larger than the calyx, which is of one leaf, superior, five-toothed, small. Leaves elliptical, serrated, very smootb, veiny, curved backwards. Root fibrous, much branched, wbitish. Stems erect, shrubby. Branches opposite, leafy, green, speckled with dark purple spots, flowering at the top.
JASMINE, WHITE.

Jasminum Officinale.

Josminum, L. from the Greek ، $\nsim \mu \mu$, a fragrant ointment, or perfume, alluding to the sweet scent of the flowers.

Jasminum, a genus containing plants of the bardy and tender, deciduous, and evergreen, shrubby kinds: rarely double, with varieties of white, or yellow flowers. Our common white Jasmine, is a native of the East, hardy, but not evergreen.

Jasmines, some like silver spray,

Some like gold in the morning ray;

Fragrant stars, and favourites they.

Indian Bride. Garland of Flora.

The Jussamine, with which the queen of flowers, To charm her God, adorns his favourite bowers; Which brides, by the plain hand of neatness drest, Unenvied rival! wear.

Churchill.

The flowers of this genus have a perianth of one leaf, inferior, tubular, oblong; its margin five-toothed, and erect. Corolla of one petal, salver-shaped; its segments from five to eight.

\section{CAROLINA YEIXOW JASMINE. Bignonia.}

Bignonia-The flowers of this genus so named by Tournefort, in honour of the Abbe Bignon.

Jerome Bignon was born at Paris, in 1590. He was esteemed a prodigy of literature. About the age of ten, while acting as page to the young Prince of Conde, he published "A description of the Holy Land," which was esteemed to be more accurate than any then extant. And, at the age of fourteen, composed, for the use of the young Duke of Vendome, a "Treatise on Roman Antiquities." These works were mere compilations; but at the age of fourteen, he also composed an original work, entitled "Election of the Popes," which displayed a degree of erudition, that surprised the most learned men of the age. By Henry IV. he was appointed page of honour to the Dauphin, afterwards Louis XIII. Upon the death of Henry, he withdrew from Court, but continued to write, and to publish several works of celebrity.

Cardinal Richelieu, although not his friend, appointed him Royal Librarian. Queen Anna of Austria, during her regency, availed herself of his advice on many interesting occasions; and he was employed in various delicate negotiations. He died at the age of sixty-seven; having maintained, through life, a character universally respected and esteemed for his piety, and useful services to his country.

Bignonia, Trumpet-flower; or, Scarlet Jasmine. Bignonias are trees, or shrubs, inhabitants of the hot climates of the East and West Indies, and eminently beautiful. Flowers in panicles, large and handsome, of various colours, red, blue, yellow, or white.

Rees' Encyclopedia.

The common Catalpa, Bignonia Catalpa, is a beautiful tree of this genus, indigenous to South Carolina, \&cc. Catalpa is an Indian name. The seeds of this tree are said to be 
fatal to poultry. Honey-bees do not feed on the nectar of these flowers.

Rees tells us that Bignonia Sempervirens, C. Yellow Jasmine, does not belong to this genus, according to Martyn, but to that of lisanthus. Upon examination, lisanthus is found to be of the class and order Pentandria Monogyqnia: Natural order Rotaceæ Linn. Grentianæ Juss.

The Carolina Yellow Jasmine, Bignonia Sempervirens, grows, naturally, in South Carolina, where it spreads over the hedges, and, at the season of flowering, perfumes the air to a great distance. It is also found in some parts of Virginia-called Yellow Jasmine, probably from the odour of its flowers. So says Recs.

Leaves simple, lanceolate, stem twining; rising with slender stalks, to a considerable height, with single opposite leaves at every joint, that remain green throughout the year.

The general character of the flowers of the class Bignonia, is a perianth, one-leafed, erect, cup form, five-cleft. Corolla monopetalous, campanulate; tube small, the length of the calyx; throat very long, ventricose beneath, oblongcampanulate; border five-parted, the two upper divisions reficx, lower patulous; stamens four, two longer than the other two: pistulum germ oblong; style filiform, stigma capitate.

\section{ICE PLANT.}

Mesembryanthemum Crystallimum.

Mesembryanthemum is a vast genus of succulent plants, formerly known by the name of Ficoides, from its affinity to the Indian fig, or Cactus. Breynius* first named it Mesembryanthemum, meaning to express its flowers expanding at mid-day; which is true of many of the species, but not of all. Dillenius, $\dagger$ therefore, by altering one letter in the orthography, had recourse to another etymology, from Mesos, the middle; embrion, an embryo; and anthos, a flower-because the embryo (meaning the germen) is in the middle of the flower. He observes, that the flower does not altogether stand on the top of the fruit, but is perforated, as it were, by the latter; whilst it so closely adheres to the middle, as not to be separable from it without laceration. We confess our predilection for the original idea of Breynius: the refulgent and radiating petals of some of this genus, seem to welcome, as well as to emulate, the noon-tide sun, folding themselves up as it withdraws.

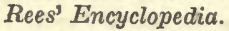

The Mesembryanthemum, Cristallinum, or Ice Plant,

* All that is said of Breynius, in Rees' Encyclopedia, is, that a South -sea plant was named Breymia, in commemoration of a father and son of the same name, (Jacquin Breynius,) both celebrated Botanists.

f John James Dillenius, one of the most celebrated Botanists of the 18th century; especially for his knowledge of Mosses, and their allies. He was a German, born at Darmstadt, in 1687. In 1721, he was persuaded to settle in England, by William Sherard, once Consul at Smyr na; who, afterwards, endowed a Professorship of Botany, at Oxfordgiving, for this purpose, the sum of 23,000 . This Professorship was bestowed upon Dillenius.

A magnificent East Indian genus of plants was, by Linnæus, named Dillenia, in honour of him: "because" (to use Linnaus' own words) " it is of all plants the most distinguished for the beauty of its flower and fruit, like Dillenius among Botanists." is a well known tender annual, much admired for appearing as if frosted over, or encrusted with frozen dew. This ap. pearance is caused by innumerable little bladders in the cuticle, filled with a limpid juice: to the touch the whole herb is cold, and remarkably faccid. Its stem spreads widely on the ground, bearing numerous broad undulating leaves, alternate, ovate, waved, papillary; flovers nearly sessile, copious, of a pale rose-colour; fruit dark purple.

\section{JONQUIL.}

Rush-leaved, or Common Jonquil. Narcissus Jonquilla.

(For $\mathcal{N}$ arcissus, see note on that Flower.)

Jonquil, E.-Fr. Jonquille; It. giunchiglia, giunco; L. Juncus, a rush, and It. giglio, a lily. It is sometimes called the rush leaved daffodil.

Webster.

The Jonquil is distinguished from the other species of $\mathcal{N} a r c i s s u s$, by its rush-like foliage, and hence its name, which is derived from juncus, rushy. Gerard, and old writers, call it "the rush Daffodil," and Narcissus Juncifolius.

The Rush-leaved Jonquil, is a favourite species, generally cultivated in a single and double state, for the sake of its rich and powerful perfume. It is said to be a native of Spain. Its narrow rushy leaves, at once distinguish it from the other varieties of Narcissus. The Flowers are of a golden yellow, scarcely more than half the size of $\mathcal{N}$. Poeticus, whose form they most resemble; the cup being very short and crenate, or notched, and the petals elliptical, spreading widely their sides somewhat deflexed, or bent downwards. The number of flowers is from three to six, and they droop, in some degree, though less than the nodding Jonquil or $\mathcal{N}$. nutans.

\section{IRIS.}

Iris, so named from the various, and somewhat concentric hues of the flower, which give an idea of the rainbow.

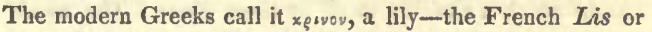
Fleur-de-lis.

We are, also, told that the ancients named this plant after Iris, the messenger of the gods, and more particularly of Jnno. She is represented with wings variegated with all the beautiful colours of the rainbow, sitting bebind her mistress, ready to execute her commands.

"The various Iris Juno sends with haste."

Ovid.

She is, likewise described as supplying the clouds with water to deluge the world.

Then clad in colours of a various die, Junonian Iris breeds a new supply

To feed the clouds.

Dryden's Ovid.

The genus Iris, contains plants of the fibrous, tuberous, and bulbous-rooted, flowery, herbaceous, perennial kinds. With flowers of every colour. The Calyx, a spathe of two valves, separating the flowers, permanent. Corolla, in sir 
deep segments, united into a tube by their narrow base; the three outermost reflected, the three inner, erect, and most acute.

Nor Iris, with her glorious rainbow clothed,

So fulgent, as the cheerful gardens shine,

With their bright offspring, when they're in their bloom.

Columella.

The Iris claims connexion with the lilies; and often passes under their name, notwithstanding botanical laws.The blue Iris of Persia, is the most fragrant.

About the middle of the 12th century, Louis the 7th of France, when about to undertake the second crusade, chose the Iris flower for his blazon. It was, hence, called Fleur de Louis, Louis' flower, and afterwards contracted to Fleur de Luce, and again into Fleur-de-lis, or lily flower, although it has no affinity to the lily.

The number of Fleur-de-lis, used in emblazoning the arms of France, were reduced to three, in the reign of Charles the 6 th, about the year 1381 .

IVY.

Hedera.

Ivy, E.-Saxon, ifig; German, epheu; a parasitic plant of the genus Hedera.

Webster.

Hedera, according to some etymologists derived from Hædus, a kid, because it was given to goats by the ancients.* We are also told that it is called in the Greek Hissos, from Cissos a favourite of Bacchus, whom poets fable to bave been transformed into this plant, and hence it became sacred to that God, who is represented crowned with Vine, and Ivy leaves. In Egypt it was consecrated to Osiris, which some say is another name for Bacchus.

The Ivy formed the crown of the Roman Poets. In modern times, woman's love, constancy, dependence, \&c., have been expressed by it.

The Hedera helix, common European Ivy, is that so celebrated for its picturesque effect upon old buildings, trees, \&c., to which it attaches itself by short fibres. The whole plant has a peculiar aromatic flavour. The evergreen leaves, dark, with white veins, upper ones, ovate, lower, five-lobed, all standing on foot-stalks. Flowers green, of many umbels, forming a corymbus. Calyx very small perianth, five toothed. Petals five, dilated at the base, their tops incurved. Berries globular, black, mealy within.

$$
\begin{aligned}
& \text { A jolly } \\
& \text { Verse, crown'd with ivy and holly, } \\
& \text { That tells of winter's tales and mirth, } \\
& \text { That milk-maids make about the hearth. }
\end{aligned}
$$

Robt. Herrick.

\section{LABURNUM.}

Cytisus Laburnum.

Cytisus, a shrub said by Pliny, to be found in the island of Cythnus, one of the Cyclades, whence its name.

Ainsworth.
Laburnum, probably from Laborenum, fertile grounds in Italy, between Puteoli and Cumæ, in the road to Capua.

The lexicographers give me no aid in the etymology of this word.

The C. Laburnum is a native of Austria, Switzerland, \&c. Its wood is hard and valuable. Hares and rabbits are particularly fond of its leaves and bark; but its seeds are said to be bitter and poisonous. The flowers yellow, papilionaceous; calyx one-leafed, bell shaped, two lipped; leaves ternate; stem shrubby and thornless.

There are several species of Cytisus-one with purple flowers, C. Purpureus, an elegant Austrian species, now much cultivated: another, resembling the weeping Willow, in its drooping boughs, \&c.

"When the dark-leafed Laburnum's drooping clusters, Reflect, athwart the stream, their yellow lustres."

Cowper.

And the Laburnum, with its golden strings, Waving in the wind.

Southey.

The pale Laburnum graced with yellow plumes.

Anon.

\section{LADY'S SLIPPER.}

\section{Cypripedium.}

Cypripedium L. from the Greek xurpss, Venus, and mod tov, a shoe.

It is the most magnificent and admired genus of the Orchis family, and distinguished from all the rest by being truly diandrous, (two stamens only in the same flower with the pistil) as well as by its inflated bladder-like lip.

There is only one species native of England-the $C$. Calceolus-several of Siberia. Eight species have been enumerated by Swartz. The C. Spectabile, C.Parviflorum, C. Acaule, are the three assigned to North America, in Rees' Encyclopedia.

In the neighbourhood of Baltimore, (Md.) may be found the C. Pubescens, Vulgo, Noah's Ark, Yellow Mocasin flower; and the C. Humile, Synon, C. Acaule, Vulgo, Purple Mocas in flower, Lady's slipper.

The Candidum is assigned to Pennsylvania: the $P a r-$ viflorum to Virginia: the Spectabile to Canada: the Pubescens and Calccolus are supposed, by Dr. W. Darlington, to be the same.

The flowers of this genus have a calyx two-leafed, spreading, one of which is erect, the other dependent; the latter often cloven. Petals two, alternate, with the calyx declining, often twisted; lip large, inflated, hollow. Filaments two, very short, inserted into the style, under two opposite lobes. Colour of the flower various-purple, pink, yellow, scc.

\section{INDIAN LAGERSTR EMIA.}

Lagerstræmia, so called by Linnæus in commemoration of his friend Magnus Lagerstræm, a director of the Swedish East India Company, member of the Royal Societies of tósal and Stockholm, who communicated to him many natu-

* The reason given why the Goot was sacrificed to Bacchus; was on account of the great propensity of that animal to destroy.the. $V_{i n t}$. - 
ral productions, and some other curiosities. Amongst these was an exqusitely carved horn of a Rhinoceros, which represents a leaf of the Cyamus Nelumbo, accompanied by the flower and fruit in a snıaller size.

The Cyamus Nelumbo, native of the East Indies, Cochin-China, \&c. In many parts of which it is esteemed a sacred plant, and makes a conspicuous figure in their mythology, as the symbol of fertility. Herodotus gives both it and the Lotos the common denomination of lily, a term which appears to have been applied by the Greeks to various plants with large specious flowers. It appears, also, to have been an Egyptian plant: their sculptures and mosaics, which are still preserved, testify that it, as well as the Lotos, has obtained religious reverence.

The exotic C. Nelumbo, was generally called the Egyptian bean, and is expressly said, by Strabo, to be so called, because in its fruit it resembles the Grecian bean, differing only in size and taste. According to Dioscorides, it was sometimes called the Pontic bean; and is said to be not only of Egypt, but also of Asia Proper and Silicia.

Dr. Smith conjectured that it was the real mystical bean of Pythagoras, concerning the prohibition of which, to his followers, so much has been written, and so little determined. It is supposed that this celebrated philosopher imbibed the notion of its sacred character during his travels: and as it did not grow in his own country, he took a substitute for it-a common seed resembling $\mathrm{tt}$, which the common horse bean does very nearly.

[See Rees' Cyclopedia.]

This digression will, I hope be excused.

To return to the Lagerstræmia: The shrub is about the size of a pomegranitc-tree, rather straggling, smooth, with angular twigs. Leaves opposite or alternate, nearly sessile, of an elliptical form, slightly pointed, entire, finely dotted. Flowers in a large terminal, of a fine rose-colour, not unlike a double stock, but far more delicate, and without scent. The petals heart-shaped, pointed, excessively crumpled and curled, with long slender claws. Anthers yellow; called, by some, the fringed rose.

\section{LARKSPUR.}

\section{Delphinium.}

The $\Delta_{i} \varphi_{\text {cwviov }}$ of the ancient Grecks, "because," says Dioscorides, "the slender segments of its leaves resemble Dolphins." The resemblance rather to be found, according to the vulgar ideas of that fish, between the curvature of its body, and the horned nectary of the flower. Delphin, being both the Latin and Greek for $a$ Dolphin.

The flower-buds, before they are expanded, are thought to resemble the Dolphin. In the natural single state of this flower, the outer petals form a kind of horn-shaped nectary, at the back of the corolla, which is similar to the spur of the Lark's.foot-hence the name of Larkspur.

Flora Historica.

The Delphinium, although it loses its spur by the increase of its petals, yet retains an advantage over the double stock, and many other double flowers, by retaining its anthers and stigmas, and consequently produces seed; but this seed, if suffored to sow itself in the Autumn, generally returns to its natural single state; whilst the seed, sown later in the season, or in the Spring, produces double flowers.

The Delphinium is annual, perennial, and biennial: natives of the South of Europe, Siberia, America, \&c. It is without a calyx; petals five, the upper one spurred; nectary cloven, with a posterior spur. Leaves, the lower are digitate, or palmate; the upper, sometimes, undivided. Flowers loosely spiked, or panicled, various in colour.

\section{LAUREL.}

Ivy Tree of America. Calico Bush. Kalmia.

Kalmia-a genus so named by Linnæus, in honour of his friend and pupil, Peter Kalm, D. D., Professor of Economy at the University of Abo. He spent several years in North America, exploring whatever was worthy of observation: and on his return, cultivated a botanical garden, at his own expense, for the use of the Academy of Science, at Abo, although straitened in his circumstances.

Laurel E.-Sp. Laurel. Fr. Laurier. It. Lauro. Lat. Laurus. Laur coincides in elements with flower, floreo. Floreo, to flourish, to bear flowers, to blossom.

There are many species of the Kalmia, indigenous in North America. The whole genus is remarkable for its elegant flowers and foliage; decorating the sides of hills, and sometimes found in the woods.

The narrow-leaved Laurel, $\boldsymbol{K}$. Angustifolia, a shrub of from two to six feet high, produces the most brilliant cupshaped flowers, in loose lateral bunches, and in the greatest abundance, of a bright red colour, when they first open; but afterwards fading to a blush or peach colour, beautifully variegated with crimson. Leaves of a shining green above, paler beneath, lanceolate, on short foot-stalks, placed without order. All the species are said to be poisonous to sheep and cattle.

The broad-leaved Laurel, $K$. Latifolia, rises to the height of from ten to twelve feet. Blossoms like the first.

K. Hirsuta, or Hairy-leaved Kalmia, has purplish flowers: native of South Carolina, in swampy soil.

\section{LAURUSTINUS. \\ Viburnum Tinus.}

Viburnum-reckoned by Linnæus among the Latin names whose origin cannot be ascertained. It is traced by Ainsworth, Vaillant, and Martyn, to the verb vieo, to bind.

Tinus-a kind of Bay tree, a Laurustinus.

Ainsworth.

Laurustinus-an evergreen shrub, which flowers about Michaelmas, and holds its flower through the winter.

Johnson.

Rees tells us that it is a compound word, meaning Laurus, which is called Tinus; and Ovid teaches us that the first syllable of Tinus is long: "Et bicolor myrtus, et baccis cærula 'Tinus."

Tinus is a name given in Pliny, B. 15, chap. 30, for what he says is sometimes termed a sort of Wild Laurel, and is distinguished by the blue colour of its berries. This description is universally agreed to apply to our Laurustinus, or Yiburnum Tinus of Linnæus. 
Varieties of this genus are to be found in Japan, Mexico, \&c. Several species, with white flowers, are scattered all over the United States.

The common Laurustinus of our green-houses, is a native of Spain, Portugal, and Italy. A shrub never above five feet high, spreading widely, twigs smooth, dark red; leaves ovate, entire, dark green above, veiny, with glandular hairs at the origin of each large vein; flowers tinged with red, of one petal, bell-shaped, cut half way down; berries blue.

\section{I.AVENDER. Lavandula.}

Lavandula, from the Latin word lavo, to wash, or besprinkle, alluding to its ancient use in baths, or fomentations; or to its distilled water, in more modern times.

A genus known and esteemed in our gardens and greenhonses. All are shrubby, with blue or purplish, occasionally white, fragrant, spiked flowers. Their foliage likewise aromatic, generally of a grey, or hoary-green, narrow, either simple or compound. The spike is supported on a longish, naked, square stalk. Perianth of one leaf; corolla monopetalous, ringent, reversed: native of Africa, Europe, \&c.

The common Lavender, L. Spica, cultivated for the sake of its scent, when dried; and the essential oil and distilled water which is made from it. To be "laid up in Lavender," is become proverbial for any thing stored up with peculiar care.

\section{LEMON.}

\section{Citrus Limon.}

Citrus, derivation unknown.

(Rees' Cyclopedia.)

Citrus, a citron-tree, growing upon Mount Atlas, in Africa, of the wood of which they made tables at Rome. Also, another sort which bore fruit of an excellent grateful smell. A lemon or orange tree, a pome-citrul, Plin.

[See Ainsworth.]

Skinner tells us, the word citron is like the thing itself; of Porsian or Moorish origin.

In Lemon's English etymology we find "Citron, Greek, хитеьо , a citron apple, a fruit brought from Media." And in the same book, under the word Lemon, we are told that "Junius supposes, with great justness, that it ought to be written limon: and, after quoting the word in several languages, in which it appears always limon, he says, they suppose it to be from the Greek word $\lambda_{\iota \mu}, \xi$, hunger, because, it sharpens hunger."

"Lemon, from the French gallic limon-Italian limone -Lemone, perhaps all from the Greek nsupwy, a meadow, a garden, as if it were said the ornament of the garden."

[See Skinner.]

The genus citrus comprehends plants of the citron, lemon, and orange-tree kinds.

The common Lemon, Citrus limon, and lime, C.Aoris, are, by botanists, referred to one species. They, as well as the orange, are natives of the East, now naturalized in all warm climates.

The lime is said to grow to the height of from twelve to fourteen feet. Its fruit is esteemed a much more grateful acid than that of the lemon; and in the West Indies; where they are most cultivated, the lemon is in little repute, and seldom used. From the varietics of the lime, the powerful perfume called Bergamot, is obtained; which is said to have derived its name from Bergamo, in Italy.

The flowers of the genus citrus, bave a one-leafed, fivecleft calyx, small and withering; petals five, oblong, and spreading. The leaf of the lemon is ovate-lanceolate, acuminate, somewhat serrated.

\section{LICHEN; or, TREE MOSS.}

Lichen, a name borrowed by the Romans from the Greeks, for the disease called the tetter, or ringwoorm, and applied to some plants of a mossy nature.

They are fleshy or leather-like substances growing on rocks, trees, and old buildings: the most common species may be observed in the form of a rough yellow and bluish crust, on gooseberry bushes, and old palings, to which they impart a picturesque appearance.

They are called Rock moss, or Tree moss; some of the Liver-worts are of this order.

They, also, include the Iceland moss, now much used in medicine; and the Reindeer moss, of Lapland, which grows to the height of a foot, and is the principal food of the noble animal whose name it bears. But they are entirely distinct from the true mosses, (Musci.)

Where frowning Snowden bends his dizzy brow

O'er Conway, listening to the surge below;

Retiring Lichen climbs the topmost stone,

And drinks the acrial solitude alone-

Bright shine the stars, unnumber'd, o'er her head, And the cold moon-beam gilds her flinty bed;

While, round the rifted rocks, hoarse whirlwinds breathe, And dark with thunder sail the clouds beneath.-

\section{Darwin.}

This plant is the first that vegetates on naked rocks covering them with a kind of tapestry, and draws its nourishment, perhaps chiefly from the air. Darnoin.

The Lichen which grows on the bark of the White Oak tree is, in medical books, called lung-roort, as it is there said-from its resemblance to the lungs,-or rather, perhaps, from its being used in diseases of the lungs. It is said to possess the same qualities as the Iceland moss, so celebrated in the cure of pulmonary consumption.

\section{LILAC Syring $\alpha$.}

Lilac, of Turkish origin. French lilas-Sp. lilac.

Syringa, so called by Linnæus, from ougurg, ouevergros, Greek for a pipe, on account of the use which the Turks make of its straight and tubular branches, when deprived of the pith, for tobacco pipes.

"It is called in Barbary Seringa. It may well be imagined that this African word came from the Greek; and originated in the resemblance of the branches to a reed. We have no doubt that Linnæus had both words in view."

The name may possibly owe its origin to the nymph Sy. 
rinx, fabled to bave been transformed into reeds; from which her admirer formed the famous instrument called Syrinx, or Pan's Pipes.

The Philadelphus of Linnæus, and others, now commonly called Syringa, in the gardens, is confounded in its nomenclature and history, with the above, its branches being capable of serving the same purposes.

The Syringa Vulgaris, or common garden Lilac, has nsually purple flowers, but there is a beautiful white variety.

The Persian Lilac, S. Persica, is a shrub of a slender habit, growing only to the height of four or five feet. The flowers are larger than those of the common lilac, and equally fragrant; but fewer in each panicle, and less crowded. The flowers purple, or white; the white peculiarly brilliant and elegant.

The common Lilac is, also, a native of Persia. The Turks appear to have long cultivated it, and its common English name is derived from them; belonging, also, in their language, to the privet. It was introduced into England about the middle of the sixteenth century, from Constantinople.

There is, also, a Chinese variety, now cultivated, but more rare, the $S$. Chinensis, of humble stature, generally taken for a broad-leafed variety of the S. Persica.

The Lilac, various in array, now white,

Now sanguine, and her beauteous bead now set

With purple spikes pyramidal, as if studious of ornament,

Yet unresolved which hues she most approved,

She chose them all.

Coroper.

O, were my love yon Lilach fair,

Wl' purple blossoms to the spring;

And I a bird to shelter there,

When wearled on my little wing!

Burns.

The flowers of this genus have a pcrmanent ealy $x$, small tubular, bordered with four erect teeth. Corolla of one petal, funnel-shaped; tube cylindrical, several times longer than the calyx; limb in four deep elliptic, oblong, spreading segments.

\section{LILY.}

Lilium Candidum.

Lilium, appears to be a name of rather obscure origin; (says the Encyclopedia) deduced by some from the Greek $\lambda_{\varepsilon s \rho+o v}$ a Lily, derived from $\lambda_{s i o g}$, smooth, not rough, also handsome, because the plant is conspicuous for the beauty of its flowers. It has moreover been called xeıvor, from x seem in general to be sprinkled with a powdery substance, from the abundance of their pollen.

Ainsworth derives Lilium from the Greek $\lambda s s \rho_{s} s v$, or

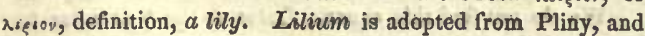
other Latin authors.

Candidum, from candido, (L.) to bleach, to make white. L. Candidum, is said to be indisputably a native of the Holy Land.
In Heathen Mythology, the Lily is said to have been originally of the colour of crocus, but Juno having dropped some milk upon the earth, changed the colour from purple to white. It tells us, also, that this flower was a great favourite with Juno, and consecrated to her by Heathen nations.

All nations agree in making the Lily the symbol of puri ty and modesty.

O, dress the Lily in its rest of lawn,

Whiter, than foam upon the crested wave,

Pure, as the spirit, parted from its grave,

When every stain that earth had left is gone.

Percival.

The white Lily has leaves lanceolate, scattered, attenuated at the base, numerous, long, smooth. Flowers large, white, in a cluster at the top of the stem. Corolla bell-shaped, smooth on the inside. Root a large scaly bulb, from which proceeds many scaly fibres.

The Yellow Lily is a native of Persia, whose chief city was called Shusan, and one of its provinces Susiana. In Hebrew language, the name of Susanah signifies Lily.

Once, Emir! thy unheeding child,

'Mid all this havoc, bloomed and smiled,

Tranquil, as on some battle plain,

The Persian's lily shines and towers;

Before the contest's reddening stain,

Has fallen upon its golden flowers.

Moore. Fire Worshippers.

\section{LILY OF THE VALLEY. \\ Convallaria.}

Convallaria, from the Latin word Convallis, a valley, or dale, enclosed on both sides with hills.

Ainsworth.

There are many of the species idigenous in North America. Flowers generally white, or variegated with green. A variety from Japan has violet coloured flowers.

This exquisitely beautiful monopetalous flower is modestly concealed in the broad, bright green leaves, which surround its delicate and graceful bells.

And ye, whose lowlier pride,

In sweet seclusion seems to shrink from view,

You of the Valley nam'd, no longer hide

Your blossoms, meet to twine the brow of purest bride.

Barton.

That shy plant-the lily of the vale,

That loves the ground, and from the sun withholds

Her pensive beauty, from the breeze ber sweets.

Evening's Excursion.

G. $F$.

The Lily whose sweet beauties seem,

As if they must be sought.

Barton.

And sweetest to the view,

The lity of the vale, whose virgin flower

Trembles at every breeze, beneath its leafy bower.

Same. 
The name of Lily has been improperly applied to it, as it has not the least affinity with the Lily, either in its root, fruit, or flower. Perhaps, from the purity of its white corol$\mathrm{la}$, as the idea of delicacy and purity is attached to the very name of Lily.

Flowers of Convallaria, monopetalous, bell-shaped, sixcleft, nodding, sometimes double: leaves large, elliptical, ribbed, entire, acute, on long petioles: root perennial.

\section{LOTOS.}

Lotos, a name which has been more variously applied, and of which, perhaps, more has been written than of any other plant. Those who have sought for its origin, in the Greek language, have found nothing nearer than $\lambda_{\infty}$, the Greek for to will, or to desire, alluding, as they suppose, to the plant being greatly esteemed.

[Rees' Cyclopedia.]

It has been suggested by one who has read this note, that, from the Greek verb $\lambda_{\omega}$, there is derived an adjective, whose superlative is $\lambda_{\omega \varsigma} \circ s$, signifying the best-which accords with the estimate in which the ancients held this plant; and that, by dropping the letter $\sigma$ in this superlative, for the sake of euphony, which the ancients frequently did, we have precisely the Greek name of this plant, $\lambda$ wros: a conjecture by no means so strained as many of those in which etymologists often indulge.

Ainsworth derives Lotos and Lotus, from the nymph Lotis, and refers to Ovid; who tells us, in the story of the unfortunate Dryope, who was punished, by instant transformation, for inadvertently plucking a flower from the plant into which the nymph had been metamorphosed.

" Not distant far a wat'ry Lotos grew;

The spring was new, and all the verdant boughs

Adorn'd with blossoms, promised fruits that vie,

In glowing colours, with the Tyrian die.

Lotis, the nymph, (if rural tales be true,)

Forsook her form; and fixing here, became

A flow'ry plant, which still preserves her name.

Pope's Ovid.

In Camoens' Luciad, we find a mention of the shrub Lotus, corresponding with the Lotos of Ovid, with its fruit of "Tyrian die." The Lybian Lotos is there described as " a shrub like a bramble; the berries like the myrtle, but purple when ripe, and about the bigness of an olive. Mixed with bread-corn, it was used as food for slaves: they, also, made an agreeable wine of it, but which would not keep above ten days."

This corresponds, also, with the plant described by Park, as abounding in Africa, particularly in sandy soils. He took a drawing of a branch in flower; the fruit of which was a small farinsceous berry, about the size of an olive; which, when dried, was made into excellent cakes, resembling, in colour and flavour, the sweet ginger-bread. The natives, also, prepare from it a liquor delicately sweet; the same, perhsps, which is fabled to have produced such, extraordinary effects on the companions of Ulysses.
Though some have conjectured that the Lotus Glycycalamus of the ancients, and that which is mentioned by Homer, is our sugar-cane.

"Not prone to ill, nor strange to foreign guest, They eat, they drink, and nature gives the feast; The trees around them all their fruit produce; Lotos the name; divine nectarious juice; (Thence call'd Lotophagi) which whoso tastes, Insatiate, riots in the sweet repasts,

Not other home, nor other care intends,

But quits his house, his country and his friends:

The three we sent, from off th' enchanting ground,

We drsgg'd reluctant, and by force we bound,

The rest, in haste, forsook the pleasing shore,

Or, the charm tasted, had return'd no more."

Pope's Odyssey.

The definition of Lotos in the Greek Lexicon, is this: "A tree whose fruit is so sweet, that foreigners, having tasted of it, forget their own country-whence the proverb to have eaten of the Lotus, is applied to those who prefer a foreign country to their own."

There was a neat proverb among the Romans, derived from this fruit-it was in two words: "Lotum gustavit"that is, "He has tasted the Lotus." It was applied to those who remsined longer than was proper among foreign nations: because the fruit of the Lotus is so sweet, that strangers, for that cause, used to stick to the place where it grew, and where they have once tasted it. [See Pliny, 13th, 17th.]

In Herodotus, we find a description of another species of Lotos, an aquatic plant.

[Book 2d, Euterpe.]

In speaking of the Egyptians, who inhabit the marshy grounds, he says: "To procure themselves the means of sustenance more easily, they make use of the following expedient:- When the waters have risen to their extremest height, and all their fields are overflowed, there appears above the surface, an immense quantity of plants of the Lily species, which the Egyptians call Lotos: having cut down these, they dry them in the sun. The seed of the flower, which resembles that of the poppy, they bake, and make into a kind of bread: they, also, eat the root of the plant, which is round, of an agreeable flavour, and about the size of an apple. There is a second species of the Lotos, which grows in the Nile; and which is not unlike $\alpha$-rose. The fruit, which grows from the bottom of the root, is like a wasp's nest: it is found to contain a number of kernals, of the size of an olive-stone, which are very grateful, either fresh or dried."

A note in Herodotus tells us-"The Lotos is an aquatic plant peculiar to Egypt, which grows in rivulets, and by the side of lakes. There are two species-the one, bearing a white, the other a blue flower. The root of the first species is round, resembling a potato, and is eaten by the inhabitants who live near the lake Menzala."

Savary.

We do not find this aquatic Lotos to be "peculiar to Egypt." It is abundant in India, where it is held in the highest veneration. Among the Brahmans, and enthusiastic Hindoos, no object in nature is looked on with more superstition; and their writings abound with mystical allusions to this lovely 
plant. As an aquatic, the Lotos is a symbol of the Indian God $V$ ishnu,* he being a personification of water, or humidity. Brahma, the creative power, is also sometimes represented as seated on the Lotos, and is borne on its calyx in the whimsical representation of the renovation of the world.

In the northern parts of India, the petals of the Lotos are blue, as well as red and white: while, in the Southern provinces, the blue flower is not seen. The poets have hence feigned that the crimson hue was imparted to it by the blood of Siva, $\dagger$ issuing from the wound made by the arrow of Kama, $\ddagger$ when the God of Love daringly endearoured to inspire the "king of dread" with an amorous passion; for which presumption, he was reduced to ashes: or, as some say, to a mental essence, by the fire which issued from the forehead of the "three-eyed God."

This aquatic Lotos, is also held in high veneration in Egypt. A fine bust of Isis, (one of their deities,) emerging from a flower of the Lotos, which belonged to the late Mr. Townley, was, on its arrival in England, taken, without hesitation, for Clytie changing into a sun-flower; what is meant for the Lotos, having a great resemblance to the Helianthus. This error, very striking to botanists, was immediately corrected by the excellent Mr. Dryander, whose accuracy only exceeded his vast knowledge.

[See Rees' Cyclopedia.]

*Vishnu, in Hindoo Mythology, is one of the chief deities of the trimurti or triad. He is reckoned the second person of this mysterious Unity, being a personification of the preserving power, wisdom, space, the present, water.

Brahma, the first person, or creative power, matter, the past, earth.

I Siva, the third person in the triad, represents the destructive energy, justice, time, the future, fire.

$\$ K a m n$, is the Hindoo God of Lore. And, according to Sir William Jones, " appears evidently the same with the Grecian Eros, and the Roman Cupid."

His bow of Sugar-cane or flowers, with a string formed of bees, and his five arrows, each pointed with an Indian blossom of a heating quality, are equally new and beautiful.

Sir W. Jones has addressed a spirited hymn to this deity, in which Vasanta, (the personification of the season Spring) the bosom friend of $K a m a$, is represented as preparing the bow and shans for his mischievous friend.

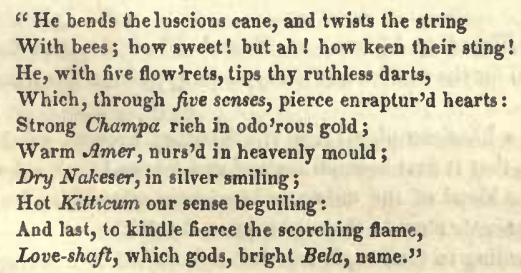

The Champa, or Champaka, is a polyndria polygynian flower, the Micheha of European Botanists; it is of two sorts, white and yellow; small, and in its foliage like an expanded rose-bud, and of a powerful fragrance.

The Amer, is said by some to be the Mango flower.

Dry Nakeser, is a handsome flower with white and yellow petals. The Bela, is a beautiful species of Jasmine.

\section{LOVE IN-A-MIST.}

Nigella Damascena. the seeds.

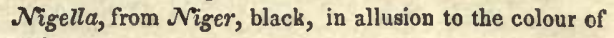

There are several species of $\mathcal{N}$ igella, or fennel flower. Nigella Damascena, or common Fennel flower, Devil in-abush, Love in-a-puzzle, etc., is a native of corn-fields in the South of Europe, a hardy annual, with double varieties, varying with white and pale-blue petals. Flovoers terminal, solitary, encompassed by a circle of leaves, much like the rest. Nectaries five, alternate with the petals; their claw purple; limb green, bent upward at a right angle, with a spreading, purple, flat, bluntly two-lobed, hairy under lip. The petals, in the double variety, are multiplied; but numerous stamens remain to perform their office: leaves as finely cut as those of fennel, but flat.

\section{LOVE LIES-A-BLEEDING. Amaranthus Caudatus.}

(See Amaranth.)

The long pendulous Amaranth, with pink seeds, and purple-red flowers, is commonly called "Love lies-a-bleeding."

Campbell has introduced it into his poem of " $\mathrm{O}$ 'Connor's child."

And wherefore dost thou love this flower

To call "My love-lies-bleeding?"

This purple flower my tears have nursed;

A hero's blood supplied its bloom:

I love it, for it was the first

That grew on Connocht-Moran's tomb.

$$
\text { * * * * }
$$

And cherish, for my warrior's sake,

The fiower of "Love-lies-bleeding."

\section{LUPINE. \\ Lupinus.}

Lupinus, so called by Pliny, and other ancient writers. Professor Martyn says, that the name owes its origin to $L u$ pus, a wolf, because plants of this genus ravage the ground, by overrunning it, after the manner of that animal.

Lupinus is, also, said to be derived from the Greek $\lambda_{v \pi n}$, grief, whence Virgil's epithet "tristes lupini"-from the fanciful idea of its acrid juices, which, tasted, produced a sorrowful appearance in the countenance. Both of these ideas are avowedly taken from Vossius.

R. Ency.

Lupine is a kind of pulse, which was much cultivated by the Romans. Pliny recommends the white lupine as giving a fresh colour and cheerful countenance to those who ate them.

The eating of Lupines was, also, thought to brighten the mind, and quicken the imagination It is related of Protogenus, a celebrated painter of Rhodes, who flourished about the year 328 before Christ, that, during the seven years ho was employed in painting the hunting piece of Jalysus, who is supposed to be the founder of the state of Rhodes, he lived entirely upon lupines and water-with an idea that this aliment would give him greater flights of fancy. 
The species of this genus, most cultivated for their flowers, are the white, blue, yellow, and rose-coloured.

The caly $x$ is of one leaf, cloven; corolla papilionaceous.

\section{MAGNOLIA.}

A noble genus of shrubs, named, by Plumier, in honour of Peter Magmol, Botanical Professor at Montpellier, where he practised physic for a long course of years; snd, at the same time, very assiduously cultivated Botany, not only as an ausiliary to medicine, but with the most enlarged views to its advancement as a science of itself. He was not appointed to the professorship till the year 1694; being a Protestant, his religion had been in the way of his promotion. He was beloved for his urbanity, and esteemed for his knowledge; and, previous to his appointment, as public professor, he had a botanical class; among whom were Fagan and the illustrious Tournefort. He published several celebrated botanical works. In 1708, he was admitted a member of the Academie des Sciences of Paris, in the place of his distinguished friend Tournefort, who died that year.

Among his communications to this Academy, was an easy method of tinging the flowers of the Tuberose with a solution of some kind of lake. He died at the age of 77 , in the year 1715 .

The Magnolia Grandiflora, Laurel-leafed Magnolia, is the most magnificent and beautiful evergreen tree of this genus. In southern latitudes, it rises to the height of eighty feet, often much loftier; almost unobstructed by brsnches, and terminated by a spreading top of the deepest perennial verdure. Its flowers are terminal, solitary, each as large as a pint basin; white, deliciously fragrant, like the flavour of cold lemonade. The petals obovate, have the texture and aspect of delicate white leather. The bark of the root of this tree is also used as a substitute for the Peruvian barkaccording to some of our medical books.

The $\boldsymbol{M}$. Glauca, Swamp Mrgnolia, a small tree, with large cream-coloured flowers, terminal, concave, with a rich vinous fragrance. Calyx of three leaves; petals six to twelve, obvoate, The leaves are, also, beautiful, about three inches long, varying in breadth, veiny, bright green above, glaucous, and somewhat silky beneath. To the North, deciduous; in the South, evergreen.

This species is said to have been the first of its genus introduced into the gardens of England; having been cultivated by Bishop Compton, at Fulham, in 1688.

There are about fifteen species of this genus, almost equally divided between China and N. America: there is, also, one species in tropical America. All of them with a bark more or less camphorated and aromatic.

The Cucumber tree of North America, Magnolia Acuminata, is a tree of a noble height and beauty: umbrageous, deciduous; the rood yellow. Leaves clustered at the end of each branch; but, on its subsequent elongation; becoming alternate, stalked, pointed at each end, several inches long, and nearly half as broad; green and smooth above; paler, and, at first, downy beneath. Flowers neither fragrant. nor beautiful, though remarkable for their pea-green glaucous petals more than six, which vary in shape, but are always concave or channelled, and, usually, about two inches long. The cones, or seed vessels, have been advantageously used in the Western States in the form of tincture, in rheumstic complaints. The cone has very much the form of a cucumber; and, when perfected, is of a vivid red colour.

Several species of this genus are to be found in the East and West Indies, but none so beautiful as the North American plants, $\boldsymbol{M}$. Grandifiora, etc.

\section{MARIGOLD. Calendula.}

Calendula, according to Martyn, a diminutive from Caltha, the name of the most common species, in old suthors.

Caltha, supposed to be derived from the Greek $x \propto \lambda \propto 9_{0 \xi}$, a basket, alluding to the shape of the flower.

Ventenat derives calendula from calenda, the Latin for the first day of every month, because it continues long in flower.

Marigold E. called in Welsh gold, which is said to be from gol, going round. In Dutch gondsbloem, gold flower.

Wcbster.

Johnson derives the name from Mary, and gold, and supposed it to have been devoted to the Virgin Mary. And in Hone's Every Day Book, the flower is devoted to the Annunciation of the B. V. Mary, for the 25th March.

The Calendula closes its petals at ccrtain hours of the day, and is one of those styled by Linnæus, the Horologe, (Horologium, L.) or Watch of Flora. The Leontodon, Convolvulus, Malva, or Mallow, and many others, are of this class.

And bright Calendula, with golden hair;

Watch with nice eye, the earth's diurnal way,

Marking her solar, and siderial day,

Her slow nutation, and her varying clime,

And trace, with mimic art, the march of time.

Darroin.

The flowers of this genus have a calyx with many divisions: corolla radiate; florets of the disk, numerous, tubular, the length of the calyx; the ray strap-shaped, very long, three-toothed, hairy at the base; seeds of the circumference of the disk, different from those of the ray, both fertile. Perennial.

The Tagetes, African, or French Marigold, was first designated for the emblem, (cruelty) now applied to the whole genus.

It is a Mexican plant; and the fabulous account of this species is, that it first became stained and marked with a dark red, by the blood of the unhappy Mexicans, whom the insatiable Spaniards slew in their own peaceful fields.

According to Gerard, it was first introduced into Europe about the time that a famous conquest of Tunis was achieved by a Roman Emperor, and, in compliment to that monarch, for having given liberty to twenty-two thousand Christian slaves, it was called Flos. Africanus, or African Marygold. Its appellation of French Marygold, is from the seeds being first obtained from France.

M. Piralle tells us, that these flowers were called Tage- 
tes, from the Greek rarn, meaning principality, (or Tagos, a commander,) which shows the rank these plants held in the parterre.

[See Flora Historica.]

\section{MARVEL OF PERU. Mirabilis.}

The Spaniards applied the appellation Mirabilis del Peru, the Marvel of Peru, to this plant, on account of the great diversity of colour in its flowers, on the same root.

The French call it Belle de Nivit, because the flowers expand and smell sweet, at night only. And because its flowers seem too timid to expand their variously coloured corollas to an European sun.

Sous le voile mysterieux

De la craintive modestie,

Tu veux échapper à nos yeux,

Et tu n'en es que plus jolie.

On cherche, on aime ã dêcouvrir

Le doux trésor que tu récèles;

Ah! pour encore les embellir,

Donne ton secret à nos belles.

M. Constant Dubos.

The flowers of this genus have a calyx inferior, five-cleft; corolla funnel-shaped, its base inflated and permanent; nectary a gland surrounding the germen. Plant perennial, in its several species.

\section{MEADOW SAFFRON.}

\section{Colchicum Autumnale.}

Colchicum, supposed to be so called from Colchis, where it is said to grow in great abundance.

According to fabulous history, this Autumnal flower owes its origin to some drops being spilt in the fields, of the magic liquor, which Medea had prepared to restore the aged Fson to the bloom and vigour of youth; and, on this account, the Colchicum was anciently regarded as a preservative against all sorts of maladies. It is suggested, also, that, as Medea is sometimes called Colchis, it was the Colchicum that relieved Æson from bis infirmities.

The foaming juices, now, the brink o'erewell;

The barren heath, where'er the liquor fell,

Sprang out with vernal grass, and all the pride

Of blooming May.

Tate's and Stonestreet's Ovid.

The moon shines bright *****

* * * * In such a night **

Medea gathered the enchanted herbs

That did renew old AEson.

Shaks.

Meadow Saffron.-Saffron, E.; Welsh safmon, safyr; Fr. safran; Dutch saffraan; Turkish zafran, to be yellow, to be empty; the root of cipher.

Webster.

The root of Colchicum is bulbous, nearly as large as the Tulip, and is, unquestionably, poisonous. The ealyx a spathe; corolla monopetalous, tubular, very long, six-cleft; the tube springing immediately from the root. There are three species of it, purple, reddish, and variegated with purple spots: natives of Europe.

Darwin remarks of the C. Autumnale, or Meadow Saffron, that "the germ is buried within the root, which thns seems to constitute a part of the flower. These singular flowers appear in the Autumn, without any leaves; whence, in some countries, they are called naked ladies: in the March following, the green leaves spring up; and, in April, the seedvessel rises from the ground: the seeds ripen in May, contrary to the usual habits of vegetables, which flower in the Spring, and ripen their seeds in the Autumn."

The defoliation of deciduous trees is announced by the flowering of the Colchicum; of these the Ash is the last that puts forth its leaves, and the first to lose them.

[See Darvin's Notes.]

Then, bright from earth, amid the troubled sky,

Ascends fair Colchicum, with radiant eye,

Warms the cold bosom of the hoary year,

And lights, with beauty's blaze, the dusky sphere.

Darvoin.

\section{MIGNONETTE.}

\section{Reseda Odorata.}

Reseda, a name which occurs in Pliny, and is evidently derived from resedo, to allay or mitigate-the second syllable long.

Pliny reports, that this herb is known in the neighbourhood of Rimini, and was used for dispersing tumours, and all kinds of inflammations.

The Reseda Odorata first found its way to the South of France, where it is called Mignonette, Little Darling. Cowper calls it "The Frenchman's Darling."

Mignonette is said to be derived from the Italian $m i$, and nonnette, my young nun. Spanish, Minoneta.

Linnæus observes, that there is scarcely any genus whose character is more difficult to determine-there being snch a diversity of shape and parts, in different species.

The Reseda Odorata, Sweet Mignonette, is a native of Egypt; a hardy annual, blooming all the year round, if properly sheltered. Its flowers are deliciously fragrant, resembling that of the vine-blossom, or fruit of the raspberry. The petals several, unequal; segments all very deep, of a pale buff colour, prettily contrasted with the red anthers; calyx equal to the corolla, inferior, of one leaf, deeply divided; leaves flat, undivided, or three-lobed.

No gorgeous flowers the meek reseda grace,

Yet sip, with eager trunk, you busy race,

Her simple cup, nor heed the dazzling gem,

That beams in Fritillaria's diadem.

Evans.

\section{MIMOSA; or, SENSITIVE PLANT.}

From Mimus, an actor or imitator-its motions imitating the sensibility of animal life.

The plants of this genus, naturally contract themselves 
in the evening, and expand with the morning's iight. (See "Structure of Plants," upon the effect of light upon leaves.)

Whence does it happen that the plant, which well We name the sensitive, should move and feel? Whence know her leaves to answer her command, And, with quick horror, fly the neighbouring hand?

Prior.

Naturalists have not explained the immediate cause of the collapsing of the sensitive plant, when exposed to external violence. Darwin asks, "May it not be owing to a numbness, or paralysis, consequent to too violent irritation, like the fainting of animals from pain or fatigue?"

Weak with nice sense, the chaste Mimosa stands, From each rude touch withdraws her timid hands; Oft, as light clouds o'erpass the summer's glade, Alarm'd she trembles at the moving shade, And feels alive through all her tender form, The whisper'd murmurs of the gathering storm; Shuts her sweet eye-lids to approaching night, And hails, with freshen'd charms, the rosy light.

Darwin.

There are many species of Mimosa-some, tall trees, others, humble plants: natives of the East and West Indies, \&c.

The Mimosa Pudica, common Sensitive Plant, is a native of South America: it is naturally shrubby; leaves pinnate, or somewhat fingered; leaflets very numerous, oblong, rather bristly; the flowers are pale purple, in round, axillary, stalked tufts.

\section{MOCK ORANGE.}

Philadelphus Coronarius.

Philadelphus, the name of a shrub mentioned by Athenæus, which it is impossible for us to ascertain. Caspar Bauhin first applied it to our Syringa, or Mock Orange, with which it remains, as the generic appellation. Linnæus supposes it was designed to commemorate Ptolemy Philadelphus, king of Egypt; but a more probable opinion seems to be, that the plant of Athenæus was of the twining or clasping kind; and that the word, by a poetical fancy, was intended to express its brotherly love for those near it.

Philadelphus was a title, or surname, borne by several ancient kings-formed from the Gr. $\Phi / \lambda_{\circ}$, friend, lover, and $\alpha f i \lambda$ cos, brother; i. e.-one who loves his brother, or brethren.

The specific name Coronarius, L. that belongeth to, or serveth to make crowns or garlands.

The flowers of $\boldsymbol{P}$. Coronarius are white, and something like those of the orange; much larger, in dense, terminal, upright clusters, powerfully scented; leaves elliptical, recurved, opposite, on short stalks, dark green, smooth, with broad shallow teeth; their flavour, on the palate, very like the cucumber.

\section{MOsS MUSCUS.} Mosses Musci.

Moss, E.-Sax.meos; Welsh mwoswg, from mwos, that shoots up, and of a strong scent. Latin muscus; Greek

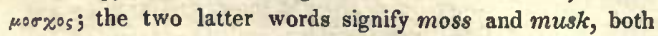
from shooting out; the Greek word also signifies a young animal, and a shoot or twig. French mousse, from which comes mousseline, muslin, from its softness or resemblance to muslin. Lunier says it is from Mossoul, a city of Mesopotamia.

Webster.

Musci, origin unknown. The word occurs often in the best Latin writers. Ambrosinus deduces it from a Greek word, Morxos - a young calf, or lamb, as well as the young shoot or tendril of a plant, which is not an improbable etymology, and is adopted by Ray.

The older botanists have still more difficulty in defining the nature of a Moss, than in the derivation of its name.

Rees' Cyclopedia.

Mosses are interesting little evergreens, with distinct leaves, and frequently as distinct a stem. They are found in the hottest, as well as the coldest climates, and have the singular property of reviving vith moisture, however much dried up.

Ray tells us, that the most perfect kinds are furnished with organs containing a pulpy matter, that becomes dry in ripening; and, when arrived at maturity, flies off in the form of an extremely subtile powder, serving for the propagation of the plant. Modern botanists, with the aid of magnifying glasses, have thought that they have discovered both stamens and pistils, enclosed in a roundish body that grows out of the bottom of the leaves; and which, when the seed ripens, falls off.

Mosses are fond of moisture, shade, and retirement: enlivening the dark recesses of solitude by the vivid green of their diminutive foliage.

The mossy fountains, and the sylvan shades Delight no more.

Pope

\section{MYRTLE. Myrtus.}

Myrtus, so named from Myrsine, or Myrene, a Grecian female and priestess, in the Temple of Venus. She was a great favourite of Minerva; and Venus, as a proof of her own regard, changed her into the Myrtle; which, at the same time, she decreed should be green and odoriferous throughout the year.

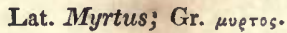

In the calendar of Julius Cæsar, we find the month of April under the protection of the goddess Venus: and the first day of the month, dedicated to Venus, with flowers and Myrtles.

A myrtle crown was worn by the general to whom an oration was decreed; the reason of which, according to Plutarch, in his life of Marcellus, was, that, as an oration was decreed for some remarkable success, obtained by treaty, or without much bloodshed, it was proper that the general, at his public appearance, should be crowned with a tree sacred to Venus; who, of all the deities, was supposed to be most averse to the horrors of war. 
We find, elsewhere, this Roman crown of Myrtle was called the oval crown, and given to those who were entitled to the honours of the lesser triumph, called ovation. It was customary for the Roman generals, in the greater triumphs, to sacrifice an ox; and, in the lesser, a sheep-in Latin ovis, whence the word ovation.

In Sparta, the general who put a period to a war, by policy or persuasion, sacrificed a bullock; but he, whose success was owing to force of arms, offered only a cock: for, though they were a very warlike people, they thought it more honourable, and more worthy of a human being, to succeed by eloquence and wisdom, than by courage and force.

In Herodotus, we are told that the ancients expressed triumph and joy by the Myrtle. "The hero wore it ss a mark of victory; the bridegroom, on his bridal day; and friends presented each other with myrtle garlands, in the conviviality of the banquet. Venus is said to have been adorned with it, when Paris decided.in her favour the prize of beauty; and, for this reason, it was deemed odious to Minerva."

[See notes on Polymnia.]

Myrtle was the symbol of authority for magistrates at Athens.

Concordia, the goddess of Peace and Concord, at Rome, is represented holding in one hand a pomegranate; in the other, a bundle of Myrtle. The nature of these trees is, that, if they be planted a good space spart, they will meet, and mingle or entwine their branches.

The Myrtle, on thy breast or brow,

Would lively hope and love avow.

\section{J. H. Wiffin.}

\section{NARCISSUS POETIC.}

Narcissus Poeticus.

Narcissus, a name adopted from the poets, who have fabled that the flower which bears it, originated in the transformation of a beautiful youth, who pined away with admiration of his own image in a fountain. Some have derived it from a Greek word, vхexy, stupor-alluding to the effects of the too powerful odour of the flower; which, in some instances, produce head-ache, and a partial loss of recollection.

The name of the youth might aptly apply to the stupidity of his passion, in slighting the fair Echo, in favour of his own shadow: as, also, to the flower, with its reputed narcotic properties, before Ovid elegantly combined them.

"When one fair virgin of the slighted train, Thus pray'd the Gods, provok'd by his disdain; $O$, may he love like me, and love in vain."

Addison's Ovid.

For, as his own bright image he survey'd,

$H e$ fell in love with the fantastic shade;

And o'er the fair resemblance hung unmov'd,

Nor knew, fond youth! it was himself he lov'd.

Same.

The Poetic Narcissus, $\mathcal{N}$. Poeticus, is the largest of the white kinds; and known, from all others, by the crimson border of its very shallow, and almost flat, cup of the nectary.
The double variety is most frequent in gardens: sometimes, there are two flowers in a sheath.

The $\mathcal{N}$ : Angustifolia, narrow-leafed, crimson-edged Narcissus, is the only one of the genus that resembles it; but it is scarcely above half so large, with lesves of a narrower proportion and flatter form, and the edge of the nectary more erect.

It flowers in April, full six weeks before the Poeticus.

Narcissus fair,

As o'er the fabled fountain hanging still.

Thomson.

For him the sister-nymphs prepare his urn, When, looking for his corps, they only found A rising stalk, with yellow blossoms crown'd.

Addison's Ovid.

\section{NASTURTIUM.}

Tropxolum.

Tropæolum, the diminutive of Tropæum, a voarlike trophy.

This fanciful, but elegant name, was chosen by Linnæus for the present singular and striking genus, because he conceived the shield-like leaves and the brilliant flowers, shaped like golden helmets, pierced through and through, and stained with blood, might, very well, justify such sn allusion.

$\mathcal{N}$ asturtium -All that I can find in relation to this word is in Ainsworth; he says "nasitertium, quod nasum torqueat-the herb called cresses, or nose-smart." Varro.

The name of Indian cress, applied to it, is in reference to the cress-like flavour of the herbage.

The Nasturtium major, or Indian Cress, is now the most commonly cultivated species. It was a daughter of Linnæus, Elizabeth Christina, who first observed it to emit sparks, or flashes of light, in the morning, before sun-rise, during the hottest months of summer; as, also, at twilight in the evening: but not after total darkness came on. These singular scintillations were shown to her father, and other philosophers.

The ceasing to shine of this plant, after twilight, might induce one to conceive that it absorbed and emitted light, like the Bolognian phosphorus, or calcined oyster-shells, so well explained by Mr. B. Wilson, and others.

The light of the evening, at the same distance from noon, is much greater than the light of the morning. This is supposed to be owing to the phosphorescent quality of almost sll bodies, in a greater or less degree; which thus absorb light during the sunshine, and continue to emit it again for some time afterwards; though not in such quantity as to produce appsrent scintillations, as in this flower.

[See Darwin's Notes.]

"Ere the bright star, which leads the morning sky, Hangs o'er the blushing east his diamond eye, The chaste Tropæo leaves her secret bed; A saint-like glory trembles round her head;

O'er her fair form, the electric lustre plays, And cold she moves amid the lambent blaze 
So shines the glow-fly, when the sun retires,

And gems the night-air with phosphoric fires."

Damoin.

Bright the $\mathcal{N}$ asturtium glows, and, late at eve,

Light, lambent, dances o'er its sleepless bed.

Biblake.

The Tropæolum has a calyx of one leaf, five-cleft, slightly spreading, acute, coloured, decidnous, with a nectariferous spur behind. Five unequal petals, roundisb, inserted between the segments of the calyx; the two uppermost sessile; three lower, with oblong fringed claws.

Darwin observes, that "The nectary grows from what is supposed to be the calyx; but this calyx is coloured, and, perhaps, from this circumstance, of its bearing the nectary, should rather be esteemed a part of the corolla."

The seeds are hot and pungent, much used for pickles: and the flowers are often intermixed with sallad herbs, both for ornament and flavour.

There is a double-flowered perennial variety of this species, common in green-houses, and readily increased by cuttings.

\section{NETTLE.}

Urtica.

Urtica, derived from Uro, to burn, or sting, in allusion to the property which our common nettles are known to possess.

Nettle, E.-Sax. netl, netele; Dutch, netal; Greek, $x y<\delta$, from the root of $x y c\{\omega, x y \alpha \omega$, , to scratch.

The finely acuminated prickles of the Nettle, if examincd with a microscope, will be found to resemble the stings of insects, and teeth of adders. Notwithstanding their minuteness, they are hollow, and convey a poisonous fluid, which lurks in a small bag at the base of the sting; upon the sting meeting with resistance, it presses upon this little reservoir, and ejects the fluid, a caustic essential oil, into the wound made by the point.

Nettle is supposed to be derived from the Greek word

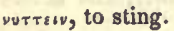

[See Skinner, and Lemon, word nettle.]

\section{Urtica flings}

Her barbed shafts, and darts her poison'd stings.

Darwin.

The flowers of this genus have no corolla. The stamniferous flowers have a cup or calyx of four ronndish leaves: instead of the petals, a honey-cup is placed in the centre of the flower. The pistilliferous flowers are not, always, on the same plant, but are sometimes seen on distant ones: they have a cup formed of two valves, which, closing, supplies the place of a seed vessel. Seed, solitary, superior, polished.

\section{NIGHT-SHADE}

\section{Solanum, and Atropa.}

Solanum, is among the few ancient names whose sonrce cannot be traced.

Rees Cyclopedia.

Ainsworth, derives Solanum, from Sole, but whether he means the ablative case of Sol, the Sun, or Solee, a city of Cilicia, (founded by Solon, from whom it took its name) from whence it may have been originally brought, or where it may have been first observed, does not appear

Atropa, from Atropos, the third Fate, who is supposed to cut the thread of life. Atropa is the deadly $\mathcal{N}$ ight-shade of Linnæus, and other botanists.

Solanum and Atropa, are of the same class and order, as designated for Solanum in the glossary.

Of $\mathcal{N}$ ight-shade, Skinner offers the following etymo. logy:

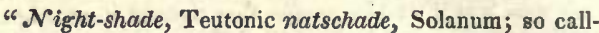
ed, either from its dark colour, or, because it produces sleep, the representative of night; or, rather, according to the Teutonic mode of writing, from the Teutonic nacht, night, and schade, damage, as much as to say the damage or destruction of night: because, to wit, it induces perpetual night, at least, if liberally taken."

The genus Solanum, contains plants of the herbaceous, shrubby, and tuberous-rooted kinds. Many of them esculent, as the potato, egg-plant, tomato, \&c.

The Solanum Nigrum, Garden Night-shade, has white flowers, with yellow anthers; corolla of one petal, wheelshaped, tube very short; calyx of one leaf, cut half way down into five erect, acute, permanent segments; berries the size of currants, usually black, sometimes yellow; stem bushy; leaves scattered, stalked, ovate, slightly downy, elongated at the base; wavy, or coarsely toothed at the margin.

Atropa Belladonna has, also, a one-leafed perianth, fiveparted, gibbous; divisions acute, permanent; corolla one-petalled, bell-shaped, of a dirty violet colour, longer than the calyx; anthers white, large; berry depressed, furrowed, when ripe, of a shining black colour, sweet, juicy; stem herbaceous, about three feet high; leaves ovate, entire, two together, of unequal size, petiolated, smooth, of a dull green. The plant is to be avoided, being a strong narcotic poison. In some instances, even half a berry has produced fatal effects. Its root is perennial.

In the genus Atropa is found the celebrated Mandrake, or $\mathcal{A}$. Mandragora, native of the South of Europe. The fancied resemblance of some of the roots of this plant to the human form; the danger of taking them out of the ground, (it was supposed to cause the certain death of the person who dared to attempt such a deed,) and the groans emitted by it when violence was offered, as well as other surprising virtues ascribed to it, are all equally fabulous.

Would curses kill, as doth the mandrake's groan, I would invent as bitter, searching terms,

As curst, as harsh, and horrible to hear

Shaks.

And shrieks, like mandrakes, torn out of the earth, That living mortals, hearing them, run mad. Same.

The Mandrake has a soporific quality, and the ancients used it when they wanted a narcotic of the most powerful kind.

[See Johnson.]

Come, violent death,

Serve for Mandragora, to make me sleep.

Webster's Duchess of Malfy. 
Quercus, supposed to be derived from the Celtic, quer, fine, and cuez, a tree. The Oak tree was, also, called in the Celtic tongue, derro-whence came the word Druid, or Priest of the Oak.

The etymology of druid, preferred by Skinner, is the Greek word $\delta v_{5}$, signifying an Oak: "Which tree they held sacred, and under which they offered their sacrifices." (See Pliny and others.) "For I have no doubt," he adds, "that the Massilian Greeks called these priests by this name, on account of their worship of oak trees, from whom the word was transferred to the Romans, and not that these priests called themselves druids."

Oak, E. Sax. ac, æc; Dutch eik or eikboom; Danish eege-træe. It is probable that the first syllable, oxk, was originally an adjective, expressing some quality, as hard, or strong, and by the disuse of the tree, $O_{A K}$ became the name of the tree.

Webster.

The Oak has no corolla, a calyx of one leaf, bell-shaped, membraneous, with about five small sharp, often cloven, segments. The varieties of the species are too great, to attempt a description of their foliage, and too well known to require it.

Several of the species yield the well known substance called cork, particularly the $Q$. Suber, or Cork tree, native of the South of Europe, and North of Africa. When this tree is about fifteen years old, the $b a r k$, which is a remarkably thick and spongy coat, may be stripped off, successively, for about eight years; it immediately renews itself-and, if not removed, it is pushed up, by a second growth, forming under that of the preceding year. Its quality improves with the age of the tree.

The oak attains to a great age.

The monarch oak, the patriarch of the trees,

Shoots rising up, and spreads, by slow degrees:

Three centuries he grows, and three he stays

Supreme in state, and in three more decays.

Dryden.

Among the Romans, there were various kinds of crovons distributed as rewards of military achievements. The civic crown, made of a branch of green oak, was given to him who had saved the life of a citizen in a battle or assault. This was esteemed more honourable than any other crown. Virgil calls it "civilis quercus." This crown was conferred on Cicero, for detecting Cataline's conspiracy-and, afterwards, on Augustus Cæsar himself.

Most worthy of the oaken wreath

The ancients him esteem'd,

Who in a battle had from death

Some man of worth redeem'd.

Drayton.

The oak was sacred to Jupiter, the great guardian of their city; and the Romans might, therefore, deem it the most proper ornament for him who had preserved a citizen.

Ovid tells us:

In witness of renown,

An Oaken garland did the victor crown.

The Laurel was not yet for triumph borne;

But ev'ry green, alike, by Phœbus worn,

Did, with promiscuous grace, his flowing locks adorn.

\section{OATS.}

Avena.

Avena, supposed to be derived from aveo, to desire, or covet, cattle being very fond of it.

[Rees' Cyclopedia.]

"Oates, from the Anglo-Saxon Aten, Avena: this, perhaps, from the Saxon Etan, to eat; for, every where, it is food for horses-and, in some places, for men."

[See Skinner.]

So that Doctor Johnson's offensive definition of Oats: "A grain which, in England, is generally given to horses; but, in Scotland, supports the people,"-is only a specific appropriation of what Skinner had left general; and is, therefore, not quite so original a piece of wit as it has been thought.

The English name Oat is seldom used in the singularonly in compound words, as Oat-meal, etc. The second definition of Oat, in Johnson, is " A small pipe made of oaten straw." And in Pitt's Virgil, we are told that "the musical instruments used by shepherds, were at first made of Oat and Wheat-straw, and were called Avena; then of reeds, and hollow pipes of box-afterwards of other materials.

In Virgil, Shakspeare, Milton, and others, there is frequent mention of this rural pipe of the pastoral ages.

Then the shrill sound of a small rural pipe,

Was entertainment for the infant stage.

\section{Roscommon.}

When shepherds pipe on Oaten-straws,

And merry larks are ploughmen's clocks.

Shaks.

Playing on pipes of corn, and versing love.

Same.

In beachen shades, you 'Tit'rus, stretch'd along,

Tune to the slender reed your sylvan song. Virgil’s Eclogrues.

Charm'd with Arcadian pipe. Milton.

In the third eclogue of Virgil, we find an amusing contest for supremacy, in music, between two shepherds: 


\section{Menalcas. \\ You win a goat by music? *** \\ $*$ \\ * * Whose sole ambition was to draw}

The mob in streets to hear thy grating straro.

Damoetas.

Howe'er that be, suppose we trial make?

I to provoke you more, yon heifer stake.

* * * *

Pollio approves, though rough my rural reed, etc.

The flowers of the Oat have no petals, and are disposed in a loose panicle. The essential character of the Oat consists in the jointed, twisted awn, or beard, that grows from the back of the blossom. It is remarkable for the elegance of its panicle, and the flexibility of the fruit-stalk, which turns with the slightest breath of wind.

The Oat, from its simply graceful growth, is now considered a tasteful ornament for a lady's hair; and; for this purpose, beautiful imitations are frequently made of it in gold and silver.

\section{OLEANDÉR.}

\section{Nerium.}

Nerium-this Latin name is derived from the Greek Nneroy; and this, again, from the Greek adjective Nyeos, signifying humid, or wet, because it grows about rivers.

[See Ainsworth; and Schrcvelius' Lexicon.]

Oleander, E. Fr. Oleandre; the plant rosebay.

Johnson.

Nerium Oleander, or common Rosebay, natives of the South of Europe, East Indies, etc. All the species are beautiful tall shrubs, evergreen, with splendid flowers, usually of a rose colour. The white variety is the most tender.

Oriental travellers have, with great taste and probability, supposed this to be the Bay-tree to which the righteous man is compared by the royal Psalmist.

The flowers are large and rich, with a calyx in five deep, acute, permanent segments: corolla monopetalous, salvershaped, contorted; its mouth crowned with five divided leaflets; inodorous; seeds crowned with down.

All the species are supposed to have a poisonous quality. Ladies would do well, therefore, to beware of applying it to their lips, as is too generally their custom with their bouquets.

\section{OLIVE.}

Olea.

Olea, L. the celebrated $\lambda_{\alpha a t x}$ of the Greeks. The word is derived from the Greek $\lambda_{\varepsilon v 0}$, smooth; alluding, probably, to the nature and qualities of the oil-for there is no remarkable smoothness about the plant, unless it be the upper surface of its leaves. Its value, on account of its oil, has rendered it famous throughout all antiquity.

The Olive was sacred to Minerva. The Athenians held it in such repute, that they ascribcd its production to their tutelar deity, Minerva. The famous dispute between Nep- tune and her, as to the right of worship in the capital of Attica, being referred to the gods, it was decided that which ever of the two should give to the inhabitants of the earth the most useful present, should have the patronage of the city. The Olive, produced by Minerva, being the emblem of peace and comfort, was, unanimously, pronounced to be superior to Neptune's Horse - the symbol of war and bloodshed. 'Thenceforth she became the tutelar deity of the city, to which she gave her own name Athenæ: therefore, it had been called Cecropia, in honour of its founder Cecrops.

The Olive, as an emblem of peace, is as old as the deluge. It was a branch of Olive, brought back to the Ark by Noah's dove, which testified that the waters, the ministers of Heaven's vengeance, had subsided.

I hold the Olive in my hand: my words are

As full of peace as of matter.

Shaks.

To thee the Heavens, in thy nativity,

Adjur'd an Olive branch, and laurel crown,

As likely to be blest in peace and war.

Shaks.

In Rome, a particular sort of coronet, made with Olive boughs, was bestowed in consideration of some signal act of valour.

The Olive is a remarkably long-lived tree. According to some authorities, flourishing more than five centuries. In France it is asserted, that there are trees which two men can scarcely encompass with their arms. The flowers of the Olive are small, white, slightly odoriferous, and disposed in clusters like those of the currant: sometimes the clusters are almost as numerous as the leaves. Each flower consists of a one-leaf calyx; a monopetalous corolla, divided into four lobes, funnel-shaped. The fruit is called, by botanists, a drupe, (drupa, Latin.) Leaves generally smooth, and of a light green above, whitish and somewhat downy, with a prominent rib beneath.

The Olive is said to be extremely tenacious of life; and it is asserted that, when the trunk has perished by frost or fire, it sprouts anew. And that, even if a bit of the bark, with a thin layer of wood, be buried in the earth, it becomes a perfect plant

[See "Michaux's North American Sylva."]

The ancients relied chiefly upon propagation by slips; an easy and expeditious mode, still generally followed in Spain.

\section{ORANGE.}

Citrus Aurantium.

(For Citris, see Lemon.)

Skinner says, the Orange takes its name from the barba. rous Latin, Aurantium-which denotes its golden colour.

From aureo (L.) golden, colore, colour. The aureum malum, or golden apple of the ancients. Johnson.

We are told that Citrus Aurantium, China, or Sweet Orange, which first made its appearance in Europe, was sent as a present to the old Condé Mellor, then prime minister to the king of Portugal: but that, of the whole case sent to Lisbon, there was only one tree which lived, and became the 
parent of all the flourishing trees since cultivated by the gardeners.

The Orange tree is of a middling size. The lea $f$ of the Swect, or China Orange, is ovate, lanceolate, alternate, very little toothed, or not at all; sprinkled with small, resinous, transparent tubercles, resembling those of some species of Hypericum. The flowers of the Orange are white, odorous, in short racemes, towards the end of the branches: its scent has no rival, and is said to be as salutary as it is delicious, not affecting the nerves, as that of other flowers, but strengthening them.

Know'st thou the land, where groves of citron flower,

The golden Orange, darkling leaves embower!

The gentle breezes wave the azure skics;

The myrtle still, and high the laurel rise?

Know'st thou the land: Oh there! oh there!

I long with thee, my lov'd one, to repair.

Oh there! oh there!

Goethe.

\section{OX EYE.}

Buphthalmum. eye.

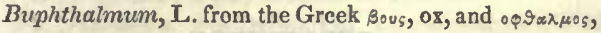

A genus of plants to be found every where between the tropics: some of them evergreen, all, with yellow terminal flowers. Herbaccous, shrubby, perennial. Flovers, a common calyx. Corolla compound, radiate; florets of the disk numerous, funnel-shaped, with a five-parted, rather spreading border. Receptacle chaffy.

Ox-Eye, still green, and bitter patience.

Garland of Flora.

\section{PARSLEY.}

Apium.

Apium, perhaps, derived from Apes, Bees-because these insects are fond of it. The genus Apium includes parsley, small-age, cellery, etc.-all umbelliferous plants.

Parsley E.-Fr. persil; Swedish persilva; Danish pe-

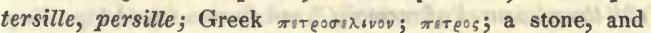

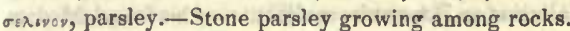

Although parsley is so commonly used at table, it is said not to agree with all constitutions; sometimes occasioning epilepsy, and producing inflammation of the eyes.

[See Rees' Cyclopedia.]

It has the reputation of being a great purifier of the breath from the smoke of a cigar, etc.

\section{PASSION FLOWER. \\ Passiflora.}

Passiflora, a name altered by Linnæus from the Flos Passionis: derived from the Latin Patior, to suffer, and Flos, a flower.

The Passion flowers are natives of America: some of the varieties, to the South, are of a bright red colour: those of the North are, generally, pale blue, or yellow.

It is said that the plant owes its name to the missionaries, who first discovered it while travelling over the country. The instruments of our Saviour's passion, were thought to be represented by it. The five stamens were compared to his five wounds; the three styles, the nails by which he was fixed to the cross; the column which elevates the germen, to the cross itself; and the rays of the nectary to his crown of thorns.

The calyx is of one leaf, in five deep coloured segments; petals five, inserted into the calyx; nectary a complex radiating crown; seeds with a pulpy tunic, about the size of a lime.

The common blue Passion-flower, P. Crmulea, has leaves deeply palmate, in five smooth segments.

High o'er the pointal, deck'd with gold,

(Emblem mysterious to behold,)

A radiant cross its form expands;

Its opening arms appear to embrace

The whole collective human race,

Refuge of all men, in all lands!

Harte.

\section{PEA EVERLASTING.}

\section{Lathyrus Latifolius.}

Lathyrus, a name adopted from Theophrastus, whose Iathuros appears evidently to be, like ours, something of the pea or vetch kind.

The chief distinction between the pea (pisum) and the vetchling, (lathyrus) consists in the shaft; in the pea, it is triangular, keel-shaped, and woolly; whilst that of the vetchling is flat and upright, with a woolly summit.

Pisum is said, by De Theis, to be derived from the Celtic Pisen, and that Pisen is the common root of this word in all languages. Hence the Anglo-Saxon pisa-the English pea, pease, and still in obsolete Norfolk, peasen; the French, pois, pesiere; Italian, piso; Welsh, pus; all synonymous with pisum, said by the learned to be deduced from the Greek $\pi\llcorner\sigma o y$, which means the same thing.

The common garden Pea, Pisum sativum, bearing pearly-white, inodorous flowers. The field, or grey pea, $\boldsymbol{P}$. Arvense, with solitary purplish flowers, whose wings are of a violet purple. The marrow-fat, etc. are the esculent pea kinds; the roots annual.

Vetchling, or Vetch, is of common origin with vicia, an old Latin name, derived by some etymologists from vincio, to bind together, as the various species of this genus twine, with their tendrils, round other plants.

Lathyrus latifolius, or Great Everlasting Pen, well known to most people; cultivated for its flowers: it has roots that endure for a long course of years, throwing out long climbing stems, which bear large bunches of beautiful crimson flowers; leaflets elliptical, in pairs; stem winged; perianth inferior, of one leaf, bell-shaped; corolla papilionaceous; standard very large, inversely heart-shaped, refiexed at the sides and summit; wings smaller, oblong, somewhat crescentshaped; keel semicircular, the size of the wings, but broader, separating about the middle, inwards. Native of Europe.

\section{SWEET PEA. \\ Lathyrus Odoratus.}

Common Sweet Pea, L. O. is a hardy annual, native of Sicily and Ceylon. Stalks two-flowered. Leafets ovate, oblong, two to cach branched tendril; legumes hairy. 
The fragrance of the Sweet Pea blossom is similar to that of the Orange flowers, with a mixture of the rose. These blossoms are peculiar for their elegant negligence of form, and delicacy and richness of colouring, varied with claret-colour, blue, lilac, rose, white, etc., all in the same flower. It is much cultivated by the market florists.

Here are Sweet Peas, on tip-toe for a flight, With wings of gentle flush o'er delicate white,

And taper fingers catcling at all things,

To bind them all about, with tiny rings.

Keats.

\section{PEACH BLOSSOM.}

Amygdalus.

(For Amygdalus, see Almond.)

Peach E.-Fr. peche; It. pesca; Lat. matum persicum, a tree and fruit.

See Webster and Johnson.

The native country of the peach is not known. It came to the Romans from Persia.

Rees' Cy.

Skinner tells us that the name of the fruit, Peach, comes through the French pesche or peche, and Italian pesca, from persica, in allusion to the country of its origin.

\section{PENNYROYAL.}

Cunila pulegioides, and Mentha pulegium.

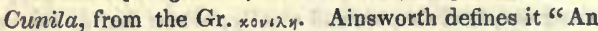
herb whereof there are three sorts, viz. savory, marjoram, and pennyroyal."

It may be that the word is derived from the Latin cunio, to defile, on account of its strong scent, which to many persons is disagreeable.

Cunila pulegioides, the N. American species, has stems seven or eight inches high, erect, pubescent, branched; leaves oblong, two-toothed, opposite, smooth above, roughish with short hairs underneath, on short petioles; root annual; flowers in axillary whorls, shorter than the leaves, continued from the upper to the lower pair of leaves; two lower divisions of the calyx bristle-shaped, ciliated. It has a strong scent, and an infusion of it is said by $\mathrm{Kalm}$ to be used by persons who have taken cold, and have a pain in their limbs.

Mentha, the name of the English plant, is an ancient Latin name, mostly written menta, adopted from the Greeks,

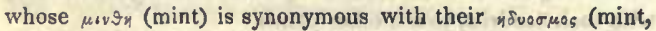
cinnamon) the latter being generally used. See Dioscorides, book 3, chap. 41 .

The nymph Mintha, a favourite of Pluto, is fabled to have been changed by Proserpine into this herb.

Our common mint, is of this genus.

The Mentha pulegium, common pennyroyal of England, has flovers whorled. Leaves ovate. Stems prostrate. Flower-stalks downy. Calyx hairy all over, with fringed teeth. Corolla twice the length of the calyx; very hairy externally, shorter than the stamens. The broadest segment of the corolla is decidedly cloven, as it ought to be in the Mentha. The flavour of pennyroyal is peculiarly strong, resembling Thymus $\mathcal{N}$ epeta, but not confined to these plants. Some cunilæ have the same scent.

Class and order of Mentha, Didynamia, Gymnospermia. Nat. Ord. same as Cunila.

\section{PEONY.}

Pæonia.

Pronia, in memory of Pron, the physician, whom Homer records as having cured Pluto with this herb, when he was wounded by Hercules.

Pæon was a pupil of Esculapius, who, being jealous on account of this famous cure, is said to have secretly caused the death of Pron; but Pluto, in gratitude, changed bim into the flower which bears his name, and which has been celebrated throughout all antiquity, for its wonderful virtues; protecting persons from enchantment, driving away evil spirits, etc.

The superb double crimson Peony of our gardens, P. officinalis, is a native of Switzerland and the Alps. Calyx of five leaves; petals roundish, concave, contracted at their base, spreading, very large, terminal, solitary; stem herbaceous, annual, two feet high, with large spreading, compound, dark-green leaves; the root perennial.

There might ye see the Peony spreading wide.

Coroper.

\section{PERIWINKLE.}

Vinca.

Vinca, the best derivation may, perhaps, be from $V$ incio, to bind, or wrap up: because its long, trailing, or twining branches, wind themselves around, and entangle every other plant in their way. Rees' Cyclopedia.

Perivoinkle, Latin, Vinca, Sax. Wincle, a shell-fish. 2. A plant of the genus Vinca.

[See Webstcr.]

Skinner says: "Perwinkle, or Periwinkle, Clematis Daphnoides-Anglo-Saxon, Pcrwinc, Peruince, barbarous Latin, $V_{\text {inca, }}$ Pervinca, so called, perhaps, because $V_{\text {incit }}$, it binds up-that is, stops the flowing of wounds, and some other hemorrhages; or, according to Lobelius, because it always flourishes, and conquers, and overcomes continually (vincit and pervincit) the injuries of the air.

In France, the Perivoinkle has been made the emblem of "the pleasures of memory," and sincere friendship. Possibly in allusion to Rosseau's recollection of his friend Madam de Warrens, after the lapse of thirty years, produced by the sight of the flower they had admired together.

The general character of this genus, is a perianth, inferior, of one leaf; corolla monopetalous, contorted, salvershaped, inferior.

The Vinca minor, found in every garden, with scentless flowers, of a deep blue, white in the centre-or white flowers, with a variegated leaf-both perennial; stcms erect; while in flower they become trailing, creeping extensively; leaves evergreen, opposite, about an inch long, elliptic-lanceolate, smooth at the edges. Native of Egypt.

$V$. Rosea, Madagascar Periwinkle, has an erect, shrubby stem; flovers sessile in pairs; leaves elliptic-oblong, entire, rather downy, bluntish, two inches long. Native of the East Indies, now become a popular green-house plant, flowering the greater part of the year; corolla either rose colour, or pure white; the centre always of a peculiarly rich crimson, with a yellow eye. 
Phlox-Greek No $_{0}$-the Phlox of Theophrastus. The name is synonymous with flame; alluding, as is supposed, to the bright colour, or fiery hue of some of the species.

The genus was termed Lychnidea, by Plukenet and Dillenius, because of its resemblance to Lychnis. But a name so constructed, being against all rule, Linnæus evidently took up the idea of Luchnis (Lychnis) as alluding either to the shape or to the wick of a lamp, (see Lychnis) and adopted Phlox, as a word nearly expressive of the same thing.

Fourteen species of this handsome tribe have been enumerated. All, except $P h$. Sibirica, are natives of N. America; and, as far as we know, of no other country.

Rees' Cyclopedia.

The flowers are showy, of various hues of purple, or pink; and, in one instance, of a brilliant white, as in the $P h$. Suaveolens, fragrant white Phlox.

$\mathrm{Ph}$. Paniculata, Great Common Phlox, or Panicled Lychnidea, has blossoms of a fine lilac hue; scentless.

Ph. Pyramidalis, Pyramidal Phlox, has flowers in a dense pyramidal cluster, of a rich purple; honey-scented; stem purple-spotted: a very ornamental species.

Ph. Maculata, Spotted-stalked Lychnidea, or Wild Sweet William, is a more slender and narrow-leafed species, frequent in our gardens; distinguished from the last named, by the recurved teeth of its calyx.

The flowers of this genus have a corolla salver-shaped, monopetalous; calyx of one leaf, tubular, with five angles, and five deep acute teeth, permanent; perennial, herbaceous, entire leafed.

\section{PINE. \\ Pinus.}

Linnæus places $P$ inus amongst ancient Latin names, of unknown origin. Rees' Cyclopedia.

Pinus, Latin, from the Greek Mtvos, which, according to Schrevelius, comes from the Greek adjective Mıov, signifying fat, because the tree abounds in rezin-resin.

Pine, Fr. pin; Sp. It. pino; L. pinus; Sax. pinntreow, pin-tree; Dutch, pyn-boom; Welsh, pin-bren, pin-tree, and pin-groyz, pin-wood. These words all indicate that this name is from the leaves of the pine, which resemble pins.

Webster.

According to Heathen mythology, the pine was sacred to Rhea, mother of Jupiter. (Rhea, one of the names under which the earth was worshipped.)

"To Rhea, grateful still the pine remains."

Congreve's Ovid.

Lempriere tells us, that Atys, a celebrated shepherd of Phrygia, much esteemed by Cybele, (Cybele, same as Rhea, $V$ esta, Ceres, etc.) because he had introduced her worship and festivals into Asia Minor, was, after his death, changed into a Pine tree, by Cybele, and, ever after, that tree was sacred to the mother of the gods.

Pan, one of the rural deities, was crowned with Pine. He was in love with the nymph Syrinx, who was transformed into a bundle of reeds, from which Pan afterwards formed the musical instrument called Syrinx, or Pan's pipes.
"A crown of Pine upon his head he wore;

And thus began her pity to implore."

Dryden's Ovid.

Black Spruce Pine, $\boldsymbol{P}$. Nigra, to be found from Canada to Carolina. The black, or double spruce, Abies $\mathcal{N i g r c}$, of Michaux-the young branches of which are used in making the well known spruce beer. The leaves are of a dark, gloomy green; cones ovate, hardly above an inch long, crowded about the sides of the last year's shoots, which have protruded beyond them, and before they become dry, are of a rich purple.

Pinus rigida, is known all over the United States, by the name of pitch pine-sometimes in Virginia called black pine. The spines of the cones being reflexed, not inflexed, will, at any time, distinguish them.

Pinus Abies, Norway Spruce Fir, much cultivated as an ornament in gardens, etc. The long, sweeping, fan-like branches, often borne down by loads of snow, have a beautiful appearance. The leaves are copiously scattered all around the branches, ascending, somewhat imbricated, each scarcely an inch long, on a short stalk. Cones pendulous, solitary at the end of each branch, a span long, nearly cylindrical, light brown, smooth, of numerous, flattish, rigid, rhomboid scales, waved at the edge, and notched at the point. The Burgundy pitch is prepared from this species.

PINK.

Dianthus.

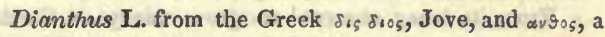
flower. A name given by Linneus to the pink and carnation genus, and which signifies Jove's flower.

"Pink, English; Pince, French, from pink, Dutch, an eje: whence the French word allet, i.e. eyelet; Caryophillum, Latin." Johnson.

The primitive pink is simple, red, or white, and scented; by culture the petals have been enlarged and multiplied, and its colour infinitely varied.

With hues on hues expression cannot paint,

The breath of Nature and her endless bloom.

Thomson.

Each Pink sends forth its choicest sweet

Aurora's warm embrace to meet.

M. Robinson.

Florists designate two principal subdivisions, Carnations and Pinks. The latter are distinguished by an eyelike spot, and a more humble growth, and by some asserted to be a distinct species.

\section{Carnation.}

Spencer writes it Coronation, probably because they were used on such festive occasions; and from hence, probably, the present name.

Bring Coronations, and sops in wine,

Worn of paramours.

Spencer.

It was also called "Clove-Gilly flover," from its clove- 
like scent: and "sops in wine," as it was frequently used to flavour liquors and choice dishes; being thought medicinal, as well as agreeable. Hence, also, its modern specific name, from Caryophyllum, Latin for a clove.

Some derive the English name Carnation, from Carnes, Latin, for flesh colour, which may have been the predominant original colour of the flower.

"Carnation'd like a sleeping infant's cheek."

Byron.

The flower of the Carnation is, sometimes, more than three inches in diameter. The petals crenate, but less fringed, or notched, than those of the pink-sometimes not at all so. The calyx more than an inch in length, terminating with broad points, calyx-scales, somewhat rhomboid, very short.

\section{Indian Pink; or, China Pink.}

Its flowers placed singly on branching stems, like those of the common pink, of glowing vivid red colours. The marks of colouring most beautiful, in its single state, obscured when the petals multiply. It is scentless, and generally considered as an annual; but the plant may be preserved several years in a dry loamy soil, by cutting down their flower-stalks before the seeds ripen. They require but little water.

Mountain Pink. Grey-leafed; or, Chedder Pink.

From its being observed to grow chiefly on Chedderrocks, near the village of Chedder, in England. Native of lime-stone rocks and mountains. The leaves are very glauceous; flowers pale pink, very sweet-scented; of an humble growth, but aspiring ambition as to situation. Cæsius, Latin, alludes to the grey colour of its herbage.

\section{Red Pink}

The double, of an uniform colour, without blotches, designated.

Pinks have a cylindrical calyx of one leaf, divided into five teeth at the orifice, two pair of scales at their base. Corolla, in its single state, of five petals, with long claws tapering downwards, inserted into the receptacle; borders horizontally spreading, wedge-shaped, abrupt, crenate, or notched.

\section{PLEURISY ROOT. Asclepias}

Asclepias, from IEsculapius, the god of medicine, who is said to have discovered the virtues of the plants of this genus, and to whom one of the species was anciently consecrated.

The English name Swallow-wort, applied to the whole genus, is from the Dutch Swaluw-wortel-from the fancied resemblance of the seeds to a swallow flying. The seeds are winged, as those of many other flowers, which facilitates their dissemination, being more easily borne off by the wind.

The United States furnishes the greatest variety of this beautiful and useful genus of plants. The tender shoots of some are eaten as asparagus. The down furnishes a silk or cotton used in making mattresses, and manufactured in various ways. The root is in great repute in the materia medica.

The Asclepias Tuberosa (or Tuberous-rooted Swallow wort) is variously denominated, as Pleurisy; or Ache-in-theside plant, from its medicinal virtues: Butterfly-weed, from its being a favourite resort of the insects of that tribe, etc. Its flowers are of a bright orange colour; stems a foot high, hairy, round, dusky red; leaves alternate, lanceolate. Native of Virginia, and cultivated in the royal garden at Hampton court, in England.

The $\mathcal{A}$. Decumbens has, also, bright orange coloured flowers; stem decumbent, a foot and a half high, hairy; leaves narrow, flat, opposite; umbel compact, at the extremity of the branches.

There are rose-coloured varieties, white, etc. The general character of their flowers is, a calyx five-cleft, sharp, very small, permanent; corolla monopetalous, flat, or reflex, five-parted; nectaries five, growing to the tube of the filaments, putting forth a sharp little horn, protruding from the bottom, bending inwards.

The Asclepias Syriaca, or Syrian Swallow wort, abundant in North America, is much used in medicine, as an alterative, tonic, etc. the whole plant filled with a milky juice, perfectly harmless. Flowers of a dingy purple, succeeded by large oval pods. It is the shoots of this plant, more particularly, that is made a substitute for asparagus. The Canadians are said to make sugar from its flowers, and to prefer the cotton of this species.

Asclepias incarnata, flesh coloured swallow-wort. Leaves lanceolate; stem divided at the top; umbels erect, twin. This puts out several upright stalks about two feet high; at the top of which are produced close umbels of pink flowers in August.

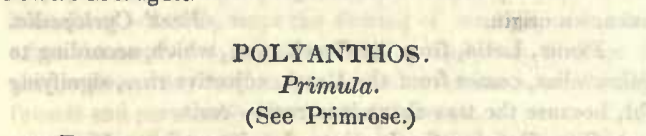

Polyanthos, a word used in general to denote a plant which bears several or more flowers. It is compounded from

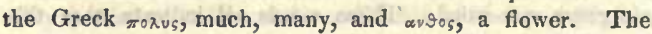
Polyanthos, like the Auricula, produces an umbel of many flowers on one common scape or stem.

Those most admired, are shaded with a dark rich crim. son, resembling velvet, with bright golden yellow edges.

"Cinque spotted like the crimson drops

I' the bottom of a cowslip.

Shaks.

-Bring the rathe Primrose that forsaken dies,

With cowslips wan that hang the pensive head,

And every flower that sad embroidery wears. Milton's Lycidas.

And Polyanthos of unnumber'd dyes. Thomson.

The love-sick cowslip, that head inclines,

To hide a bleeding heart.

Hurdis. 


\section{POMEGRANATE. \\ Punica.}

Punica, the malum punicum of the ancients, so called, it is presumed, because the Romans first obtained this fruit from the north of Africa. It was sometimes called malum granatum, in allusion to its internal granulations-whence its English name Pomegranate.

Punica L. from Pæni, the Carthagenians.

Ainsworth defines punica-1. Of Africa-2. Red, scsrlet colour.

Gen. cha. of the flowers--calyx, superior of one leaf, be]l-shaped, coloured, permanent, in five acute segments. Corolla of five petals, roundish, rather spreading, inserted into the calyx. 'There is a beautiful double variety, valued on account of their flowers.

The punic granite op'd its rose-like flowers;

The orange breath'd its aromatic powers.

Harte.

\section{POPPY.}

Papaver.

Papaver, according to the most learned etymologists, because the flowers, or fruit, of this plant was formerly mixed with the pap, or papa, given to children in order to procure sleep.

This genus is so variously diversified, that two plants are seldom alike in their flowers.

In the time of Gesner,* the village Damons and Phyllises proved the sincerity of their lovers by placing a petal of the poppy in the hollow of the palm of the left hand; which, on being struck by the other hand, gave a sound that denoted true attachment, or faithlessness, when it failed to snap.

“By a prophetic poppy-leaf I found

Your changed affection, for it gave no sound,

Though in my hand struck hollow as it lay,

But quickly withered, like your love, away."

The largest heads of the single flowering white poppies are preferred for the making of opium. These, being wounded as they grow, yield a milky juice, which, by drying, becomes opium.

Ceres is supposed to have given rise to the poppy to assuage her grief, during her search after her daughter Proserpine, who was carried away by Pluto.

Indulgent Ceres knew my worth,

And to adorn the teeming earth,

She bade the poppy rise.

Coroley.

Sleep-bringing poppy, by the ploughman late, Not without cause, to Ceres consecrate.

W. Browne.

* Gesner was prononuced to be " the greatest Naturalist the world had seen since Aristotle; the first who ever collected a museum of natural history, and the discoverer of the only true principles of botanical arrangement in the flower and fruit, to which the very existence of botany, as a science, is owing," born at Zurich, in 1516, and lived to the age of forty-uine.
The herb of the White Poppy, $\boldsymbol{P}$. Somniferum, is erect, branched, very glaucous, with broad, obtuse, simple, wavy leaves, clasping the stcm, the upper part of which is clothed with coarse, spreading hairs; calyx smooth, of two leares; petals nearly globose; root snnual.

From a poppy I have taken

Mortals' balm, and mortals' bane:

Juice, that creeping through the heart,

Deadens ev'ry sense of smart;

Doom'd to heal, or doom'd to kill,

Fraught with good, or fraught with ill.

Mrs. M. Robinson.

Nox (or Night) daughter of Chaos, was crowned with poppies.

\section{PRIDE OF CHINA. \\ Melia Azedarach.}

Melia, a name adopted by Linnæus for this tree; apparently because its leaves resemble those of the $A s h$. It is a native of Syria: thrives well in our Southern States.

The pulp which surrounds the nut is said to be poisonous; but the berries, when ripe, are eagerly sought for and eaten by cattle and birds, particularly the red-breast, without any ill effect. The bark of its roots and branches is esteemed an effectual vermifuge.

In the southern parts of Europe, the nuts are threaded for beads, to assist the devotion of good Catholics; for which purpose they are peculiarly suited, having a natural perioration through the centre. Hence the tree has been called $\Omega(r$ bor Sancta; and by the Spaniards Arbol Parayso. It has, also, the English names of Bead-tree, or Pride of India.

The flowers have a reddish lilac hue: they form axillary clusters at the extremity of the branches, and exhale a delicious odour. Calyx of one leaf, five-toothed; petals five; nectary cylindrical, toothed at its mouth, bearing anthers; drupa a nut of five cells; leaflets ovate, notched, pointed, bright grcen above, paler beneath.

\section{EVENING PRIMROSE. Enothera.}

Enothera, L., from the Greek oเvos, winc, and ingu, a searching or catching, bestowed upon the plant on account of the root having caught the perfume of wine, from being dried.

The Enothera Biennis, or Tree Primrose, is a North American plant, with a stem two or three feet high, sometimes branched, leafy, angular, rough, with minute tubercles, hairy; leaves alternate, ovate, or lanceolate, toothed, downy; the lowest stalked, longer, and somewhat waved; flowers sessile in the bosoms of the upper leaves, so as to form a large spike; of a fine pale yellow, delicately fragrant; expanding in the evening. The unfolding of the petals is so sudden, as to cause an audible sound, from the scparation of the calyxleaves suddenly appearing in a cup shape, progressively expanding, until they become quite flat; biennial.

You Evening Primroses, when day has fled,

Open your pallid flowers, by dew and moonlight fed.

Barton. 
Enothera sheaths in many a fold, Of primrose scent and hue her fainter gold, Nor yet unbinds the firmly clasping zone,

Till eve's mild lustre mingles with her own.

Evans.

\section{A tuft of Evening primroses,}

O'er which the wind may hover till it dozes;

O'er which it well might take a pleasant sleep,

But, that 'tis ever startled by the leap

of buds into ripe flowers.

Keats.

Enothera Odorata, Sweet-scented, or Curl-leafed Evening Primrose, was introduced into England by Sir J. Banks, from the coast of Patagonia, and seems to be likely to supersede the other species. It is a tolerably hardy perennial plant-the stem of which does not die completely down; beautiful with its waved foliage, yellow blossoms, and desirable for its perfume. Its flowers expand, also, only in the evening.

Than vainer flowers-tho' sweeter far,

The Evening Primrose shuns the day;

Blossoms only to the western star, And loves its solitary ray.

Dr. Langhorne.

And one, who mark'd with depth of thought,

How the bright day-flowers droop away,

An Evening primrose only bought,

Which opens at the close of day.

Judgment of Flovers.

Enothera pumila, Dwarf CEnothera, is another North American species: the smallest of the genus with small yellow sessile, spiked flowers, which remain expanded in the day as well as evening. Perennial root; stems scarcely a foot high, smooth, reddish; leaves sessile, light green, tinged with red at their points, rather blunt.

There are also varieties of purple, pink, etc.

\section{PRIMROSE, PURPLE.} Primula.

Primula, from primus, first, a name given to this genus from their early bloom, being the first offering of Spring.

The Cowslip, Polyanthus, Primrose, Auricula, etc., are all of this family.

The primrose was anciently called Paralisos, the name of a beautiful youth, son of Priapus and Flora, who died of grief for the loss of his betrothed Melicerta, and by his parents was metamorphosed into this flower, which has since divided the favour of the poets, with the Violet and the Rose.

Beneath the sylvan canopy, the ground

Glitters with flowery dyes; the primrose first

In mossy dell, return of Spring to greet.

Gisborne.

The primrose pale, is Nature's meek and modest child.

Balfour.
The primrose, tenant of the glade,

Emblem of virtue in the shade.

Jno. Mayne.

The general character of the flowers of the genus primula, is a calyx of one leaf, tubular, with five angles, and five acute upright teeth, permanent; corolla monopetalous, tube cylindrical; limb spreading, cut half way down into five heart-shaped segments.

\section{PRIVET.}

Ligustrum.

Ligustrum, a name found in Pliny, and other Latin writers, by which the Oriental Cypros [Lawsonia inermis] seems originally to have been intended, but which is, now, universally received for our Privet.

The species generally cultivated is the common Privet, L. vulgaris. A shrub of five or sis feet high; white flow. crs; perianth inferior, of one leaf, tubular, very small; corolla monopetalous, funnel-shaped, four-cleft; berries dark purple, very bitter, like the foliage and bark: almost evergreen. It was formerly known by the name of print, or prim-print, probably from its neat and regular appearance, when clipped and trimmed.

\section{QUAMOCLIT} Ipomæa.

Ipomæa, a name given by Linnæus, which he derived from the Greek I $\psi$; and o $\mu_{0}$ เos, like: by which appellation he evidently intended to express the close resemblance of the present plant to Convolvulus. It lias been remarked, that Linnæus mistook the meaning of the first Greek word, I $\psi$ which signifies a creeping sort of worm that infests and corrodes vines, and not the Convolvulus plant.

Quamoctit, an Indian name, retained by Plumier, and Tournefort as generic-but, by Linnæus used only as the specific appellation of a beautiful species of Ipomæa, popularly denominated busy-body. It is an East Indian vine, remarkable for its finely pectinated leaves and rich crimson blossoms. This vinged-leaf Ipomæa has a calyx deeply five-cleft, naked. Corolla monopetalous, funnel, or bell-shaped; limb five-cleft, spreading, with five plaits; capsule of two or three cells; seeds two in each cell.

There are two other varieties, with white and orange coloured flowers.

\section{QUEEN'S ROCKET. Hesperis. \\ (See also Rocket.)}

Hesperis, the Esperos, or Evening flower of Pliny. The ancients named this family of plants from Hesper, or Vesper, Latin, or E $\sigma_{\pi \xi \rho}{ }$, Greek, signifying Evening-because they do not discharge their perfume until the evening, reserving their fragrance for vesper hours.

The Rocket was deemed sacred to Priapus, the god who presided over gardens and orchards. One of its reputed properties is, to raise the passions and to excite love.

The Hesperis Matronalis, Queen's Gilly-flower, or Purple Dame's Violet, has pale purple flowers, very abundant, exhaling, only in the evening, a very sweet perfume like that 
of a pink or stock. Leaves ovate, lanceolate, finely toothed; calyx of four leaflets, cohering, longitudinally, incumbent at the top, opening at the bottom, deciduous, having two of its leaves gibbous at the base; corolla of four cruciform, oblong petals, bent obliquely, with attenuated claws, the length of the calyx. The whole plant clothed with short hairs. There is a variety with white flowers,

That keep

Their odour to themselves all day;

But when the sun-light dies away,

Let the delicious secret out

'To every breeze that roams about.

Moore.

RAGGED ROBIN.

Lychnis. Flos Cuculi.

(For Lychnis, its generic name, see Scarlet Lychnis.)

Flos Cuculi, or Cuckoo-flower, Meadow Pink, Ragged Robin, is a species of Lychnis which has had the last witty name given to it, on account of the finely cut or ragged appearance of its petals. And Cuckoo-flower, in common with several other plants that blossom about the time this welcome and merry messenger of spring begins to sing.

The root is perennial; stem about eighteen inches high, with rough angles, viscid above; leaves narrow; panicles forked; corolla of five petals, in four deep linear segments; pink, very delicate, with a brown, angular, smooth calyx of one leaf. There is a double variety, as also a white one.

(For Ranunculus, see Butter-cup.)

ROCKET.

Hesperis inodora.

(See Queen's Rocket.)

Hesperis inodora, the common English garden Rocket, or scentless dame's violet, resembles the sweet-scented Italian Rocket $\boldsymbol{H}$.'Matronalis, in all except its fragrance. It is a biennial plant, which thrives well in fresh unmixed earth; stable litter does not suit it.

The English name Rocket, seems to haye come to us through the Lacin Eruca, which signifies canker-worm, as well as the name of this plant. And this may have been supposed applicable to it, from its often perishing, without any known or visible cause.

In rival pomp, see either rocket blow

Bright as the sun, or as the new-fallen snow.

Evans.

\section{ROSE.}

Rosa.

Rosa, derived, with most probability, from the Celtic ros, or rhos. De Theis remarks, that the Celtic rhodd or rhudd, red, is the primary root of these words, the rose colour being almost synonymous with redness.

The Rose was consecrated to Venus: and, according to ancient fable, to her may be traced the red colour of the rose. When flying to the relief of her beloved Adonis, a thorn pierced her delicate foot, causing the blood to flow.
Which, on the white rose, being shed, Made it for ever after red.

Herrick.

Its beautiful tint is poetically traced to another source, by a modern poet:

As erst, in Eden's blissful bowers,

Young Eve survey'd her countless flowers,

An opening Rose of purest white,

She mark'd with eye that beam'd delight,

Its leaves she kiss'd, and straight it drew

From beauty's lip the vermil hue.

J. Carey.

Since first it bloomed in Eden's bowers, The Rose is termed the quecn of flowers.

Balfour.

Their smell divine, their colour strangely red.

Coroley.

Its breath

Is rich beyond the rest; and when it dies

It doth bequeath a charm to sweeten death.

Flood of Thessaly. G. of Flora.

The genus is too extensive for an attempt at description, in detail, and I find it necessary to suppress the appropriate notice of each, in their turn, of those before me; confining myself to only a few of the most interesting species. Among these I cannot forbear to notice the Moss Rose, if only for the purpose of introducing the fanciful origin of its pre-eminence in beauty.

The Angel of the flowers one day,

Beneath a Rose Tree sleeping lay;

That spirit, to whose charge is given,

To bathe young buds in dews from Heaven:

Awaking from his light repose,

The angel whispered to the Rose,

"Oh! fondest object of my care,

Still fairest found where all are fair,

For the sweet shade thou'st given to me,

Ask what thou wilt, 'tis granted thee."

"Then," said the Rose, with deepening glow,

"On me another grace bestow:"

The spirit paused, in silent thought, -

What grace was there that flower had not?

'Twas but a moment-o'er the Rose,

A veil of Moss the Angel throws;

And, robed in Nature's simplest weed,

Could there a flower that Rose exceed?

Monthly Anthology. G. of Flora.

There is another strongly marked variety in the Thornless Rose.-Lemaistre, in his touching tale of the "Leper of Aost," tells us that the thorns are produced by cultivation-this is, I believe, contrary to the received opinion:his theory, however, naturally suggested the emblem of ingratitude, which has been adopted. This too, it must be confessed, is a wide departure from the ideas usually asso- 
ciated with a rose without $a$ thorn, which would more naturally present the image of happiness without alloy.

In the "Legend of the Rose," we find another account of the armour by which this plant is defended:

Young Love, rambling through the wood,

Found me in my solitude-

Bright with dew, and freshly blown,

And trembling to the Zephyr's sighs;

But as he stooped to gaze upon

The living gem, with raptured eyes,

It chanced a Bee was busy there,

Searching for its fragrant fare;

And Cupid, stooping, too, to sip,

The angry insect stung his lip-

And gushing from the ambrosial cell,

One bright drop on my bosom fell.

Weeping, to his Mother he

Told the tale of treachery;

And she, her vengeful Boy to please,

Strung his bow with captive Bees;

But placed upon my slender stem

The poisoned stings she plucked from them;

And none since that eventful morn,

Have found the flower without a Thorn.

The origin of the red and white Rose becoming the badges of the two houses of York and Lancaster, is beautifully presented to us by Shakspeare, in his " Henry the Sixth." The white, being selected by the York faction, the red, by that of Lancaster.

Plantagenet. Since you are tongue-ty'd, and so loath to speak,

In dumb significants proclaim your thoughts:

Let him, that is a true-born gentleman,

And stands upon the honour of his birth,

If he supposes that I have pleaded truth,

From off this briar pluck a white rose with me.

Somerset. Let him that is no coward, nor no flatterer, But dare maintain the party of the truth,

Pluck a red rose from this thorn with me.

The subsequent blending of their interests, and union of the two houses, is prettily typified in the colouring of the York and Lancaster Rose. Whilst its specific appellation will always bring to recollection the vars which their contentions gave rise to.

We find in ancient lore, the Rose was made the symbol of silence, and consecrated by Cupid to Harpocrates, the God of silence.

The proverbial expression "under the Rose," arose no doubt from the two badges of the houses of York and Lancaster. These factions were continually plotting and counterplotting against each other. And when a matter of vital interest to either party was communicated to his friend in the same quarrel, it was natural for him to add, that he said it under the rose; meaning that, as it concerned the faction, it was religiously to be kept secret.

Sub rosa (under the rose) has, by some, been traced to the ancient custom in Symposiac* meetings, of the attendants wearing chaplets of roses about their heads.

The Rose is too well known to require a botanical description, which could only apply to the single rose; only remarking that it has but five petals; with an urceolate, or pitcher-shaped calyx.

The Bridal Rose, Rubus Rosæfolius, or Rose-leaved Bramble, is of the genus Rubus, which includes all the Bramble family. It has beautiful, double, white flowers, rather smaller than those of the Cinnamon Rose; slender round stems: prickles somewhat hooked, small. Leaflets usually seven, ovate-lanceolate, doubly serrated. It agrecs altogether in the class and order, as designated for the Rose in the Glossary. It is a rose usually cultivated in greenhouses-first patronised in England by Sir Joseph Banks. Its native country not known.

\section{ROSE CAMPION. Agrostemma.}

Agrostemma, L. from the Greek areou $5 \sigma \mu \mu x$, the garland of the field. A genus scarcely distinct from the Lychnis.

There are four species designated; one is the Corn-Campion, or Cockle, $A$. Githago, which is hirsute or hairy, with a calyx longer than the corolla, petals entire, or slightly emarginate, and naked.

A. Coronaria, or Rose Campion, is a biennial plant, with rose, or flesh-coloured, or white flowers, sometimes doubled, tomentose, with leaves ovate-lanceolate. The petals of the corolla slightly emarginate, crowned, and serrate. This species is usually cultivated in gardens.

\section{ROSEMARY.}

\section{Rosmarinus.}

Rosmarinus, from ros, dew, and marinus, alluding to its situation on the sea shore. Those who have observed it mantling the rocks of the Mediterranean, with its grey flowers glittering with dewo in Winter, cannot but be struck with the elegant propriety of the name.

Rosmarinus, sea-rose.-Webster.

The flowers of the garden Rosemary, $\boldsymbol{R}$. officinalis, are of a bright blue colour, variegated with purple and white, having, like the leaves, a strong aromatic fragrance.

It is an crect evergreen shrub, about four feet high, much branched, downy, leafy on all sides. Leaves opposite, spreading in a recurved manner, linear-oblong, obtuse, revolute, entire; smooth, dark green, and shining above, downy and veined beneath. Flowers axillary, terminal, on very short stalks, erect.

* Symposiac, from the Greek $\Sigma_{\cup \mu \pi r \sigma \triangleleft s,}$ a drinking together; ouv together, and $\pi i v \omega$ to drink.

Symposiac, a conference or conversation of philosophers at a banquet.-Plutarch has niue books, which he calls Symposiacs; or symposiac questions, q. d. disputations at table. Webster and Rees. 
From an old opinion of Rosemary-juice having the property of strengthening the memory, this plant has been poetically made the emblem of Remembrance, or Fidelity; and this was probably the origin of its being worn or used at funerals, and weddings.

There's rosemary, that's for remembrance;

Pray you, love, remember; and there is pansies,

That's for thoughts.

Shaks.

And the humble rosemary,

Whose sweets so thanklessly are shed

To scent the desert, and the dead.

Lalla Rookh.

Reverend Sirs,

For you there's rosemary and rue: these keep

Seeming, and savour, all the winter long:

Grace, and remembrance, be to you both.

Shaks.

\section{RUE.}

Ruta

Ruta, an ancient Latin name derived from the Greek ¡vw, to flow, in allusion to some reputed expelling qualities of the plant.

Rue, E. a contracted word, and so named from its bitter taste. Sax. reovian, hreovoian; Welsh rhuaw; Dutch rouven; Ger. reun, to repent. Greek ęry, from ģvs.

Johnson tells us, it was called Herb of Grace, because holy water was sprinkled with it. Jeremy Taylor says of it, "They (the Romish exorcists) are to try the Devil by holy water, incense, sulphur, rue, and from thence, as is supposed, it received the appellation of Herb of Grace."

\section{What savery is better}

For places infected, than wormwood and rue.

Tusser.

The Weasel, to encounter the serpent, arms herself with eatung rue.

[See Johnson.

There's fennel for you, and columbines:

There's rue for you: and here's some for me:-

We may call it herb of grace, $o$ ' Sundays: you

May wear yeur rue with a difference. There's a

Daisy:-I would give you some violets, but they

Wither'd all, when my father died.

Shaks.

Here did she drop a tear; here in this place

I'll set a bank of rue, sour herb of grace.

Same.

Common Rue, Ruta graveolens, is a hardy shrub, cultivated, time out of mind, in every garden. The whole herb has a peculiarly acrid, pungent smell, supposed, powerfully, to prevent contagion. The bruised leaves excoriate the lips if incautiously applied to them. The stem is busby, smooth. Leaves alternate, twice or thrice compounded, smoeth, of a deep bluish glaucous hue; their leaflets obleng, entire, tapering at the base. Flowors of rather a dull yellow; copious, interminal, corymbose panicles.
SAGE.

Salvia.

Salvia, an ancient Latin name, supposed to allude to the salubrious qualities of the plant-perhaps from the $\mathbf{I}$. verb salve, God save you, or the adv. salve, well in health.

Sage was supposed by the ancients to possess the virtue of prolonging human life; hence the following line:

"Cur moriatur homo, cui salvia crescit in horto?" "How can a man die, in whose garden there grows sage?"

The common garden Sage, salvia afficinalis, is a plant as well known to the simple, as the wise. Its agreeable aromatic bitter, forms a component part in almost all culinary preparations: and for its medicinal virtues, it has been ever held in great esteem by all domestic practitioners. An infusion of the leaves, in the form of tea, is considered particn. larly serviceable to persons of cold phlegmatic habits, labouring under nervous debility. And with the addition of a little lemon juice and sugar, is a grateful drink in febrile disorders.

"Marbled with sage the hard'ning cheese she press'd."

Gay.

Locke tells us that "by the colour, figure, taste, and smell, we have as clear ideas of sage, and hemlock, as we have of a circle."

Its flowers are bluish, an inch long, with a brewn viscid calyx of one leaf, somewhat bell-shaped, two-lipped. Corolla ringent.

\section{SCABIOUS.}

Scabiosa.

Scabiosa, derived from scaber, rough, because of the roughness usual in these herbs, and especially of the scaly harshness of their heads of flowers.

One of the species, S. atro-purpurea, swect, or musky, scabious, has been long cultivated in gardens. Its native country unknown. Its flowers are very sweet, and there is a great variety in their colour, some being of a purple, appreaching to black, others of a pale purple, red, variegated, etc. It also varies in the leaves, some being finer cut than others.

The dark purple has been popularly called "the mourning bride."

\section{SCARLET LYCHNIS.}

Iychnis chalcedonica.

Iychnis, L. from the Gr. $\lambda v \chi_{v i s}$, derived from $\lambda v \chi_{v o s}$, a lamp. Some have supposed that the appellation arose from the down of the plant having been used to make wicks of lamps.

The most probable and apparent explanation of the name, is, from the resemblance of the calyx of some of the species to a lanthorn, its sides being semi-transparent between the ribs or veins, or the whole, in some instances, quite membranous, round, and inflated, like the horn lanthorns still used by the Chinese. The appearance of the stigmas, stamens, or crown of the corolla, in several species, would favour the idea of a lamp with a flame. 
The addition of Chalcedonica may possibly be derived from Chalcedon, a city of Bithynia, on the Asiatic coast of the Black Sea, over against Constantinople.

Gerard tells us the flower in question was called "Flower of Constantinople, and Campion of Constantinople." He also calls it Lychnis Chalcedonica.

Lychnis was formerly used by botanists for all the Campion tribe, though now restricted by Linnæus and his followers to one particular genus of that family.

The $L$. chalcedonica, is said to grow wild in all parts of Russia and Siberia. It is one of the chief ornaments of modern flower gardens. A hardy perennial, very showy, and remarkable for the rich vivid scarlet of its blossoms, especially when double. These appear about June, forming a large, dense, convex, terminal tuft, two or three inches wide, with flowers of five petals, border flat, wedge-shaped, often divided. Caly $x$ perianth inferior, of one leaf, oblong, tubular, membranous, five toothed, permanent. Seeds somewhat kidney-shaped, roughish. The stem is several feet high, round, hairy, leafy, but little branched. Leaves ovate, rough, somewhat undulated.

\section{SNAP DRAGON. Antirrhinum.}

Antirrhinum, from the Greek wrt، (L. æqualis,) equal, and $\varrho_{\text {*v }}$ (L. nasus, ) a nose. Equalis defined by Ainsworth, (2) "of the same shape, or stature, as another."

On pressing the sides of this flower, it opens like a gaping mouth, the stigma appearing to represent the tongue; on removing the pressure, the lips of the corolla snap together, and hence its name. Some have traced a resemblance to a calf's snout in the form of its seed vessel, or fruit.

The monopetalous corolla forms a mask, which resembles the face of an animal.

There are many American species, of various colours. The Calyx is a five-leafed perianth, permanent. Corolla nectariferous, ringent. Nectary at the base of the corolla, produced downwards, prominent.

\section{SNOW BALI.}

\section{Viburnum.}

\section{(See Laurustinus.)}

Tiburnum Opulus, Common Guelder-rose, Water Elder, or Snow Ball, is an European shrub, or small tree, smooth in all its parts, only the backs of the leaves being occasionally downy. Their three lobes are unequally toothed or serrated. Their foot-stalks bear towards the top, several cuplike glands, and towards the base, a pair or two of linear stipules. Cymes large, smooth, stalked, of numerous white flowers. Berries scarlet. A variety with globose cymes, composed entirely of radiant flowers, is commonly cultivated in gardens.

Here the Guelder-rose shall fling

Silver treasures to the spring.

L. E. L.

Her silver globes, light as the foamy surf,

That the wind severs from the broken wave.
The balls that hang like drifted snow, Upon the guelder-rose.

Landon.

\section{SNOW DROP. \\ Galanthus.}

Galanthus, L. from the Greek rosos, milk, and av 905 , a flower; alluding to its milky whiteness.

The G. nivalis, or common Snow Drop, is the only species noticed in this genus. It has two varieties, the semidouble and double flowered. An European plant. It is the first flower that appears after the winter solstice.

Warm with sweet blushes, bright Galantha glows, And prints, with frolic step, the melting snows.

Chides with her dulcet voice the tardy spring, Bids slumbering Zephyr stretch his folded wing.

Darwin.

Fair handed spring unbosoms every grace,

Throws out the Snow-drop and the crocus first.

Thomson.

As Flora's breath, by some transforming power,

Had changed an icicle into a flower,

Its name, and hue, the scentless plant retains,

And winter lingers in its icy veins.

Mrs. Barbauld.

Calyx, a spatha, opening at the flat side, permanent. Corolla of six petals, the three innermost shortest, emarginate. Bulbous rooted.

\section{SORREL.}

Oxalis.

Oxalis, L. from the Gr. ॰ ॰ $_{\text {us }}$, sour; a name adopted from the Greeks; whose oxalis, however, is probably the acetosa of the Latins, and belongs to the genus rumex.

Skinner derives the name sarrel from the word sour. And both the oxalis and rumex have species noted for the peculiar and grateful acid of their leaves; the plants are designated as the wild sorrel, (oxalis,) and garden sorrel, (rumex,) the latter much used in French cookery, the former admired for the delicate beauty of its flowers.

Thirteen species of the curious and pretty genus Oxalis, are natives of America; many of the Cape of Good Hope; only two of Great Britain.

The Calyx is a perianth of five leaves. Corolla of five petals connected by their claws, obvate, obtuse, emarginate, spreading. Seeds with an elastic tunic of two valves. Leaves generally ternate, or three-leafed. Some varieties have twin leaves, others simple leaves.

The species most abundant in Virginia have pink or lilac flowers variously shaded-sometimes a bright yellow: farther north it is found of a pale yellow, delicately pencilled with crimson, or a pure white, pencilled with pink or purple.

See trim oxalis with her pencilled flower.

Evans.

In woodland bowers,

There spring the sorrel's veined leaves.

Charlotte Smith 


\section{SPEEDWELL.}

Veronica.

(For Veronica, see Belvidere.)

Many of the species are peculiarly beantiful. Flowers, generally blue, some a pale pink.

The $V$. Virginica, Virginian Speedwell, has clusters obscurely whorled, with nearly sessile flowers. Tube of the monopetalous five cleft coroll $\alpha$, twice as long as the five cleft calyx. Leaves, four or five in a whorl, elliptic-lanceolate, stalked; perennial. Spikes long, white or blush-coloured.

There is a purple flowered variety, extremely beautiful, to be found on the mountains of Virginia.

\section{SPIDER WORT.}

Tradescanti. Virginica.

(See American Star Wort.)

Called Tradescanti, after the two Tradescants, futher and son.

The Spider Wort, $T$. Virginica, the original species of this genus, was carried from Virginia to Europe by the younger Tradescant, before the year 1629, as appears by Parkinson's Paradisus. It is common from Pennsylvania to Carolina, in shady woods. It has long fibrous roots. Stems about eighteen inches high, round, leafy, scarcely branched. Leaves lanceolate, smooth, sheathing, concave, taperingpointed, of a dark shining green. Flowers large, of a rich violet blue, each lasting but a day, or rather a few hours in the early part of the day, after which they roll up into a liquifying pulpy mass; but there being a great number in each umbel, or tuft, there is a long succession.

The Flower has a calyx of three leaves, permanent and spreading. Corolla of three petals, ovate, flat, widely spreading, their claws sometimes combined. The six golden anthers are brilliantly contrasted with the dark purple shaggy filaments. It is a perennial plant, blooming throughout the summer.

\section{STAR OF BETHLEHEM. Ornithogalum.}

Ornithogalum, L. from the Gr. ogvas, oẹvi9os, a bird, and $\gamma \approx \lambda_{\alpha}$, milk. But the application has proved a stumblingblock to most etymologists.

The Flora Historica, tells us, that this bulbous-rooted flower received the reverential title of Star of Bethlehem, from the formation of its corolla.

It is an extensive genus, the essential character of which is a coroll $\alpha$ of six petals, erect, permanent, their upper part spreading. No calyx.

\section{ST. JOHN'S WORT. Hypericum.}

Hypericum. Linnæus deduces the name from the Greek $\mathbf{r}_{\text {re }}$, above, and Eเxoy, a figure or image. Boerhave says, " $\}_{\pi \sharp \ell-s t \times o v}(\mathrm{Gr}$.) quasi herba, cujus imago eminet."

Native of America-Europe-China, etc. a copious and handsome genus. The stems either shrubby or herbaceous, usually angular. Roots perennial. Leaves simple, opposite, sessile, entire. Herbage generally smooth, with glandular pellucid dots, and an aromatic scent. Flowers terminal, cymose, yellow and brilliant. Calyx often fringed. Generally five petals, oblong-ovate, obtuse, spreading.

\section{STRAWBERRY TREE.}

\section{Arbutus.}

Arbutus, a Latin name given to a kind of wild Strawberry or Cherry tree, bearing fruit so sour, that Pliny calls them unedones, because one of them is enough at a time.

[See Ainsworth.

Strawberry, E. from straw and berry;-perhaps from the practice of placing straw under the berries, or fruit, whilst ripening, to keep them clear of the soil.

Horne Took considers strawberry, as straw'd-berry, from straw, or strew, from the manner in which the plants are set in beds, not cast in heaps, but, as it were, strewed here and there, at manifest distances.

Several species of the Arbutus are natives of America, abundant in our swamps.

The berries of the $A$. Thymifolia, or Thyme-leafed Arbutus, are brought to the Philadelplia market late in Autumn, and used for tarts. Considerable quantities of them are exported to Europe and the West Indies-they are much used in London, though thought to be inferior to the cranberry of British growth.

The Ess. Char. a Calyx five-parted. Corolla, ovate, diaphanous at the base.

\section{SUMACH. \\ Rhus.}

Rhus - of doubtful origin. De Theis deduces it from the Celtic rhudd or mub, red. The fruit of some of the species justifies this derivation, those particularly most common in the United States, as the Rhus glabrum, smooth Sumach. Neglected corn-fields are soon overrun with this tree, whose roots subsequently render ploughing very difficult. Its leaves consist of from eight to twelve pair of longish taper-pointed leaflets, smooth and naked on both sides. Fruit, a globular crimson, berry, slightly hisped, the size of an Elder berry. And the Rhus viridiflorum, green-flowered Sumach, growing on the edges of woods, in dry sunny situations in Pennsylvania and Virginia. The flowers are of a yellowish-green. Leaves numerously pinnate, ovate-lanceolate, serrated, glaucous, and somewhat downy beneath, though not always so.

According to Medical books, the Rhus copallinum, Lentiscus-leafed Sumach, (called by Dr. Ewell common sumach, berries red, and very acid, is a valuable plant. An infusion of the berries, sweetened with honey, forms an excellent gargle for sore throats, or to cleanse the mouth in putrid fevers. The bark of the root is considered one of the best antiseptics produced by vegetation, and forms an important ingredient in decoctions for hectic, and scrofulous diseases.

Some of the species of this genus are celebrated for producing valuable resins for varnish, as the $R$. Vernix, Varnish Sumach, found in low copses, from Canada to Carolina; the whole tree very smooth. Leaflets about six pair with one odd one; elliptical, entire, somewhat abrupt, pointed. Flowers diæcious. Berrics, the size of a pea, white and remarkably polished, both in a fresh and dry state. 
Others, from their caustic nature, have acquired the name of Poison trees, as the Dwarf Carolina Sumach, Rhus Pumilum, stem not above a foot high. Leaves numerously pinnate, oval, scarcely pointed, deeply toothed, downy beneath. Branches, and foot-stalks downy. Fruit clothed with a velvet down.

The R. Toxicodendron, Trailing Poison-Oak, or Sumach, common in woods, fields, and hedges, from Carolina to Georgia, is a very pernicious plant. Stem creeping, never erect, but when it meets with support, will climb like ivy to the tops of the highest trees. Leaves ternate, the leaflets are of a broad, ovate, or rhomboidal form, pointed, always more or less downy, at least about the ribs; crenate, cut, or lobed. Flowers in compound axillary clusters, greenish, diæcious. Berries white.

The Rhus cotinus, or Venice Sumach, cultivated in gardens, is much admired for the very singular and ornamental appearance of its elongated feathery fruit-stalks. The shrub grows to about the height of a man, bushy. Leaves smonth, orbicular, entire. Flowers greenish, or purplish, small, in terminal compound panicles. Fruit gibbous. The leaves and stalks, when bruised, have an aromatic but pungent and acid odour. The whole plant is used in Italy for tanning-as are the different species of this genus in other countries.

\section{SUN FLOWER. \\ Helianthus.}

Helianthus, L. derived from the Gr. $\eta \lambda \cdot 05$, the sun, and avos, a flower. The name applied, no doubt, from the resemblance which its broad golden disk and ray bear to the San.

The power ascribed to it of constantly presenting its flowers to that luminary, renders it quite appropriate. But there are many other plants which possess this power in a higher degree. This property, where it is eminently conspicuous, has been poetically construed into a sort of sympathy or perception in the plant, like that of the ancient Heliotrope. (See Note upon that Flower.)

The $H$. indicus, Dwarf annual Sun-flower, is a diminutive species, now much cultivated.

The $\boldsymbol{H}$. annuus, or annual Sun flower, was the first discovered, and the largest species. A native of Mexico and Peru. On account of its resemblance to the Sun, it was used in the religious ceremonies of the ancient Peruvians, who worshipped that luminary. The virgins, who officiated in the Temple of the Sun, were crowned with the Helianthus made of pure gold, and wearing them, also, in their breast, and carrying others in their hands, which reflecting the rays of their deity by the brilliancy of the metal, formed an effect of the most imposing grandeur.

In its native country, it is said to grow to the height of twenty feet or more, and the flowers to be about two feet broad.

\section{Great Helianthus}

Climbs the upland lawn,

And bows, in homage, to the rising dawn;
Imbibes, with eagle eye, the golden ray,

And watches, as it moves, the orb of day.

Darroin.

Helianthus, like the God of day,

Binds round his nodding disk the golden ray.

Uplift, proud Sun-flower, to thy favourite orb,

That disk whereon his brightness seems to dwell,

And as thou seem'st his radiance to absorb,

Proclaim thyself the garden's sentinel.

B. Barton.

The $H$. Tuberosus, tuberous-rooted Helianthus, or Je rusalem Artichoke, is a native of Peru. Now much cultivated in kitchen gardens, for the sake of its roots, which, when boiled, have the flavour of the real Artichoke.

There are many species of the Helianthus, eleven of which belong to America. Their general character is a calyx imbricated, somewhat squarrose. Receptacle chaffy, flat, seed-crown of two leaves. Corolla compound, radiated; florets of the disk, very numerous, perfect, cylindrical, shorter than the common calyx. Most of them are perennial herbaceous, with large, alternate, heart-shaped, or ovate leaves. Stalks roughish.

\section{SWEET BRIAR.}

\section{Rosa Suaveolens.}

(For Rosa, see Rose.)

Suaveolens, Lat. sweet-smelling.

Rosa Suaveolens, is the American Sweet Briar. Flowers pale pink, small, often, but not always solitary. Foliage delightfully fragrant.

The wild-briar rose, a fragrant cup,

To hold the morning's tear.

Landon.

Yet, Iovely flower, I find in thee

Wild sweetness which no words express,

And charms in thy simplicity,

That dwell not in the pride of dress. John Langhorn. Fables of Flora.

\section{SWEET WILLIAM.}

Dianthus Barbatus.

(For Dianthus, see Carnation or Pink.)

The Sweet William, D. barbatus, is a species of I'ink, indigenous to Germany. The Dutch formerly gare it the name of Keykens, which is their familiar name for a nosegay or a large bunch of flowers.-One stem supporting a large and brilliant bunch of blossoms.

This species of Dianthus has been named Barbatus, from the hairy or pointed scales of the calyx, which is ovate awl-shaped, of one leaf. Flovers aggregate, in separate bundles. Leaves lanceolate. A hardy perennial plant, thriving best, in a dry calcareous soil.

Sweet William has a form and aspect bright, Like that sweet flower that yields great Jove delight; 
Had he majestic bulk, he'd now be styled Jove's flower; and if my skill is not beguiled, He was Jove's flower when Jove was but a child.

Take him with many flowers, in one, conferr'd,

He's worthy Jove, e'en now he has a beard.

Covoley.

\section{SYRINGA CAROLINA.}

Philadelphus inodorus.

(For Philadelphus, see Mock-Orange.)

The name Syringa, which Tournefort retained for this shrub, originated in a confusion of ideas. It equally belongs to the Lilac; is of Moorish origin, and supposed to be derived from the Greek ougry young branches of Lilac are used in Africa and the Levant for tobacco pipes. - See Lilac.

Those of Philadelphus are, also, reported to serve the same purpose.

The $P$. Inodorus, Carolina, scentless Mock-Orange, rises with a shrubby stalk, sometimes to the height of sixteen feet. Leaves shaped like those of a pear tree, entire, opposite, on pretty long foot-stalks. The Flowers are produced at the ends of the branches, large, inodorus, with four white oval petals, spreading open. Calyx large, composed of four acute-pointed leaflets.

The sweet Syringa yields but in scent

To the rich orange.

Mason.

\section{THISTLE.}

\section{Carduus.}

Carduus, said to be derived from caro, a technical verb denoting the operation of cleaning wool from its impurities.

Ainsworth defines caro, to card, to tease or card wool.

Carduus, is a name given by the ancients to several kinds of prickly plants, particularly to the Teasel, Dipsacus fullonum, also called Carduus fullonum, or Fuller's Thistle, formerly used in carding wool, as it is still in dressing cloths.

Thistle, English-Diestel, Dutch-a prickly weed growing in fields.

[See Johnson.]

Tough Thistle chock'd the fields, and kill'd the corn, And an unthrifty crop of weeds was born.

Dryden.

The roots of Thistle have my hunger fed, Two roods of cultur'd barley give me bread, A rock my pillow, and green moss my bed.

Harte.

Widc o'er the Thistle lawn, as swells the breeze,

A whitening shower of regetable down

Amusive floats.

Thomson.

In Scotland, the order of St. Andrew, or the Thistle, was instituted by Achaius, one of their kings, to preserve the memory of the famous league, offensive, and defensive, entered into between himself and Charlemagne, king of France. The tressure* of Fleur de lys was added to the

* Tressure, in heraldry, is a kind of border.

The arms are a lion, with a border, or tressure, adorned with flower-de-luces.
Lion, the then royal arms of Scotland, and their king took for his device the Thistle and Rue, which he composed into a collar of his order: his motto "Pour ma Defence." To this collar was hung a jewel, the figure of St. Andrew bearing his cross.

Triumphant be the Thistle still unfurl'd, Dear symbol wild! on freedom's hills it grows, Where Fingal stemmed the tyrants of the world, And Roman eagles found unconquered foes.

Campbell.

\section{THORN APPLE.}

Datura.

Datura, from do dare, daturus, Latin for to give, to bestoro, which will give, etc., because it is given as a stimulant. This is the only explanation of the name, that the etymologists give of it, at least such is given in the Encyclopedia.

The Flora Historica tells us, that the generic name of Datura is the original name by which it was received from the Turks; and that it is called Thorn Apple from the nature of its fruit, which is prickly.

De Theis derives Datura from Datorah, or Tatorah, the Arabic name of the plant.

It appears to have been carried from Perc through the East Indies and Persia to Europe. The seed was brought from Constantinople by Lord Edward Zouch, who gave it to Gerard, in the reign of Queen Elizabeth, and was much used in medicine. It is a powerful narcotic.

Their powers mysterious let thy knowledge shift,

Their useful poisons, and their healing gift. De Lille.

Skinner suggests that the word thorn probably comes from the Saxon verb tæran, to tear.

The D. Stramonium, Thorn Apple, or James-Town Weed, is a dangerous plant to be allowed to grow where there are children, as the beauty of its flowers and fruit tempts them to their destruction. There are several beautiful varieties of this genus. The $D$, arborea of Peru is the most splendid of all-each flower being often two feet in length, and sometimes $\mathbf{1 5 0}$ open at the same time on the tree.

The Datura Stramonium is said to liave received the name of James-Town Weed from the circumstance of a number of Sailors having been made violently ill from eating the boiled plant at James-Town, in the first settlement of Virginia.

The flowers of Datura have a calyx of one leaf, inferior, tubular, five-angled, five-toothed, partly deciduous, Corolla monopetalous, funnel-shaped, plaited. There is a singular provision of nature obscrved in these flowers, to protect them from the humidity of the night air, the leaves nearest the flowers rise up so as to enclose them and form a complete shelter.

\section{THYME.}

Thymus.

Thymus, from the Greek Iviv , which Schrevelius trans- 
lates by the Latin verb suffio, and this latter verb Ainsworth explains by the verb to perfume. Ainsworth gives the same etymology of the word thymum or thymus, Thyme.

To enter into a minute description of this plant, would be certainly time thrown away, both in the writer and the reader.

T. vulgaris, or garden Thyme, has been known in all time and to all persons. There are many varieties of the genus, too tedious to enumerate. The wild thyme has often been noticed by the Poets:-

No more, my goats, shall I behold you climb

The steepy cliffs, or crop the flow'ry thyme.

Dryden's Virgil.

Guide my way

Through fair Lyceum's walk, the green retreats

Of Academus, and the thymy vale. Akenside.

\section{TUBEROSE.}

\section{Polyanthes tuberosa.}

Polyanthes, a name given by Linnæus, and we must therefore accept his own explanation of it, which is-

From two Greek words $\Pi_{0} \lambda_{4 \xi}$, a town, and Av9os, a flowser, because this plant is generally cultivated, and sold in towons, for the sake of its elegance and fragrance.

The French know it by the name of Tubereuse-the English call it Tuberose-both words taken from the Latin appellation which it first obtained of Hyacinthus tuberosus.

Some write it Polyanthes, as Linnaus originally printed the generic name; and suppose the etymology to be from a Greek word roגus, many.

Tuberose, originated in the old appellation of Tuberous Hyacinth, Hyacinthus tuberosus, alluding to the tuberous root, and the resemblance of the flower to a Hyacinth.

It is usually supposed to be a native of the East Indies. More recently, it has been believed to have come from South America.

The colour of the flower is white, sometimes tinged with a blush of pink; its odour rich and delicious, most powerful at night, resembling the flavour of ginger, with great sweetness, several in a terminal, oblong, bracteated spike. No Calyx. Corolla monopetalous, funnel-shaped, incurved; its limb in six equal segments. Leaves scattered, linearlanceolate, taper-pointed, sheathing, smooth, pale, and rather glaucous, Stem simple, erect, round, lenfy, sometimes a yard or more in height. Root perennial, tuberous, somewhat creeping.

Eternal spring, with smiling verdure here, Warms the mild air, and crowns the youthful year; The tuberose ever breathes, and violets blow. Garth.

The tube-rose, with ber silvery light,

That in the gardens of Malay

Is call'd the mistress of the night,

So like a bride, scented and bright,

She comes out when the sun's away.

\section{TULIP.}

Tulipa.

Tulipa, an acknowledged barbarous name, said to be of Persian origin, and to signify a turban. Nor is this article of dress, in a Persian of rank, unlike the swelling form of a tulip.

It is supposed to have been brought from Persia to the Levant. So late as the year 1554, the Turks charged a high price for these flowers, which would not have been the case had the Tulip been then growing spontaneously in that country. Pliny makes no mention of the Tulip, which is corroborative of this inference.

Moore alludes to the similarity of the tulip to the turban, in his "Veiled Prophet."

"What triumph crowds the rich Divan to-day,

With turban'd heads, of every hue and race,

Bowing before that veil'd and awful face,

Like tulip-beds, of different shape and dyes,

Bending beneath th' invisible west-wind's sighs."

Skinner gives the same etymology as the above, and says that the tulip is the "lily of Solomon."

What in conmon language is called a bulbous-root, is by Linnæus termed the hybernacle, or winter-lodge of the young plant. As these bulbs in every respect resemble buds, except in their being produced under ground, and include the leaves and flowers in miniature, which are to be expanded in the ensuing spring. By the careful dissection of a tulip root during the winter, cautiously cutting through the concentric coats, longitudinally from the top to the base, and taking them off successively, the whole flower of the next summer's tulip is beautifully seen by the naked eye, with its petals, pistil, and stamens.

The method of making a tulip variegated, or striped with divers colours, is by transplanting from a rich soil to one meagre and sandy. The plant is weakened when this effect is produced, and loses almost half its height. [See Darwin.

And sure more lovely to behold Might nothing meet the wistful eye,

Than crimson fading into gold, In streaks of fairest symmetry. Dr. John Langhorn. Fables of Flora.

The Tulip has no calyx. Corolla bell-shaped, of six petals, ovate-oblong, concave, erect, deciduous, inferior. Seeds numerous. The eommon garden tulip is called $\boldsymbol{T}$. Gesneriana. Native of the country bordering on Mount Cancasus. In a wild state, the petals are crimson, yellowish at the base-now called the parrot tulip.

There are three species of this Tulip, the Cappadocia, Turkey, and Gesneriana. The last, named after the great Conrad Gesner, mentioned in the note on Poppy, and it is distinguished from the others, by its pubescent scape, spreading sweet-scented corolla, smallness of its size, and early flowering.

The Tulip is made the emblem by which an oriental lover makes a declaration of love-presenting the idea,

Lalla Rookh. 
that like that flower, he nas a countenance all on fire, and a heart reduced to a coal.

"Whose leaves, with their ruby glow,

Hide the heart that lies burning and black below."

\section{TULIP TREE}

\section{Liriodendron Tulipifera.}

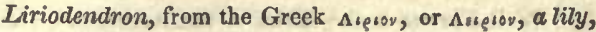
and sayseov; a tree; the Tulip-tree. The Encyclopedia has it Liriodendrum,-Nuttall, and other Botanists, write it Liriodendron.

The $L$. Tulipifera, American Tulip-tree, or yellow Poplar, bears flowers resembling a small tulip, variegated with pale green, yellow, and orange-standing solitary at the end of the buds of the branches. The flowers have a calyx of three leaves, inferior. Corolla, bell-shaped, of six petals.

The young bark of this tree is very aromatic; and the remarkable shape of the leaves cannot fail to strike the most careless observer; they seem as if cut off with scissors at the ends. The elliptical obtuse deciduous stipulas, which curiously enfold the young leaves, are also remarkable. The tree is celebrated for its size and beauty. Botanists indicate two varieties of it.

Our attention has lately been drawn to this tree by the public prints, which tell us, the root has been discovered to be a sovereign antidote to the venomous bite of snakes. The bark to be chipped from the root and made into a decoction; of which half a pint is to be drunk every half hour-the wound frequently bathed with the fluid, and the bark applied in the form of a poultice to the part.

Of this genus there are two other species in China, and one in the Mountains of Amboina.

\section{VENUS' LOOKING-GLASS.}

\section{Campanula speculum.}

Campanula, Latin, for a little bell.

Speculum, Looking-glass, a name bestowed upon it, as some suppose, on account of the glossy nature of the seeds; others, from the corollas seeming to reflect the rays of the sun.

The flowers are purple, inclining to violet, solitary. Calyx, perianth, superior, five-cleft, its segments the length of the corolla. Corolla, monopetalous, flat, wheel-shaped, deeply divided; segments egg-shaped; valves of the nectary scarcely discernible. Leaves sinall, sessile, oblong, slightly scolloped. Stem, from six to ten inches high. Root, annual. A native of corn-fields in the south of Europe, common in English gardens.

Towards evening the corollas fold up into a pentagonal figure, and open, again, with the rays of Aurora.

VERBENA, OR VERVAIN.

Verbena, De Theis derives it from the Celtic ferfaen, to remove; alluding to one of its supposed medicinal virtues.

Some derive verbena from verro, to sweep or cleanse. The Greeks called it the sacred hcrb-and it was with this plant alone that they cleaned the festival table of Jupiter, before any great solemnity took place.

Verbena, among the Romans, was the name of some evergreen aromatic shrub, esteemed sacred, and employed in various solemn ceremonies.

It was, also, one of those plants dedicated to Venus. $V$ enus the victorious, wore a crown of myrtle interwoven with vervain. The Roman Ambassadors, or heralds at arms, were crowned with vervain, when they went to denounce war.

A wreath of vervain heralds wear,

Amongst our gardens named,

Being sent the dreadful news to bear, Offensive war proclaimed.

Drayton.

From its reputed medicinal and divine properties, it was sometimes worn as an amulet around the neck; and the Romans, in the beginning of the year, made a present of this herb to their friends.

The common Verbena officinalis, grows wild in England-seldom found above a quarter of a mile from a house, which occasioned its being called simpler's joy, because it denoted a house to be near, for the relief of the weary traveller. This species is without fragrance.

The general character of the flower of the Verbena is a calyx with five teeth, inferior. Corolla, funnel-shaped, rather unequal, curved; limb spreading, cloven half way down into five, more or less, unequal rounded segments.

\section{VIOLET.}

Viola.

Viola, the common Latin name for Violet, etymology uncertain.

[See Rees' Cyclo.]

Violet, Latin, viola, is, by Ainsworth, derived from via, a way where men go: so, he says, the Greek for the Violet,

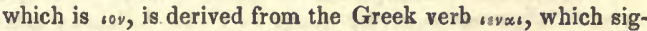
nifies to go: possibly, from its being found wild on road. sides.

Some etymologists trace the name of this flower to $I a$, danghter of Midas, who was changed by Diana into a Violet, to hide her from Apollo. And the beautiful modest blossom atill retains the bashful timidity of the nymph, partially concealing itself amidst its foliage, from the gaze of Phœbus.

The trembling violet, which eyes

The Sun but once, and unrepining dies.

H. Smith.

Another fabulous account of the violet, is that it sprung up on purpose to be the food of the metamorphosed Io, daughter of Inachus, who had been changed by Jupiter into a beautiful white heifer, but fed by Juno's order upon bitter herbs.

"On leaves of trees, and bitter herbs she fed."

Dryden's Ovid. 
The poetry, the romance, the scenery of every country, is embroidered with violets.

\section{Violets dim}

But sweeter than the lids of Juno's eyes Or Cytherea's breath.

Shaks.

It has a scent as though love, for its dower

Had on it all his odorous arrows tost;

For though the rose has more perfuming power,

The violet (haply 'cause 'tis almost lost,

And takes us so much trouble to discover)

Stands first with most, but always with a lover.

Corneall.

The prizes of the Floral Games of the Ancients, consisted of a golden violet.

And in that golden vase was set,

The prize-the golden violet.

Butler, in ridicule of love speeches, and, at the same time, in recognition of the lover's attachment to this flower, makes his hero, Hudibras, say to his mistress:

Where'er you tread your foot shall set

The primrose and the violet.

'The flower of the genus Viola, has a perianth inferior, short, permanent, of five ovate-oblong, erect leaves, extended at their base. Corolla of five petals, irregular, spurred behind, unequal. Nectary projecting betwixt the calyx leaves.

\section{VIRGIN'S BOWER.} Clematis. twig.

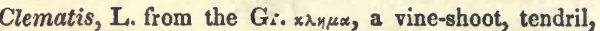

The flowers of this genus have no calyx. Petals four, five, or six, sometimes eight, oblong, lax, pubescent. Seeds tailed.

There are many species of them scattered over the globe; several indigenous to America.

The C. Cirrhosa, Evergreen Virgin's bower-called in England sometimes Traveller's joy, wild climber, bride's wreath, virgin's bower, etc. Is a native of Andalusia-quite hardy, first cultivated in England by Gerard, plants of which have stood more than fify years, in the Chelsea garden. It has white flowers, petals large, elliptical, pubescent on the outside. Peduncle, or flower-stalk, scarcely an inch long, lateral, axillary, one-flowered. Stem, woody, resembling that of the vine, sending out branches from every joint, which renders it a thick bus'ty plant. Leaves, on the same plant, both simple and ternate.

C. Viorna, native of Virginia and Carolina. Root perennial; has purple or bluish-violet flowers, petals with a whitish cottony border. Anthers terminated with a tuft of hairs. Leaves, compound and twice compound, opposite, petioled; leaflets from nine to twelve, three on each pinna, gencrally entire. Seeds with long plumose tails.

To late summer's fragrant breath

Clematis' feathery garlands dance.
And Virgin's-bover, trailing airily, With others of the sisterhood.

Keats.

WALL FLOWER. Cheiranthus.

(See Gilly Flower.)

Flower.

Cheiranthus, comprehends Gilly Flower, and Wall

Wall Flower is the Keiri of the Arabians. The modern name Cheiranthus, for wall-flower, and the stock, was given by Linnæus, who derived it from the Arabic.

C. Cheiri, named by Gerard, Yellow Stock, and Wall Gilly-flower, is one of the cruciform flowers, having only four petals, which expand in the form of a cross. The two principal varieties are the yellow, and the yellow and bloody. Numerous trivial varieties have arisen from these.

It is the flower with which the romance writers embellish all decaying embattlements, falling iowers, and monastic ruins; enlivening those relics of more prosperous times, by its gay foliage, and sweet perfume-fit emblem of "Fidelity in Misfortune."

The Wall-flower springs from the disjointed stones.

Greenwood.

To me it speaks of loveliness

That passes not with youth;

Of beauty which decay can bless, of constancy and truth.

But in adversity's dark hour When glory is gone by;

It then exerts its gentle power The scene to beautify.

B. Barton.

An emblem true thou art

Of love's enduring lustre, given

To cheer a lonely heart.

Same.

\section{WEEPING WILLOW.}

\section{Salix Babylonica.}

Salix, according to some etymologists, derived from salio, to rise or spring up. In allusion to the quick growth of these plants.

The Greek synonyme, means to go, because it grows fast. De Theis deduces salix from the Celtic sal, near, and lis, water; applicable to the ordinary situation of the Willow tribe. The Weeping Willow is usually planted near the water, over which its drooping foliage has an appropriate and picturesque effect, yet we are told that it thrives best in a dry gravelly soil, being then less apt to split or decay.

It received its name Salix Babylonica from Linnæus, in allusion to the 137 th Psalm.

Afflicted Israel shall sit weeping down, Their harps upon the neighb'ring willows hung, Nor joyous hymn encouraging their tongue.

Prior. 
On the willow thy harp is suspended, Oh Salem! its sound should be free,

And the hour when thy glories were ended,

But left me that token of thee.

And ne'er shal! its soft notes be blended

With the voice of the spoiler by me.

Byron.

Silent their harps-each cord unstrung,

On pendant willoro-branches hung.

Booker.

Willow, (gritou, Welsh,) is defined by Johnson to be "a Tree, of the boughs of which a garland was said to be worn by forlorn 'overs."

In love, the sad forsaken wight

The willowo garland weareth.

Drayton.

I offered him my company to a willow tree, to make him a garland, as being forsaken.

Shaks.

In such a night

Stood Dido, with a willow in her hand, Upon the wild sea-banks, and waved her love

To come again to Carthage.

Shaks.

IIl wear the willow garland for his sake.

Same.

The S. Babylonica is a native of the east. Leaves lanceolate, taper-pointed. Catkin naked, accompanying the leaves. As the branches droop, the catkins ascend in a recurved manner.

\section{WHEAT.}

\section{Triticum.}

Triticu:n, an old Latin name, derived from tritum, ground or rubbed-in allusion to the manner in which grain is prepared for the food of mankind.

Wheat E. Sax. hroote; Gothic, hroit; Dutch, weit, wheat-grass, or corn.

Corn is a term applied to all sorts of grain fit for food, particularly Wheat, Rye, etc. These also belong to the grand civision of Grasses, which are distinguished from other plants by their simple, straight, unbranched stalk, hollow, and jointed, commonly called straw, with long narrow tapering leaves, placed at each knob or joint of the stalk, and sheathing or enclosing it, as if by way of support. The T. Caninum or bearded wheat-grass, is that which most pleases the eye on account of the greater.length of its beard, or arista.

The Romans cultivated only the bearded wheat, its bristles serving to protect it from birds, etc.

The flower of triticum, consists of a calyx of two valves, common receptacle zigzag, elongated into a spike. Glume (the husk or chaff,) transverse, containing about three, or more flowers. Corolla of two nearly equal valves, the size of the calyx.

Ceres, the goddess of corn and harvests, was represented with a garland of ears of corn on her head. And the commemoration of the loss of her daughter, Proserpine, was celebrated about the beginning of harvest; that of her search after her, at the time that corn is sown in the earth.

\section{WOODBINE.}

\section{Lonicera.}

(See Honeysuckle.)

Woodbine, or Woodbind, no doubt from the flexibility of its branches, and its habit of twining round, or binding the trees, or wood, that may be placed near it.

But those who wear the woodbine on their brow, Were knights of !ove who never broke their vow; Firm to their plighted faith, and ever free

From fears, and fickle chance, ard jealousy.

Dryden's Vision of Chaucer.

\section{YARROW}

\section{Achillea, Millefolium.}

Achillea, Milfoil, so called from Achilles, who is supposed to have acquired some knowledge of botany from his master Chiron, and to have used this plant for the cure of wounds, etc. The $A$. Millefolium, or Yarroro, is reputed to have great medicinal virtue.

The Yarrow, wherewithal he stopt the wound-made gore.

Drayton.

We find in Medical books, that the green leaves of Yarrow pounded, and applied to a bruise, dissipates it in a few days.

Millefolium, of the two Latin words, mille, a thousand, and folium, a leaf.

Yarroro,-Skinner derives it from the Anglo-Saxon Gearewe, etc., and adds, that Minshrew derives it from arrow, because it is the best healer of wounds, and was, therefore, in former times, happily applied to wounds made by $a r$. rovos-or, perhaps, says he, it comes from the Saxon gear, the year, because it retains its foliage almost through the whole year.

The common Yarrow, $A$. Millefolium, is mixed instead of hops, in their ale, by the inhabitants of Dalekarlia, in order to give it an inebriating quality.

It is generally esteemed a troublesome and noxious weed in pastures. Its white blossoms, nevertheless, beautify our fields, and could not well be spared by the lovers of flowers. Their pearly blossoms have sometimes been seen, at this day, forming a beautiful ornament for a lady's hair.

\section{ZINNIA.}

Zinnia, named by Linnæus, in honour of $D r$. Jno. G. Zinn, professor of physic and botany at Gottingen, etc.

There are many species of Zinnia, native of warm climates; many of them indigenous in America. The common red Zinnia, or Z. Multiflora, is found on the banks of the Mississippi. Rays, yellow, orange, or brick dust colour. The flowers stand each on a hollow, deeply furrowed, terminal stalk, from one to two inches long, much thicker than the stem, and gradually swelling upwards. The disk is coni- 
cal and acute, composed of reddish or tawny florets, accompanied by the prominent, dark-green, or blackish, scales of the receptacle; the radius of this compound flower, consists of ten or more broad, elliptical, usually emarginate florets, of a deep brick-red, and very smooth above; pale greenish, and rough beneath; reticulated with veins, and finally becoming rigid, or membranous. Calyx imbricated, somewhat ovate, with numerous obtuse, erect, permanent scales.

Zinnia contains plants of the annual flowering kind, of which the species cultivated are the N. American plant just noticed. The Z. Pauciflora, Yellow Zinnia, with a less hairy stem, and greater breadth of leaf, somewhat heartshaped, at their base. Native of Peru. Z. Verticillate, whorl-leafed $\boldsymbol{Z}$. Flozoers, a multiplied radius of deep scarlet, the disk broader, and less conical, than either of the others. Z. Elegans, purple-flowered Zinnia. And Z. Tenuiflora, slender-flowered $Z$. The flowers being the smallest of their genus, and distinguished by their bright red narrow revolute radiant florets, very rough at the edges; the tubular florets are yellow. The three last named are natives of Mexico. 


\section{EXPLANATION OF BOTANICAL TERMS USED IN FLORA'S DICTIONARY.}

Aculeus, prickly, sharp-pointed projections from the bark, as in the rose. A thorn or spine, is a sharp-pointed projection growing from the voody substance of a plant, as in hawthorn.

Acuminate, pointed, having a taper, or awl-shaped extremity.

Amentum, see Catkin.

Articulate, jointed; where one leaf grows out of the top of another; or the jointed culm or straw of grasses.

Awol-shaped, see Subulate.

Awn, the sharp points or beards issuing from the glume, are called awns, or aristæ, as in bearded wheat.

Axillary, when the flower-stalk grows between the leaf and the stem.

Banner, see Standard.

Binate, growing in pairs.

Biternate, twice ternate, or doubly three-leafed.

Bracteated, (L. bractea,) a floral leaf, differing from the other leaves in shape and colour, generally situated on the peduncle, so near the corolla, as easily to be mistaken for the calyx.

Caducous, falling early. A caducous calyx falls before the corolla is well unfolded, as in the poppy. Caducous leaves, fall before the end of the summer.

Campanulate, in the form of a bell.

Canaliculate, channeled, having a deep furrow or channel; applied to the stem, leaf, or -petiole of plants, sometimes to the calyx.

Capitate, growing in a head, applied to a flower, or stigma.

Capsule, the seed-ressel of a plant; a dry membranaceous hollow pericarp.

Catkin, (or Amentum, L. a thong, or strap,) is a composition of flowers and chaff, on a long, slender threadshaped receptacle; the whole somewhat resembling a cat's tail in shape, as in the villow.

Ciliate, fringed with parallel hairs.

Claro, the narrow part of the petal below, by which it is inserted or attached.

Compound flower, a flower of the class syngenesia, consisting of florets with united anthers.

Cone, a scaly fruit like that of the pine. See Strobiles.

Connate, opposite, with the bases united, or growing into one; as in the upper leaves of honeysuckle.

Coriaceous, (from corium, leather,) stiff, like leather, or parchment.

Corollule, one of the partial flowers which make a compound one; the floret in an aggregate flower.

Corymb, (corymbus, L. a top, head, or cluster,) a kind of spike, in which the partial-stalks are gradually longer as they stand lower on the common stalk, so that all the flowers are nearly on a level.

Cotyledon, (a hollow, or cavity.) In botany, the perishable lobe of the seeds of plants. It involves, and nourishes the embryo plant, and then perishes. Some seeds have two lobes, others only one, and some none.
Crenate, (scolloped,) when the teeth are rounded, and not directed towards either end of the leaf, as in ground Ivy.

Cucullate, hooded or cowled; rolled or folded in; as in the spathe of Arumtriphyllum, or Indian turnip.

Culm, or straw, is the peculiar stem of grasses, rushes, etc.

Cyme, has the general appearance of an umbel; as in umbel. liferous plants, its common stalks, all spring from one centre, but, differing from those plants, in having the stalks variously and alternately subdivided, as in elder, and guelder-rose.

Deciduous, falling, not perennial, or permanent. A deciduous leaf, falls in Autumn. A deciduous calyx, that which falls after the coral opens.

Decumbent, leaning upon the ground, the base only erect.

Deflexed, bending downward arch-wise.

Dentate, toothed, notched, having points like teeth on the margin of the leaf.

Denticulate, minutely toothed.

Depressed, where the radical leaves are pressed close into the ground.

Dichotomous, forked; dividing into two equal branches.

Diaphanous, transparent, clear.

Digitate, fingered, when several leaflets, or little leaves proceed from the summit of a common foot-stalk; or, a leaf which branches into several distinct leaflets, like fingers.

Disk, the central part of a radiate compound flower. Or the whole surface or top, in distinction from the edge.

Divaricate, standing out wide.

Dorsal, pertaining to the back, dorsal anon, etc.

Drupe, (Drupa, Drupæ,) a pulpy seed-vessel, consisting of a hard nut or stone, encompassed by a soft pulpy substance, as the cherry, olive, etc.

Emarginate, notched at the end; applied to the leaf, coral, or stigma.

Ensiform, see sword-shaped leaf.

Entire. An entire leaf is without teeth or notches. An entire stem, is one without branches.

Fascicle, (a bundle,) a term applied to flowers on little footstalks, variously inserted, and subdivided, collected into a close bundle, level at the top, as in sweet-william.

Filiform, having the form of thread, or filament; of equal thickness from top to bottom.

Floral-leaf, see Bractea.

Floret, a little flower; the separate little flower of an aggregate flower.

Floscule, a partial, or lesser floret of an aggregate flower.

Gibbous, swelling on both sides, or on one .

Gland, Glandular, having excretory, or secretory ducts or vessels. Abundant on the stalk, and other parts of the Moss Rose, and constituting the most prominent character of that flower. 
Glume, or Husk, the calyx or blossom of grasses and corn, formed of one or more thin, dry, semi-transparent leaves, called valves, embracing the seed, often terminated by the arista, or beard. The chaff.

Hirsute, rough with hairs.

Hispid, rough; having strong hairs, or bristles, more than hirsute.

Imbricated, lying over each other, like tiles on a roof; as leaves in the bud.

Inferior. An inferior flower, is one in which the calyx and corolla are below the germ.

Inflexed, turned, bent.

Inflorescence, a term used to express the particular manner in which flowers are situated upon a plant. As a bunch, (thyrsus) a dense or close panicle, corymb, spike, raceme, umbel, whorl, cyme, fascicle, etc.

Involucre, or involucrum, a sort of general calyx serving for many flowers; generally situated at the base of an umbel, or head; as in cosnus florida, or dogwood.

Involute, rolled spirally inwards; the reverse of revolute.

Keel, the under petal of a papilionaceous flower. Also the lower side of the midrib of a leaf.

Keeled, or carinated, having a longitudinal prominence on the back.-See also Papilionaceous.

Labiate, having an upper and lower lip, as in flowers of the class Didynamia.

Lamina, the border, the upper part, broad or spreading part of a petal, in distinction from its claw.

Lanceolate, shaped like a lance, oblong, and gradually tapering towards each extremity, spear-shaped, as in the willoro.

Leaflet, a little leaf, or one of the divisions of a compound leaf.

Legume, a seed-ressel of two valves, in which the seeds are fixed to one suture only. A pod: differing from sili$q u a$, (silique, E.) in which the seeds are attached to both suiures.

Limb, the border or upper spreading part of a monopetalous corol.

Linear, of the same breadth throughout, except at the extremities; as in most of the grasses.

Lip, the upper or under side of the mouth of a labiate corolla, as in sage, hyssop, etc.

Lobed, when divided to the middle, into parts distant from each other, with rounded, or convex margins, as in the leaves of sassafras, etc.

Membranaceous, flatted or resembling parchment. A membranaceous leaf has no distinguishable pulp between the two surfaces. Very thin and delicate.

Midrib, the large central vein of a leaf, which is a continuation of the petiole.

Monopetalous, having only one petal, consisting of two parts, a tube, or lower part, and a limb.

Multifid, many cleft; having many divisions.

$\mathcal{N}$ erves, parallel veins.

Obovate, inversely ovate; having the narrow end downward.

Officinal, officinalis, kept for sale as medicine.

Orbiculate, in the form of an orb; a leaf that has both its longitudinal, and transverse diameters equal.
Dvate, egg-shaped; and the base wider than the other end.

Palmate, hand-shaped; with the fingers extended, or spread.

Panicle, (L. Panicula) a species of inflorescence in which the flowers or fruits are scattercd on peduncles, variously subdivided, without order, as in Oat, and grasses.

Paniculated, having branches variously subdivided, as a paniculate stem. Or having the flowers in panicles.

Papilionaceaus, resemuling the butterfly; as the pea. Usually four-petaled, having an unper spreading petal, called the banner or standard: two side petals, termed wings, and a lower petal styled keel.

Pappus, the down of seeds; as that of the dandelion. A feathery appendinge.

Parasitic, growing on another plant, and drawing nourishment from it; as the Mistletoe.

Patulous, spreading: as a patulous calyx, etc.

Pectinated, a pinnatifid leaf, the segments of which are remarkably narrow, like the teeth of a comb.

Pedate, a ternate leaf, with its lateral leaflets compounded in their fore- art.

Pedical, the ultimate branch of a peduncle. A little stalk.

Peduncle, or flower-stalk, is a partial trunk, springing from the stem, and supporting the flowers, but not the leaves.

Pcllicle, a very thin stratum, or coat.

Peltate, or sinield-formed, when the foot-stalk is inserted into, or near the centre of the lower surface of the leaf, as in the nasturtium.

Pencilled, ending like a painter's pencil, or brush.

Perfoliate, surrounding the stem on all sides and perforated by it. It differs from connate, iu not consisting of two leaves; as in Eupatorium perfoliatum, or American Thorough-wort.

Pericarp, the seed-vessel of a plant.

Persistent, not falling off. Those parts of a flower are persistent which remain till the fruit is ripe.

Personate, masked. Having the mouth of the corolla closed by a prominent palate; as in the Toadfax, (Antirrhinum.)

Petiole, a leaf-stalk; the foot-stalk of a leaf.

Petiolated, growing on foot-stalk, as in the currant.

Pilose, hairy. IVith a stiff pubescence.

Pinnate, a species of compound leaf whorein a simple petiole has several leaflets attached to each side of it.

Pinnatifid, a species of simple leaf, divided transversely, by oblong horizontal segments, not extending to the midrib.

Raceme, or cluster, consists of numerous, rather distant flowers, each on its own proper stalk, and all connected by one common stalk, as a bunch of currants.

Radiant, rayed, or radiate coral or flower, is a compound flower, consisting of a disk, in which the corollets or florets are tubular, and regular, and of a ray, in which the florets are irregular.

Radical, proceeding immediately from the root; as the leaves of the coroslip.

Ray, the diverging florets or petals which form the outside of radiate flowers, cymes, and umbels. 
Receptacle, the end of a flower-stalk; being the base to which most or all the parts of fructification are attached.

Recurved, bent back or downward.

Reflexed, bent backward.

Reniform, kidney-shsped. Heart-shaped without the point.

Reticulate, net like. Having veins distributed like net-work.

Revolute, ro!led back, or downward.

Rhomboid, diamond-shape, approaching to a square.

Ringent, or labiate corol, one which is irregular, monopetalous, with the border usually divided into two parts, called the upper, and lower lip; gaping like the mouth of an animal.

$R$ ugose, as leaves of sage.

Runcinate, having large teeth pointing backward; as the leaves of the dandelion.

Sarmentose, running on the ground and striking roots from the joints, as the strawberry.

Scabious, rough.

Scape, a stalk which springs from the root, and supports flowers and fruit, but no leaves. As in Narcissus, Dandelion, and Hyacinth.

Scarious, tough, thin, and semi-transparent, dry, and sonorous to the touch; as a perianth.

Serrated, Serratures, like the teeth of a saw, and pointing towards the extremiy of the leaf, as in the nettle and rose. Some leaves are doubly serrated, having the teeth again cut into other little teeth, as in canterbury bell.

Sessile, or sitting, when a leaf grows immediately to the stem, or stalk, branch, or root, without any foot-stalk. A Sessile flower, has no peduncle, or flower-stalk.

Sheath, a tubular or folded leafy portion inclosing the stem; as the leaves of grasses.

Silique, (Siliqua, L.) a pod or seed-vessel usually longer than it is broad, with two valves or covers, and separated by a linear receptacle, the seeds alternately fixed to both sutures, or seams, as in the common stock.

Simple leaves, are such as have only a single leaf on the petiole or foot-stalk; not divided, branched or compounded.

Simple, not divided, branched, or compounded.

Sinuate, having sinuses at the edge.

Sinus, a large rounded indentation or cavity.

Spadix, an elongated receptacle of flowers, commonly proceeding from a spathe.

Spathe, a sheathing calyx opening lengthwise on one side, and consisting of one or more valves; as in the onion. See Spadix.

Spike, a species of inflorescence, in which sessile flowers are alternate, on a common simple peduncle, as in Wheat, Rye, Lavender, etc. An ear of corn, or grain, is called a spike; it is particularly applicable to ears of maize.

Spur, a sharp hollow projection from a flower, commonly the nectary.

Standard, the upper petal, or banner, of a papilionaceous corol.
Stipule, a scale or small leaf situated on each side, and sometimes on one side only, of the base of the leaf-stalks, for the purpose of supporting them at their first appearance, as in vetches. Sometimes it is united latterly to the foot-stalk, as in the rose.

Striated, marked with fine hollow parallel lines.

Strobiles, or Cone, a kind of seed-vessel, formed by a catkin, with hardened scales, and containing a seed within the base of each scale, as in the fir.

Subsessile, almost sessile; having very short foot-stalks.

Subulate, awl-shaped; linear, or slender at the base, and gradually tapering towards the end, like an awl.

Sutures, or seams, the edges by which the valves are connected, which is the external covering of the seed.

Sword-shaped, or Ensiform, two edged, tapering to a point, and somewhat convex on both surfaces, as in Iris.

Tendril, a filiform appendage of certain vines, which supports them by turning round other objects.

Terminal, when it terminates a stem, or branch.

Ternate, growing by threes, as in Trefoils.

Thread-shaped, see filiform.

Tomentous, downy, nappy, cottony; covered with hairs so close as to be scarcely discernible.

Trifid, divided into three parts; by linear sinuses, with straight margins; three-cleft.

Truncate, having a square termination as if cut off; as the leaves of the Tiriodendron Tulipifera.

Tuberous, from tuber, a bunch. Consisting of roundish fleshy bodies, or tubers, connected into a bunch by intervening threads; as the roots of potatoes, artichokes, etc.

Umbel, a kind of infiorescence in which the flower-stalks diverge from one centre like rays; as in the Parsnip, Parsley, etc. See Cyme.

Undulate, when the middle part of the leaf, especially as it approaches the margin, is acutely folded up and down, as in the Mallows.

Valve, the outer coat, shell or covering of a capsule or other pericarp, or rather one of the pieces which compose it; also, one of the leaflets composing the calys and corol in grasses.

Veiny, when the fibres on the surface of the leaf are branched, as in the havothorn.

Ventricose, swelling out in the middle; as a ventricous perianth.

Verticillate, whorled. Having leaves given off in a circle round the stem.

Villous, having the hairs long and soft.

Vivaparous, producing a collateral offspring by means of bulbs.

Whorl, or Verticillate, in which the flowers surround the stem in a sort of ring, though they may not perhaps be inserted on all sides of it, but merely on two opposite sides, and even on one side only.

Wings, the two lateral petals of a papilionaceous flower. Winged, having the sides extended into a leafy expansion. 


\section{G U (1) $9 \mathbb{R} \mathbb{8}$}

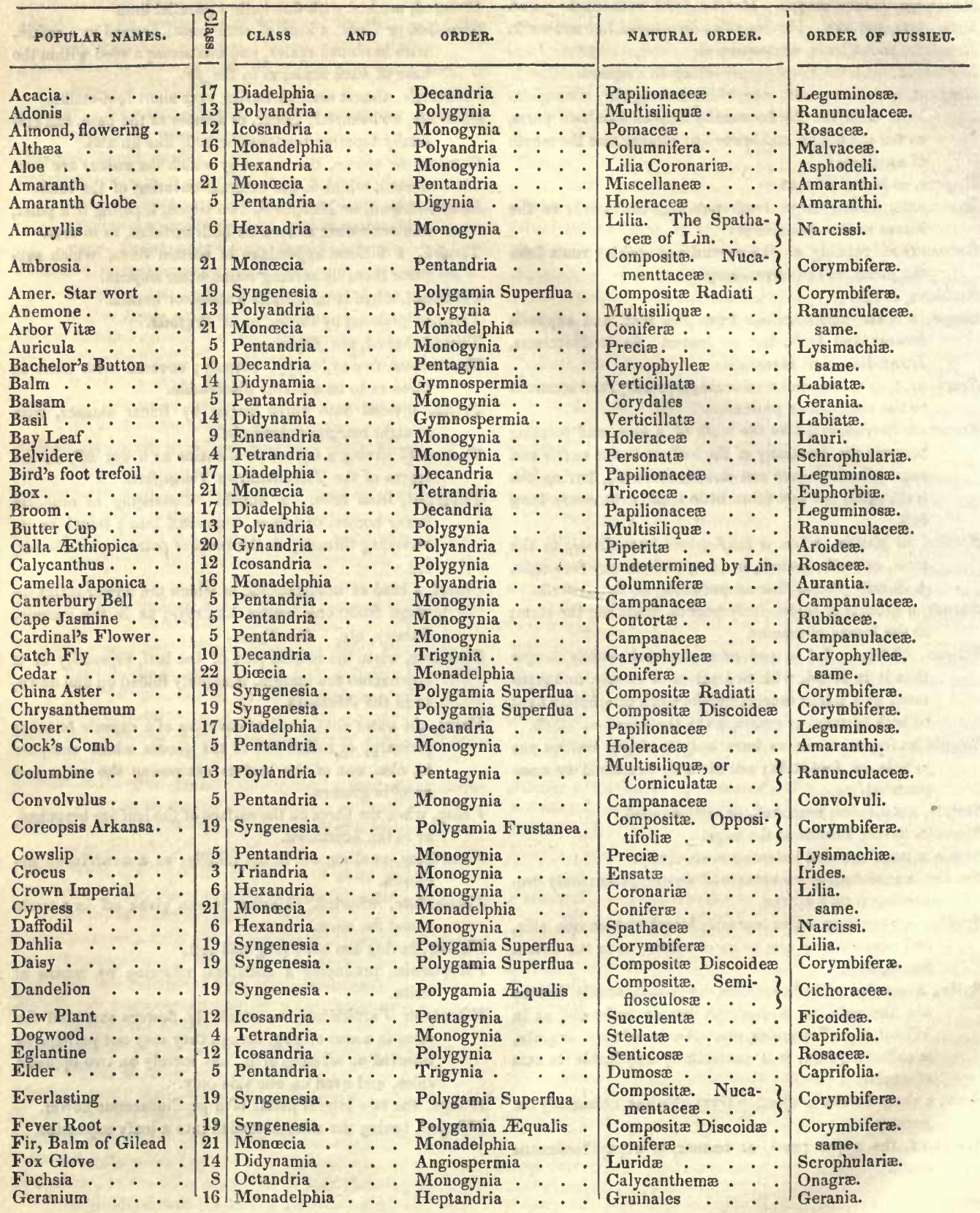




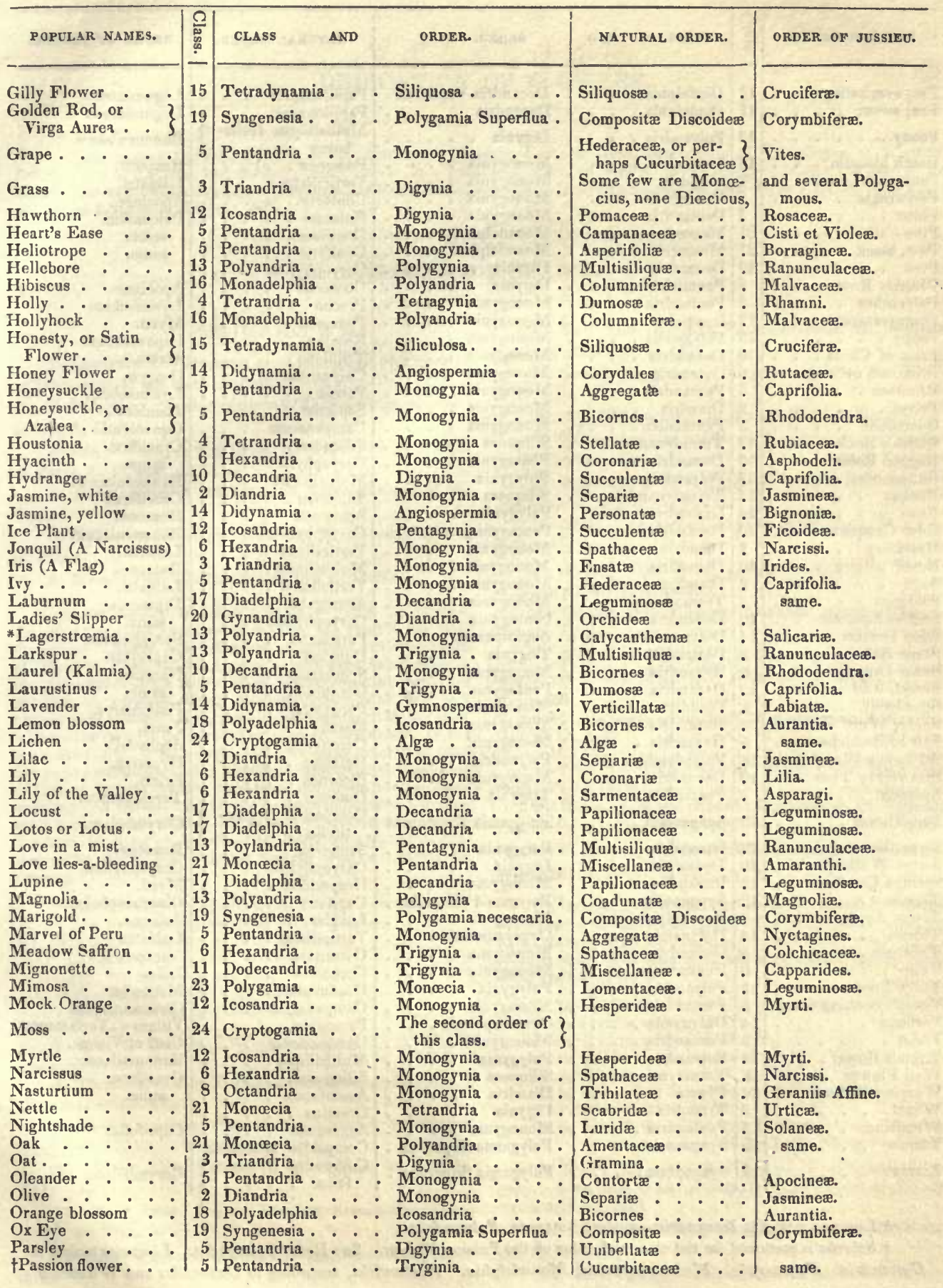




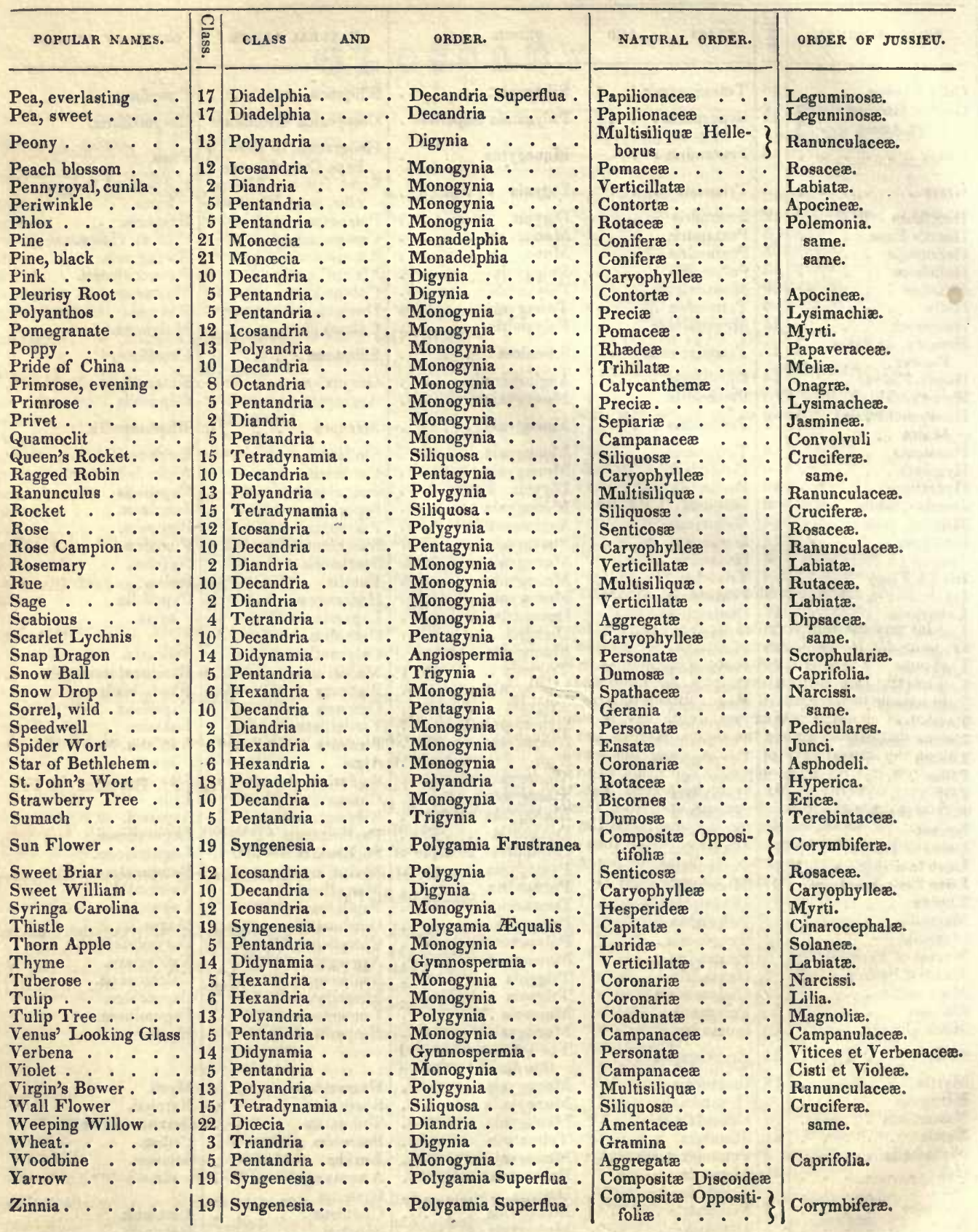

* Linnæus makes it Icosandria-modern botanists, Polyandria.

+ Schrebe is preferred for the class and order of the Passion Flower. See Rees' Cyclopedia. Linnæus makes it Gynandria. Pentandria. Modern botanists, Monadelphia. Pentandria, according to Cavanilles and Wildenow 


\section{DEDICATION OF FLOWERS.}

The Roman Catholic Monks, or the observers of Roman Catholic rules, have compiled a catalogue of Flowers, for each day in the year, and dedicated each flower to a particular Saint, on account of its fowering about the time of the Saint's festival. Such appropriations form a Floral Directory, which has been abstracted from Hone's Every Day Book, printed in London in the year 1826.

\section{FLORAL DIRECTORY.}

\section{JANUARY.}

1. Laurustinus, Viburnum tinus, St. Faine or Fanchea, an Irish saint, of the sixth century.

2. Groundse], Senecio vulgaris, St. Macarius, of Alexandria, A. D. 394.

3. Iris, Persian, Iris persica, St. Genevieve, patroness of Paris, A. D. 422. Paul.

4. Hazel, Corylus avellana, St. Titus, disciple of St.

5. Hellebore, Helleborus fœtidus, St. Simeon Stylites, of Rome.

6. Moss, screw, Tortula rigida, St. Nilammon.

January the 6th, is called twelfth day, (by the French, Ie jour des Rois, ) because it falls on the twelfth day after Christmas. There is a difference of opinion as to the origin of Troelfth Day, yet all concur in the same end; that is, to do honour to the Eastern Magi. Brand tells us, "that the practice of choosing a king on twelth day, is similar to a custom that existed among the ancient Greeks and Romans, who on the festival days of Saturn, about this season of the year, drew lots for kingdoms, and like kings, exercised their temporary authority." Mr. Fosbroke affirms that "the king of Saturnalia was elected by beans, and from thence came our king and queen, on this day." In France the Twelfthcake is plain, with a bean; the drawer of the slice containing the bean, is King or Queen. All drink to her, or his $\mathbf{M a}$ jesty, who reigns, and receives homage from all during the evening.

"They come! they come! each blue-eyed sport,

The twelfth-night king, and all his court-

'Tis mirth fresh crown'd with mistletoe;

Music, with her merry fiddles,

Joy, ' on light fantastic toe,'

Wit, with all his jests and riddles,

Singing and dancing as they go."

7. Laurel, Portugal, Prunus lusitanica, St. Kentigerna.

8. Tremella, yellow, Tremella deliquescens, St. Gudula. Patroness of Brussels.

9. Laurel, common, Prumus lauro-cerasus, or common small fruited cherry-St. Marciana, of Rome.

10. Gorse, Ulex Europæus, St. William, of Bourges, A. D. 1207 .

11. Moss, early, Bryum hornum, Swan-neck threadmoss. St. Theodosius. dius.

12. Moss, hygrometic, Funaria hygrometica, St. Arca-
13. Yew Tree, common Taxus baccata, St. Veronica. A nun of Milan, A. D. 1497.

14. Strawberry, barren, Fragaria sterilis, St. Hilary, A. D. 368 .

15. Ivy, Hedera helix, St. Paul-the first Hermit.

16. Nettle, common red Dead, N. Lamium purpureum, St. Marcellus. Pope.

17. Anemone, garden, Anemone hortensis, St. Anthony. Patriarch of Monks, A. D. 251.

18. Moss, four-toothed, Bryum pellucidum, St. Prisca. A Roman Martyr.

19. Nettle, white Dead, Lamium album, St. Martha. A Roman Martyr, A. D. 270.

20. Nettle, woolly Dead, Lamium garganicum, St. Fabian. Pope.

21. Hellebore, black, Helleborus niger, St. Agnes. A special Patroness of purity. Beheaded at the age of 13, A. D. 304 :

22. Grass, early whitlow, Draba verna, St. Vincent. A Spanish Martyr.

23. Peziza, Pcziza acetabulum, St. Raymond, of Pennafort, A. D. 1275.

24. Moss, stalkless, Phascum muticum, St. Timothy. Disciple of St. Paul, A. D. 250.

25. Hellebore, winter, Helleborus hyemalis. The conversion of St. Paul.

On this day, (25th Jan.) prognostications of the months were drawn for the whole year. If fair, and clear, there was to be plenty; if cloudy, or misty, much cattle would die; if rain, or snow fell, then it presaged a death; and if windy, there would be wars.

If Saint Paul's Day be fair and clear,

It does betide a happy year;

But if it chance to snow or rain,

Then will be dear all kinds of grain:

If clouds, or mists, do dark the sky,

Great store of birds and beasts shall die;

And if the winds do fly aloft.

Then wars shall vex the kingdoms oft.

Willsford's Nature's Secrets.

St. Paul's Day, is the first festival of an Apostle, in the year. According to Dr. Foster, it is the festival of the conversion of St. Paul.

26. Butter-bur, white, Tussilago alba, or Colt's foot. St. Polycarp.

27. Moss, earth, Phascum cuspidatum, St. Chrysostum. 
28. Daisy, double, Bellis perennis plenus, St. Margaret of Hungary, A. D. 1271.

29. Fern, flowering, Osmunda regalis, St. Francis of Sales, A. D. 1622.

30. Spleen-wort, Asplenium trichomanes, St. Martina.

31. Hart's tongue, or spleen-wort, Asplenium scolopendrium, St. Marcella, A. D. 410.

\section{FEBRUARY.}

1. Moss, lesser water, Fontinalis minor, St. Ignatius.

And Bay tree, Laurus nobilis, to St. Bridget, $\mathbf{P a -}$ troness of Ircland.

2. Snow-drop, Galanthus nivalis, the purification of the blessed Virgin Mary.

3. Moss, great water, Fontinalis antipyretica, St. Blase, of Armenia, A. D. 316.

4. Moss, common hair, or Goldilocks, Polytrichum commune, St. Jane, or Queen Joan, A. D. 1505.

Bay, Indian, Laurus Indica, St. Margaret, of England.

5. Primrose, common, Primula vulgaris, St. Agatha. A Sicilian Martyr, A. D. 251.

Primrose, red, Primula acaulis, St. Adelaide, A. D. 1015.

6. Hyacinth, blue, Hyacinthus orientalis, St. Dorothy, A. D. 308 .

7. Cyclamen, round-leafed, Cyclamen coum, St. Romuald, 1027 .

8. Moss, narrow-leafed, spring, Mnium androgynum, St. John, of Matha, 1213.

9. Narcissus, Roman, Narcissus Romanus, St. Apollonia, A. D. 249.

10. Mezereon, Daphne Mezereon, St. Scholastica, A. D. 543.

Moss, silky fork, Mnium heteromallum, St. Coteris, 4th Century.

11. Primrose, red, Primula verna-rubra, St. Theodora, Empress, 367.

12. Anemone-noble Liverwort, Anemone hepatica, St. Eulalia, of Barcelona.

13. Polyanthos, Primula Polyanthos, St. Catharine de Ricci, 1559.

14. Crocus, yellow, Crocus mæsiacus, or C. aureus, St. Valentine. St. Valentine, is the lover's saint. He was Priest, of Rome, and married there, about the year A. D. 270.

'The 14th of February, is the day on which those charming littlo missives, yclep'd Valentines, cross, and intercross cach other, at every street and turning. The weary, and allfor-spent twopenny postnian sinks beneath a load of delicate embarrassments, not his own.

"Where can the postman be, I say?

He ought to fly-on such a day!

Of all days in the year, you know,

Its monstrous rude to be so slow:

The fellow's so exceeding stupid-

Hark - there he is!-oh the dear cupid."

15. Crocus, cloth of gold, Crocus sulphureus, St. Sigifrida, Bishop of Sweden, A. D. 1002.

16. Primrose, lilac, Primula acaulis plena, St. Juliana.
17. Crocus, Scotch, Crocus susianus, St. Flavian, Archbishop of Constantinople, 449.

18. Speedwell, wall, Veronica vernus arvensis, St. Simeon, Bishop of Jerusalem, A. D. 116.

19. Speedwell, field, Veronica agrestis, St. Barbatus, patron of Benevento, Bishop, A. D. 682.

20. Cynoglossum omphalodes, or C. lusitanicum, St. Mildred, Abbess of Munster.

21. Crocus, white, Crocus albus, St. Servianus, Bishop, A. D. 452 .

22. Margaret, herb, Bellis perennis, St. Margaret, of Cortona, 1297.

23. Apricot tree, Prunus armeniaca, St. Milburge, of England.

24. Fern, great, Osmunda regalis, St. Ethelbert, King of Kent, England.

25. Peach blossom, Amigdalus persica, St. Walburg, Abbess of Swabia, Germany.

26. Periwinkle, lesser, Vinca minor, St. Victor, 7th Century.

27. Lungwort, Pulmonaria officinalis, St. Leander, Bishop, 596.

28. Crocus, purple, Crocus vernus, St. Proterius, Patriarch of Alexandria, A. D. 557.

\section{MARCH.}

1. Leek, common, Allium porrum, St. David, of Wales, Archbishop, A. D. 544.

Wearing the Leek, was customary in the time of Shakspeare. It is noticed in his K. H. V.

The Welshman, Fluellen, wears his leek in the battle of Agincourt.

2. Chickweed, dwarf mouse-ear, Cerastium pumilum, St. Chad, or Ceada, Martyr under the Lombards, in the 6th century.

3. Marigold, golden-fig, Mesembryanthemum aureum, St. Cunegundes, Empress, A. D. 1640.

4. Chickweed, common, Alsine media, St. Casimir, Prince of Poland, A. D. 1453.

5. Hellebore, green, Helleborus viridis, St. Adrian, A. D. 309 .

6. Lily, lent, Pseudo-narcissus multiplcx, St. Colette, Bishop.

7. Daffodil, early, Narcissus simplex, St. Perpetua. She was martyred, under the Emperor Severus, A. D. 203.

8. Rose, ever blowing, Rosa semperflorens, St. Rosa, of Viterbo, A. D. 1261.

Jonquil, great, Narcissus loetus, St. Felix, A. D. 646.

9. Daffodil, hoop-petticoat, Narcissus bulbocodium, St. Catharine of Bologna, A. D. 1463.

10. Chick weed, upright, Veronica triphyllos, St. Droctarceus, Abbot, A. D. 580.

11. Heath, cornish, Erica vagans, St. Eulogius, of Cordova, A. D. 851.

12. Ixia, or crocus leaved Mistletoe, Ixia bulbocodium, or Viscum albus bulbus: St. Gregory, the Great, Prator of Rome, A. D. 574. 

410.

13. Heart's Ease, Viola tricolor, St. Euphrasia, A. D.

14. Bindweed, mountain, Soldanella alpina, St. Maud, or Matilda, Qucen, A. D. 968.

15. Colt's-foot, common, Tussilago farfara, St. Zachery, Pope, A. D. 752.

16. Daffodil, nodding, Narcissus nutans, St. Julian, of Cilicia.

17. Violet, sweet, Viola odorata, St. Gertrude, Abbess, A. D. 626 .

17. Shamrock, White Trefoil, or Dutch clover, Trifolium repens, St. Patrick, Apostle of Ireland.

18. Leopard's bane, great, Doronicum pardalianches St. Cyrill, Archbishop of Jernsalcm, A. D. 386.

19. Star of Bethlehem, yellow, Ornithogalum luteum, St. Joseph, spouse of the Virgin Mary.

20. Violet, dog's, Viola canina, St. Wulfran, Archbishop of Sens, $\Lambda$. D. 720.

21. Fumitory, bulbous, Fumaria bulbosa, St. Bennet, or Benedict, Abbot, Founder of the order of St. Benedict, of Rome, A. D. 543.

22. Ficaria verna, St. Catharine of Sweden, Abbess, A. D. 1381.

23. Daffodil, pecrless, Narcissus incomparabilis, St. Alphonsus Turibius, Archbishop of Lima, A. D. 1606.

24. Saxifrage, golden, Chrysosplenium oppositifolium, St. Irenxus, Bishop of Sirmium, A. D. 304.

25. Marigold, Calcndula officinalis, Annunciation of the B. V. Mary.

26. Henbane, night-shade leaved, Hyoscyamus scopalia, St. Braulio, Bishop of Saragossa, A. D. 646.

27. Jonquil, sweet, Narcissus odorus, St. John, of Egypt, Hermit, A. D. 394.

2S. Leopard's bane, Doronicum Plantagineum, St. Priscus, A. D. 260.

29. Ox-lip, or great cowslip, Primula elatior, St. Eustatius, Abbot, A. D. 625.

Fumitory, Fumaria officinalis, St. Jonas, A. D. 327.

30. Water-cress, Cardamine hirsuta, St. John, of Climacus.

Daffodil, lesser, $\mathcal{N}$ arcissus minor, St. Zozimus, Bishop of Syracuse, A. D. 660.

31. Benjamin tree, Laurus benzoin, St. Benjamin, Deacon, Msrtyr, A. D 424.

\section{APRIL 1. ALL FOOLS' DAY.}

The Romans consecrated the first day of April to Venus, the goddess of beauty, queen of laughter, etc. It is customary on this day, to practise jocular deceptions, as various, as the fancies of the gay youngsters, who delight in playing off the humours of the day, upon all ages and ranks, that come their way.

1. Mercury, French annual, Mercurialis annua, St. Hugh, Bishop, A. D. 1132. labrisn.

2. Violet, white, Viola alba, St. Francis, of Paula, A Ca-

3. Alkanet, evergreen, Anchusa sempervirens, St. Agape, A. D. 304.
4. Crown Imperial, Red Fritillaria imperialis, St. Isidore, Bishop of Seville, 636.

5. Crown Imperial, Fritillaria imperialis lutea, St. Vincent Ferrer, A. D. 1419.

6. Hyacinth, starch, Hyacinthus racemosus, St. Sixtus I. Pope, A. D. 2.

7. Anemone, wood, Anemone nemorosa, St, Aphraates, 4th Century.

8. Ivy, ground, Glcchoma hederacea, St. Dionysius, Bishop of Corinth, A. D. 2. 421.

9. Polyanthos, red, Primula, St. Mary, of Egypt, A. D.

10. Violet, pale, Viola tonbrigens, St. Mechtildes, $\mathbf{A b}$ bess-after 1300 .

11. Dandelion, Leontodon taraxacum, St. Leo, the Great, Pope, A. D. 461.

12. Saxifrage, great thick-leaved, Saxifragum crassifolium St. Zeno, Bishop, 380.

13. Narcissus, green, $\mathcal{N}$ arcissus viridiflorus, St. Hermenigild, Martyr, 586.

14. Borage, common, Borago afficinalis, St. Lidwina, A. D. 1184.

15. Stitch-wort, greater, Stellaria holostea, St. Peter Gonzales, 1246.

16. Tulip, yellow, Tulipa sylvestris, St. Joachim, of Sienna, A. D. 1305.

17. Arum, Friar's-cowl, broad-leaved, Arum arisarum, St. Stephen, of Citeaux, Abbot, A. D. 1134.

18. Narcissus, musk, Narcissus Moschato, St. Apollonius, A. D. 186. 1054.

19. Garlic, Allium ursinum, St. Leo IX. Pope, A. D.

20. Snow-flake, spring, Leucoium vernum, St. Agnes, of Monte Pulciano, A. D. 1317.

21. Narcissus, cypress, $\mathcal{N}$ arcissus orientalis albus, St. Anselm, Archbishop of Canterbury.

22. Crow-foot, wood, or goldilocks, Ranunculus auri comus, St. Rufus, of Glendaloch.

23. Harebell, Hyacinthus non scriptus, St. George, the Martyr, Patron of England.

24. Black thorn, Prunus spinosa, St. Fidelis.

25. Tulip, clarimond, Tulipa præcox, St. Mark, the Evangelist.

26. Erysimum, yellow, Erysimum barbarea, St. Richarius, Abbot, A. D. 645.

27. Daffodil, great, Narcissus major, St. Anastasius, Pope, 401.

28. Arum, spotted, Arum maculatum, Sts. Didymus and Theodora, A. D. 304.

29. Herb Robert, Geranium robertianum, St. Robert, Abbot of Molesme, A. D. 1110.

30. Cowslip, Primula veris, St. Catharine, of Sienna, A. D. 1380.

\section{MAY 1.}

"May day is chiefly spent in dancing round a tall pole, which is consecrated to the Goddess of Flowers-without the least violation to be offered to it, in the whole circle of the year." 
The May-pole is up,

Now give me the cup,

I'll drink to the garlands around it;

But first, unto those

Whose hands did compose

The glory of flowers that crown'd it.

Herrick.

1. Tulip, Gesner, Tulipa Gesnerina, St. Philip, supposed to have been the first of Christ's Apostles.

Bachelor's Button, Lychnis dioica, St. James the just, and the less. Apostle. Martyred in the tumult in the temple.

2. Charlock, (a Leek,) Rhaphanus raphanistrum, or sinapis arvenus, St. Athanasius, Patriarch of Alexandria, A. D. 373.

3. Narcissus, poetic, $\mathcal{N}$ arcissus poeticus, the discovery of the cross, A. D. 326.

4. Gilly flower, stock, Cheiranthus incanus, St. Monicla, mother of St. Augustine.

5. Apple-tree, Pyrus malus, Sts. Angelus, and Pius V. Pope, A. D. 1572.

6. Globe flower, bright yellow, Trollius Europæus, St. John Damascen, A. D. 780.

7. Globe flower Asiatic, bright orange, Trollius Asiaticus, St. John, of Beverly, England.

8. Lily of the Valley, Convalaria majalis, St. Selena.

9. Lily of the Valley, Convalaria multiflora, St. Gregory, of Nazianzen, A. D. 389 or 391.

10. Peony, slender-leafed, Pæonia tenuifolia, St. Comgal, Irish Abbot, A. D. 601.

11. Asphodel, Lancashire, Asphodelus luteus, St. Mammertus, Archbishop of Vienna, A. D. 477.

12. Iris, German, Iris Germanica, St. Germanus, Patriarch of Constantinople, A. D. 733.

13. Comfrey, common, Symphytum officinalis, St. John, the silent, Bishop, A. D. 558.

14. Peony, common, Pronia officinalis, and Peony, coralline, $\boldsymbol{P}$. corollina, St. Pontius, A. D. 258.

15. Poppy, Welsh, Papaver cambricum, St. Dympna, 7 th Century.

16. Star of Bethlehem, great, Ornithogalum umbella. tum, St. John Nepomucen, A. D. 1383.

17. Poply, early red, long rough-headed P. Papaver argemone, St. Paschal, Babylon, A. D. 1592.

18. Mouse ear, or Hawk-weed, Hieracium pilosella, St. Eric, King of Sweden, 1151.

19. Monk's hoof, Aconitum napellus, St. Dunstan, Archbishop of Canterbury, A. D. 9S8.

20. Horse-chesnut, Aschylus hippocastanum, St. Bernardine of Sienna, A. D. 1444.

21. Ragged Robin, Lychnis flos cuculi, St. Felix, of Cantalicio, 1587.

22. Star of Bethlehem, yellow, Tragopogon pratensis, St. Yvo, 1303.

23. Lilac, Syringa vulgaris, St. Julia, 5th Century.

24. Poppy, monkey, Papaver orientale, St. Vincent, of Lerins, 450 .

25. Herb Bennet, common, Geum urbanum, St. Urban, Pope, A. D. 223.

26. Rhododendron, purple, Rhododendron ponticum, St. Augustine, Archbishop of Cahterbury, 604.
Azalea, yellow, Azalea pontica, St. Philip Neri, A. D. 1595.

27. Butter-cup, Ranunculus acris, St. John, Pope, A. D. 526 .

Bachelor's Button, yellow, Ranunculus acris plenus, St. Bede, 735.

28. Iris, lurid, Iris lurida, St. Germain, Bishop of Paris, 576. 275.

29. Blue Bottle, Centaurea montana, St. Cyril, about

30. Spear-wort, lesser, Ranunculus flammula, St. Ferdinand III. Confessor, King of Castile and Leon, A. D. 1252.

31. Lily, yellow Turk's cap, Lilium pomponium, St. Petronilla, century 1st.

\section{JUNE.}

1. Rose, yeilow, Rosa lutea, St. Justin, Martyr, A. D. 167.

2. Pimpernel, common scarlet, Anagallis arvensis, St. Erasmus, 303 .

3. Rose de meaux, Rosa provincialis, St. Cecilius, A. D. 211.

4. Pink, Indian, Dianthus chinensis, St. Quirinus, Bishop, A. D. 304.

5. Rose, three-leafed China, Rosa sinica, St. Boniface, First Missionary from England to Friesland. Afterwards Archbishop of Mentz, and Primate of Germany and Belgium, century Sth.

6. Pink, common, Dianthus deltoides, St. Norbert, A. D. 1134 .

7. Centaury, red, Chironia centaureum, St. Paul, Bishop of Constantinople, A. D. 350.

8. Money-wort, Herb Two pence, or creeping Loosestrife, Lysimachia numularia, St. Medard, Bishop, 6th Century.

9. Barberry, Pipperidge bush of England, Berberis vulgaris, St. Columba, A. D. 597.

10. Iris, bright yellow, Iris pseudo-acorus, St. Margaret, Queen of Scotland, A. D. 1093.

11. Daisy, midsummer, Chrysanthemum leucanthemum, St. Barnabas, Apostle, century 1st.

12. Rose, wbite dog, Rosa arvensis, St. John, Hermit, A. D. 1479 .

13. Ranunculus, garden, Ranunculus Asiaticus, St. Anthony of Padua, 1231.

14. Basil, sweet, Ocimum basilicum, St. Basil, Archbishop, 379.

15. Sensitive plant, Mimosa sensitiva, St. Vitus, Martyr, 4th Century.

16. Rose, Moss province, Rosa muscosa, St. Julitta, Martyr, 304.

17. Monkey flower, yellow, Mimulus luteus, St. Nicander, about A. D. 303.

18. Poppy, horned, Chelidonium glaucium, St. Marina, Sth Century.

19. La Julienne de nuit, Hesperis tristis, St. Juliana Falconieri, 1340.

20. Poppy, doubtful, Papaver dubium, St. Silverius, Pope, A. D. 538. 
21. Bugloss, Viper's, Echium vulgare, St. Aloysius, A. D. 1591.

22. Canterbury Bell, Campanula medium, St. Paulinus, Bishop of Nola, A. D. 431.

23. Ladies' slipper, Cypripedium calceolus, St. Etheldreda, 679.

24. St. John's wort, Hypericum pulchrum, the nativity of St. John the Baptist.

25. Sweet William, Dianthus barbatus, St. William, of Monte Vergine, A. D. 1142.

26. Sow-thistle, Alpine hairy blue, Sonchus cæruleus, St. Reingarda, Widow, 1135.

27. St. John's wort, perforated, Hypericum perforatum, St. John, of Montier, 6th Century.

28. Corn-flower, blue, Centaurea cyanus, St. Irenæus, Bishop of Lyons, A. D. 202.

29. Rattle, yellow, Rhinanthus crista-galli, St. Peter, the Apostle.

30. Cistus, yellow, Cistus helianthemum, St. Paul, the Apostle, Martyr.

\section{JULY.}

1. Agrimony, Agrimonia Eupatoria, St. Aaron.

2. Lily, white, Lilium candidum, the Virgin Mary.

3. Mallow, common, Malva sylvestris, St. Phocas, a Gardener, A. D. 303.

4. Lily, tawny Day, of China, Hemerocallis fulva, St. Ulric, Bishop of Augsburg.

5. Rose, double yellow, Rosa sulphurea, St. Edana, of Elphim and Tuam.

6. Hawk-weed, or purple-eyed succory, Crepis barbata, St. Julian, Anchorite, 4th Century.

7. Nasturtium, Tropæolum majus, St. Felix, Bishop of Nantes, 584.

8. Primrose, evening, Enothera biennis, St. Elizabeth, Queen of Portugal, A. D. 1336. ildis.

9. Sow-thistle, Tall marsh, Sonchus palustris, St. Ever-

10. Snapdragon, speckled, Antirrhinum triphyllum, Sts. Rufina and Secunda, 257.

11. Lupine, yellow, Lupinus fiævru, St. James, Bishop of Nisibis, 350 .

12. Snapdragon, great, Antirrhinum purpureum, $\mathrm{St}_{\text {. }}$ John Gualbert, Abbot, 1073.

13. Lupine, blue, Lupinus hirsutus, St. Eugenius, Bishop, A. D. 505.

14. Lupine, red, Lupinus perennis, St. Bonaventure, Cardinal, Bishop, A. D. 1274.

15. Marigold, small cape, purple and white, Calendula pluvialis, St. Swithin, Bisbop, A. D. 862.

"If it rains on St. Swithin's Day, there will be rain the next forty days afterwards."

In this month is St. Swithin's day,

On which, if it rain, they say

Full forty days after it will

Or more, or less, some rain distill. Poor Robin's Almanac for the year 1697.

St. Swithin's day, if thou dost rain, For forty days it will remain:
St. Swithin's day, if thou be fair,

For forty days 'twill rain na mair.

Hone's E. D. B.

16. Convolvulus, Convolvulus purpureus, St. Eustathius, Patriarch of Antioch, A. D. 338.

17. Pea, sweet, Lathyrus odoratus, St. Marcellina, A. D. 397 .

18. Marigold, autumn, Chrysanthemum coronarium, St. Bruno, Bishop of Segni, A. D. 1125.

19. Hawk-weed, golden, Hieracium auranticum, St. Vincent, of Paul, 1660.

The corolla of this flower, a rich orange hue, contrasted with the black hairy calyx, which gave rise to the popular name of Grim the collier.

20. Dragon's head, Virginian, Dracocephalus Virginianum, St. Margaret, of Antioch.

21. Lily, Philadelphian, Lilium Philadelphicum, St. Praxedes.

22. Lily, African, Agapanthus umbellatus, St. Mary Magdalen.

23. Musk flower, Scabious atro purpurea, St. Apolli. naris, Bishop of Ravena.

24. Lupine tree, Lupinus arboreus, St. Lupus, Bishop, A. D. 478 .

25. Herb Christopher, pure white, Actæa spicata, St. Christopher.

26. Chamomile, field, or corn Fever-few, Matricaria chamomilla, St. Ann, Mother of the Virgin Mary.

27. Loose strife, purple Lythrum, Lythrum salicaria, St. Pantaleon, A. D. 303.

28. Groundsel, mountain, Senecio montanus, St. Innocent I. Pope, 417.

29. Chironia, red, Chironia centaurium, St. Martha, V.

30. Mullein, white, Verbascum lychnitis, St. Julitta, A. D. 303 .

31. Mullein, yellow, primrose-leafed, Verbascum virgatum, St. Ignatius, of Loyola, founder of the Jesuits, A. D. 1556.

\section{AUGUST.}

The Romish church, professing to possess one of St. Peter's chains, wherewith he was bound, and from which the Angel delivered him, indulges its votaries with a festival in its honour, on the first day of this month, or the Feast of St. Peter's chains.

1. Stramony, or Thorn Apple, Datura stramonium, St. Peter ad Vincula.

2. Lily, tiger, Lilium tigrum, St. Alfrida, A. D. 834.

3. Hollyhock, Althea rosea, the discovery of St. Stephen's relics, 415 .

4. Blue Bells, Campanula rotundifolia, St. Dominic, Confessor, Founder of the Friar Preachers, A. D. 1221.

5. Lily, Egyptian, water, Nelumbo nilotica, St. Mary ad Nives.

6. Saffron, meadow, Colchicum autumnalis, the transfiguration of our Lord, on Mount Tabor.

7. Amaranth, common, Amaranthus hypochondriacus, St. Csjetan, 1547. 
8. Love lies-a-bleeding, Amaranthus procumbens, St. Hormisdas.

9. Rag-wort, yellow Jacobean, Senecio jacobea, St. Romanus.

10. Balsam, Impatiens balsamea, St. Lawrence, Roman Martyr, 258.

11. China Aster, Aster Chinensis, St. Susanna, 3rd Cent.

12. Sow-Thistle, great corn, Sonchus avensis, St. Clare, Abbess, A. D. 1253

13. Groundsel, marsh, Great Fen Rag-wort, or Bird's Tongue, Senecio paludosus, St. Radigundes.

14. Zinnia, elegant, Zinnia elegans, St. Eusebius, Priest, 3rd Century.

15. Virgin's Bower, white, Clematis vitalba, the Assumption of the B. V. Mary, or the miraculous ascent of her body into heaven.

16. Lily, belladonna, Amaryllis belladonna, St. Hyacinth, A. D. 1257.

17. Snapdragon, Toad-flax, Antirrhinum linaria, St. Manus, A. D. 275.

18. Marigold, African, Tagetes erecta, St. Helen, Empress, A. D. 382.

19. Timothy, branched-cat's tail grass, Phleum panniculatum, or Ph. asperum, St. Timothy, A. D. 304.

20. Dandelion, Leontodon serotinus, St. Bernard, Abbot, A. D. 1153.

21. Marigold, French, Tagetus patula, St. Jane Francis, de Chantal, A. D. 1641.

22. Timothy, common cat's tail grass, Phleun pratense, St. 'Timothy, A. D. 311.

23. Tansy, common, Tanacetum vulgare, St. Philip Beniti, A. D. 1285.

24. Sun-flower, tall, Helianthus annuus, St. Bartholomew, Apostle.

25. Sun-fiower, perennial, Helianthus multiflorus, St. Louis, King of France, A. D. 1270.

26. Amaryllis, banded, Amaryllis vittata, St. Zephyrinus, Pope, A. D. 219.

27. Hawk's-weed hedge, Hieracium umbellatum, St. Cæsarius, Archbishop of Arles, A. D. 542.

28. Golden-rod, Solidago, virga aurea, St. Augustine, Bishop, and Doctor of the Church, A. D. 430.

29. Hollyhock, yellow, Althea flava, St. Sabina, King, about 697 .

30. Lily, Guernsey, Amaryllis sarniensis, St. Rose, of Lima, V. 1617.

31. Pheasant's eye, Adonis autumnalis, St. Raymund Nonnatus, 1240.

\section{SEPTEMBER.}

1. Orpine, or Live-long, great, Sedum telephium, St. Giles, Patron of Beggars and Cripples. Born at Athens. Made Abbot of the Abbey at Nismes, in France. Died A. D. 750 .

2. Golden-rod, Solidago, St. Margaret, B., 13th Cent.

3. Flea-bane, common yellow, Inula dysenterica, St. Simeon Stylites, the younger, A. D. 592.

4. Soap-wort, pale pink, Saponaria officinalis, St. Rosalia, A. D. 1160.
5. Mushroom, or champignon, Agaricus campestris, St Laurence Justinian, First Patriarch of Venice, A. D. 1455.

6. Dandelion, Leontodon autumnalis, St. Pambo, of Nitria, A. D. 385.

7. Star-wort, golden, Aster solidaginoides, St. Cloud, A. D. 560 .

8. Star-wort, Italian, blue, Aster amellus, St. Adrian, A. D. 306 .

On this day (September 8th) The Nativity of the B. V Mary is celebrated.

9. Golden-rod, Canadian, Solidago Canadensis, St. Omer, A. D. 607.

10. Crocus, autumnal, Crocus autumnalis, St. Pulcheria, Empress, A. D. 453.

11. Meadow saffron, variegated, Colchicum variegatum, St. Hyacinthus, A. D. 257.

12. Passion-flower, Passiflora peltata, St. Eanswide, Abbess, 7 th Century.

13. Crocus, Crocus sativus, St. Eulogius, Patriarch of Alexandria, 608.

14. Passion-flower, Passiflora cærulea, the cxaltation of the Holy Cross, 629 .

15. Saffron, Byzantine, Colchicum Byzanticum, St. Nicetas, 4th Century.

16. Star-wort, sea, blue, Aster tripolium, St. Editha, A. D. 984 .

17. Mallow, narrow-leaved, Malva angustiflora, St. Lambert, Bishop, A. D. 709.

18. Star-wort, pendulous, Aster pendulus, St. Thomas, Archbishop of Valentia, 1555.

19. Scabious, Devil's bit, Scabiosa succisa, St. Lucy, A. D. 1090 .

20. Meadow saffron, common, Colchicum autumnali, St. Eustachius.

21. Passion-flower, fringed-leaved, variegated, Passiflora ciliata, St. Mathew, A postle and Evangelist.

22. Boletus, tree, Boletus arboreus, St. Maurice, 4th Century.

23. Star-wort, white, bushy, Astcr dumosus, St. Thecla, 1st Century.

24. Fungus, Agaricus fimetarius, St. Gerard, Bishop of Chonad, 1046.

25. Boletus, great, order Fungi, Boletus bovinus, St. Ceolfrid, Abbot, 716.

26. Golden-rod, great, Solidago gigantea, St. Justina, A. D. 304 .

27. Star-wort, white and small-leaved, N. American, Aster multiflorus, St. Delphina, A. D. 1323.

28. Golden-rod, evergreen, Solidago sempervirens, St. Eustochium, Vicar, A. D. 419.

29. Michaelmas Daisy, Aster tradescanti, St. Michael, and all Angels. The dedication of St. Michael's church.

30. Amaryllis, golden, Amaryllis aurea, St. Jerome, Priest, Doctor of the church, A.D. 420.

\section{OCTOBER.}

1. Amaryllis, lowly, Amaryllis humitis, St. Remigius, Bishop of Rheims, A. D. 533. 
With bays, and rosemary,

And laurel complete;

And every one now

Is a king in conceit.

From "Poor Robin's Almanac, for 1695."

26. Heath, purple, Erica purpurea, St. Stephen, the first Martyr.

27. Heath, flame, Erica flammea, St. John, the Apostle and Evangelist.

28. Heath, bloody-flowered, Erica cruenta, the Holy Innocents who suffered from Herod's cruelty.

29. Heath, Erica genistopha, St. Thomas, Archbishop of Canterbury, 1170.

30. Ponthieva, glandular, Ponthieva glandulosa, St. Anysia, A. D. 304.
There is no flower appropriated to the 31st December.

"If New Year's eve night-winds blow South,

It betokens warmth and growth;

If West, much milk, and fish in the sea;

If North, much cold, and storms there will be;

If East, the trees will bear much fruit;

If North-east, flee it man and brute."

And the next to this is New-Year's day, Whereon to every frende,

They costly presents in do bring,

And New-Year's gifts do sende.

These gifts the husband gives his wife, And father eke the childe,

And master on his men bestowes The like, with favour milde.

From the Latin of Thos. Naogeorgus, written in 1553. Translated by Barnarbe Googe. 


\section{DEFINITION OF THE SPECIFIC NAMES OF THE FLOWERS USED IN FLORA'S DICTIONARY.}

Abies, L. Ainsworth defines it-1. A Fir tree-2. A ship3. A plant. The Pinus abies being much used in the construction of slips, etc.

Acris, L. Sharp, sour.

Alba, Albus, I. White, hoary, pale, wan.

Annuus, L. Annual, yearly; living but one year

Argentifolium, L. Silver-leaved.

Atro-purpurea, of a dark purple colour.

Autumnale, I. Of Autumn.

Aurantium, L. Orange coloured.

Azedarach, from Azed, an Arabian word, signifying large.

Babylonica, of Babylon.

Balsamea, L. Balmy.

Barbatus, L. Bearded.

Bella donna. Because the ladies make a cosmetic of the juice, or distilled water. Some derive the name from the intoxicating quality of the plant-Atropa bella donna.

Bicolor, L. Of two colours, parti-coloured.

Campanula, see note on Venus' Looking glass.

Canadensis, L. Of Callada.

Candidum, L. See note on white Lily.

Capitatum, L. From caput, a head.

Cærnlea, L. Azure, blue.

Cæsius, L. Grey coloured.

Caryophyllus, L. For a clove-see note on Pink.

Caudatus, L. Tailed, that hath a tail.

Centifolia, L. Hundred-leaved.

Chalccionica, see note on scarlet Lychnis.

Cheiranthus, see note on Wall Flower.

Chinensis, L. Of China.

Coronarius, L. That belongs to, or serves to make garlands.

Cotinus, see note on Sumach.

Cristata, L. Crested, tufted.

Crystallinum, L. A crystal glass; like it in clearness.

Cuculi, L. From cuculio, a kind of hood, to keep off rain.

Damascena, probably from the name of the country of $D a$ mascene, around Damascis.

Dioica, see note on Bachelor's Button.

Dulcis, L. Sweet.

Florida, Floridus, L. Flowery, adorned with flowers.

Formosissima, L. Beautiful, handsome.

Glauca, glaucus, L. Grey or blue, sea-green, palo bluishgreen.

Globosa, L. Globular.

Graveolens, L. Of a bad odour; that hath a strong smell.

Hispida, L. Hairy, bristly.

Hortensis, L. Pertaining to, or growing in gardens.

Incanus, see note on Gilly Flower.

Indica, Indicum, L. Of India.

Inermis, I. Thornless; unarmed, without arms.

Inodorus, L. Without scent.

Inquinans, L. Defiling, blemishing

Laburnum, see note.

Latifolia, I. Broad-leaved.
Lutea, L. Pale yellow, like the yolk of an egg.

Maculatum, L. Spotted.

Major, L. Greater, bigger.

Matronalis, L. Modest, pertaining to Matrons.

Medium, L. Middle sized, moderate sized.

Millefolium, L. A thousand-leaved.

Minor, L. Less, smaller.

Multiflora, L. Many-leaved.

Muschato, L. Musky.

Muscosa, L. Mossy, or full of moss.

Nivalis, L. Snowy.

Niger, nigrum, L. Black.

Nobilis, L. Known, or well known.

Odorata, Odoratissimum, L. Sweet scented.

Officinale, officinalis, L. Kept for sale as medicinal.

Opulus, I. Ainsworth defines it "A tree which the Fronch call opier-some a Witch-hazel."

Parvifolia, small-leaved.

Peltatum, L. Having the shape of a target, or shield.

Persica, persicus, of, or belonging to Persia. A Peach tree.

Pomifragrans, L. Apple-scented.

Pratense, L. From pratensis, of, or belonging to a meadow.

Pseudo, L. Counterfeit, false.

Pumila, L. A Dwarf.

Punica, L. Scarlet colour, the Tyrian or Carthaginian dye.

Quercifolium, L. Oak-leaved.

Quotidiana, L. Daily, every day.

Rigida, L. Rigid, hard.

Rusea, L. Like a rose.

Rosxfolius, L. Rose-leaved.

Rubeus, L. Red, ruddy.

Rubiginosa, see note on Eglantine.

Rubor-virginea, L. Rubor, red; Virginea, Virgin like.

Rubrifolia, L. Of a red colour.

Sempcrvirens, L. Always flourishing, always green.

Somniferurn, L. Causing sleep.

Speculum, see note on Venus' Looking glass.

Stramonium, L. Probably from stramcn, a spreading

Suavcolens, L. Sweet scented.

Syriacus, L. Syrian.

Taraxacum, see note on.Dandelion.

Tinctoria, L. Of or belonging to Dyers.

Tradescanti, see note on American Star-wort.

Tricolor, Fr. Three coloured.

Trionum, see uote on Hibiscus.

Tuberosa, see note on Tuberose.

Tulipifora, L. Tulip bearing, bearing flowers of a tulip form.

Unica, L. Unique, singular, notable, excellent.

Variegatus, L. Variegated.

Vernalis, L. From Vernus, of, or belonging to the spring.

Vcris, L. Real, true.

Versicolor, L. Of sundry colours.

Virginica, L. Of Virginia.

Vinifera, L. Vine bearing.

Vulgaris, L. Ordinary, common, much used. 


\section{II $\mathbb{N}$ 思区。}

Absence, .. . . . Z Zinnia.

Activity, . . . . . Thyme

Affection beyond the grave, Locust.

A heart that is ignorant of ?

love, . . . S

Ambassador of Love, . . . Rose, cabbage.

Ambition, .. . Hollyhock.

Ambition, Female, . . Hollyhock, white.

Amability, . . . . Jasmine, white.

Am I forgotten? . . . Holly.

An appointed meeting, . Everlasting pea.

An expected meeting, : Geranium, nutmeg.

Anger, a frown,. . . . Pcony.

Anxious and trembling, . Columbine, red.

Aspiring, . . . . . Pink, mountain.

Avarice, ...... Auricula.

Aversion, . . . . . Pink, Indian.

Bashful shame, . : Rose, deep red.

Beauty, . . . . Rose, red, full blown.

Beauty unknown to the pos- 3 Daisy.

Benevolence, : : : Calycanthus.

Beware! . . . . Oleander.

To bind, . . . . . Snow Ball

Bonds of affection, . . Gilly Flower.

A Bosster, . : Hydranger.

Bravery, . . . . Oak Leaf.

Busy Body, . . : Quamoclit.

Call me not Beautiful, . . Rose, unique.

Calumny, Scandal, . . Hellebore.

Capricious Beauty, : . Lady's Slipper

Charity, . . . . Grape, wild.

Charming, : : : Rose, Musk.

Cheerfulness, $:$ Crocus

Cheerfulness in old Age,. . American Starwort.

Chivalry,. . . . . Daffodil.

Compassion,. . . . Elder.

Concealed Love, . . Acacia, yellow.

Confession, . : : Rosebud, Moss.

Confidence, . . . . Polyanthos.

Consolation,. . . . Poppy, red.

Constancy, . . . . Box.

Consumed by Love, . . Althæa.

Coutent, . . . Houstonia.

Coquetry, . . . . Dandelion.

Counterfeit, . . . . Mock Orange.

Cruelty, : : : : Marigold.

To Cure, . . . . . Yarrow.

Cure for the Heart-ache, - Pleurisy root.

Deceitful charms, . . . Thorn Apple.

Declaration of Love,. . . Tulip, red.

Delay,. . . : : Fever Root.

Delicacy,. . . . . Lily of the Valley.

Delicate Beauty, . . . Hibiscus.

Departure, : : : Pea Sweet.

Despair, . . . . Cypress.

Devotion,. : : : Heliotrope.

Disappointment, : : Syringa Carolina.

Disappointed Expectation,. Geranium, fish.

Discretion, . . . Lemon blossom.

Disdain . Rue.

Dissension, : : Pride of China.
Distinction, . . . . Cardinal's flower

Distrust, . . . . . Lavender.

Domestic virtues, . . . Sage.

Fgotism, self-love, . . Narcissus.

Elegance, . . . . Acacia, white.

Eloquence, . . . Lagerstræmia

Encouragement, . . Virga aurea; or, Golden Rod.

Envy, . . . . . . Geranium, Crane's bill.

Esteem and Love, . . . Strawberry Tree.

I esteem, but do not love you, Spider wort.

Estranged love, . . . Lotos flower.

Expectation,. . . . Anemone.

Falsehood, . . . . Lily, yellow.

Farewell! . . . . Pine, spruce.

Female Fidelity, . . . Specdwell.

Feminine Modesty, . . Calla. æthiopica.

Fickleness, . . . . Larkspur, pink col.

Fidelity in misfortune, - Wall Flower.

Filial love, . . . . . Virgin's Bower.

Finesse, . . . . . . Sweet William.

Flattery, . . . Venus' Looking Glass.

Flee away, . . . . . Pennyroyal.

Foppery, Affectation,. . . Cock's Comb.

For ever thine,. . . . Dahlia.

Forget me not,.... Heart's Ease, yellow and pusForsaken, ..... Weeping Willow.

Fraternal love, : : Woodbine

Freshness, . . . . Rose, damask

Friendship, . . A cacia, rose.

Generous and devoted Love, Honeysuckle, wild.

Good wishes, . . . . Basil, Sweet.

Grace, . . . . Rose, Multiflora.

Grace and Elegance, . : Jasmine, Yellow.

Gratitude, . . . . Canterbury Bell.

Happy Love, . . . . Rose, Bridal.

Hope, . . . . . . Almond flower.

Hope, . . . . . Hawthorn.

Hopeless Love, . . . Tulip, yellow.

Hopeless, not Heartless, - Love lies-a-bleeding a

Humility, . . . Broom.

I am dazzled by your charms, Ranunculus.

I am perfectly indifferent to ? you,......

I am worthy of you, . . Rose, white.

I am your Captive, . . Peach blossom.

I change but in dying, : Bay leaf.

I declare against you,. . . Belvidere.

I desire a return of affection, Jonquil.

I fall into the Trap laid for $\}$ Catch Fly, white.

If you do love me, you will Rose, Maiden's Blush. find me out,

I have a message for you, . Iris.
I have lost all!.

I live for thee, . . . : . Cedar.

I love,...: Chrysanthemum, rose colour.

Imagination,. . . . Lupine.

Immortality, . . . Amaranth.

Impatience, . : : Balsam, yellow.

Impatient resolves, . . Balsam, red.

Inconstancy, . . . Primrose, Evening. 
Industry, . . . . . Clover, red.

Ingenuousness, . . . Pink, white.

Ingratitude, . . . . . Rose, without a Thorn.

Innocence, . . . . Daisy, white.

I partake your sentiments, . China Aster, double.

I will think of it, . . . China Aster, single.

I with the morning's love ? Bachelor's Button. have oft made sport, ${ }^{-}$Honeysuckle, Monthly.

I would not answer hastily, Honeysuck

Jealousy, . . . . . Hyacinth.

Iady, deign to smile, . . Geranium, Oak.

Le plus loin, Le plus cher, . Tuberose.

Lightness, . . . . Larkspur.

Live for me, . . . . . Arbor Vitz.

Lively and pure affection, . Pink, red.

Love, . . . . . Violet, blue.

Love at first sight, . . . . Coreopsis, Arkansa.

Love in idleness, . . . . Heart's Ease, wild.

Love positive, . . . . Myrtle.

Love returned,. . . . Ambrosia.

Majesty, Power, . . . Crown Imperial.

Matrimony, . . . . Ivy.

Mature and finished elegance, Pomegranate Flower.

Mildness,. . . . . Privet.

Misanthropy, . . . . Thistle.

Modesty,. . . . . Violet, white.

Music, . : Oat.

My Bane, My Antidote,. . Poppy, white.

My best days are past, . Meadow Saffron.

Never ceasing Remembrance, Everlasting.

Only deserve my love, . . Rose Campion.

Patience, . . . : Ox Eye.

Peace,. . . . . . . Olive.

Pensive Beauty, . . Laburnum.

Perplexity, . . . . . Love in-a-mist.

Perseverance, . . . Magnolia.

Pity, . : : Camellia Japonica.

Pity, . . . . . . Pine, black.

Pleasures of Memory, . Periwinkle, blue.

Pleasing Reminiscences, Periwinkle, white.

Preference, . . . . Geranium, rose.

Present preference, . . Geranium, apple.

Presumption, . . . . Snap Dragon.

Pride, . . . . Rose, hundred leaved.

Pride, Haughtiness, . : Sun-flower, tall.

Prosperity, . . . . Wheat.

Purity and sweetness,. : : Lily, white.

Recall, . . . . Geranium, silver-leaved.

Recantation, . . . Iotos leaf.

Recluse, . . . . . Moss.

Reconciliation,. . . . Star of Bethlehem.

Refinement, . . . . Snow drop.

Refusal, . . . . . Pink, variegated.

Rejected addresses, : . Ice Plant.

Religious Superstition, : Aloe.

Remembrance, . . . Rosemary.

Resolved to win, : . Columbine, purple.

Revenge,. . . . . Bird's-foot Trefoil.

Riches, . . . . Butter-cup.

Rivalry, : . : . . Rocket.

Rural Happiness, . . . Tulip tree.

Scepticism, . . . Night shade.

Sensibility, . . . Verbena.
Sensitiveness, . . . Mimosa.

Serenade, . . . Dew Plant.

Simplicity, . . . . . Sweet Briar.

Sincerity,. . . . . Honesty, or Satin Flower.

Slander, . . . . Nettle.

Slighted love, . . . Chrysanthemum, yellow.

Solitude, . . . . . Lichen.

Sorrowful Remembrances, . Adonis.

Speak low, if you speak love, Honey Flower.

Splendid Beauty, . . . Amaryllis.

Splendour, . . . . Sumach, Venice.

Submission, . . . . Grass.

Sunbeam'd Eyes, . . . Scarlet Lychnis.

Superior Merit, . . . . . Rose, Moss.

Superstition, ... . St. John's wort.

Susceptibility, . . . Passion Flower.

Sympathy, . . . . Balm.

That smile I would aspire Rose, Daily. to, . . . .

The ambition in my love Fuchsia. thus plagues itself, : .

The colour of my fate, : Honeysuckle, coral.

The decrease of love on bet- $\}$ Rose, yellow. ter acquaintance, first emotions of love, Lilac, purple.

The first emotions of love, . Lilac, purple.

The reward of Merit, . . Bay Wreath.

Thou art all that is lovely, Rose, Austrian.

Time, . . . . . . Fir, Balm of Gilead.

Time and Philosophy, . Pine, Pitch.

Timidity,. . . . . Marvel of Peru.

A Token, . . . . . Laurustinus.

Transient Impressions, : Rose, white and withered.

Transport, Ecstacy, . . . Cape Jasmine.

Treachery, . . . . Laurel.

Truth,. . . . Chrysanthemum, white.

Unanimity, . .... Phlox.

Uncertainty, . . Convolvulus.

Unchangeable, . . . Amaranth, Globe.

Unconscious Beauty, . . Rose, Burgundy.

Unfortunate attachment, - Scabious. The Mourning Bride

Unpatronized Merit, . . Primrose.

Useful knowledge, . . . Parsley.

Variety, . . . . Rose, Mundi.

War, . . . . . Rose, York, and Lancaster.

Warlike Trophy, . . Nasturtium.

Winning Grace, . . . Cowslip.

A Wish, . . . Fox Glove.

Wit, . . . . . Ragged Robin.

Wit, ill timed, . . . . Sorrel.

Woman's Love, : : Pink. The Carnation.

You are the Queen of $\left.\mathrm{Co}^{-}\right\}$Queen's rocket. quettes, . a d i beautiful, Rose-bud, red.

You occupy my thoughts, - Heart's Ease, purple.

Your devout adorer, . . Sun-flower, Dwarf.

Your hand for the nextquad- ? rille?

Geranium, Ivy.

Your purity equals your love- ? liness,

Your qualities surpass your loveliness,

Youth, ..... Lilac, white.

Youthful love, : : : Catch fly, red. 
2. Soap-wort, Saponaria officinalis, Feast of the holy guardian Angels.

3. Helenium, downy, Helenium pubescens, St. Dionysius, the Arenpagite, A. D. 51.

4. Southern-wood, dwarf, Artemisia abrotanum, St. Francis, of Assisium, A. D. 1226.

5. Chamomile, star-like, a Fungus, Boltonia asteroides, St. Placidus, A. D. 546.

6. Feverfew, creeping-rooted, Pyrethrum serotinum, St. Bruno, Founder of the Carthusian Monks, A. D. 1101.

7. Chrysanthemum, Indian, Chrysanthemum Indicum, St. Mark, Pope, A. D. 336.

8. Maudlin, sweet, Achiller ageratum, St. Bridget, A. D. 1373 .

9. Mushroom, milky, Agaricus lactifluus acris, or, $\mathcal{A}$. Listeri, St. Denys, Patron saint of France.

10. Aletris, cape waved-leaved, Aletris viridifolia, $\mathbf{S t}$. Francis Borgia, A. D. 1572.

11. Holly, common, Ilex aquifolium, St. Ethelburge, A. D. 664 .

12. Flea-bane, wavy, Inula undulata, St. Wilfred, Bishop of York, A. D. 709.

13. Helenium, yellow, smooth, Helenium autumnale, St. Edward, King, and Confessor, A. D. 1066.

14. Flea-bane, Indian, Inula Indica, St. Calixtns, Pope, A. D. 222.

15. Sultan, sweet, purple, Centaurea moschata, St. Teresa, Virgin, 1532.

16. Yarrow, Achillea millefolium, St. Gall, Abbot, A. D. 646 .

17. Sun-flower, Dwarf, Helianthus indicus, St. Anstrudis, A. D. 683 .

18. Mushroom, Agaricus floccosus, St. Luke, the Evangelist, A. D. 63.

19. Tick-seed, perennia], Coreopsis procera, St. Frideswide, Patroness of Oxford, 8th Century.

20. Sultan, yellow, sweet, Centaurea suaveolens, $\mathrm{St}$. Artemius, 362.

21. Silphium, hairy-stalked, Silphium asteriscus, St. Ursula, 5 th Century.

22. Silphium, rough, three-leaved, Silphium trifoliatum, St. Nunilo, 840.

23. Star-wort, slender-stalked, Aster junceus, St. Theodoret, A. J. 362.

24. Star-wort, carolina, Astcr carolinus flexuosus, St. Proclus, Archbishop of Constantinople, A. 1. 447.

25. Star-wort, flea-bane, Astcr Conizoides, St. Crispin, A. D. 237.

Star-wort, meagre, Aster miser, St. Crispinian, 287.

These were both Brothers, and Martyrs, Shoemakers, and Patrons of that art.

26. Golden-rod, late-flowered, Solidago petiolaris, St. Evaristus, Pope, A. D. 112.

27. Star-wort, floribund, Aster floribundus, St. Frumentius, A postle of Ethiopia, Century 4th.

28. Chrysanthemum, late flowering, creeping, Chrys. serotinum, St. Simon, Apostle, the Zealot. Apostle.
29. Narcissus, green, autumnal, Narcissus vividiflorus, St. Narcissus, Bishop of Jerusalem, 2nd Century.

30. Mushroom, mixen, Agaricus fimetarius, St. Marcellus, the centurion, A. D. 298.

31. 'Tick-seed, fennel-leaved, Coreopsis ferulæfolia, St. Quintin, 287.

"The 31st October is all Hallow E' en, or the vigil of All Saints' day, in which young people try their fortune, by drawing cabbages from the ground, blindfolded. Or, burning nuts in the fire, etc.

'The cabbage, or kale, being large or small, straight or crooked, is deemed prophetic of the size and form of the grand object of their spells. If any earth adhere to the root, that is tochcr, or fortune; the taste of the heart of the stem, is indicative of the natural temper aud disposition. Lastly, the stems are placed over the door, and the christian name of the person who first enters through the door, will be the name sought for. If more than one be so affixed, it will be decided according to the priority of placing the runts or stalks.

The nuts are named, and accordingly as they hurn quietly together, or start from beside each other, the course, and issue of their love will be."

These glowing nuts are emblems true

Of what in human life we view;

The ill-matched couple fret and fume,

And thus, in strife themselves consume;

Or, from each other wildly start,

And with a noise for ever part.

But see, the happy, happy pair,

Of genuine love and truth sincere;

With mutual fondness, while they burn,

Still to each otlier kindly turn:

And as the vital sparks decay,

Together gently sink away:

Till life's fierce ordeal being past,

Their mingled ashes rest at last. Charles Graydon, Esqr.

From his collection of poems. Dublin, 1801.

\section{NOVEMBER.}

1. Laurustinus, Laurustinus sempervirens, St. Fortunatus.

2. Cherry, winter, Physalis, St. Marcian, A.D. 387.

3. Primrose, Primula vulgaris, St. Flour, A. D. 389.

4. Strawberry tree, Arbutus, St. Brinstan, Bishop of Winchester, A. D. 931.

5. Cherry, common winter, orange coloured fruit, Physalis alkakengi, St. Bcrtille, Abbess of Chelles, A. D. 692.

6. Yew tree, common, of Europe, Truxus baccata, St. Leonard, 6th Century.

7. Furcræa, large, Furcræa gigantea, St. Willebord, First Bishop of Utrecht, 738.

8. Aletris, cape, Veltheimia glauca, the four crowncd Brothers, Martyrs, A. D. 304.

9. Aletris, glaucous-leafed, Veltheimia glauca, St. John Lateran.

10. Fir, Scotch, Pinus sylvestris, St. Nympha, 5th Century.

11. Pine, Weymouth, Pinus strobus, St. Martiu, Bishop, A. D. 397.

12. Aloe, great orange flowering, Veltheimia, or Aletris uvaria, St. Nilus, A. D. 390.

13. Bay, Laurus poetica, St. Homobonus, A. D. 1197. 
14. Laurel, Portugal, Cerasus lusitanica, St. Lawrence, Archbishop of Dublin, 1180.

15. Colt's-foot, sweet-scented, Tussilago fragrans, St. Gertrude, Abbess, 1292.

16. Hemp, African bow-string, Saniseviera guineensis, St. Edmund, Archbishop of Canterbury, A. D. 1242.

17. Stramony, or Thorn Apple tree, Datura arborea, St. Gregory Thaumaturgus, Bishop, A. D. 270.

18. Passion-Flower, notched-leafed, with curling rays to flower, Passiflora serratifolia, dedication of the churches of St. Peter and St. Paul, at Rome.

19. Passion-Flower, apple fruited, Passiflora maliformis, St. Elizabeth, of Hungary, A. D. 1231.

20. Stapelia, red, Stapelia rubra, St. Edmund, King and Martyr, 870.

21. Sorrel, wood, Oxalis grandiflora, the presentation of the B. V. Mary.

22. Sorrel, wood, tube-flowered, Oxalis tubiflora, St. Cecilia, A. D. 230.

St. Cecilia, a Sicilian Martyr. She is the tutular Saint and Patroness of Music, particularly of Sacred Music. She is supposed to be the inventress of the organ; and to have drawn down an Angel from Heaven by the music of her voice.

At last divine Cecilia came,

Inventress of the vocal frame;

The sweet enthusiast, from her sacred store,

Enlarg'd the former narrow bounds,

And added length, to solemn sounds,

With Nature's Mother-wit, and arts unknown before.

Let old Timotheus yield the prize,

Or both divide the crown;

He rais'd a mortal to the skies;

She brought an Angel down.

Dryden.

23. Sorrel, convex, Oxalis convexula, St. Clement, Pope, A. D.: 100.

24. Stapelia, starry, Stapelia radiata, St. John of the cross, A. D. 1591.

25. Butterbur, sweet, Tussilaga fragrans, St. Catharine, Patroness of Spinsters, 3rd Century.

26. Sorrel, linear, Oxalis linearis, St. Conrad, Bishop of Constance, 976.

27. Sorrel, lupine-leaved, Oxalis lupinifolia, St. Virgil, Bishop of Saltzburg, A. D. 784.

28. Stapelia, va riegated, Stapelia variegata, St. Stephen the younger, 764 .

29. Sphenogyne, Sphenogyne piliflora, St. Saturninus, Bishop, A. D. 257. Bishop.

30. Sorrel, three-coloured, Oxalis tricolor, St. Sapor,

November 30th is St. Andrew's Day, Patron saint of Scotland, one of the Apostles. A Martyr. The form of the cross of St. Andrew, is believed to be that of the letter X, styled a cross Decussate. 'The Muscovites, say he preached among them, and claim him as the tutular saint of their Em. pire.

\section{DECEMBER.}

1. Stapelia, dark, Stapelia pulla, St. Eligius, Bishop of Noyon, A. D. 659.
2. Geodorum, lemon, Geodorum citrinum, St. Bibiania, A. D. 363 .

3. Indian Tree, Euphorbia tirucalli, St. Francis Xavier, A. D. 1552 .

4. Goose-berry, Barbadoes, Cactus pereskia, St. Peter Chrysologus, 450 .

5. Hibiscus, long-stalked, Hibiscus pedunculatus, St. Crispina, A. D. 304.

6. Heath, nest-flowered, Erica nudiflora, St. Nicholas, Arcbbishop of Myra, 342.

7. Achania, hairy, Achania pilosa, St. Ambrose, A. D. 397. Mary.

8. Arbor Vitæ, American, Thuja occidentalis, the B. V.

9. Spruce, Corsican, Pinus Laricio, St. Leocadia, 304.

10. Cypress, Portugal, Cupressus pendula, St. Eulalia.

11. Pine, Aleppo, Pinus halepensis, St. Damascus, Pope, 384.

12. Heath, crowded, Erica abietina, St. Eadburge, A. D. 751.

13. Arbor Vitæ, African, Thuja cupressoides, St. Lucy, A Syracuse Martyr, A. D. 304.

14. Pine, swamp, Pinus palzstris, St. Spiridion, Archbishop, A. D. 348.

15. Pine, pitch, Pinus resinosa, St. Florence, Abbot.

16. Arbor Vitæ, Chinese, Thuja orientalis, St. Alice, or Adelaide, Empress, A. D. 999.

17. Cedar, white, Cupressus thyoides, St. Olympias, A. D. 410 .

18. Cypress, New Holland, Cupressus australis, St. Winebald, 760 .

19. Heath, two-coloured, Erica bicolor, St. Samthana, Abbess, 738.

20. Pine, stone, Pinus pinea, St. Philogonius, Bishop of Antioch, 322.

21. Sparrow-wort, Erica passerina, St. Thomas, the Apostle.

22. Heath, pellucid, Erica pellucida, St. Cyril, A. D. 881.

23. Cedar of Lebanon, Pinus cedrus, St. Victoria, 250.

24. Pine, frankincense, Pinus tæda, Sts. Thrasilla, and Emiliana.

25. Holly, Ilex aculeata baccifera, the nativity of our Saviour.

Some say, that ever 'gainst that season comes

Wherein our Saviour's birth is celebrated,

This bird of dawning singeth all night long.

And then, they say, no spirit stirs abroad;

The nights are wholesome; then no planet strikes;

No fairy takes, nor witch hath power to charm-

So hallow'd, and so gracious is the time.

Shaks. Hamlet.

Christmas, the joyous period of the year!

Now with bright Holly all the temples strow,

With Laurel, green, and sacred Mistletoe.

Gay.

With Holly and ivy,

So green and so gay,

We deck up our houses As fresh as the day. 


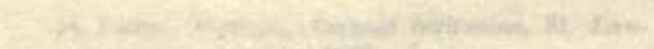

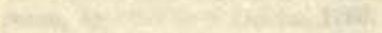

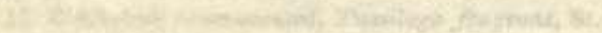

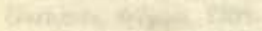

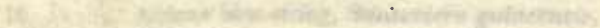
ana

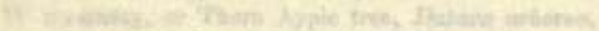

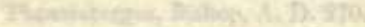

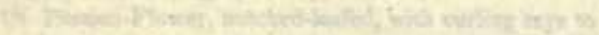

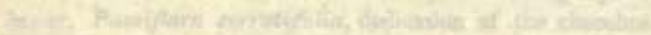

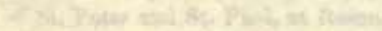

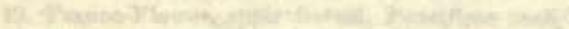

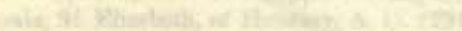

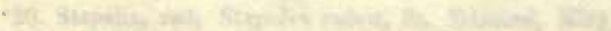

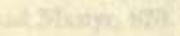

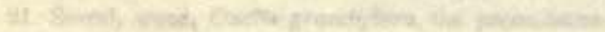

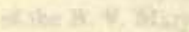

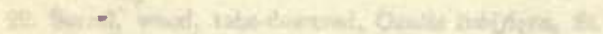

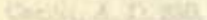

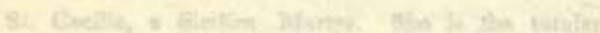

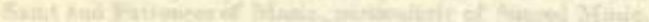

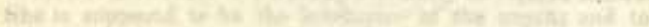

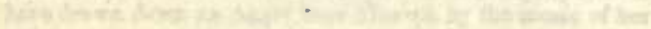

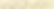

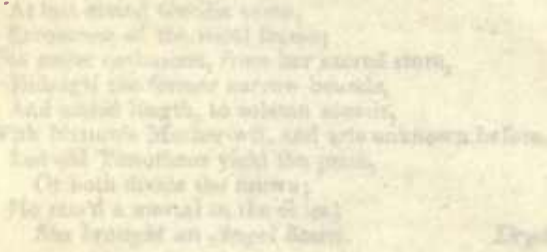

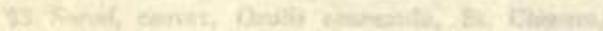

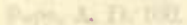

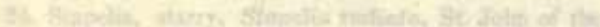

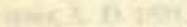

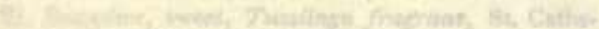

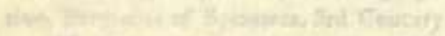

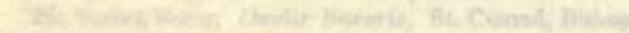

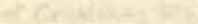

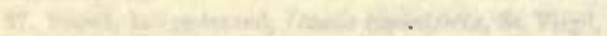

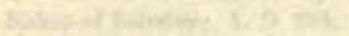

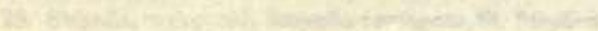

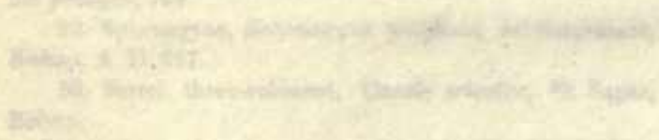

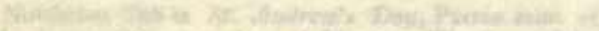

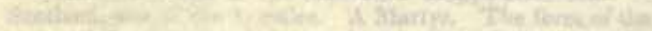

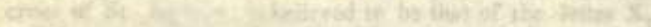

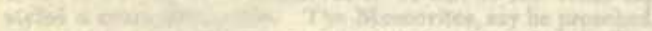

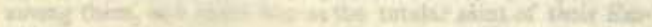
pitas

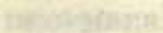

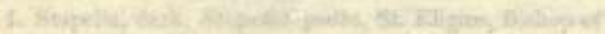
Whice, A. DR Bty

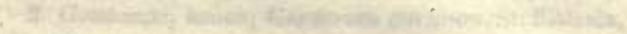
A. 0.365

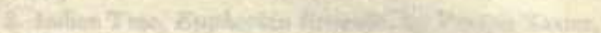
A. 73, 2932

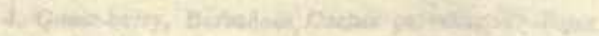

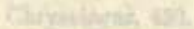

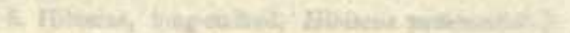

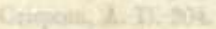

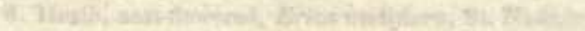

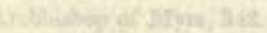

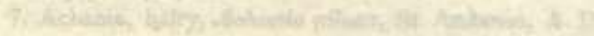

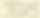

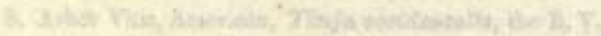
anc

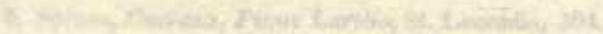

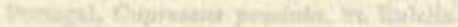

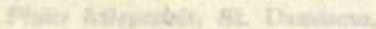

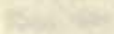

34

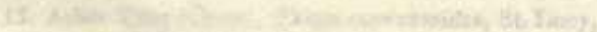

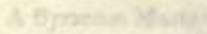

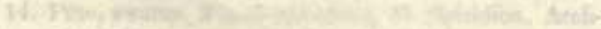

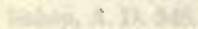

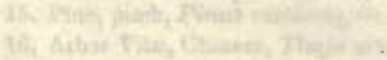

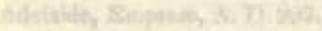

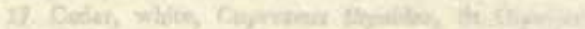
A. 12.410

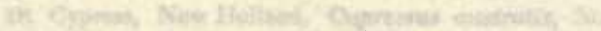
(47)

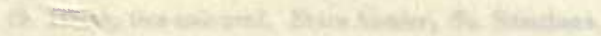

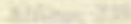

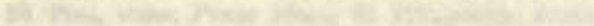

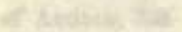

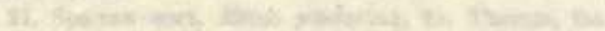
(1) +46

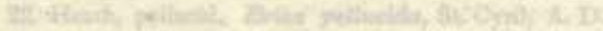
self

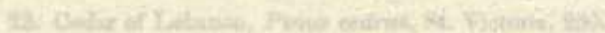

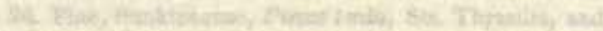
Fithing

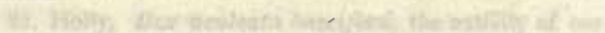
Sathatis

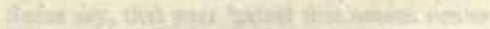

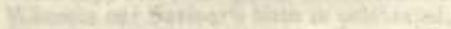

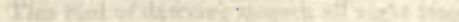

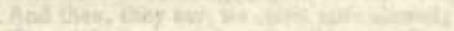

7.

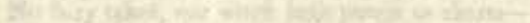

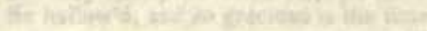

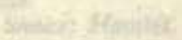

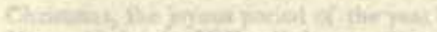

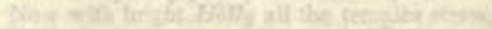

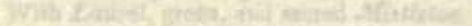

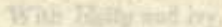

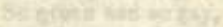

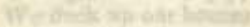

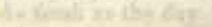







\section{$\left(x^{2}\right)$}


